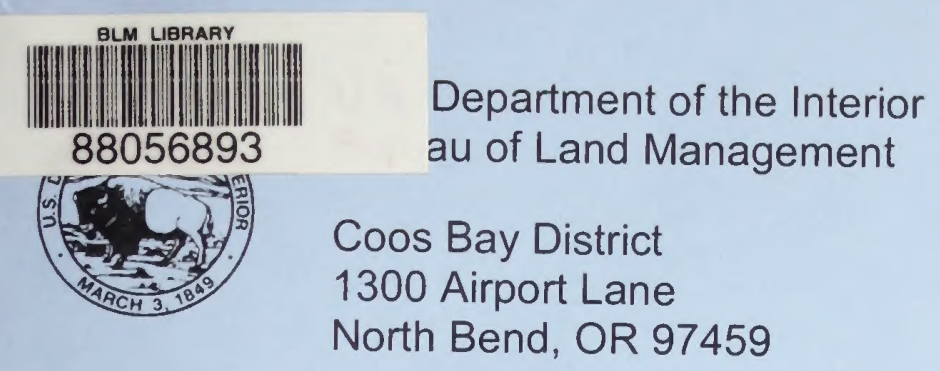

November 2002

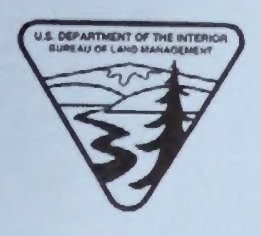

\title{
Coos County Natural Gas Pipeline \\ Final Environmental Impact Statement
}
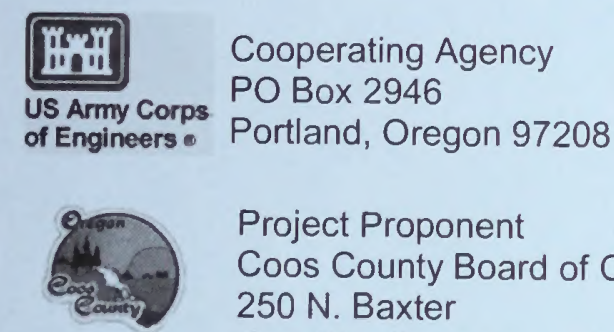

Project Proponent

Coos County Board of Commissioners

250 N. Baxter

Coquille, Oregon
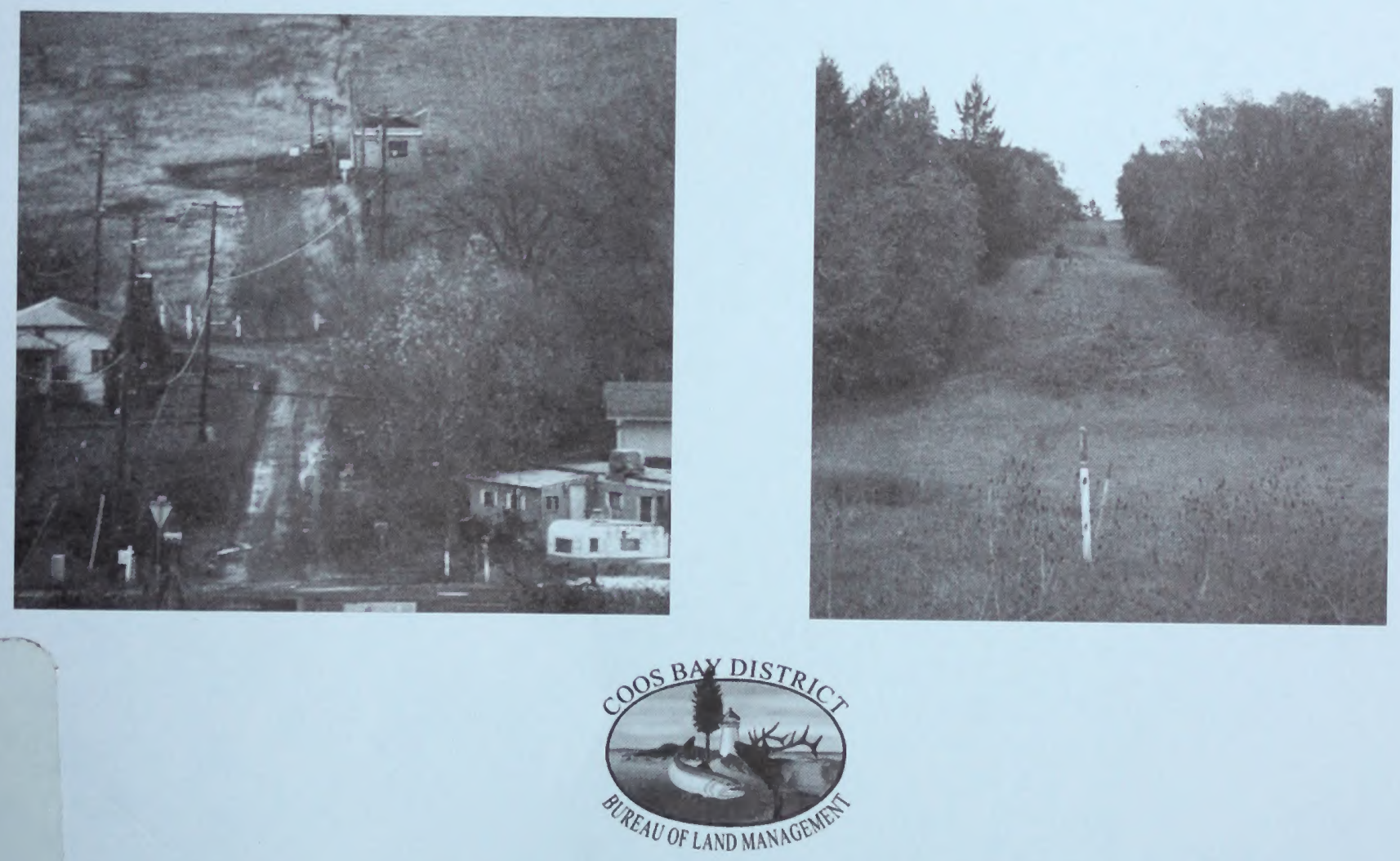
As the Nation's principal conservation agency, the Department of the Interior has responsibility for most of our nationally owned public lands and natural resources. This includes fostering the wisest use of our land and water resources, protecting our fish and wildlife; preserving the environmental and cultural values of our national parks and historical places, and providing for the enjoyment of life through outdoor recreation. The Department assesses our energy and mineral resources and works to assure that their development is in the best interest of all our people. The Department also has a major responsibility for American Indian reservation communities and for people who live in Island Territories under U.S. administration.

BLM/OR/WA/PL-02/038+1792

Comments, including names and street addresses of respondents, will be available for public review at the Coos Bay District Office, 1300 Airport Lane, North Bend, during regular business hours (7:45 a.m. to 4:30 p.m.), Monday through Friday, except holidays. Individual respondents may request confidentiality. If you wish to withhold your name or street address from public review or from disclosure under the Freedom of Information Act, you must state this prominently at the beginning of your written comment. Such requests will be honored to the extent allowed by law. All submissions from organizations or businesses, and from individuals identifying themselves as representatives or officials of organizations or businesses, will be made available for public inspection in their entirety. 


\section{Abstract}

\section{Coos County Natural Gas Pipeline}

Final Environmental Impact Statement

1. Responsible Agency: United States Department of the Interior, Bureau of Land Management (Lead Agency) and Department of Defense, Army Corps of Engineers (Cooperating Agency)

2. Draft ( )

\section{Administrative Action $(\mathrm{X})$}

Final $(X)$

\section{Legislative Action ( )}

4. Abstract: This Final Environmental Impact Statement (FEIS) addresses the effects of constructing a proposed natural gas pipeline approximately 60 miles in length from near Roseburg, Oregon, to Coos Bay, Oregon. The proposed action includes crossing approximately 3.0 miles of federal land administered by the Bureau of Land Management (BLM). This document analyzes the proposed action as compared to two alternatives, including no action. The proposed action includes the construction, operation and maintenance of a 12-inch diameter natural gas pipeline within existing rights-of-way (ROW) designated for road or utility corridors. Suitable habitat for three federally protected species (the marbled murrelet, the northern spotted owl and the bald eagle) is adjacent to the proposed action corridor. The proposed action would cross 188 streams, 1 wetland and is adjacent to approximately 2 miles of floodplain. This document discusses Direct. Indirect and Cumulative effects, including socio-economic impacts, and addresses agency and public concerns.

5. Difference between the Final and Draft Environmental Impact Statement: Comments were taken both orally and in writing for a period of 60 days on the draft environmental impact statement released in January 2002. Substantive comments were responded to both in a question and answer format, and/or by making changes, additions or corrections in the text of the FEIS.

Note: The BLM will issue a Record of Decision addressing whether or not to grant a ROW permit crossing federal lands 30 days after the Notice of Availability for this FEIS appears in the Federal Register.

6. For Further Information contact:

Bob Gunther, Project Coordinator

1300 Airport Lane

North Bend, OR 97459

Telephone: (541) 751-4295, Fax: (541)751-4303

E-mail: Bob_Gunther@or.blm.gov

For technical information contained in the EIS contact:

Melanie Little, Biologist

Biological Information Specialists, Inc.

P.O. Box 27

Camas Valley, OR 97416

Telephone: (541) 445-2008

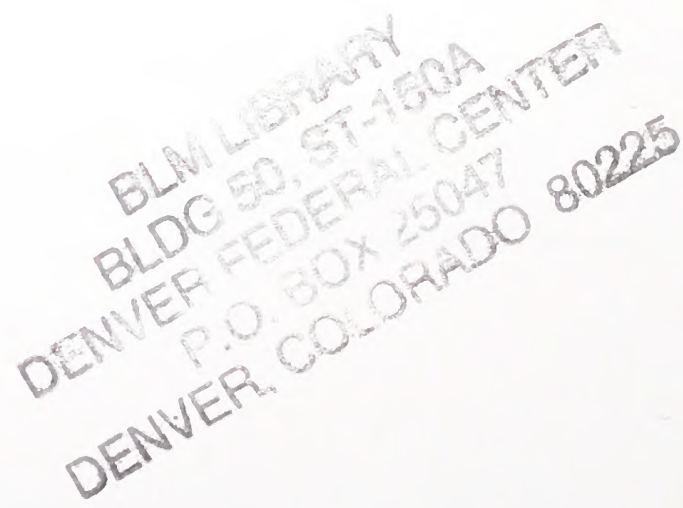




\section{Summary}

\section{Summary of Changes between Draft and Final EIS}

Based on public comments received on the Draft EIS, numerous corrections and clarifications were made to the Final EIS. Specific changes are identified at the beginning of each chapter. The following list summarizes the key changes.

- Clarification of the "No Action" alternative is summarized in this section.

- Additional information regarding air quality, including emissions fuel combustion was added to Chapter 4.

- Additional information regarding fire safety was added to Chapter 4.

- Appendix E, formerly the Aquatic Ecosystem Assessment, has been replaced with an Aquatic Biological Assessment due to the Federal Ninth Cireuit Court of Appeals ruling on December 14, 2001 reinstating protections under the federal Endangered Species Act for Oregon Coho salmon.

- A revised Appendix H: Erosion Control Plan (ECP) has replaced the former ECP providing additional Project Design Criteria.

- A revised Appendix J: Pipeline Design, Construction, Operation and Maintenance has replaced the former Appendix J.

- Maps in Appendix C were replaced with 10 black and white sheets delineating BLM lands adjacent to the proposed action.

- Letters received during the 60-day comment period and responses to these letters have been added to this document as Appendix G-1 and G-2.

The Coos County Board of Commissioners is proposing to construct, operate and maintain a natural gas pipeline between Roseburg and Coos Bay, Oregon. This pipeline would begin at an existing natural gas pipeline a few miles south of Roseburg and terminate in the city of Coos Bay where a distribution facility would be built. This pipeline would be approximately 60 miles long and have a capacity of 70 million cubic feet of natural gas per day. The entire pipeline would be located within existing road and utility ROW. Approximately 3.0 miles of the pipeline would cross lands within utility ROW managed by the U.S. Department of Interior, Bureau of Land Management (BLM).

Coos County contracted three independent consulting corporations (Pipeline Solutions, Ine., Industrial Gas Service, Inc.) as professional advisors and Biological Information Specialists, Inc. for preparation of this FEIS.

To gain easements on public and privately owned lands, the Coos County Board of Commissioners filed an application with the BLM for a perpetual and renewable ROW in May 2000, and filed an application with Bonneville Power Administration (BPA) for consent to construct portions of the natural gas line within BPA utility corridors in August 2000 .

Coos County submitted an application to the U.S. Army Corps of Engineers (COE) for permission to construct the pipeline across streams and wetlands in November 2000.

\section{Agency Roles and Decisions to Be Made}

Numerous agencies were involved in the preparation, consultation and permitting decisions for this project, as shown in Table S-I.

The BLM is the Lead Agency. The Secretary of the Interior, through the BLM, is mandated to process Mineral Leasing Acl (MLA) applications across federal lands. Assuming the Record of Decision (ROD) selects the proposed action for construction of the pipeline, BLM will then issue authorization (ROW grant) under the MLA for use of federal lands. 
Table S-1. Overview of Permit, Approval and Consultation Requirements for the Proposed Action

\begin{tabular}{|c|c|}
\hline Agency & Permit/Authority \\
\hline \multicolumn{2}{|l|}{ Federal Government } \\
\hline \multirow[t]{4}{*}{$\begin{array}{l}\text { U.S. Department of the Interior, } \\
\text { Bureau of Land Management } \\
\text { (BLM) }\end{array}$} & $\begin{array}{l}\text { Record of Decision (ROD) } \\
\text { Minerals Leasing Act: Title 1, Section } 28 \text { (c)(2) of the Mineral Leas- } \\
\text { ing Act of 1920, as amended, November 16, } 1973 \text { authorizes the Sec- } \\
\text { retary of the Interior to grant or renew ROW or permits and to enter } \\
\text { into agreements with other land-managing federal agencies for the } \\
\text { processing of applications for pipelines to transport oil natural gas, } \\
\text { synthetic liquid or gaseous fuels, or refined products produced there- } \\
\text { from. }\end{array}$ \\
\hline & ROW Grant Minerals Leasing Act \\
\hline & Notice to Proceed \\
\hline & Consultation \\
\hline \multirow{3}{*}{$\begin{array}{l}\text { U.S. Army Corps of Engineers } \\
\text { (COE) }\end{array}$} & Cooperating Agency \\
\hline & Section 404 Clean Water Act \\
\hline & Section 10 Rivers and Harbors Act \\
\hline $\begin{array}{l}\text { National Marine Fisheries Service } \\
\text { (NMFS) }\end{array}$ & Consultation and Concurrence \\
\hline \multirow{2}{*}{$\begin{array}{l}\text { U.S. Department of the Interior, } \\
\text { Fish and Wildlife Service } \\
\text { (USFWS) }\end{array}$} & Consultation and Concurrence \\
\hline & Section 7 Endangered Species Act \\
\hline $\begin{array}{l}\text { Bonneville Power Administration } \\
\text { (BPA) }\end{array}$ & $\begin{array}{l}\text { ROW and consent to build sections of a natural gas pipeline within } \\
\text { BPA utility corridors }\end{array}$ \\
\hline \multicolumn{2}{|c|}{ All Land Owners Along the Pipeline ROW } \\
\hline Pacific Power and Light (PP\&L) & $\begin{array}{l}\text { ROW and consent to build sections of a natural gas pipeline within } \\
\text { PP\&L utility corridors }\end{array}$ \\
\hline Private land owners & ROW ownership agreements \\
\hline
\end{tabular}




\section{Purpose and Need for Action}

The purpose of the proposed action is to construct a 12 inch natural gas transmission pipeline from near Roseburg to Coos County. Natural gas transported by the pipeline would provide an alternative source of energy for existing or potential residential, commercial or industrial customers within the Coos County service area.

The total length of the pipeline is about 60 miles. Approximately 28 miles of smaller pipeline laterals would eventually be constructed to serve the Coos County cities of Coquille, Myrtle Point and possibly Bandon. This EIS provides the analysis necessary for BLM to make a decision on granting a discretionary right-of-way permit for the construction, operation, and maintenance of the pipeline on approximately three miles of BLM-administered land.

Coos County has never had direct access to natural gas as an energy source, but has relied on petroleum products and propane, electricity, or wood for energy sources. In 1999, Coos County leaders recognized the necessity for natural gas as critical to the community's economic survival. Government and civic leaders supported a public awareness campaign which resulted in a grant from the State of Oregon to publicly fund a gas pipeline. Ballot Measure \#6-63, authorizing additional taxpayer funds for construction of a natural gas pipeline, was passed by a double majority of Coos County voters in November 1999.

\section{Alternatives Analyzed in the Environmental Impact Statement (EIS)}

\section{Proposed Action: Natural Gas Pipeline}

The proposed action responds to the above-stated Purpose and Need by transporting natural gas from Roseburg, Oregon, to Coos Bay, Oregon, at a lower cost than other alternatives.

The proposed natural gas pipeline would originate at an existing Williams Gas pipeline just south of Roseburg, extend southwest for approximately 60 miles where it would terminate at a distribution facility that would be built in Coos Bay. The proposed action would include construction of pipeline laterals supplying natural gas the communities of Coquille, Myrtle Point and possibly Bandon. The routes of these laterals are not yet finalized. Approximately 3.0 miles of the preferred pipeline route would cross BLM-managed lands within BPA utility ROW. The remainder of the pipeline would be located within the ROW of the Coos Bay Wagon Road (CBW Road), other public roads and utility ROW crossing privately owned properties. The pipeline would cross 188 streams and 1 wetland.

The pipeline would be a 12 -inch diameter pipe, operating at a pressure from 500 to 800 pounds per square inch (psi). With the exception of line markers, test stations, bridge crossings and valve settings, the pipeline would be buried for its entire length.

\section{No Action}

For the purposes of this EIS the "No Action Alternative" is defined as the BLM would not grant Coos County a discretionary Right-of-Way permit for construction, operation, and maintenance of the natural gas pipeline on lands administered by the BLM. Affects addressed in the EIS associated with the No Action Alternative assume that the present conditions remain as they currently exist, that is, the pipeline would not be constructed.

However, if the Proposed Action as described in the EIS is denied, Coos County will proceed with plans to construct, operate, and maintain the natural gas pipcline within public roads and private easements included in the Proposed Action, avoiding crossing Federal land as necessary. Obtaining a right-of-way permit for crossing federal lands would not be necessary. Segments C, E, and G of the described Proposed Action would be built, mostly in the CBW Road. Approximately 86 percent of the proposed route would be built in the location described in the EIS Proposed Action. This re-route would result in the construction of approximately 4.0 additional miles of pipeline and cost an estimated \$2.3 million dollars more than the proposed action.

\section{The Hwy 42 Alternative}

This alternative would deliver natural gas from near Roseburg to Coos Bay by constructing a pipeline under or beside the road bed of Oregon Hwy 42 for approximately 83 miles. This route would cross sensitive wildlife areas and be located within difficult construction zones for approximately 7 miles. Construction would be more difficult due to the existing fiber optic cables buried on each side of the road. Construction along Hwy 42 would result in considerable traffic delays for an extended period of time. 
This route would cross 209 streams and 9 wetlands. A route summary of environmental and economic impacts is given in Table $\mathrm{S}-2$.

Table S-2. Impacts and Route Summary Including No Action

\begin{tabular}{|l|c|c|c|}
\hline \multicolumn{1}{|c|}{ Alternative } & Proposed Action & Hwy 42 & No Action \\
\hline Total length (miles) & 59.1 & 82.7 & 63.1 \\
\hline Total stream crossings & 188 & 209 & 188 \\
\hline Total wetlands crossed & 2 & 9 & 2 \\
\hline Federally listed species & No Impact & No Impact & No Impact \\
\hline Survey and Manage species & No Impact & No Impact & No Impact \\
\hline Estimated Costs & $\$ 34$ million & $\$ 48$ million & \$36.3 million \\
\hline
\end{tabular}

\section{Alternatives Considered but Eliminated from Detailed Study}

Alternatives to the proposed action that were determined not to meet the need included alternative sources of natural gas; Compressed Natural Gas (CNG), Liquefied Natural Gas (LNG), Pacific Gas Transmission (PGT) and an alternative route following Hwy 38 or direct route. All of these alternatives were rejected because they were not economically feasible.

\section{Potential Impacts}

Five categories were used to evaluate potential impacts to the natural and built environments: negative impact, no negative impact, no anticipated impact, no effect and beneficial impact. For the resources discussed in this EIS, potential impacts from construction and operation are estimated to be "negligible short-term" to "no effect." 


\section{List of Acronyms Used Within this Document}

ACEC - Area of Critical Environmental Concern

ACS - $\quad$ Aquatic Conservation Strategy

AD - $\quad$ Anno Domini

AMA - Adaptive Management Area

API - American petroleum Institute

BA - Biological Assessment

BIS - Biological Information Specialists

BLM - Bureau of Land Management

BMP - Best Management Practice

BP - Before Present

BPA - Bonneville Power Administration

CBW Road-Coos Bay Wagon Road

CEQ - Council on Environmental Quality

CHU - Critical Habitat Unit

CFR - Code of Federal Regulations

cfs - $\quad$ cubic feet per second

CNG - Compressed Natural Gas

COE - U.S. Army Corps of Engineers

CR - County Road

CSZ - Cascadia Subduction Zone

CWTD - Columbian White-Tailed Deer

CZMA - Coastal Zone Management Act

DLCD - Department of Land Conservation and Development

DEQ - Department of Environmental Quality

DO'T - Department of Transportation

DSL - Department of State Lands (Oregon)

EA - Environmental Assessment

ECA - Equivalent Clearcut Area

ECP - Erosion Control Plan

ECR - Environmental Compliance Representative

EIS - Environmental Impact Statement

EPA - Environmental Protection Agency

ERMA - Extensive Recreation Management Area

ESA - $\quad$ Endangered Species Act (1973)

FLPMA - Federal Land Policy and Management Act 
FONSI - Finding of No Significant Impact

FSEIS - Final Supplemental Environmental Impact Statement

GIS - Geographical Information System

GLO - General Land Office

GWV - Gross Weight Vehicle

ha - hectares

HUC - Hydrologic Unit Code

IDT - Inter-disciplinary Team

IMPLAN - Impact Analysis for Planning

km - kilometer

kV - kilovolt

Kw - Kilowatt

LCDC - Land Conservation and Development Commission

LNG - Liquefied Natural Gas

LRMP BO - Land Resource Management Plan Biological Opinion

LSR - Late Successional Reserve

LSOG - Late Successional-Old-Growth

LWD - Large Woody Debris

mi - miles

MAOP - Maximum Allowable Operating Pressure

MMCFD - Million Cubic Feet Per Day

MOP - Maximum Operating Pressure

NEPA - National Environmental Policy Act (1969)

NMFS - National Marine Fisheries Service

NRHP - National Register of Historic Places

NFP - Northwest Forest Plan

NTU - Nephelometric Turbidity Unit

O\&C - Oregon and California (land designation)

O\&M - Operation and Maintenance

ODF - Oregon Department of Forestry

ODFW - Oregon Department of Fish and Wildlife

ODOT - Oregon Department of Transportation

OHV - Off-highway Vehicles

OMP - Operation and Maintenance Plan

ONHP - Oregon Natural Heritage Program

OPUC - Oregon Public Utilities Commission

OCMP - Oregon Coastal Management Plan

OSHA - Office of Safety and Health Administration 


\section{PDC - Project Design Criteria \\ PE - Polyethylene \\ POC - Port-Orford-cedar \\ pH - Potential of Hydrogen}

PP\&L - Pacific Power and Light

psi - pounds per square inch

psig - pounds per square inch gauge

PUE - Public Utility Easement

RCYBP - Radiocarbon Years Before Present

RMP - Resource Management Plan

ROD - Record of Decision

ROW - Right-of-Way

SC - Species of Concern

SCADA - Supervisory Control and Data Acquisition

SDP - Site Discovery Probes

SHPO - State Historic Preservation Office

SMYS - Standard Maximum Yield Strength

SWOCC - Southwest Oregon - Coos County

T\&E - $\quad$ Threatened and Endangered

TMDL - Total Maximum Daily Load

T\#\#S, R\#\#W, Sec. \#\# - Township \#\# South, Range \#\# West, Section \#\#

USDI - United States Department of Interior

USFWS - United States Fish and Wildlife Service

USGS - United States Geological Service

VRM - Visual Resource Management

WA - Watershed Analysis

WAU - Watershed Analysis Unit 


\section{Table of Contents}

\section{Chapter $1 \quad$ Purpose and Need}

Purpose and Need 1

Summary of Scoping and significant issues of the FEIS 1

Conformance with BLM Resource Management Plan EIS 2

Authorizing Actions and Relationship to Statutes and Regulations 2

Interrelationship with Other Projects 2

Interdependencies 3

\section{Chapter 2 Alternatives Including the Proposed Action}

Description of Proposed Action $\quad 5$

Location of the Proposed Action 5

Description of the Proposed Action Corridor $\quad 7$

$\begin{array}{ll}\text { Pipeline Laterals } & 8\end{array}$

Lateral Routes $\quad 8$

Proposed Action - Utility Corridors and the CBW Road 11

No Action Alternative $\quad$ II

Hwy 42 Alternative (the South Route) 12

Alternatives Considered But Rejected $\quad 13$

\section{Chapter $3 \quad$ Affected Environment}

$\begin{array}{ll}\text { Introduction } & 15\end{array}$

General Setting of the Proposed Action 15

$\begin{array}{ll}\text { Environment } & 16\end{array}$

Air Quality 16

Geology 16

Natural Resources 16

Cultural Resources (Including Native American Religious Concerns) 16

Soils 16

$\begin{array}{ll}\text { Proposed Action Vegetation } & 17\end{array}$

$\begin{array}{ll}\text { Forest Types } & 17\end{array}$

$\begin{array}{ll}\text { Vegetation of the Hwy } 42 \text { Alternative Route } & 17\end{array}$

Farmlands, Prime and Unique $\quad 17$

$\begin{array}{ll}\text { Floodplain } & 17\end{array}$

Water Quality, Quantity and Domestic Use 18

Waters Along the Hwy 42 Alternative 19 
Wild and Scenic Rivers

Wilderness or Wilderness Study Areas

Wildlife

Federally Listed, Proposed or Candidate Species

BLM Special Status Species 21

Survey and Manage Species 23

General Wildlife Groups 24

Human Environment 25

Area of Critical Environmental Concern (ACEC) 25

Public Health and Safety 26

Environmental Justice 26

Socio-economics in Coos County 26

Socio-economics within the Proposed Action $\quad 26$

$\begin{array}{ll}\text { Waste - Solid or Hazardous } & 27\end{array}$

Land Uses 28

Transportation 29

Utility Corridors 32

Encumbrances

\section{Chapter 4 Environmental Consequences}

Introduction $\quad 35$

Proposed Action Effects Summation 36

$\begin{array}{ll}\text { Environment } & 37\end{array}$

Air Quality $\quad 38$

Natural Resources

Cultural Resources (Including Native American Religious Concerns) 39

Soils $\quad 39$

Vegetation $\quad 40$

Floodplains $\quad 42$

Wild and Scenic Rivers $\quad 43$

Wildlife $\quad 43$

Aquatic Ecosystem $\quad 48$

Human Environment

Areas of Critical Environmental Concern (ACEC) 62

$\begin{array}{ll}\text { Socio-economics } & 62\end{array}$

$\begin{array}{ll}\text { Environmental Justice } & 72\end{array}$

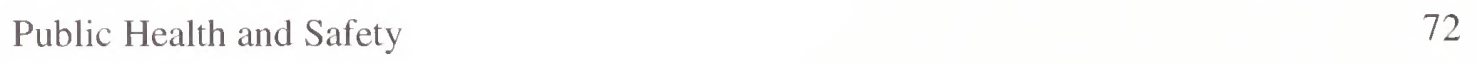

$\begin{array}{ll}\text { Waste - Solid or Hazardous } & 73\end{array}$ 
Transportation

Utility Corridors

\section{Chapter 5 Consultation and Coordination}

Consistency with other Agency Plans and Programs

List of Contributors

Organizations Consulted

Distribution List and Document Availability on the Internet

\section{List of Appendices}

Appendix A Geotechnical Engineering Report

Introduction

List of References

Appendix B Cultural Resources

Introduction

References Cited

\section{Appendix C Sheets 1-10}

Appendix D Agency Management Plans for Resources Adjacent to the Proposed Action

Visual Resource Management

D-2

Riparian Reserve and Aquatic Conservation Strategy Management

D-2

Watershed Management Plans

D-3

Appendix E Aquatic Biological Assessment

Introduction

Dichotomous Key for Section 7 Determination of Effects

\section{Appendix EI Essential Fish Habitat Assessment}

Appendix F U.S. Fish and Wildlife Service Endangered Species Consultation Letter of Concurrence

Appendix G Questions and Concerns from the Public

Questions

G-2

Comments 
Appendix G1 Letters Received During Draft Environmental Impact Statement Comment Period

Appendix G2 Responses to Letters Received During Draft Environmental Impact Statement Comment Period

Appendix H Erosion Control Plan

Best Management Practices (BMPs)

Active Stream Crossing Project Design Criteria (PDC)

Appendix I Watersheds and Streams

Appendix J Pipeline Design, Construction, Operation and Maintenance Plan

Construction Methods and Operations

Directional Drilling and Reaming Procedures

Operation Description

Maintenance Description

Appendix K Survey and Manage Species

Appendix K1 Special Status Species

Appendix L Glossary of Terms

Appendix M List of References

Appendix N Consistency Determination 


\section{List of Tables}

Table 1: Proposed Action Segment Description $\quad 7$

Table 2: Action Alternatives Route Summary $r$

Table 3: Route Summary for Proposed action 11

Table 4: Route Summary for Alternative 3 (along Hwy 42) 12

Table 5: Special Status Fish Species in Streams Near the Proposed Action 23

Table 6: Portions of the CBW Road Affected $\quad 30$

Table 7: Other Roads Affected by Pipeline $\quad 32$

Table 8: Definition of Key, Direct, Indirect and Cumulative Impacts 35

Table 9: Metal Emissions from Fuel Combustion 38

Table 10: Airborne Emissions from Fuel Combustion 38

Table 11: Acreage of soil area impacted by watershed in the proposed action 40

Table 12: Noxious Weeds in Utility Corridor 41

Table 13: Stream Description and Crossing Type on Utility Corridor within the Lower South Umpqua

Watershed (5th field HUC) 51

Table 14: Stream Description and Crossing Type on Road Corridor within the Ollala Creek/Lookingglass Creek Watershed (5th field HUC)

Table 15: Stream Description and Crossing Type on Utility Corridor within the Ollala Creek/Lookingglass Creek Watershed (5th fietd HUC)

Table 16: Stream Description and Crossing Type on Road Corridor within the East Fork Coquille Watershed (5th field HUC)

Table 17: Stream Description and Crossing Type on Utility Corridor within the East Fork Coquille Watershed (5th field HUC)

Table 18: Stream Description and Crossing Type on Road Corridor within the North Fork Coquille River Watershed (5th field HUC)

Table 19: Stream Description and Crossing Type on Utility Corridor within the North Fork Coquille River Watershed (5th field HUC)

Table 20: Stream Description and Crossing Type on Road Corridor within the Middle Main Coquille River Watershed (5th field HUC)

Table 21: Stream Description and Crossing Type on Road Corridor within the Lower Coos River/Coos Bay Watershed (5th field HUC)

Table 22: Stream Description and Crossing Type on Utility Corridor within the Lower Coos River/Coos Bay Watershed (5th field HUC)

Table 23: Pipeline Construction Spending for the $\$ 48$ Million Scenario

Table 24: Pipeline Construction Spending for the \$34 Miltion Scenario 
Table 25: Direct Impact of $\$ 48$ Million in Pipeline Construction on Coos County in Year 2000 Dollars and Person-Years of Employment

Table 26: Direct, Indirect, Induced and Total Economic Impacts on Coos County From $\$ 48$ Million in Pipeline Construction Spending in Year 2000 Dollars and Person-Years of Employment

Table 27: Direct Impact of \$34 Million in Pipeline Construction on Coos County in Year 2000 Dollars and Person-Years of Employment

Table 28: Direct, Indirect, Induced, and Total Economic Impacts on Coos County From \$34 Million in Pipeline Construction Spending

Table 29: Annual Spending on Pipeline Operations (in 2000 dollars)

Table 30: Annual Direct Impact of Pipeline Operations Spending on Coos County in Year 2000 Dollars and Person-Years of Employment

Table 31: Annual Direct, Indirect, Induced, and Total Economic Impacts on Coos County Because of Pipeline Operations Spending in Year 2000 Dollars and Person-Years of Employment

Table 32: Comparative Population Growth Rates 1980-2000

Table 33: Propane and Heating Oil Dealers

Table 34: Statistics Involving Natural Gas Pipelines in Oregon and Washington (1984-2000)

Table 35: Impacts Summary

Table 36: Technical Consultation

Table 37: Pipeline Meetings

Table A-1: Survey of Foundation Soil and Rock, Coos County Natural Gas Pipeline

Table E-1: Proposed Action Route Summary

E-3

Table E-2: Matrix of Factors and Indicators (All WAs \& NMFS, 1998)

Table E-3: Checklist for Documenting Environmental Baseline and Effects of Proposed Actions on Relevant Indicators (E. Fork Coquille)

Table E-4: Checklist for Documenting Environmental Baseline and Effects of Proposed Actions on Relevant Indicators (Lower Coos)

Table E-5: Checklist for Documenting Environmental Baseline and Effects of Proposed Actions on Relevant Indicators (N. Fork Coquille)

Table E-6: Checklist for Documenting Environmental Baseline and Effects of Proposed Actions on

Relevant Indicators (Lower South Umpqua)

Table E-7: Checklist for Documenting Environmental Baseline and Effects of Proposed Actions on Relevant Indicators (Middle Main Coquille)

Table E-8: Checklist for Documenting Environmental Baseline and Effects of Proposed Actions on

Relevant Indicators (Ollala-Lookingglass)

Table H-1: Fish-bearing Streams Identified for Avoiding Ground Disturbance within them

Table H-2: Specified ODOT Seed Mixture for Coast Range

Table I-1: Stream and Wetland Crossings within the Proposed Project Corridor

Table K-1: Survey and Manage Fungi, Lichens, Bryophytes and Vascular Plants

Table K1-1: Special Status Fungi, Lichens, Bryophytes and Vascular Plants

Table K1-2: Special Status Fish

Table K1-3: Special Status Invertebrates 


\section{List of Figures}

Figure A-1: West-east geologic cross-section along Oregon Hwy

Figure A-2: View of BPA powerline on steep hillside

Figure A-3: Rise of BPA powerline, up steep 20 percent slope

Figure A-4: View along Brewster Canyon at Mile 21 on CBW Road

Figure A-5: View along Brewster Canyon at Mile 26 on CBW Road

Figure B-1: Location of the Proposed Natural Gas Pipeline

Figure B-2: Survey status and location of recommended SDP, Coos Bay to Catching Creek

Figure B-3: Survey status and location of recommended SDP, Isthmus Slough to Sitkum

Figure B-4: Survey status, location of identified cultural materials, and location of recommended SDP, Sitkum to Flournoy Valley

Figure B-6: Site Map

Figure H-1: Stream Crossing: Trenching across a flowing stream

Figure J-1: Directional-Drill Crossing: Pilot Hole

Figure J-2: Reaming Process

Figure J-3: Pull Back

Figure J-4: Typical Block Valve Setting 


\section{List of Maps}

Map 1 - Alternative Routes

Map 2 - Preferred Alternative and Laterals

Sheets 1-10 - BLM managed lands adjacent to the proposed action. 


\section{Chapter 1 Purpose of and Need for Action}

The following changes were made in Chapter 1 between the Draft and Final Environmental Impact Statement. Minor corrections, explanations and edits are not included in this list.

- The former Purpose and Need section has been replaced with a more detailed description.

\section{Background}

On May 17, 2000, Coos County, Oregon (hereafter referenced as "the County"), acting by and through its Board of Commissioners, filed application OR55754 with the U.S. Bureau of Land Management (BLM) for a perpetual or renewable (with the longest allowable initial term) ROW to construct, operate and maintain a 12-inch diameter natural gas transportation pipeline across BLM-managed lands. Portions of the proposed action will be located within 3 miles of BLM ROW designated for roads or utility corridors.

Application is made to establish the pipeline in accordance with: 1) The Mineral Leasing Act of 1920, Section 28, as amended (30 USC 185); and 2) regulations at 43 Code of Federal Regulation (CFR) 2800.

In August, 2000, the County filed application (Form BPA F 4300.03e) with Bonneville Power Administration (BPA) for consent to build sections of its natural gas pipeline within BPA utility corridors.

On November 10,2000, the County filed application to the COE, a cooperating federal agency, for authorization to construct the proposed pipeline across streams and wetlands along the proposed action. The COE has assigned application No. 2000-00544 to the project.

\section{Purpose and Need}

The purpose of the proposed action is to construct a 12 inch natural gas transmission pipeline from near Roseburg to Coos County. Natural gas transported by the pipeline would provide an alternative source of energy for existing or potential residential, commercial or industrial customers within the Coos County service area. This EIS provides the analysis necessary for BLM to make a decision on granting a discretionary right-of-way permit for the construction, operation, and maintenance of the pipeline on approximately three miles of BLM-administered land.

The total length of the pipeline is about 60 miles. Approximately 28 miles of smaller pipeline laterals would eventually be constructed to serve the Coos County cities of Coquille, Myrtle Point and possibly Bandon. Gas distribution systems would be built in each city, most likely by Northwest Natural Gas (hereafter referred to as NW Natural). The laterals and distribution lines would be located entirely on private properties.

Coos County has never had direct access to natural gas as an energy source, but has relied on petroleum products and propane, electricity, or wood for energy sources. Utility gas is available in every state, including Alaska and Hawaii. More than half of all homes in the United States are heated with natural gas. Natural gas accounts for about onequarter of all energy needs in the country. Natural gas is more efficient and less expensive than electricity, heating oil or propane, and much cleaner than wood fuel. Natural gas service is nearly as common to US towns and cities as are electricity, community water and sewer, and telephone services.

Of the 17 Western states, natural gas is available in approximately 950 of 1,060 counties, with about 99 percent of the population of the West. With a population of about 63,000 (Census 2000), Coos County is the largest county in the Western United States that does not have natural gas.

In 1999, Coos County leaders recognized the necessity for natural gas as critical to the community's economic survival. Government and civic leaders, local industries and support businesses all supported a public awareness campaign, which resulted in a grant from the State of Oregon to publicly fund a gas pipeline. Ballot Measure \#6-63, authorizing additional taxpayer funds for construction of a natural gas pipeline, was passed by a double majority of Coos County voters in November 1999. 


\section{Summary of scoping and significant issues of the EIS}

Scoping is required for preparation of an EIS. Its use with the proposed action was a help in determining some potential effects to assess. The formal scoping notice for preparation of the EIS was published in the Federal Register on March 29, 2001. A public scoping meeting was held in Coos Bay on April 4, and at the McKinley Grange on April 18, 2001. The formal scoping period closed on April 30, 2001. A total of 40 letters were received during the scoping period.

The proposed action is a result of numerous feasibility studies conducted over the course of approximately 35 years. Participants in the EIS analysis used these studies, along with additional recent studies, for the basis of information included in this EIS.

The following issues arose from the Inter-disciplinary Team (IDT) scoping process:

- Regulations affecting the proposed action;

- Impacts (effects) - (1) Impacts on aquatic and riparian habitats and water quality; (2) Impacts on air pollution and soil productivity; (3) Impacts on plants and terrestrial species and habitats, which includes PortOrford-cedar, Noxious Weeds, Special Status Species, Survey \& Manage Species, T\&E Species, as well as related Critical Habitat Units (CHUs); (4) Cultural resource-site protection (including Native American Religious Concerns); and (5) Economic impacts;

- Under private or public (Federal, State or local) jurisdiction or ownership;

- Direct, Indirect and Cumulative effects: short and long term effects of the proposed action and its ancillary facilities;

- Agency concerns (Federal, State or local agency analysis of impacts);

- Public concerns: All public comments, questions and concerns are listed in Appendices G-G2.

This FEIS addresses the proposed action's real or potential impacts to environmental resource components. Impacts are presented for affected land ownership. The impact analysis defines the interaction of the component(s) of the proposed action with its surrounding environment, including affected environments extending beyond the project construction boundary (the ROW easement).

\section{Conformance with BLM Resource Management Plan EIS}

Both the Coos Bay and Roseburg BLM District Resource Management Plans (herein referred to as 'RMP'), specifically encourage use of existing ROW, such as the BPA corridor utilized in the proposed action. Both RMPs suggest that the location of new ROW are placed in these existing utility corridors. Placement of a pipeline in the CBW Road, the BPA utility corridor and the Pacific Power \& Light (owned by Pacificorp, herein referred to as PP\&L) utility corridor would be consistent with the RMP guidelines and recommendations.

\section{Authorizing Actions and Relationship to Statutes and Regulations}

The proposed action would comply with the following:

- Federal Land Policy and Management Act ("FLPMA") of 1976 (90 Stat. 2743, 43 U.S.C. 1701, et seq.);

- Revested Oregon and California (O\&C) Railroad and Reconveyed Coos Bay Wagon Road Grant Lands Act of 1937 (50 Stat. 874, U.S.C. 1181 a., et seq.);

- National Environmental Policy Act of 1969;

- Federal Pipeline Safety Regulations 49 CFR, parts 190-199;

- United States Environmental Protection Agency (EPA) Air and Water Quality guidelines;

- Oregon Department of Transportation (ODOT) regulations (relating to Oregon Highways);

- American Indian Religious Freedom Act (42 USC 1996). Guidelines for protecting sites;

- Northwest Forest Plan (NFP) 1994;

- Endangered Species Act (ESA) of 1973;

- Magnuson-Stevens Conservation and Management Act as amended by the Sustainable Fisheries Act of 1996; 
- Section 10, Rivers and Harbors Act 1899 (33 U.S.C. 402);

- Section 404, Clean Water Act (33 U.S.C. 1344).

\section{Interrelationship with Other Projects}

\section{Anticipated Future Gas Pipeline Projects}

Anticipated Interrelationships with future projects would likely (not automatically) take place after approval of the proposed action.

Additional (smaller) pipelines would likely be installed to the communities of North Bend, Coquille, Myrtle Point, Empire, Charleston and possibly Bandon if this community grants a franchise to NW Natural. NW Natural also plans to extend the pipeline to the North Spit of Coos Bay within three to four years of completion of the proposed action. These future projects would be planned based on market needs within the area they would serve, which would include determination of pipeline size. Funding for these projects, except in the case of Bandon, will be provided by NW Natural. Bandon would have the option to build their own distribution system, including a pipeline extending from the proposed action or its lateral pipelines, if they decide to have natural gas supplied to their community.

Although the final locations of the laterals are not known, it is anticipated that 28 miles of pipeline laterals would likely be constructed to Coquille, Myrtle Point and Bandon. Impacts associated with construction of the laterals are anticipated to be similar to, but of lower magnitude than, the main pipeline because the laterals would cross fewer streams and would not be adjacent to late-successional habitats. No Federal land would be impacted.

\section{New Industrial Gas Users}

This natural gas pipeline project was proposed by Coos County and funded by county and state taxpayers for economic development. The proposed action would result in the availability of natural gas to most commercial and industrial areas of Coos County. It is hoped that the availability of natural gas will attract new manufacturing and commercial facilities to Coos County. It is also likely that existing industrial users of oil, wood and other fuels would convert to natural gas.

Natural gas is often an important factor in site selection, but other critical factors include transportation facilities (access to Interstate highways, rail, ports and airports), location relative to raw materials and markets, available work force, local wages, educational resources, quality of life and other factors. Natural gas availability alone, however, would not cause new manufacturing facilities to be built. Because no industrial commitments have yet occurred, it is not possible to quantify the potential environmental impacts of unknown future facilities and their potential locations. Future new facilities utilizing natural gas will be required to undergo their own environmental impacts analyses, within the required permitting processes for new construction.

\section{Interdependencies}

Interdependencies are projects that would likely occur upon approval of the proposed action. That is, approval of the proposed action would likely "trigger" the interdependent action.

\section{Natural Gas Distribution System}

The proposed action 12-inch mainline would end at Ocean Boulevard by the old water plant in Coos Bay. The city gate station would include a meter, a piping manifold to send gas in different directions, and possibly pressure regulators to reduce pressure. NW Natural will build a gas distribution system. The design of the system will not be finalized until more marketing studies are finished to identify size and type of gas loads.

Location and construction of the distribution lines to natural gas end customers would be funded by NW Natural. Distribution lines are not expected to cross any federally managed lands. Impacts associated with the lateral lines and distribution system would be subject to regulation by the Oregon Public Utility Commission ("OPUC"). 


\section{Chapter 2 Alternatives Including the Proposed Action}

The following changes were made in Chapter 2 between the Draft and Final Environmental Impact Statement. Minor corrections, explanations and edits are not included in this list.

- Additional information has been added to the description of the Proposed Action which specifies locations of delivery stations in Douglas County.

\section{Description of Proposed Action}

Natural gas is available near Roseburg from Williams Gas Pipeline - West, formerly Northwest Pipeline Company. The Williams pipeline system transports gas from producing wells in the Rocky Mountain region of the U.S. and Canada. The natural gas produced from the wells is stripped of corrosive elements, excess water and heavier hydrocarbons before entering the pipeline system. The natural gas is delivered via pipelines from these wells to Portland and the Willamette Valley. The Williams Grants Pass lateral extends south of Eugene, generally along Interstate-5, to Grants Pass.

In the Roseburg area, Williams has a single 10-inch steel pipeline operating at 500 to 800 pounds per square-inch (psi). The proposed action would be a 12 -inch steel pipeline connecting to the existing 10-inch pipeline a few miles south of Roseburg.

The pipeline would be buried for its entire length. Its only above-ground components would be line markers, test stations, several bridge crossings and valve settings. It would be built and hydrostatically tested to 1,500 psi which allows a Maximum Allowable Operating Pressure (MAOP) of 1,000 psi. It would operate at the same pressure as the Williams pipeline, which is normally 500 to 800 psi.

As noted in Chapter 1, approximately 3 miles of the preferred pipeline route would cross BLM-managed lands within the BPA power line ROW. The remainder of the pipeline would be located within the ROW of the CBW Road and other public roads, or within PP\&L and BPA ROW crossing privately owned properties.

The pipeline would terminate at Ocean Boulevard in Coos Bay where a NW Natural distribution system would be built. NW Natural has been granted the "exclusive territory" rights for gas distribution in Coos County, excluding the city of Bandon.

In Douglas County, natural gas would be made available to a delivery station in the town of Lookingglass where exclusive rights are held by Avista Utilities Corporation (hereafter referred to Avista). The delivery station would be relatively small, not requiring a city gate station, and would be loeated near the Lookingglass school.

The straight-line distance from the Williams connection location (just south of Roseburg) to Ocean Boulevard is about 44 miles, whereas, the proposed action traverses approximately 60 miles. The proposed action within existing road and utility corridors is the shortest practical route from source to destination.

The permanent easement on BLM-managed lands would total approximately 14 acres. Additional temporary utility corridor construction ROW width (as necessary) is also requested. The additional utility corridor construction area of approximately 7 acres would also be completely inside the BPA utility corridor and returned to BLM control after completion of construction and site restoration.

Several delivery stations would deliver gas to end users at various locations in Coos County and Douglas County. None of these delivery stations would be located on BLM-managed lands. For safety reasons, the proposed action includes 5 block valves (see Appendix J), placed at intervals along the pipeline corridor. Placement of the valves is based upon pipeline safety regulations and operational factors, such as local distribution and lateral pipeline placement. None of these block valves would be installed on BLM-managed lands.

\section{Location of the Proposed Action}

The corridor for the proposed action would traverse the Coast Range in southern Oregon from the western region of Douglas County Township 27 South, Range 6 West, Section 33 (T27S, R6W, Sec. 33) to the western region of Coos 
County (T25S, R13W, Sec. 27). The terrain varies from gentle to very steep as the corridor follows 230 kilovolt (kV) transmission lines operated by BPA and PP\&L, the CBW Road, and BPA and PP\&L $115 \mathrm{kV}$ transmission lines and roads into Coos Bay. (Refer to Map 1).

The proposed action would connect to the Williams Gas Pipeline near Happy Valley, approximately 4 miles southwest of I-5 freeway exit 124 (Harvard Avenue) in Roseburg. The pipeline route continues - as described below until it connects to its delivery facility at Ocean Boulevard.

The following is a sequential list (east to west) of section locations which contain a portion of the proposed action:

Douglas County

T27S, R6W, Sections 33, 32 and 31;

T27S, R7W, Sections 36, 35, 34, 33, 32 and 31;

T271/2S, R7W, Section 6;

T28S, R7W, Section 6;

T28S, R7 1/2W, Section 6;

T28S, R8W, Sections 1, 2, 11, 14, 15, 16, 17, 18 and 7.

Coos County

T28S, R9W, Sections 12, 13, 14, 11, 10, 9, 8 and 7;

T28S, R10W, Sections 12, 11, 10, 9, 8, 5 and 6;

T28S, R11W, Sections 12, 11, 10, 3 and 4;

T27S, R11W, Sections 33, 32, 29, 30 and 19;

T27S, R12W, Sections 24, 23, 14, 15, 16, 9, 10 and 4;

T26S, R12W, Section 33, 32, 29, 30 and 19;

T26S, R13W, Sections 25, 24, 23, 14, 15, 10 and 3;

T25S, R13W, Sections 34 and 27. 


\section{Description of the Proposed Action Corridor}

The proposed action corridor is delineated into Segments A through K (Table 1). These segments aid discussion of the proposed action by breaking it into manageable portions.

Table 1: $\quad$ Proposed Action Segment Description

\begin{tabular}{|c|c|c|c|}
\hline Segment & Begins & Ends & Distance in Miles \\
\hline $\mathrm{A}$ & $\begin{array}{l}\text { Williams Delivery Station, } \\
\text { approximately } 4 \text { miles south- } \\
\text { west of Roseburg, OR. } \\
\text { (T27S, R6W, Sec.33) }\end{array}$ & $\begin{array}{l}\text { BPA Reston Substation } \\
\text { (T27S, R7W, Sec.31) }\end{array}$ & 8.1 \\
\hline $\mathrm{B}$ & $\begin{array}{l}\text { BPA Reston Substation } \\
\text { (T27S, R7W, Sec.31) }\end{array}$ & $\begin{array}{l}\text { Tenmile Block Valve } \\
\text { CBW Road Mile Point } 1.7 \\
\text { (T28S, R8W, Sec. 16) }\end{array}$ & 5.7 \\
\hline $\mathrm{C}$ & $\begin{array}{l}\text { Tenmile Block Valve } \\
\text { (T28S, R8W, Sec.16) }\end{array}$ & $\begin{array}{l}\text { Douglas-Coos County Line } \\
\text { Douglas County Mile Point } 6.0 \\
\text { (T28S, R9W, Sec.12) }\end{array}$ & 2.8 \\
\hline $\mathrm{D}$ & $\begin{array}{l}\text { County Line } \\
\text { Coos County Mile Point } 36.3 \\
\text { (T28S, R9W, Sec. } 12 \text { ) }\end{array}$ & $\begin{array}{l}\text { Lone Pine Lane } \\
\text { CBW Road Mile Point } 17.5 \\
\text { (T28S, R11W, Sec.10) }\end{array}$ & 18.3 \\
\hline $\mathrm{E}$ & $\begin{array}{l}\text { Lone Pine Lane } \\
\text { (T28S, R11W, Sec.10) }\end{array}$ & $\begin{array}{l}\text { Cherry Creek } \\
\text { CBW Road Mile Point } 17.9 \\
\text { (T28S, R11W, Sec.4) }\end{array}$ & 1.6 \\
\hline $\mathrm{F}$ & $\begin{array}{l}\text { Cherry Creek } \\
\text { (T28S, R11W, Sec.4) }\end{array}$ & $\begin{array}{l}\text { McKinley, OR } \\
\text { CBW Road Mile Point } 17.1 \\
\text { (T27S, R11W, Sec.32) }\end{array}$ & 0.9 \\
\hline $\mathrm{G}$ & $\begin{array}{l}\text { McKinley, OR } \\
\text { (T27S, R11W, Sec.32) }\end{array}$ & $\begin{array}{l}\text { Fairview, OR } \\
\text { CBW Road Mile Point } 12.5 \\
\text { (T27S, R12W, Sec.24) }\end{array}$ & 3.6 \\
\hline $\mathrm{H}$ & $\begin{array}{l}\text { Fairview, OR } \\
\text { (T27S, R12W, Sec.24) }\end{array}$ & $\begin{array}{l}\text { Sumner Lane at PP\&L } \\
\text { CBW Road Mile Point } 2.7 \\
\text { (T26S, R12W, Sec.30) }\end{array}$ & 9.9 \\
\hline 1 & $\begin{array}{l}\text { Sumner Lane } \\
\text { (T26S, R12W, Sec.30) }\end{array}$ & $\begin{array}{l}\text { U.S. } 101 \\
\text { CBW Road Mile Point } 0.0 \\
\text { (T26S, R13W, Sec.23) }\end{array}$ & 2.4 \\
\hline $\mathbf{J}$ & $\begin{array}{l}\text { U.S. } 101 \\
\text { (T26S, R13W, Sec.23) }\end{array}$ & $\begin{array}{l}\text { Red Dike Road CR } 183 \\
\text { (T26S, R13W, Sec.10) }\end{array}$ & 2.7 \\
\hline $\mathrm{K}$ & $\begin{array}{l}\text { Red Dike Road } \\
\text { (T26S, R13W, Sec.10) }\end{array}$ & $\begin{array}{l}\text { Coos Bay, OR } \\
\text { Off Ocean Blvd. } \\
\text { (T25S, } 13 \mathrm{~W}, \text { Sec. } 27)\end{array}$ & 3.1 \\
\hline
\end{tabular}




\section{Pipeline Laterals}

The Coos County 12-inch mainline would extend to the edge of the city of Coos Bay. The Coos County project would also include smaller pipeline laterals to serve Coquille, Myrtle Point and possibly Bandon.

These lateral pipelines would be smaller in diameter than the 12-inch mainline. The projected demand in the smaller towns could be served with 6-inch and 4-inch pipelines. The laterals would be built with welded and coated steel pipe, to the same 1,000 pounds per square inch (psi) MAOP and Department of Transportation (DOT) standards as the mainline. The laterals would be operated at the same pressure as the mainline. The same Project Design Criteria (PDCs) and Best Management Practices (BMPs) described for the mainline will be implemented for these laterals.

The routes of these lateral pipelines are not yet finalized. The pipelines would generally follow existing road, power and other ROW. There is no route being considered that would impact BLM or other Federal lands (refer to Map 2 of the Draft EIS).

\section{Lateral Routes}

The lateral pipeline route would likely follow a BPA utility ROW to Bandon, and a former railroad ROW to Coquille and Myrtle Point.

\section{Fairview to Hwy 42}

Present plans would have the lateral begin at the Fairview block valve (Segment G). The lateral pipeline would likely leave the site of the block valve along a former railroad grade and follow Fairview Road (County Road [CR] 9 from Coquille) for approximately 1.6 miles.

At about 1.6 miles from the Fairview block valve, the lateral route would likely follow the BPA Fairview-Rogue 230 $\mathrm{kV}$ powerline utility corridor. This route heads southwest over the ridge at Rink Peak at 1,070 feet above sea level. The BPA corridor descends into the Coquille River valley, crossing Hwy 42 at Mile Marker (MM) 14.4. The pipeline lateral would be bored-under Hwy 42 and would follow a former Southern Pacific Railroad ROW adjacent to the highway corridor. Near the BPA crossing of the railroad grade, a block valve would be at the end of this 7.5-mile lateral segment. This segment would cross Lee Valley Road (CR 2B) and Hwy 42, Steele Creek, Blair Creek, Lost Creek and Aiken Creek in the Coquille watershed. This segment would be built of 6-inch or 8-inch diameter pipe.

\section{Coquille Lateral}

This lateral would likely start at the Hwy 42 block valve and travel north, following a former railroad ROW. The railroad from Coos Bay to Coquille still has limited traffic, but is currently under abandonment discussion. The lateral route would be in or beside the railroad grade, subject to agreement with the railroad. If such an agreement is not made, the pipeline would be installed on highway ROW or on private land between the two corridors. The Coquille Lateral would then follow rail or road corridors to the south edge of Coquille. This segment would be built of 4 -inch diameter pipe and approximately 2 miles long.

\section{Myrtle Point Lateral}

This lateral would likely start at the Hwy 42 block valve and travel south along a former railroad ROW. The anticipated route would be in the railroad ROW, Hwy 42 or on private land. The Myrtle Point Lateral would end at the north edge of Myrtle Point near Hwy 42. This segment would cross 4 county roads. The North Fork of the Coquille River would be directionally-drilled. This segment would be built of 4-inch diameter pipe and approximately 6 miles long.

\section{Bandon Lateral}

This lateral would likely start at the Hwy 42 block valve and travel west, following the BPA ROW to the east edge of Bandon. The pipeline would be directionally-drilled under the Coquille River near river mile 27. This route would follow BPA Rogue $230 \mathrm{kV}$ line to Fat Elk Road. Near Rollan Creek, the BPA Rogue corridor converges with the BPA Number 1 Fairview-Bandon $115 \mathrm{kV}$ line. The lateral would then follow a county road for a short distance. At Lampa Creek, the pipeline would follow county and/or forest roads for easier negotiation of creek crossings and elevation changes.

This segment would cross 8 county roads. The Coquille River would be directionally-drilled. The anticipated route would cross approximately 12 named streams, and numerous unnamed perennial and intermittent streams. The segment would be built of 4 -inch diameter pipe and approximately 12 miles long. 

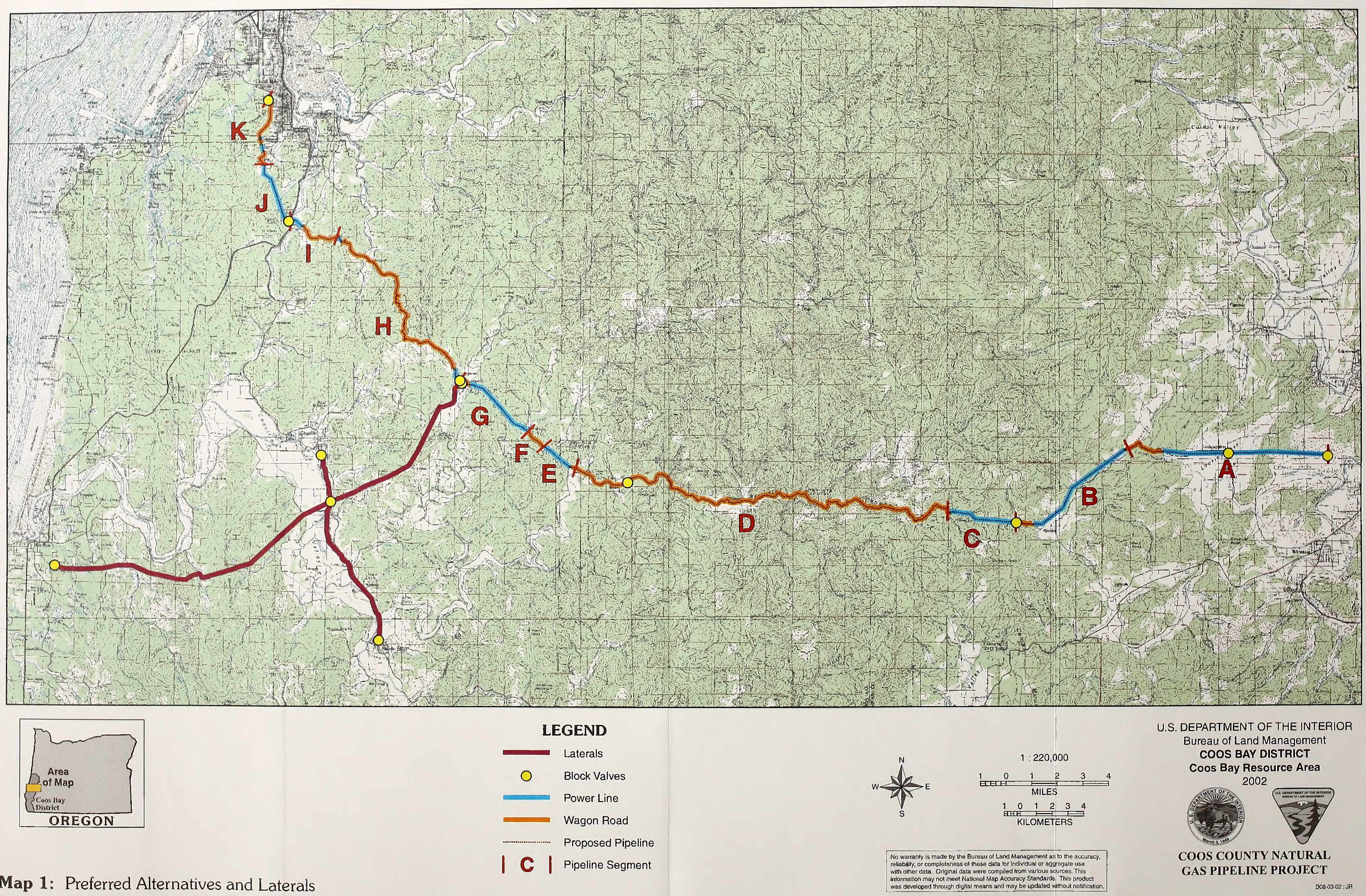

S. DEPARTMENT OF THE INTERIOR Bureau of Land Managemen COOS BAY DISTRICT Coos Bay Resource Area 



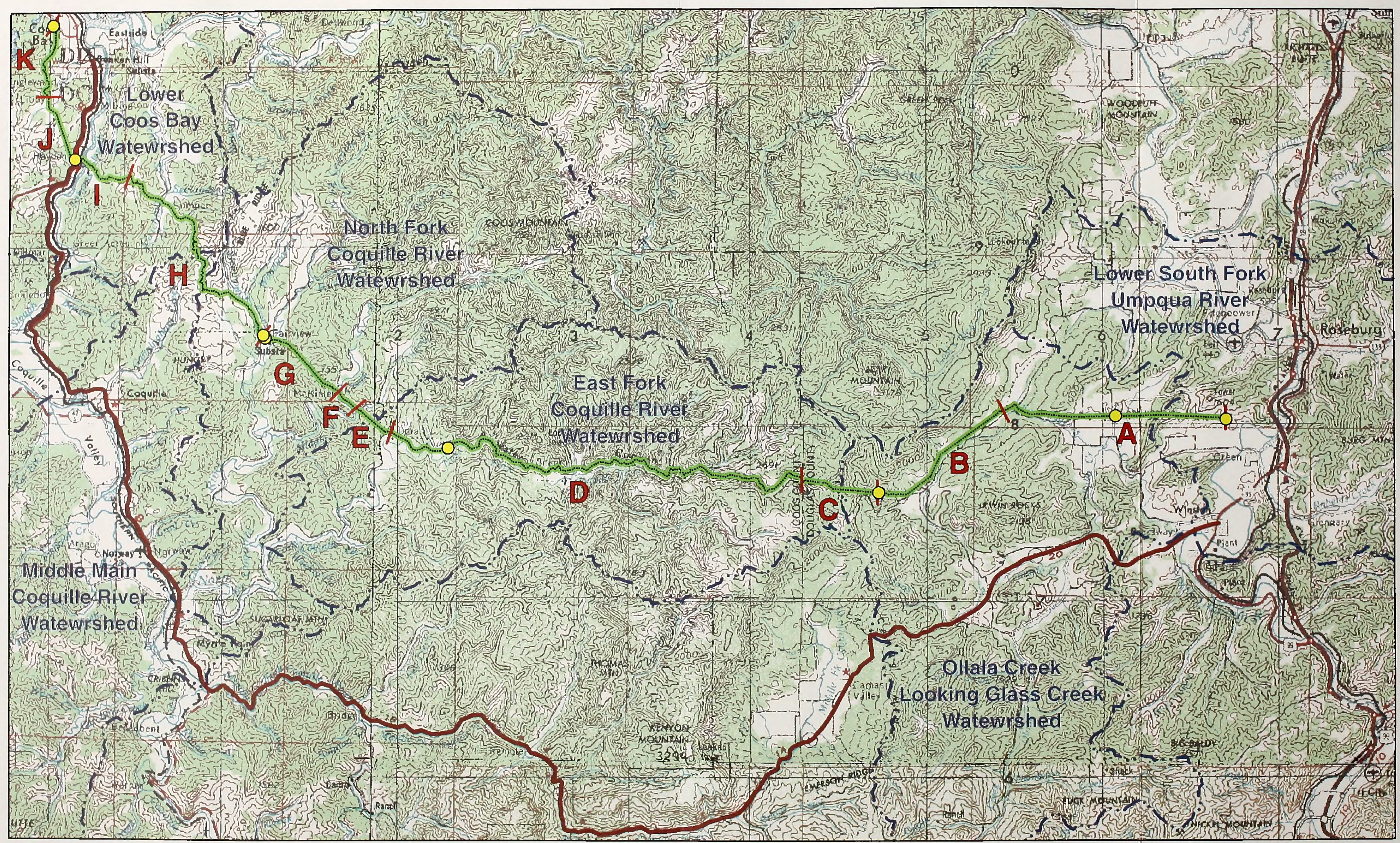

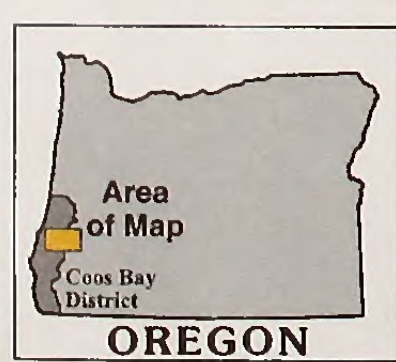

Map 2: Alternate Routes

\section{LEGEND}

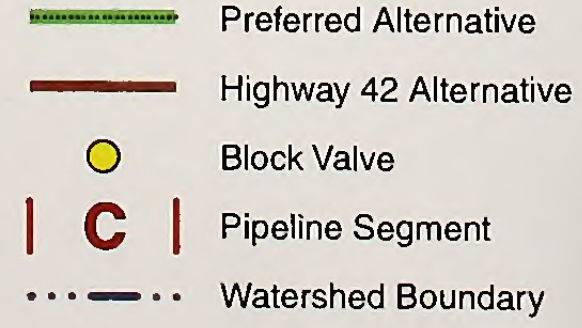

...... Watershed Boundary $\hbar_{s}^{n}$

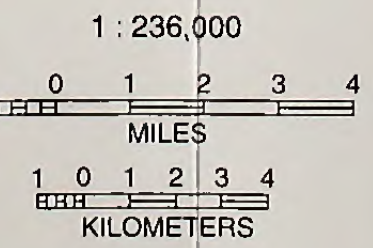

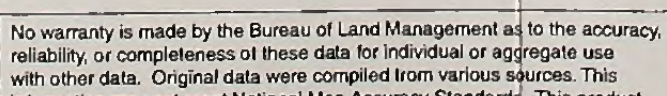

U.S. DEPARTMENT OF THE INTERIOR Bureau of Land Management COOS BAY DISTRICT
Coos Bay Resource Area

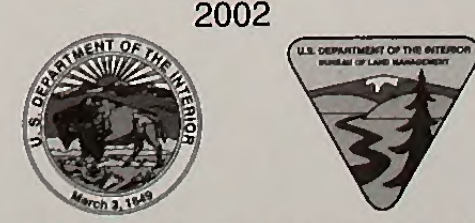

COOS COUNTY NATURAL GAS PIPELINE PROJECT 



\section{Schedule, Sizing and Route Selection Factors}

The Coos County 12-inch mainline is scheduled for completion into Coos Bay by the end of 2002. The smaller pipeline laterals are anticipated to be finished by the end of 2003. There are several factors, including the size of lateral pipelines and selection of the lateral routes, which are not yet confirmed.

Gas distribution to Bandon is an unknown factor. NW Natural has been authorized by the OPUC to serve all parts of Coos County with natural gas, except within the city limits of Bandon. Bandon has not yet decided whether to build its own gas distribution system, allow NW Natural a franchise, or prohibit natural gas and protect its existing electric power. Bandon may also wish to install or contract for a natural gas-fired generator to provide electricity. These unknown factors could result in: 1) a 4-inch lateral constructed as envisioned now; 2) a larger lateral for greater power generation; 3) no lateral if gas distribution is not permitted; or 4) a re-route of the pipeline to accommodate a generator adjacent to the Bandon area.

The Beaver Hill area presents another unknown factor. Coos County operates a solid waste disposal plant near Beaver Hill in Section 24-T27S-R14W near U.S. 101 between Coos Bay and Bandon. This site is close to a PP\&L utility corridor, has suitable zoning and could be a potential power generation site. Pipeline access to Beaver Hill would be feasible from Fairview via Coquille or along U.S. 101 from Coos City.

No proposals have been made to Coos County. None of the likely routes to Coquille, Myrtle Point, Bandon or Beaver Hill involve BLM-managed lands. At this point in the planning process for these laterals, it is premature to formulate a detailed assessment on any of the possible lateral routes. Without BLM involvement, the COE would become the lead Federal agency for any lateral projects, and all environmental regulations would be adhered to.

\section{NW Natural Gas Facilities (Coos County)}

NW Natural plans to install three types of gas mains:

Welded steel main lines capable of intermediate to mainline pressure (up to 1,000 psi);

Polyethylene (PE) main lines at 60 psi or less (4-inch to 8-inch diameter);

PE pipes down side streets at 60 psi or less (2-inch diameter).

NW Natural plans to extend service to industrial users on the North Spit. This service would likely be an 8-inch to 12-inch diameter welded steel pipeline. Tentative plans for this line would follow Ocean Boulevard and Newmark Avenue to Empire, serving as the primary source for the Coos Bay to North Bend distribution system.

The North Spit extension would be built within 4 years of completion of the proposed action. The extension would be directionally-drilled under Coos Bay, and placed within the Trans Pacific Parkway ROW to Weyerhaeuser. Directionally-drilling under Coos Bay would require a permit from the COE. This extension will be subject to NEPA when plans are finalized. The bay crossing has been discussed as a joint venture with the local water board to upgrade water service on the North Spit.

While the main lines can be used to directly serve larger users, most customers would be serviced by a 2-inch PE main line connecting in their street or alley where a plastic tapping tee is fused onto the main line and a 1 -inch diameter PE service pipe is run through the yard to a meter at a house or building. Each customer would have a separate service line and meter.

Utility distribution mains are installed in public streets, utility easements and other existing ROW. Mains must be installed with 18 to 36 inches of cover in public corridors depending on pressure rating and location. Construction of mains would be entirely in existing streets, alleys and public utility easements (PUE). Crossings of streams and wetlands usually occur in the roadway or on bridges with no impact to the off-road areas. NW Natural is certified by the OPUC to install gas distribution systems and serve all parts of Coos County with natural gas, except within the city limits of Bandon.

\section{Avista Natural Gas Facilities (Douglas County)}

Avista currently supplies natural gas to many communities in Douglas County, including the city of Roseburg. Installation of a small delivery station in the town of Lookingglass would allow Avista to extend services to consumers in the Lookingglass area. This service would likely be a 2-inch diameter welded steel pipeline. 
Pipeline Construction Alternatives Summary

Table 2: $\quad$ Action Alternatives Route Summary

\begin{tabular}{|l|c|c|}
\hline \multicolumn{1}{|c|}{ Description } & Proposed & Alt. 42 \\
\hline Total length (miles) & 59.1 & 82.7 \\
\hline $\begin{array}{l}\text { Total Number of Streams Crossed } \\
\text { Total Number of Large Streams Crossed (streams 30+ feet summer wet- } \\
\text { ted width) }\end{array}$ & 188 & 209 \\
\hline $\begin{array}{l}\text { Total Number of Medium Streams Crossed (streams 15 to 30 feet summer } \\
\text { wetted width) }\end{array}$ & 6 & 18 \\
\hline $\begin{array}{l}\text { Total Number of Small Streams Crossed (streams less than 15 feet sum- } \\
\text { mer wetted width) }\end{array}$ & 180 & 179 \\
\hline $\begin{array}{l}\text { Total Number of Wetlands } \\
\text { Adjacent Floodplain (miles) }\end{array}$ & 2 & 9 \\
\hline
\end{tabular}

Pipeline placement, except for certain bridges, would be entirely underground within existing roads and utility (powerline) corridors. Along the utility ROW, the pipeline would be placed near the edge away from adjacent trees. The CBW Road would receive full-width repaving where the pipeline is installed under the present asphalt road surface. In addition, the gravel-surfaced road sections will be paved after construction of the pipeline. This includes 10.6 miles of Sitkum Lane east of Sitkum to the county line and 4.5 miles of Sumner Lane north of Fairview.

The proposed action is adjacent to some areas designated by the USFWS as Critical Habitat Units (CHUs). The proposed action also includes some difficult construction areas, including narrow canyon road beds and steep slopes along the utility corridors. The proposed action contains 188 stream crossings and 1 wetland crossing. Of the streams crossed, 180 are small streams (less than 0.2 cubic feet per second [cfs] of summer waterflow). The total length of 100-year floodplains adjacent to the proposed action is 2.2 miles. The CBW Road and utility corridors ROW would return to their current condition within 1 or 2 years.

Construction equipment would include bulldozers, backhoes, side-booms and other standard equipment typically used for pipeline construction. For the CBW Road segments, construction equipment would also include the typical road paving equipment necessary for full-width asphalt paving.

Operation and maintenance of the pipeline would be in accordance with all Federal, State and local regulations. (See Appendix J for Construction, Operation and Maintenance). Delivery of natural gas to the franchise holder (NW Natural) would generate revenue for the County, which would be applied toward the County's expenses to operate the pipeline. NW Natural anticipates to initially deliver 2 billion cubic feet of natural gas per year to customers in Coos County. The maximum potential throughput of the Coos Pipeline would be 25 billion cubic feet per year. 


\section{Proposed Action - Utility Corridors and the CBW Road}

This alternative builds a pipeline along or near the CBW Road, as described in Table 3 below.

Table 3: $\quad$ Route Summary for Proposed Action

\begin{tabular}{|c|l|c|c|}
\hline Segment & \multicolumn{1}{|c|}{ Description } & ROW Type & Distance \\
\hline A & Williams to Reston Substation & PP\&L & 8.1 miles \\
\hline B & Reston to Tenmile & BPA & 5.7 miles \\
\hline C & Tenmile to County Line & BPA & 2.8 miles \\
\hline D & County Line to Lone Pine Lane & CBW Road & 18.3 miles \\
\hline E & Lone Pine Lane to Cherry Creek & BPA & 1.6 miles \\
\hline F & Cherry Creek to McKinley & CBW Road & 0.9 mile \\
\hline G & McKinley to Fairview & BPA & 3.6 miles \\
\hline H & Fairview to Sumner Lane & CBW Road & 2.4 miles \\
\hline I & Sumner Lane to U.S. Highway 101 & BPA & 2.7 miles \\
\hline J & U.S. Highway 101 to Libby & BPA & 3.1 miles \\
\hline K & Libby to Coos Bay & Total Length & 59.1 miles \\
\hline
\end{tabular}

\section{No Action Alternative}

For the purposes of this EIS, the "No Action Alternative" is defined as the result if the BLM would not grant Coos County a discretionary ROW permit for a natural gas pipeline on lands administered by BLM. Effects addressed in this FEIS associated with the No Action Alternative assume that the result would be the present condition: the proposed natural gas pipeline is not constructed.

However, "No Action" by BLM will not necessarily result in the prevention of a new pipeline. If the Proposed Action is denied or unduly delayed, Coos County may very likely proceed on constructing the pipeline entirely within public roads and private easements included in the Preferred Route, avoiding Federal land administered by BLM.

This re-routing is not assessed as a unique or separate alternative, because the environmental impacts are nearly identical to those of the preferred alternative.

Approximately $86 \%$ of the proposed route (Segments A-B-D-F-H-I-J-K) would be built as described. Segments CE-G of the proposed project would be built primarily in the CBW Road, rather than within nearby powerline corridors crossing Federal land as described in the Proposed Action. Detailed descriptions of these segments are given in Appendix I.

If BLM lands are not affected by the proposed action, the county would seek a permit from the COE, which would then be the lead Federal agency, to cross waterways within the corridor. The number and general location of streams and wetlands crossed would be virtually identical. Of the 188 streams and adjacent wetlands inventoried for the proposed action, there are only 4 small, intermittent drainage channels actually located on BLM land. The no action alternative would result in one of those channels being crossed on the CBW Road. Three of the BLM channels would be avoided entirely. 
The hydrologic change of avoiding BLM land is two additional culvert crossings and two short bores or bridge crossings of the upper East Fork. No other perennial stream would be affected by this change.

Impacts to terrestrial habitats resulting in the re-routing of the proposed action off BLM-managed lands to the CBW Road would not be significantly different.

However, this minor re-route would require approximately 4 miles of additional construction and approximately $\$ 2.3$ million additional county spenditure.

For the purposes of this document, "No Action" means no "federal discretionary action" to grant a ROW across BLM land, and is assessed as such.

\section{Hwy 42 (the South Route)}

The Hwy 42 alternative (Table 4) would supply Coos Bay, North Bend and possibly other small communities within Coos and Douglas Counties with natural gas.

Pipeline placement would be underground, under or beside the road beds. No trees would be removed, since the pipeline would be located within the highway ROW.

Table 4: $\quad$ Route Summary for Alternative 3 (along Hwy 42)

\begin{tabular}{|c|l|c|c|}
\hline Segment & \multicolumn{1}{|c|}{ Description } & ROW Type & Distance \\
\hline \hline L & Winston to Tenmile & ODOT & 12.9 miles \\
\hline M & Tenmile to Camas Valley & ODOT & 7.5 miles \\
\hline N & Camas Valley to County Line & ODOT & 10.5 miles \\
\hline O & County Line to Powers Rd. Jct. & ODOT & 24.0 miles \\
\hline P & Powers Rd. Jct. to Myrtle Point & ODOT & 2.0 miles \\
\hline Q & Myrtle Point to Hwy 10l Jct. & ODOT & 20.0 mile \\
\hline$R$ & Hwy 101 Jct. to Coos City & BPA & 5.6 miles \\
\hline$S$ & Coos City to Ocean Boulevard & Total Length & 82.7 miles \\
\hline \hline
\end{tabular}

Relatively few private landowners would experience impact from construction activity. Construction equipment would be bulldozers, backhoes, side-mount cranes, etc., typically used for pipeline construction. Smaller equipment would be required in some portions, where the allowable working space is tighter.

This pipeline route would enter sensitive wildlife areas and difficult construction zones (including bedrock road beds) for a distance of about 7 miles. The difficulty would be further increased due to the fiber optic cables buried along either side of the road. Terrestrial and aquatic habitats would experience short-term disturbance, because not all negative effects can be minimized or avoided completely. This route would encounter 209 stream crossings and 9 wetlands. It is unlikely that visual impacts would remain after construction.

Traffic disruption would be considerable. Traffic volume along this alternative is high, as it is a major truck route to the population centers of Coos and Curry Counties. It is also a major tourist route to the Coastal region. For a period of 6 months or more, traffic would be delayed. (Refer to Map 1). 
Pipeline capacity and throughput would be nearly identical to the proposed action. Pipeline operation and maintenance plans are expected to be similar to the description given in Appendix J.

\section{Alternatives Considered But Rejected}

\section{Alternative Routes Rejected Without Intensive Studies}

Straight-line route - The shortest route to the Coos County natural gas delivery point (just south of Coos Bay), would be a straight-line traverse from Roseburg. However, a straight-line alternative would encounter very steep topography containing critical habitats for federally protected and special status species. Significant impacts to the environment would likely be unavoidable, because no road or utility corridors exist along this straight-line route. This option was rejected after considering costs and environmental impacts.

Hwy 38 route - This route would connect with the Williams pipeline near the Hwy 38 / I-5 junction near Curtin, OR. This alternative is on the upstream side of the Winchester, OR, natural gas compressor station. This route would require a new compressor station and would be approximately 20 miles longer than the proposed action. This route was not considered economically feasible.

\section{Alternative Sources of Natural Gas}

Compressed Natural Gas (CNG) - Natural gas can be stored and shipped via truck in high-pressure gas transport cylinders. The retail cost of $\mathrm{CNG}$ is substantially higher than the retail cost of propane and therefore is not economically feasible for the Coos County.

Liquefied Natural Gas ( $\mathbf{L N G}$ ) - Natural gas can be liquefied at cryogenic temperature (-250 degrees F). Transport and storage are both expensive and technically challenging. Due to specialized facilities and associated costs, this method has been limited to non-industrial uses. LNG can be shipped in ocean-going tankers and barges. The nearest LNG sources are at gas production facilities in Alaska, Australia, Indonesia and the Mideast. This alternative would require a new docking facility that may require dredging of Coos Bay. The estimated cost of facilities are more than twice the cost of Coos County's portion of the estimated cost for the proposed action. LNG costs to the consumer would likely exceed the cost of most fuels presently being utilized in Coos County. NW Natural has LNG facilities in two Oregon locations and has studied LNG for various unserved communities. NW Natural owns the distribution rights for natural gas in Coos County and has determined that LNG is not economically feasible for Coos Bay.

Alternate Pipeline - Pacific Gas Transmission (PGT) operates an interstate pipeline system from Canada to California. The mainline runs through Bend and Klamath Falls, OR. The nearest pipeline connections would likely be at the Diamond Lake Junction northeast of Crater Lake, or at Medford, OR. A pipeline connecting to PGT would be approximately 100 miles longer than the proposed action. 


\section{Chapter 3 Affected Environment}

The following changes were made in Chapter 3 between the Draft and Final Environmental Impact Statement. Minor corrections, explanations and edits are not included in this list.

- Additional information regarding Port-Orford-cedar surveys conducted by the BLM within the proposed action corridor are given in the Natural Resources section.

- Additional information regarding documented locations of various fish, bird and mammal species according to the Coos Bay district BLM database are given in the Natural Resources section.

\section{Introduction}

This chapter presents the baseline environment in and around the corridor of the proposed action. Where appropriate, this chapter also includes baseline information of the southern route (Hwy 42).

\section{General Setting of the Proposed Action}

The proposed action is contained within utility corridor ROW or road ROW (principally the CBW Road) over its entire course.

The CBW Road was established in 1872. This road is currently maintained by Coos and Douglas Counties, with each county maintaining the segment of road within its respective jurisdiction.

The utility corridor ROW include BPA and PP\&L facilities. The BPA ROW was established in the mid-1950's. Immediately prior to the time of its construction, the timber was removed from the 150 -foot wide utility corridor. Construction of the BPA utility corridor included access roads and towers supporting the power lines. The PP\&L ROW was established in 1969 in Douglas County. Its construction is similar to that of the BPA ROW.

The proposed action crosses both private and public lands. Each parcel of land is managed by its respective landowner or the landowner's designated land management entity.

The public lands include BLM-managed lands and county parks. BLM lands are managed in accordance with their District Resource Management Plans and the Northwest Forest Plan (NFP). Public lands in Douglas County are primarily managed by the Roseburg District BLM office. BLM lands in Coos County are managed by the Coos Bay District BLM office. The county parks are managed by their respective County Parks Departments.

The private lands are owned by timber companies, large and small business enterprises, electric power transmission facilities, small woodlot owners, ranchers and homeowners. Prior to entering the Coos Bay area, the proposed action would pass through or near the small communities of Lookingglass, Sitkum, Dora, Fairview, Sumner and old Coos City.

\section{Native American Lands}

None

\section{Physical Description of the Area, Including Visual Resources}

Numerous valleys and drainages dissect the proposed action within the Coast Range, with several steep canyons (including Brewster Canyon). The CBW Road corridor crosses farms, residential areas, rivers, streams and forests.

The Coos Bay District RMP Record of Decision, page 41, discusses Visual Resource Management (VRM) for the District. VRM Class II and Class III areas are described as follows: Representative Class II areas include lands along Hwy 101 and the Coquille Valley. Lands adjacent to most county roads in rural residential areas (such as along 
the CBW road) are primarily Class III. Lands along Hwy 42 are managed as VRM Class III. The majority of forest lands in the District are managed as VRM Class IV.

The CBW Road is adjacent to some BLM-managed lands classified as Visual Resource Management Class IV areas. This classification could change to VRM Class III if the CBW Road is designated as a scenic byway. None of the BLM-managed lands bordering the proposed action are VRM Class III viewsheds. See Appendix D for VRM descriptions.

Although they are not BLM-managed lands, the following areas adjacent to the proposed action are classified as VRM Class III viewsheds: 1) Iverson Memorial Park, 2) Dave Busenbark County Park, 3) Judge Hamilton County Park, 4) Dora, 5) Frona County Park, and 6) the region east of the North Fork Coquille River as viewed from Fairview.

\section{General Setting of the Hwy 42 Alternate Route}

The Hwy 42 alternative route has a general setting similar to those noted for the proposed action. This route is mostly within VRM Class IV viewsheds. Traffic on this route is considerably heavier than on the CBW Road. This highway is an important commercial and tourist travel corridor.

This alternative is a total of 82.7 miles in length. It would border approximately 2 miles of VRM Class III viewsheds, affecting approximately 340 rural residences and 15.7 miles of urban area.

\section{Environment}

\section{Air Quality}

The proposed action includes no special airshed management policies. However, Roseburg has been identified as a designated area under the Oregon Smoke Management Plan. This plan controls the timing for agriculture and timber lands that are burned as part of normal land-management practices.

The air quality of the proposed action corridor is typical of the rural air quality in southwest Oregon. Although no data is available regarding the current levels of noxious gases, they are assumed to be at very low levels due to the absence of heavy traffic and heavy industrial development.

Airborne particulates are at low levels in the proposed action corridor. Minor and temporary increases in dust particulate levels occur occasionally due to farming and logging operations in the area. A minor amount of smoke is common during cool weather periods near residences using wood-burning appliances.

\section{Geology}

Refer to the Geotechnical Report in Appendix A for this information.

\section{Natural Resources}

\section{Cultural Resources (Including Native American Religious Concerns)}

Refer to the Cultural Resources Report in Appendix B for the proposed action information. The Hwy 42 alternative contains no known cultural resources, as all construction would occur on highway road fill.

\section{Soils}

Refer to the Geotechnical Report in Appendix A for this information. 


\section{Proposed Action Vegetation}

Roadside vegetation along the CBW Road ROW often lacks trees due to the county road maintenance practices for maintaining traffic safety. The vegetation is primarily grasses and small trees.

Vegetation within the utility corridors of the proposed action is typical of the area's vegetation, except it lacks trees due to vegetative management practices. The utility corridors support colonies of noxious weed species (from constant disturbance) that are annually targeted for control or removal by BPA and PP\&L maintenance crews.

Current vegetation patterns along the proposed action are a result of past anthropogenic management from timber harvesting, farming and human settlements.

Happy Valley contains open oak woodlands and farmland. Vegetation from Lookingglass to Reston is primarily pasture grasses and agricultural crops with interspersed oak woodlands. Small to medium parcels of agricultural land are located near Sitkum, Dora, McKinley, Fairview and old Coos City. In total, agricultural lands border approximately 10 miles of the proposed action corridor. Less than 1 percent of the landscape adjacent to the proposed action corridor is residential. The remaining vegetated lands bordering the proposed action corridor are coniferous forest.

Forest-types are as follows: 1.4 miles of young forest (0-15 years old); 38.2 miles of second-growth forest (16-79 years old); and 9.1 miles of mature forest $(80+$ years old $)$.

\section{Forest Types}

The forest types along the proposed action corridor are classified under three categories:

Young Forest: Young forests are areas cleared with stands established within the past 15 years. Stand structure is simple with hand-planted and naturally seeded coniferous trees 3 to 25 feet tall and are interspersed with naturally established hardwoods and shrubs. Disturbed soils and residual forest materials from logging are common. Hardwood release treatments and animal damage control measures are commonly used to accelerate development of young conifer.

Second-growth Forest: Dominated by Douglas-fir, these stands are generally between 16 to 80 years old and range from 25 to 150 feet tall. Younger stands contain high stem densities, while older stands have experienced natural thinning and selection influences from wind-throw, insect or disease infestation and competition for sunlight. Openings appear in the canopy where these influences have caused tree mortalities. Silvicultural prescriptions often include tree thinning operations within these stands to reduce stem density.

Mature (Late Seral) Coniferous Forest: Dominated by Douglas-fir, these stands are older than 80 years. Trees range from 80 to over 200 feet tall. Old-growth stands (200+ years) typically have multi-layered canopies and low stem density.

No Port-Orford-cedar were found during a survey conducted by the BLM along the proposed action corridor.

\section{Vegetation of the Hwy 42 Alternative Route}

Vegetation within the Hwy 42 route is similar in nature to the vegetation within the CBW Road ROW, except the safety margin (removed trees for improved visibility) is often wider.

This route borders 29.0 miles of second-growth forest land and 4.5 miles of mature forest land. In addition, it borders 28.3 miles of agricultural lands.

\section{Farmlands, Prime and Unique}

None of the farms along the proposed action or Hwy 42 alternate route have been designated as Prime or Unique Farmland. 


\section{Floodplain}

The proposed action is adjacent to 2.2 miles of 100-year floodplain located along the CBW Road near Sumner. The Hwy 42 route borders 15.3 miles of 100-year floodplain from near Myrtle Point to the coast.

\section{Water Quality, Quantity and Domestic Use}

Domestic-use (Proposed Action): Pipeline construction will disturb the top 5 feet of the soil, with $65 \%$ of the disturbance occurring within road fill of 5 to 10 feet deep. Domestic-use water wells nearest the proposed action generally exceed 50 feet depth. No registered domestic-users of water exists in streams along the proposed action.

Domestic-use (Hwy 42 Route): Pipeline construction would be limited to disturbance within road fill areas.

Water Quality (Both): Water quality environmental baselines may be affected from pipeline construction that crosses streams (188 stream crossings for the proposed action and 209 stream crossings for the Hwy 42 route). See discussion below of waters along the routes; Appendix E, which contains specific water quality baseline conditions by watershed; and Appendix I, which contains a list of streams that would be crossed by the proposed action.

Water Quantity (Both): Water quantity will not be impacted by either action alternative, as any active streams crossed during pipeline construction will have water piped around the construction area back into its natural stream channel.

\section{Waters Along the Proposed Action}

Appendix I contains a listing of intermittent and perennial flowing waters within the proposed action corridor. The corridor crosses 188 natural waterways (streams, tributaries or natural drainage channels). Of these waterways, 2 are large streams (greater than 30 feet wide) and 6 of them are medium streams ( 15 feet to 30 feet wide). Isthmus Slough is an estuary with a width of approximately 400 feet at the crossing point.

During periods of extended rainfall, the streams in the coast range reach their high water mark. During this time, the floodplains (referenced in "Floodplain" above) become inundated with water. During the proposed pipeline's construction season (June 1 to November 1), these floodplains would lack standing water.

The proposed action crosses two wetlands on private land near Coos Bay, OR. Refer to "Wetlands" (below) for further detail.

\section{Wetlands}

Jurisdictional wetlands are defined as:

"... areas that are inundated or saturated by surface or groundwater at a frequency and duration sufficient to support, and that under normal circumstances do support, a prevalence of vegetation typically adapted for life in saturated soil conditions." (33 [CFR] 328.3, 40 [CFR] 230.3)

\section{Wetlands Identified Along the Proposed Action}

Wetland delineation efforts were conducted during field surveys within the proposed action corridor. A series of small seasonal "potholes" were identified as wetlands near the town of Fairview. If pipeline construction occurs at this location during the season when these wetlands are dry, they will be conventionally trenched. If pipeline construction occurs at this location during the season when these wetlands are wet, they will be directionally drilled to avoid any potential negative impacts.

The majority of tidal wetlands along the Isthmus Slough will be avoided by the proposed action. The slough channel, Hwy 101 and the adjacent railroad grade would be directionally-drilled to avoid any potential negative impacts. The drill entry point (west side) is approximately 20 feet above sea level, therefore well-drained. The drill exit (east side) is adjacent the slough in the bottomlands, therefore poorly drained. A wetland survey conducted along this portion of the proposed action corridor indicated that the majority of the vegetation adjacent to the slough bottoms is not associated with jurisdictional wetlands. However a small seasonal wetland was delineated during this survey just east of the drill exit point. If pipeline construction occurs at this location during the season when the slough bottoms are dry, they will be conventionally trenched. If pipeline construction occurs at this location during the season when the bottoms are wet, they will be directionally drilled to avoid any potential negative impacts. 


\section{Waters along Hwy 42 Alternative Route}

The surface waters crossed by the alternate route are similar to that of the proposed action. The Hwy 42 route would cross a total of 209 streams, 18 of which are large streams and 12 of which are medium-sized streams.

\section{Wetlands Identified Along the Hwy 42 Alternative Route}

Wetlands along the alternative route were typically associated with streams or rivers flowing parallel to the course of the roadway.

The Hwy 42 alternative route has the potential to affect 9 wetlands.

\section{Wild and Scenic Rivers}

No federally designated "Wild and Scenic Rivers" are within 10 miles of the proposed or alternate routes.

\section{Wilderness or Wilderness Study Areas}

No federally designated Wilderness or Wilderness Study Area are within 5 miles of the proposed or alternate routes.

\section{Wildlife}

The proposed action corridors lack snags and trees or other suitable breeding, feeding and sheltering habitats for federally listed, proposed, candidate or survey and manage species. No breeding or sheltering habitats for special status species occurs in the proposed action corridor. However, the proposed action utility corridor may contain foraging habitat for a few special status bats and birds. The Hwy 42 corridor contains no habitat for terrestrial species. In general, roadways and utility corridors have been cleared of trees and brush wherever they grow within the Hwy 42 and proposed action corridors. There is one location in the proposed action where 25 -year old trees on private ownership will be removed during pipeline construction (approximately 0.2 -acre total). Overall, the action alternatives (including the proposed action) contain either no wildlife habitat (CBW Road, Hwy 101 and Hwy 42) or no suitable nesting/ roosting habitat for wildlife species (utility corridors).

No part of the construction area within the proposed action corridor is managed under special habitat requirements.

However, BLM-managed lands adjacent to the proposed action corridor are managed for requirements related to special status, threatened and endangered species, as well as overall protection of ecosystem functions. Some of these lands are designated for special management as prescribed in the NFP Record of Decision. In the vicinity of both action alternatives, Late-Successional Reserves (LSR) and Riparian Reserves are included. The proposed action corridor bisects LSR \#261 and three CHUs: One spotted owl CHU (OR-60) and two marbled murrelet CHUs (OR-06-b and OR-06-d), which are delineated on maps in Appendix C of the Draft EIS.

\section{Federally Listed, Proposed or Candidate Species}

Species listed as "endangered" under the ESA are those which are in danger of extinction in all or a portion of their range. Species listed as "threatened" are under threat of endangerment. Six listed species potentially exist near the proposed alternatives.

(Because of the sensitivity of nest site data, the exact location of nests is only provided on a need-to-know basis and is therefore not included).

\section{Northern Spotted Owl (Strix occidentalis)}

The northern spotted owl is a federally listed threatened species. Suitable habitat is adjacent to both action alternative routes. Approximately 30 percent of the proposed action is within 0.25 -mile of suitable northern spotted owl habitat. Approximately 20 percent of the Hwy 42 alternative is within 0.25 -mile of suitable northern spotted owl habitat. This habitat generally consists of late-successional forest, but mature stands with closed canopy and diverse structure are also considered suitable.

The suitable habitat within 1.5 miles of the proposed action has been surveyed for northern spotted owls. The Pacific Northwest Research Station, Ecosystem Processes Research Program, has conducted 13 years of northern spotted 
owl research on the BLM-managed lands, and the BLM funded a 5-year Pacific Southwest Research Station demography study. The only suitable habitat within 0.25 -mile of Hwy 42 or proposed action corridors is on federal land.

Within the general study area there is a $1,011 \mathrm{~km}^{2}$ (approximately $400 \mathrm{mi}^{2}$ ) density study area where intensive spotted owl survey and monitoring is conducted (Forsman and Anthony, 1999).

The key issue related to northern spotted owls and the proposed action is possible nest site disturbance. The USFWS considers nest sites disturbed when activities causing moderate noise above ambient levels occur (such as pipeline construction) within 0.25 -mile of the nest site (except for blasting, which may disturb northern spotted owls up to a distance of 1.0 mile). Some segments of all the action alternatives are near suitable habitat. The most recent documentation (surveys through 2001) of northern spotted owl sites show that one pair is within 0.25-mile of the proposed action.

\section{Marbled Murrelet (Brachyramphus marmoratus)}

The marbled murrelet is a federally listed threatened species. Suitable marbled murrelet nesting habitat, as defined by the USFWS marbled murrelet survey protocol, is present within 0.25 -mile of both action alternative routes. Habitat was confirmed using Geographical Information Systems (GIS) stand age-class data, aerial photographs and field observation. Biologists on the ground further refined and delineated suitable habitat into areas needing protocol surveys. In general, forest stands within 50 miles of the coast with nesting platforms (usually 80+ year-old trees) are considered suitable habitat. Approximately 30 percent of the proposed action is within 0.25 -mile of suitable marbled murrelet habitat. Approximately 20 percent of the Hwy 42 alternative is within 0.25 -mile of suitable marbled murrelet habitat.

Studies in 1992 and 1997 found marbled murrelet abundance to be low in southwestern Oregon. Of 889 intensive 2hour surveys, only 17 resulted in marbled murrelet detections, and only three stands overall were considered occupied based on these surveys (USDA/USDI, 1998).

Unsurveyed suitable habitat and nest site disturbance from construction activities is the primary management concern in the proposed action.

Marbled murrelets may be disturbed up to 0.25-mile from pipeline construction activities (except for blasting, which may disturb marbled murrelets up to 1.0 mile).

Surveys conducted on the Coos Bay BLM District indicate there are two occupied stands within 0.25 mile of the proposed action corridor.

\section{Designated Critical Habitat for the Northern Spotted Owl and Marbled Murrelet}

Critical habitats have been designated for the northern spotted owl and marbled murrelet in Oregon. The USFWS has designated CHUs for northern spotted owl and marbled murrelet on some BLM lands adjacent to all the action alternatives. CHUs are protected under the ESA and cannot be adversely modified unless impacts can be completely mitigated (see maps showing critical habitats in Appendix $\mathrm{C}$ of the Draft EIS). The determination of impact avoidance, minimization and mitigation for these critical habitats is conducted through the ESA and not NEPA. However, to meet the disclosure requirements for NEPA, Chapter 4 identifies the types of impacts that may occur and makes reasonable predictions as to the likelihood that impacts can be effectively avoided, minimized or mitigated.

It is also important to distinguish between designated CHUs (regulatory definition) and currently suitable habitat, which is a biological definition. CHUs are lands specifically designated by the USFWS to protect a listed species, whereas, suitable habitats are areas that provide shelter, breeding sites, foraging habitat or other elements necessary for a species' life-cycle. Because CHUs are regulatory and suitable habitat is biological, not all suitable habitat for marbled murrelets or northern spotted owls are designated critical habitat; and conversely, not all designated critical habitat is suitable habitat.

\section{Bald Eagle (Haliaeetus leucocephalus)}

Currently, the bald eagle is a federally listed threatened species. Key habitats include wintering areas, nest areas, roost sites and foraging areas, such as waterfowl concentration areas and areas of abundant fish availability.

The Umpqua River is an area of high eagle concentration (Kritz pers. com.). There are 6 documented occurrences of bald eagle nests within 1.0 mile of this river. No occupied bald eagle nests are within 1.0 mile of the proposed action or Hwy 42 corridors. 


\section{Columbian White tailed Deer (Odocoileus virginianus leucurus)}

This federally listed endangered species utilizes the lowlands of the interior valley, with preference for oak woodlands and meadows with nutritious forage. The geographic range for the Roseburg population of Columbian Whitetailed deer (CWTD) is confined to Douglas County, Oregon. It was defined as follows in the 1983 CWTD Recovery Plan:

"From Oldham Creek 3 miles northeast of Oakland, south to Cow Creek, 3 miles southwest of Riddle. Morgan Creek, 1.1 miles north of its intersection with the South Umpqua River, is the southeastern-most extent of its known range, whereas the northwest boundary extends to the town of Umpqua. The eastern boundary is Fall Creek, 0.3-mile south to Little River; the western boundary is Hawkins Lake. Since 1983, the population range has expanded 5 to 10 miles in all directions, with more dispersal occurring along riparian corridors." (Peterson, USFWS, pers. com.).

CWTD are likely to occur around the easternmost portion of the project area where habitat is suitable. This species is documented to exist in Cottage Grove, Callahan, Garden Valley, Nonpareil, Oak Creek Valley and Winchester United States Geological Service (USGS) quadrangles. Since the last recovery plan revision in 1983, the population has increased from 2,000-2,500 to 5,000-7,000 individuals, and approximately 4,000 ha (10,000 acres) of habitat has been secured (Peterson, USFWS, pers. com.). The USFWS published a "Proposed Rule to Delist the Columbian White-Tailed Deer" on May 11, 1999 (Federal Register Notice 64FR25263). The Oregon Department of Fish and Wildlife (ODFW) has delisted the CWTD from its previous threatened status to its current vulnerable state status.

Disturbance from construction activities is the only management concern in the Hwy 42 alternative and proposed action. There are no disturbance-related management requirements for CWTD.

\section{Brown Pelican (Pelecanus occidentalis)}

The brown pelican is a federally listed endangered species. They are documented in areas mapped on the Lakeside USGS quadrangle. Although the brown pelican may forage in and around the coastal bays during the summer, they rarely come inland. They are considered unlikely breeders north of California. No known breeding sites are within 20 miles of either the Hwy 42 alternative or proposed action.

\section{Western Snowy Plover (Charadrius alexandrinus)}

The nearest documented nesting area for this threatened species is the North Spit of Coos Bay (BLM 1994a) on the sandy beaches and dunes of the immediate coast.

\section{BLM Special Status Species}

\section{Terrestrial Wildlife}

The BLM Special Status Terrestrial Wildlife Species list for the project area is in Appendix K1 No suitable nesting or roosting habitats occur within the action alternatives. Field surveys found no special status wildlife occurring within the proposed action's construction corridor. The primary issue related to special status wildlife and the proposed action is disturbance (noise). The T\&E species disturbance issue is addressed under the Federally Listed, Proposed or Candidate Species sections in Chapters $3 \& 4$. No other special status species in the Hwy 42 or proposed action vicinity have disturbance-related management requirements.

\section{Special Status Birds}

No special status bird species' roosts or nests are known to occur within or adjacent to the Hwy 42 or proposed action corridors. There is no breeding and sheltering habitat available in either action alternatives' corridors. It is possible that peregrine falcons and northern goshawks may move through and forage in the proposed action powerline corridor intermittently throughout the year, because both the Hwy 42 alternative and proposed action occurs within the range of these species. However, these two species have never been documented in the BPA or PP\&L powerline corridors. No other special status birds are known to exist in or adjacent to either action alternative areas.

\section{Special Status Mammals}


Bats - Bat species occurring in this area are found using various habitats that provide shelter and adequate temperatures for thermal regulation, including caves, mines, man-made structures and trees with cavities and/or ex foliating bark. Suitable bat roosts are typically found in higher densities in older forests, because they tend to contain larger trees and snags. In general, bats utilize forest openings and water bodies for navigation and foraging. No suitable hibernacula exists within the Hwy 42 or proposed action corridors.

Fisher - Although in the range of fisher (Maser 1998), no confirmed sightings of fisher have occurred within the Hwy 42 or proposed action project areas. Neither action alternative contains any suitable habitat for fisher, nor is it likely individuals exist adjacent to the Hwy 42 or proposed action corridors.

Disturbance from construction during foraging activity is the primary management concern for special status mammals and the proposed action. There are no disturbance-related management requirements for foraging special status mammals.

\section{Special Status Amphibians}

Although considered possible on both BLM Districts, no documented sightings of special status amphibians have occurred near the Hwy 42 or proposed action project areas. Neither action alternative contains suitable habitat for special status amphibians.

\section{Special Status Reptiles}

Neither action alternative contains suitable habitat for any special status reptiles, except the western pond turtle. One documented sighting occurs within 2 miles of the proposed action corridor. The Isthmus Slough tidal marsh area and the private wetland near Coos Bay are the two places containing potential western pond turtle habitat within the proposed action. The Hwy 42 alternative crosses 9 wetlands containing potential western pond turtle habitat. No western pond turtles are known to occur in any of these potential habitat areas. All areas for both action alternatives containing potential western pond turtle habitat would be directionally-drilled to avoid aquatic system impacts, thus avoiding any potential impacts to western pond turtles.

\section{Plants (including lichens, bryophytes and fungi)}

The BLM Special Status Vegetation Species lists for the project area is in Appendix K 1 The primary issue related to special status vegetation and the proposed action is destruction or physical injury to individuals from soil disturbance during construction. Field surveys found no special status vegetation occurring within the Hwy 42 alternative or proposed action construction corridors. Vegetal species have no noise disturbance-related management requirements.

\section{Invertebrates}

The BLM Special Status Invertebrates Species list for the project area is in Appendix K1. The primary issue related to special status invertebrates and the proposed action is destruction or physical injury to individuals from soil disturbance during construction. Field surveys found no special status invertebrates habitats occurring within the Hwy 42 or proposed action construction corridors. Invertebrates have no noise disturbance-related management requirement.

\section{Fish}

Essential Fish Habitat (EFH) for all anadromous fish species was considered as part of the Aquatic Biological Assessment (Appendix E).

Under section 305 of the Magnuson-Stevens Act, Federal agencies which authorize, fund or undertake any action which may adversely affect any EFH are required to consult with the NMFS in order to receive recommendations on measures necessary to conserve and enhance EFH.

The NMFS is required to provide EFH conservation recommendations to the BLM for actions that adversely affect EFH. Since the impacts of the proposed actions are likely to be insignificant or negligible, no EFH conservation recommendations are proposed for these projects. The BLM must reinitiate consultation with NMFS if the action is substantially revised in a manner that may adversely affect EFH or if new information becomes available that affects the basis for NMFS' EFH conservation recommendations (50 CFR Section 600.920 [k].) 
Table 5: $\quad$ Special Status fish species in streams near the proposed action

\begin{tabular}{|l|l|l|}
\hline \multicolumn{1}{|c|}{ Fish } & \multicolumn{1}{|c|}{ Status } & \multicolumn{1}{c|}{ Related Streams } \\
\hline $\begin{array}{l}\text { Oregon Coast Coho } \\
\text { Salmon }\end{array}$ & $\begin{array}{l}\text { Federally Threat- } \\
\text { ened Species }\end{array}$ & $\begin{array}{l}\text { Cherry Creek, Middle Creek, E. Fork Coquille River, N. Fork } \\
\text { Coquille River, Evans Creek, Hantz Creek, Steel Creek, Catching } \\
\text { Creek, Bill's Creek, China Creek, Rock Creek, Morgan Creek and } \\
\text { others }\end{array}$ \\
\hline $\begin{array}{l}\text { Oregon Coast } \\
\text { Steelhead }\end{array}$ & $\begin{array}{l}\text { Federal Candidate } \\
\text { Species }\end{array}$ & $\begin{array}{l}\text { Tenmile Creek, Cherry Creek, Middle Creek, E. Fork Coquille River, } \\
\text { Catching Creek }\end{array}$ \\
\hline $\begin{array}{l}\text { Oregon Coast } \\
\text { Cutthroat Trout }\end{array}$ & $\begin{array}{l}\text { BLM Special Status } \\
\text { Species }\end{array}$ & $\begin{array}{l}\text { E. Fork Coquille River, Stcel Creek, lsthmus Slough, N. Fork } \\
\text { Coquille, Middle Creek and Cherry Creek }\end{array}$ \\
\hline $\begin{array}{l}\text { Federal Candidate } \\
\text { Cherry Creek, Middle Creck, E. Fork Coquille River, N. Fork } \\
\text { Coquille River, Evans Creek, Hantz Creek, Steel Creek, Catching } \\
\text { Creek, Bill's Creek, China Creek, Rock Creek, Morgan Creek and } \\
\text { others }\end{array}$ \\
\hline
\end{tabular}

\section{Survey and Manage Species}

Survey and Manage Species surveys are normally done when: (1) A project has the potential of being a ground-disturbing activity which may alter vegetation or other habitat elements on federally managed lands; (2) the project is within the suspected range covered by the protocol; and (3) the project must occur within suitable habitat for the species.

The BLM Districts' Survey and Manage Species list for their administration areas are in Appendix K Field surveys revealed no suitable Survey and Manage habitats on BLM-administered lands within the proposed action and Hwy 42 construction corridors. Field surveys for Survey and Manage Species/Habitats were conducted in autumn of 2000. The primary issue related to Survey and Manage Species and the proposed action is disturbance (noise). Survey and Manage species do not have disturbance-related management requirements.

\section{Red Tree Vole}

The red tree vole (Phenacomys longicaudus) is a Northwest Forest Plan Survey and Manage species, generally found more abundant in late-successional coniferous forests containing Douglas-fir. Field surveys found no individuals or suitable habitat within the proposed action or Hwy 42 corridors. However, noise disturbance during construction activities in the proposed corridor do have the potential to temporarily disturb individuals in adjacent suitable habitat. Once pipeline construction is complete, disturbance will be minimal. No mitigation for noise disturbance is needed for Survey and Manage species.

\section{Survey and Manage Mollusks}

The Amendment to the Survey and Manage Protection Buffer and other Mitigation Measures Standards and Guidelines (USDA 2001) gives the interagency standards and guidelines for identifying species to be protected through survey and management strategies. Among those listed are terrestrial and aquatic mollusks that occur within the range of the northern spotted owl. Survey protocols were also established.

Field surveys found no Survey and Manage mollusks habitats within the proposed action alternatives.

\section{Survey and Manage Amphibians}


Only one amphibian species, the Del Norte salamander, has potential for living within any of the proposed corridors. The nearest known Del Norte salamander site is approximately 25 miles south of the Hwy 42 alternative and proposed action areas.

Field surveys revealed no findings of individuals or potential habitat for the proposed alternatives. Del Norte salamander suitable habitat is rocky outcrops and talus within forested areas, especially older and wetter stands.

\section{Survey and Manage Bryophytes, Lichens, Fungi and Vascular Plants}

Field surveys revealed no findings of habitats for the proposed action alternatives.

\section{General Wildlife Groups}

Complete lists of general wildlife occurring on the Coos Bay and Roseburg BLM Districts can be found in their respective Resource Management Plans published for each district.

\section{Raptors}

Raptors include hawks, falcons, owls, eagles and vultures. Although incomplete, the current BLM database does not indicate any known nest sites occuring within 0.25 -mile of the proposed action corridor, other than the one spotted owl nest site (previously discussed under federally-listed species).

Daytime foraging activities from some of these species may be within the 0.25 -mile radius of construction. Disturbance from construction activities is the primary management concern for the proposed action. There are no disturbance-related management requirements for unlisted species of foraging raptors.

\section{Cavity-Nesting Birds}

Cavity-nesting birds generally nest inside tree cavities and rock crevices. Examples include woodpeckers, American kestral, western bluebird, Pacific-slope flycatcher and northern pygmy-owl. These species typically require largerdiameter trees (greater than 10 inches). Suitable trees are typically dead or dying and tend to occur more frequently in older forests. However, residual snags from logging or fire can provide suitable habitat in younger age-classes. Some species, such as the western blue bird and northern pygmy owl, prefer early-seral stands that have natural or disturbance-related openings containing suitable cavity-producing snags. The utility corridors and roadways that will be used for pipeline construction contain no cavity-related suitable habitat. The utility corridors, however, may provide foraging opportunities for some cavity-nesting species.

\section{Other Birds}

A variety of other migratory and resident birds exist within the project area. A variety of song-birds and waterfowl typically migrate from southern latitudes to breed in southwest Oregon.

Resident birds (juncos, chickadees, crows, ravens, etc.) may have seasonal movements, but tend to stay within their home-range vicinity all year. Game birds, such as quail, grouse and wild turkey, are also resident birds. Some of these species spend at least part of their life-cycle in ground-disturbed habitat, such as foraging within powerline utility corridors and agricultural lands.

\section{Deer and Elk}

Deer and elk occur throughout the project area. They provide recreational opportunities for people (i.e., hunting and wildlife observation) and are important prey species for black bears and cougars. Individuals are often seen feeding in forest clearings and wet meadows. Both species may use utility corridors and agricultural lands for feeding and travel/migration.

\section{Carnivorous/Omnivorous Mammals}

The project area may support populations of coyote, red fox, common gray fox, black bear, ringtail, raccoon, porcupine, opossum, river otter, bobcat and cougar. The cougar and black bear are game animals in Oregon, providing recreational opportunities (hunting) within the project area. Carnivorous/Omnivorous mammals may use utility corridors and roadways for travel/migration. 


\section{Small Mammals}

Several species of small rodents such as shrews, rats, mice, squirrels and voles may be present within the powerline utility corridor. These species tend to prefer the early-successional habitats common in utility corridors and agricultural lands, although a few species such as the flying squirrel and white-footed vole prefer developed forests. This type of habitat is adjacent to both action alternatives.

\section{Burrowing Mammals}

Burrowing mammals such as the mole, rabbit, mountain beaver, ground squirrel and pocket gopher are known to occur throughout both of the proposed alternatives. Some of these mammals may be locally abundant and provide an important food source to predators. Because burrowing animals usually require deep, loose soil, areas containing deeper soils are the most suitable habitat for them.

\section{Reptiles}

Various non-sensitive reptiles (such as turtles, lizards and snakes) have habitat ranges within the project vicinity. Most reptiles with populations in Oregon are likely to occur in developed forests or drier environments east of the coastal mountains.

\section{Invertebrates}

Various species such as mollusks and insects are found in the project vicinity. Insects are an important source of food for some species of birds, fish and reptiles.

\section{Amphibians}

Both action alternatives include a number of stream crossings that include trenching dry and flowing streams as part of pipeline construction. These stream crossings would include some potential habitat for amphibians during portions of their life-history cycle.

Various non-sensitive amphibian species (for example, frogs and salamanders) may be found intermittently in the project vicinity. These are a food source for mammals, fish, birds and reptiles. Amphibians use habitat features such as large down woody material, talus slopes, creeks, seeps and ponds.

\section{Fish}

The fish resources in the proposed action corridor include resident, anadromous and fluvial species. Three streams (Tenmile, Morgan and Rock Creek) to be trenched using "Bag and Flume" along the pipeline route contain enough summer waterflow ( $>0.1 \mathrm{cfs}$ ) to contain fish during active construction. Eighteen other small drainages with very low summer waterflow $(<0.06 \mathrm{cfs})$ will be trenched in the utility corridor portions of the pipeline construction. There is no realistic potential for fish to be in the upper reaches of these 18 small streams in the area of active construction during the summer, as their flows during that time are too small for sustaining fish. The primary issue related to fish and Hwy 42 alternative/proposed action is short-term increases in stream sediment and turbidity from construction soil disturbance. This issue is directly addressed in Appendix E. Although no critical habitat streams exist in or near the proposed action corridors, Essential Fish Habitat (EFH) for fish species was considered as part of the EIS Aquatic Ecosystem Assessment (Appendix E-1).

\section{Human Environment}

\section{Area of Critical Environmental Concern (ACEC)}

Part of the North Spit of Coos Bay (sand dunes area) has been designated as an ACEC. NW Natural plans to build a distribution system to commercial manufacturing facilities already operating on the North Spit would avoid this area completely and stay within areas zoned for manufacturing or public roads. This distribution system would be constructed under both action alternatives. 


\section{Public Health and Safety}

The primary issue of safety for the proposed action/Hwy 42 alternative is traffic on roads where pipeline construction is occurring. Accidents are possible if pedestrians or vehicles fail to heed signs and flaggers controlling traffic flow or enter active construction areas without permission. After construction is completed, the primary issue for public safety and pipeline operation would be damage from someone digging without permission with heavy equipment (such as a backhoe) or unauthorized use of explosives in the near vicinity of the pipeline.

\section{Environmental Justice}

Executive Order 12898 of February 11, 1994 requires each federal agency to identify and address any disproportionately high and adverse human health or environmental effects of its programs, policies and activities on minority populations, Native American groups and on low income populations.

There is no indication that households along either the Proposed Action or alternative Hwy 42 route are composed of a mix of minority or Native American residents which differs from elsewhere in Coos County. Therefore, analysis focused on whether a disproportionately high percentage of low income households are found along either route. This was accomplished by comparison of household income information from several geographic areas of Coos County, by reference to Census Tracts and Blocks within Census Tract. Year 2000 Census data concerning household income is not yet available, so 1990 Census data was used.

No minority or disadvantaged communities are adjacent to the proposed action or Hwy 42 alternative routes.

\section{Socio-economics in Coos County}

The economic simulation model, Impact Analysis for Planning (IMPLAN), used by ECONorthwest shows natural gas has the potential to stimulate the manufacturing sector of the local economy. The study is based upon a planning framework called IMPLAN (developed by the U.S. Forest Service), using local and national data to produce estimates of economic impact. Similar analysis of communities such as Newport, Corvallis, Albany and Grants Pass would re-affirm the significant favorable economic impacts from the introduction of natural gas to a local economy.

\section{Socio-economics within the Proposed Action}

The proposed action is adjacent to the following business entities: Lookingglass Store, Northwest Hardwoods, Southport Lumber Co., Coos Country Club, Dora Store, Four Corners Grocery and the Sumner Store.

The proposed action corridor is also adjacent to 37 rural residences. Less than 2 percent of the corridor's urban settings are outside of the Coos Bay area. These urban settings are small components of the overall Coos County economy.

The Hwy 42 route would affect the communities of Winston, Brockway, Tenmile, Camas Valley, Remote, Bridge, Myrtle Point, and Coquille.

\section{Regional Assessment of the Natural Gas Market}

According to the ECONorthwest report, the competitive advantage of natural gas over other energy sources in general for Oregon is evident: "60 percent of Oregon's urban area homes use natural gas, while about 40 percent of the homes in outlying areas use natural gas" (ECONorthwest 2000). Such statistics indicate a wide-spread consumer acceptance of natural gas.

\section{Coos County General Economic Data}

Coos County 2000 Census reports it has 62,779 residents. Its economy centers around forest products and the deepwater ocean Port of Coos Bay, but the economy continues its long struggle which began in the early 1980's, when timber production diminished significantly following the impacts of several forestry-related environmental issues 
(Helvoigt, 2000). According to the Oregon Employment Department, the current (November, 2001) unemployment rate in the County is approximately 6.7 percent, as compared to Oregon's average unemployment rate of 6.4 percent. For further comparison, the November, 2000, national average unemployment rate was 4 percent, according to the Wall Street Journal. Historical data indicates the County's unemployment statistics are approximately double those of the national average (Coos/Curry/Douglas, 2000).

As shown in the Coos County Budget, the County's current tax structure includes real estate taxes, timber taxes and county fees. The County receives gross tax receipts for the general fund in the amount of approximately $\$ 2.96 \mathrm{mil}-$ lion per year. Payments-in-lieu-of-taxes to the County is approximately $\$ 6,752$ per year. Additional general fund revenue comes to the County from O\&C lands timber revenues and from federal lands timber revenues (from the sale of timber on BLM and U.S. Forest Service lands); in 1991, these amounted to 19 percent and 22 percent (respectively) of the County's total annual budget (Maxwell et al., 1999).

Total personal income of the County is approximately $\$ 1.1$ billion, which is an average annual per capita personal income of $\$ 19,494$; this is approximately 82 percent of the Oregon average annual per capita personal income (Coos) Curry/Douglas, 2000).

\section{Energy Market Competition in Coos County}

Much of this information regarding energy market competition is derived from the most recent ECONorthwest report submitted for the proposed action.

Much of the electrical energy supplied to Coos Bay comes from PP\&L. This employer (and its employees) would receive no significant adverse effects from the proposed action. Natural gas can only supplement (not replace) the use of electricity, and the equipment supplying the electricity would require the same amount of maintenance, regardless of the presence of a natural gas supply.

The Coos County economy currently supports propane and heating oil distributors. These supply approximately 20 percent of the heating energy needs of the cities of Coos Bay and North Bend. Small businesses transport propane and heating oil to rural residences as well as in-lown businesses and residences. Businesses based outside of the County operate wholesale fuel oil and propane supply companies. Conglomerated, the nine businesses delivering fuel oil or propane to County residents and businesses (listed below) employ a total of 69 persons (ECONorthwest 2000).

The following propane dealers operate within the County: All Star Gas (North Bend), Ferrellgas (Coos Bay) and Ron's Oil Co. (Coquille).

The following heating oil dealers operate within the County: Bassett-Hyland Energy Co. (Coos Bay), Davis Oil Inc. (North Bend), Graham Oil Co. (North Bend), Tyree Oil Inc. (Coos Bay), Goddard Energy Co. (Bandon) and Hodge Distributor, Inc. (Myrtle Point).

Currently, Oregon supports an average of 1,147 residents per fuel oil or propane distributor employee. This ratio is higher than the ratio for Coos County ( 847 residents per distributor), due to the widespread availability of natural gas across most of Oregon (ECONorthwest 2000).

\section{Waste - Solid or Hazardous}

No waste sites, lagoons, landfills, transfer stations or water treatment plants exist in or near the proposed action corridor. Illegal dumping of refuse occurs intermittently on public lands. Sewage disposal ponds are located approximately 0.5 -mile west of the proposed action corridor at Libby, and the Roseburg city dump is approximately 2 miles northeast of the Williams Gas Pipeline.

No waste sites or refuse dumping sites exist in or near the alternative route. The Myrtle Point waste water treatment plant is located approximately I mile from the Hwy 42 corridor, and the Coquille waste water treatment plant is approximately 0.1 -mile from the Hwy 42 alternative route. 


\section{Land Uses}

\section{Forestry}

The general region of the proposed action is typical in its forest products history. Since the $1850 \mathrm{~s}$, timber was milled into lumber or it was used as whole logs to be sold on the market. Today, forest lands are still an important source of logs for lumber, paper and plywood mills near Roseburg, Myrtle Point, Coquille and Coos Bay. The production of timber is expected to continue as an important local economic resource.

The local forests are also an important source of firewood for residences. Many rural homes are heated with woodburning facilities (fireplaces and wood heating units). The BLM may allow wood cutting on BLM-managed lands adjacent to the proposed action corridor. The proposed action corridor includes access routes used by individuals harvesting firewood or other special forest product items within the surrounding areas.

\section{Livestock Grazing}

Farmers and ranchers in the area between Lookingglass and Coos Bay raise domestic livestock, which are the typical varieties suited to Western Oregon.

\section{Recreation along the Proposed Action}

\section{BLM-Managed Lands}

The CBW Road traverses through scattered sections of BLM public lands in the Coos Bay and Roseburg Districts. BLM public lands in the Roseburg District are part of the South River Extensive Recreation Management Area (ERMA). Public lands in the Coos Bay District are within both the Myrtlewood and the Umpqua ERMAs. Recreation uses within these ERMAs are generally characterized by dispersed types of activities that require little or no management as well as small developed recreation sites with limited facilities that support recreation uses.

The Coos Bay District RMP proposes that the CBW Road be designated as a backcountry byway. While some preliminary work was done on a backcountry byway proposal several years ago, work to complete the designation process has not been finished to date.

According to the Coos Bay District RMP (USDI 1995a), the County's BLM-managed lands are characterized as "Roaded Natural" areas. The proposed action corridor includes no BLM-managed camping or picnicking facilities.

\section{County Parks}

The parks listed below include facilities for picnicking and hiking, as well as protecting the environment and increasing the safety of facility-users. In some cases, facilities are designed and constructed to accommodate camping by conventional motorized use (car and tent, camper, truck and trailer, and motor home).

Dave Busenbark County Park (Douglas County), located at T28S, R9W, Section 16.

Severt Iverson Memorial County Park (Douglas County), located at T28S, R9W, Section 16.

Judge Hamilton County Park (Coos County), located east of Sitkum at T28S, R9W, Section 7.

Frona County Park (Coos County), located west of Dora at T28S, R11W, Section 11.

Judge Hamilton County Park is undeveloped and remains in a natural state. Frona County Park has basic facilities including toilets, picnic tables and primitive camp sites with fire rings. Both parks are Congressional withdrawals (1926) of BLM public lands for the purpose of reserving these lands in Coos County as public parks and campsites, for recreational purposes, and to preserve the rare groves of Myrtle trees.

\section{Boat Ramps}

Gold Brick Boat Ramp at Dora

Frona Boat Ramp at Frona County Park 


\section{Recreation along the Alternative Route}

Hwy 42 is an important access route for recreation users. This route includes several small campgrounds and picnic areas adjacent to the highway, which are used by tourists traveling to and from the coastal recreational areas. This highway is also an important access route for those travelling to secondary roads.

The Coos Bay District RMP (USDI 1995a) indicates this route is used for recreation year-round. Bear Creek is a public camping area adjacent to Hwy 42, receiving thousands of visitors each year.

\section{Transportation}

Roads affected by the Proposed Action

\section{CBW Road}

The proposed action affects approximately 1 mile of the CBW Road in Douglas County and approximately 32 miles of the CBW Road in Coos County. The length of road between Lookingglass and U.S. Hwy 101 is approximately 54 miles. A 10-mile portion of the CBW Road, between Dora and Fairview, receives a significant amount of traffic related to administrative, commercial and residential purposes. The Four Corners Grocery is located along this affected portion of the road.

Two dairies are located in the general region of the proposed action. The proposed action corridor is not adjacent to these dairies; however, each dairy relies on milk-transport tank trucks that use the CBW Road for milk shipments.

The 0.8 mile portion of the CBW Road (west end which joins to U.S. Hwy 101) receives high usage for access to Northwest Hardwoods, Southport Forest Products and Coos Country Club.

The 10.6-mile gravelled portion of the CBW Road between the County line and Sitkum (T28S, R10W, Sec. 10) is one of the least travelled portions of the CBW Road. The CBW Road is rarely used as a transit route from Roseburg to Coos Bay, due to the many sharp curves and gravel surface east of Sitkum.

The paved portions of the CBW Road provide access to residences, timber lands and farms. Commercial traffic on this road is mostly logging trucks and equipment and dairy tank trucks. This road is a primary access route for forest fire protection efforts, land management and law enforcement. Reston Road, Myrtle Pt.-Sitkum Road and the Coquille-Fairview Road provide access from Hwy 42 to the CBW Road.

In total, approximately 33 miles of the CBW Road would be affected by the proposed pipeline project (Table 6). In some cases, the proposed pipeline crosses the road; in the remainder of the affected portions of the road, it would be buried beneath the roadway. 
Table 6: $\quad$ Portions of CBW Road affected

\begin{tabular}{|c|l|c|c|}
\hline Mile marker & \multicolumn{1}{|c|}{ Description of area } & $\begin{array}{c}\text { Road } \\
\text { affected } \\
\text { (miles- } \\
\text { gravel) }\end{array}$ & $\begin{array}{c}\text { Road affected } \\
\text { (miles-paved) }\end{array}$ \\
\hline \hline 6.4 & CR 5, cross near Lookingglass in north edge of PP\&L & & X \\
\hline 7.5 to 8.6 & CR 5, lay in road, cross Morgan Creek & & 0.7 \\
\hline 1.0 to 1.7 & CR 112, lay in road, cross Tenmile Creek & X \\
\hline 2.3 & CR 112, cross in north edge of BPA & 10.6 & 8.2 \\
\hline 36.3 to 25.7 & CR 1G, lay in gravel road through Brewster Canyon & & X.8 \\
\hline 25.7 to 17.5 & CR 1C and 1D, in pavement through Sitkum and Dora & & 0.3 \\
\hline 17.1 to 17.9 & CR 60B, lay in road, cross Middle Creek & & 3.5 \\
\hline 13.7 & CR 60B, cross south of Fairview in north edge of BPA & & 1.9 \\
\hline 12.75 to 12.5 & CR 60B, lay in road through Fairview & & 1.3 \\
\hline 12 to 4.1 & CR 59, lay in road from north Fairview to Sumner & 4.4 & miles \\
\hline 4.1 to 2.2 & CR 57, lay in road from Sumner to PP\&L & & \\
\hline 1.7 to 0.4 & CR 57, lay in road from top of hill to Coos City & & \\
\hline
\end{tabular}

\section{Sitkum Lane (Formally Myrtle Point - Sitkum Road)}

The proposed action corridor includes approximately 0.4-mile of the Myrtle Point-Sitkum Road. The portion of affected road is between the BPA utility ROW and its intersection with the CBW Road (Table 7).

\section{Fairview Road (formerly Coquille-Fairview Road)}

The proposed action corridor includes approximately 0.1-mile of the Coquille-Fairview Road. The portion of affected road is between the PP\&L utility ROW and the Four Corners intersection where it crosses the CBW Road.

\section{U.S. Hwy 101}

U.S. Hwy 101 is an important commercial truck route along the coast. At the crossing location within the proposed action corridor, trucks are destined for Coos Bay, North Bend, Bandon, Langlois, Port-Orford, Coquille, Myrtle Point and small communities or farms in the surrounding areas. It is also a major commuting route for many residents in the area. The proposed action crosses Hwy 101 once. It will be directionally-drilled to avoid impacts. At the crossing, U.S. Hwy 101 is a four-lane highway with a median strip. 
Table 7: Other Public Roads Affected by Pipeline

\begin{tabular}{|c|c|c|c|}
\hline Segment & Description of area & $\begin{array}{l}\text { Road } \\
\text { affected } \\
\text { (miles- } \\
\text { gravel) }\end{array}$ & $\begin{array}{c}\text { Road } \\
\text { affected } \\
\text { (miles- } \\
\text { paved) }\end{array}$ \\
\hline A & $\begin{array}{l}\text { Lookingglass Road CR } 47 \text {, cross just south of Looking- } \\
\text { glass with PP\&L }\end{array}$ & & $\mathrm{X}$ \\
\hline A & $\begin{array}{l}\text { Dairy Farm Road CR 108, cross } 1.5 \text { miles west of Look- } \\
\text { ingglass with PP\&L }\end{array}$ & & $\mathrm{X}$ \\
\hline $\mathrm{E}$ & $\begin{array}{l}\text { Sitkum Lane CR 1C, lay in road west of CR } 60 \text { B for } 2200 \\
\text { feet }\end{array}$ & & 0.4 \\
\hline $\mathrm{F}$ & $\begin{array}{l}\text { McKinley Lane CR 13, cross at CBW Road near Cherry } \\
\text { Creek }\end{array}$ & & $\mathrm{X}$ \\
\hline $\mathrm{H}$ & Fairview Road CR 9, cross just south of Fairview & & $\mathrm{X}$ \\
\hline I & $\begin{array}{l}\text { U.S. 101, cross at MM } 243.4 \text { near Coos City and Sumner } \\
\text { Bridge }\end{array}$ & & $\mathrm{X}$ \\
\hline $\mathrm{J}$ & North Meadow Drive (not dedicated), cross gravel road & $\mathrm{X}$ & \\
\hline $\mathrm{J}$ & Red Dike Road CR 183, cross to Fruitdale Drive & & $\mathrm{X}$ \\
\hline $\mathrm{K}$ & Fruitdale Drive CR 185, lay in road for 100 feet & & 0 \\
\hline $\mathrm{K}$ & Cooley Drive, lay in road for 1800 feet, mostly gravel & 0.3 & \\
\hline $\mathrm{K}$ & Libby Lane CR 184, lay in road for 1200 feet & & 0.2 \\
\hline $\mathrm{K}$ & Lapping Road, lay in gravel road for 100 feet & $\mathrm{X}$ & \\
\hline $\mathrm{K}$ & 21 st Street, lay in gravel road for 2200 feet & 0.4 & \\
\hline $\mathrm{K}$ & Idaho Drive, lay in gravel road for 2200 feet & 0.4 & \\
\hline $\mathrm{K}$ & California Drive, cross in steep dirt portion & $X$ & \\
\hline $\mathrm{K}$ & Anderson Avenue, cross in east side of PP\&L & & $\mathrm{X}$ \\
\hline & & 1.1 miles & 0.6 mile \\
\hline
\end{tabular}

\section{Roads affected by the Alternate Hwy 42 Route}

\section{Oregon Hwy 42}

Oregon Highway 42 is an important commercial truck route connecting the I-5 freeway and the inland communities to the coastal communities. Truck traffic along this route is destined for Coos Bay, North Bend, Bandon, Langlois or Port-Orford, Coquille and Myrtle Point. This highway is also a commuting and access route for residents of the coast. During the summer months, it is a major tourist route. Many portions of this route include three or four lanes of traffic. Extra lanes are supplied to traffic climbing uphill grades in several locations. The portions of the highway 
from Myrtle Point to Coquille, and the last seven miles (approximately) as the highway approaches U.S. Hwy 101, are four lanes of traffic with no median strip.

\section{U.S. Hwy 101}

The Hwy 42 Alternative includes portions of U.S. Hwy 101 within the proposed route. The Hwy 42 route includes a segment approximately 0.8 -mile in length, from its intersection with Hwy 42 , to the BPA utility corridor very close to the CBW Road end point. This portion of the highway includes intersections with two secondary roads leading westward.

\section{Utility Corridors}

\section{Power Lines}

The proposed action corridor begins within the PP\&L power line utility corridor. It continues within this corridor until it reaches the Flournoy Valley substation. For nearly half the distance from Flournoy Valley to Fairview, the proposed action corridor is adjacent to or within the BPA $230 \mathrm{kV}$ power line utility corridor. For approximately 0.2 mile near Coos City, the pipeline is within the PP\&L $230 \mathrm{kV}$ power line utility corridor, which traverses the region parallel to the BPA utility corridor along its northward edge. A short segment of the proposed action follows a recently abandoned BPA utility corridor to the west of U.S. Hwy 101. In total, approximately 23 miles of the proposed action corridor follows power line utility corridors.

\section{Substations}

The proposed action corridor lies adjacent to several power line substation properties. These include: Co-op substation in Lookingglass Valley, the BPA Reston substation in Flournoy Valley and the Fairview substation.

\section{Power Line Utility Corridor Access Roads}

Utility crews access the power lines: 1) by working from the CBW Road or from some other county road, wherever the lines cross over the road; or 2) by working from access roads connecting to the CBW Road and other public roads,

Graveled access roads into utility corridors are constructed and maintained by the utility company. Some of these roads would be used for access to the proposed action corridor, both during pipeline construction and during maintenance procedures of the pipeline during its operation.

\section{PP\&L and BPA Access (Douglas County)}

Access roads are spaced at approximately half-mile increments along the CBW Road between Lookingglass and Tenmile Creek. From there to the county line, four BPA access roads connect to the CBW Road.

\section{BPA Access (Fairview-Reston circuit)}

Access roads for this portion of the corridor are located as follows:

- Two access roads in T28S, R11W, Sec. 3.

- One access road in T28S, R11W, Sec. 4.

- Extensive road access in T27S, R1IW, Sections 32 and 30.

- Four access roads in T27S, R12W, Sec. 24.

\section{PP\&L Access (Fairview-Isthmus circuit):}

Access road to Segment $\mathrm{H}$ (along the PP\&L utility corridor) is located as follows:

- One access road in T26S, R12W, Sec. 30. 


\section{BPA Access (part of the Fairview-Reedsport circuit)}

Access roads to Segment $\mathbf{J}$ (the region west of U.S. Hwy 101) were established for BPA access. Their use for power line maintenance is no longer needed, since the power line was recently relocated. The access roads into this corridor are as follows:

- One access road coming from U.S. 101 in T26S, R12W, Sec. 23.

- One access road in T26S, R12W, Sec. 15 (again coming from U.S. 101).

- One access road in T26S, R12W, Sec. 10, coming from Shinglehouse Slough Road.

- One access road in T26S, R12W, Sec. 10, coming from North Meadow Drive.

\section{Fiber Optic Line}

Buried fiber optic line currently exists at the edge of the CBW Road and Hwy 42 over their entire lengths. This utility is buried approximately 2 feet deep at or near the edge of the roadways, and is marked with plastic markers at $1 /$ 10th-mile increments. Pipeline construction on or just outside the centerline of the CBW Road would not affect the fiber optic line. At its option, Coos County may decide to install a fiber optic carrier pipe in the pipeline ditch. The carrier pipe is typically 1.25 or 2 -inch polyethylene pipe similar to gas pipe. It would be installed above the pipeline while the ditch is backfilled, with no extra excavation or site preparation required.

\section{Encumbrances}

Several timber companies have access road ROW across BLM lands. These are for gaining access to timber tracts adjacent to or near the BLM tract.

The Coos Curry Electric Cooperative also has a power line ROW in T27S, R12W, Sec. 5.

The County is seeking permission from private land owners in the proposed action corridor to install the proposed natural gas pipeline within the already-established utility corridor crossing their land. Each land parcel requires a separate easement from the underlying owner. Most land under the utility corridors is owned by individuals, forest companies and BLM. The BPA also owns a few short segments. 


\section{Chapter 4 Environmental Consequences}

The following changes were made in Chapter 4 between the Draft and Final Environmental Impact Statement. Minor corrections, explanations and edits are not included in this list.

- Additional Project Design Criteria for the spotted owl and the marbled murrelet in the Environmental Consequences and Comparison of Alteratives sections.

- Additional information regarding air quality, including emissions fuel combustion is given in the Environmental Consequences and Comparison of Alternatives sections.

- A new section titled "Pipeline Safety and Fire Data" has been added to the Public Health and Safety section of this chapter

\section{Introduction}

This chapter describes aspects of the environment likely to be directly affected by the proposed action. Also described are anticipated direct and indirect effects from the proposed action under the alternatives, and the potential cumulative impacts, which form the scientific and analytical basis for the Comparison of Effects of the Alternatives.

Because the proposed action and alternatives analyzed are relatively precise in scope, the effects analysis also mirrors this precision, thus avoiding unfocused and speculative assessments. The impacts on Threatened and Endangered (T\&E) species are described and submitted for informal consultation with the USFWS.

\section{Key, Direct, Indirect and Cumulative Impacts}

Table 8: $\quad$ Definition of Key, Direct, Indirect and Cumulative Impacts

\section{Definition of Impacts Used in This Assessment}

Key Effects: Elements identified from project assessment and public comments/scoping that would likely impact the human or natural environment if the proposed action is implemented.

Direct Effects: Those foreseeable impacts that will directly result from implementation of the proposed action.

Indirect Effects: Those foreseeable impacts that are likely to indirectly occur as a result of proposed action implementation.

Cumulative Effects: Those additive impacts from the incremental effects of a proposed action when placed in context with other past, present and reasonable foreseeable future actions (CEQ regulation, 40 CFR 1508.7).

The analysis for this EIS assesses all direct, indirect and cumulative impacts for all affected lands within the scope of the proposed action, regardless of ownership. For virtually all of the terrestrial species addressed here, the interactions between the indirect effects (noise disturbance) on federally managed lands and non-federal lands where construction-induced ground disturbance occurs, are expected to be very limited, because few species' breeding and sheltering habitats occur in roads and powerline corridors. However, the aquatic ecosystem does contain some interactions between the direct effects (sediment and turbidity), ground-disturbing activities and potential impacts between federal and non-federal lands. The Aquatic Ecosystem Assessment (Appendix E) addresses these potential impacts in detail.

Categories of Key Effects: (1) Impacts on aquatic and riparian habitats and water quality; (2) Impacts on air pollution and soil productivity; (3) Impacts on terrestrial species and habitats, which includes Port-Orford-cedar, Noxious 
Weeds, Special Status Species, Survey \& Manage Species, T\&E Species, as well as related CHUs; (4) Cultural resource-site protection (including Native American Religious Concerns); and (5) Economic impacts.

\section{Proposed Action Effects Summation}

The EPA recently published a final regulation for the Total Maximum Daily Load (TMDL) program under Section 303(d) of the Clean Water Act. There are water bodies within the NFP area that have been identified as not meeting applicable water quality standards. The federal land-managing agencies have developed an Aquatic Conservation Strategy (ACS) protocol to bring the water bodies into compliance with applicable standards. Watershed analysis recommendations, if followed, can maintain or improve protection of aquatic and riparian habitats in the short-term, while promoting long-term recovery goals. The proposed actions of the preferred alternative are consistent with watershed analysis recommendations (See Appendix E).

The individual species direct, indirect and cumulative effects analyses for birds, mammals, reptiles, amphibians, fish and vegetation (including bryophytes, fungi and lichens) addresses potential adverse impacts associated with the proposed action on both federal and non-federal lands. Because the proposed actions are limited to pre-disturbed nonhabitat areas (roadways and powerlines) and use BMPs and PDCs throughout the proposed action for all affected watersheds (i.e., span six 5th fields), the direct, indirect and cumulative impacts are so small as to be negligible at the 5th field Hydrologic Unit Code (HUC). These six affected watersheds are listed and analyzed in Appendix E. The proposed action would provide both short and long-term beneficial impacts to the affected watersheds as well. Approximately 15 miles of gravel road would be paved, promoting long-term restoration to the sediment and turbidity baselines in 4 watersheds (Appendix E). Three culverts presently blocking fish passage in the East Fork Coquille Watershed would be replaced, providing upstream and downstream passage to anadromous fish and other aquatic wildlife, promoting immediate restoration benefits to the physical barrier baseline in the watershed.

Air quality may suffer some short-term direct localized (7th field) impacts wherever pipeline construction has heavy equipment operating. The Roseburg RMP/EIS (USDI 1995a) found that effects of dust from road use by heavy equipment were both localized and transitory. The long-term direct and cumulative effect of the proposed action is a reduction in sulfurous emissions from fossil and wood fuels utilized by industries and private residences within Coos County as users switch to natural gas from alternate fuels.

Negligible impacts to soil productivity from ground disturbance are anticipated at the watershed (5th field) scale. Most of the construction (approximately 65\%) would likely occur within road fill on the CBW Road or other roads. The rest of the ground disturbance would be limited to powerline utility corridors, where normal maintenance regularly removes (disturbs) vegetation with mechanical and chemical applications. In the pipeline trench areas where soil is removed and backfilled after pipe placement, soil productivity in the utility corridors will likely be reduced permanently from compaction. In roadways, soil productivity should remain unchanged.

Cultural resource sites (including Native American Religious Concerns) have been surveyed for and identified. In construction areas where the potential for these sites exists, a certified archaeologist and tribal member will both be onsite to monitor this resource. No impacts are anticipated, because all cultural resources and Native American resource sites will be identified and avoided (See Appendix B).

The short-term and long-term direct, indirect and cumulative economic benefits of the proposed action are the primary reasons Coos County seeks to construct a natural gas pipeline.

For the details of these assessments, refer to the specific effects analysis sections later in this chapter.

\section{Northwest Forest Plan (NFP) Implementation}

Late-Successional Reserve Assessments are required before implementing actions in LSRs. Late-Successional Reserve Assessments have been developed for the BLM-Coos Bay District's LSR \#261 containing CHU OR60 (northern spotted owl), and CHUs OR06-B and OR-06-D (marbled murrelet). Because of implemented PDCs, impacts to these listed species and their designated habitats are avoided. None of the proposed actions will affect or degrade any late-successional habitats in these CHUs/LSRs, nor will they slow habitat development in these CHUs/ LSRs.

Watershed analysis is required in Key Watersheds and Riparian Reserves prior to determining how proposed management actions meet the ACS for maintaining or promoting long-term recovery. Watershed analysis was conducted 
within the scope of the proposed action area. All proposed management actions in the proposed action meet the ACS (Appendix E), and would not retard attainment of ACS objectives.

\section{Environment}

\section{Air Quality}

Environmental Consequences and Comparison of Alternatives

\section{Direct and Cumulative Effects}

Because natural gas is the cleanest burning fossil fuel, it can help improve the quality of air, especially when used in place of other, more polluting energy sources. Natural gas combustion results in virtually no atmospheric emissions of sulfur dioxide or small particulate matter, and far lower emissions of carbon monoxide, reactive hydrocarbons, nitrogen oxides and carbon dioxide than combustion of other fossil fuels.

Natural gas is more environmentally attractive than other fossil fuels because it is composed chiefly of methane - a molecule made up of one carbon atom and four hydrogen atoms. When methane is burned completely, the principal products of combustion are carbon dioxide and water vapor.

In comparison, fuel oils, currently one of the primary energy sources used by industries in Coos County, have much more complicated molecular structures. They include a higher ratio of carbon, as well as various sulfur and nitrogen compounds; therefore do not burn as cleanly. Industrial fuel oil combustion also produces ash particles, which do not burn at all; however, they can be carried into the atmosphere. The largest heat users burn the cheapest fuel oil, \#6 bunker fuel, a thick asphalt-like compound which must be heated to flow, and which is high in sulfur and other contaminants, including heavy metals.

Because natural gas burns cleanly, its use can be an effective means of reducing pollution. The combustion of natural gas produces virtually no sulfur dioxide and very little nitrogen oxide. Natural gas emits, on average, 0.00006 pounds of sulfur oxides per therm of fuel burned. (A therm is $100,000 \mathrm{BTU}$, or about 0.7 gallons of fuel oil.) In contrast, a typical bunker fuel emits up to 0.2 pounds of sulfur oxides per therm, which is approximately 3500 times higher than gas (www.epa.gov//ttn/chief/ap42).

The Clean Air Act Amendments of 1990 require plants to reduce their sulfur dioxide emissions by 10 million tons annually, and their nitrogen oxide emissions by 2 million tons annually. The following tables show the reduced emissions caused by converting a typical plant from \#6 bunker fuel to natural gas. In the NW Natural system, an average-size industrial plant uses about 2 million therms of gas per year.

These benefits also extend to smaller residential and commercial customers converting to natural gas. Most users now heat with electricity, fuel oil, propane and wood. An average home would use about 800 therms per year of natural gas. Accompanying tables compare emissions from natural gas relative to fuels burned onsite. Natural gas results in lower emissions of particulates (soot), nitrogen and sulfur oxides (NOx and SOx), carbon dioxide and organic compounds. Approximately half of the electricity in the region is generated from fossil fuels, at an overall 30 percent thermal efficiency. Thus a therm of natural gas consumed onsite in Coos Bay will offset the consumption of 1.6 therms of oil, gas or coal in an offsite electric generating plant. Emissions are reduced proportionally.

Natural gas should make an immediate improvement in the existing and future air quality within Coos County. 
Table 9: $\quad$ Metal Emissions from Fuel Combustion (lbs/thermal unit)

\begin{tabular}{|c|c|c|c|}
\hline Element & \#6 Bunker Fuel & Natural Gas $^{1}$ & Average Industry Yearly Reduction $^{2}$ \\
\hline Arsenic & 0.000009 & $<0.000001$ & 18 \\
\hline Barium & 0.000017 & $<0.000001$ & 34 \\
\hline Beryllium & $<0.000001$ & $<0.000001$ & 5 \\
\hline Cadmium & 0.000003 & $<0.000001$ & 11 \\
\hline Chromium & 0.000006 & $<0.000001$ & 80 \\
\hline Cobalt & 0.000040 & $<0.000001$ & 23 \\
\hline Copper & 0.000012 & $<0.000001$ & 40 \\
\hline Manganese & 0.000020 & $<0.000001$ & 10 \\
\hline Mercury & 0.000001 & $<0.000001$ & 1,127 \\
\hline Molybdenum & 0.000005 & $<0.000001$ & 9 \\
\hline Nickel & 0.000563 & $<0.000001$ & 424 \\
\hline Selenium & 0.000005 & $<0.000001$ & 382 \\
\hline Vanadium & 0.000212 & $<0.000001$ & 2 \\
\hline Zinc & 0.000194 & 0.000003 & N \\
\hline
\end{tabular}

Table 10: Airborne Emissions from Fuel Combustion (lbs/thermal unit)

\begin{tabular}{|c|c|c|c|}
\hline Element & \#6 Bunker Fuel & Natural Gas $^{1}$ & Average Industry Yearly Reduction $^{2}$ \\
\hline Carbon Dioxide & 16.2667 & 0.0082 & $(9,804)$ \\
\hline Carbon Monoxide & 0.0033 & 0.0001 & 409,749 \\
\hline Sulfur Oxides & 0.2049 & 0.0186 & 25,412 \\
\hline Nitrous Oxides & 0.0313 & 0.0002 & 28,427 \\
\hline Filterable Particulate Matter & 0.0144 & 0.0011 & $(450)$ \\
\hline Total Organic Compounds & 0.0009 & 0.0002 & 882 \\
\hline Methane & 0.0007 & $<0.000001$ & 29 \\
\hline Benzene & $<0.000001$ & 0.000007 & 2 \\
\hline Formaldehyde & 0.000022 & $<0.000001$ & 8 \\
\hline Napthalene & 0.000001 & $<0.000001$ & $(9,804)$ \\
\hline Toluene & 0.000004 & 0.0082 & 29 \\
\hline
\end{tabular}

${ }^{1}$ Annual use for average industrial customer on NW Natural system in Oregon.

${ }^{2}$ Figures are calculated per Emission Factors from EPA manual AP-42, "Compilation of Air Pollutant Emission Factors" AP-42, Fifth Edition, Volume 1 Chapter 1, Tables 1.3-1 and 1.4-1, et seq. \{www.epa.gov//ttn/chief/ap42\} 


\section{Natural Resources}

\section{Cultural Resources (Including Native American Religious Concerns)}

\section{Background}

See Appendix B for background information regarding this resource. Recommendations given in Appendix B will be followed prior to and during construction.

\section{Environmental Consequences and Comparison of Alternatives}

\section{Direct, Indirect and Cumulative Effects}

\section{No Action Alternative}

No impacts.

\section{Proposed Action}

- Direct Impacts: Onsite monitoring by qualified archaeologists and designated tribal representatives will be present to monitor during construction, areas that historical records and field tests have identified as having potential cultural resources (see maps in Appendix B). All identified resource areas would be avoided (go around or directionally-drill underneath the area) by construction activities for the proposed action. Therefore, there are no anticipated potential direct impacts from pipeline construction. After construction, paving of approximately 15 miles of gravel road on the CBW Road will occur. If this is the case, a formal Determination of Eligibility document will be prepared for the CBW Road and submitted to the State Historic Preservation Office for evaluation prior to paving. If the CBW Road is determined to be eligible for the National Register for Historic Places, then a Determination of Effect would be prepared for the proposed alterations (paving) to the gravel portions of the CBW Road.

- Indirect Impacts: None

- Cumulative Impacts: None

\section{Hwy 42 Alternative}

- Direct Impacts: No anticipated impacts, as all construction would occur on paved roads.

- Indirect Impacts: None

- Cumulative Impacts: None

\section{Soils}

Refer to Appendix A for background information on soils.

\section{Environmental Consequences and Comparison of Alternatives}

Direct, Indirect and Cumulative Effects

\section{No Action Alternative}

No impacts. 


\section{Proposed Action}

- Direct Impacts: The proposed action alternatives require placement of a pipeline in existing road grades and/or utility corridors. Any potential short-term risk of soil loss has been minimized or eliminated by the Erosion Control Plan (Appendix H) and the PDCs for culvert placement to be so small, as to be unmeasurable (i.e., negligible) at the watershed level of assessment (5th field HUC). In areas where ground-disturbing activities occurs outside of roadways, the proposed action may negatively impact soil productivity due to compaction and backfilling with soils containing less organics than the material removed for pipe placement. The total acres of potentially reduced soil productivity under the proposed action is approximately 56 acres (Table 11).

Table 11: Acreage of soil area impacted by watershed in the proposed action.

\begin{tabular}{|c|c|c|}
\hline Watershed & Total Acres Impacted & Percent of Total Impact \\
\hline Lower South Umpqua & 5.6 & 10 \\
\hline Ollala-Lookingglass & 25.3 & 45 \\
\hline East Fork Coquille & 5.5 & 10 \\
\hline Lower Coos-Coos Bay & 6.6 & 12 \\
\hline North Fork Coquille River & 13.0 & 23 \\
\hline Middle Main Fork Coquille & 0.0 & 0 \\
\hline Totals & 56.0 & 100 \\
\hline
\end{tabular}

The proposed action's watersheds listed in Appendix E are approximately 55,000 to over 100,000 acres in size. The few acres of potentially reduced soil productivity in each basin is so small that it would be unmeasurable (i.e., negligible). The Middle Main Fork Coquille Watershed has no construction area outside of roadways, therefore, there is no anticipated impact to its watershed soil productivity.

- Indirect Impacts: Potential changes in soil bulk density and drainage on the approximately 56 acres of impacted construction area.

- Cumulative Impacts: None

\section{Hwy 42 Alternative}

- Direct Impacts: No anticipated impacts, as all construction would occur on paved roads.

- Indirect Impacts: None

- Cumulative Impacts: None

\section{Vegetation}

\section{Background}

One of the goals of the management guidelines in the Roseburg RMP (USDI 1995a), Integrated Weed Control EA (USDI 1995b) and Coos Bay BLM RMP (USDI 1994) concerning noxious weeds, was to prevent the spread or infestation on BLM-managed lands. For Port-Orford-cedar (POC), a primary management objective is to limit the spread of the root pathogen Phytophthora lateralis (PI), which causes rapid mortality to POC.

Because the proposed action requires ground-disturbance in existing utility corridors, some preventative PDCs will be implemented to avoid further spread of noxious weeds and Pl within the powerline ROWs. 


\section{Vegetation, Including T\&E, Survey and Manage, Special Status, and Noxious Weeds}

The proposed action corridor was surveyed in autumn of 2000 and spring/summer of 2001 for T\&E, Special Status, Survey and Manage and noxious weed species. There is considerable man-made disturbance already occurring within it. The CBW Road sits on an average of five feet of fill dirt. In the powerline ROW, sub-climax vegetation predominates. All trees have been removed except in one draw on private property, where they will not interfere with powerlines. The powerline is serviced by access roads which are maintained by periodic bulldozing. In addition, there are dirt roads leading to the electrical towers leaving areas of exposed soil. Invasive weeds (including noxious weeds) are prevalent throughout this utility corridor. Because of the continuous intensive vegetation removal required by the County, BPA/PP\&L management plans, little change in the sub-climax/disturbed vegetal regime is anticipated. Botanical field surveys found no presence of Threatened \& Endangered, Special Status or Survey and Manage habitats or species (including bryophytes, lichens and fungi) in the pipeline construction corridor. Some noxious weeds, however, were found (Table 12).

\section{Table 12: $\quad$ Noxious Weeds in Utility Corridor}

\begin{tabular}{|c|c|}
\hline Common & Scientific \\
\hline Butt thistle & Cirsium vulgare \\
\hline Canada thistle & Circium arvense \\
\hline Gorse & Ulex europaeus \\
\hline Himalayan blackberry & Rubis discolor \\
\hline Scotch broom & Cytisus scoparius \\
\hline St. Johns Wort & Hypericum perforatum \\
\hline Tansey ragwort & Senecio jacobaea \\
\hline
\end{tabular}

Himalayan blackberry, Scotch broom, St. Johns Wort and Bull thistle occur throughout the utility corridor, varying in abundance from dense to scattered. Gorse was found on private land adjacent to BLM (T28S, R11W Sect. 10, NW 1/ 4 NE 1/4). Tansy ragwort and Canada thistle occur in an adjacent riparian area on Reston Ridge.

The nearest plant of concern was the federally endangered Western lily (Lilium occidentale) focated along the coastal strand which extends 4 miles inland near Bandon. Site surveys made for Oregon Natural Heritage tracking species in the vicinity of the proposed action corridor, listed only Cusick's Checker Mallow (Sidalcea cusickii), which was found in the Umpqua and Coquille Valleys in moist habitat.

\section{Environmental Consequences and Comparison of Alternatives}

\section{No Action Alternative}

- Direct Impacts: This alternative would have no direct impacts on the plant community in the proposed action area. No ground disturbance would occur under this alternative.

- Indirect Impacts: This alternative would have no indirect effects on the plant community in the proposed action area. No ground disturbance would occur under this alternative.

- Cumulative Impacts: This alternative would have no cumulative effects on the plant community in the proposed action area. No ground disturbance would occur under this alternative. 


\section{Proposed Action}

- Direct Impacts: Because field surveys found no T\&E, Special Status or Survey and Manage species (including bryophytes, lichens and fungi) or habitats in the proposed action area, the project would have no direct impact to these species.

- Bare soil would be temporarily exposed to possible invasion of noxious weeds. After ground disturbing activities, the bare soil areas on BLM property will be seeded and mulched with approved BLM-seed mixtures to enhance propagation of desirable plant species and minimize potential for weed encroachment. Private land areas would receive the same post-construction treatment, except that a state-approved seed mix for the Oregon Coast Range (Appendix H) will be used on those ownerships. There would be no impact to POC since none exist in the proposed action corridor. Prior to ground-disturbing activities, construction areas with noxious weeds that have not been sprayed as part of the County's CBW Road or BPA/PP\&L corridor maintenance plans, will be treated mechanically. Post-construction treatment (mechanical or herbicides) of disturbed areas for noxious weeds will occur the following year in areas where noxious weeds have invaded disturbed ground from pipeline construction.

- Because of the treatments for noxious weeds and the ongoing disturbance in the CBW Road and utility corridors, no measurable direct impacts from noxious weeds is anticipated from the proposed action

- Temporary removal of grasses, weeds and small shrubs would occur in the proposed action from ground-disturbing activities. Until the vegetation regrows, the seeded plants will temporarily replace the sub-climax grasses, weeds and small shrubs now present in the 56 acres to be disturbed within the utility corridors.

- Indirect Impacts: Indirect effects would include the potential for long-term increased spread of noxious weeds in the project area which may displace native plant species habitats. There would be no indirect effects for T\&E, Special Status or Survey and Manage species (including bryophytes, lichens and fungi), since none exist in the proposed action area.

- Cumulative Impacts: The cumulative effects would include the potential increase of noxious weeds in the powerline utility corridor area. There would be a temporary reduction in the amount of vegetation which protects the soil in the existing powerline ROW, thus increasing the risk of weed invasion. There would be no cumulative impacts for T\&E, Special Status or Survey and Manage species (including bryophytes, lichens and fungi), since none exist within the proposed action area.

\section{Hwy 42 Alternative}

- Direct Impacts: This alternative would have no anticipated direct impact on the plant communities, including POC in the proposed action area, as ground disturbance would be limited to roadways.

- Indirect Impacts: This alternative would have no indirect effect on the plant communities in the proposed action area, as no ground disturbance outside of roadways were anticipated.

- Cumulative Impacts: This alternative would have no cumulative effect on the plant community in the proposed action area.

\section{Floodplains}

\section{Direct, Indirect and Cumulative Effects}

\section{No Action Alternative}

No impact.

\section{Action Alternatives}

Both corridors are adjacent to 100-year floodplains. Each corridor's adjacent area (2.2 miles for proposed action and 15.3 miles for Hwy 42 alternative) to the floodplain are on roadways that sit well above the floodplain on 5-10 feet of road fill. No anticipated impacts. 


\section{Wild and Scenic Rivers}

\section{All Alternatives}

No Wild and Scenic Rivers exist in any alternative. No effect.

\section{Wildlife}

\section{Federally Listed, Proposed or Candidate Species}

This section discusses the potential effects to species listed as threatened or endangered, or proposed for listing, under the Endangered Species Act of 1973, as amended. It only discusses in detail those listed terrestrial species that have the potential to be affected by the proposed actions. Other listed, candidate and proposed species will not be affected by the proposed actions. Also see Appendix F for the USFWS Letter of Concurrence.

\section{Northern Spotted Owl}

\section{Background}

The management and recovery of northern spotted owls is an important consideration and received extensive attention to the Northwest Forest Plan Final Supplemental Environmental Impact Statement (FSEIS) (USDA, USDI 1994a, pp. 3\&4; 211 through 245 and Appendices G, J1, J3). Late-Successional Reserve Assessments have been developed for the BLM-Coos Bay District's LSR \#261 containing CHU OR60 (northern spotted owl), and CHUs OR06-B and OR-06-D (marbled murrelet). Because of implemented PDCs, impacts to these designated species and habitats are avoided. None of the proposed actions will affect or degrade any late-successional habitats in these CHUs/LSRs, nor will they slow habitat development in these CHUs/LSRs.

Detailed accounts of the taxonomy, ecology and reproductive characteristics of the spotted owl are found in the Status Reviews produced by the USFWS (USDI 1987, 1990a); the 1989 Status Review Supplement (USDI 1989); the Interagency Scicntific Report (Thomas et al. 1990); and the final rule designating the spotted owl as a threatened species (USDI 1990b). There are approximately 5,608 pairs of northern spotted owls and resident singles (activity centers) and approximately 8.1 million acres of suitable habitat currently cstimated across the range of the species (Holzman, USFWS, pers. comm. 1995). Recent demographic studies (Burnham et al. 1994) indicate that the population is declining. While such a decline is expected to continue as spotted owl sites with severely degraded habitat conditions become inactive, implementation of the NFP is expected to abate the decline by protecting all spotted owl sites within LSRs. The NFP will provide for the conservation of the species by allowing non-suitable, but capable habitat to regenerate within the LSRs to allow the population to increase and stabilize across its range. Preliminary results from a more recent (December 1998) meta-analysis of available demographic data for the period 1985-1998, though, found no evidence of a dechine in reproduction or in the overall annual survival probability during the period of study (Forsman and Anthony 1999).

The 1990 Spotted Owl Status Review Committee stated that population size is primarily a function of the amount and distribution of available habitat (USDI 1990a). In developing a conservation strategy for late-successional and oldgrowth forest-associated species, the Departments of Interior and Agriculture developed a network of late-successional and old-growth habitat reserves across the Pacific Northwest. This network of Late-Successional Reserves is designed to conserve forest species closely associated with late-successional and old-growth forest habitat where habitat conditions are relatively intact and also provide for the regeneration of late-successional forest habitat where habitat is extremely limited and the reliant plant and wildlife populations are low.

On the Coos Bay District BLM, the early nesting season is considered March 1 through June 30 . The intent in selecting 30 June is to insure that nearly all young northern spotted owls will have left the nest tree and be somewhat mobile by this date. We reviewed over 700 nesting status records for 1990-1994 on the District; 0.1 percent of the records indicated young owls were still in the nest tree by June 30 suggesting that this date is reasonable.

\section{Environmental Consequences and Comparison of Alternatives}

\section{Direct and Cumulative Effects}




\section{All Alternatives}

None of the alternatives have direct or cumulative impacts on the northern spotted owl, because they do not remove or degrade any suitable habitat for this species.

\section{Indirect Effects}

\section{All Alternatives}

The potential indirect impacts due to disturbance from equipment noise are avoided in the PDCs (listed below), which provide both seasonal and daily timing restrictions that would eliminate most, if not all, potential short-term (1-7 days) adverse indirect effects.

Habitat or Individuals

A. No habitat would be removed from proposed actions.

\section{Disturbance}

A. Work activities such as trenching, pipe-laying and re-paving, would not take place within 0.25 -mile of any nest site or activity center of known pairs and resident singles between March 1st and June 30th.

B. This PDC may be waived in a particular year by the USFWS, if nesting or reproductive success surveys conducted according to the USFWS-endorsed survey guidelines reveal that northern spotted owls are non-nesting or that no young-of-the-year are present. Waivers are only valid until March 1st of the following year. Previously known sites and activity centers are assumed occupied unless surveys indicate otherwise.

C. No helicopter activities will occur during construction.

D. Blasting would not occur within 1 mile of suitable habitat March 1st to June 30th.

E. Blasting would not occur within 1 mile of known nest sites March 1st to September 30th.

F. A wildlife Biologist will monitor the above measures on-site.

\section{Marbled Murrelet}

\section{Background}

The management and recovery of marbled murrelets is an important consideration and received extensive attention to the Northwest Forest Plan Final SEIS (USDA, USDI 1994a, pp. 3\&4; 245 through 249, and Appendices G and J2). Late-Successional Reserve Assessments have been developed for the BLM-Coos Bay District's LSR \#261 containing CHU OR60 (northern spotted owl), and CHUs OR06-B and OR-06-D (marbled murrelet). Because of implemented PDCs, direct and cumulative impacts to these designated species and habitats are avoided. None of the proposed actions will affect or degrade any late-successional habitats in these CHUs/LSRs, nor will they slow habitat development in these CHUs/LSRs.

An account of the taxonomy, ecology, and reproductive characteristics of the marbled murrelet is found in Marshall 1988, USDI 1992b, USDI 1996, USDI 1994, USDA USDI 1994b, and USDI 1997. The U.S. Forest Service has published the Ecology and Conservation of the Marbled Murrelet, an up-to-date and comprehensive summary of the status of the species, which was peer reviewed by representatives of numerous wildlife and ecological societies (Ralph et al. 1995). This document makes several key points regarding the status of the marbled murrelet. Population trends are clearly downward. Ralph et al. (1995) and USDI (1997) suggested possible reasons for the decline include the species' dependence on older forests for nesting (forests which are now scarce and highly fragmented); its low reproductive rate; and adult mortality due to predation, capture in gill nets, and encounters with oil spills. The amount and distribution of the remaining suitable habitat is considered to be the most important determinant of the long-term population trend and further loss may severely hamper the stabilization and recovery of the species. 
Most population estimates for marbled murrelets have been conducted using at-sea surveys and are subject to many sources of error, such as the methods of counting flying birds, environmental conditions, and observer ability (Ralph et al. 1995). These sources of error may also change with the season and location of the surveys.

Population estimates for the marbled murrelet in Oregon vary substantially. For example, Varoujean and Williams (1995) used aerial surveys conducted along the entire Oregon Coast in August and September 1993 to estimate that 6,600 marbled murrelets occur in Oregon. In a different study, Strong et al. (1995) used boat surveys to estimate that 15-20,000 marbled murrelets occur in Oregon; they caution that large numbers of non-breeding adults and low numbers of fledglings on the water may be due to a lack of suitable nesting habitat.

Population estimates for Washington and California are less variable. Spiech and Wahl (1995) concluded that marbled murrelet populations in Puget Sound are lower now than they were at the beginning of this century, and total estimates for Washington are about 5,500 marbled murrelets (Ralph et al. 1995). Ralph and Miller (1995) estimated the California population to be approximately 6,500 birds.

Beissinger (1995) constructed a demographic model of the marbled murrelet and concluded that the population may be declining at rates of 4-6 percent per year; but this estimate is limited by the possibility that the age-ratio data used in the model are reflective of a relatively temporary decline due to unusual ocean conditions (Ralph et al. 1995).

Ralph et al. (1995) summarized some of the reasons for population estimate variability among researchers, including differences in methodology, assumptions, spatial coverage, and survey and model errors. Nevertheless, both Ralph et al. (1995) and USDI (1997) have concluded that the listed population appears to be in a long-term downward trend.

There are approximately 979 known marbled murrelet occupied sites within Washington, Oregon, and California (Holzman, USFWS, pers. comm. 1995). Total number of suitable habitat acres in these three states is unknown. Ralph et al. (1995) estimated there are 2,561,500 acres of suitable habitat for the marbled murrelet on Federal lands in the listed range of this species.

\section{Environmental Consequences and Comparison of Alternatives}

\section{Direct and Cumulative Effects}

\section{All Alternatives}

None of then alternatives have direct or cumulative impacts on the marbled murrelet, because they do not remove or degrade any suitable habitat for this species.

\section{Indirect Effects}

\section{All Alternatives}

The potential indirect impacts due to disturbance from equipment noise are addressed in the PDCs (listed below), which provide both seasonal and daily timing restrictions that would eliminate most, if not all, potential short-term (1-7 days) adverse indirect effects.

\section{Disturbance}

A. Daily timing of the project's "Moderately above ambient noise levels for less than 1 week" and related activities occurring within 0.25 -mile of unsurveyed suitable habitat, shall be no earlier than 2 hours after sunrise and no later than 2 hours before sunset from April 1st to September 15th.

B. Daily timing of the project's "Moderately above ambient noise levels for less than 1 week" and related activities occurring within 0.25 -mile of occupied habitat, shall be seasonally restricted from April 1st to August 5 th.

C. Daily timing of the project's "Moderately above ambient noise levels for less than 1 week" and related activities occurring within 0.25 -mile of occupied habitat, shall be no earlier than 2 hours after sunrise and no later than 2 hours before sunset from August 6th to September 15th. 
D. No blasting will occur within 1 mile of occupied or unsurveyed suitable habitat April 1st to September 15th.

E. No helicopter activities will occur during construction.

F. A wildlife Biologist will monitor the above measures on-site.

\section{Bald Eagle}

\section{Background}

Breeding and wintering populations of the bald eagle occur throughout Southwest Oregon. Recovery efforts for Bald Eagles have allowed populations to increase to the extent that the species is now proposed for delisting in the lower 48 states (USFWS 1999).

The population in Oregon is listed as threatened. Its present status is a result of past and present destruction of habitat, a declining food base, environmental contaminants, disturbance, electrocution, and illegal harassment including, but not limited to shooting, and poisoning. Currently the primary threats to bald eagles are habitat degradation and, in some areas, environmental contaminants.

In the Pacific Northwest, bald eagles typically nest in multi-layered, coniferous stands with old-growth trees located within a mile of large bodies of water (USDI 1986). Availability of suitable trees for nesting and perching is critical for maintaining bald eagle populations. The Pacific Northwest is a key area for wintering bald eagles and supports over 25 percent of the wintering bald eagles in the lower 48 states (USDI 1986). Wintering sites are typically in the vicinity of concentrated food sources such as anadromous fish runs, and high concentrations of waterfowl or mammalian carrion.

A number of habitat features are desirable. Eagles need perch trees for hunting and resting. These trees typically provide an unobstructed view of the surrounding area and are usually near nests or feeding areas such as large rivers.

\section{Environmental Consequences and Comparison of Alternatives}

\section{Direct and Cumulative Effects}

\section{All Alternatives}

None of the alternatives would have direct or cumulative effects on bald eagles or bald eagle habitat management because no suitable habitat would be removed.

\section{Indirect Effects}

\section{All Alternatives}

The potential indirect impacts due to disturbance of resident bald eagle nests along these corridors from equipment noise are addressed in the PDCs (listed below), which provide both seasonal and daily timing restrictions that would eliminate most, if not all, potential adverse effects.

\section{Disturbance}

A. Work activities that cause disturbance would not take place within 1312 feet of active nests and roosts, or within 2625 feet line-of-sight from nests and roosts during periods of eagle use unless field surveys demonstrate that the nest or roosts are not being used during the normal season of use. For nests, the period of eagle use is January lst to August 31 st (or two weeks post-fledging). For roosts, the period of eagle use is November 15th to March 15 th.

B. No helicopter activities will occur during construction. 


\section{BLM Special Status Species}

\section{Background}

According to the definition in the BLM 6840 policy, a special status designation includes species that could easily become endangered or extinct in state. They are either restricted in range or have natural or human-caused threats to survival. Special Status species are not listed, proposed or candidate species, but are eligible for federal or state listing or candidate status. BLM Special Status Species are designated by the BLM State Director. BLM 6840 policy requires that any BLM action will not contribute to the need to list any of these species. (A list of these species is found in Appendix K1.) Noise disturbance is assessed out to 0.25-mile from all construction-related activities.

\section{Environmental Consequences and Comparison of Alternatives}

\section{Direct and Cumulative Effects}

\section{All Alternatives}

Both action alternatives would have no direct or cumulative effect on Special Status Species. No individuals or suitable habitat would be removed due to the proposed or Hwy 42 alternative actions.

\section{Indirect Effects}

\section{All Alternatives}

Vertebrates spending part of their life-history cycle adjacent to the proposed action corridor during active construction may be disturbed by short-term (1-7 days) ambient noise from heavy equipment used to lay pipe. There are no management requirements or PDCs for any special status species. Although no documented locations of special status vertebrates are known adjacent to the pipeline corridor, some minor disturbance potential is assumed, because adjacent suitable habitat has not been surveyed for special status species.

Some special status bats and birds that use the utility corridors for diurnal and nocturnal foraging, may be disturbed away from those areas where construction is active, to alternate foraging areas further from construction noise. The number of special status species individuals utilizing the powerline corridor for foraging has not been documented, and is unknown. Because construction is short-term ( $1-7$ days) with moderate noise above ambient background levels, any indirect impacts to special status species from indirect noise effects would be negligible.

\section{Survey and Manage Species}

Survey and Manage species represent flora and fauna in the NFP area that are believed to be locally rare, with a limited habitat range requiring late-successional forests; some are endemic to western forests in southwestern Oregon. See Appendix K for list of these species. Noise disturbance is assessed out to 0.25 -mile from all construction-related activities.

\section{Environmental Consequences and Comparison of Alternatives}

\section{All Alternatives}

- Direct Impacts: The proposed action would have no direct effects on Survey and Manage Species habitats or individuals.

- Indirect Impacts: Except for the possibility of noise disturbance affecting individual red tree voles in adjacent suitable habitat areas, the proposed action would have no other anticipated indirect impacts on Survey and Manage Species in the proposed action areas, as no ground-disturbing activities occur within their habitats. The number of red tree vole individuals utilizing habitat adjacent to the pipeline corridor for breeding, feeding 
and sheltering has not been documented and is unknown. Because construction is short-term (1-7 days) with moderate noise above ambient background levels during the daytime only, any indirect impacts to nocturnal red tree voles from indirect noise effects would be negligible.

- Cumulative Impacts: None

\section{Other Wildlife}

Noise disturbance is assessed out to 0.25 -mile from all construction-related activities.

\section{Environmental Consequences and Comparison of Alternatives}

\section{No Action Alternative}

No anticipated Direct, Indirect or Cumulative Impacts.

\section{Proposed Action}

- Direct Impacts: Birds that utilize small shrubs as part of their life-history cycle may temporarily lose some potential shrub habitat in the utility corridor in areas of ground disturbance from construction. Approximately 0.2 -acre of conifer plantation trees on private land would be removed in the utility corridor (under the powerlines that span two hillsides). Although these trees are immature ( 25 years old) and densely packed ( 300 trees per acre), they do offer perches for flycatchers and other avian insect foragers that may use the powerline/utility corridor for feeding. Habitat loss from tree and shrub removal would be long-term impacts.

- Indirect Impacts: Short-term (1-7 days) noise disturbance from heavy equipment in the proposed action corridor during the active construction period may briefly impact individual diurnal mammals, herptofauna and birds that utilize powerline corridors or adjacent habitats for travel or foraging. Nocturnal use of the powerline ROWs (by owls, bats, etc.) would remain relatively unchanged and undisturbed, as no nighttime construction activity is anticipated.

- Cumulative Impacts: None

\section{Hwy 42 Alternative}

- Direct Impacts: None are anticipated, as no individuals or habitat would be removed.

- Indirect Impacts: Noise disturbance from heavy equipment in the Hwy 42 corridor during the active construction period may briefly impact individual mammals, herptofauna, and birds that utilize habitats adjacent to the highway. However, construction noise should not be measurably greater (i.e., negligible) than normal levels caused by highway traffic and should not add any measurable impacts.

- Cumulative Impacts: None

\section{Aquatic Ecosystem}

\section{Background}

The ACS is a habitat-based approach for restoration and maintenance of watersheds and the aquatic ecosystems contained within them on federally managed lands (USDA, USDI 1994a and USDA, USDI 1994b). When assessing discretionary federal actions (as in this document), analyses must include effects on the non-federal lands contained in the proposed actions. This is exactly what occurred. In fact, the emphasis of this document's assessment is on nonfederal lands in the proposed action, because BLM-managed lands represent only 3.5 percent of the proposed action corridor. The foundation principle for maintaining and restoring aquatic habitats within the NFP area was avoidance 
of species-specific strategies in the ACS objectives. The NFP Record of Decision emphasized this foundation strategy by stating:

"Any species-specific strategy aimed at defining explicit standards for habitat elements would be insufficient for protecting even the targeted species. The Aquatic Conservation Strategy must strive to maintain and restore ecosystem health at watershed and landscape scales to protect habitat for fish and other ripariandependent species and resources and restore currently degraded habitats." (USDA, USDI 1994b, p. B-9)

The components of the proposed action aquatic management plan (watershed analysis and watershed protection/restoration), provide the fundamental building blocks for protecting aquatic and riparian-dependent flora and fauna. Coupled with watershed analysis (Appendix E), other elements of the aquatic management plan (Appendix H) within the proposed action are designed to protect in the short-term and enhance in the long-term, water quality and aquatic/ riparian habitats for those aquatic/riparian-dependent species throughout all federal and non-federal landholdings within the scope of the proposed action. The Coos Bay and Roseburg Distriets' Watershed Analyses (containing the Hwy 42 and the proposed action's affected areas) give watershed baseline conditions that are used to assess impacts of the proposed actions on the aquatic ecosystem.

\section{Environmental Consequences and Comparison of Alternatives}

Following the ACS provides significant protection for aquatic and riparian-dependent flora and fauna, regardless of the alternative selected. All of the alternatives in this EIS are consistent with the ACS objectives (Appendix E), and the action alternatives contain specific measures to minimize risk to aquatic and riparian-dependent flora and fauna.

\section{No Action Alternative}

Under this alternative, there would be no impaets (including no potential beneficial impaets).

\section{Hwy 42 Alternative}

The Hwy 42 action alternative would contain the same proteetive measures for building a natural gas pipeline as the proposed action, which successfully minimizes potential adverse impacts to the aquatic ecosystem. The differences occur mainly in corridor length (the proposed action is the shortest) and in the number of streams/wetlands erossed (the proposed action has the least). (See Action Alternatives Route Summary Table 2, Chapter 2) Also, the Hwy 42 alternate route lacks the beneficial mitigation measures (adding cross-drains and paving) contained in the proposed action for enhancing the sedimentation and turbidity baseline habitat elements.

\section{HABITAT ELEMENT}

Sedimentation

Turbidity

Improvement in the physical barrier baseline would be achieved by replacing at least 2 deteriorating culverts that presently block fish passage.

\section{Proposed Action}

After assessing potential impacts in all six watershed analyses, the proposed action effects on baseline conditions of two habitat elements were identified for their potential insignificant impacts to the aquatic ecosystem. These two elements are sedimentation and turbidity. (Appendix E contains the specific assessments by watershed for each habitat element identified in their pertinent watershed analysis area.) The protective measures (Appendix H) contained in the proposed action's overall ECP, are specifically designed to avoid most adverse impacts to the two habitat elements (sedimentation and turbidity) identified as potentially impacted by pipeline construction. Furthermore, specific mitigation has been identified to restore the sedimentation, turbidity and physical barrier (fish passage) baselines. That is, the proposed action is designed to avoid adverse impacts to the aquatic ecosystem while providing substantive beneficial impacts. 


\section{HABITAT ELEMENT}

Sedimentation

Turbidity

\section{IMPACT}

Insignificant

Insignificant

Improvement in the sedimentation and turbidity baselines would be achieved through paving approximately 15 miles of the CBW Road that is presently a gravel-dirt surface. This paving would be spread across 4 watersheds: East Fork Coquille - 10.3 miles, Middle Main Coquille - 1.9 miles, North Fork Coquille - 1.0 mile and Lower Coos/Coos Bay 1.9 miles. Gravel-dirt roads have been identified as the major source of sediment and turbidity, and paving of approximately I5 miles would provide long-term benefits to these watersheds.

Improvement in the physical barrier baseline would be achieved by replacing 3 deteriorating culverts that presently block anadromous fish passage within the East Fork Coquille Watershed. 


\section{Summary of the Lower South Umpqua Watershed Road Corridor Stream Crossings}

A total of 8 intermittent streams within the Lower South Umpqua Watershed would be affected by the proposed action (Table 13). All of the construction (trenching) in this watershed would occur when these streams are dry within the utility ROWs.

Table 13: $\quad$ Stream Description and Crossing Type on Utility Corridor within the Lower South Umpqua Watershed (5th field HUC)

\begin{tabular}{|c|c|c|c|c|c|c|}
\hline Slope & $\begin{array}{l}\text { Stream } \\
\text { Width } \\
\text { (feet) }\end{array}$ & $\begin{array}{c}\text { Dry } \\
\text { Streams }\end{array}$ & $\begin{array}{l}\text { Bag \& } \\
\text { Flume }\end{array}$ & $\begin{array}{l}\text { Directionally } \\
\text { Drilled }\end{array}$ & $\begin{array}{c}\text { Hang on } \\
\text { Bridge }\end{array}$ & $\begin{array}{c}\text { Cross } \\
\text { Culvert (in } \\
\text { road fill) }\end{array}$ \\
\hline \multirow{3}{*}{$\begin{array}{l}\text { Gentle Peren- } \\
\text { nial } \\
(<2 \% \text { rise })\end{array}$} & $0-15$ & 0 & 0 & 0 & 0 & 0 \\
\hline & $15-30$ & 0 & 0 & 0 & 0 & 0 \\
\hline & $>30$ & 0 & 0 & 0 & 0 & 0 \\
\hline \multirow{3}{*}{$\begin{array}{l}\text { Moderate } \\
\text { Perennial } \\
(2-4 \% \text { rise })\end{array}$} & $0-15$ & 0 & 0 & 0 & 0 & 0 \\
\hline & $15-30$ & 0 & 0 & 0 & 0 & 0 \\
\hline & $>30$ & 0 & 0 & 0 & 0 & 0 \\
\hline \multirow{3}{*}{$\begin{array}{l}\text { Steep } \\
\text { Perennial } \\
(>4 \% \text { rise })\end{array}$} & $0-15$ & 0 & 0 & 0 & 0 & 0 \\
\hline & $15-30$ & 0 & 0 & 0 & 0 & 0 \\
\hline & $>30$ & 0 & 0 & 0 & 0 & 0 \\
\hline \multirow{3}{*}{$\begin{array}{l}\text { Gentle } \\
\text { Intermittent } \\
(<2 \% \text { rise })\end{array}$} & $0-15$ & 0 & 0 & 0 & 0 & 0 \\
\hline & $15-30$ & 0 & 0 & 0 & 0 & 0 \\
\hline & $>30$ & 0 & 0 & 0 & 0 & 0 \\
\hline \multirow{3}{*}{$\begin{array}{l}\text { Moderate } \\
\text { Intermittent } \\
(2-4 \% \text { rise })\end{array}$} & $0-15$ & 5 & 0 & 0 & 0 & 0 \\
\hline & $15-30$ & 0 & 0 & 0 & 0 & 0 \\
\hline & $>30$ & 0 & 0 & 0 & 0 & 0 \\
\hline \multirow{3}{*}{$\begin{array}{l}\text { Steep } \\
\text { Intermittent } \\
(>4 \% \text { rise })\end{array}$} & $0-15$ & 3 & 0 & 0 & 0 & 0 \\
\hline & $15-30$ & 0 & 0 & 0 & 0 & 0 \\
\hline & $>30$ & 0 & 0 & 0 & 0 & 0 \\
\hline \multicolumn{2}{|l|}{ TOTAL } & 8 & 0 & 0 & 0 & 0 \\
\hline
\end{tabular}




\section{Summary of the Olalla Creek/Lookingglass Creek Watershed Road Corridor Stream Crossings}

A total of four streams within the Olalla Creek/Lookingglass Creek Watershed would be affected by the proposed action in the CBW Road. Two crossings occur within the roadbed of existing public roads, and two perennial streams would be crossed using the bag and flume method (Table 14).

Table 14: Stream Description and Crossing Type on Road Corridor within the Olalla Creek/ Lookingglass Creek Watershed (5th field HUC)

\begin{tabular}{|c|c|c|c|c|c|c|}
\hline Slope & $\begin{array}{l}\text { Stream } \\
\text { Width } \\
\text { (feet) }\end{array}$ & $\begin{array}{c}\text { Dry } \\
\text { Streams }\end{array}$ & $\begin{array}{l}\text { Bag \& } \\
\text { Flume }\end{array}$ & $\begin{array}{l}\text { Directionally } \\
\text { Drilled }\end{array}$ & $\begin{array}{l}\text { Hang on } \\
\text { Bridge }\end{array}$ & $\begin{array}{l}\text { Cross } \\
\text { Culvert (in } \\
\text { road fill) }\end{array}$ \\
\hline \multirow{3}{*}{$\begin{array}{c}\text { Gentle Peren- } \\
\text { nial } \\
(<2 \% \text { rise })\end{array}$} & $0-15$ & 0 & 1 & 0 & 0 & 0 \\
\hline & $15-30$ & 0 & 0 & 0 & 0 & 0 \\
\hline & $>30$ & 0 & 0 & 0 & 0 & 0 \\
\hline \multirow{3}{*}{$\begin{array}{c}\text { Moderate } \\
\text { Perennial } \\
(2-4 \% \text { rise })\end{array}$} & $0-15$ & 0 & 0 & 0 & 0 & 0 \\
\hline & $15-30$ & 0 & 0 & 0 & 0 & 0 \\
\hline & $>30$ & 0 & 0 & 0 & 0 & 0 \\
\hline \multirow{3}{*}{$\begin{array}{c}\text { Steep } \\
\text { Perennial } \\
(>4 \% \text { rise })\end{array}$} & $0-15$ & 0 & 1 & 0 & 0 & 0 \\
\hline & $15-30$ & 0 & 0 & 0 & 0 & 0 \\
\hline & $>30$ & 0 & 0 & 0 & 0 & 0 \\
\hline \multirow{3}{*}{$\begin{array}{c}\text { Gentle } \\
\text { Intermittent } \\
(<2 \% \text { rise })\end{array}$} & $0-15$ & 0 & 0 & 0 & 0 & 1 \\
\hline & $15-30$ & 0 & 0 & 0 & 0 & 0 \\
\hline & $>30$ & 0 & 0 & 0 & 0 & 0 \\
\hline \multirow{3}{*}{$\begin{array}{c}\text { Moderate } \\
\text { Intermittent } \\
(2-4 \% \text { rise })\end{array}$} & $0-15$ & 0 & 0 & 0 & 0 & 1 \\
\hline & $15-30$ & 0 & 0 & 0 & 0 & 0 \\
\hline & $>30$ & 0 & 0 & 0 & 0 & 0 \\
\hline \multirow{3}{*}{$\begin{array}{c}\text { Steep } \\
\text { Intermittent } \\
(>4 \% \text { rise })\end{array}$} & $0-15$ & 0 & 0 & 0 & 0 & 0 \\
\hline & $15-30$ & 0 & 0 & 0 & 0 & 0 \\
\hline & $>30$ & 0 & 0 & 0 & 0 & 0 \\
\hline \multicolumn{2}{|l|}{ TOTAL } & 0 & 2 & 0 & 0 & 2 \\
\hline
\end{tabular}




\section{Summary of the Olalla Creek/Lookingglass Creek Watershed Utility Corridor Stream Crossings}

A total of thirty-nine streams within the Olatla Creek/Lookingglass Creek watershed would be crossed within existing utility corridors (Table 15) Thirty-one streams would crossed by the dry trench method, and eight streams would be crossed by the bag and flume method.

Table 15: Stream Description and Crossing Type on Utility Corridor within the Olalla Creek/ Lookingglass Creek Watershed (5th field HUC)

\begin{tabular}{|c|c|c|c|c|c|c|}
\hline Slope & $\begin{array}{l}\text { Stream } \\
\text { Width } \\
\text { (feet) }\end{array}$ & $\begin{array}{c}\text { Dry } \\
\text { Streams }\end{array}$ & $\begin{array}{l}\text { Bag \& } \\
\text { Flume }\end{array}$ & $\begin{array}{l}\text { Directionally } \\
\text { Drilled }\end{array}$ & $\begin{array}{c}\text { Hang on } \\
\text { Bridge }\end{array}$ & $\begin{array}{l}\text { Cross } \\
\text { Culvert (in } \\
\text { road fill) }\end{array}$ \\
\hline \multirow{3}{*}{$\begin{array}{c}\text { Gentle Peren- } \\
\text { nial } \\
(<2 \% \text { rise })\end{array}$} & $0-15$ & 0 & 3 & 0 & 0 & 0 \\
\hline & $15-30$ & 0 & 0 & 0 & 0 & 0 \\
\hline & $>30$ & 0 & 0 & 0 & 0 & 0 \\
\hline \multirow{3}{*}{$\begin{array}{c}\text { Moderate } \\
\text { Perennial } \\
(2-4 \% \text { rise })\end{array}$} & $0-15$ & 0 & 2 & 0 & 0 & 0 \\
\hline & $15-30$ & 0 & 0 & 0 & 0 & 0 \\
\hline & $>30$ & 0 & 0 & 0 & 0 & 0 \\
\hline \multirow{3}{*}{$\begin{array}{c}\text { Steep } \\
\text { Perennial } \\
(>4 \% \text { rise })\end{array}$} & $0-15$ & 0 & 3 & 0 & 0 & 0 \\
\hline & $15-30$ & 0 & 0 & 0 & 0 & 0 \\
\hline & $>30$ & 0 & 0 & 0 & 0 & 0 \\
\hline \multirow{3}{*}{$\begin{array}{c}\text { Gentle } \\
\text { Intermittent } \\
(<2 \% \text { rise })\end{array}$} & $0-15$ & 6 & 0 & 0 & 0 & 0 \\
\hline & $15-30$ & 0 & 0 & 0 & 0 & 0 \\
\hline & $>30$ & 0 & 0 & 0 & 0 & 0 \\
\hline \multirow{3}{*}{$\begin{array}{c}\text { Moderate } \\
\text { Intermittent } \\
(2-4 \% \text { rise })\end{array}$} & $0-15$ & 2 & 0 & 0 & 0 & 0 \\
\hline & $15-30$ & 0 & 0 & 0 & 0 & 0 \\
\hline & $>30$ & 0 & 0 & 0 & 0 & 0 \\
\hline \multirow{3}{*}{$\begin{array}{c}\text { Steep } \\
\text { Intermittent } \\
(>4 \% \text { rise) }\end{array}$} & $0-15$ & 23 & 0 & 0 & 0 & 0 \\
\hline & $15-30$ & 0 & 0 & 0 & 0 & 0 \\
\hline & $>30$ & 0 & 0 & 0 & 0 & 0 \\
\hline \multicolumn{2}{|l|}{ TOTAL } & 31 & 8 & 0 & 0 & 0 \\
\hline
\end{tabular}




\section{Summary of the East Fork Coquille Watershed Road Corridor Stream Crossings}

A total of 58 streams along the CBW Road in the East Fork Coquille Watershed would be affected by the proposed action (Table 16). Fifty-four crossings would occur above the streams within the roadbed of existing public roads; three crossings would be hung on bridges; and one crossing would be directionally-drilled below the stream.

Table 16: Stream Description and Crossing Type on Road Corridor within the East Fork Coquille Watershed (5th field HUC)

\begin{tabular}{|c|c|c|c|c|c|c|}
\hline Slope & $\begin{array}{l}\text { Stream } \\
\text { Width } \\
\text { (feet) }\end{array}$ & $\begin{array}{c}\text { Dry } \\
\text { Streams }\end{array}$ & $\begin{array}{l}\text { Bag \& } \\
\text { Flume }\end{array}$ & $\begin{array}{l}\text { Directionally } \\
\text { Drilled }\end{array}$ & $\begin{array}{c}\text { Hang on } \\
\text { Bridge }\end{array}$ & $\begin{array}{l}\text { Cross } \\
\text { Culvert (in } \\
\text { road fill) }\end{array}$ \\
\hline \multirow{3}{*}{$\begin{array}{c}\text { Gentle Peren- } \\
\text { nial } \\
(<2 \% \text { rise })\end{array}$} & $0-15$ & 0 & 0 & 0 & 1 & 3 \\
\hline & $15-30$ & 0 & 0 & 0 & 0 & 0 \\
\hline & $>30$ & 0 & 0 & 0 & 0 & 0 \\
\hline \multirow{3}{*}{$\begin{array}{c}\text { Moderate } \\
\text { Perennial } \\
(2-4 \% \text { rise })\end{array}$} & $0-15$ & 0 & 0 & 1 & 0 & 5 \\
\hline & $15-30$ & 0 & 0 & 0 & 0 & 0 \\
\hline & $>30$ & 0 & 0 & 0 & 0 & 0 \\
\hline \multirow{3}{*}{$\begin{array}{c}\text { Steep } \\
\text { Perennial } \\
(>4 \% \text { rise })\end{array}$} & $0-15$ & 0 & 0 & 0 & 0 & 14 \\
\hline & $15-30$ & 0 & 0 & 0 & 2 & 0 \\
\hline & $>30$ & 0 & 0 & 0 & 0 & 0 \\
\hline \multirow{3}{*}{$\begin{array}{c}\text { Gentle } \\
\text { Intermittent } \\
(<2 \% \text { rise })\end{array}$} & $0-15$ & 0 & 0 & 0 & 0 & 3 \\
\hline & $15-30$ & 0 & 0 & 0 & 0 & 0 \\
\hline & $>30$ & 0 & 0 & 0 & 0 & 0 \\
\hline \multirow{3}{*}{$\begin{array}{c}\text { Moderate } \\
\text { Intermittent } \\
(2-4 \% \text { rise })\end{array}$} & $0-15$ & 0 & 0 & 0 & 0 & 3 \\
\hline & $15-30$ & 0 & 0 & 0 & 0 & 0 \\
\hline & $>30$ & 0 & 0 & 0 & 0 & 0 \\
\hline \multirow{3}{*}{$\begin{array}{c}\text { Steep } \\
\text { Intermittent } \\
(>4 \% \text { rise })\end{array}$} & $0-15$ & 0 & 0 & 0 & 0 & 26 \\
\hline & $15-30$ & 0 & 0 & 0 & 0 & 0 \\
\hline & $>30$ & 0 & 0 & 0 & 0 & 0 \\
\hline \multicolumn{2}{|l|}{ TOTAL } & 0 & 0 & 1 & 3 & 54 \\
\hline
\end{tabular}




\section{Summary of the East Fork Coquille Watershed Utility Corridor Stream Crossings}

Only three streams would be crossed by the proposed action within the East Fork Coquille Watershed within utility ROW (Table 17). Two intermittent streams would be crossed by the dry trench method and one small perennial stream would be crossed by the bag and flume method.

Table 17: Stream Description and Crossing Type on Utility Corridor within the East Fork Coquille Watershed (5th field HUC)

\begin{tabular}{|c|c|c|c|c|c|c|}
\hline Slope & $\begin{array}{l}\text { Stream } \\
\text { Width } \\
\text { (feet) }\end{array}$ & $\begin{array}{c}\text { Dry } \\
\text { Streams }\end{array}$ & $\begin{array}{l}\text { Bag \& } \\
\text { Flume }\end{array}$ & $\begin{array}{l}\text { Directionally } \\
\text { Drilled }\end{array}$ & $\begin{array}{l}\text { Hang on } \\
\text { Bridge }\end{array}$ & $\begin{array}{l}\text { Cross } \\
\text { Culvert (in } \\
\text { road fill) }\end{array}$ \\
\hline \multirow{3}{*}{$\begin{array}{c}\text { Gentle Peren- } \\
\text { nial } \\
(<2 \% \text { rise })\end{array}$} & $0-15$ & 0 & 0 & 0 & 0 & 0 \\
\hline & $15-30$ & 0 & 0 & 0 & 0 & 0 \\
\hline & $>30$ & 0 & 0 & 0 & 0 & 0 \\
\hline \multirow{3}{*}{$\begin{array}{c}\text { Moderate } \\
\text { Perennial } \\
(2-4 \% \text { rise })\end{array}$} & $0-15$ & 0 & 0 & 0 & 0 & 0 \\
\hline & $15-30$ & 0 & 0 & 0 & 0 & 0 \\
\hline & $>30$ & 0 & 0 & 0 & 0 & 0 \\
\hline \multirow{3}{*}{$\begin{array}{c}\text { Steep } \\
\text { Perennial } \\
(>4 \% \text { rise })\end{array}$} & $0-15$ & 0 & 1 & 0 & 0 & 0 \\
\hline & $15-30$ & 0 & 0 & 0 & 0 & 0 \\
\hline & $>30$ & 0 & 0 & 0 & 0 & 0 \\
\hline \multirow{3}{*}{$\begin{array}{c}\text { Gentle } \\
\text { Intermittent } \\
(<2 \% \text { rise })\end{array}$} & $0-15$ & 0 & 0 & 0 & 0 & 0 \\
\hline & $15-30$ & 0 & 0 & 0 & 0 & 0 \\
\hline & $>30$ & 0 & 0 & 0 & 0 & 0 \\
\hline \multirow{3}{*}{$\begin{array}{c}\text { Moderate } \\
\text { Intermittent } \\
(2-4 \% \text { rise })\end{array}$} & $0-15$ & 0 & 0 & 0 & 0 & 0 \\
\hline & $15-30$ & 0 & 0 & 0 & 0 & 0 \\
\hline & $>30$ & 0 & 0 & 0 & 0 & 0 \\
\hline \multirow{3}{*}{$\begin{array}{c}\text { Steep } \\
\text { Intermittent } \\
(>4 \% \text { rise })\end{array}$} & $0-15$ & 2 & 0 & 0 & 0 & 0 \\
\hline & $15-30$ & 0 & 0 & 0 & 0 & 0 \\
\hline & $>30$ & 0 & 0 & 0 & 0 & 0 \\
\hline \multicolumn{2}{|l|}{ TO'TAL } & 2 & 1 & 0 & 0 & 0 \\
\hline
\end{tabular}




\section{Summary of the North Fork Coquille Watershed Road Corridor Stream Crossings}

A total of seven streams within the CBW Road in the North Fork Coquille Watershed would be affected by the proposed action. Six crossings occur within the roadbed of existing public roads (Table 18).

Table 18: Stream Description and Crossing Type on Road Corridor within the North Fork Coquille Watershed (5th field HUC)

\begin{tabular}{|c|c|c|c|c|c|c|}
\hline Slope & $\begin{array}{l}\text { Stream } \\
\text { Width } \\
\text { (feet) }\end{array}$ & $\begin{array}{c}\text { Dry } \\
\text { Streams }\end{array}$ & $\begin{array}{l}\text { Bag \& } \\
\text { Flume }\end{array}$ & $\begin{array}{c}\text { Directionally } \\
\text { Drilled }\end{array}$ & $\begin{array}{c}\text { Hang on } \\
\text { Bridge }\end{array}$ & $\begin{array}{c}\text { Cross } \\
\text { Culvert (in } \\
\text { road fill) }\end{array}$ \\
\hline \multirow{3}{*}{$\begin{array}{c}\text { Gentle Peren- } \\
\text { nial } \\
(<2 \% \text { rise })\end{array}$} & $0-15$ & 0 & 0 & 0 & 0 & 1 \\
\hline & $15-30$ & 0 & 0 & 0 & 0 & 0 \\
\hline & $>30$ & 0 & 0 & 0 & 0 & 0 \\
\hline \multirow{3}{*}{$\begin{array}{c}\text { Moderate } \\
\text { Perennial } \\
(2-4 \% \text { rise })\end{array}$} & $0-15$ & 0 & 0 & 0 & 0 & 0 \\
\hline & $15-30$ & 0 & 0 & 0 & 0 & 0 \\
\hline & $>30$ & 0 & 0 & 0 & 0 & 0 \\
\hline \multirow{3}{*}{$\begin{array}{c}\text { Steep } \\
\text { Perennial } \\
(>4 \% \text { rise })\end{array}$} & $0-15$ & 0 & 0 & 0 & 0 & 0 \\
\hline & $15-30$ & 0 & 0 & 0 & 0 & 0 \\
\hline & $>30$ & 0 & 0 & 1 & 0 & 0 \\
\hline \multirow{3}{*}{$\begin{array}{c}\text { Gentle } \\
\text { Intermittent } \\
(<2 \% \text { rise })\end{array}$} & $0-15$ & 0 & 0 & 0 & 0 & 5 \\
\hline & $15-30$ & 0 & 0 & 0 & 0 & 0 \\
\hline & $>30$ & 0 & 0 & 0 & 0 & 0 \\
\hline \multirow{3}{*}{$\begin{array}{l}\text { Moderate } \\
\text { Intermittent } \\
(2-4 \% \text { rise })\end{array}$} & $0-15$ & 0 & 0 & 0 & 0 & 0 \\
\hline & $15-30$ & 0 & 0 & 0 & 0 & 0 \\
\hline & $>30$ & 0 & 0 & 0 & 0 & 0 \\
\hline \multirow{3}{*}{$\begin{array}{c}\text { Steep } \\
\text { Intermittent } \\
\text { (>4\% rise) }\end{array}$} & $0-15$ & 0 & 0 & 0 & 0 & 0 \\
\hline & $15-30$ & 0 & 0 & 0 & 0 & 0 \\
\hline & $>30$ & 0 & 0 & 0 & 0 & 0 \\
\hline \multicolumn{2}{|l|}{ TOTAL } & 0 & 0 & 1 & 0 & 6 \\
\hline
\end{tabular}




\section{Summary of the North Fork Coquille Watershed Utility Corridor Stream Crossings}

Eight stream crossings and one wetland would occur within the utility ROW (Table 19). One stream would be crossed by the dry trench method; six streams would be crossed by the bag and flume method; two stream crossings and one wetland would be directionally-drilled.

Table 19: Stream Description and Crossing Type on Utility Corridor within the North Fork Coquille Watershed (5th field HUC)

\begin{tabular}{|c|c|c|c|c|c|c|}
\hline Slope & $\begin{array}{c}\text { Stream } \\
\text { Width } \\
\text { (feet) }\end{array}$ & $\begin{array}{c}\text { Dry } \\
\text { Streams }\end{array}$ & $\begin{array}{l}\text { Bag \& } \\
\text { Flume }\end{array}$ & $\begin{array}{l}\text { Directionally } \\
\text { Drilled }\end{array}$ & $\begin{array}{c}\text { Hang on } \\
\text { Bridge }\end{array}$ & $\begin{array}{c}\text { Cross } \\
\text { Culvert (in } \\
\text { road fill) }\end{array}$ \\
\hline \multirow{3}{*}{$\begin{array}{c}\text { Gentle Peren- } \\
\text { nial } \\
(<2 \% \text { rise })\end{array}$} & $0-15$ & 0 & 0 & 0 & 0 & 0 \\
\hline & $15-30$ & 0 & 0 & 1 & 0 & 0 \\
\hline & $>30$ & 0 & 0 & 0 & 0 & 0 \\
\hline \multirow{3}{*}{$\begin{array}{c}\text { Moderate } \\
\text { Perennial } \\
(2-4 \% \text { rise })\end{array}$} & $0-15$ & 0 & 1 & 0 & 0 & 0 \\
\hline & $15-30$ & 0 & 0 & 0 & 0 & 0 \\
\hline & $>30$ & 0 & 0 & 0 & 0 & 0 \\
\hline \multirow{3}{*}{$\begin{array}{c}\text { Steep } \\
\text { Perennial } \\
(>4 \% \text { rise })\end{array}$} & $0-15$ & 0 & 4 & 0 & 0 & 0 \\
\hline & $15-30$ & 0 & 0 & 0 & 0 & 0 \\
\hline & $>30$ & 0 & 0 & 1 & 0 & 0 \\
\hline \multirow{3}{*}{$\begin{array}{c}\text { Gentle } \\
\text { Intermittent } \\
(<2 \% \text { rise })\end{array}$} & $0-15$ & 0 & 0 & 0 & 0 & 0 \\
\hline & $15-30$ & 0 & 0 & 1 & 0 & 0 \\
\hline & $>30$ & 0 & 0 & 0 & 0 & 0 \\
\hline \multirow{3}{*}{$\begin{array}{c}\text { Moderate } \\
\text { Intermittent } \\
(2-4 \% \text { rise })\end{array}$} & $0-15$ & 0 & 0 & 0 & 0 & 0 \\
\hline & $15-30$ & 0 & 0 & 0 & 0 & 0 \\
\hline & $>30$ & 0 & 0 & 0 & 0 & 0 \\
\hline \multirow{3}{*}{$\begin{array}{c}\text { Steep } \\
\text { Intermittent } \\
(>4 \% \text { rise })\end{array}$} & $0-15$ & 1 & 0 & 0 & 0 & 0 \\
\hline & $15-30$ & 0 & 0 & 0 & 0 & 0 \\
\hline & $>30$ & 0 & 0 & 0 & 0 & 0 \\
\hline \multicolumn{2}{|l|}{ TOTAL } & 1 & 5 & 3 & 0 & 0 \\
\hline
\end{tabular}




\section{Summary of the Middle Main Coquille Watershed Road Corridor Stream Crossings}

A total of 17 streams within the Middle Main Coquille Watershed would be affected by the proposed action. All of these crossings would occur above the stream within the roadbed of existing public road ROW (Table 20).

Table 20: $\quad$ Stream Description and Crossing Type on Road Corridor within the Middle Main Coquille Watershed (5th field HUC)

\begin{tabular}{|c|c|c|c|c|c|c|}
\hline Slope & $\begin{array}{l}\text { Stream } \\
\text { Width } \\
\text { (feet) }\end{array}$ & $\begin{array}{c}\text { Dry } \\
\text { Streams }\end{array}$ & $\begin{array}{l}\text { Bag \& } \\
\text { Flume }\end{array}$ & $\begin{array}{l}\text { Directionally } \\
\text { Drilled }\end{array}$ & $\begin{array}{l}\text { Hang on } \\
\text { Bridge }\end{array}$ & $\begin{array}{l}\text { Above } \\
\text { Stream (in } \\
\text { road fill) }\end{array}$ \\
\hline \multirow{3}{*}{$\begin{array}{c}\text { Gentle Peren- } \\
\text { nial } \\
(<2 \% \text { rise })\end{array}$} & $0-15$ & 0 & 0 & 0 & 0 & 11 \\
\hline & $15-30$ & 0 & 0 & 0 & 0 & 0 \\
\hline & $>30$ & 0 & 0 & 0 & 0 & 0 \\
\hline \multirow{3}{*}{$\begin{array}{c}\text { Moderate } \\
\text { Perennial } \\
(2-4 \% \text { rise })\end{array}$} & $0-15$ & 0 & 0 & 0 & 0 & 0 \\
\hline & $15-30$ & 0 & 0 & 0 & 0 & 0 \\
\hline & $>30$ & 0 & 0 & 0 & 0 & 0 \\
\hline \multirow{3}{*}{$\begin{array}{c}\text { Steep } \\
\text { Perennial } \\
(>4 \% \text { rise })\end{array}$} & $0-15$ & 0 & 0 & 0 & 0 & 0 \\
\hline & $15-30$ & 0 & 0 & 0 & 0 & 0 \\
\hline & $>30$ & 0 & 0 & 0 & 0 & 0 \\
\hline \multirow{3}{*}{$\begin{array}{c}\text { Gentle } \\
\text { Intermittent } \\
(<2 \% \text { rise })\end{array}$} & $0-15$ & 0 & 0 & 0 & 0 & 6 \\
\hline & $15-30$ & 0 & 0 & 0 & 0 & 0 \\
\hline & $>30$ & 0 & 0 & 0 & 0 & 0 \\
\hline \multirow{3}{*}{$\begin{array}{c}\text { Moderate } \\
\text { Intermittent } \\
(2-4 \% \text { rise })\end{array}$} & $0-15$ & 0 & 0 & 0 & 0 & 0 \\
\hline & $15-30$ & 0 & 0 & 0 & 0 & 0 \\
\hline & $>30$ & 0 & 0 & 0 & 0 & 0 \\
\hline \multirow{3}{*}{$\begin{array}{c}\text { Steep } \\
\text { Intermittent } \\
(>4 \% \text { rise })\end{array}$} & $0-15$ & 0 & 0 & 0 & 0 & 0 \\
\hline & $15-30$ & 0 & 0 & 0 & 0 & 0 \\
\hline & $>30$ & 0 & 0 & 0 & 0 & 0 \\
\hline \multicolumn{2}{|l|}{ TOTAL } & 0 & 0 & 0 & 0 & 17 \\
\hline
\end{tabular}




\section{Summary of the Lower Coos River/Coos Bay Watershed Road Corridor Stream Crossings}

A total of 29 streams within the CBW Road in the Lower Coos River/Lower Coos Bay Watershed would be affected by the proposed action. Crossings occur within the roadbed of existing public roads (Table 21).

Table 21: Stream Description and Crossing Type on Road Corridor within the Lower Coos River/ Coos Bay Watershed (5th field HUC)

\begin{tabular}{|c|c|c|c|c|c|c|}
\hline Slope & $\begin{array}{l}\text { Stream } \\
\text { Width } \\
\text { (feet) }\end{array}$ & $\begin{array}{c}\text { Dry } \\
\text { Streams }\end{array}$ & $\begin{array}{l}\text { Bag \& } \\
\text { Flume }\end{array}$ & $\begin{array}{l}\text { Directionally } \\
\text { Drilled }\end{array}$ & $\begin{array}{c}\text { Hang on } \\
\text { Bridge }\end{array}$ & $\begin{array}{c}\text { Above } \\
\text { Stream (in } \\
\text { road fill) }\end{array}$ \\
\hline \multirow{3}{*}{$\begin{array}{c}\text { Gentle Peren- } \\
\text { nial } \\
(<2 \% \text { rise })\end{array}$} & $0-15$ & 0 & 0 & 1 & 0 & 15 \\
\hline & $15-30$ & 0 & 0 & 0 & 0 & 0 \\
\hline & $>30$ & 0 & 0 & 0 & 0 & 0 \\
\hline \multirow{3}{*}{$\begin{array}{c}\text { Moderate } \\
\text { Perennial } \\
(2-4 \% \text { rise })\end{array}$} & $0-15$ & 0 & 0 & 0 & 0 & 0 \\
\hline & $15-30$ & 0 & 0 & 0 & 0 & 0 \\
\hline & $>30$ & 0 & 0 & 0 & 0 & 0 \\
\hline \multirow{3}{*}{$\begin{array}{c}\text { Steep } \\
\text { Perennial } \\
(>4 \% \text { rise })\end{array}$} & $0-15$ & 0 & 0 & 0 & 0 & 2 \\
\hline & $15-30$ & 0 & 0 & 0 & 0 & 0 \\
\hline & $>30$ & 0 & 0 & 0 & 0 & 0 \\
\hline \multirow{3}{*}{$\begin{array}{c}\text { Gentle } \\
\text { Intermittent } \\
(<2 \% \text { rise })\end{array}$} & $0-15$ & 0 & 0 & 0 & 0 & 10 \\
\hline & $15-30$ & 0 & 0 & 0 & 0 & 0 \\
\hline & $>30$ & 0 & 0 & 0 & 0 & 0 \\
\hline \multirow{3}{*}{$\begin{array}{c}\text { Moderate } \\
\text { Intermittent } \\
(2-4 \% \text { rise })\end{array}$} & $0-15$ & 0 & 0 & 0 & 0 & 1 \\
\hline & $15-30$ & 0 & 0 & 0 & 0 & 0 \\
\hline & $>30$ & 0 & 0 & 0 & 0 & 0 \\
\hline \multirow{3}{*}{$\begin{array}{c}\text { Steep } \\
\text { Intermittent } \\
(>4 \% \text { rise })\end{array}$} & $0-15$ & 0 & 0 & 0 & 0 & 1 \\
\hline & $15-30$ & 0 & 0 & 0 & 0 & 0 \\
\hline & $>30$ & 0 & 0 & 0 & 0 & 0 \\
\hline \multicolumn{2}{|l|}{ TOTAL. } & 0 & 0 & 1 & 0 & 29 \\
\hline
\end{tabular}




\section{Summary of the Lower Coos River/Coos Bay Watershed Utility Corridor Stream Crossings}

Thirteen crossings, including one wetland within the Lower Coos River/Coos Bay Watershed would occur on existing utility ROW (Table 22). Six streams would be crossed using the dry trench method; two streams would be crossed using the bag and flume method; and five crossings would be directionally-drilled below the stream.

Table 22: Stream Description and Crossing Type on Utility Corridor within the Lower Coos River/ Coos Bay Watershed (5th field HUC)

\begin{tabular}{|c|c|c|c|c|c|c|}
\hline Slope & $\begin{array}{l}\text { Stream } \\
\text { Width } \\
\text { (feet) }\end{array}$ & $\begin{array}{c}\text { Dry } \\
\text { Streams }\end{array}$ & $\begin{array}{l}\text { Bag \& } \\
\text { Flume }\end{array}$ & $\begin{array}{l}\text { Directionally } \\
\text { Drilled }\end{array}$ & $\begin{array}{l}\text { Hang on } \\
\text { Bridge }\end{array}$ & $\begin{array}{c}\text { Above } \\
\text { Stream (in } \\
\text { road fill) }\end{array}$ \\
\hline \multirow{3}{*}{$\begin{array}{c}\text { Gentle Peren- } \\
\text { nial } \\
(<2 \% \text { rise })\end{array}$} & $0-15$ & 0 & 0 & $* 2$ & 0 & 0 \\
\hline & $15-30$ & 0 & 0 & 0 & 0 & 0 \\
\hline & $>30$ & 0 & 0 & 1 & 0 & 0 \\
\hline \multirow{3}{*}{$\begin{array}{c}\text { Moderate } \\
\text { Perennial } \\
(2-4 \% \text { rise })\end{array}$} & $0-15$ & 0 & 1 & 1 & 0 & 0 \\
\hline & $15-30$ & 0 & 0 & 0 & 0 & 0 \\
\hline & $>30$ & 0 & 0 & 0 & 0 & 0 \\
\hline \multirow{3}{*}{$\begin{array}{c}\text { Steep } \\
\text { Perennial } \\
(>4 \% \text { rise })\end{array}$} & $0-15$ & 0 & 1 & 0 & 0 & 0 \\
\hline & $15-30$ & 0 & 0 & 0 & 0 & 0 \\
\hline & $>30$ & 0 & 0 & 0 & 0 & 0 \\
\hline \multirow{3}{*}{$\begin{array}{c}\text { Gentle } \\
\text { Intermittent } \\
(<2 \% \text { rise })\end{array}$} & $0-15$ & 2 & 0 & 0 & 0 & 0 \\
\hline & $15-30$ & 0 & 0 & 0 & 0 & 0 \\
\hline & $>30$ & 0 & 0 & 0 & 0 & 0 \\
\hline \multirow{3}{*}{$\begin{array}{l}\text { Moderate } \\
\text { Intermittent } \\
(2-4 \% \text { rise })\end{array}$} & $0-15$ & 1 & 0 & 0 & 0 & 0 \\
\hline & $15-30$ & 0 & 0 & 0 & 0 & 0 \\
\hline & $>30$ & 0 & 0 & 0 & 0 & 0 \\
\hline \multirow{3}{*}{$\begin{array}{c}\text { Steep } \\
\text { Intermittent } \\
(>4 \% \text { rise })\end{array}$} & $0-15$ & 3 & 0 & 1 & 0 & 0 \\
\hline & $15-30$ & 0 & 0 & 0 & 0 & 0 \\
\hline & $>30$ & 0 & 0 & 0 & 0 & 0 \\
\hline \multicolumn{2}{|l|}{ TOTAL } & 6 & 2 & 5 & 0 & 0 \\
\hline
\end{tabular}

* These crossings would occur approximately 200 feet outside of the existing utility corridor and would include 1 small wetland. 


\section{Reasonably Foreseeable Future Actions}

Laterals to Coquille, Myrtle Point and possibly Bandon, OR, would be constructed in the future. These proposed laterals would start near the Fairview block-valve, and likely be placed within the roads or utility corridors to those cities from the CBW Road. Decisions relating to timing and placement of the laterals have not been finalized.

Although construction and placement are not finalized, the anticipated design would still follow the PDCs and BMPs contained in the construction plans for the proposed action. The amount of disturbance from in-stream work and culvert placement would be determined by whether the laterals are placed in utility corridors or on road fill. The proposed laterals would be approximately 28 miles in total length. The present plans include construction and placement of 6-inch and 4-inch pipe. The amount of ground disturbance would be less than the mainline (proposed action), because smaller construction equipment and less ground area would be necessary.

NW Natural has announced plans to extend service to existing industrial users on the North Spit of Coos Bay. An 8 to 12-inch pipe would be placed under the road from Ocean Boulevard to Newmark Avenue to Empire. From there, the extension would be directionally-drilled under Coos Bay to a paved road on the North Spit. This distribution pipeline would likely be built concurrently with the Coos County Pipeline. Impacts to aquatic habitats will be avoided, as construction will be limited to paved areas in Coos Bay, and directionally-drilled under the bay itself. Portions of the North Spit are designated as an ACEC. All construction plans identified by NW Natural keep the North Spit Extension on utility corridors or road ROW, thus avoiding all potential impacts to the ACEC area.

\section{Summary of Direct, Indirect and Cumulative Effects for the Alternatives}

Both the Hwy 42 and proposed action alternatives include measures to minimize the risk of potential short-term sedimentation from construction, which can affect water quality and water-dependent flora and fauna at the site scale. Short-term potential sedimentation impacts have been anticipated, and adequate PDCs and BMPs are utilized to minimize these potential impacts (i.e., make negligible). None of the alternatives would affect the analysis or planned outcomes as developed in the NFP Final SEIS and as implemented through its Record of Decision (USDA, USDA 1994b). See Appendix E for all watershed baselines and the specific rationale behind the effects determinations. See Appendix $\mathrm{H}$ and the ODOT Erosion Control and Sediment Manual for specific aquatic system protection measures for the proposed action.

\section{Direct Effects}

1. No Action: Alternative: No negative or beneficial impacts anticipated.

2. Proposed Action: Negligible impacts from pipeline construction in each watershed (5th field HUC) may occur. Normal background sedimentation and turbidity present in the watersheds will receive no measurable impacts at the 5th field level. At the 7th field HUC (sub-subwatershed level), small, localized and transitory increases to sedimentation and turbidity will likely occur during active trenching of small perennial streams, and during the first significant autumn precipitation event. These impacts would likely be small and insignificant. Beneficial impacts from placement of new stream and cross-drain culverts and paving approximately 15 miles of gravel-dirt road (on the CBW Road), will likely improve watershed baseline conditions in the long-term for sedimentation and turbidity, with immediate improvement in the baseline for physical barriers (fish passage).

3. Hwy 42 Alternative: Negligible negative impacts from pipeline construction in each watershed (5th field HUC) may occur. Normal background sedimentation and turbidity present in the watersheds will receive no measurable impacts at the 5th field level. At the 7th field HUC (sub-subwatershed level), small, localized and transitory increases to sedimentation and turbidity will likely occur during active trenching of live streams, and during the first significant autumn precipitation event.

\section{Indirect Effects}

1. No Action Alternative: None.

2. Proposed Action: Negligible impacts to sedimentation and turbidity baselines and beneficial impacts to physical barrier baseline. 
3. Hwy 42 Alternative: Negligible impacts to sedimentation and turbidity baselines and beneficial impacts to physical barrier baseline.

\section{Cumulative Effects}

1. No Action Alternative: No foreseeable incremental effects.

2. Proposed Action: Beneficial incremental effects anticipated for the aquatic ecosystem from reduced sedimentation from the CBW Road and improved access to habitat for fish.

3. Hwy 42 Alternative: Beneficial incremental effects anticipated for habitat access for fish.

There would be no direct or indirect effects to the Coos Bay Estuary due to the implementation of PDCs. Currently, there are no known new industries entering Coos Bay following construction of the proposed natural gas pipeline, however it is likely. Any potential impacts would be addressed by such industries.

\section{Human Environment}

\section{Areas of Critical Environmental Concern (ACEC)}

The North Spit of Coos Bay contains the only ACEC near the action alternatives. Both the Hwy 42 alternative and the proposed action would trigger NW Natural to develop a distribution system to the manufacturing facilities presently located on the North Spit. NW Natural's distribution system would be built under paved roads within Coos Bay and the North Spit. To access the North Spit manufacturing area, NW Natural would cross under the bay using the directionally-drill method (shown in Appendix J).

\section{Environmental Consequences and Comparison of Alternatives}

Direct, Indirect, and Cumulative Effects

\section{All Alternatives, including No Action}

None of the alternatives would affect the North Spit ACEC, as that area would be avoided. No impacts.

\section{Socio-Economic}

\section{Background}

In February 1999, ECONorthwest published a study forecasting the economic impacts of a new pipeline. This study also measured the impacts of the distribution system, the long-term benefits to manufacturing employment, and the effects the distribution system would have on government revenues. The report was prepared for Northwest Natural and distributed to the public. The 1999 study itself was a revision of an earlier report by ECONorthwest completed in 1997 for Northwest Natural Gas and Carbon Energy International. It discussed the impacts of a natural gas distribution system confined to the County's two largest cities - North Bend and Coos Bay.

Both the 1997 and the 1999 studies relied on rough cost estimates for the pipeline. The route, timing, and dimensions of the pipeline had not been determined at the time the impact studies were completed.

In this report, cost estimates provided by Coos County are used. As such, it is ECONorthwest's understanding that the pipeline construction cost estimates are more precise than those used in the 1999 and 1997 studies. Two scenarios suggested that the pipeline would cost approximately $\$ 34$ million (proposed action) or $\$ 48$ million (Hwy 42 alternative) depending on which route is chosen. Furthermore, these cost estimates reflected dollar values for the 2000 fiscal year. 
This report shows the results of a model estimating the economic impacts on Coos County from the construction and operation of a natural gas pipeline. The economic impact model reports values in year 2000 dollars. IMPLAN expresses employment in terms of person-years of employment. A person-year equals enough hours of work to keep one person fully employed for one year. In actuality, two or more people may share those hours. An employment impact is a mixture of new jobs, some additional part time work and added hours of work for people who are already employed.

\section{Environmental Consequences and Comparison of Alternatives}

\section{No Action Alternative}

The anticipated beneficial impacts from the proposed action would not occur.

\section{Action Alternatives}

There are three kinds of economic impacts. They are direct, indirect, and induced. A direct impact occurs when a person who builds or operates a pipeline: 1) Buys local goods and services and 2) hires local labor. The money they use to do this is a direct impact. Their spending, in turn, causes indirect impacts because those who supply goods and services to the gas pipeline will make some purchases in Coos County. Total employment and income in the County goes up. That puts more purchasing power in the hands of Coos County citizens. They then will increase their local spending and savings. This causes an additional stimulus to the County's economy called an induced (i.e., cumulative) impact. Money spent locally by pipeline workers is included as an induced impact.

The economic modeling framework which best captures these direct, indirect, and induced effects is called InputOutput Modeling. Input-Output Models are mathematical representations of the economy which incorporate how different parts (or sectors) of the economy are linked. With an Input-Output Model, one can trace the effects of a change in one sector through the rest of the economy.

Because Input-Output Models generally are not available for state and regional economies, special techniques have been developed to estimate the necessary relationships using national data and county-level measures of economic activity. This planning framework is called IMPLAN (for IMpact Analysis for PLANing). ECONorthwest used the most current version, IMPLAN Professional 2.0, to estimate the impacts of the natural gas pipeline on Coos County.

IMPLAN was developed by the Forest Service of the US Department of Agriculture in cooperation with the Federal Emergency Management Agency and the Bureau of Land Management of the US Department of the Interior to assist federal agencies in their land and resource management planning.

\section{Pipeline Construction}

ECONorthwest built an Input-Output Model for Coos County to estimate the economic impacts of the construction and operation of the natural gas pipeline on the County. This model was used to estimate economic impacts under two scenarios of construction costs. They are: 1) A $\$ 48$ million proposal, which would follow, in part, a railroad ROW; and 2) a more direct path, which would result in a lower construction cost of \$34 million.

\section{Construction Cost Estimates}

ECONorthwest estimated the cost breakdown of the pipeline construction along three major categories: Materials, labor and contractors, and ROW. In addition, those expenditures were divided according to where those dollars would likely be spent. Table 23 shows the construction spending estimates for a $\$ 48$ million construction cost pipeline project. 
Table 23: $\quad$ Pipeline Construction Spending for the $\$ 48$ Million Scenario (in 2000 Dollars)

\begin{tabular}{|l|r|r|r|r|}
\hline & Materials & \multicolumn{1}{|c|}{$\begin{array}{c}\text { Labor and } \\
\text { Contractors }\end{array}$} & ROW & \multicolumn{1}{|c|}{ Total } \\
\hline \hline Coos County & $\$ 1,436,000$ & $\$ 14,361,200$ & $\$ 9,800$ & $\$ 15,807,000$ \\
\hline Elsewhere & $5,744,500$ & $26,328,800$ & 119,700 & $32,193,000$ \\
\hline \hline Total & $\$ 7,180,500$ & $\$ 40,690,000$ & $\$ 129,500$ & $\$ 48,000,000$ \\
\hline
\end{tabular}

Table 24 provides the estimate for the direct pipeline route. Under this scenario the cost of building the pipeline is expected to total $\$ 34$ million (proposed action estimate is closest to this).

Table 24: $\quad$ Pipeline Construction Spending for the \$34 Million Scenario (in 2000 Dollars)

\begin{tabular}{|l|r|r|r|r|}
\hline & Materials & \multicolumn{1}{|c|}{$\begin{array}{c}\text { Labor and } \\
\text { Contractors }\end{array}$} & ROW & \multicolumn{1}{c|}{ Total } \\
\hline \hline Coos County & $\$ 1,017,200$ & $\$ 10,172,500$ & $\$ 6,900$ & $\$ 11,196,600$ \\
\hline Elsewhere & $4,069,000$ & $18,649,600$ & 84,800 & $22,803,400$ \\
\hline \hline Total & $\$ 5,086,200$ & $\$ 28,822,100$ & $\$ 91,700$ & $\$ 34,000,000$ \\
\hline
\end{tabular}

The pipeline construction project would have the greatest effect on the local economy if all of the expenditures were made in Coos County. However, Coos County lacks some of the resources needed for the specialized undertaking of constructing a natural gas pipeline. Consequently, a significant portion of the expenditures will go to contractors, labor, and manufacturers based outside of Coos County.

Parts of the project that use general skills will likely rely on local workers. Local contractors, for example, may perform the construction, restoration, and replanting of the pipeline ROW. Specialized work unique to pipeline construction will use non-local labor. However, this also can have a positive impact on the local economy.

Consumption spending by these workers, many of whom will come from out-of-state, will benefit the Coos County economy. These non-local workers can be expected to spend a significant fraction of their pay (including their per diems) on consumption items within the Coos County, in addition to special lodging, food and drink, and other services associated with their temporary residence.

As shown in Table 23 and Table 24, ECONorthwest isolated spending that will occur wholly outside the County, and accordingly, they assumed this spending would generate no impacts on Coos County. For example, the purchases of pipe manufactured in California, or accounting services in Portland, OR, are not included in the estimate of direct spending, as these expenditures affect activity outside Coos County.

\section{Economic Impact of the $\$ 48$ Million Construction Scenario}

The direct impacts of a $\$ 48$ million natural gas pipeline construction project are shown in Table 25. These are divided into five categories, and these categories are used throughout this report. 
Table 25: Direct Impact of \$48 Million in Pipeline Construction on Coos County in Year 2000 Dollars and Person-Years of Employment

\begin{tabular}{|l|r|}
\hline \multicolumn{2}{|c|}{ Direct Impact } \\
\hline Output & $\$ 15,184,300$ \\
\hline Employees' Income & $\$ 2,300,800$ \\
\hline Proprietor's Income & $\$ 387,300$ \\
\hline Other Income & $\$ 1,574,100$ \\
\hline Employment & 114.3 \\
\hline
\end{tabular}

The first category, output, is the value of increased business activity in Coos County due to the construction. The IMPLAN model calculated that the construction of a $\$ 48$ million pipeline would directly contribute nearly $\$ 15.2$ million to the Coos County economy.

The next three categories measure the gains in local incomes. They are employees income, income going to proprietors (such as an independent construction contractor), and other property-type income such as rents received on properties, royalties from contracts, and corporate profits. ECONorthwest forecasts that the $\$ 48$ million project will have the direct impact of adding $\$ 4,262,200$ in income to Coos County.

The last impact category on Table 25 is employment. The construction project is projected to support directly over 114 person-years of employment for county residents.

Table 26 shows the total impact of the $\$ 48$ million project on Coos County. Even though most of the materials and workforce necessary to complete the project will originate from outside the county, the project will still have an impressive positive impact on the economy. It will boost output in Coos County by $\$ 18,679,600$ and support the equivalent of over 162 jobs for local residents.

\section{Economic Impact of the \$34 Million Construction Scenario}

Table 27 shows the direct impacts of a $\$ 34$ million natural gas pipeline construction project. The project would contribute nearly $\$ 10.8$ million directly to the Coos County economy and over $\$ 3,019,000$ in higher incomes to its residents. The project would be able to support the equivalent of over 80 full-time jobs for local workers. 
Table 26: Direct, Indirect, Induced, and Total Economic Impacts on Coos County from $\$ 48$ Million in Pipeline Construction Spending in Year 2000 Dollars and Person-Years of Employment

\begin{tabular}{|r|r|r|r|r|r|r|}
\hline Impact & Output & \multicolumn{1}{|c|}{$\begin{array}{c}\text { Employee's } \\
\text { Income }\end{array}$} & $\begin{array}{c}\text { Proprietor's } \\
\text { Income }\end{array}$ & \multicolumn{1}{|c|}{$\begin{array}{c}\text { Other } \\
\text { Income }\end{array}$} & Jobs & $\begin{array}{c}\text { Average } \\
\text { Annual } \\
\text { Wage }\end{array}$ \\
\hline \hline Direct & $\$ 15,184,300$ & $\$ 2,300,800$ & $\$ 387,300$ & $\$ 1,574,100$ & 114.3 & $\$ 23,500$ \\
\hline Indirect & $\$ 1,602,600$ & $\$ 424,200$ & $\$ 119,900$ & $\$ 272,300$ & 20.5 & $\$ 26,600$ \\
\hline Induced & $\$ 1,892,700$ & $\$ 565,900$ & $\$ 104,000$ & $\$ 397,100$ & 28.2 & $\$ 23,700$ \\
\hline \hline Total & $\$ 18,679,600$ & $\$ 3,290,900$ & $\$ 611,200$ & $\$ 2,243,500$ & 162.9 & $\$ 23,900$ \\
\hline
\end{tabular}

Table 27: Direct Impact of \$34 Million in Pipeline Construction on Coos County in Year 2000 Dollars and Person-Years of Employment

\begin{tabular}{|l|r|}
\hline \multicolumn{2}{|c|}{ Direct Impact } \\
\hline \hline Output & $\$ 10,755,500$ \\
\hline Employees' Income & $\$ 1,629,700$ \\
\hline Proprietor's Income & $\$ 274,300$ \\
\hline Other Income & $\$ 1,115,000$ \\
\hline Employment & 80.9 \\
\hline
\end{tabular}

Table 28: Direct, Indirect, Induced, and Total Economic Impacts on Coos County from \$34 Million in Pipeline Construction Spending

\begin{tabular}{|r|r|r|r|r|r|r|}
\hline Impact & Output & $\begin{array}{c}\text { Employee's } \\
\text { Income }\end{array}$ & $\begin{array}{c}\text { Proprietor's } \\
\text { Income }\end{array}$ & $\begin{array}{c}\text { Other } \\
\text { Income }\end{array}$ & Jobs & $\begin{array}{c}\text { Average } \\
\text { Annual } \\
\text { Wage }\end{array}$ \\
\hline \hline Direct & $\$ 10,755,500$ & $\$ 1,029,700$ & $\$ 274,300$ & $\$ 1,115,000$ & 80.9 & $\$ 23,500$ \\
\hline Indirect & $\$ 1,135,200$ & $\$ 300,500$ & $\$ 84,900$ & $\$ 192,900$ & 14.5 & $\$ 26,600$ \\
\hline Induced & $\$ 1,340,700$ & $\$ 400,800$ & $\$ 73,700$ & $\$ 281,300$ & 20.0 & $\$ 23,700$ \\
\hline \hline Total & $\$ 13,231,400$ & $\$ 2,331,000$ & $\$ 432,900$ & $\$ 1,589,200$ & 115.4 & $\$ 23,900$ \\
\hline
\end{tabular}




\section{Pipeline Operations}

ECONorthwest used the IMPLAN model to estimate the annual economic impact on Coos County attributable to pipeline operating expenses. The expenses include the costs of on-site monitoring, inspection, maintenance, and repairs of the pipeline. Costs related to the distribution of gas, that is the delivery of natural gas from the pipeline to individual customers, are considered local utility functions and are not included in this analysis.

\section{A) Operating Cost Estimate}

The annual operating costs for modern natural gas transmission pipelines of the length and capacity needed for Coos County are low relative to the amounts of money needed for their construction. Unlike the construction phase, however, the economic impact of operating the pipeline will be a reoecurring benefit. Such benefits will continue for the life of the pipeline. A well maintained natural gas transmission pipeline eould theoretically last indefinitely.

ECONorthwest estimates that the Coos County pipeline will require six, predominantly full-time equivalent workers. Employees of natural gas transmission pipeline systems are generally highly skilled and well compensated. The labor cost estimate, which appears in Table 29, is based on the Oregon statewide average for workers in the gas transmission industry. Most of their work must be done on-site; thus, approximately 75 percent of the spending on labor will aecrue to Coos County. ECONorthwest estimates annual expenses for equipment and materials are expected to total $\$ 60,000$, with 20 percent eoming from within the county. However, actual annual expenses are expeeted to be $\$ 20,000$ (pers. com. Coos County Commissioners).

Table 29: $\quad$ Annual Spending on Pipeline Operations (in 2000 Dollars)

\begin{tabular}{|l|r|r|r|}
\hline & \multicolumn{1}{|c|}{$\begin{array}{c}\text { Equipment \& } \\
\text { Materials }\end{array}$} & Labor \& Contractors & Total \\
\hline \hline Coos County & $\$ 12,000$ & $\$ 371,254$ & $\$ 383,254$ \\
\hline Elsewhere & 48,000 & 123,751 & 171,751 \\
\hline \hline Total & $\$ 60,000$ & $\$ 495,005$ & $\$ 555,005$ \\
\hline
\end{tabular}

Annual spending for pipeline operations will total $\$ 550,005$ a year. ECONorthwest anticipates $\$ 383,254$ of the total will be spent within Coos County each year. Initially the number of operating personnel required for the pipeline will be half the projeeted work force that ECONorthwest has estimated. Therefore, the annual spending will more likely be $\$ 250,000$ in the first few years of operation, rather than $\$ 555,005$ as indicated in Table 29. For the purpose of this EIS, the projected annual spending in Coos County as the result of pipeline operations would more likely be $\$ 170,000$ in the early years, rather than $\$ 383,254$.

\section{B) Economic Impact of the Pipeline Operations}

The economic impacts from operating a well-run and properly maintained natural gas pipeline are relatively modest. Pipelines normally do not require extensive equipment replacements, nor further construetion work. ECONorthwest estimated, through its use of a Coos County IMPLAN model, that $\$ 378,100$ in direct economic output for the local economy would result every year that the pipeline operates. Table 30 is a list of the annual direct impaets. Much of it will be in the form of eompensation for the estimated six employees who will be needed in Coos County to operate the pipeline.

As indicated above, the initial number of personnel required to operate the pipeline would be approximately one half of the projected work force that ECONorthwest indicated. Therefore, the annual spending would be approximately $\$ 236,800$ in the first few years rather than the amount given in Table 30 . 
Table 30: Annual Direct Impact of Pipeline Operations Spending on Coos County in Year 2000 Dollars and Person-Years of Employment

\begin{tabular}{|l|r|}
\hline \multicolumn{2}{|c|}{ Direct Impact } \\
\hline \hline Output & $\$ 378,100$ \\
\hline Employees' Income & $\$ 372,200$ \\
\hline Proprietor's Income & $\$ 9,600$ \\
\hline Other Income & $\$ 40,200$ \\
\hline Employment & 6.0 \\
\hline
\end{tabular}

The indirect and induced impacts from the pipelines operation will be largely due to the personal spending of the pipeline employees. In total, these "downstream" impacts will contribute $\$ 87,000$ to total output, and that would be sufficient to support less than two more jobs in the County. Aggregate income in Coos County will be $\$ 468,800$ higher every year throughout the operating life of the pipeline.

Table 31: Annual Direct, Indirect, Induced, and Total Economic Impacts on Coos County Because of Pipeline Operations Spending In Year 2000 Dollars and Person-Years of Employment

\begin{tabular}{|r|r|r|r|r|r|r|}
\hline Impact & Output & $\begin{array}{c}\text { Employee's } \\
\text { Income }\end{array}$ & $\begin{array}{c}\text { Proprietor's } \\
\text { Income }\end{array}$ & $\begin{array}{r}\text { Other } \\
\text { Income }\end{array}$ & $\begin{array}{c}\text { Average } \\
\text { Annual } \\
\text { Wage }\end{array}$ \\
\hline \hline Direct & $\$ 378,100$ & $\$ 372,200$ & $\$ 9,600$ & $\$ 40,200$ & 6.0 & $\$ 63,100$ \\
\hline Indirect & $\$ 39,800$ & $\$ 10,500$ & $\$ 3,000$ & $\$ 6,800$ & 0.5 & $\$ 26,800$ \\
\hline Induced & $\$ 47,200$ & $\$ 14,100$ & $\$ 2,500$ & $\$ 9,900$ & 0.7 & $\$ 23,600$ \\
\hline Total & $\$ 465,100$ & $\$ 396,800$ & $\$ 15,100$ & $\$ 56,900$ & 7.2 & $\$ 56,800$ \\
\hline
\end{tabular}

\section{C) Economic Impacts of the Distribution System}

Ultimately, most of the benefits to Coos County that will arise because of the pipeline's construction will come about from the operations of a distribution system (Table 31). A distribution system takes gas from the pipeline and delivers it to industrial, commercial, and residential consumers. An economic impact analysis of a distribution system is outside the scope of work for this report. Nonetheless, it is necessary to address the economic impacts such a system would have on the Coos County area, as distribution is an essential element in the overall plan to build a pipeline. This EIS does not speculate on the number or type of industries that might locate in Coos County because of the availability of natural gas. Northwest Natural has not included in their market forecast the number or type of industries, or volume usage that may be required by industries that may locate in Coos County in the future.

\section{D) Static and Dynamic Efficiency Effects}

A distribution system will stimulate the economy over the long run through what economist call static and dynamic efficiency effects. 
Static efficiency occurs when a development (in this case distributing a low cost fuel to Coos County consumers) reduces the costs of living and doing business. By simply spending less money on their utility bills, local people and businesses will have more money to spend on other goods and services. The savings created by the introduction of natural gas will give residents, schools, businesses and others more disposable income. They will spend much of that extra income locally, stimulating the economy.

Lacking natural gas, the Coos Bay area currently depends on electricity, heating oil, propane, and wood for its fuel needs. In many circumstances, natural gas is more efficient and less expensive than electric, oil, or propane. For example, about half of all the households in the county use electric heating. A typical single family home would save $\$ 410$ in annual utility bills by switching from electric to natural gas heat. The competitive advantage of natural gas is evident in Oregon communities where it is available. In urban areas about 60 percent of the homes use natural gas while in outlying areas about 40 percent utilize it.

Residents, commercial businesses and small industrial businesses in the Coos Bay area will save increasing amounts of money each year as the distribution system is built out and as new consumers convert to natural gas. ECONorthwest estimates that by the tenth year, consumers will save over $\$ 6.7$ million a year. The static efficiency effect of these savings is sufficient to support nearly 50 jobs and nearly $\$ 1.9$ million in additional personal, business, and other income within Coos County.

Dynamic efficiency effects are caused by a change that allows the local economy to expand in ways that would otherwise be impossible or unlikely without the change. Economists often use the term "production possibilities frontier" to describe the limits of what can be done given what is available locally.

For example, the introduction of natural gas may make it possible, or at minimum more practical, to build a metal fabricating plant or ammonia fertilizer factory in Coos County. However, Northwest Natural has not assumed that any such industries will locate in Coos County in making economic projections to justify the construction of its planned distribution system. Nor does this EIS make any speculative projections concerning the type, or types of industry that might locate in the county. New businesses, who otherwise would avoid Coos County because of the lack of natural gas, would now consider locating there. Existing businesses that currently depend on expensive propane fuel may be able to compete more effectively once they can switch to lower cost natural gas. This would allow them to expand their sales and payrolls. These are examples of dynamic efficiency. The frontier of what businesses can do in Coos County expands.

Forecasting the dynamic efficiency effect is problematic. While the economic development impact of natural gas would be great, determining the timing and extent of the impact is extremely difficult. ECONorthwest previously estimated that dynamic efficiencies would lead to over 1,500 new manufacturing jobs after ten years. This was based on a comparison between parts of Oregon with natural gas and those without. There is a strong relationship between the availability of natural gas and manufacturing employment. In turn, manufacturing jobs stimulate employment in other local economic sectors. Through the use of the IMPLAN model, ECONorthwest estimates that because of the dynamic efficiency effect, total employment in the Coos Bay area would be over 2,900 jobs higher ten years after natural gas is introduced.

It is instructive to compare the Coos Bay area with Newport, Oregon-a coastal city that shares many of the same characteristics as Coos Bay, except that it has natural gas. Table 32 shows the population growth rates from 1980 to 2000 for the Zip codes comprising the Coos Bay and Newport areas. While the Coos Bay area population has experienced decline or little growth, Newport and its neighboring community of Toledo have seen substantial population gains. The availability of natural gas was one of the reasons for this difference, although other factors also played major roles. 
Table 32: $\quad$ Comparative Population Growth Rates 1980 - 2000

\begin{tabular}{|c|l|c|c|c|}
\hline Zip Code & \multicolumn{1}{|c|}{ City Name } & $\begin{array}{c}1980 \\
\text { Population }\end{array}$ & $\begin{array}{c}\text { 2000 } \\
\text { Population }\end{array}$ & $\begin{array}{c}\text { Percent } \\
\text { Change }\end{array}$ \\
\hline \hline Coos Bay Area: & 6,275 & 6,329 & $0.9 \%$ \\
\hline 97411 & Bandon & 24,476 & 23,679 & $-3.3 \%$ \\
\hline 97420 & Coos Bay & 8,061 & 7,443 & $-7.7 \%$ \\
\hline 97423 & Coquille & 5,845 & 5,506 & $-5.8 \%$ \\
\hline 97458 & Myrtle Point & 16,021 & 15,489 & $-3.3 \%$ \\
\hline 97459 & North Bend & 60,678 & 58,446 & $-3.7 \%$ \\
\hline \hline Coos Bay Area Total & & & 10,956 & $27.0 \%$ \\
\hline Newport Area: & Newport & 8,624 & 6,286 & $5.3 \%$ \\
\hline 97365 & Toledo & 14,593 & 17,242 & $18.2 \%$ \\
\hline 97391 &
\end{tabular}

\section{E) Adversely Affected Businesses}

While Coos County businesses and consumers will benefit from the availability of natural gas, there is one segment of the local economy that will sustain setbacks large enough to have a notable effect on employment. That segment consists of propane and heating oil distributors. They will likely experience declining market shares and will reduce their employee counts as a result.

Consumers who now use propane for heating, drying, fireplaces, and cooking, in most cases will be able to readily switch to natural gas. Pricing and convenience advantages give natural gas a strong competitive advantage over propane. Heating oil, too, will lose customers to natural gas. However, the rate of substitution will be much slower because conversion costs are high and price advantages are less.

Other sectors that compete with natural gas will be adversely affected; however, the impact on employment will be far less consequential. There will be negative up and down stream effects caused by revenue and employment losses by propane and heating oil distributors. There will be revenue losses for businesses that transport and wholesale propane, heating oil and residual fuel oil. If any such business is heavily dependent on these fuels and local workers, the revenue loss could lead to job losses. Electricity demand will be affected as natural gas gradually replaces electric based heating, cooking and clothes drying. Natural gas, though, can only supplement and not replace electricity. Thus, its impact on electric utility employment will be negligible.

ECONorthwest expects that local propane and heating oil distributors will sustain the only marked reduction in employment over the long run. Table 33 is a list of the distributors who will be affected by the new natural gas distribution system. The list is from the American Business Directory database for the year 2000. The directory assigns an employment range for each listing. ECONorthwest averaged these ranges and arrived at an estimate that the nine propane and heating oil distributors employ 69 individuals. 
Table 33: $\quad$ Propane and Heating Oil Distributors

\begin{tabular}{|l|l|l|c|}
\hline \multicolumn{1}{|c|}{ Company } & \multicolumn{1}{|c|}{ Address } & \multicolumn{1}{c|}{ City } & \multicolumn{1}{c|}{ Fuel } \\
\hline All Star Gas Inc. & 425 Virginia Ave & North Bend & Propane \\
\hline Bassett-Hyland Energy Co & 425 W Lockhart Ave & Coos Bay & Heating Oil \\
\hline Davis Oil Inc. & 280 Newmark St. & North Bend & Heating Oil \\
\hline Ferrellgas & 1165 Newmark Ave \# D & Coos Bay & Propane \\
\hline Goddard Energy Co & 2 nd \& Elmira & Bandon & Heating Oil \\
\hline Graham Oil Co & 1765 Sheridan Ave & North Bend & Heating Oil \\
\hline Rons Oil Co & 580 N Central St. & Coquille & Propane \\
\hline Tyree Oil Inc. & 2395 N Bayshore Dr. & Coos Bay & Heating Oil \\
\hline Hodge Distributing Inc. & 1893 Roseburg Rd. & Myrtle Point & Heating Oil \\
\hline
\end{tabular}

According to the 2000 Census data, Coos County has a population of 62,779 . There are approximately 850 residents for each of the 69 propane and heating oil distributor employees. In the state of Oregon, using Claritas and American Business Directory data, ECONorthwest determined that the ratio is approximately I, 150 residents per distributor employee. The statewide ratio is higher because natural gas is widely available and distribution systems have been long in-place throughout most of Oregon. Therefore, propane and heating oil distributors need a higher population base to draw upon so that they may generate enough sales to support an employee.

ECONorthwest estimates that if the Coos County area were to mirror the highly competitive market characteristic of the rest of the state, it too would be able to only support one propane and heating oil distributor employee for every I,150 residents. Given that statewide ratio and applying it to an approximate population base of 60,000 , ECONorthwest estimates that the affected area would be able to sustain 51 propane and heating oil distributor employees over the long run. Thus, there is a projected eventual loss of 18 jobs in this sector.

\section{Summary of Direct, Indirect and Cumulative Economic Effects for Action Alternatives}

Construction of a natural gas pipeline will have a simulative impact on the Coos County economy of between $\$ 13.2$ and $\$ 18.7$ million depending on the route taken. The construction project will support the equivalent of 115 to 163 full-time jobs for local residents. From then on, pipeline operations spending will have an annual economic impact of $\$ 465,100$ to Coos County. This is sufficient to sustain over seven full-time jobs with an average wage rate of $\$ 56,800$.

The pipeline will deliver natural gas to a distribution system that will supply gas to homes and businesses. The economic impact of the distribution system will be great.

Clearly the area to be served with natural gas from the pipeline would be better off over the long run with natural gas than without. No one could easily argue that other areas of Oregon with natural gas and similar populations, such as Grants Pass, Albany, or Corvallis, would be better off without natural gas. If gas were taken away from those cities, one would expect businesses to move, factories to close, and jobs to be lost. Conversely, one can expect the major economic benefits over time once natural gas becomes available to Coos County.

ECONorthwest believes that there will be static efficiency benefits to the local economy that will steadily grow as natural gas consumption increases. These will be partly offset by losses in businesses that will find it difficult to compete against natural gas. The net impact, however, will be positive because consumers will enjoy much greater benefits in the form of lower energy costs. They will spend much of their savings locally. 
Long-term, one expects to see dynamic efficiency effects that will lead to substantial increases in manufacturing employment. This will then stimulate employment in other sectors of the local economy. Predicting the net impact is difficult and requires some level of speculation. However, within ten years employment could increase by over 2,900 in the region because of the availability of natural gas.

\section{Environmental Justice}

\section{Direct, Indirect and Cumulative Effects}

\section{All Alternatives, including No Action}

Household Income (Variable 80) in Census Database C90STF3A was examined for each of ten geographic areas within Coos County, and cumulative frequency plots were constructed for the 25 income levels as compared to other portions of mid-Coquille basin, and just slightly lower than average income levels as compared to other geographic areas within Coos County.

Pipeline construction activities will have a similar affect upon all households residing in the vicinity of the construction zone. As documented elsewhere, construction activities may result in inconvenient travel delays or equipment noise. However, this analysis shows that low income populations will not be disproportionately affected because of the route choice. Therefore, Environmental Justice concerns will not be created by pipeline construction activities.

No minority or disadvantaged groups or communities are within or adjacent to the proposed action or Hwy 42 Alternative. No impact.

\section{Public Health and Safety}

\section{Direct Effects}

\section{No Action Alternative}

No anticipated impacts.

\section{Proposed Action}

Approximately 40 miles of pipeline construction would occur in roadways, creating short-term (1-7 days) delays for traffic. If individual vehicles, bicyclists, pedestrians, etc. fail to yield to flaggers and other warning signs, and enter active construction areas without supervision, injury potential from heavy equipment or falling into the pipeline ditch would exist. Spill containment kits on site of active construction will be required.

\section{Hwy 42 Alternative}

Approximately 80 miles of pipeline construction would occur in roadways, creating long-term (6 months) delays for traffic. If individual vehicles, bicyclists, pedestrians, etc. fail to yield to flaggers and other warning signs, and enter active construction areas without supervision, injury potential from heavy equipment or falling into the pipeline ditch would exist. Spill containment kits on site of active construction will be required.

\section{Indirect Effects}

\section{No Action Alternative}

No anticipated impacts.

\section{Action Alternatives}

Illegal use of explosives within or digging-up of soil containing the operational natural gas pipeline with heavy equipment such as a backhoe, could lead to physical injury to the participants in these activities. 


\section{Cumulative Effects}

\section{All Alternatives, including No Action}

None

\section{Waste (Solid or Hazardous)}

\section{Direct, Indirect and Cumulative Effects}

\section{No Action Alternative}

No anticipated impacts.

\section{Action Alternatives}

No hazardous waste would be created by either action alternative. Each contractor will prepare and implement as necessary Spill Prevention and Control Countermeasure Plans (40 C.F.R. 112) for applicable equipment and their supplies. All solid waste from construction and/or construction crews will be removed offsite for disposal. Copies of the above will be maintained and made available on request by the pipeline construction contractor. Spill containment kits will be kept on site. No anticipated impacts.

\section{Pipeline Safety and Fire Data}

The US Department of Transportation, Research and Special Projects Administration, Office of Pipeline Safety is the Federal agency with jurisdiction over natural gas transmission pipelines, including the proposed Coos Pipeline. The gas pipeline safety regulations (49 CRF Part 192) were made effective for all gas transmission pipelines constructed after 1970. The OPUC has inspection and enforcement jurisdiction over the proposed action through US DOT.

Pipeline safety statistics have been recorded since 1984 and are publicly available through various sources. Separate statistics are maintained for gas transmission pipelines, for gas distribution systems, and for liquid pipelines.

Gas distribution systems are generally small diameter (2- to 4-inch) and low pressure (under 60 psi), and serve more than 50 percent of all homes and virtually 100 percent of major urban industries in the US.

Gas transmission lines also carry natural gas, are generally in more rural areas, are usually much larger in diameter (up to 42 inches) and are operated at much higher pressures (typically 500 to $1000 \mathrm{psi}$ ). There are gas transmission lines in every state of the US except Hawaii, as well as approximately 90 percent of the counties in the continental US.

The hazardous liquids transported by DOT pipelines can be crude oil, refined gasoline, jet fuel and diesel, fertilizer, propane or butane, petrochemicals like butylene, carbon dioxide, and others. Liquid pipelines are operated at higher pressures (typically $1800 \mathrm{psi}$ ) and if spilled result in a much different environmental and safety hazard than natural gas.

\section{Natural Gas Transmission Pipeline Statistics}

The Gas Research Institute commissioned a pipeline safety study in 2000 by Allegro Energy Group. The study analyzed DOT incident reports for gas transmission pipelines from 1985 through 1998. A reportable incident is defined as any pipeline release or failure which cause a human death or injury requiring hospitalization, or $\$ 50,000$ in damage, including lost gas. This analysis reported the following for onshore gas transmission pipelines:

- 1 incident per year for every 6,300 miles of pipeline

- 1 fatality per year for every 200,000 miles of pipeline

As a response to an inquiry from BPA, Coos Pipeline advisors analyzed statistics for 8,10 and 12-inch DOT pipelines. These sizes are the most common for regional supply and comprise approximately 27 percent of the 296,000 miles of U.S. gas transmission pipelines. Analyses conducted between 1984 and 2000 report the following:

- 82 reportable pipeline incidents 
- 23 injuries, 2 deaths

- Average damage $\$ 106,000$ for all reported incidents

Pipelines built after 1970 under DOT regulations represent approximately half of the total pipelines in this 16 year analysis, yet comprise proportionally fewer incidents:

- 17 percent of all incidents

- 10 injuries, no deaths

- $\$ 50,000$ average damage

Note: 58 percent of these incidents were caused by external damage.

\section{Pipelines in the Northwest}

DOT statistics from 1984 to 2000 reported 12 incidents involving natural gas transmission pipelines in Oregon and Washington. No injuries or deaths were reported.

Of the 12 reportable incidents (Table 34), 10 involved pipelines built before DOT regulations. Six incidents were attributed to defective older pipe; there were no corrosion failures. The possibility of technology-related failures such as corrosion and construction defects have been virtually non existent since 1970. Other failures are attributed to third party damage (excavators), which account for nearly 70 percent of all incidents analyzed in this study.

Approximately 88 percent of all incidents occurred in unpopulated areas where the majority of pipelines are located. The route for the proposed action is presently classified as 97 percent in unpopulated areas. The portion of the proposed action corridor along the CBW Road is sparsely populated and is at less risk of excavation than the Hwy 42 Route that would pass through many urban areas.

\section{Fire Risk and Fire Suppression}

Of the 12 pipeline incidents in Oregon and Washington since 1984, there was minimal or no fire spread to adjacent forest. Total acreage burned was estimated by pipeline safety officials to be approximately 5 acres.

Based on pipeline statistics in Oregon and Washington, the operation of a gas pipeline in Coos County would not measurably add to the existing risk of forest fire or the present cost of fire suppression. 
Table 34: DOT Statistics Involving Natural Gas Pipelines in Oregon and Washington (19842000)

\begin{tabular}{|c|c|c|c|c|}
\hline Pipeline & $\begin{array}{c}\text { Date of } \\
\text { Incident }\end{array}$ & Cause of Incident & $\begin{array}{c}\text { Pipeline } \\
\text { Diameter } \\
\text { (inches) }\end{array}$ & $\begin{array}{c}\text { Date of } \\
\text { Pipeline } \\
\text { Construction }\end{array}$ \\
\hline \hline Cascade Natural Gas & $10 / 86$ & Third party damage & 8 & 1957 \\
\hline Williams NWPL & $10 / 88$ & Third party damage & 8 & 1957 \\
\hline Williams NWPL & $05 / 90$ & Pipeline defect & 4 & 1956 \\
\hline Williams NWPL & $04 / 91$ & Third party damage & 22 & 1956 \\
\hline Pacific Gas & $04 / 94$ & Pipeline defect & 42 & 1992 \\
\hline Williams NWPL & $03 / 95$ & Earth movement & 26 & 1956 \\
\hline Williams NWPL & $02 / 97$ & Earth movement & 26 & 1956 \\
\hline Williams NWPL & $02 / 97$ & Earth movement & 26 & 1963 \\
\hline Williams NWPL & $01 / 98$ & Pipeline defect & 10 & 1970 \\
\hline Pacific Gas & $07 / 98$ & Pipeline defect & 36 & 1956 \\
\hline Williams NWPL & $01 / 99$ & Pipeline defect & 22 & 1956 \\
\hline Williams NWPL & $02 / 99$ & Earth movement & 26 & \\
\hline
\end{tabular}

\section{Land Uses}

\section{Forestry}

Direct, Indirect and Cumulative Effects

All Alternatives, including No Action

No impact.

\section{Livestock Grazing}

Direct, Indirect and Cumulative Effects

All Alternatives, including No Action

No impact. 


\section{Recreation}

\section{Direct and Cumulative Effects}

\section{All Alternatives, including No Action}

No anticipated impacts.

\section{Indirect Effects}

\section{No Action Alternative}

No anticipated impacts.

\section{Proposed Action}

No anticipated impacts.

\section{Hwy 42 Alternative}

Long-term (6 months) delays of traffic may influence recreationists' activities and other optional travel to other areas within driving distance containing similar recreational opportunities.

\section{Transportation}

\section{Direct Effects}

\section{No Action Alternative}

No anticipated impacts.

\section{Proposed Action}

Approximately 40 miles of pipeline construction would occur in roadways, creating short-term (1-7 days) delays for local traffic in those construction areas. Approximately 40 houses are adjacent to the portions of the CBW Road in the proposed action. Some residents may also experience the temporary inconvenience of traffic interference, including reduced speeds and stopped traffic in construction zones, due to pipeline installation and repaving activities.

\section{Hwy 42 Alternative}

Approximately 80 miles of pipeline construction would occur in roadways, creating long-term (6 months) delays in a number of locations simultaneously for a State and U.S. highways with high traffic volumes. The urban areas of Coquille and Myrtle Point, as well as approximately 200 houses in rural areas, boarder this route. Since Hwy 42 is a major access route, highway upgrades (including relocation, widening and straightening) are very likely. The risk of contractor-induced damage to the pipeline, as well as pipeline relocation, is also a possibility.

\section{Indirect Effects}

\section{No Action Alternative}

No anticipated impacts. 


\section{Proposed Action}

No anticipated impacts.

\section{Hwy 42 Alternative}

Long-term (6 months) delays of traffic may influence tourist activity and other optional travel to the Coos Bay North Bend area for travelers whose only realistic travel option is the Hwy 42 corridor.

\section{Cumulative Effects}

\section{All Alternatives, including No Action}

No anticipated impacts.

\section{Utility Corridors}

\section{Direct, Indirect and Cumulative Effects}

\section{All Alternatives, including No Action}

Current utility corridor management, management plans, activities and uses would continue unchanged. No impact.

As required by Executive Order 13212, BLM has determined the proposed action and alternatives considered for this project will have a positive effect for natural gas energy transmission and no adverse impacts on energy resources such as exploration and development of oil and gas, or geothermal, or production from wind, solar, hydroelectric, or biomass energy resources. Location of the natural gas pipeline as proposed within the existing electronic transmission ROW will not have a negative effect on transmission of electricity to the southern Oregon coast. 


\section{Impacts Summary Table}

Table 35: Impacts Summary

\begin{tabular}{|c|c|c|c|}
\hline & No Action Alternatives & Proposed Action & Hwy 42 Alternative \\
\hline $\begin{array}{l}\text { Aquatic } \\
\text { Ecosystems }\end{array}$ & $\begin{array}{l}\text { No beneficial impacts to sedi- } \\
\text { mentation, turbidity or physical } \\
\text { barriers (fish passage). }\end{array}$ & $\begin{array}{l}\text { Negligible short-term } \\
\text { impacts to sedimentation and } \\
\text { turbidity baselines. } \\
\text { Beneficial long-term impacts } \\
\text { to sedimentation and turbid- } \\
\text { ity baselines. Immediate } \\
\text { beneficial impacts to physi- } \\
\text { cal barriers (fish passage). }\end{array}$ & $\begin{array}{l}\text { Negligible short-term } \\
\text { impacts to sedimentation and } \\
\text { turbidity baselines. } \\
\text { Immediate beneficial } \\
\text { impacts to physical barriers } \\
\text { (fish passage). }\end{array}$ \\
\hline Air Quality & $\begin{array}{l}\text { No beneficial impacts from } \\
\text { reduced fossil fuel pollution. }\end{array}$ & $\begin{array}{l}\text { Negligible transitory, local- } \\
\text { ized, short-term impacts in } \\
\text { construction areas. } \\
\text { Beneficial long-term impacts } \\
\text { from reduced fossil fuel } \\
\text { pollution. }\end{array}$ & $\begin{array}{l}\text { Negligible transitory, local- } \\
\text { ized, short-term impacts in } \\
\text { construction areas. } \\
\text { Beneficial long-term impacts } \\
\text { from reduced fossil fuel } \\
\text { pollution. }\end{array}$ \\
\hline $\begin{array}{l}\text { Soil } \\
\text { Productivity }\end{array}$ & No negative impacts. & $\begin{array}{l}\text { Approximately } 56 \text { acres of } \\
\text { reduced soil productivity. }\end{array}$ & No negative impacts. \\
\hline T\&E Plants & No Effect. & No Effect. & No Effect. \\
\hline $\begin{array}{l}\text { Special Status } \\
\text { Species }\end{array}$ & No Effect. & $\begin{array}{l}\text { Short-term disturbance of } \\
\text { individuals that utilize pow- } \\
\text { erline corridor or adjacent } \\
\text { habitats. }\end{array}$ & $\begin{array}{l}\text { Short-term disturbance of } \\
\text { individuals that utilize } \\
\text { adjacent habitats. }\end{array}$ \\
\hline $\begin{array}{c}\text { Survey \& } \\
\text { Manage Species }\end{array}$ & No anticipated impacts. & $\begin{array}{l}\text { Short-term disturbance to } \\
\text { red tree vole individuals that } \\
\text { utilize adjacent habitats. }\end{array}$ & $\begin{array}{l}\text { Short-term disturbance to } \\
\text { red tree vole individuals that } \\
\text { utilize adjacent habitats. }\end{array}$ \\
\hline Other Wildlife & No anticipated impacts. & $\begin{array}{c}\text { Short-term disturbance of } \\
\text { individuals that utilize pow- } \\
\text { erline corridor or adjacent } \\
\text { habitats. }\end{array}$ & $\begin{array}{l}\text { Short-term indirect effects } \\
\text { (disturbance) of individuals } \\
\text { that utilize adjacent habitats. } \\
\text { Direct effects on utility cor- } \\
\text { ridor species' habitats. } \\
\text { (shrubs, weeds and grasses } \\
\text { utilized by birds and rodents) }\end{array}$ \\
\hline \multicolumn{4}{|l|}{ T\&E Species: } \\
\hline Spotted Owl & No Effect. & $\begin{array}{l}\text { Disturbance impacts avoided } \\
\text { from timing restrictions. }\end{array}$ & $\begin{array}{l}\text { Disturbance impacts avoided } \\
\text { from timing restrictions. }\end{array}$ \\
\hline
\end{tabular}




\section{Table 35: Impacts Summary}

\begin{tabular}{|c|c|c|c|}
\hline & No Action Alternatives & Proposed Action & Hwy 42 Alternative \\
\hline $\begin{array}{l}\text { Marbled } \\
\text { Murrelet }\end{array}$ & No Effect. & $\begin{array}{l}\text { Disturbance impacts avoided } \\
\text { from timing restrictions. }\end{array}$ & $\begin{array}{l}\text { Disturbance impacts avoided } \\
\text { from timing restrictions. }\end{array}$ \\
\hline $\begin{array}{r}\text { Bald Eagle, } \\
\text { Columbian } \\
\text { White-tailed } \\
\text { deer, Western } \\
\text { Snowy Plover, } \\
\text { Brown Pelican }\end{array}$ & No Effect. & No Effect. & No Effect. \\
\hline Floodplains & No impact. & No impact. & No impact. \\
\hline $\begin{array}{l}\text { Waste (Solid or } \\
\text { Hazardous) }\end{array}$ & No impact. & No anticipated impacts. & No anticipated impacts. \\
\hline Traffic Safety & No impact. & $\begin{array}{c}\text { Short-term ( } 1-7 \text { days) } \\
\text { impacts in low-traffic CBW } \\
\text { Road. }\end{array}$ & $\begin{array}{c}\text { Long-term (6 months) } \\
\text { impacts in high-traffic Hwy } \\
42 .\end{array}$ \\
\hline Traffic Delays & No impact. & $\begin{array}{c}\text { Short-term ( } 1-7 \text { days) } \\
\text { impacts in low-traffic CBW } \\
\text { Road. }\end{array}$ & $\begin{array}{c}\text { Long-term (6 months) } \\
\text { impacts in high-traffic Hwy } \\
42 .\end{array}$ \\
\hline Financial Costs & No impact. & Approximately $\$ 34$ million. & Approximately $\$ 48$ million. \\
\hline $\begin{array}{l}\text { Economic } \\
\text { Benefits }\end{array}$ & $\begin{array}{l}\text { Loss of direct, indirect and } \\
\text { induced short and long-term } \\
\text { beneficial impacts. } \\
\text { Long-term increase in commer- } \\
\text { cial and residential fuel costs. } \\
\text { No increase in property tax } \\
\text { assessments to fund pipeline } \\
\text { construction bond. }\end{array}$ & $\begin{array}{l}\text { Approximately } \$ 13 \text { million } \\
\text { direct, indirect and induced } \\
\text { benefit from short-term } \\
\text { investment (pipeline con- } \\
\text { struction). } \\
\text { Long-term increase in jobs } \\
\text { available in Coos County } \\
\text { after pipeline construction. } \\
\text { Long-term reduction in com- } \\
\text { mercial and residential fuel } \\
\text { costs. } \\
\text { Property tax increase averag- } \\
\text { ing } \$ 19 \text { per county resident. }\end{array}$ & $\begin{array}{l}\text { Approximately } \$ 18 \text { million } \\
\text { direct, indirect and induced } \\
\text { benefit from short-term } \\
\text { investment (pipeline con- } \\
\text { struction). } \\
\text { Long-term increase in jobs } \\
\text { available in Coos County } \\
\text { after pipeline construction. } \\
\text { Long-term reduction in com- } \\
\text { mercial and residential fuel } \\
\text { costs. } \\
\text { Property tax increase averag- } \\
\text { ing } \$ 62 \text { per county resident. }\end{array}$ \\
\hline
\end{tabular}




\section{Chapter $5 \quad$ Consultation and Coordination}

The following changes were made in Chapter 5 between the Draft and Final Environmental Impact Statement. Minor corrections, explanations and edits are not included in this list.

- An additional section titled "Consistency with Other Agency Plans and Programs" has been added to this chapter.

\section{Introduction}

This chapter describes aspects of consultation and coordination, including information regarding persons, agencies and methods involved with scoping, consultation and research for compilation of this EIS.

Initial scoping of this project was administered by the BLM management team following the County Commissioner's initial meeting with BLM on April 28, 2000. The scoping identified environmental issues and alternatives appropriate for inclusion in this Environmental Impact Statement. All concerns received from the various meetings (listed below) were evaluated. This resulted in the list of specific impact topics for detailed analysis in this EIS.

Public scoping was accomplished by inviting the public to the various meetings listed below. The public comments or questions were taken into consideration for the EIS assessment. The general issues received from the public were concerning socio-economic impacts of the proposed action, fish and wildlife concerns, and future impacts of the proposed action in regard to potential industrial growth within the County. Public comments and questions are presented in Appendix G, G1- and G-2 No comments received by the public varied from issues already identified in the initial scoping process with the BLM management team and Coos County. All public concerns regarding potential human/environment impacts are addressed in this EIS.

\section{Consistency with Other Agency Plans and Programs}

\section{General}

BLM requires that projects be "consistent with officially approved or adopted resource-related plans and the policies and procedures contained therein of other federal agencies, state and local governments, and Indian tribes, so long as the guidance and projects are also consistent with the purposes, policies and programs of federal laws and regulations applicable to public lands...". Consistency is construed as the absence of conflict. Based on BLM's knowledge of the plans of such other agencies, the proposed project has been compared to the following agencies' plans for consistency, and BLM has reached the conclusions stated.

The Coos Bay District of BLM received an application from Coos County to construct, operate, and maintain a natural gas pipeline from near Lookingglass in Douglas County to the Coos Bay area. The total length of the project is approximately 60 miles with approximately 3.0 miles located on lands administered by the BLM. Under the proposed action, the BLM would grant Coos County a ROW permit for construction of the pipeline on BLM administered lands. Additionally, COE and the Oregon Department of State Lands (DSL) would issue permits for crossing streams under their jurisdiction. Numerous other permits would be required of a variety of agencies to permit the construction and operation of the natural gas pipeline project. As the project proponent, Coos county, has the responsibility to obtain all local, state, and federal permits. Coos County prepared an Environmental Impact Statement for the BLM analyzing the effects of construction of the pipeline on the entire 60 miles covered by the proposed action. The draft EIS has been available for public review and comment. The Oregon Department of Fish and Wildlife (ODFW) indicated satisfaction with the analysis conducted. The Department of Land Conservation and Development (DCLD) indicated the need to prepare a consistency determination. No other state agencies provided comments on the Draft EIS. The requested consistency determination is included as Appendix N. 


\section{List of Contributors}

Albert Oetting

Cultural Resources

Education: Ph.D Anthropology, University of Oregon

M.A. Anthropology, San Diego State University

B.A. Anthropology, University of California, Berkeley

Experience: 25 years

Robert Whelan

Socio-Economics

Education: B.S. Geology, Adelphi University

M.S. Mineral Economics, Pennsylvania State University

Post Graduate Courses, Economics, Columbia University

Experience: 22 years

Dave Leonard

Geotech and Soils

Education: B.S. Environmental Engineering, Southern Illinois University

M.B.A. Business Administration, University of Illinois

Experience: 29 years

Brian Cox

Plants, Fish, Wildlife and NEPA

Education: B.S. Wildlife Biology, University of Montana

M.S. Range Ecology, Texas A\&M University

Experience: 13 years

Melanie Little

Fish, Wildlife and NEPA

Education: B.S. Wildlife and Fishery Science, University of Tennessee

Experience: 10 years 
Ted Schattenkerk

Botany

Education: B.S. Range Science, Oregon State University

Experience: 30 years

Steve Shute

Pipeline Construction, Public Scoping

Education: B.S. Electrical Engineering, Kansas State University

Experience: 25 years

Steve Oxford

Pipeline Construction, Public Scoping

Education: B.S. Petroleum Engineering, Louisiana State University

Experience: 22 years

Technical matters related to this EIS (construction requirements, for example) were resolved with the help of specialists and consultants as listed in Table 36.

\section{Table 36: Technical Consultations}

\begin{tabular}{|l|l|}
\hline \multicolumn{1}{|c|}{ Consultant } & \multicolumn{1}{c|}{ Contribution Role } \\
\hline $\begin{array}{l}\text { Industrial Gas Services, Inc. } \\
\text { Pipeline Solutions, Inc. }\end{array}$ & $\begin{array}{l}\text { Project advisors; technical, permitting and construction } \\
\text { requirements }\end{array}$ \\
\hline ECONorthwest & Economic analysis \\
\hline Dave Leonard & Geotechnical report \\
\hline Heritage Research Associates, Inc. & Cultural Resources study of the proposed action \\
\hline $\begin{array}{l}\text { Biological Information Specialists, } \\
\text { Inc. }\end{array}$ & EIS document and BAs \\
\hline
\end{tabular}

\section{Organizations Consulted}

BLM-Roseburg

BLM-Coos Bay

Coos County Commission

National Marine Fisheries Service

Oregon Dept. of Fish \& Wildlife

U.S.Fish \& Wildlife Service

Cow Creek Band of the Umpqua

Coquille Indian Tribe 
Confederated Tribe of the Coos

Army Corps of Engineers

Oregon Public Utilities Commission

Bonneville Power Administration

NW Natural Gas

PacifiCorp (Pacific Power \& Light)

Oregon National Historic Preservation Administration

Table 37: $\quad$ Pipeline Meetings

\begin{tabular}{|c|c|}
\hline Date & Meeting \\
\hline January 7,1999 & Work session - Natural Gas Pipeline - Commissioners' Courtroom, Coquille Courthouse \\
\hline January 25,1999 & Chamber of Commerce Economic Development Committee \\
\hline February 22, 1999 & Chamber of Commerce Economic Development Committee \\
\hline March 29, 1999 & Chamber of Commerce Economic Development Committee \\
\hline April 21, 1999 & Economic Forum on Natural Gas \\
\hline April 26, 1999 & Chamber of Commerce Economic Development Committee \\
\hline May 19, 1999 & Work session - Natural Gas Pipeline - Commissioners' Courtroom, Coquille Courthouse \\
\hline June 2, 1999 & $\begin{array}{l}\text { Work session - Tim Bishop Re: Pipeline Project - Commissioners' Courtroom, Coquille Court- } \\
\text { house }\end{array}$ \\
\hline June 21, 1999 & Review of RFQ's - Commissioners' Courtroom, Coquille Courthouse \\
\hline June 28, 1999 & Chamber of Commerce Economic Development Committee \\
\hline July 13, 1999 & Radio Interviews KWRO \\
\hline July 26, 1999 & Chamber of Commerce Economic Development Committee \\
\hline July 26, 1999 & Democratic Central Committee \\
\hline July 28, 1999 & $\begin{array}{l}\text { Work session - Timing Issues Re Bond Measure for November Ballot - Commissioners' Court- } \\
\text { room, Coquille Courthouse }\end{array}$ \\
\hline July 29, 1999 & Rental Owners Association \\
\hline August 19, 1999 & Board of Realtors \\
\hline September 1, 1999 & Hearing - Bond Measure - Coquille Annex Planning Conference Room \\
\hline October 1,1999 & McKinley Grange \\
\hline October 5, 1999 & Bay Broadcasting \\
\hline October 5, 1999 & Rotary - Natural Gas \\
\hline October 12,1999 & Rotary - Natural Gas \\
\hline October 13,1999 & FONSI Rally - North Bend Community Center \\
\hline
\end{tabular}


Table 37: Pipeline Meetings

\begin{tabular}{|c|c|}
\hline Date & Meeting \\
\hline November 4, 1999 & Economic Development -- SWOCC \\
\hline November 17, 1999 & Economic Development Forum \\
\hline November 22, 1999 & Chamber of Commerce Economic Development Committee \\
\hline December 8, 1999 & $\begin{array}{l}\text { Hearing - Supplemental Budget (To include bond funds and give authority to spend funds received } \\
\text { for pipeline) }\end{array}$ \\
\hline March 8,2000 & Commissioners interview Project Advisors, Courthouse. \\
\hline April 12,2000 & Work session with Industrial Gas Solutions, Inc. and Pipeline Solutions, Inc. \\
\hline April 12,2000 & OPUC hearing on NW Natural case - Coquille community center \\
\hline April 28,2000 & * BLM staff meeting - North Bend BLM office \\
\hline May 17,2000 & $\begin{array}{l}\text { Open House - Pipeline - Coquille Annex Conference Room } \\
\text { Public meeting on pipeline, Courthouse basement. }\end{array}$ \\
\hline June 7,2000 & *Fed / State agency meeting, Coquille "War Room" \\
\hline July 12,2000 & Pipeline Town Hall Meeting - Courthouse Conference Room \\
\hline August 23, 2000 & Pipeline Meeting - Courthouse Conference Room \\
\hline October 3,2000 & OPUC staff meeting - Salem OPUC offices \\
\hline October 23,2000 & * BLM Specialists Management Team - BLM offices, North Bend \\
\hline November 29,2000 & Pipeline Update Meeting - Coos Bay Council Chambers \\
\hline December 14,2000 & Work session - EA Public Comment Period - Commissioners' Courtroom, Courthouse, Coquille \\
\hline January 30,2001 & * Oregon Department of Fish and Wildlife \\
\hline April 4, 2001 & Public Scoping meeting for EIS - Coos Bay Library \\
\hline April 10,2001 & Public Scoping meeting for EIS - Courthouse Conference Room \\
\hline April 18, 2001 & Public Scoping meeting for EIS - McKinley Grange \\
\hline September 6, 2001 & Lookingglass School meeting \\
\hline October 18,2001 & Lookingglass School meeting \\
\hline November 7, 2001 & BLM public meeting on Draft EIS - North Bend Library \\
\hline February 19,2002 & BLM public meeting on Draft EIS - Coos Bay Library \\
\hline February 19, 2002 & Coos County Commission meeting \\
\hline February 20,2002 & Coquille Rotary Club meeting \\
\hline March 28, 2002 & BLM open house on EIS public comment \\
\hline March 28, 2002 & Coos County Planning and Zoning public hearings \\
\hline
\end{tabular}


Table 37: Pipeline Meetings

\begin{tabular}{|l|l|}
\hline \multicolumn{1}{|c|}{ Date } & \multicolumn{1}{c|}{ Meeting } \\
\hline \hline April 4, 2002 & Douglas County Planning and Zoning public hearing \\
\hline April 7, 2002 & Senator Wyden town meeting in Coos Bay \\
\hline May 2, 2002 & Coos County Planning and Zoning public hearing \\
\hline May 7, 2002 & Natural gas safety conference in Coquille \\
\hline
\end{tabular}

* Unless otherwise indicated by an asterisk, the meetings listed in Table 37 were open for public attendance.

\section{Distribution List and Document Availability on the Internet}

This Final Environmental Impact Statement is being sent to the following individuals, groups, and organizations. In addition, the Final EIS will be available on the internet at: the BLM web site (www.or.blm.gov/coosbay), and the Coos County web site (http://www.co.coos.or.us).

\section{Elected Officials}

Honorable Gordon Smith

Honorable Ron Wyden

Honorable Peter DeFazio

Governor's Office

Coos County Board of Commissioners

Douglas County Board of Commissioners

Curry County Board of Commissioners

\section{Federal Agencies}

USDI- Natural Resources Library

Director USDI BLM

Bureau of Mines

U.S. Fish and Wildlife Service

Mineral Management Service

National Park Service

Environmental Protection Agency

Office of Environmental Compliance

Department of Transportation

U.S. Geological Survey

Department of Energy

Bureau of Reclamation 
U.S. Government Printing Office

USDI-BLM Library

Federal Energy Regulatory Commission

NW Power Planning Council

USDI-BLM Oregon/Washington State Director

Army Corps of Engineers

Bonneville Power Administration

National Marine Fisheries Service

Reg. Environ. Officer, Office of the Secretary, DOI

Bureau of Indian Affairs

Eugene District BLM

BLM Coos Bay District

BLM Roseburg District

BLM Medford District

\section{American Indian Tribes and Nations}

Confederated Tribes of Coos, Lower Umpqua, and Siuslaw Indians

Coquille Indian Tribe

Cow Creek Band of Umpqua Indians

\section{State, County and Local Governments}

Oregon Department of Fish \& Wildlife

Oregon Dept of Environmental Quality

Oregon Department of Geology \& Mineral Industries

Oregon Water Resources Department

Oregon Public Utilities Commission

Oregon Department of Economic Development

Oregon Department of Energy

Oregon Department of Transportation

Oregon Division of State Lands

Historic Preservation Office

Parks and Recreation Department

Oregon Dept. of Land Conservation \& Development

Oregon International Port of Coos Bay

City of Coos Bay

City of North Bend

Bandon Public Library 
Coos Bay Public Library

Coos County Library Service District - Extended Services Office

Coquille Public Library

Dora Public Library

Douglas County Library System

Flora M. Laird Memorial Library

Lakeside Public Library

Hazel M. Lewis Library

North Bend Public Library

Southwestern Oregon Community College Library

\section{Businesses, Organizations and Individuals}

Association of O\&C Counties

Association of Oregon Counties

Bay Area Chamber of Commerce

B. I. S. Inc.

Douglas Timber Operators

Fairview RFPD

Industrial Gas Services Inc.

Kalmiopsis Audubon Society

Klamath-Siskiyou Wildland Center

Native Plant Society of Oregon

Northwest Natural Gas

Oregon Natural Resources Council

PacifiCorp

Pinnacle Engineering

Pipeline Solutions Inc.

Umpqua Watersheds, Inc.

Christina Alexander

Hilary and Brad Baker

Lester Barkley

George Barton

Jaye Bell

Joe T Briscoe

Jim Brown

Will Bunnell

Stephen Brown 
Jody and Michelle Clawson

Robert and Carol Doty

Dana Gabb

James Gomez

Hal K. Graham

Bob Gunther

Ronnie Herne

Jolly Hibbits

David Hopkins

Laura Hughes

George and Eulia Johnson

Bonnie Joyce

Kate Kenyon

Mrs. F. L. Kolby

Lynne Leisy

Les Lemke, The Watch Report

Steve and Wesa Liles

Cliff McClelland

Jim Metcalf

Gary Montesano

Bill and Pam Nelson

Bill Poppe

Mrs. Ruth Randall

Jason Reed

Richard D. Robertson

Debra Roth

Peter Ryan

Ron Sadler

Don Schoonmaker

Monica Schreiber

Pat \& John Simpson

John and Jennifer Shank

Roberta Stewart

Eric Stone

John and Peggy Swindle

Leo Taconi

Larry D. Tams

Bill and Pat Titus 
Charlie Vincent

Keith E. Vrell

Edward Werner

Ronald S. Yockim 


\section{List of Appendices:}

Appendix A. Geotechnical Engineering Report

Appendix B. Cultural Resources

Appendix C. Sheets 1-10

Appendix D. Agency Management Plans for Resources Adjacent to the proposed action corridor

Appendix E. Aquatic Biological Assessment

Appendix F. U.S. Fish and Wildlife Service Endangered Species Consultation Letter of Concurrence

Appendix G. Questions and Concerns from the Public

Appendix G1. Letters Received During Draft Environmental Impact Statement Comment Period

Appendix G2. Responses to Letters Received During Draft Environmental Impact Statement Comment

Period

Appendix H. Erosion Control Plan

Appendix I. Watersheds and Streams

Appendix J. Construction, Operation and Maintenance Plan

Appendix K. Survey and Manage Species

Appendix K1. Special Status Species

Appendix L. Glossary of Terms

Appendix M. List of References

Appendix N. Consistency Determination 


\section{Appendix A. Geotechnical Engineering Report}

The following changes were made in Appendix A between the Draft and Final Environmental Impact Statement. Minor corrections, explanations and edits are not included in this list.

- Maps of the proposed action have been removed from this document. Please refer to the Draft EIS.

Site Reconnaissance and Construction Recommendations

for the Coos County Natural Gas Pipeline

Project

Prepared by:

Pinnacle Engineering, Inc.

3329 NE Stephens St.

Roseburg, OR 97470

Project \# 20517.2 


\section{GEOTECHNICAL ENGINEERING REPORT}

Route Reconnaisatance and Construction Recommendations for the Covs County Natural Gas Pipeline Project

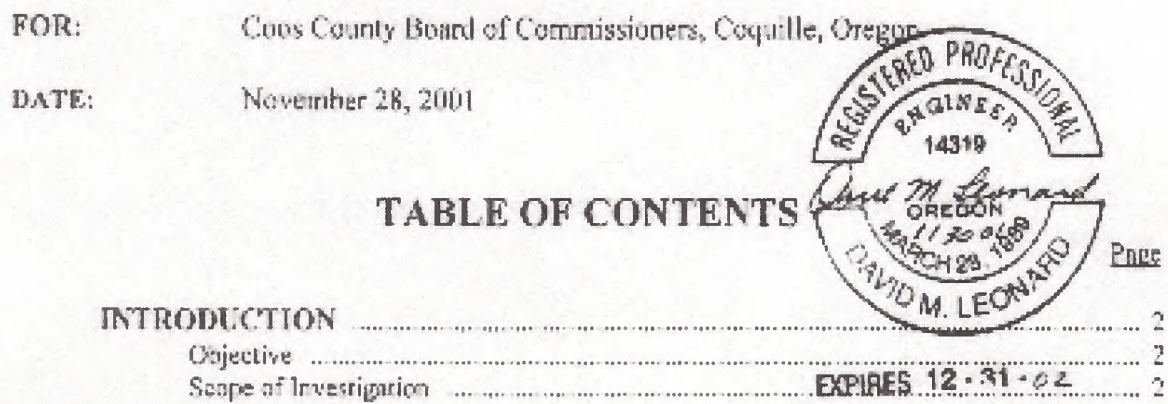

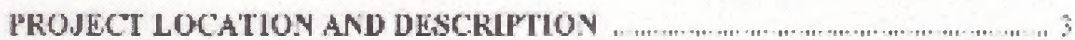

Sive Losation ird Destription ....................................................................................... J

Dessiption of Proposed Pipelixs .........................................................

GEOLOGIC SFTTING AND NATURAL HAZARDS .............................................

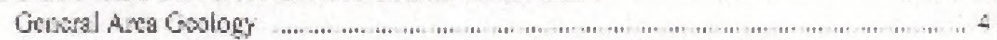

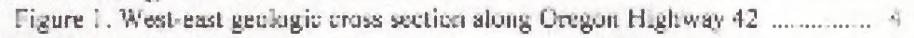
Surficial ज̧oils

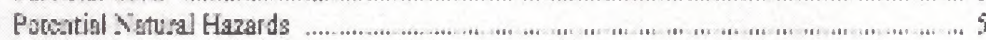

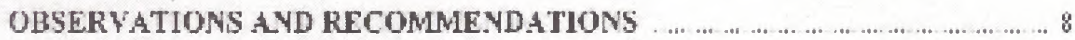

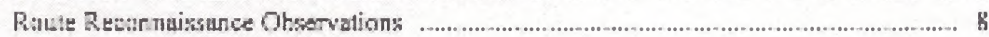

Porential Construction Problen:

Figure 2. View of BPA power line an steep hillside ....................................... 12

Figure 3 Riss of BP.A powser line up steep 20 per cent, slope ................... 2

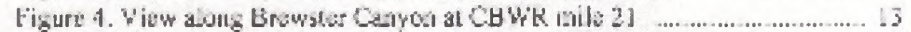

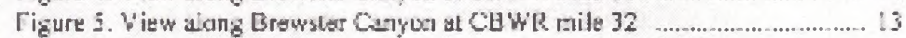

Discussisan of Poiential Geagagis llaxards ................................................................. .

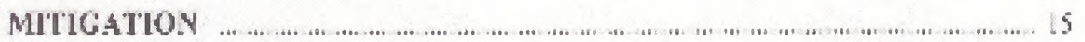

RECOMMENDATIOYS FOK FUTLRH WORK ..................................... IS

REPORT LIMITATIONS _.................................................................................. Is

TABLIC 1. Sarvey of Foundation Soil and Rock, Coos Counn' Naturn Gas Pipeline Projest . 1 ?

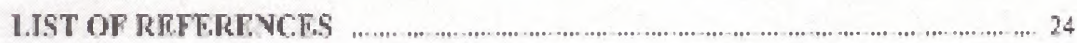

APPENDIX A - TOPOGRAPHIC MAPS OF PROPOSED ALIGNMENT ........ 26

APYLEDIX B - SLRFACE GEOLOCY MAPS ................................ 36 


\section{Introduction}

\section{Objective}

The Coos County Natural Gas Pipeline ("the pipeline") is proposed for construction between Roseburg and Coos Bay, Oregon, along the route depicted in Appendix A. The route will utilize the ROW of the CBW Road and the Bonneville Power Administration (BPA) power line and will pass through or near the communities of Lookingglass, Reston, Sitkum, Dora, McKinley, Fairview and Sumner, ending near Coos Bay.

Engineering design and construction of the pipeline will be directly affected by:

- geologic features,

- the type and thickness of soil deposits,

- depth to rock,

- gradient of soil and rock slopes within the construction limits,

- width of working space available,

- watercourses and stream crossings,

- natural and man-made obstacles.

This report presents the results of a geotechnical engineering reconnaissance survey of the proposed route. The observations and opinions presented herein are focused on constructability of the pipeline from a surface soils, i.e., geotechnical engineering, standpoint.

The original report was prepared by S. Joseph Spigolon, Ph. D., P.E. for the Coos County Board of Commissioners and Biological Information Specialists, Inc. Subsequent to preparation of the draft report and while agency review was being conducted, Dr. Spigolon succumbed to a sudden illness. Pinnacle Engineering, Inc. was then engaged to review Dr. Spigolon's report and agency review comments and to issue a final report, including responses to agency comments.

Also while agency review was being conducted, portions of the route alignment were changed from that evaluated by Dr. Spigolon. Accordingly, geotechnical review and opinion of the revised route is also contained herein. The scope of services performed by Pinnacle for the route change were identical to those conducted for the original report.

Data presented in Dr. Spigolon's report [21] have been reviewed to the extent practical and, where appropriate, relied upon in this revised report.

\section{Scope of Investigation}

The level of investigation for this study was limited to reviewing appropriate geotechnical and geological literature and conducting a site observation and reconnaissance of the proposed pipeline route. The literature review searched for relevant information about project soils and surficial rock contained in published and unpublished geological and Soil Survey documents. Reconnaissance of the entire proposed pipeline route was conducted to observe soil and rock outcrops. morphology, limitations to construction access, and evidence of existing or potential natural hazards. 


\section{Project Location and Description}

\section{Site Location and Description}

The proposed natural gas pipeline will start at the Williams Gas Pipeline metering facility southwest of Roseburg and end near Coos Bay. At Coos Bay, the pipeline will connect with proposed Northwest Natural Gas (NW Natural) distribution facilities to service the surrounding communities and possibly the industrial properties on the North Spit. All of the fifty nine mile route is to be located within existing ROW of either the CBW Road and other public roads or within existing power line corridors. The pipeline route (maps) is depicted fully in Appendix $\mathrm{C}$ to this EIS.

Virtually the entire length of the proposed pipeline route is within the Coast Range, a long narrow band of moderately high mountains that ends in coastal headlands at Coos Bay. The Coast Range in Oregon extends from the Columbia River to the Middle Fork of the Coquille River at the southern limits of Coos County [1] $]^{1}$. The Coast Range is about fifty miles wide at the project location and the terrain, consisting of steep hills and sharp crests, ranges in height from sea level to crests at about 3,000 feet above sea level.

The Coast Range is mainly formed of weakly consolidated sandstone and siltstone and is easily weathered and eroded. The major streams in the area west of the Coast Range, including the East Fork of the Coquille River, flow westward toward the ocean or, in the Coos Bay area, north toward the bay. East of the Coast Range, the major streams flow easterly to the South Umpqua River, then north and west toward the ocean at Reedsport. The terrain is formed of a succession of ridges and small valleys. The heavily dissected erosion gullies are typically oriented northsouth. Many of the valleys have differences in elevation along the BPA power line route of 1,000 feet or more between ridge crest and valley bottom.

In the eastern 75 percent of Coos County and the western part of Douglas County, the soils along the proposed pipeline route are mostly well drained and loamy or clayey and are well suited to timber production [2] except in Brewster Canyon. Some of the land adjoining the route has been clear-cut by timbering operations. The ROW of both the CBW Road and the BPA power line have been cleared as a result of prior construction activity.

\section{Description of Proposed Pipeline}

The main line of the Coos County Natural Gas Pipeline will consist of a 12.75 -inch outside diameter, 0.25 inch wall thickness, welded steel pipe having a minimum yield strength of 2,039 pounds per square inch gauge (psig). The maximum allowable operating pressure will be 1,000 psig. The pipe will be coated and packaged magnesium anodes will be attached at approximate 1,000 feet intervals to limit corrosion. Where the pipeline is constructed within the power line corridor, additional measures may be taken to mitigate potential hazards due to induced current.

A number of block valves will be included in the project. Mitigation of potential geologic and geotechnical impacts along the route will be accomplished by installation of an assortment of additional automatic and/or remote control valves at strategic locations to be selected during final design. Automatic or remote control valve locations will be selected during final design. Preliminary locations are recommended in subsequent sections of this report.

Pipeline construction will best be accomplished using a working space of 25 to 30 feet, which may require a total width of up to 60 feet in steep side slope areas. Where sufficient width is not available, short sections of the project may be constructed in a more restricted width.

The pipe will be installed with 36 inches of cover where practical. In areas with less than 3 feet depth to consolidated rock, a minimum of 18 inches of cover is allowed. The existing ROW will be restored to current or better condition as construction is completed.

\section{Geologic Setting and Natural Hazards}

The following discussion of surface geology and natural hazards near or affecting the project route is based on published and unpublished information from the following sources:

- various bulletins and geologic maps published by the Oregon Department of Geology and Mineral Industries,

- reference texts discussing the geology of the project route, 
- unpublished air photos and pedologic soil descriptions from the Douglas County Area Office of the Natural Resources Conservation Service, Roseburg,

- the Soil Survey of Coos County [2] published by the Natural Resources Conservation Service and

- various documents published by the USGS, including the Geologic Map and Database of the Roseburg Quadrangle.

\section{General Area Geology}

The bedrock forming the Coast Range consists of materials that were deposited in the ocean and later uplifted by tectonic action. Layers of basalt were deposited under water by volcanic activity and subsequently covered by sand and silt sediments eroded from the Klamath Mountains. Much later, after the sand and silt became sandstone and siltstone, the mass of rock was raised and crumpled into folds by the slow landward movement of the Pacific Ocean floor [3]. The present day outcrops of the rock show a sequence of north-south exposures consisting of a few relatively narrow bands of basalt interspersed with large, wide expanses of the sandstone and siltstone of several formations. The soils resulting from weathering of the underlying bedrock reflect the mineralogy of the parent rock. A west-east cross section of the route along U. S. Highway 42 [3, p. 106], south of and roughly parallel to the CBW Road, is shown in Figure 1 as an illustration of the typical geologic section along the pipeline route.

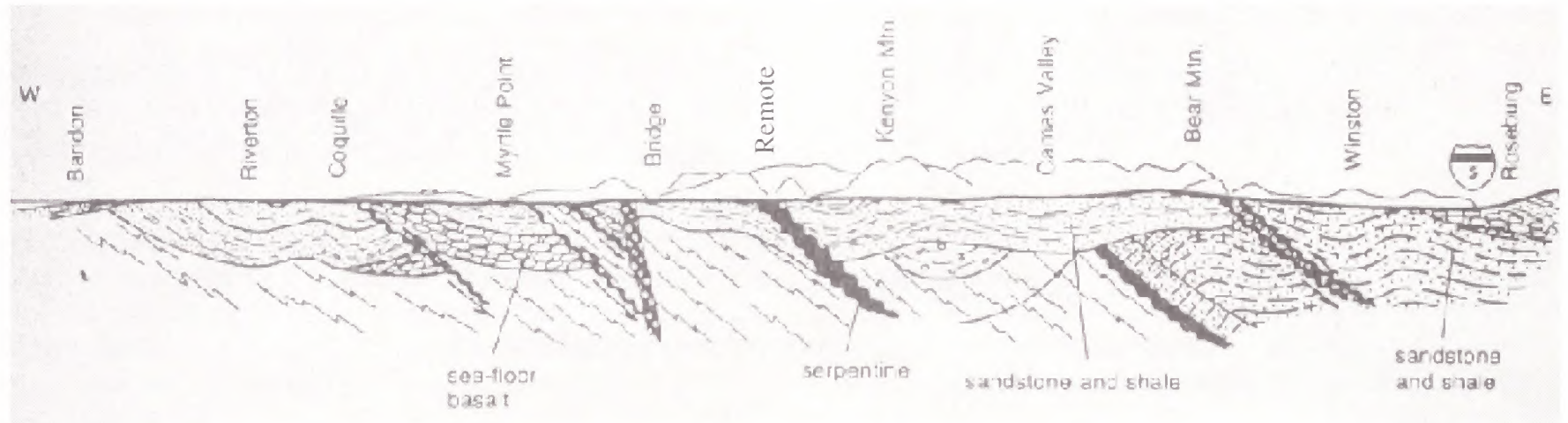

Figure A-1. West-east geologic cross-section along Oregon Highway 42, south of and parallel to the CBW Road, showing compression and tilting of strata.

The folding of the rocks illustrated in Figure A-1 resulted in a series of lineaments or fault lines, more or less oriented perpendicular to the direction of push $[4,5]$. These are ancient lines of movement and are not active fault lines.

Starting at the eastern end of the project, the bedrock underlying much of the city of Roseburg, and extending westward to the west slope of the hills immediately east of Lookingglass, is a layer of basalt. This is the Roseburg Formation, the basal member of the Umpqua Formation [6].

As the route enters Lookingglass Valley, the underlying bedrock is a rhythmically bedded sandstone and siltstone of the Lookingglass Formation. Near the western edge of the Lookingglass Valley, the pipeline route crosses the inactive Reston-Bonanza Fault. Between Lookingglass and Reston the terrain is underlain by the mudstone, siltstone, and fine grained sandstone of the Flournoy Formation.

West of Reston the route enters the outcropping of the Tyee Formation, an arkosic sandstone with siltstone interbeds. Arkosic sandstone is described in the geologic literature [7] as a light pink sandstone predominantly of feldspar and 
quartz, coarse grained, porous and easily eroded. Brewster Valley and the surrounding heavily eroded ridge and valley terrain are underlain by the Tyee Formation.

West of Dora the route enters a short north-south outcrop of the Lookingglass Formation, as described above [6].

Northwest of Dora, the area encompassing the communities of McKinley and Fairview is underlain by the Roseburg Formation. In this area, the bedrock is a rhythmically bedded sandstone and siltstone with localized, thin interbeds of basalt.

At the western end of the proposed pipeline, between Fairview and Coos Bay, the route is underlain by the sandstone and interbedded siltstone of the Coaledo Formation.

Surface geology along the route is depicted with maps at the end of this report.

\section{Surficial Soils}

Construction of the pipeline will be affected by the properties and thickness of surface and near-surface soils and the depth from the ground surface to underlying rock. Generally, the surface soils were derived from mechanical and chemical weathering of the underlying parent rock. Most of the soils within project limits are residual in nature, although significant expanses of transported soils, i.e., colluvial and alluvial material exist, especially in the western section.

Research during preparation of this report depended heavily on the soil profile descriptions contained in the soil survey documents of the Douglas County [11] and Coos County Soil Conservation Service [2] offices. Field work conducted for those studies was generally limited to a determination of the soil profile to a depth of five to six feet, the depth appropriate for this project.

Within the project limits, residual soils are typically a minimum of two to three feet thick. The underlying layer of weathered rock typically ranges from a few feet to tens of feet. Excavation within the weathered layer can be accomplished normally by use of a high energy track excavator. Along steeper slopes, the thickness of residual soils is typically less.

\section{POTENTIAL NATURAL HAZARDS}

Natural site hazards are naturally occurring conditions that may impact the completed project. Credible natural hazards include, in varying degrees of probability;

- flooding, either tidal or surface streams,

- erosion,

- mass soil movement, either creep or landslides,

- seismic activity, i.e., earthquakes, liquefaction and tsunamis,

- general land subsidence.

Of these potential natural hazards, only stream flooding, erosion, mass soil movement and seismic activity are considered credible potential natural hazards for the project.

\section{Stream Flooding}

Except in the alluvial floodplains around the several communities along the route and in Brewster Canyon, the proposed pipeline route is within the BPA power line ROW in the hillsides, well above stream levels, and stream flooding is not a credible hazard. Stream flooding in the alluvial floodplains and in Brewster Canyon, however, is likely to occur during the design life of the project, but would only be significant to the extent that it affected integrity or operability of the completed pipeline. 
Integrity of the pipeline would not be affected by inundation, as the pipeline will be buried, air-tight, and under internal pressure. Further;

- there is no record of past flooding of rivers and major streams to a degree that would compromise integrity of the proposed pipeline.

- the CBW Road in Brewster Canyon, along the East Fork of the Coquille River, is rarely flooded above roadway level.

Operability of the pipeline, specifically certain of the valves, could be affected by flooding. Potential impacts to operability can be mitigated by location of critical valves above flood elevations or by incorporating design features that would allow valve operation regardless of flood conditions.

\section{Erosion}

Since the proposed gas pipeline is anticipated to be bored beneath major stream crossings, damaging erosion will be effectively mitigated by vertical separation. Minor erosion is possible at crossings of intermittent streams, but damage to the pipeline from such erosion is not credible.

\section{Mass Soil Movement}

Slopes are susceptible to mass movement any time the weight of the soil mass acting along the slope travel angle exceeds the soil shear strength available to resist the movement. Slope movement can occur even at a very gradual slope gradient. Naturally occurring landslides, those not caused by the action of man such as loading of the top of the slope or removal of soil at the bottom, invariably result from a decrease in shear strength of the soil mass due to increased water content or by an increase in effective weight of the soil mass, such as would occur during a seismic event. Damage from mass soil movement is directly related to Landslide Velocity Class and volume of mobilized mass. Landslide Velocity Class ranges from unnoticeable (creep) to sudden.

- Soil Creep. Soil creep is a very slow downhill movement of soil that is typically a continuous movement which proceeds at an average rate of less than a foot per decade [20]. It occurs more commonly in deep deposits of high plasticity soils on moderate slopes. Shrinkage cracks may form in the soil during the dry season, becoming partially filled with drier soil particles. During the following wet season, moisture content of the clayey soil increases, usually more at the surface than below. The moisture increase decreases the shear strength to a nearly critical state where shear failure is imminent and a slight movement can occur, greater at the surface than at depth. This combination of effects usually leads to very slow downhill movement. Over a period of many years, the movement can become noticeable and significant damage can occur. Severity of damage experienced is directly dependent upon Landslide Velocity Class [20]. Soil creep is not considered a credible hazard, as the probable rate of movement would allow many years for mitigation to be accomplished.

- Sudden Movement. Sudden movement of soil masses ranging in size from small to medium are likely to occur at several locations within the project limits during its design life. Locations of most concern are described in subsequent sections of this report, as are recommended mitigation measures.

\section{Earthquake}

Earthquakes are the result of a sudden differential displacement of a portion of the earth along a fault plane. The movement releases elastic energy that causes violent shaking of the earth's surface in both the horizontal and vertical directions. Such shaking can induce mass soil movement. As noted above, the historical record of earthquakes in Oregon only extends back to 1833 [15].

Earthquakes in Oregon originate from one of three different source areas [13, 14, 22]:

- Crustal earthquakes, that occur along relatively short and shallow faults that exist within the upper 6 to 12 miles of the surface. These are faults, such as those illustrated in Figure A-1, that are sometimes, but not always, visible at the surface and, therefore, may not create horizontal displacements at the ground surface. The resulting earthquake can reach a magnitude as large as 6.5 to 7 . The March 1993 Scotts Mills earthquake, magnitude 5.6, and the September 1993 Klamath Falls main shocks, magnitude 5.9 and 6.0, were crustal earth- 
quakes.

Intraplate earthquakes occur within the remains of the ocean floor, the San Juan de Fuca Plate, that has been subducted under the North American Plate. These are deep movements, occurring at depths of 25 to 37 miles below the ground surface, that can reach a magnitude as large as 7 to 7.5 . The Puget Sound earthquakes of 1949 and 1965 were intraplate earthquakes.

- Cascadia Subduction Zone (CSZ) slippage. Great subduction zone earthquakes occur around the world when tectonic plates collide. The dipping interface between the two plates is the origin of some of the most powerful earthquakes ever recorded, often having magnitudes of 8 to 9 [22]. In the northwest, the Cascadia Subduction Zone has been recognized for many years, but no earthquakes have occurred during our 200 year recorded history. In the CSZ, the San Juan de Fuca Plate is slowly moving under the North American Plate along a line about 40 to 50 miles offshore extending from British Columbia to northern California. Sliding friction between the two plates is believed to be causing the edge of the North American Plate, in the region of the coastal area of the Coast Range, to bow upward. Periodically, the friction is believed to be overcome along a section of the CSZ, allowing that portion to drop a short distance and cause violent shaking.

Although no CSZ earthquakes have occurred in the past 200 years, there is widespread evidence that very large earthquakes have occurred repeatedly in the past, most recently about 300 years ago. The best available evidence indicates that CSZ earthquakes occur on average about every 500 to 540 years, with an interval between individual events ranging from $100-300$ years to about 1,000 years.

Discussion. Crustal earthquakes of low magnitude are common in northern and eastern Oregon, but not in the Coos-Douglas County area. Jacobson [16] plotted the Oregon earthquake database record on a map of Oregon and showed that there have been no earthquakes recorded within 50 miles of the proposed pipeline route except for a magnitude 3.0 quake in central Douglas County. Geologic evidence of fault movement has been summarized in the map by Madin and Mabey [17]. They showed that there has been no known fault movement within the past $1,600,000$ years along the route of the proposed pipeline. There are, however, a few faults that have moved within the past 10,000 years south of Coos Bay.

The major earthquake concern along the southern Oregon region is the potential for a CSZ displacement and the damage that would result. Geologic evidence of such events [18] indicates that at least five such earthquakes have occurred within the past 300 to 3,500 years, each occurring along a limited, 150 to 300 miles, length of the coast in the region between Vancouver, B.C. and northern California. It is estimated that the most recent event occurred about 300 years ago.

Estimates of coastal subsidence [18] for a subduction zone event are on the order of a maximum of 1.5 to 3 feet. This will create a ground acceleration of about $0.4 \mathrm{~g}$ (gravity) along the coast at Coos Bay [19] if that part of the coast is included in the CSZ slippage zone. The acceleration rate is attenuated by distance from the slippage so that acceleration of the bedrock at Roseburg would be reduced to about $0.2 \mathrm{~g}$ from the same event. A similar attenuation will occur at Coos Bay if the slippage occurs at some distance north or south along the length of the subduction zone.

The most severe damage due to earthquakes is commonly localized and generally caused by one or more of the following;

- Amplification of ground shaking by a soft soil column.

- Liquefaction of water-saturated sand, silt or gravel, creating areas of "quicksand".

- Landslides triggered by shaking, even on relatively gentle slopes.

- Amplification is not deemed a credible risk, as;

- The depth of soft soil and properties conducive to amplification do not generally exist along the alignment.

- Damage from amplification is most critical to above ground structures, where the fundamental site period and first period of vibration of the structure are similar.

Liquefaction can occur in deep, saturated deposits of loose, clean sand, gravel or silt if shaking causes the grain structure of the soil to lose inter-particle friction and collapse, i.e., a temporary loss of shear strength. When liquefied, the soil deposit behaves like a viscous liquid. Since deposits subject to liquefaction are not likely to exist along the proposed pipeline route, liquefaction is not considered a credible risk to the project.

Landslides triggered by shaking, although low probability, are deemed the most likely seismically induced hazard that could affect the project. Mitigation measures for seismically induced landslides are identical to those recommended for landslides induced by increased moisture and are described in subsequent sections of this report. 


\section{Observations and Recommendations}

\section{Route Reconnaissance Observations}

Six visual reconnaissance trips [21] along the proposed route of pipeline were made for this report, four by vehicle on the CBW RoadCBW Road and one each by helicopter and airplane along the BPA power line route. The objective of each reconnaissance trip was to observe soil and rock outcrops, slopes, width available for construction, and to discover evidence of existing or potential natural hazards. In addition, several segments of the BPA right of way, where potentially significant problem areas were noted by aerial or photo reconnaissance, were observed on foot.

A tabulated summary of the near-surface soils along the route is contained in Table A-1, Survey of Foundation Soil and Rock, Coos County Natural Gas Pipeline, included subsequently in this report. The information and observations contained in Table I were derived from a combination of;

- field and office interpretations of geologic features along the route,

- field and office interpretations of the Douglas County and Coos County Soil Survey data cited above and

- field observations made during the six reconnaissance trips.

The proposed route of the Coos County Natural Gas Pipeline, consists of six distinct sections:

a) from the connection to the Williams pipeline south of Roseburg to about the Coos County line, west of Reston, it will follow the Pacificorp/ BPA ROW.

b) at the Coos/Douglas County line, the pipeline will follow the ROW of the CBW Road through Brewster Canyon to three miles west of Dora.

c) from three miles west of Dora to the Lone Pine Bridge, it will follow the BPA right of way.

d) from the Lone Pine Bridge to McKinley, it will follow the CBW Road.

e) from McKinley to Fairview it will first follow the power line right of way, then from Fairview to the Coos City Bridge, it will follow the CBW Road.

f) the final segment will rejoin the BPA ROW and continue to the end of the pipeline near Coos Bay.

Physical conditions along the pipeline route are generally described as;

1. Section from Williams Pipeline to Lookingglass. This five mile section of the project passes through a hill of basalt with an overlying layer of high plasticity clay soil. Slopes along the roadway and the Pacificorp power line are typically less than 10 percent, although a short section of between 20 and 40 percent slope exist as the route descends into the Lookingglass Valley.

The soil is estimated to be over five feet thick along the power line. There are two rock quarries at ground level near the alignment, indicating a possible thin soil overburden at isolated locations. The soil in Lookingglass Valley is quaternary alluvium, typically firm, with depth to rock greater than five feet.

Between the Williams sub-station and Lookingglass, the pipeline will cross a small remnant of an ancient landslide and a localized seepage area along the east slope of Powderhouse Canyon. Neither of these features are likely to impact project integrity or constructability.

2. Section from Lookingglass to Reston. At the Lookingglass Valley, bedrock is sandstone and siltstone of the Flournoy Formation and the residual soils are sandy clay and silty clay of low plasticity. Because of low resistance to erosion, the rocks in this region and the remainder of the route are at an increased slope gradient and the valleys are deeper. Both the CBW Road and the power line sometimes follow hillsides. Slopes along the paved roadway and the BPA power line are typically less than 10 percent, although short sections exist where the slope is between 20 and 45 
percent. Soil thickness over rock is generally greater than five feet along both the CBW Road and power line routes. The roadway is a full two lanes wide in this section of the project.

West of Lookingglass, as the pipeline joins the road, a hummocky area was noted on the south side of the road. At Reston, a short stretch of recent slumps were noted. Neither of these features are likely to impact project integrity or constructability, however, the slumps should be further investigated during final design and mitigated conventionally.

3. Section from Reston to Sitkum. West of Reston the CBW Road enters hillier terrain, the most rugged along the proposed route. Bedrock is soft sandstone and siltstone of the Tyee Formation and is heavily eroded. Residual soils over the rock are either sandy or silty clay of low to moderate plasticity. Depth of soil along the steep hillside route of the BPA power line is generally more than five feet.

Hillside slopes along the power line are typically greater than 20 percent and reach as much as 33 percent. Short stretches exist that are steeper. Ridges can be as much as 1,000 and more feet apart with 1,000 feet of elevation change from ridge top to valley bottom.

The power line route crosses a small slump and a large hummocky area before descending to join the CBW Road. At the junction of the power line right of way and the CBW Road, the alignment passes longitudinally through an ancient landslide. None of these features are likely to affect project integrity or constructability, although landslide mitigation measures discussed more fully herein should be incorporated.

The CBW Road enters Brewster Canyon near the Coos County line. Between the Coos County line and Sitkum, the Brewster Valley route of the CBW Road is in a deep valley created by the East Fork of the Coquille River. The roadway is unpaved and is at the bottom of a series of steep, nearly vertical, rock cliffs. The width of the roadway varies from one lane to barely two lanes and the width from cliff face to river drop-off is occasionally less than 30 feet. The road generally follows very close to the river which is typically at some depth below roadway level. The river bottom is exposed and appears to be unweathered rock. The depth of soil along the roadway is unknown but is probably less than five feet except, perhaps, at the edge away from the cliff face. The roadway generally is at a gentle grade and crosses the Coquille River twice over bridges. Sitkum is at the entrance to the Brummit Creek valley.

Except for short sections where competent rock may be within three feet of surface, there are no features of geotechnical concern in the CBW Road segment.

4. Section from Sitkum to Dora. This section of the CBW Road also follows Brewster Canyon and the Tyee Formation, but is slightly less rugged. Roadway widths continue to be narrow and rock cliffs still form one side of the unpaved roadway. Soil depth along the roadway is still probably less than five feet. Slopes along the BPA power line remain steep, often reaching 26 percent to 28 percent, with long distances between ridge lines. Depth to fractured sandstone in the hillside soils is occasionally less than five feet.

A geologic map [5] of the area indicates that there are small sections, each between 100 and 3,000 feet long, along either the CBW Road or the East Fork of the Coquille River, that consist of landslide deposits of geologically recent (Holocene and Pleistocene epochs, i.e., within the past 1,600,000 years) age. These deposits are described as "fragments of bedrock mixed with gravel, sand, silt or clay." Observations of these "landslide" areas concluded that they are mainly characterized by more gentle slopes than the surrounding hills and large, over 15 feet wide, boulders scattered about. This is typical of the debris at the lower part of a slide in the soft sandstone and siltstone bedrock. The slides are ancient, as demonstrated by formation of the Coquille River floodplain at several areas at the bases of the slides and weathering of the exposed surface of the boulders. These slides appear to be stable and are not likely to impact project integrity or constructability.

5. Section from Dora to McKinley and Fairview. At Dora the CBW Road and the BPA power line leave the valley of the East Fork of the Coquille River and Brewster Canyon and turn northwest. Bedrock is the Roseburg Formation consisting of sandstone and siltstone with localized, thin interbeds of basalt. The residual soils are a sandy or silty clay of low to moderate plasticity. Soil depths appear to be greater than five feet. The terrain is less rugged than along the Brewster Canyon segment, although hillside slopes along the BPA power line route can reach as much as 15 percent to 20 percent. The roadway becomes two-lane and paved at McKinley and remains paved to just beyond Fairview. 
One mile west of Dora, an ancient landslide similar to that described above is located north of the CBW Road. A recent rockfall was noted clear of the route, south of the CBW Road about 1.1 miles northwest of McKinley. Neither of these features are likely to impact project integrity or constructability.

6. Section from Fairview to Sumner. At Fairview, the pipeline continues along the CBW Road, which is unpaved for several miles but is at least two lanes wide. The terrain continues to be more gentle than that to the east, with hillside slopes ranging from 5 percent to 12 percent. Short sections of steeper topography exist. Soil depths are expected to be greater than five feet.

There are no features of geotechnical concern which would impact project constructability or integrity in this segment.

7. Section from Sumner to near Coos Bay. After passing South Slough Road, the BPA power line and the proposed pipeline route leave the CBW Road and continue along the Coos-Sumner Road, finally reaching and crossing Isthmus Slough and U. S. Highway 101. West of the highway the BPA power line turns north to the end of the proposed pipeline near Coos Bay. Bedrock is Coaledo Formation sandstone and siltstone and continues to be less rugged, with much more gentle slopes.

There are no features of geotechnical concern which would impact project constructability or integrity in this segment, although the horizontal bore beneath Isthmus Slough will require typical scrutiny during final design.

\section{POTENTIAL CONSTRUCTION PROBLEMS}

There are no particularly unusual or difficult construction problems anticipated for the proposed pipeline project. Soils over most of the route will be deep enough and firm enough to stand open without bracing the three to four foot deep trench necessary for construction and will not be below the groundwater level, except at isolated locations.

Where the pipeline is located within the roadway, short sections may be encountered where depth to competent rock is less than five feet. We anticipate, however, that most of these areas can be excavated to a satisfactory depth using a high energy track hoe.

Final design is expected to be typical for the size, type and location of the proposed project. Of normal concern are;

1. Sideslope Construction. Along several locations, the BPA power line was constructed on relatively steep sideslopes, illustrated by Figure A-2. Since pipeline construction equipment will require a reasonably level working space of 25 to 30 feet wide, as much as 60 feet in width will be required to allow excavation and leveling of the work area. Except for minor impacts on schedule, this feature does not present unusual complexity.

2. Steepness of Slopes. The heavily eroded ridge and valley ground surface along the route from Reston to Dora has resulted in very steep slopes with large elevation differences between the ridge top and valley bottom. Steep slopes reaching, and occasionally exceeding, 20 percent grade exist along the sections of the pipeline originally proposed to be placed in the BPA power line ROW. This is illustrated in Figure A-3. 


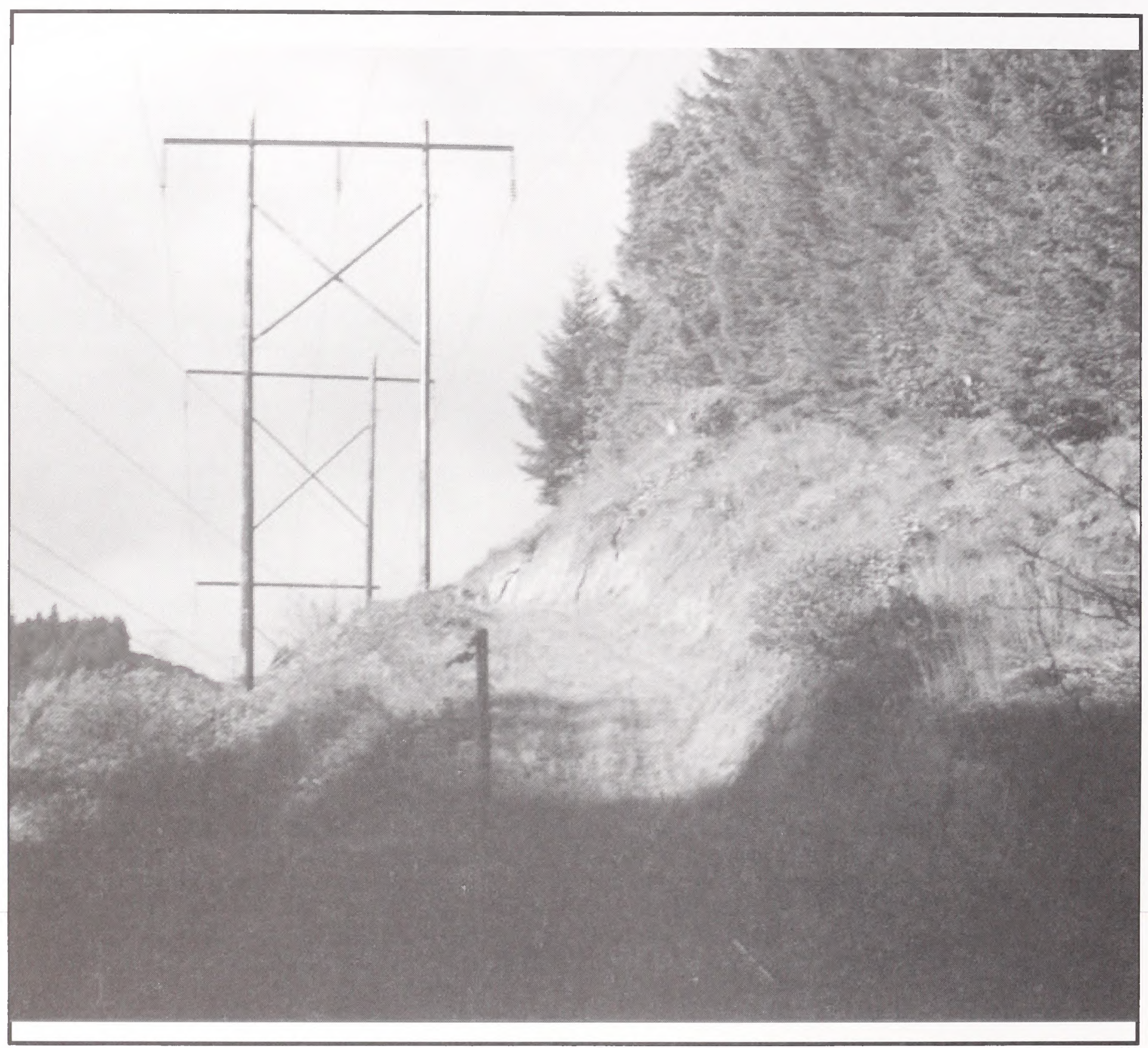

Figure A-2. View of BPA powerline on steep hillside at Mile 10 on CBW Road. 


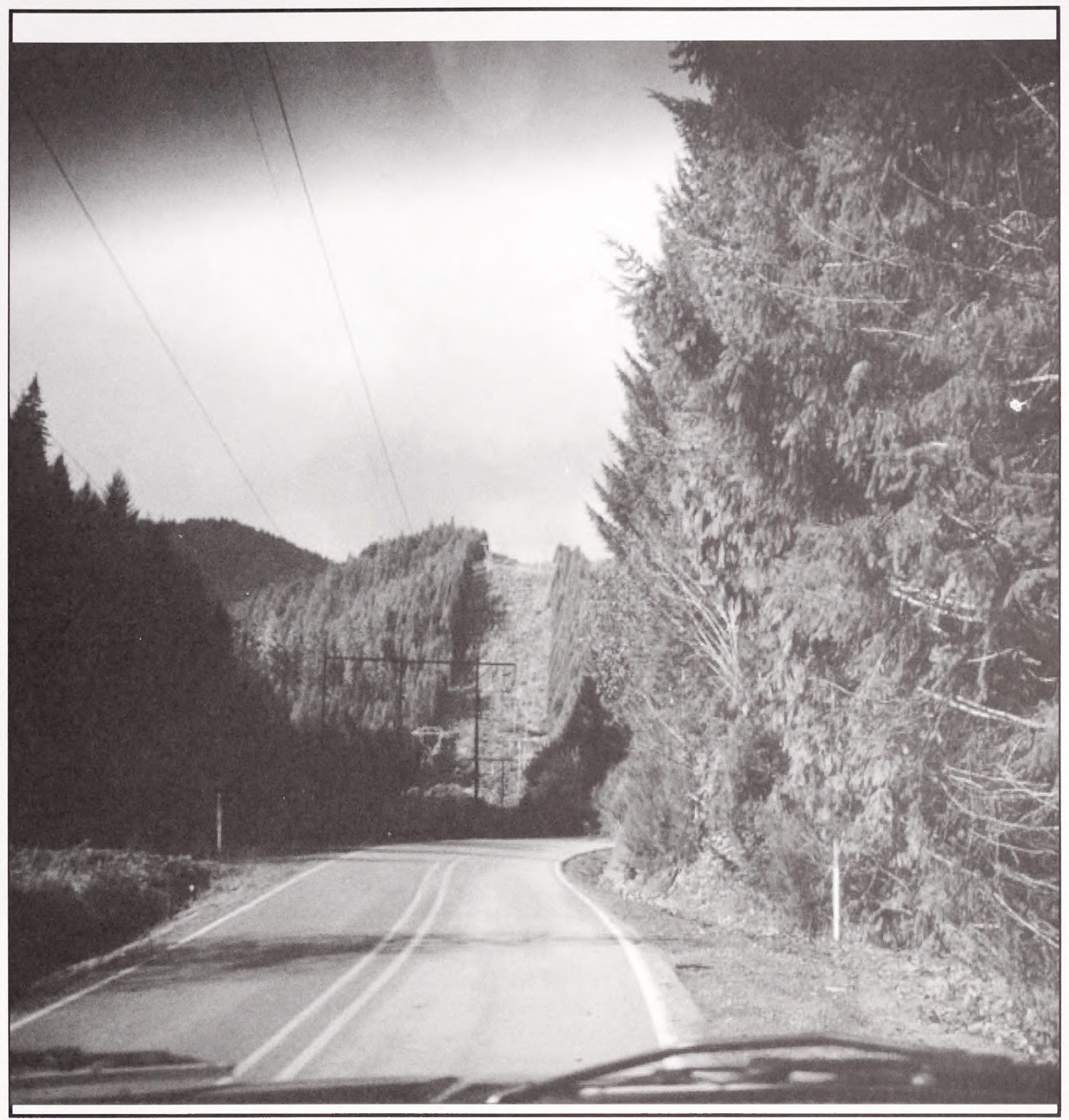

Figure A-3. Rise of BPA powerline up steep 20 percent slope at Mile 13 on CBW Road 


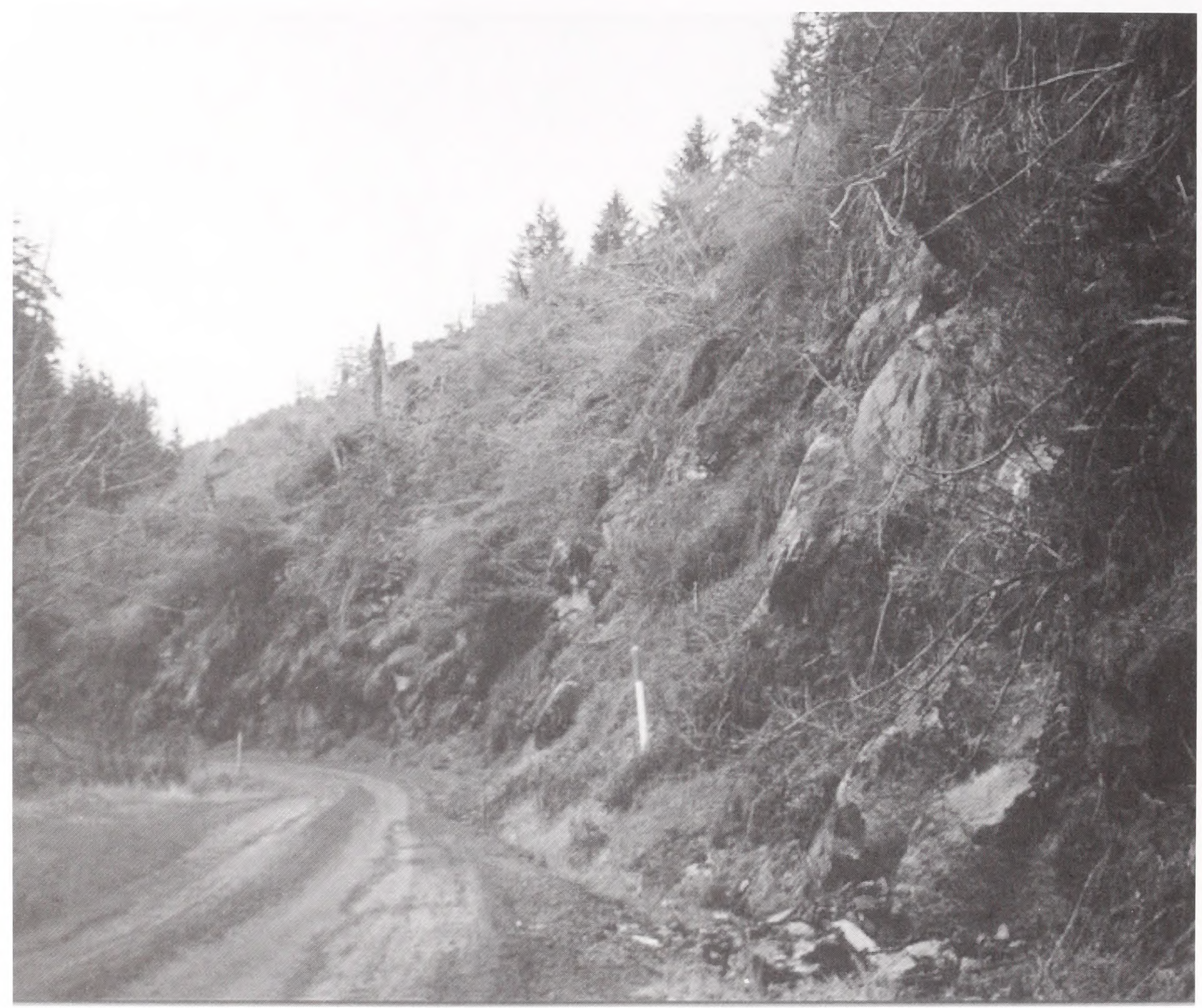

Figure A-4. View along Brewster Canyon at Mile 21 on CBW Road. Left side of road leads down at steep angle to the East Fork of the Coquille River 


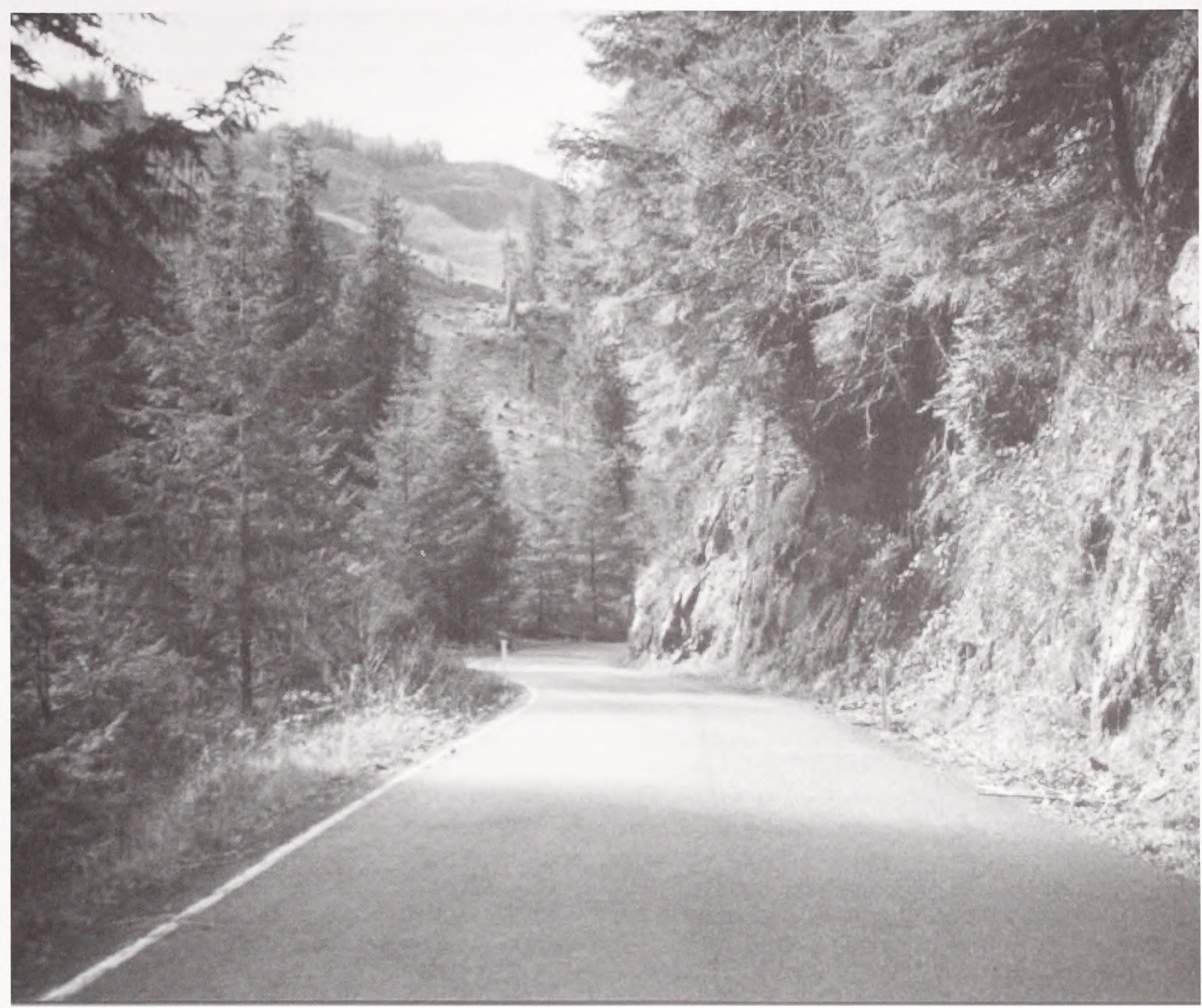

Figure A-5: View Along Brewster Canyon on CBW Road.

3. Shallow Depth to Rock. At a few locations along the CBW Road, especially in Brewster Canyon, the depth to rock along the centerline of the roadway may require isolated use of air tools to achieve the desired three feet of cover. Sections of the CBW Road that may have rock very close to the roadway surface are illustrated in Figure 3 and 4 and are more fully delineated in Table A-1. Since depth of competent rock has not been verified by field test, inferred instead from the appearance of rock along the side of the road at roadway level and from the probable method of construction used during the 1870 's, locations determined to be especially problematic or to pose unacceptable budgetary uncertainty should be explored using an auger drill during design.

Considering the recent experience gained during construction of a separate underground utility project, for which a trencher was used with little difficulty to excavate a three to four feet deep trench, we anticipate that rock excavation requirements will not be unusually difficult. 
4. Rock in Coquille River. At two locations in Brewster Canyon, the CBW Road crosses the East Fork of the Coquille River. At both locations the exposed river bottom is composed of apparently unweathered sandstone-siltstone bedrock. We recommend that these two crossings be accomplished by either direct excavation and burial or by suspending the pipeline from the two existing bridge structures, since directional drilling will be very difficult.

\section{Discussion of Potential Geologic Hazards}

The steel, continuously welded and buried pipeline is similar to a long elastic string and can sustain some general lateral and/or vertical movement or direct tension. The potential causes of rupture of the pipeline along the proposed route are either shearing movement of the supporting soil, in which there is an abrupt lateral and/or vertical displacement of soil and pipeline, or a tensile failure resulting from the pipeline being "stretched" as it resists a sliding soil mass. Shear or tensile forces are most likely to result from landsliding.

\section{Seismic Activity}

Earthquake shaking of the ground causes general ground movement but does not normally cause surface shearing movements. The principal source of earthquake induced shear displacement at the surface is landsliding, which can be triggered by a seismic acceleration of the soil mass.

The probability of an earthquake-induced landslide resulting in shearing of the pipeline is dependent on earthquake recurrence interval. As noted in preceding sections of this report, the principal seismic concern is a CSZ event originating along a line about 40 to 50 miles off the coast of Oregon, resulting in lateral accelerations between 0.2 and 0.4 g. Although the probability of a CSZ event occurring during the design life of the project is highly speculative, if one does occur, it is more probable than not that landslides will result. Accordingly, mitigation of potential landslide impacts should be incorporated into the design.

\section{Moisture Induced Landsliding}

Moisture induced landsliding is deemed no more likely along the proposed route than in any other route that would logically serve the project. Considering the high ductility of the pipe material and the considerable tensile strength of the completed pipeline, along with the probable size of conceivable instabilities, we believe that landslide induced failure of the pipeline is of low probability.

Although landslide induced failure of the pipeline is of low probability, several past instabilities were noted during project reconnaissance, as more fully described in the preceding Route Reconnaissance Observations. Mitigation measures are recommended subsequently herein.

The effect of recent timbering clear cuts on the inducement or probability of landsliding along the route cannot be assessed adequately with the limited information available for this study. Generally, however, we anticipate that timber activities will have no impact on stability of the pipeline.

\section{Erosion}

The potential for erosion exists along the pipeline alignment at virtually any of the stream crossings. Considering the very short sections of pipe at most crossings, along with the pipe's ductility, few of the crossings should require special attention during design. At most locations, if permit conditions allow, we recommend that the pipeline should be buried beneath the stream bottom using conventional excavation instead of boring.

Several of the crossings under more substantial streams should be bored. Preliminarily, the recommended boring locations include;

- Brummit Creek

- Cherry Creek

- Middle Creek

- North Fork of the Coquille

- Isthmus Slough

- Blossom Gulch Creek 


\section{MITIGATION}

The proposed project is of average or less complexity. There is little risk of impact to constructability or integrity due to geotechnical considerations. Seismically induced impacts are of low probability. To the extent that short term pipeline integrity is compromised by any of the hazards noted herein, however, mitigation is recommended. All potential impacts, regardless of probability or source can best be mitigated by installation of automatic or remotely controlled valves at strategic locations.

Although the final location, type and special features, if any, of the valves are best addressed during final design, we recommend that automatic or remote control valves be considered at the following locations;

- Williams sub-station connection

- east side of Douglas County Road 52

- Reston

- Dora

- Isthmus Slough at Ross Slough Road

\section{RECOMMENDATIONS FOR FUTURE WORK}

As a result of this reconnaissance level study, we are satisfied that no additional geotechnical work is necessary for the current phase. During final design, a number of other efforts, including site specific geotechnical exploration, will be beneficial.

\section{REPORT LIMITATIONS}

Exclusivity of Report. This report has been prepared for the exclusive use of the Coos County Board of Commissioners and Coquille, Oregon, and/or their designees for specific application to the proposed Coos Bay Natural Gas Pipeline, Coos-Douglas Counties, Oregon. No other use is authorized without the written permission of Pinnacle Engineering, Inc., Roseburg, Oregon.

Report Limited to Scopes of Service. The observations and conclusions described in this report are based solely on the scope of service described in and implemented pursuant to the Agreement of August 27, 2000, between Biological Information Specialists, Camas Valley, Oregon, and Dr. S. Joseph Spigolon, P.E. as supplemented by contract dated October 17, 2001, between Pinnacle Engineering, Inc. and Coos County, Oregon. Neither Spigolon nor Pinnacle have performed any observation, investigation, study or testing that is not specifically listed in the scope of service and, therefore, shall not be liable for failing to discover any condition whose discovery required the performance of services not authorized by the Agreement.

Conceptual-level Study. The visual reconnaissance and evaluative approaches used in this limited, preliminary study are believed to be consistent with those normally used in geotechnical engineering practice for preparation of environmental documents. The scope of our effort was intentionally less than that required for design purposes, but is deemed are sufficient for developing preliminary design guidelines. When design concepts have been better defined, soil/rock sampling and testing, and additional evaluation should be considered for use in final design. 
Table A-1. Survey of Foundation Soil and Rock, Coos County Natural Gas Pipeline

\begin{tabular}{|c|c|c|c|c|}
\hline $\begin{array}{l}\text { CBW } \\
\text { Road } \\
\text { miles }\end{array}$ & $\begin{array}{l}\text { Power line } \\
\text { miles } \\
\text { (approx.) }\end{array}$ & Route Features & $\begin{array}{c}\text { CBW Road Soils/Rock and } \\
\text { Comments }\end{array}$ & $\begin{array}{l}\text { BPA Power line Soils/Rock } \\
\text { and Comments }\end{array}$ \\
\hline \multirow[t]{2}{*}{0.0} & 0.0 & $\begin{array}{l}\text { William's North- } \\
\text { west Pipeline; start } \\
\text { of Coos County } \\
\text { pipeline. Enter Sec- } \\
\text { tion } 28 .\end{array}$ & $\begin{array}{l}\text { Dark brown clay; high plastic- } \\
\text { ity; residuum derived from } \\
\text { basalt bedrock; depth to rock < } \\
5 \mathrm{ft} \text {. No evidence of soil creep - } \\
\text { trees are vertical. Road is } \\
\text { paved in Douglas County. }\end{array}$ & $\begin{array}{l}\text { Pacificorp transmission line. } \\
\text { Same as CBW Road; average } 10 \\
\text { percent slopes. }\end{array}$ \\
\hline & 1.2 & $\begin{array}{l}\text { Powderhouse Can- } \\
\text { yon. }\end{array}$ & Same as above. & $\begin{array}{l}\text { Same as above; slopes about } 6 \\
\text { percent. }\end{array}$ \\
\hline \multirow[t]{2}{*}{1.9} & & Basalt rock quarry. & $\begin{array}{l}\text { Rock at or very near road sur- } \\
\text { face. Slopes about } 6 \text { percent. }\end{array}$ & \\
\hline & 1.7 & $\begin{array}{l}\text { Tributary of } \\
\text { Marsters Creek. }\end{array}$ & & $\begin{array}{l}\text { Black clay; alluvium from weath- } \\
\text { ered basalt; high plasticity; depth } \\
>5 \mathrm{ft} \text {. }\end{array}$ \\
\hline 3.0 & 2.8 & $\begin{array}{l}\text { Slope down to enter } \\
\text { Lookingglass Val- } \\
\text { ley. }\end{array}$ & $\begin{array}{l}\text { Gray brown gravelly silty clay; } \\
\text { moderate plasticity; alluvium } \\
\text { from sandstone; flat; depth }>5 \\
\text { ft. }\end{array}$ & $\begin{array}{l}\text { Same as CBW Road; slopes aver- } \\
\text { age } 10 \text { percent. }\end{array}$ \\
\hline \multirow[t]{2}{*}{3.2} & 3.1 & $\begin{array}{l}\text { Tributary of Look- } \\
\text { ingglass Creek; in } \\
\text { valley. }\end{array}$ & $\begin{array}{l}\text { Brown sandy clay; moderate to } \\
\text { high plasticity; mixed allu- } \\
\text { vium; flat; depth > } 5 \mathrm{ft} \text {. }\end{array}$ & $\begin{array}{l}\text { Same as CBW Road; flat grade; } \\
\text { depth }>5 \mathrm{ft} \text {. }\end{array}$ \\
\hline & 3.6 & $\begin{array}{l}\text { Tributary of Look- } \\
\text { ingglass Creek; in } \\
\text { valley. }\end{array}$ & $\begin{array}{l}\text { Brown clay; moderate plastic- } \\
\text { ity; alluvium; flat; depth }>5 \mathrm{ft} \text {. }\end{array}$ & $\begin{array}{l}\text { Same as CBW Road; flat grade; } \\
\text { depth }>5 \mathrm{ft} \text {. }\end{array}$ \\
\hline 4.5 & 3.9 & $\begin{array}{l}\text { Downtown Look- } \\
\text { ingglass; intersec- } \\
\text { tion of Lookingglass } \\
\text { Road and CBW } \\
\text { Road; CBW Road } \\
\text { turns west; enter } \\
\text { Sec. } 35 \text {. }\end{array}$ & $\begin{array}{l}\text { Brown clay; moderate to high } \\
\text { plasticity; mixed alluvium; } \\
\text { flat; depth > } 5 \mathrm{ft} \text {. }\end{array}$ & $\begin{array}{l}\text { Same as CBW Road; flat grade; } \\
\text { depth }>5 \mathrm{ft} \text {. }\end{array}$ \\
\hline $\begin{array}{c}4.6 \text { to } \\
5.1\end{array}$ & 4.0 to 4.5 & $\begin{array}{l}\text { Three tributaries of } \\
\text { Lookingglass Creek; } \\
\text { valley. }\end{array}$ & $\begin{array}{l}\text { Brown clay; moderate to high } \\
\text { plasticity; mixed alluvium; } \\
\text { flat; depth > } 5 \mathrm{ft} \text {. }\end{array}$ & $\begin{array}{l}\text { Same as CBW Road; flat grade; } \\
\text { depth }>5 \mathrm{ft} \text {. }\end{array}$ \\
\hline
\end{tabular}


Table A-1. Survey of Foundation Soil and Rock, Coos County Natural Gas Pipeline

\begin{tabular}{|c|c|c|c|c|}
\hline $\begin{array}{l}\text { CBW } \\
\text { Road } \\
\text { miles }\end{array}$ & $\begin{array}{l}\text { Power line } \\
\text { miles } \\
\text { (approx.) }\end{array}$ & Route Features & $\begin{array}{c}\text { CBW Road Soils/Rock and } \\
\text { Comments }\end{array}$ & $\begin{array}{l}\text { BPA Power line Soils/Rock } \\
\text { and Comments }\end{array}$ \\
\hline 5.9 & 5.4 & $\begin{array}{l}\text { Power line crosses } \\
\text { road; substation. }\end{array}$ & $\begin{array}{l}\text { Brown silty clay; moderate to } \\
\text { high plasticity; colluvium; road } \\
\text { in hillside several feet above } \\
\text { floodplain level; depth }>5 \mathrm{ft} \text {. }\end{array}$ & $\begin{array}{l}\text { Same as CBW Road; on hillside } \\
\text { above roadway; depth }>5 \mathrm{ft} \text {. }\end{array}$ \\
\hline 7.2 & 6.6 & $\begin{array}{l}\text { Power line goes up } \\
\text { and down hills. } \\
\text { Minor gullies. }\end{array}$ & $\begin{array}{l}\text { Brown silty clay; moderate to } \\
\text { high plasticity; colluvium; road } \\
\text { starts vertical curves; several } \\
\text { rock outcrops at side of road; } \\
\text { depth > } 5 \mathrm{ft} \text {. }\end{array}$ & $\begin{array}{l}\text { Same as CBW Road. On hillside } \\
\text { above roadway; depth }>5 \mathrm{ft} \text {. }\end{array}$ \\
\hline 8.2 & 7.5 & Cross Rock Creek. & $\begin{array}{l}\text { Gravelly sand; alluvium; non- } \\
\text { plastic; depth > } 5 \mathrm{ft} \text {. }\end{array}$ & Same as CBW Road. \\
\hline 8.3 & 7.6 & $\begin{array}{l}\text { Power line crosses } \\
\text { road. }\end{array}$ & $\begin{array}{l}\text { Brown gravelly silty clay; } \\
\text { residuum from siltstone; mod- } \\
\text { erate plasticity; no rocks show- } \\
\text { ing in road cuts; depth }>5 \mathrm{ft} \text {. }\end{array}$ & Same as CBW Road. \\
\hline 8.6 & & $\begin{array}{l}\text { Tributary of Rock } \\
\text { Creek. }\end{array}$ & $\begin{array}{l}\text { Dk. red silty clay; residuum } \\
\text { from siltstone; hillside; } \\
\text { moderate plasticity; depth to } \\
\text { rock = } 5 \mathrm{ft} \text {. }\end{array}$ & \\
\hline \multirow[t]{2}{*}{8.7} & 8.0 & $\begin{array}{l}\text { Reston substation; } \\
\text { start BPA power } \\
\text { lines. }\end{array}$ & $\begin{array}{l}\text { Dk. red silty clay; residuum } \\
\text { from siltstone; hillside; } \\
\text { moderate plasticity; depth to } \\
\text { rock } 5 \mathrm{ft} \text {. }\end{array}$ & $\begin{array}{l}\text { Brown gravelly sand; alluvium of } \\
\text { Flournoy Valley; non-plastic; } \\
\text { depth }>5 \mathrm{ft} \text {. }\end{array}$ \\
\hline & 8.8 & $\begin{array}{l}\text { Tributary of Rock } \\
\text { Creek. }\end{array}$ & & $\begin{array}{l}\text { Dk. brown clay; alluvium; high } \\
\text { plasticity; depth }>5 \mathrm{ft} \text {. }\end{array}$ \\
\hline \multirow[t]{2}{*}{10.2} & & Rock Creek. & $\begin{array}{l}\text { Gravelly sandy clay; colluvium } \\
\text { from sandstone; none to low } \\
\text { plasticity; depth }>5 \mathrm{ft} \text {. }\end{array}$ & $\begin{array}{l}\text { Ridge and steep valley terrain; } 12 \\
\text { percent slope. }\end{array}$ \\
\hline & 10.1 & Rock Creek. & $\begin{array}{l}\text { Sandstone showing in steep } \\
\text { road cut on south side of CBW } \\
\text { Road. }\end{array}$ & $\begin{array}{l}\text { Dk. red silty clay; residuum from } \\
\text { siltstone; hillside; moderate plas- } \\
\text { ticity; depth to rock }=5 \mathrm{ft} \text {. }\end{array}$ \\
\hline 12. & 11.1 & $\begin{array}{l}\text { Hillside; downgrade } \\
\text { toward Reston. }\end{array}$ & $\begin{array}{l}\text { Sandstone-siltstone rock in } \\
\text { road cuts on side of roadway. }\end{array}$ & Hillsides reach 10 percent grade. \\
\hline
\end{tabular}




\section{Table A-1. Survey of Foundation Soil and Rock, Coos County Natural Gas Pipeline}

\begin{tabular}{|c|c|c|c|c|}
\hline $\begin{array}{l}\text { CBW } \\
\text { Road } \\
\text { miles }\end{array}$ & $\begin{array}{l}\text { Power line } \\
\text { miles } \\
\text { (approx.) }\end{array}$ & Route Features & $\begin{array}{c}\text { CBW Road Soils/Rock and } \\
\text { Comments }\end{array}$ & $\begin{array}{l}\text { BPA Power line Soils/Rock } \\
\text { and Comments }\end{array}$ \\
\hline 12.8 & 12.0 & $\begin{array}{l}\text { Intersection with } \\
\text { Reston Road. Sub- } \\
\text { station. }\end{array}$ & $\begin{array}{l}\text { Sandy clay; alluvium; depth }> \\
5 \mathrm{ft} . ; \text { hills; no rock. }\end{array}$ & Power line close to road; gentle. \\
\hline \multirow[t]{2}{*}{13.8} & 12.8 & $\begin{array}{l}\text { Power line crosses } \\
\text { road. Tenmile Creek } \\
\text { crossing. }\end{array}$ & $\begin{array}{l}\text { Dk. red silty clay; residuum } \\
\text { from siltstone; hillside; moder- } \\
\text { ate plasticity; depth to rock }=5 \\
\text { ft. }\end{array}$ & $\begin{array}{l}\text { Same as CBW Road; } 8 \text { percent } \\
\text { grade. }\end{array}$ \\
\hline & 13.2 & $\begin{array}{l}\text { Tributary of Ten- } \\
\text { mile Creek. }\end{array}$ & $\begin{array}{l}\text { Pass Iverson County Park; } \\
\text { curvy road. }\end{array}$ & $\begin{array}{l}\text { Dk. red silty clay; residuum from } \\
\text { siltstone; hillside; moderate plas- } \\
\text { ticity; depth to rock = } 5 \mathrm{ft} \text {. }\end{array}$ \\
\hline 15.0 & 13.8 & $\begin{array}{l}\text { Power line crosses } \\
\text { road. Roadway very } \\
\text { curvy. }\end{array}$ & $\begin{array}{l}\text { Dk. red silty clay; residuum } \\
\text { from siltstone; hillside; moder- } \\
\text { ate plasticity; depth to rock }=5 \\
\text { ft. }\end{array}$ & Same as CBW Road. \\
\hline 15.1 & 13.9 & Steep hill. & $\begin{array}{l}\text { Same as above; road grade } \\
\text { reaches } 15 \text { percent. }\end{array}$ & $\begin{array}{l}\text { Same as CBW Road; slopes reach } \\
18 \text { percent to } 20 \text { percent. }\end{array}$ \\
\hline $\begin{array}{c}17.5 \& \\
17.9\end{array}$ & & $\begin{array}{l}\text { Cross East Fork of } \\
\text { Coquille River. }\end{array}$ & $\begin{array}{l}\text { Brown sandy clay; low plastic- } \\
\text { ity; colluvium and residuum } \\
\text { over sandstone; depth }>5 \mathrm{ft} \text {. }\end{array}$ & $\begin{array}{l}\text { Gravelly sandy clay; colluvium } \\
\text { from sandstone; depth }=3 \text { - } 4 \mathrm{ft} \text {. } \\
\text { over fractured sandstone; slopes } \\
\text { of } 10 \text { percent to } 22 \text { percent. }\end{array}$ \\
\hline 18.1 & 15.3 & $\begin{array}{l}\text { Tributary of } \\
\text { Coquille River. }\end{array}$ & $\begin{array}{l}\text { Brown sandy clay; low plastic- } \\
\text { ity; colluvium and residuum } \\
\text { over sandstone; depth }>5 \mathrm{ft} \text {. }\end{array}$ & $\begin{array}{l}\text { Same as CBW Road; slopes range } \\
14 \text { percent to } 18 \text { percent. }\end{array}$ \\
\hline 19.0 & 16.3 & $\begin{array}{l}\text { Coos County Line; } \\
\text { road is no longer } \\
\text { paved. Enter Brew- } \\
\text { ster Canyon. }\end{array}$ & $\begin{array}{l}\text { Same as above; steep canyon } \\
\text { wall on north side; depth to } \\
\text { rock is shallow. }\end{array}$ & $\begin{array}{l}\text { Same as CBW Road; slopes range } \\
\text { from } 27 \text { percent to } 32 \text { percent in } \\
\text { crossing East Fork of Coquille } \\
\text { River. }\end{array}$ \\
\hline 19.5 & 16.6 & $\begin{array}{l}\text { Cross Knapper } \\
\text { Creek. }\end{array}$ & $\begin{array}{l}\text { Soil in roadway unknown; nar- } \\
\text { row roadway - about } 15 \text { - } 20 \mathrm{ft} \text {. } \\
\text { wide; steep side wall; exposed } \\
\text { rock to road bed; depth to rock } \\
\text { is very shallow; East Fork of } \\
\text { Coquille River on south side. }\end{array}$ & $\begin{array}{l}\text { Brown sandy clay; low plasticity; } \\
\text { colluvium and residuum over } \\
\text { sandstone; depth }>5 \mathrm{ft} \text {. }\end{array}$ \\
\hline 20.1 & & Milepost 35 & Same as above & Same as above \\
\hline
\end{tabular}




\section{Table A-1. Survey of Foundation Soil and Rock, Coos County Natural Gas Pipeline}

\begin{tabular}{|c|c|c|c|c|}
\hline $\begin{array}{l}\text { CBW } \\
\text { Road } \\
\text { miles }\end{array}$ & $\begin{array}{c}\text { Power line } \\
\text { miles } \\
\text { (approx.) }\end{array}$ & Route Features & $\begin{array}{c}\text { CBW Road Soils/Rock and } \\
\text { Comments }\end{array}$ & $\begin{array}{c}\text { BPA Power line Soils/Rock } \\
\text { and Comments }\end{array}$ \\
\hline 21.1 & 17.7 & $\begin{array}{l}\text { Power line crosses } \\
\text { road }\end{array}$ & $\begin{array}{l}\text { Same as above; small slide in } \\
\text { road south toward river; sand- } \\
\text { stone in the vertical, north-side } \\
\text { wall. }\end{array}$ & $\begin{array}{l}\text { Sandy clay; colluvium and resid- } \\
\text { uum from sandstone; low plastic- } \\
\text { ity; soil depth = } 3 \text { to } 6 \mathrm{ft} \text {. }\end{array}$ \\
\hline 22.4 & 18.8 & Cross small stream & $\begin{array}{l}\text { Same as above, except no } \\
\text { slide; about } 30 \mathrm{ft} \text {. above river } \\
\text { and steep slope to river. }\end{array}$ & Same as above. \\
\hline 23.0 & 19.5 & $\begin{array}{l}\text { Milepost } 32 . \\
\text { Bridge; cross East } \\
\text { Fork of Coquille } \\
\text { River. }\end{array}$ & $\begin{array}{l}\text { Sandstone-siltstone rock } \\
\text { exposed in river bottom, and } \\
\text { river banks; no soil. }\end{array}$ & Same as above. \\
\hline 23.5 & & $\begin{array}{l}\text { Lost Creek enters } \\
\text { river from the north. }\end{array}$ & $\begin{array}{l}\text { Soil in roadway unknown; nar- } \\
\text { row roadway - about } 15 \text { - } 20 \mathrm{ft} \text {. } \\
\text { wide; steep side wall; exposed } \\
\text { rock to road bed; depth to rock } \\
\text { is very shallow; East Fork of } \\
\text { Coquille River on north side. }\end{array}$ & $\begin{array}{l}\text { Same as above; slopes reach } 27 \\
\text { percent to } 33 \text { percent. }\end{array}$ \\
\hline 24.3 & $20.1 \& 20.3$ & $\begin{array}{l}\text { Tributary to } \\
\text { Coquille River. }\end{array}$ & Same as above. & $\begin{array}{l}\text { Same as above; rock depth is }<3 \\
\mathrm{ft} \text {. }\end{array}$ \\
\hline 25.2 & & $\begin{array}{l}\text { Dead Horse Creek } \\
\text { enters river from } \\
\text { north. }\end{array}$ & Same as above. & Same as above. \\
\hline 25.5 & $20.9 \& 21.4$ & $\begin{array}{l}\text { Tributary to } \\
\text { Coquille River. }\end{array}$ & Same as above. & Same as above. \\
\hline 25.7 & & $\begin{array}{l}\text { Bridge; cross East } \\
\text { Fork of Coquille } \\
\text { River. }\end{array}$ & $\begin{array}{l}\text { Same as above. River on south } \\
\text { side of road. }\end{array}$ & Same as above. \\
\hline 26.7 & & $\begin{array}{l}\text { Hamilton County } \\
\text { Park }\end{array}$ & Same as above. & $\begin{array}{l}\text { Same as above. Rock depth var- } \\
\text { ies. }\end{array}$ \\
\hline 27.5 & 22.8 & $\begin{array}{l}\text { Cross Camas Creek; } \\
\text { roadway paved. }\end{array}$ & $\begin{array}{l}\text { Enter broad valley. Road on } \\
\text { hillside; sandy clay and fine } \\
\text { sand; alluvium; low plasticity; } \\
\text { depth }>5 \mathrm{ft} \text {. }\end{array}$ & Same as above. \\
\hline
\end{tabular}


Table A-1. Survey of Foundation Soil and Rock, Coos County Natural Gas Pipeline

\begin{tabular}{|c|c|c|c|c|}
\hline $\begin{array}{l}\text { CBW } \\
\text { Road } \\
\text { miles }\end{array}$ & $\begin{array}{l}\text { Power line } \\
\text { miles } \\
\text { (approx.) }\end{array}$ & Route Features & $\begin{array}{c}\text { CBW Road Soils/Rock and } \\
\text { Comments }\end{array}$ & $\begin{array}{c}\text { BPA Power line Soils/Rock } \\
\text { and Comments }\end{array}$ \\
\hline & 23.3 & $\begin{array}{l}\text { Enter Brewster Val- } \\
\text { ley. }\end{array}$ & Same as above. & $\begin{array}{l}\text { Enter broad valley. Sandy clay } \\
\text { and fine sand; alluvium; low plas- } \\
\text { ticity; depth }>5 \mathrm{ft} \text {. }\end{array}$ \\
\hline \multirow[t]{2}{*}{29.4} & & $\begin{array}{l}\text { Cross Brummit } \\
\text { Creek. Enter Sit- } \\
\text { kum. }\end{array}$ & $\begin{array}{l}\text { Sandy clay and fine sand; allu- } \\
\text { vium; low plasticity; depth > } 5 \\
\mathrm{ft} \text {; road at base of hill, } 10 \mathrm{ft} \text {. } \\
\text { above plain. }\end{array}$ & Same as above. \\
\hline & 25.4 & $\begin{array}{l}\text { Cross Coquille } \\
\text { River. }\end{array}$ & $\begin{array}{l}\text { Brown silty clay; hillside; } \\
\text { residuum from siltstone; depth } \\
\text { to rock varies from } 4 \mathrm{ft} \text {. and } \\
\text { more. }\end{array}$ & Same as above. \\
\hline 31.5 & 26.1 & $\begin{array}{l}\text { Road re-enters } \\
\text { Brewster Canyon. }\end{array}$ & $\begin{array}{l}\text { Same as above; one lane road; } \\
\text { hillside; depth }>5 \mathrm{ft} \text {. }\end{array}$ & Same as above. \\
\hline 32.9 & 27.6 & Milepost 22. & $\begin{array}{l}\text { Gravelly sandy clay; colluvium } \\
\text { derived from sandstone; rock } \\
\text { in road cut at road level; depth } \\
\text { to rock about } 3 \mathrm{ft} \text {. in hillside. }\end{array}$ & Same as CBW Road. \\
\hline 34.1 & 28.5 & $\begin{array}{l}\text { Tributary of } \\
\text { Coquille River. }\end{array}$ & $\begin{array}{l}\text { Soil in roadway unknown; nar- } \\
\text { row roadway - about } 15 \text { - } 20 \mathrm{ft} \text {. } \\
\text { wide; steep side wall; exposed } \\
\text { rock to road bed; depth to rock } \\
\text { is very shallow. East Fork of } \\
\text { Coquille River on south side. }\end{array}$ & $\begin{array}{l}\text { Brown silty clay; residuum and } \\
\text { colluvium derived from sand- } \\
\text { stone; slopes reach } 26 \text { percent to } \\
28 \text { percent; soil depth }>5 \mathrm{ft} \text {. }\end{array}$ \\
\hline 34.9 & 30.2 & $\begin{array}{l}\text { Enter broad Flood- } \\
\text { plains at Dora. }\end{array}$ & $\begin{array}{l}\text { Brown fine sandy clay; mixed } \\
\text { alluvium; soil depth }>5 \mathrm{ft} \text {. }\end{array}$ & Same as CBW Road. \\
\hline 37.2 & 32.3 & $\begin{array}{l}\text { Pass Frona County } \\
\text { Park; Power line } \\
\text { cross road. }\end{array}$ & $\begin{array}{l}\text { Brown silty clay; hillside; } \\
\text { residuum from siltstone; depth } \\
\text { to rock }>5 \mathrm{ft} \text {. }\end{array}$ & $\begin{array}{l}\text { Same as CBW Road; slopes reach } \\
15 \text { percent to } 20 .\end{array}$ \\
\hline 39.2 & 33.1 & $\begin{array}{l}\text { Road crosses Cherry } \\
\text { Creek and Cherry } \\
\text { Creek Road; power } \\
\text { line crosses upper } \\
\text { reach of E. F. } \\
\text { Coquille River. }\end{array}$ & $\begin{array}{l}\text { Brown silty clay; mixed allu- } \\
\text { vium; soil depth }>5 \mathrm{ft} \text {. }\end{array}$ & $\begin{array}{l}\text { Brown gravelly sandy clay; resid- } \\
\text { uum from sandstone; depth to } \\
\text { fractured rock }<5 \mathrm{ft} \text {. }\end{array}$ \\
\hline
\end{tabular}


Table A-1. Survey of Foundation Soil and Rock, Coos County Natural Gas Pipeline

\begin{tabular}{|c|c|c|c|c|}
\hline $\begin{array}{l}\text { CBW } \\
\text { Road } \\
\text { miles }\end{array}$ & $\begin{array}{l}\text { Power line } \\
\text { miles } \\
\text { (approx.) }\end{array}$ & Route Features & $\begin{array}{c}\text { CBW Road Soils/Rock and } \\
\text { Comments }\end{array}$ & $\begin{array}{l}\text { BPA Power line Soils/Rock } \\
\text { and Comments }\end{array}$ \\
\hline 40.2 & 34.1 & $\begin{array}{l}\text { Power line crosses } \\
\text { road. }\end{array}$ & $\begin{array}{l}\text { Brown silty clay; mixed allu- } \\
\text { vium; soil depth }>5 \mathrm{ft} \text {. }\end{array}$ & $\begin{array}{l}\text { Same as CBW Road. Power line } \\
\text { in hillside; sandy clay from sand- } \\
\text { stone; low plasticity; depth }>5 \mathrm{ft} \text {. }\end{array}$ \\
\hline 41.5 & 35.0 & $\begin{array}{l}\text { Power line crosses } \\
\text { road; road crosses } \\
\text { Middle Creek. }\end{array}$ & $\begin{array}{l}\text { Brown silty clay; mixed allu- } \\
\text { vium; soil depth }>5 \mathrm{ft} \text {. }\end{array}$ & $\begin{array}{l}\text { Same as CBW Road. Power line } \\
\text { starts up steep hill with } 15 \text { percent } \\
\text { to } 19 \text { percent slope. }\end{array}$ \\
\hline $\begin{array}{c}41.5 \text { to } \\
44.3\end{array}$ & 35.0 to 37.5 & Hilly terrain. & $\begin{array}{l}\text { Brown silty clay; hillside; } \\
\text { residuum from siltstone; depth } \\
\text { to rock }>5 \mathrm{ft} \text {. Slopes reach } 8 \\
\text { percent to } 10 \text { percent. }\end{array}$ & $\begin{array}{l}\text { Same as CBW Road. Slopes } \\
\text { reach } 15 \text { percent to } 20 \text { percent. }\end{array}$ \\
\hline 44.3 & 37.5 & $\begin{array}{l}\text { Power line crosses } \\
\text { road. Steep hill } \\
\text { down to Bolton Prai- } \\
\text { rie. }\end{array}$ & $\begin{array}{l}\text { Dk. red silty clay; residuum } \\
\text { from siltstone; hillside; moder- } \\
\text { ate plasticity }(\mathrm{PI}=20-30) \text {; } \\
\text { depth to rock }=5 \mathrm{ft} \text {. Slope } \\
\text { about } 11 \text { percent. }\end{array}$ & $\begin{array}{l}\text { Same as CBW Road. Slope about } \\
11 \text { percent. }\end{array}$ \\
\hline 45.4 & 38.0 & $\begin{array}{l}\text { Cross bridge; North } \\
\text { Fork of Coquille } \\
\text { River. }\end{array}$ & $\begin{array}{l}\text { Brown silty clay; mixed allu- } \\
\text { vium; low plasticity; depth }>5 \\
\text { ft. }\end{array}$ & Same as CBW Road. \\
\hline 45.7 & 38.3 & $\begin{array}{l}\text { Cross Fairview } \\
\text { Road; enter Fair- } \\
\text { view; power line } \\
\text { crosses road. }\end{array}$ & Same as above. & Same as above. \\
\hline 46.0 & & $\begin{array}{l}\text { Rejoin CBW Road, } \\
\text { parallel Evans Creek } \\
\text { on right. }\end{array}$ & $\begin{array}{l}\text { Dark brown silty clay; mixed, } \\
\text { alluvium; low plasticity; } \\
\text { organic; slopes } 3 \text { percent; } \\
\text { depth to rock. } 5 \mathrm{ft} \text {. }\end{array}$ & \\
\hline 46.1 & & $\begin{array}{l}\text { Continue northwest- } \\
\text { erly parallel Evans } \\
\text { Creek. }\end{array}$ & $\begin{array}{l}\text { Dark gray silty clay; mixed } \\
\text { alluvium; moderate plasticity; } \\
\text { slopes }<8 \text { percent; depth to } \\
\text { rock }>5 \mathrm{ft} \text {. }\end{array}$ & \\
\hline 46.4 & & $\begin{array}{l}\text { Continue parallel to } \\
\text { Evans Creek. }\end{array}$ & $\begin{array}{l}\text { Dark brown silty clay; mixed } \\
\text { alluvium; low plasticity; } \\
\text { organic; slopes }<3 \text { percent; } \\
\text { depth to rock }>5 \mathrm{ft} \text {; some } \\
\text { areas more organic. }\end{array}$ & \\
\hline
\end{tabular}


Table A-1. Survey of Foundation Soil and Rock, Coos County Natural Gas Pipeline

\begin{tabular}{|c|c|c|c|c|}
\hline $\begin{array}{l}\text { CBW } \\
\text { Road } \\
\text { miles }\end{array}$ & $\begin{array}{c}\text { Power line } \\
\text { miles } \\
\text { (approx.) }\end{array}$ & Route Features & $\begin{array}{c}\text { CBW Road Soils/Rock and } \\
\text { Comments }\end{array}$ & $\begin{array}{l}\text { BPA Power line Soils/Rock } \\
\text { and Comments }\end{array}$ \\
\hline 46.5 & & $\begin{array}{l}\text { Begin parallel to. } \\
\text { Steinman Creek }\end{array}$ & $\begin{array}{l}\text { Dark gray silty clay; mixed } \\
\text { alluvium; moderate plasticity; } \\
\text { slopes }<8 \text { percent; depth to } \\
\text { rock }>5 \mathrm{ft} \text {. }\end{array}$ & \\
\hline 46.6 & & $\begin{array}{l}\text { Continue parallel to } \\
\text { Steinman Creek. }\end{array}$ & $\begin{array}{l}\text { Reddish brown organic silty } \\
\text { clay; mixed colluvium; slopes } \\
3 \text { to } 30 \text { percent; generally non- } \\
\text { plastic; depth to rock }>5 \mathrm{ft} \text {. }\end{array}$ & \\
\hline 47.0 & & $\begin{array}{l}\text { Continue parallel to } \\
\text { Steinman Creek. }\end{array}$ & $\begin{array}{l}\text { Dark gray silty clay; mixed } \\
\text { alluvium; moderate plasticity; } \\
\text { slopes }<8 \text { percent; depth to } \\
\text { rock }>5 \mathrm{ft} \text {. }\end{array}$ & \\
\hline 47.5 & & $\begin{array}{l}\text { Pass confluence of } \\
\text { West fork of Stein- } \\
\text { man Creek parallel } \\
\text { W. fork. }\end{array}$ & $\begin{array}{l}\text { Reddish brown organic silty } \\
\text { clay; mixed colluvium; slopes } \\
3 \text { to } 30 \text { percent; generally non- } \\
\text { plastic; depth to rock }>5 \mathrm{ft} \text {. }\end{array}$ & \\
\hline 48.1 & & $\begin{array}{l}\text { Leave West fork of } \\
\text { Steinman Creek, } \\
\text { begin climbing to } \\
\text { north. }\end{array}$ & $\begin{array}{l}\text { Reddish brown organic silty } \\
\text { clay; occasional mixed allu- } \\
\text { vium; slopes } 3 \text { to } 30 \text { percent } \\
\text { (occasional } 30 \text { to } 50 \text { percent); } \\
\text { generally non-plastic; depth to } \\
\text { rock }>5 \mathrm{ft} \text {. }\end{array}$ & \\
\hline 48.4 & & Continue & $\begin{array}{l}\text { Reddish brown organic silty } \\
\text { clay; mixed colluvium, becom- } \\
\text { ing dark red clay; moderately } \\
\text { plastic; depth to rock }>5 \mathrm{ft} \text {. }\end{array}$ & \\
\hline 48.5 & & Continue & $\begin{array}{l}\text { Reddish brown organic silty } \\
\text { clay; mixed colluvium; slopes } \\
3 \text { to } 30 \text { percent; generally non- } \\
\text { plastic; depth to rock }>5 \mathrm{ft} \text {. }\end{array}$ & \\
\hline $\begin{array}{c}48.8 \text { to } \\
49.0\end{array}$ & & Continue & $\begin{array}{l}\text { Reddish brown organic silty } \\
\text { clay; mixed colluvium, becom- } \\
\text { ing dark red clay; moderately } \\
\text { plastic; depth to rock }>5 \mathrm{ft} \text {. } \\
\text { Occasional rock }<5 \mathrm{ft} \text {. }\end{array}$ & \\
\hline & & & & (Sheet 7 of 10 \\
\hline
\end{tabular}


Table A-1. Survey of Foundation Soil and Rock, Coos County Natural Gas Pipeline

\begin{tabular}{|c|c|c|c|c|}
\hline $\begin{array}{l}\text { CBW } \\
\text { Road } \\
\text { miles }\end{array}$ & $\begin{array}{l}\text { Power line } \\
\text { miles } \\
\text { (approx.) }\end{array}$ & Route Features & $\begin{array}{c}\text { CBW Road Soils/Rock and } \\
\text { Comments }\end{array}$ & $\begin{array}{l}\text { BPA Power line Soils/Rock } \\
\text { and Comments }\end{array}$ \\
\hline $\begin{array}{l}49.0 \text { to } \\
50.3\end{array}$ & & $\begin{array}{l}\text { Parallel Wilson } \\
\text { Creek. Joins from S. } \\
\text { side of road. }\end{array}$ & $\begin{array}{l}\text { Gray brown sandy clay; heavy } \\
\text { organic, well drained; non- } \\
\text { plastic; slopes } 30 \text { to } 60 \text { per- } \\
\text { cent; depth to rock }>5 \mathrm{ft} \text {. }\end{array}$ & \\
\hline 50.7 & & $\begin{array}{l}\text { Pass Panther Creek } \\
\text { and Caldwell Creek. }\end{array}$ & $\begin{array}{l}\text { Dark gray brown silty clay; } \\
\text { heavy organic; alluvial; non- } \\
\text { plastic; slopes }<3 \text { percent; } \\
\text { depth to rock }>5 \mathrm{ft} \text {. }\end{array}$ & \\
\hline 50.9 & & & $\begin{array}{l}\text { Dark brown silty clay; heavy } \\
\text { organic content; low plastic- } \\
\text { ity; slopes } 3 \text { to } 7 \text { percent; depth } \\
\text { to rock }>5 \mathrm{ft} \text {. }\end{array}$ & \\
\hline 51.3 & & & $\begin{array}{l}\text { Dark gray brown silty clay; } \\
\text { heavy organic; alluvial; non- } \\
\text { plastic; slopes }<3 \text { percent; } \\
\text { depth to rock }>5 \mathrm{ft} \text {. occasional } \\
\text { clayey silt; organic; low plas- } \\
\text { ticity; occasional depth to rock } \\
<5 \mathrm{ft} \text {. }\end{array}$ & \\
\hline 51.4 & & Enter Sumner. & $\begin{array}{l}\text { Dark brown to yellowish } \\
\text { brown organic silty clay over- } \\
\text { lying sandy gravel; non-plas- } \\
\text { tic; slopes < } 8 \text { percent; depth to } \\
\text { rock }>5 \mathrm{ft} \text {. }\end{array}$ & \\
\hline $\begin{array}{l}51.5 \text { to } \\
516\end{array}$ & & $\begin{array}{l}\text { Cross Catching } \\
\text { Creek. }\end{array}$ & $\begin{array}{l}\text { Dark gray brown silty clay; } \\
\text { heavy organic; alluvial; non- } \\
\text { plastic; slopes }<3 \text { percent; } \\
\text { depth to rock }>5 \mathrm{ft} \text {. with occa- } \\
\text { sional silty loam; non-plastic; } \\
\text { depth to rock }>5 \mathrm{ft} \text {. }\end{array}$ & \\
\hline 52.1 & & $\begin{array}{l}\text { Cross Slough Road } \\
\text { Intersection. }\end{array}$ & $\begin{array}{l}\text { Dark grayish brown silty clay; } \\
\text { heavy organic; low plasticity; } \\
\text { slopes }<3 \text { percent; depth to } \\
\text { rock }>5 \mathrm{ft} \text {. }\end{array}$ & \\
\hline
\end{tabular}


Table A-1. Survey of Foundation Soil and Rock, Coos County Natural Gas Pipeline

\begin{tabular}{|c|c|c|c|c|}
\hline $\begin{array}{l}\text { CBW } \\
\text { Road } \\
\text { miles }\end{array}$ & $\begin{array}{l}\text { Power line } \\
\text { miles } \\
\text { (approx.) }\end{array}$ & Route Features & $\begin{array}{c}\text { CBW Road Soils/Rock and } \\
\text { Comments }\end{array}$ & $\begin{array}{c}\text { BPA Power line Soils/Rock } \\
\text { and Comments }\end{array}$ \\
\hline 52.3 & & $\begin{array}{l}\text { Head of Wilson } \\
\text { Creek. }\end{array}$ & $\begin{array}{l}\text { Dark reddish brown silty clay; } \\
\text { heavy organic; non-plastic; } \\
\text { slopes } 50 \text { to } 75 \text { percent; depth } \\
\text { to rock }>5 \mathrm{ft} \text {. }\end{array}$ & \\
\hline 52.4 & & & $\begin{array}{l}\text { Dark reddish brown silty clay } \\
\text { overflying occasional shallow } \\
\text { weathered bedrock }(<5 \mathrm{ft} \text {.); } \\
\text { low plasticity; slopes } 30 \text { to } 50 \\
\text { percent. }\end{array}$ & \\
\hline 52.6 & & & $\begin{array}{l}\text { Dark reddish brown silty clay; } \\
\text { heavy organic; non-plastic; } \\
\text { slopes } 50 \text { to } 75 \text { percent; depth } \\
\text { to rock }>5 \mathrm{ft} \text {. }\end{array}$ & \\
\hline 52.7 & & & $\begin{array}{l}\text { Dark reddish brown silt; heavy } \\
\text { organics; generally low plastic- } \\
\text { ity; slopes } 12 \text { to } 30 \text { percent; } \\
\text { depth to weathered rock }=5 \mathrm{ft} \text {. }\end{array}$ & \\
\hline 52.7 & & $\begin{array}{l}\text { Cross Cardwell } \\
\text { Creek; CBW Road } \\
\text { pavement starts. }\end{array}$ & Same as above. & Same as CBW Road. \\
\hline 53.5 & & Sumner. & $\begin{array}{l}\text { Brown silty clay; mixed allu- } \\
\text { vium; soil depth }>5 \mathrm{ft} \text {. }\end{array}$ & \\
\hline 55.2 & 46.3 & $\begin{array}{l}\text { Power line crosses } \\
\text { road. }\end{array}$ & $\begin{array}{l}\text { Brown silty clay; residuum } \\
\text { from sandstone; low plasticity; } \\
\text { slopes range } 5 \text { percent to } 12 \\
\text { percent. }\end{array}$ & Same as CBW Road. \\
\hline 56.7 & 47.8 & $\begin{array}{l}\text { Cross Ross Slough } \\
\text { Road. }\end{array}$ & Same as above. & Same as above. \\
\hline 57.7 & 48.1 & $\begin{array}{l}\text { Cross Isthmus } \\
\text { Slough. }\end{array}$ & $\begin{array}{l}\text { Gravelly sandy clay; alluvium; } \\
\text { depth > } 5 \mathrm{ft} \text {. }\end{array}$ & Same as at left. \\
\hline 57.8 & 48.2 & Cross Hwy 101. & Same as above. & Same as at left. \\
\hline
\end{tabular}


Table A-1. Survey of Foundation Soil and Rock, Coos County Natural Gas Pipeline

\begin{tabular}{|c|c|l|l|l|}
\hline $\begin{array}{c}\text { CBW } \\
\text { Road } \\
\text { miles }\end{array}$ & $\begin{array}{c}\text { Power line } \\
\text { miles } \\
\text { (approx. }\end{array}$ & Route Features & $\begin{array}{l}\text { CBW Road Soils/Rock and } \\
\text { Comments }\end{array}$ & $\begin{array}{c}\text { BPA Power line Soils/Rock } \\
\text { and Comments }\end{array}$ \\
\hline 49.5 & $\begin{array}{l}\text { Cross Shinglehouse. } \\
\text { Slough. }\end{array}$ & $\begin{array}{l}\text { Brown silty clay; residuum from } \\
\text { sandstone; low plasticity; slopes }< \\
5 \text { percent. }\end{array}$ \\
\hline 60.1 & $\begin{array}{l}\text { Reach Coos Bay } \\
\text { area. End of Coos } \\
\text { COunty Natural Gas } \\
\text { Pipeline. }\end{array}$ & $\begin{array}{l}\text { Same as above until reach } \\
\text { Coos Bay area; then enter } \\
\text { sandy clay alluvium of Coal- } \\
\text { bank Slough. }\end{array}$ & \\
\hline
\end{tabular}




\section{LIST OF REFERENCES}

1. Orr, E. L. and Orr, W. N. (1999). Geology of Oregon, Fifth Edition, Kendall/Hunt Publishing Co., Dubuque, Iowa.

2. Haagen, J. T. (1989). Soil Survey of Coos County, Oregon, USDA Soil Conservation Service (renamed Natural Resources Conservation Service), Portland, Oregon.

3. Alt, D. D. and Hyndman, D. W. (1978). Roadside Geology of Oregon, Mountain Press Publishing Co., Missoula, Montana.

4. Black, G. L. (1990). "Geologic Map of the Reston Quadrangle, Douglas County, Oregon," Geological Map Series GMS-68, Oregon Department of Geology and Mineral Resources, Portland.

5. Wiley, T. J. (1995). "Reconnaissance Geologic Map of the Dora and Sitkum Quadrangles, Coos County, Oregon," Geological Map Series GMS-98, Oregon Department of Geology and Mineral Resources, Portland.

6. Baldwin, E.M. and Beaulieu, J. D. (1973). "Geology and Mineral Resources of Coos County, Oregon," Bulletin 80, Oregon Department of Geology and Mineral Industries. Portland.

7. Goodman, R. E. (1993). Engineering Geology, John Wiley and Sons, New York.

8. Spigolon, S. J. (1993). "Geotechnical Site Investigation Strategy for Dredging Projects," Report 2 of "Geotechnical Factors in the Dredgeability of Sediments." Contract Report DRP-93-3, U.S. Army Engineer Waterways Experiment Station, Vicksburg, MS, October.

9. Terzaghi, K., Peck, R. B., and Mesri, G. (1996). Soil Mechanics in Engineering Practice, Third Edition, John Wiley \& Sons, New York.

10. Sowers, G. F. (1979). Introductory Soil Mechanics and Foundations.- Geotechnical Engineering, Fourth edition, Macmillan Publishing, New York.

11. Douglas County Area Office of the Natural Resources Conservation Service. Unpublished soil survey data sheets, Roseburg, Oregon.

12. Deere, D. U. and Patton, F. D. (1971). "Slope Stability in Residual Soils." Fourth Panamerican Conference on Soil Mechanics and Foundation Engineering, American Society of Civil Engineers, New York.

13. Madin, I. P. and Mabey, M. A. (1996). "Earthquake Hazard Maps for Oregon," Geological Map Series GMS100, Oregon Department of Geology and Mineral Resources. Portland.

14. Building Codes Structures Board, State of Oregon. (1998). "Seismic Zonation for the Oregon Coast." Final Report to the State of Oregon Building Codes Structures Board, Salem, Oregon. February 12. 
15. Johnson, A.G., Scofield, D.H., and Madin, I. P. (1994). "Earthquake Database for Oregon, 1833 through October 25, 1993." Open File Report OFR 94-04, Oregon Department of Geology and Mineral Industries, Portland.

16. Jacobson, R. S. (1986). "Map of Oregon Seismicity, 1841-1986," Geological Map Series GMS-49, Oregon Department of Geology and Mineral Resources, Portland.

17. Madin, I. P. and Mabey, M. A. (1996). "Earthquake Hazard Maps for Oregon," Geological Map Series GMS100, Oregon Department of Geology and Mineral Resources, Portland.

18. Peterson, C. D., Barnett, E. T., Briggs, G. C., Carver, G. A.,. Clague, J. J., and Darienzo, M. E. (1997). "Estimates of Coastal Subsidence from Great Earthquakes in the Cascadia Subduction Zone, Vancouver Island. B.C.. Washington, Oregon. and Northernmost California," Open File Report 0-97-5, Oregon Department of Geology and Mineral Resources, Portland.

19. Wang, Y. (1998). "Earthquake Damage and Loss Estimate for Oregon," Open File Report O-98-3, Oregon Department of Geology and Mineral Resources, Portland.

20. Transportation Research Board, National Research Council. (1996). "Landslides - Investigation and Mitigation.", National Academy Press, Washington, D.C.

21. Spigolon, S. Joseph, Ph D., Route Reconnaissance and Construction Recommendations for the Coos County Natural Gas Pipeline Project Coos and Douglas Counties, Oregon, February, 2001.

22. Madin, I. P. and Wang, Z. (1999. "Relative Earthquake Hazard Maps for selected urban areas in western Oregon," Geological Map Series IMS- 9, Oregon Department of Geology and Mineral Resources, Portland.

Numbers in brackets [ ] refer to documents included in the List of References at the end of this report 


\section{Appendix A. Geotechnical Engineering Report}




\title{
Appendix B. Cultural Resources
}

No significant changes were made to this Appendix.

\section{CULTURAL RESOURCES INVENTORY FOR A PROPOSED NATURAL GAS PIPELINE BETWEEN COOS BAY AND ROSEBURG, COOS AND DOUGLAS COUNTIES, OREGON}

\author{
Prepared for: \\ B.I.S., Inc. \\ Camas Valley, Oregon \\ Prepared by: \\ Albert C. Oetting \\ Heritage Research Associates, Inc. \\ 1997 Garden Avenue \\ Eugene, Oregon 97403 \\ October 1,2001
}

Heritage Research Associates Report No. 239 


\section{Appendix B}

\section{Cultural Resources}

\section{CULTURAL RESOURCES INVENTORY FOR A PROPOSED NATURAL GAS PIPELINE BETWEEN COOS BAY AND ROSEBURG, COOS AND DOUGLAS COUNTIES, OREGON}

\section{Introduction}

A cultural resources surface inventory survey has been conducted by Heritage Research Associates, Inc. for portions of an underground natural gas pipeline route in western Oregon from Coos Bay, Coos County, to Happy Valley near Roseburg, Douglas County. This project was conducted under contract to B.I.S., Inc. For the most part, the proposed route follows existing transmission lines or roads. Portions of the route have been previously surveyed for cultural resources; these were not re-examined for this project.

From the western end in Coos Bay (Table B-1), the proposed route first follows a new ROW corridor in the hills above the city of Coos Bay, then follows a Bonneville Power Administration (BPA) transmission line to Isthmus Slough. The proposed route then alternates between the CBW Road and a BPA transmission line ROW to cross the mountainous Coast Range. Near Reston, on the east edge of the mountains, the route returns to the BPA transmission line ROW and continues through the southern portion of Flournoy Valley, across Lookingglass Valley, and across the northern margin of Happy Valley to the eastern terminus at an existing natural gas pipeline near the South Umpqua River. The overall route is approximately 60 miles. The route portions surveyed for the current project included the new ROW section at the western end of the route, transmission line sections southeast of Cherry Creek and between McKinley and Fairview, and all of the transmission line route from the eastern terminus to the CBW Road west of Reston. All of the CBW Road sections of the proposed route were surveyed for cultural resources in 1999 (Oetting 1999), and the transmission line from the Coos City Bridge to the Libby district in Coos Bay was also surveyed in 1999 (Boersema and Minor 1999). These sections were not re-surveyed.

A background literature search conducted at the Oregon State Historic Preservation Office revealed nine previously recorded prehistoric archaeological sites located within two miles of the proposed route, and that one of these prehistoric sites is within the proposed route. Several historic buildings and properties border the route, but none will be affected by the construction or operation of the gas pipeline. With permission of landowners or the appropriate federal agencies, those portions of the proposed route not previously surveyed were inspected by one or two archaeologists in January and August, 2001. The previously recorded site within the proposed route was relocated in the field, and one new prehistoric site was found and recorded. One isolated find location was also identified. Several other areas along the proposed route were considered to have a high probability for containing prehistoric or historic cultural materials, although no surface artifacts were identified during the survey.

It is recommended that the two prehistoric archaeological sites in the proposed route (35DO819 and 35DO879) be avoided by the pipeline construction. If avoidance is not feasible, it is recommended subsurface site evaluation test excavations be undertaken to determine the significance of these two sites in terms of eligibility to the National Register of Historic Places. It is also recommended subsurface site discovery probes be excavated in eight specific areas along the route, seven where the route crosses streams or rivers, and at one location where an isolated surface artifact was observed. It is recommended a qualified archaeologist monitor the pipeline construction activities in areas along the route where archaeological sites are likely to occur, to be determined when the site discovery probes are completed. Finally, if future realignments of the route include segments that have not been examined for cultural resources, it is recommended such route segments be inspected in a manner consistent with the present project.

This survey was conducted through B.I.S., Inc. The field survey was directed by Robert Musil with the assistance of Richard Bland, Julie Ricks, and Laura White. This report has been prepared by Albert Oetting. Brian Cox, B.I.S., Inc., contributed pertinent maps and other data for the successful completion of this project. 


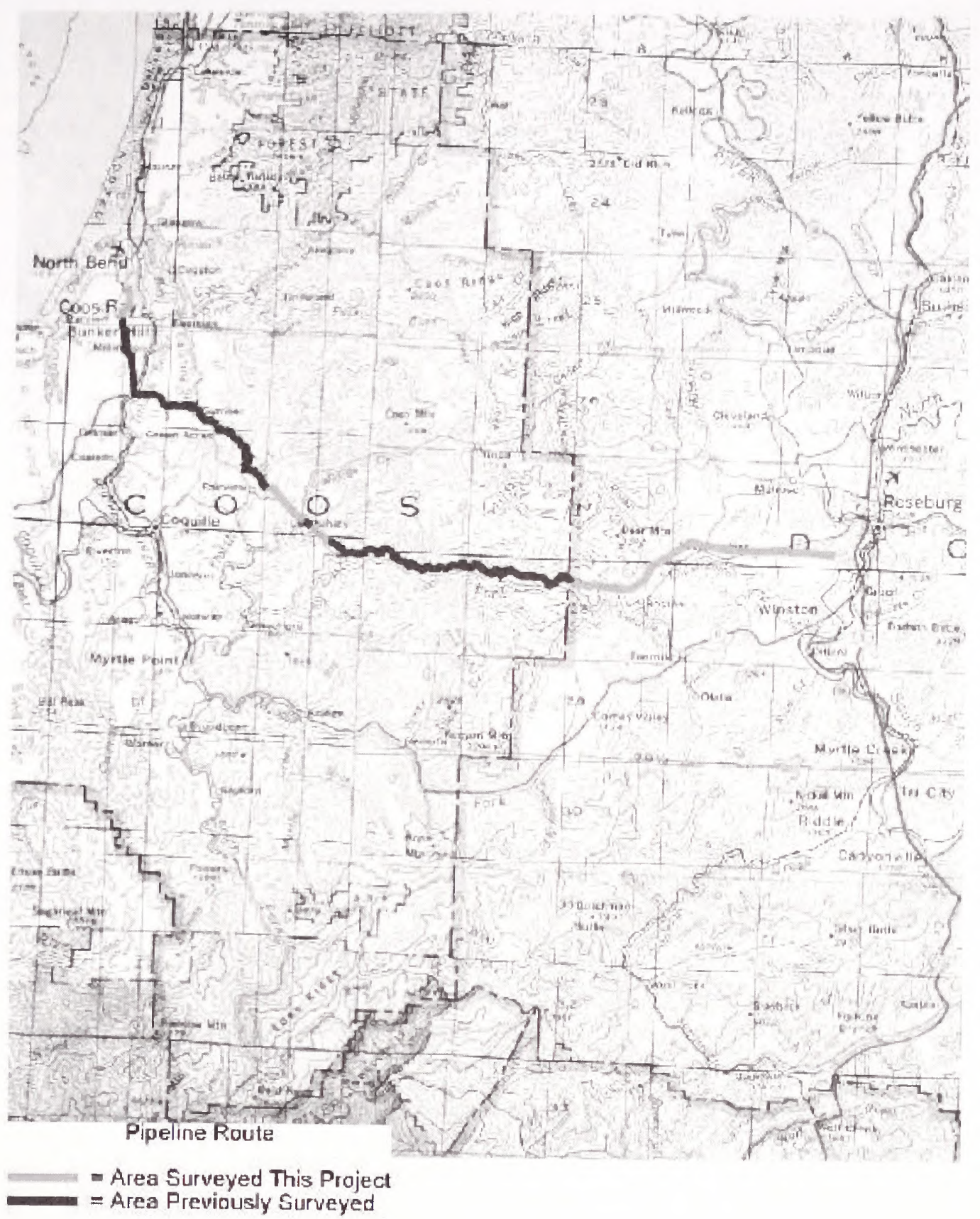

Figure B-1: Location of the Proposed Natural Gas Pipeline 


\section{Project Location and Setting}

The planned route for the underground natural gas pipeline generally follows segments of BPA transmission lines and portions of the CBW Road through the central areas of Coos and Douglas counties in western Oregon (Figure B1, see also Figures B-2 through B-5). Along the transmission lines, the gas pipeline ROW will be beneath the power lines or within the existing ROW corridor. The pipeline will be buried in the roadbed or along the road shoulder in the sections on the CBW Road. Underground fiber optic and other utility lines are already present along portions of this proposed route.

The proposed natural gas pipeline route runs between a western terminus in the city of Coos Bay to an existing natural gas pipeline in Happy Valley, just southwest of the city of Roseburg. The west end of the pipeline is the only portion of the route that does not parallel existing transmission lines or a road. From the west end of the pipeline near Ocean Blvd. in Coos Bay, the route proceeds for 1.7 miles southeast, south, and southwest to a ridge above the Englewood section of Coos Bay, where it joins a BPA transmission line ROW. The proposed route then runs south and southeast for 4.5 miles to Isthmus Slough, crossing the slough just north of the Coos City Bridge and intersecting with the CBW Road just east of the bridge. The westernmost route section, before joining the transmission line, was surveyed for this project. The BPA transmission line has been previously surveyed for cultural resources (Boersema and Minor 1999).

The proposed pipeline route then follows sections of the CBW Road and another BPA transmission line through the mountains of the Coast Range by way of Brewster Canyon on the East Fork Coquille River, and then it descends into the Umpqua River basin in Flournoy Valley southwest of Roseburg. From just east of the Coos City Bridge, where the transmission line intersects the CBW Road, the proposed route will follow the road east into the Coast Range uplands for about 11.7 miles to the community of Fairview on the North Fork Coquille River. This CBW Road section has been previously surveyed (Oetting 1999) and was not re-inspected.

The proposed route follows the CBW road southeast from Fairview for about 0.4 miles, to where a BPA transmission line crosses the road. At this point, the proposed route joins the transmission line ROW for 3.1 miles southeast to McKinley. At McKinley the proposed route shifts back to the CBW Road for about 1 mile, then back to the transmission line for about 1.2 miles over the mountainous divide between Cherry Creek and the East Fork Coquille River, rejoining the CBW Road on the north edge of the river valley. The proposed gas pipeline route then parallels the CBW Road for about 20 miles, up Brewster Canyon and through the communities of Dora and Sitkum. This portion of the CBW Road has already been surveyed for cultural resources (Oetting 1999) and was not re-examined. The two segments along the transmission line were surveyed during the present project.

The proposed route along the CBW Road intersects the transmission line about 9.7 miles east of Sitkum, just west of the crest of the Coast Range mountains. At this point, the proposed route shifts back to the transmission line ROW and follows it east for about 16.4 miles to the eastern end of the route. The transmission line and proposed route first crosses the divide, then turns northeast toward the south end of Flournoy Valley. The proposed route and transmission line then turns to the east along the south base of White Tail Ridge and crosses Lookingglass Valley south of the community of Lookingglass. Still following the transmission line, the route ascends the ridge dividing Lookingglass and Happy valleys and crosses the lower slope of the hills on the north side of Happy Valley to the eastern terminus at an existing natural gas pipeline.

Overall, this linear route is approximately 60 miles long, but about 37.6 miles have been surveyed in the recent past (Boersema and Minor 1999; Oetting 1999). Therefore, the portion of the route surveyed during the current project was about 22.4 miles in length. The surveyed route segments pass through portions of seven townships. These townships and sections containing portions of the route surveyed during the current project include:

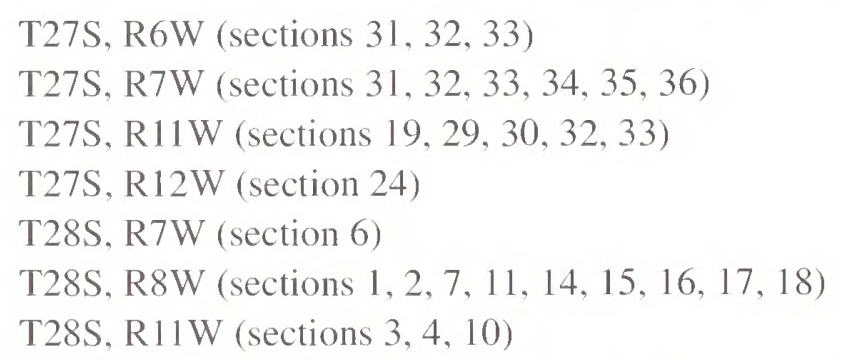

The proposed natural gas pipeline route passes through two prominent physiographic areas of southwest Oregon--the Coast Range and the Umpqua River basin. High precipitation and incisive water erosion have carved the Coast Range foothills and mountains into a rugged terrain of steep and densely forested slopes, deep narrow river and 
stream canyons, and long sinuous ridgetops that insulate the interior basins from the Pacific Ocean (Orr et al. 1992; Welcher and Greenspan 1992). The Umpqua River basin is comprised of large and small tributary stream valleys separated from one another by rolling hills and ridges. The North and South Umpqua rivers have their headwaters in the Western Cascades Mountains and have created valleys with fertile bottomlands above and below their confluence. The lower Umpqua River cuts through the Coast Range and drains into the Pacific Ocean.

The Coast Range has a mild, marine-influenced climate with high precipitation during the winter and moderate yearround temperatures. This north-south mountain range catches the moisture coming from the Pacific Ocean and creates a rain shadow effect for the eastern slopes of this range and the drainages of the neighboring Umpqua River basin. Precipitation ranges from 60 to 90 inches along the coast to as much as 200 inches along the crest of the Coast Range, but declines to only 20-40 inches in the eastern foothills and valleys (Loy et al. 1976). The Umpqua River basin has a relatively mild climate characterized by wet cool winters and warm dry summers.

The mild, wet climate of the Coast Range fosters extensive and dense stands of the Pacific Northwest temperate coniferous forests. The northwest end of the proposed pipeline route is in the Sitka Spruce (Picea sitchensis) forest zone of these widespread western forests (Franklin and Dyrness 1973), while the route crossing the Coast Range mountains is within the western hemlock-Douglas-fir (Tsuga heterophylla) vegetation zone. The principal overstory species of the Picea sitchensis zone are Sitka spruce (Picea sitchensis), western red cedar (Thuja plicata), Douglasfir (Pseudotsuga menziesii), and grand fir (Abies grandis), while the Tsuga heterophylla zone is dominated by Douglas-fir and western hemlock (Tsuga heterophylla), with a variety of other conifers and deciduous trees such as bigleaf maple (Acer macrophyllum) and alder (Alnus rubra). A dense understory of many different trees, shrubs, ferns, grasses, and forbs generally covers the floor of these forest zones.

The warmer and drier climates of the interior valleys of the Umpqua drainage support distinctive vegetation communities. Prior to agriculture and fire suppression by Euro-American emigrants in the nineteenth century, these inland valleys were predominantly open prairie grasslands. These grassy prairies were created and maintained through fires regularly set by Native Americans to promote the growth and harvest of certain plants, especially seed-bearing species, and to control the movement and concentration of game animals for more productive hunting. Scattered oaks dotted these prairies, creating oak savannahs, and oak-conifer woodlands covered the hills bordering the valleys. Rivers and streams were bordered with riparian gallery forests.

These native grasslands were extensively disturbed and altered by Euro-American introduction of agriculture and livestock grazing, but they were probably similar to the bunchgrass-needlegrass communities found in the interior valleys of California and can be generally divided into moist or dry habitats (Franklin and Dyrness 1973; Habeck 1961). These habitats supported a variety of forbs and seed-bearing grasses (e.g., danthonia [Danthonia californica], sunflower [Eriophyllum lanatum], fescue [Festuca spp.], strawberry [Fragaria spp.], needlegrass [Stipa spp.]), and the moist areas also supported marsh and wet meadow species such as camas (Camassia quamash) and sedges (Carex spp., Eleocharis spp.). The oak woodlands and savannahs of the valley floors were predominantly Oregon white oak (Quercus garryana) with some California black oak (Quercus kellogii). The oak-conifer woodlands of the foothills included elements of the upland conifer forests such as Douglas-fir, grand fir, and western red cedar, along with the oaks and other deciduous species. The bottomland gallery forests consisted of Oregon white ash (Fraxinus oregana), black cottonwood (Populus trichocarpa), Douglas-fir, bigleaf maple, and a variety of understory species.

These upland and lowland environmental settings supported a variety of fauna (Bailey 1936). Black-tailed and whitetailed deer (Odocoileus columbianus columbianus, O. virginianus leucurus) frequented lowland valleys as well as upland settings, along with Roosevelt elk (Cervus canadensis roosevelti), black bear (Euarctos americanus altifrontalis), and many smaller species of mammals. Waterfowl and terrestrial birds, both residential and migratory, were common in valley streams and wetlands. The Umpqua River and its tributaries provide spawning grounds for many anadromous salmonids, including coho salmon (Oncorhynchus kisutch), fall and spring chinook salmon (Oncorhynchus tshawytscha), winter and summer steelhead (Oncorhynchus gairdneri), and sea-run cutthroat trout (Oncorhynchus clarki) (Greenspan 1992). The Umpqua basin also supports substantial resident fish populations. 


\section{Cultural Setting}

Productive archaeological research has been conducted for several years by projects in the Umpqua River basin and on the Oregon coastal margin, through federally-mandated projects to identify and protect significant cultural properties and through research projects sponsored by regional universities. Cultural chronologies and models of settlement-subsistence adaptations have been developed for these regions. However, very little is known about the prehistory of the Coast Range. Very few sites have been found in the many archaeological surveys conducted on federal land in these rugged mountains and while some sites are known in the canyon bottoms, very few have been investigated since they are in private ownership. The archaeological background presented below blends data from overviews and research for the Oregon coast (Minor 1998; Moss and Erlandson 1998), the Umpqua River basin (Minor and Beckham 1992; O'Neill 1989), and the Coast Range (Toepel and Oetting 1992 [see also Aikens 1993]).

The proposed natural gas pipeline route crosses several discrete physiographic areas, which were home to several different Native American groups when European and American trappers and explorers first entered western Oregon. The Coos Indians resided in the vicinity of Coos Bay, the Upper Coquille Indians lived along the Coquille River, including the East Fork Coquille River which the pipeline route follows into the Coast Range. The Upper Umpqua Indians occupied the lowland areas of the upper and middle Umpqua River basin. In general, these groups followed similar seasonal rounds that incorporated lowland winter villages, with shifts to smaller, more mobile task groups in the warmer months that moved about to obtain food resources, visit with relatives and acquaintances, and trade with other groups. The following brief sketches of Native American lifeways, focusing on settlement, subsistence, and group mobility, are abstracted from Beckham (1992), Miller and Seaburg (1990), Toepel and Beckham (1981, 1992), Toepel (1987), and Zenk (1976, 1990).

Histories detailing Euro-American settlement and development of the region are available for the counties crossed by the route (Beckham 1986; Peterson and Powers 1952) and for some of the federal lands bordering the route (Minor and Beckham 1992). More complete discussions of regional archaeology, ethnography, and history may be found in the sources mentioned above.

\section{Archaeology}

Models of settlement-subsistence and cultural chronologies have been developed for the Oregon coast (Minor 1998; Moss and Erlandson 1998) and for the Umpqua River basin (O'Neill 1989; Minor and Beckham 1992). These chronologies are general, using relatively broad time periods and outlining basic settlement-subsistence adaptations. Temporal periods have been defined using radiocarbon ages obtained from specific sites, combined with typological cross-dating of projectile points from a wider range of sites. The age spans are based on uncorrected radiocarbon years before present (RCYBP). The age spans for various projectile point styles have been developed using data from throughout western Oregon.

Proposed settlement and subsistence models for each region and period are based on data excavated at a small number of sites, analogies to ethnographic groups in the region, and parallels seen with prehistoric periods elsewhere in Oregon and western North America. Finally, nearly all of the sites currently recorded west of the Coast Range are right along the coast or in the coastal river valleys. Very few sites are known for the forested areas inland from the coast or in the rugged Coast Range uplands. Therefore, the coastal chronology focuses on evidence from coastal sites and the development of coastal settlement-subsistence adaptations, while the interior chronology relies on material from valley settings and the Western Cascade Mountains in discussing settlement and subsistence strategies.

\section{Oregon Coast}

Paleo-Indian: Isolated finds of fluted points in western Oregon attest to the presence of people in the Pacific Northwest prior to $10,000 \mathrm{BP}$, but none have been identified along the modern coastline. It is likely that artifacts and other evidence of early occupation have been drowned by rising sea levels during the last 10,000 years (Minor 1998).

Early Archaic: At present, the earliest evidence for occupation of the Oregon coast occurs in the Early Archaic period (10,000-5,500 BP [Before Present]). Radiocarbon ages of 6,500 RCYBP to 9,000 RCYBP have been obtained at three sites on the central and southern coast, and similarities in point types and artifact assemblages suggest that several other sites have Early Archaic occupations (Minor 1998). However, the lifeways of these early groups are unclear. Many of the Early Archaic sites lack associated shell middens, leading some researchers to suggest that these earliest inhabitants pursued a "pre-marine" or "pre-littoral" subsistence strategy using terrestrial resources (e.g., Lyman 1991). However, early radiocarbon ages are associated with marine vertebrate faunal species or shellfish at 
the Tahkenitch Landing site and the Indian Sands site. These suggest some use of marine resources during this period, but it is perhaps too early to clearly characterize Early Arehaie adaptive strategies (Lyman 1997; Minor 1997; Moss and Erlandson 1998).

Middle Archaic: Marine-oriented subsistence strategies were elearly in use during the Middle Arehaic period (5,500-3,000 BP). Numerous sites along the Oregon coast have large shell middens which have yielded Middle Archaic radioearbon ages and artifacts (Minor 1998). Several of the larger sites are thought to have been villages (Minor 1991). Faunal material indicate Middle Archaic groups were using a variety of intertidal shellfish, eoastal birds, and mammals (terrestrial and marine). Off-shore fishing may also be indicated by fish remains at the Tahkeniteh Landing site. Sites are located on coastal headlands and bluffs, as well as on estuaries and rivers near the coast.

Late Archaic: Economies focused on intensive use of marine resources were present throughout the southern Northwest Coast region by the Late Arehaie (3,000-1,500 BP) (Minor 1998). Sites generally contain substantial middens with many varieties of shellfish, fish, birds, and mammals. Some changes in settlement patterning are apparent, as Late Arehaie sites often do not have preceding Middle Arehaic oceupations, and many eontinued to be inhabited into more reeent periods (Minor 1991). A number of these sites are large and appear to have been villages. The earliest evidenee on the Oregon coast for the reetangular plank houses and bone/antler artwork typieal of Northwest Coast late prehistorie and ethnographic societies is found during this period at the Palmrose site on the north coast. These changes may reflect the origins and early development of the eomplex soeieties of the suceeding Formative Period and the ethnographie groups of the Oregon coast.

Formative: The Formative Period (1,500-200 BP) encompassed the full emergence of ethnographie Northwest Coast culture patterns along the Oregon eoast (Minor 1998). These eultural patterns are characterized by large villages containing plank houses, ranked soeieties, and distinctive modes of artistic elaboration. Formative period sites often have underlying Late Arehaic eomponents and are found all along the Oregon eoast. The final 200 years of this period is subdivided as the Protohistorie era (Minor 1998), when non-native artifacts entered sites along the northern Oregon eoast. These artifaets, sueh as beeswax and East Asian eeramics, probably came from shipwrecks of one or more Spanish Manila galleons between about Anno Domini (AD) 1550 and 1650. The epidemic diseases that accompanied Europeans to North America apparently resulted in a rapid decline in the coastal Formative population and had a disastrous impact on their cultural and economie lifeways. The eomplexity of these late prehistorie societies is not clearly refleeted in the limited ethnographic data available from surviving coastal groups.

\section{Interior Southwest Oregon}

Paleo-Indian: The presence of a Paleo-Indian period, dating prior to $10,000 \mathrm{BP}$, is based on the isolated occurrence of fluted points in the region. Solitary fluted points have been found in the Eugene and Cottage Grove areas of the southern Willamette Valley (Allely 1975; Connolly 1994; Minor 1985) and along the North Umpqua River and lower Cascade Mountains in the Umpqua River basin (O'Neill 1989; Ozbun and Fagan 1996). No sites dating to this period are known for the region. These artifacts are thought to be equivalent in age with the well-dated 11,500 BP to 10,000 BP fluted point eomplexes in the Great Plains and Southwest. Whether these fluted points are indieative of a local lifeway of nomadic big game hunting, as suggested elsewhere in North Ameriea, remains to be determined.

Early Archaic: This period, 10,000 to 6,000 BP, is viewed as a time of adaptation to the developing Holoeene environment of western Oregon (Minor and Toepel 1981). The leaf-shaped "Caseade" projeetile point is diagnostic of this period. These points were eommon in the early levels of Cascadia Cave in the Western Caseade mountains above the eentral Willamette Valley, and are found in the lower levels of sites elsewhere in Oregon. A variety of plant and animal resourees were exploited during this period, but primary emphasis seems to have been on hunting.

The earliest radiocarbon-dated evidence for oceupation in the Umpqua region eomes from pre-Mazama components at the Dry Creek Site (O'Neill 1992) in the North Umpqua River basin and the Tiller Site (Bevill et al. 1994) in the South Umpqua drainage, as well as post-Mazama levels at the Narrows site on the North Umpqua (O'Neill 1989). The pre-Mazama occupations range in age between 7,130 and 6,500 RCYBP, while the post-Mazama component is 6,270 RCYBP. Undated pre-Mazama oecupations have also been identified at Susan Creek Campground (Musil 1994) and the Medicine Creek Site (Snyder 1981). These pre-Mazama oceupations are characterized by the presence of broad-stemmed and foliate points, and the use of andesite for the manufacture of large bifaees.

Middle Archaic: Middle Arehaic period sites, dating to between 6,000 and 2,000 BP, are found throughout western Oregon (Minor and Toepel 1981). The number of sites and their diverse settings in the Umpqua basin suggest that populations were growing and that a wide range of resources was being used. Ground stone tools are common in sites of this period and the frequency of bowl mortars, hopper mortar bases, and pestles attests to the increased importance 
Fishing for anadromous and resident species was probably a primary activity pursued from spring through fall. Large mammals such as deer, elk, and bear were plentiful in the region and were important resources (O'Neill 1989). Mountain upland areas were visited during the summer, and probably early fall, to acquire a variety of vegetal resources, such as berries, seeds, and nuts, and to hunt terrestrial game.

\section{History}

European and American trappers and traders began exploring the valleys and mountains of western Oregon in the early nineteenth century AD, trapping in the Willamette Valley in and after 1812, and crossing into the Umpqua basin between 1819 and 1821 (Beckham 1986). In 1826-1827, Alexander McLeod led a party of Hudson's Bay Company trappers and botanist David Douglas on an expedition that included the Willamette Valley, the lower Umpqua River drainage to the coast, and a return through the Coast Range on the North Fork Coquille River and through the middle Umpqua River basin back to the Willamette Valley (Davies and Johnson 1961; Peterson and Powers 1952). This party probably followed existing Indian trails for much of their journey. Trappers continued to work this region, and from 1836 to 1854, Fort Umpqua trading station was maintained by Hudson's Bay Company.

Overland exploration, travel, and then trade in the 1830 s and 1840 s linked the trading posts of Oregon with the towns of California via the Oregon-California Trail, again probably following older Indian routes through the Umpqua and Willamette valleys. By the 1840 s, the moderate climate and rich soil of the Willamette Valley was well known, and emigrants from the United States began arriving over the Oregon Trail. In 1846, a party led by Jesse and Lindsey Applegate passed through the Umpqua region in an effort to establish a new emigrant trail into the Willamette Valley, which became known as the Southern Emigrant Route, or Applegate Trail (Beckham 1986). At the same time, these explorers saw the potential for settlement and agriculture in the Umpqua River basin. Within a few years, settlers began staking lands in the northern stream valleys of the Umpqua basin. With passage of the Donation Land Claim Act in 1850 and with the increasing density of settlement in the Willamette Valley, more emigrants began moving to the Umpqua River basin, and some homesteaded the fertile river valleys of the coastal rivers. The discovery of gold in California, and then in southwest Oregon, provided markets for western Oregon agriculture and timber, as well as bringing prospectors and other speculators to the region in search of mineral wealth.

Tensions between the native population and these emigrants boiled over into hostilities in southwest Oregon in 1855 and 1856. A treaty was signed, but not ratified, and most of the native peoples of southwest Oregon were removed to reservations in the central or northern Coast Range by 1860. Since then, the Indians of the region have struggled to regain recognition and their rights as Native American groups. The Cow Creek Band of Umpqua Tribe of Indians regained federal recognition in 1982. Most Coosans and Siuslawans joined together to form the Confederated Tribes of Coos, Lower Umpqua, and Siuslaw Indians, which regained federal recognition in 1984. The Coquille Tribe, recognized in 1989, consists of Miluk Coos and Upper Coquille Athapaskan people.

Euro-American population and economic growth continued slowly through the latter half of the nineteenth century and into the twentieth century. The Oregon and California Railroad connected Roseburg to Portland in 1872. Financial troubles stopped the railroad at this point, but this proved to be a boon for Roseburg as it became the transportation hub for commerce throughout interior southwest Oregon. Construction of a military wagon road connecting Coos Bay with Roseburg began in 1870, and the CBW Road was open to traffic in 1872, providing Roseburg with a transportation link to the Pacific coast, and providing Coos Bay with a connection to the interior valleys.

Economic development in the river valleys and larger coastal estuaries has focused on agriculture and stock raising, while the dense forests and rugged terrain of the Coast Range and Western Cascades mountains fostered industrial enterprises such as logging and mining. Logging became a cornerstone of western Oregon industry in the twentieth century, but the economic importance of the timber industry has recently declined with dwindling forest reserves and increasing environmental concerns and regulations.

\section{Previous Cultural Resources Research In The Project Vicinity}

The archaeological site files and maps maintained by the State Historic Preservation Office (SHPO) in Salem, Oregon, were consulted to locate previously recorded sites in or near the project area, as well as previous investigations that have been conducted in the vicinity. In addition, the district archaeologists for the Coos Bay and Roseburg BLM districts were consulted to obtain information for the project vicinity. Finally, the Coquille Tribe provided information on areas where archaeological cultural materials have been reported in the past. 
The proposed underground natural gas pipeline route is approximately 60 miles long and crosses a total of 12 townships between its endpoints near Coos Bay and Roseburg. Due to its length, the route passes near several archaeological sites, historic properties, and areas of previous cultural resources investigations, yet because of its narrow width, the present project actually crosses very few of these recorded sites or previous projects. Overall, nine prehistoric archaeological sites recorded at the SHPO are within two miles of the proposed route. Of this total, one (35DO819) is crossed by the proposed pipeline route, one is mapped adjacent to but not within the route near Fairview, four others are within two miles in the North Fork Coquille River valley near Fairview, one is in the hills east of the Coast Range near Reston, and two are within two miles near the eastern end of the route in Happy Valley.

The probable locations of seven unrecorded archaeological sites on the East Fork Coquille River near Dora and Sitkum have been plotted on the Coos Bay BLM District cultural resources maps. These correspond closely with areas of concern noted by the Coquille Tribe. None of these appear to be intersected by the proposed route (along the CBW Road in this area), but all are located within one mile of this road.

Portions of the proposed pipeline route parallel the historic CBW Road. A historical study of this road has recently been conducted (Beckham 1997). The road, completed in 1872, was dirt for much of its length, but about 20 miles on the western end was planked. The route probably followed older Indian trails. Use of the road declined over the years, as a competing road through Camas Valley (now State Highway 42) and other routes were developed and improved. The road was little used in the 1920 s and 1930 s. With the rise of truck transportation for logging in the late 1930 s and after World War II, industrial use of the road increased. Comparison of the route shown on the General Land Office township cadastral plats with the current road indicates that the route has changed somewhat, probably reconstructed over the years to accommodate the logging traffic. Sections of the road are paved, with the remaining portions being graded and graveled. The study concluded that the CBW Road retained much of its historical landscape but that the associated historic properties generally had poor integrity and that the road was an "equivocal candidate for nomination to the National Register" (Beckham 1997:76). Furthermore, while improvements to road condition and safety would make this historical landscape more accessible, they might also compromise the historical character of the road. The CBW Road has not been formally evaluated for National Register eligibility by the Oregon SHPO.

Given the age of this road, it is not surprising that several historic properties ( 50 years old or older) are found along the route. One property, the Abernethy House in the community of Dora, is currently listed on the National Register of Historic Places. However, no historic structures or districts are within the ROW that will be affected by construction associated with the proposed pipeline route.

Several cultural resources investigations on file at the SHPO have been conducted within 2 miles of the proposed route. Most have been surveys associated with federal timber sales on the eastern slopes of the Coast Range above the proposed route. Three studies have included portions of the proposed pipeline route, including the CBW Road historical study discussed above. A survey of a BPA transmission line in the Coos Bay area included a segment of the currently proposed route (Boersema and Minor 1999). No cultural resources were found along the route, although site discovery probes were recommended at the Isthmus Slough crossing if ground disturbing construction was undertaken in this area. As mentioned in discussions above, portions of the current route along the CBW Road were included in a survey for a fiber optic line that also included the CBW Road (Oetting 1999). The archaeological site (35DO819) that is within the current project route was recorded during this survey. This site was avoided during the fiber optic line construction by boring beneath the site. Several sections along the CBW Road were monitored during this construction, but no cultural resources were encountered (Oetting 2000).

General Land Office (GLO) survey plats for the 12 townships crossed by the proposed pipeline route were also examined. The cadastral plats for townships in the Coos Bay and Roseburg areas were surveyed in the 1850s, while those crossing the Coast Range were platted in the 1870s. In general, a few cultural features such as houses and land claims were found near the current proposed route near Roseburg-two houses and Donation Land Claims in Lookingglass Valley and one Donation Land Claim with a house in Happy Valley. The CBW Road is depicted on the appropriate Coast Range township plats, and a few houses are identified, but none of the towns along this road had been developed when the plats were surveyed in the mid-1870s.

\section{Inventory Methods}

An intensive pedestrian survey was undertaken to determine if surface evidence of prehistoric or historic sites or artifacts was present along the portions of the proposed pipeline route where landowner permission had been obtained 
and that had not been previously surveyed. Four segments of the proposed route were surveyed during the current study, one in the hills above Coos Bay and three within BPA transmission line ROWs.

The proposed route segment in Coos Bay generally followed the route of one lane dirt roads up the ridges on either side of Blossom Gulch. These ridges have been logged in the past and are now covered with second growth shrubs, small trees, and brush. The route across Blossom Gulch passes through densley vegetated wet bottomland. The vegetation in this segment limited ground visibility and made walking through the area extrememly difficult. In addition, the wet bottomland ground made the Blossom Gulch area impassable. Survey along this route corridor therefore, was limited to the existing dirt roads and their shoulders. Two archaeologists surveyed this segment, either as a team on either side of the road, or independently surveying along one side of the road in one direction and returning on the opposite side of the road.

The other surveyed sections were within BPA transmission line ROWs. These surveyed segments included 3.1 miles between Fairview and McKinley, 1.2 miles between Cherry Creek (southeast of McKinley) and the East Fork Coquille River valley (west of Dora), and 16.4 miles from the CBW Road at the Douglas County line to the eastern terminus of the pipeline route. In each segment, the transmission line corridor was inspected by two archaeologists, one walking beneath each of the overhead transmission line arms, or by one archaeologist walking one direction under one line arm and returning under the other line arm. If a service road was present within the corridor, at least one archaeologist inspected the road, since it generally provided the greatest mineral soil visibility. Although large trees have been removed from the transmission line corridor, much of the ROW corridor is covered with grass and understory brush. In some areas, trees and brush have been cut but not removed, making passage difficult and further limiting ground surface visibility. Ground surface visibility was generally limited by thick surface vegetation along most of the surveyed route. The routes of each surveyor varied to maximize surface visibility within the transmission line corridor.

Both prehistoric and historic artifacts were searched for during the field inventory. "Historic" items were defined, in accordance with National Register eligibility criteria, as artifacts or features that were at least 50 years old. In addition, the field crew noted landforms, such as stream terraces, where archaeological sites were likely to occur and where site discovery probes should be recommended.

When cultural materials were located, the surveyor halted and examined the find locale to determine if the specimen was isolated or could be identified as part of a larger population of artifacts--a site. The location was flagged in the field and was returned to by the entire field crew to examine the area more closely and, if necessary, record the site. Archaeological sites were designated pragmatically, using several criteria. These criteria include the number and kind of cultural items observed, the site setting, and the conditions of observation. In general, locations with 10 or more artifacts found within a $10 \mathrm{~m}$ diameter area were recorded as sites. In areas where specific landforms created discrete surfaces (such as small benches), the presence of 10 or more items on that surface would be sufficient for designation as a site. Finds of cultural materials which were not classified as sites were also noted and mapped as isolated finds. All prehistoric and demonstrably historic materials encountered within the project limits during the survey were documented. The location of each archaeological site and isolated find was placed on the appropriate USGS 7.5' topographic maps.

Locations determined to be archaeological sites were recorded in the field and these data were subsequently transferred to SHPO Site Record forms. At each site, physical setting, primary vegetation, water source, site size, artifact density and diversity, occurrence of cultural features, and relationships to other sites were examined and recorded. The types of artifacts observed and counts or estimates of their frequency were recorded, along with brief descriptions of the exposed cultural materials. No artifacts were collected during this survey. Photographs were taken at each site to illustrate the site area and local environmental setting.

\section{Inventory Results}

The transmission line segments were surveyed in January, 2001, and the westernmost segment above Coos Bay was surveyed in August, 2001. The pedestrian survey of each section was accomplished by a field crew of one or two archaeologists, examining the transmission line corridor as described above. Survey conditions and ground surface visibility varied along the route due to terrain and surface vegetation.

The proposed route in the hills above Coos Bay crossed steep ridge slopes and wet bottomland. Survey was limited to the mineral soil visible in the existing dirt roads and road shoulders, as ground visibility away from these areas was less than 10 percent. No cultural materials, prehistoric or historic, were found in this segment. Given the difficult topography of this proposed route segment, the probability for cultural resource sites here is low. 
The two short transmission line segments on the west side of the Coast Range also crossed steep, hilly terrain and contained dense vegetation. Ground surface visibility was no more than 10 percent, with mineral soil visible only in the transmission line service road. No cultural resources were noted in these sections, but two streamside areas likely to contain archaeological sites were noted. One location is along the banks of the North Fork Coquille River just southeast of Fairview (T27S, R12W, section 24). The other high probability area is along the banks of Cherry Creek, about one mile southeast of McKinley (T28S, R11W, section 4).

The long eastern transmission line survey segment, 16.4 miles between the Douglas County line and the eastern terminus of the proposed pipeline, contained varied terrain and vegetation. The Coast Range divide was very steep, with dense vegetation. North of Reston, the route crosses rolling hills and side slopes, then descends into Flournoy Valley. The route then turns east, skirts the base of White Tail Ridge and crosses Lookingglass Valley. The transmission line then crosses a steep ridge dividing Lookingglass Valley from Happy Valley and then crosses the side slopes on the northern edge of Happy Valley to the east end of the proposed route. The valleys were pasturelands covered with grass. The side slopes contained mixtures of grasslands and woodlands. The steeper terrain was forested. Ground visibility was again about 10-15 percent, with the mineral ground surface generally visible only in disturbed areas such as dirt roads, road shoulders, rodent burrow backdirt, and other animal disturbances.

One previously recorded prehistoric archaeological site (35DO819) was observed along this segment, and one new prehistoric site (BIS-1) and one isolated prehistoric artifact (35DO879) were also discovered and recorded on this segment of the proposed pipeline route. Several areas with a high probability for archaeological sites were also noted.

ISO-1: The isolated find is a chert biface tip fragment found in the disturbed soil of a road cut near a creek just northwest of Reston (T28S, R8W, section 15). The area was carefully searched for additional artifacts, but no other items were located. This area is near a creek, an area with a high likelihood to contain archaeological sites.

Site 35DO819: This site was recorded in 1999 (Oetting 1999). It is a thin lithic scatter of chert flakes on a low rise between Rock Creek and an unnamed stream at the southwest end of Flournoy Valley (T27S, R7W, section 32). The transmission line passes over this rise, paralleling the CBW Road which bisects the rise. Twenty chert flakes were found in the cutbanks and drainage ditches bordering the road when the site was first recorded, 19 on the west side of the road nearest the transmission line. No tools or other artifacts were observed in the site area. The flakes occur for about $100 \mathrm{~m}$ ( $330 \mathrm{feet}$ ) along the road. This site area should be avoided by construction activities by altering the pipeline route or construction methods. If the site cannot be avoided, site evaluation test excavations should be conducted, to determine whether the site is eligible to the National Register of Historic Places.

Site 35DO879 (BIS-1): This small lithic scatter site was found during the current survey. It is about 1 mile west of the eastern end of the proposed pipeline route, on the top and east flank of a flat-topped knoll overlooking a small creek (T27S, R6W, section 33). Ten chert flakes, two basalt flakes, and one chert biface lip fragment were found in a $10 \times 25 \mathrm{~m}$ area. All of the artifacts were found in a road cut. Several of the flakes and the biface fragment were found down the eastern slope. They may have been pushed down this slope by road construction or by natural erosion. This site area should be avoided by construction activities by altering the pipeline route or construction methods. If the site cannot be avoided, site evaluation test excavations should be conducted, to determine whether the site is eligible to the National Register of Historic Places.

High Probability Areas: Several areas likely to contain archaeological sites were noted, but visibility was poor and no cultural materials were observed during the survey. Site discovery probe excavations should be conducted in these areas to better determine whether archaeological sites are present. These areas include an elevated bench above a creek northeast of Reston (T28S, R8W, section 11), stream banks near the head of Flournoy Valley (T27S, R7W, section 31), the valley floor just southwest of site 35DO819 (T27S, R7W, section 32), and two canyon bottom creek banks-in Powderhouse Canyon and in the next drainage to the west of Powerhouse Canyon (both in T27S, R6W, section 32). 


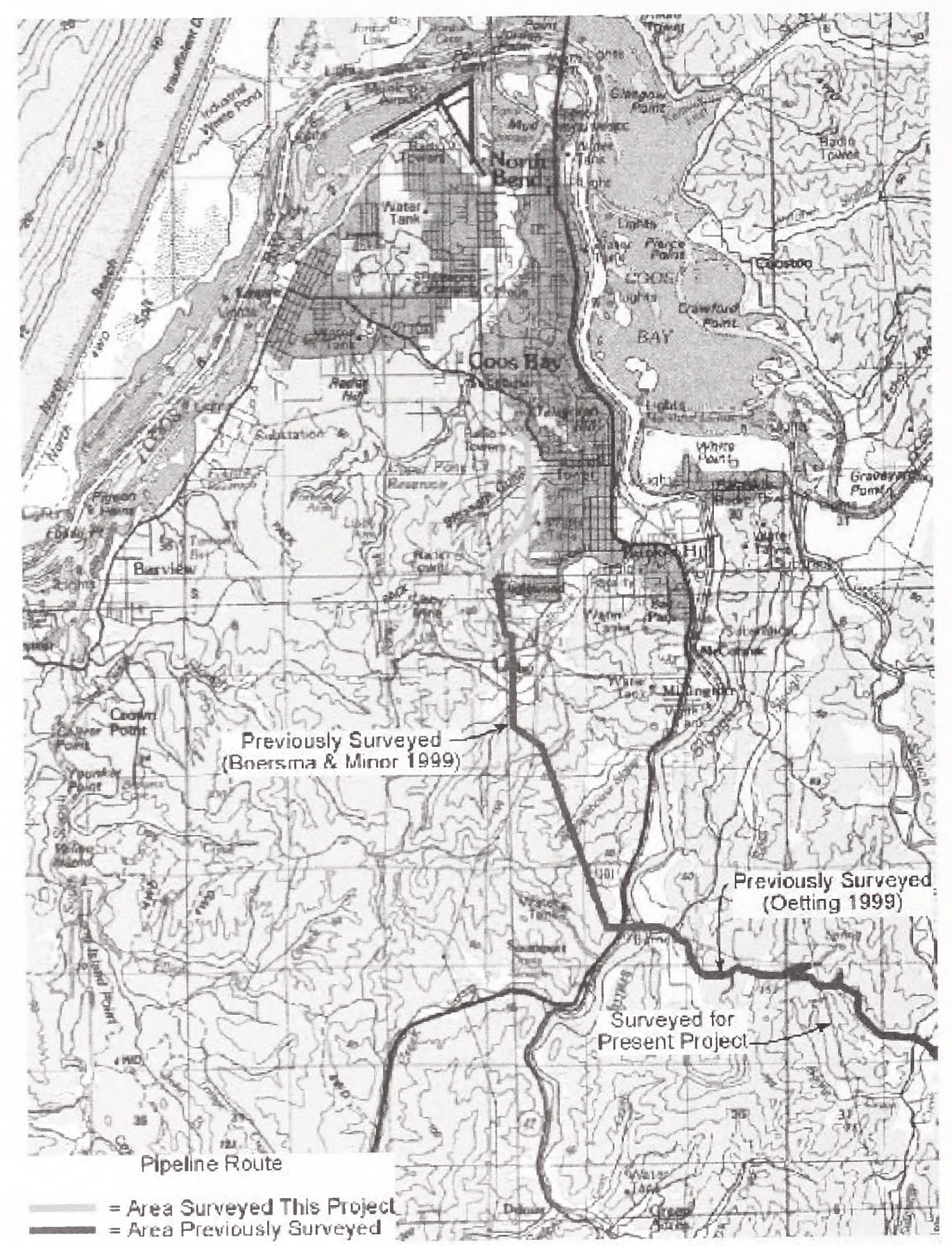

Figure B-2: Survey status and location of recommended site discovery probes (SDP), Coos Bay to Catching Creek 


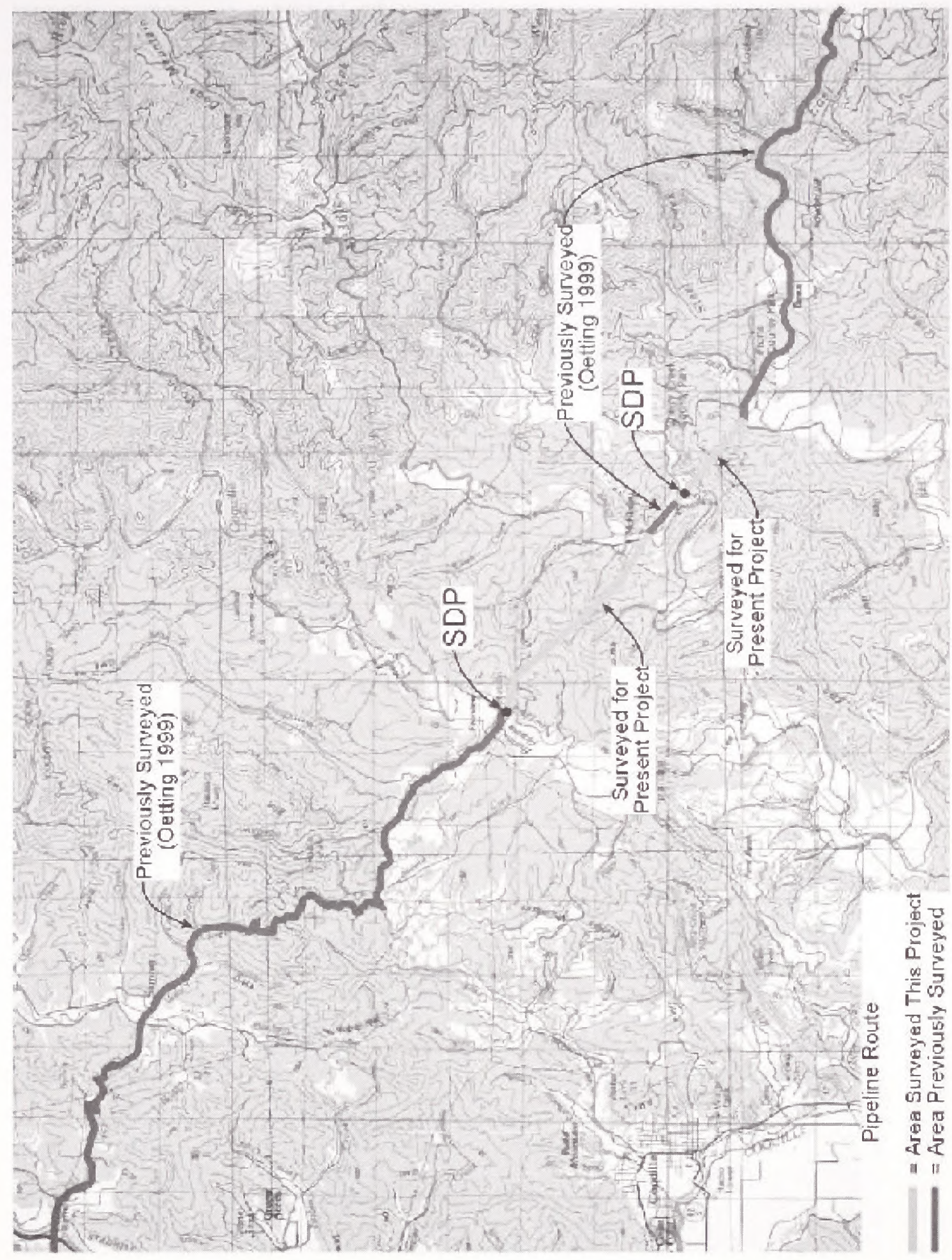

Figure B-3: Survey status an location of recommended site discovery probes (SDP), Isthmus Slough to Sitkum 


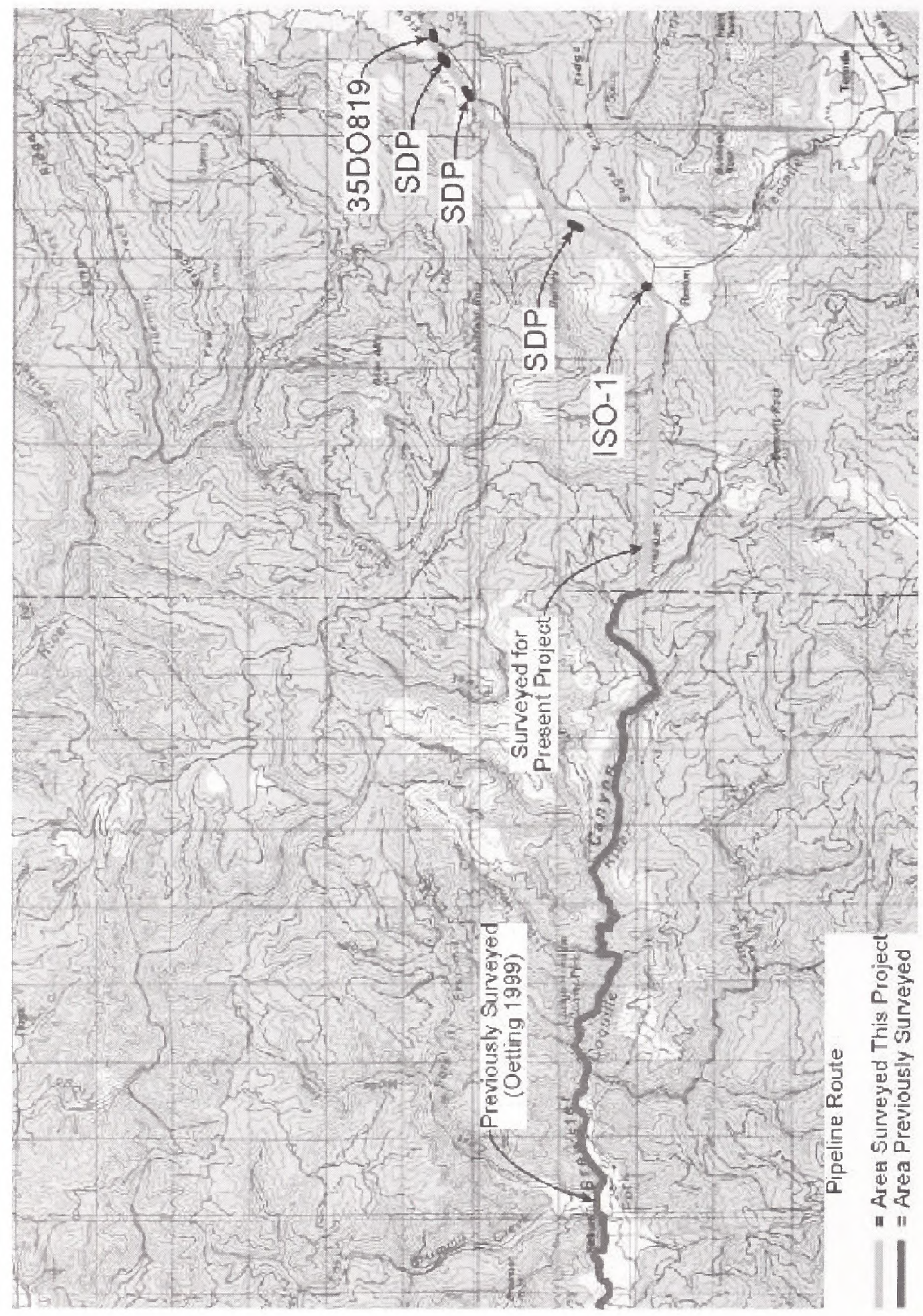

Figure B-4: Survey status, location of identified cultural materials, and location of recommended site discovery probes (SDP), Sitkum to Flournoy Valley 


\section{Summary And Recommendations}

A review of background literature and other data found that 16 prehistoric sites have been recorded within 2 miles of the proposed underground natural gas pipeline route, and that one of these recorded prehistoric sites is within the proposed route where it passes through the head of Flournoy Valley, northeast of Reston. This total ineludes nine sites recorded at the Oregon SHPO and seven unrecorded prehistoric sites near the CBW Road mapped by the Coos Bay BLM Distriet. Some historic structures are present near the CBW Road and the route passes by several Donation Land Claims in Lookingglass and Happy valleys, but no known historic structures are located in areas that will be affected by the proposed pipeline route.

The proposed pipeline route is approximately 60 miles long, but about 37.6 miles were recently surveyed for eultural resources (Boersema and Minor 1999; Oetting 1999) and were not re-examined during this project. The portions of the route surveyed for the current project were about 22.4 miles in length. A systematic pedestrian survey was undertaken to determine if surface evidenee of prehistoric or historic sites or artifacts was present along these portions of the proposed pipeline route. One route segment was 1.7 miles long in the hills above Coos Bay. The other three segments were within BPA transmission line ROWs, including 3.1 miles between Fairview and MeKinley, 1.2 miles between Cherry Creek southeast of MeKinley and the East Fork Coquille River valley west of Dora, and 16.4 miles from the CBW Road at the Douglas County line to the eastern terminus of the pipeline route.

The arehaeologists relocated the one previously recorded prehistoric arehaeological site (35DO819) that was within the proposed route, and identified one new prehistoric site (35DO879) and one isolated prehistoric artifact (ISO-1). Several areas with a high probability for archaeological sites were also noted. These locations are shown on the appropriate maps in Figures B-2 through B-5.

The proposed route passes near the reported locations of several arehaeological sites near Dora and Sitkum on the CBW Road, but this portion of the route had already been surveyed and no eultural materials were noted within the road eorridor in these areas during that survey (Oetting 1999). The CBW Road is a historic road, but its significance and National Register eligibility have not been formally evaluated by the Oregon SHPO. The physical elements of the road (road grade, road bed, surfacing, etc.) have been maintained, repaired, rebuilt, and realigned as needed in the past, but altering current road conditions could affect the historic character of the road. The natural gas pipeline route should not affect this historic transportation route if the road is returned to current conditions after pipeline eonstruction.

\section{$\underline{\text { Recommendations }}$}

The two prehistoric arehaeological sites identified along the projeet route have not been evaluated to determine whether they are eligible for listing in the National Register of Historic Places (NRHP). These are lithie seatter sites 35DO819 and 35DO879, respectively loeated in T27S, R7W, section 32, and T27S, R6W, seetion 33. If feasible, it is recommended that these site areas be avoided by any project-related construction activity. If these sites cannot be avoided, it is recommended that subsurface site evaluation test exeavations be undertaken to determine the signifieance of these two sites in terms of eligibility to the NRHP.

The pipeline crosses many landforms, especially stream banks, that are likely locations to find archaeological sites. However, vegetation in many of these areas limited surface visibility. It is recommended that subsurface site discovery probes be excavated in eight specific areas along the route where the route crosses streams or rivers, and at the location of ISO-1, an isolated flaked stone tool found on the surface. It may be prudent to monitor pipeline construetion activities in some of the high probability areas. Site discovery probes should be excavated at the following loeations (from west to east along the route):

1. the banks of the North Fork Coquille River just southeast of Fairview in T27S, R12W, section 24;

2. the banks of Cherry Creek, about 1 mile southeast of McKinley, in T28S, R11W, section 4;

3. at the location of ISO-1, a chert biface tip, found in the disturbed soil of a road cut near a creek just northwest of Reston in T28S, R8W, section 15;

4. an elevated bench above a creek northeast of Reston in T28S, R8W, section 11;

5. stream banks near the head of Flournoy Valley in T27S, R7W, section 31;

6. the Flournoy Valley floor in the transmission line corridor just southwest of site 35DO819 T27S, R7W, seetion 32;

7. the creek banks in the canyon bottom directly west of Powderhouse Canyon, in T27S, R6W, section 32; and

8. the creek banks in the bottom of Powderhouse Canyon, also in T27S, R6W, section 32. 
The CBW Road has been recognized as a historic transportation route, but it has not been formally evaluated for significance by the Oregon SHPO. The pipeline is to be buried beneath the road or road shoulder along several portions of the road. Modifications to the road may affect the historic character of this transportation route,. Therefore, it is recommended that any alteration to the existing road surface/shoulders in the planned route be avoided, by returning these sections to their existing conditions after pipeline construction.

If modifications (such as paving graveled sections to help protect the pipeline) are required, formal review and evaluation by the SHPO will be necessary prior to construction. If this is the case, it is recommended that a formal Determination of Eligibility (DOE) document be prepared for the road and submitted to the SHPO for evaluation. If the road is determined eligible for the NRHP, then a Determination of Effect (Section 106 Finding of Effect) must be prepared for the proposed alterations.

To briefly summarize, recommendations are as follows:

a) Known archaeological sites should be avoided during pipeline construction.

b) If known sites cannot be avoided, they should be tested to determine the extent and nature of the cultural deposits within the project ROW.

c) Site discovery probes should be excavated at eight specific locations delineated above where archaeological sites are especially likely to occur. If sites are discovered, the above recommendations apply.

d) If the pipeline route is re-aligned to include alignments that have not been examined for cultural resources, it is recommended that these routes be inspected in a manner consistent with the investigations conducted for the current project. In addition, portions of the route not yet surveyed pending owner permission should also be examined for cultural resources.

e) A qualified archaeologist should be present to monitor pipeline construction activities in the vicinity of defined sites and areas with a high probability for archaeological sites. These monitoring areas will be specifically defined upon the completion of the site discovery probes recommended above. The tribes and agencies should be consulted in the development and implementation of the monitoring plan.

f) The portions of the CBW Road affected by pipeline construction should be returned to the same conditions existing before construction.

g) If portions of the CBW Road must be altered, it is recommended that a formal Determination of Eligibility (DOE) document be prepared and submitted for SHPO evaluation. If determined eligible, a Determination of Effect (Section 106 Finding of Effect) will be needed for the proposed changes to the road.

There is always the possibility that buried or obscured prehistoric or historic cultural resources may be present along the chosen natural gas pipeline route. Archaeological sites and, in particular, Indian burials are protected under Oregon state law (ORS 97.745 and 358.920) and by Federal regulations where federal lands, funds, or permits are involved (e.g., 36 CFR part 800). Disturbance of graves is specifically prohibited, even through accidental discovery. If cultural resources are inadvertently encountered during the course of construction along the route, earth-disturbing activities in the vicinity of the find should be suspended immediately, in accordance with applicable laws, and a qualified archaeologist should be called in to evaluate the discovery and recommend subsequent courses of action. 


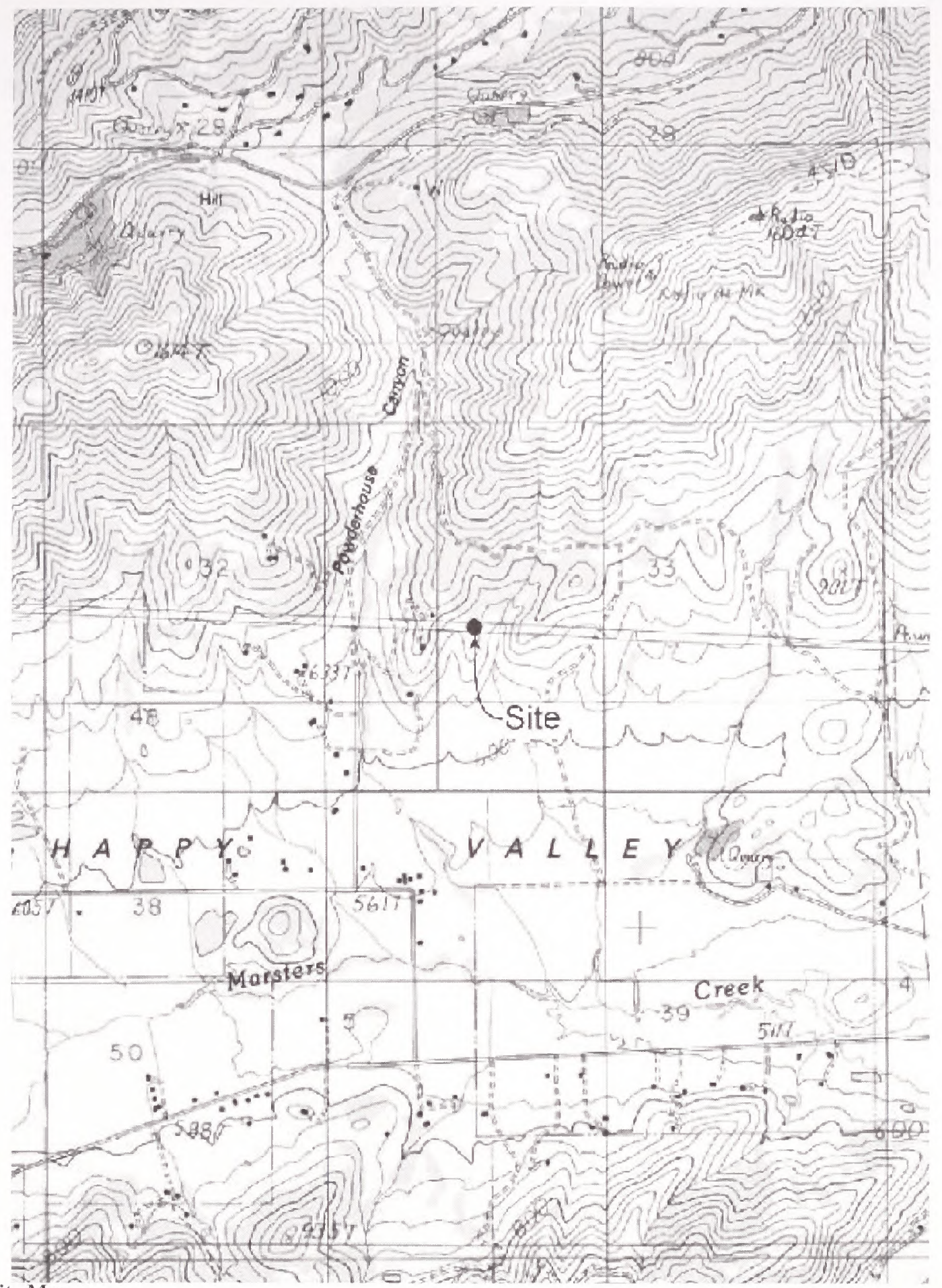

Figure B-5: Site Map 


\section{REFERENCES CITED}

Aikens, C. Melvin. 1993. The Archaeology of Oregon. U. S. Department of Interior, Bureau of Land Management, Oregon State Office, Portland.

Allely, Steven. 1975. A Clovis Point from the Mohawk River Valley, Western Oregon. In Archaeological Stndies in the Willamette Valley, Oregon, edited by C. Melvin Aikens, pp. 549-552. University of Oregon Anthropological Papers 8.

Bailey, Vernon. 1936. The Mammals and Life Zones of Oregon. North American Fauna No. 55, U. S. Government Printing Office, Washington, D. C.

Beckham, Stephen Dow. 1986. Land of the Umpqua: A History of Douglas County, Oregon. Douglas County Commissioners, Roseburg.

1992. Native Peoples. In Cultural Resource Overview of the Umpqua National Forest, Sonthwestern Oregon, by Stephen Dow Beckham and Rick Minor, pp. 101-124. Heritage Research Associates Report No. 125.

------. 1997. CBW Road: Historical Investigations and Identification of Interpretive Options. Report to the USDI Bureau of Land Management, Coos Bay and Roseburg Districts.

Bevill, Russell, Michael S. Kelly, and Elena Nilsson. 1994. Archaeological Data Recovery at 35DO37, A PreMazama Site on the South Umpqua River, Douglas County, Southwest Oregon. Report of Mountain Anthropological Research to the Umpqua National Forest, Roseburg, Oregon.

Boersema, Jana, and Rick Minor. 1999. Cultural Resources Survey for the Reedsport-Fairview Transmission Project, Coos County, Oregon. Report by Heritage Research Associates, Inc. to Bonneville Power Administration. HRA Letter Report 99-5.

Connolly, Thomas J. 1994. Paleo Point Occurrences in the Willamette Valley, Oregon. In Contributions to the Archaeology of Oregon 1989-1994, edited by Paul W. Baxter, pp. 81-88. Association of Oregon Archaeologists, Occasional Papers No. 5.

Davies, K. G., and A. M. Johnson. 1961. Peter Skene Ogden's Snake Country Journal, 1826-27. The Hudson's Bay Record Society, London.

Franklin, Jerry F., and C. T. Dyrness. 1973. Natural Vegetation of Oregon and Washington. USDA Forest Service General Technical Paper PNW-8.

Greenspan, Ruth L. 1992. Fish, Mammal, and Bird Resources in the Oregon Coast Range. In An Inventory Strategy Plan for BLM Lands in the Oregon Coast Range, by Kathryn A. Toepel and Albert C. Oetting, pp. 37-65. Report by Heritage Research Associates, Inc., Eugene, to USDI Bureau of Land Management, Oregon State Office, Portland. Heritage Research Associates Report No. 135.

Habeck, James R. 1961. The Original Vegetation of the Mid-Willamette Valley, Oregon. Northwest Science 35(2):65-77.

Loy, William G., Stuart Allan, Clyde P. Patton, and Robert D. Plank. 1976. Atlas of Oregon. University of Oregon Books, Eugene.

Lyman, R. Lee. 1991. Prehistory of the Oregon Coast. Academic Press, San Diego.

----. 1997. Assessing a Reassessment of Early "Pre-Littoral" Radiocarbon Dates from the Oregon Coast. Journal of California and Great Basin Anthropology 19(2):260-269.

Miller, Jay, and William R. Seaburg. 1990. Athapaskans of Southwestern Oregon. In Handbook of North American Indians, Volume 7: Northwest Coast, edited by Wayne Suttles, pp. 580-588. Smithsonian Institution, Washington, D.C.

Minor, Rick. 1985. Paleo-Indians in Western Oregon: A Description of Two Fluted Projectile Points. Northwest Anthropological Research Notes 19(1):33-40.

--------. 1987. Archaeology of the South Umpqua Falls Rockshelters, Douglas County, Oregon. Report to Umpqua National Forest, Roseburg. Heritage Research Associates Report No. 64. 
1991. Yaquina Head: A Middle Archaic Settlement on the North-Central Oregon Coast. USDI Bureau of Land Management, Cultural Resources Series No. 6. Oregon State Office, Portland.

1997. Pre-Littoral or Early Archaic? Conceptualizing Early Adaptations on the Southern Northwest Coast. Journal of California and Great Basin Anthropology 19(2):269-280.

1998. Southern Northwest Coast. In Archaeology of Prehistoric Native America, An Encyclopedia, edited by Guy Gibbon, pp. 791-793. Garland Publishing, Inc., New York and London.

Minor, Rick and Stephan Dow Beckham. 1992. Cultural Resource Overview of the Umpqua National Forest, Sonthwestern Oregon. Heritage Research Associates Report No. 125.

Minor, Rick and Thomas J. Connolly. 1987. Archaeological Testing at Times Square Rockshelter, Douglas County, Oregon. Heritage Research Associates Report No. 55.

Minor, Rick, and Kathryn A. Toepel. 1981. Archaeological Overview. In Prehistory and History of BLM Lands in West-Central Oregon: A Cultural Resource Overview, by Stephen D. Beckham, Rick Minor, and Kathryn A. Toepel, pp.117-183. University of Oregon Anthropological Papers 25.

Moss, Madonna L., and Jon M. Erlandson. 1998. Early Holocene Adaptations on the Southern Northwest Coast. Journal of California and Great Basin Anthropology 20(1):13-25.

Musil, Robert R. 1994. The Archaeology of Susan Creek Campground, Douglas Connty, Oregon. Report to Bureau of Land Management, Roseburg District, Roseburg. Heritage Research Associates Report No. 162.

O'Neill, Brian L. 1989. Archaeological Investigations at the Narrows and Martin Creek Sites, Donglas County, Oregon. Bureau of Land Management Cultural Resource Series No. 4.

-----. 1991. Evaluation of Six Archaeological Sites Along the North Umpqua Highway, Donglas County: Steamboat Creek to Boulder Flat Section. OSMA Report 91-1. Oregon State Museum of Anthropology, University of Oregon, Eugene.

------. 1992. Pre-Mazama Occupation of the Dry Creek Site (35DO401), Southwest Oregon. Paper presented at the 45th Annual Northwest Anthropological Conference, Burnaby, British Columbia.

Oetting, Albert C. 1999. Cultural Resources Inventory Report for the Williams Communications, Inc. Fiber Optic Cable Installation Project, Bandon Cable Landing to Jasper Regeneration Station: Coos Bay Wagon Road to Jasper Regeneration Station Section, Coos, Douglas, and Lane Counties, Oregon. Report to Jones \& Stokes Associates,

Inc., Sacramento, CA, for Williams Communications Inc., Tulsa, OK. Heritage Research Associates Report No. 222.

...-.-. 2000. Cultural Resources Monitoring for Segments of the Williams Conmunications, Inc. Fiber Optic Installation Project, Bandon Cable Landing to Jasper Regeneration Station, Coos, Douglas, and Lane County, Oregon. Report to Jones \& Stokes Associates, Inc., Sacramento, CA, for Williams Communications Inc., Tulsa, OK. Heritage Research Associates Letter Report 00-6.

Orr, Elizabeth L., William N. Orr, and Ewart M. Baldwin. 1992. Geology of Oregon. Fourth Edition. Kendall Hunt Publishing, Dubuque.

Ozbun, Terry L., and John L. Fagan. 1996. Archaeological Testing and Evaluation of the Seneca Clovis Site (35D0634). Archacological Investigations Northwest Report No. 102.

Peterson, Emil R., and Alfred Powers. 1952. A Century of Coos and Curry. Binfords and Mort Publishing, Portland.

Snyder, Sandra L. 1981. Medicine Creek: Pre- and Post-Mazama Occupation in the Cascades. Tebiwa, Miscellaneous Papers in Regional Anthropology No. 23.

Spencer, Lec. 1989. Times Square Rockshelter, 35DO212: A Stratified Dry Rockshelter in the Western Cascades, Douglas County, Oregon. Lee Spencer Archeology Paper 1989-4.

Tasa, Guy L. 1992. Human Cremation from the Island Campground Site (34DO422), Douglas County, Oregon. OSMA Report 92-1. Oregon State Museum of Anthropology, University of Oregon, Eugene.

Toepel. Kathryn A. 1987. Ethnographic Background. In Cultural Resource Overview of the Willamette National Forest: A 10-Year Update, by Rick Minor, pp.7-31. Heritage Research Associates Report No. 60. Report to Willamette National Forest, Eugene, Oregon. 
Toepel, Kathryn A., and Stephen D. Beckham. I981. Ethnographic Overview. In Prehistory and History of BLM Lands in West-Central Oregon: A Cultural Resource Overview, by Stephen D. Beckham, Rick Minor, and Kathryn A. Toepel, pp.4I-114. University of Oregon Anthropological Papers 25.

1992. Ethnography, Prehistory, and History of the Coast Range. In An Inventory Strategy Plan for BLM Lands in the Oregon Coast Range, by Kathryn A. Toepel and Albert C. Oetting, pp. 67-78. Report by Heritage Research Associates, Inc., Eugene, to USDI Bureau of Land Management, Oregon State Office, Portland. Heritage Research Associates Report No. 135.

Toepel, Kathryn A., and Albert C. Oetting. 1992. An Inventory Strategy Plan for BLM Lands in the Oregon Coast Range. Report by Heritage Research Associates, Inc., Eugene, to USDI Bureau of Land Management, Oregon State Office, Portland. Heritage Research Associates Report No. 135.

Welcher, Karin, and Ruth L. Greenspan. 1992. Physical Environment. In An Inventory Strategy Plan for BLM Lands in the Oregon Coast Range, by Kathryn A. Toepel and Albert C. Oetting, pp. 5-17. Report by Heritage Research Associates, Inc., Eugene, to USDI Bureau of Land Management, Oregon State Office, Portland. Heritage Research Associates Report No. 135.

Zenk, Henry B. 1976. Contributions to Tualatin Ethnography: Subsistence and Ethnobiology. Unpublished Master's thesis, Department of Anthropology, Portland State University.

------. 1990. Siuslawans and Coosans. In Handbook of North American Indians, Volume 7: Northwest Coast, edited by Wayne Suttles, pp. 572-579. Smithsonian Institution, Washington, D.C. 


\section{Appendix C. \\ Sheets 1-10}

The following changes between the Draft and Final Environmental Impact Statement were made in Appendix C:

- Ten black and white sheets delineating BLM managed lands adjacent to the proposed action have replaced sheets 1-10 as they appeared in Appendix C of the Draft EIS. Refer to the Appendix C of the Draft EIS for maps 6-12 found in Appendix C of the Draft EIS. 
Appendix C. Sheets 1-10

C -2 


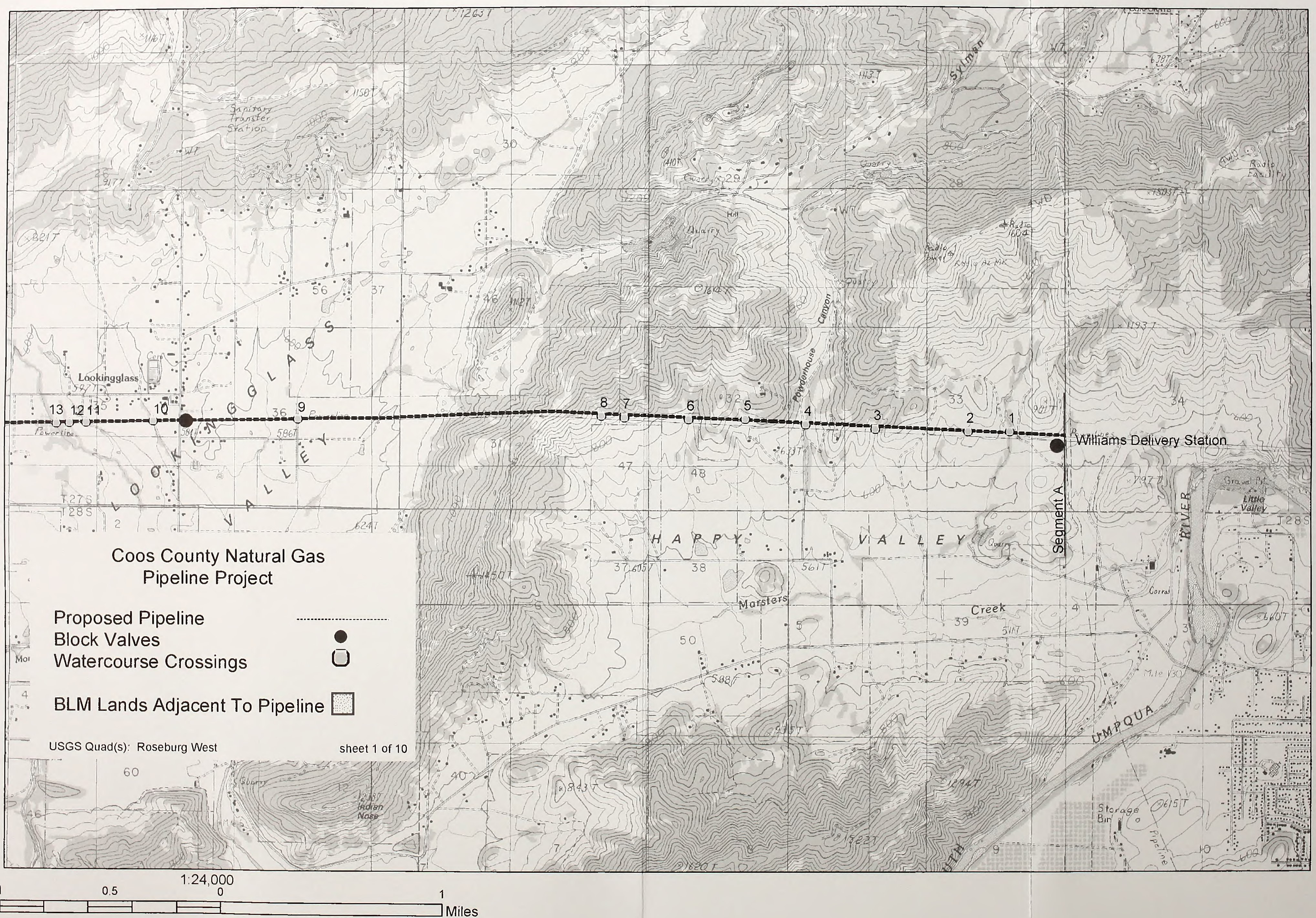





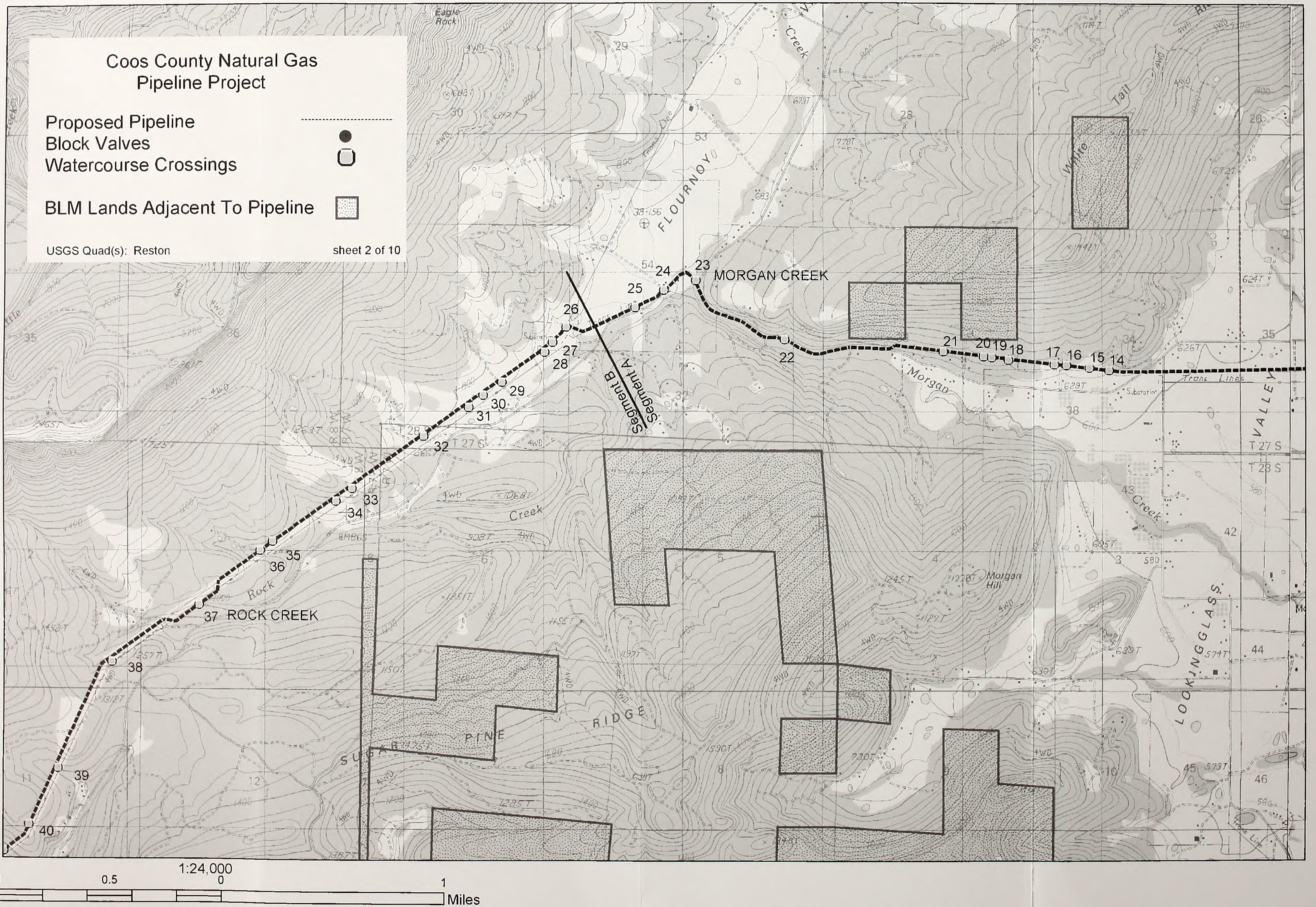





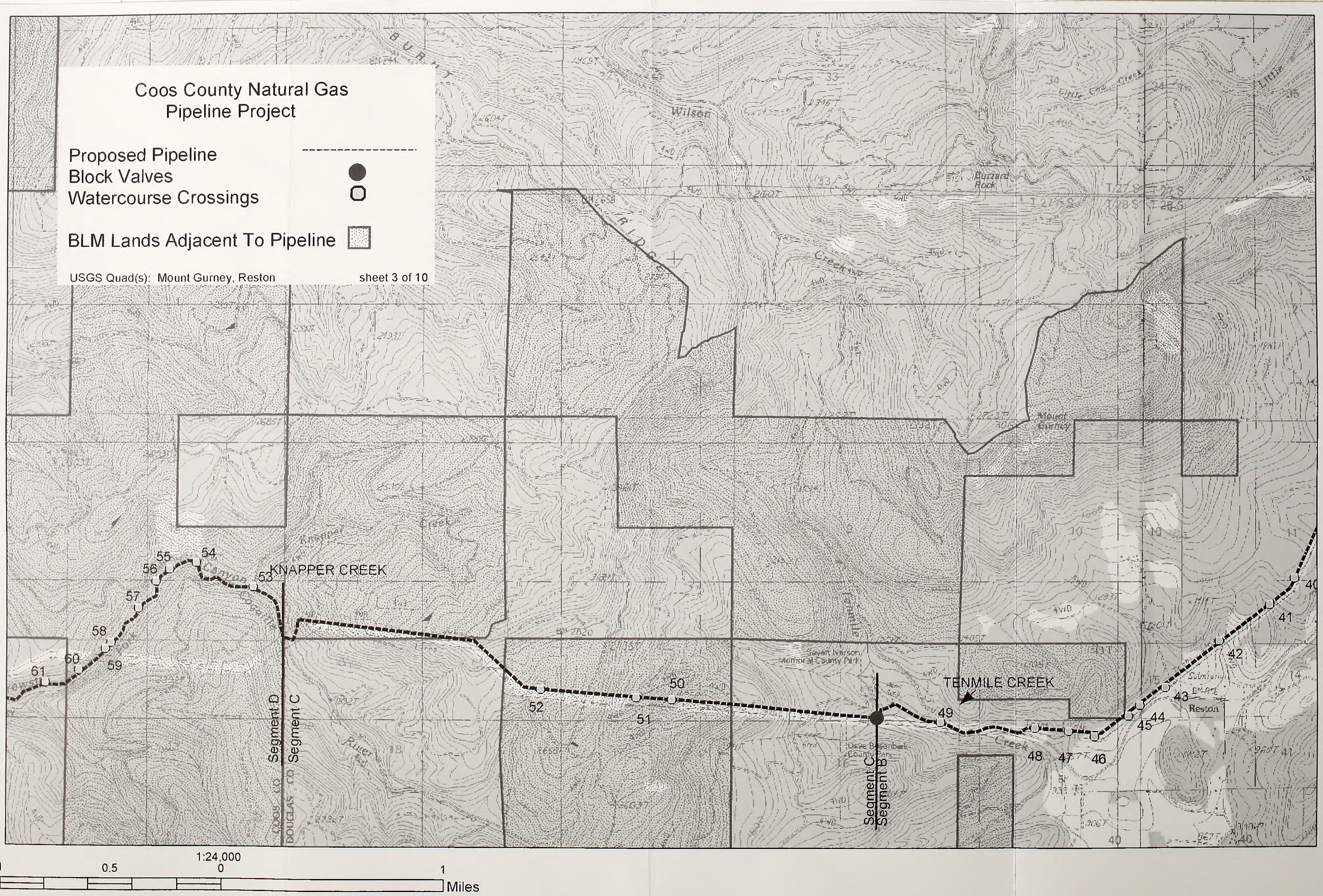





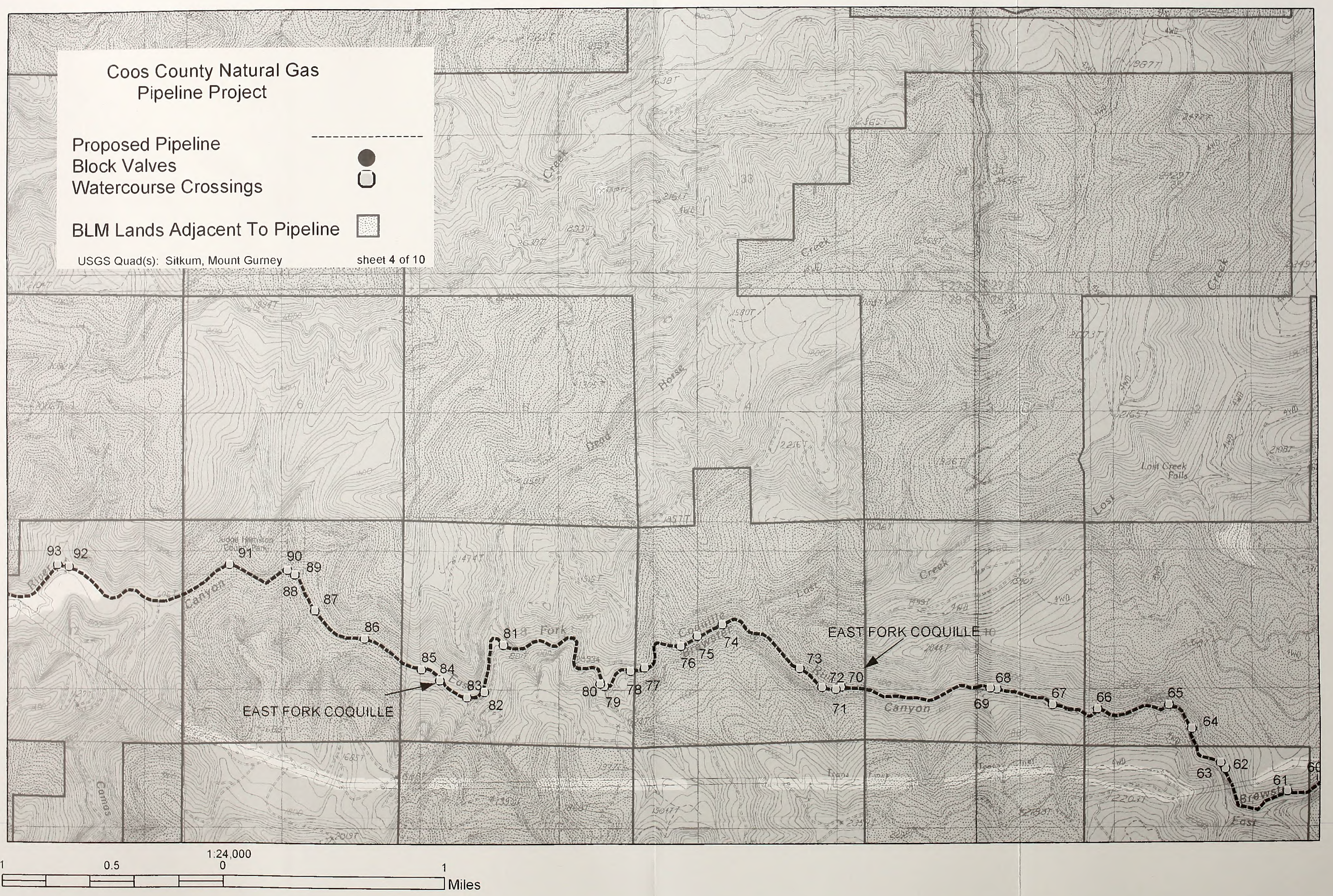





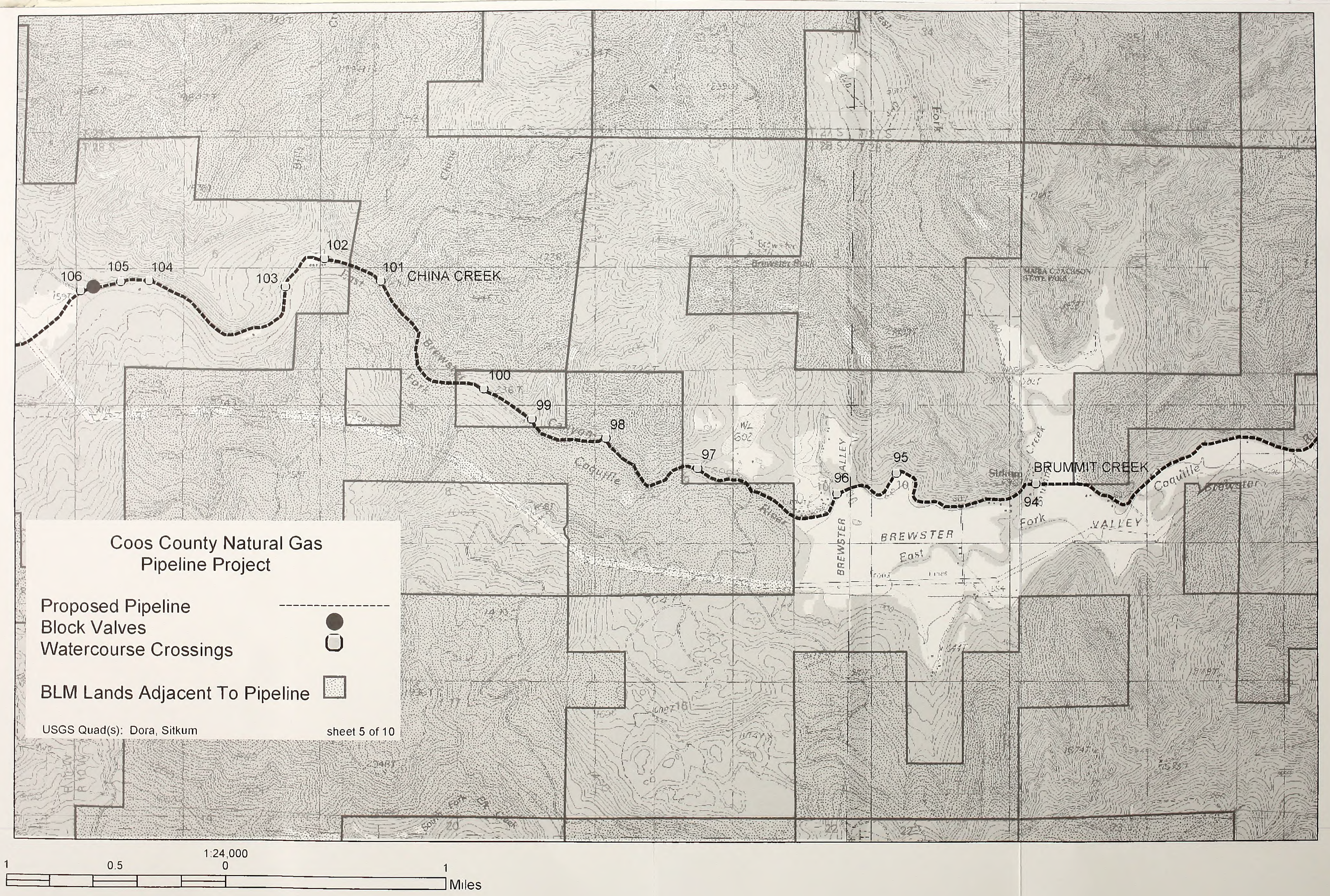





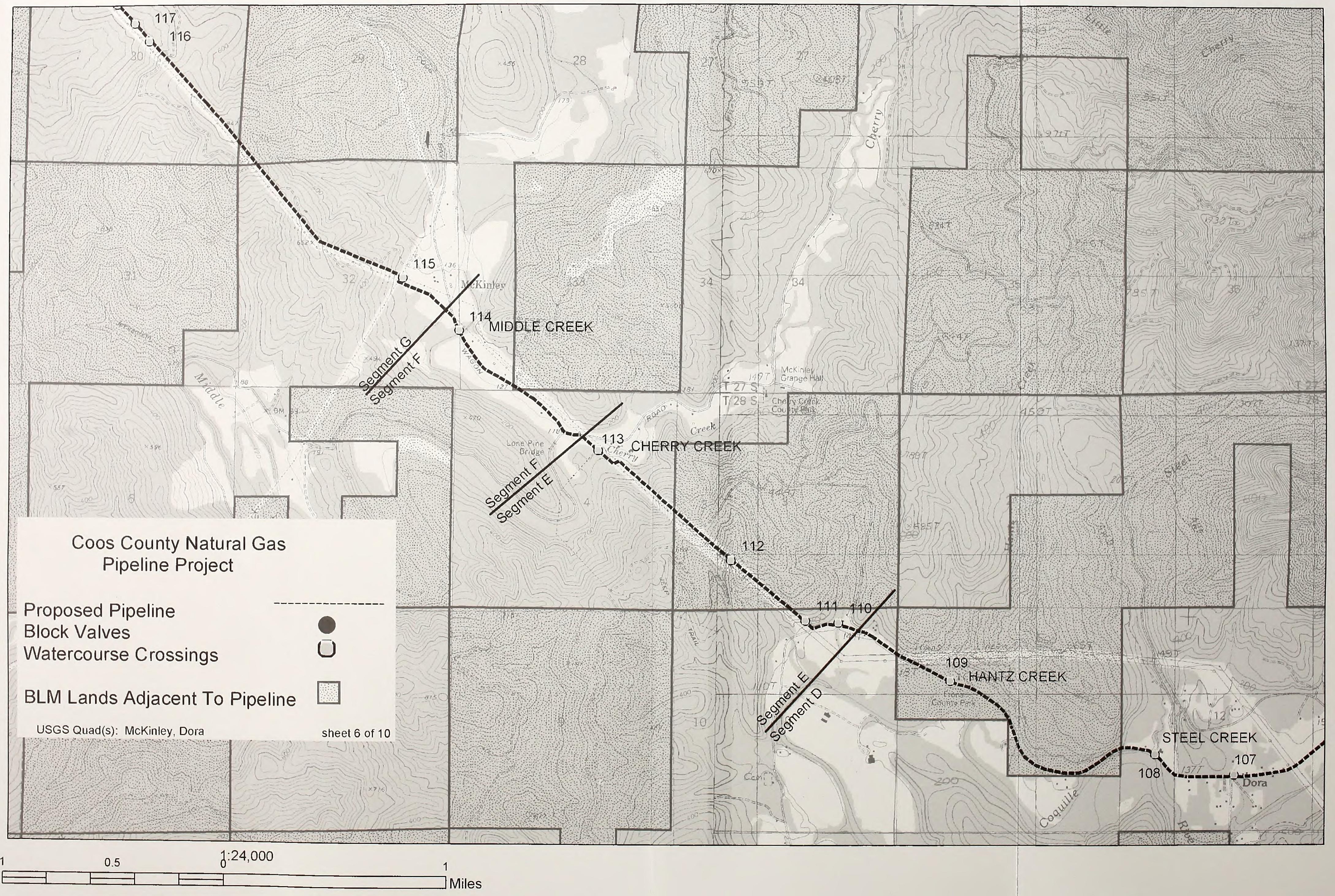





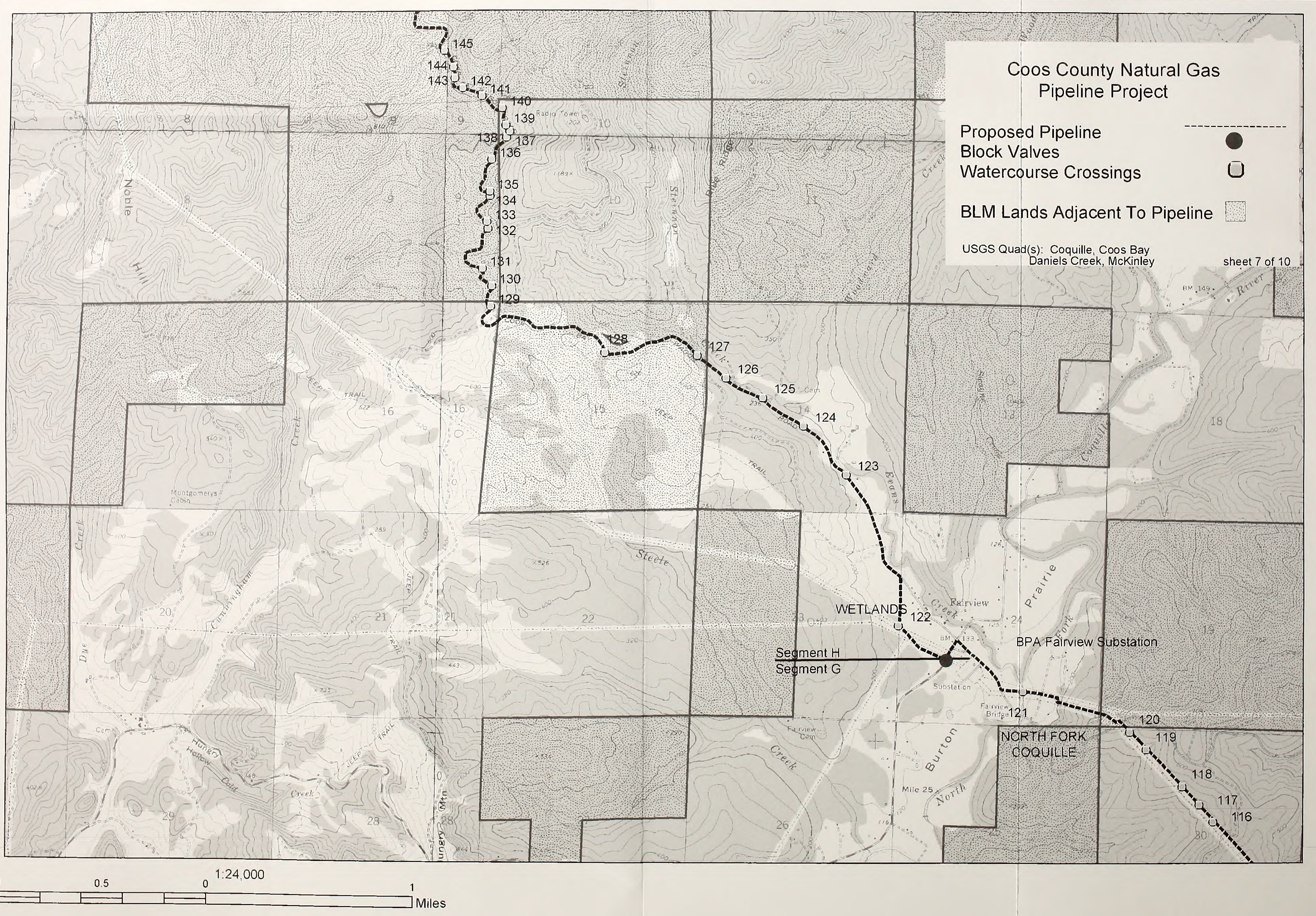





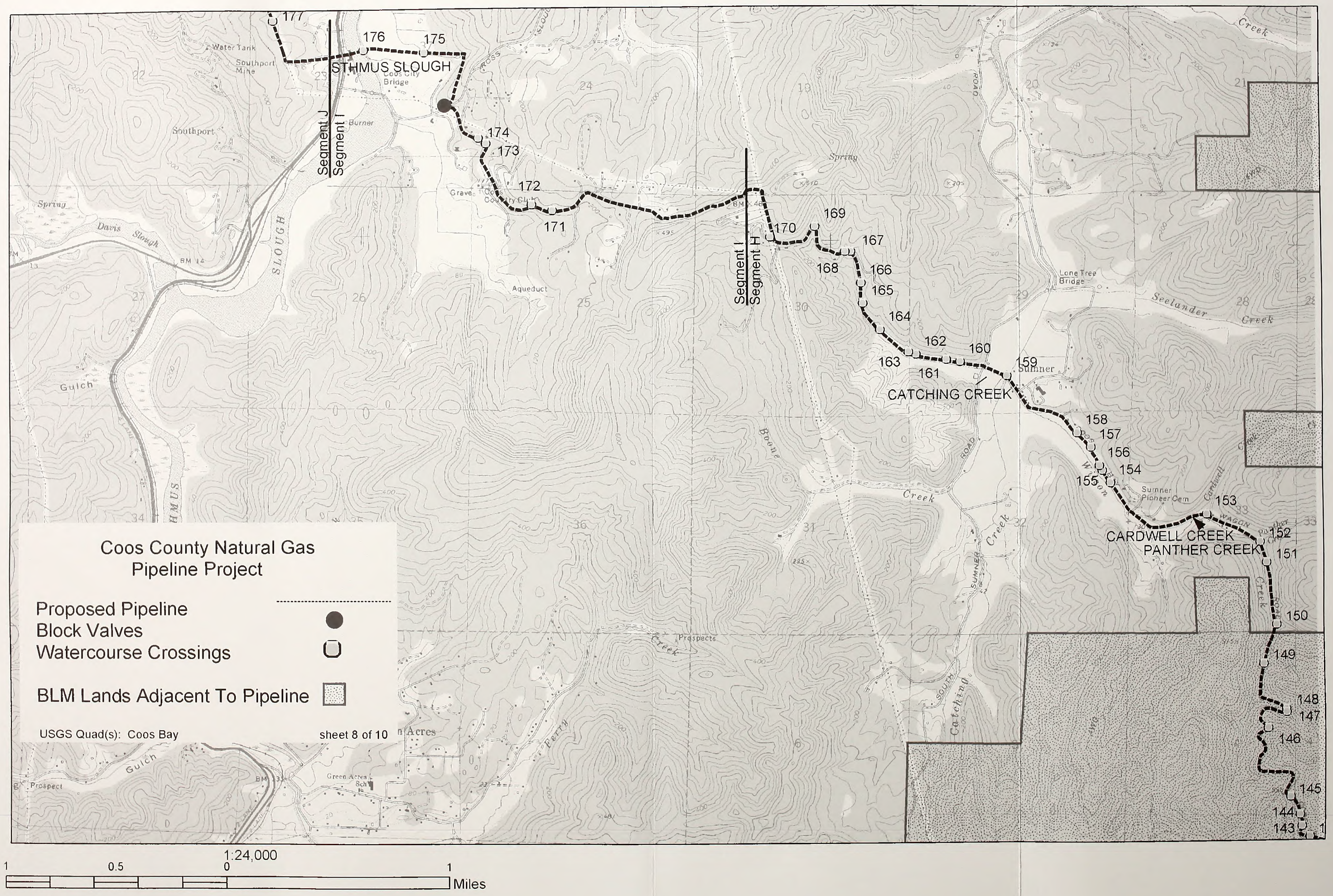





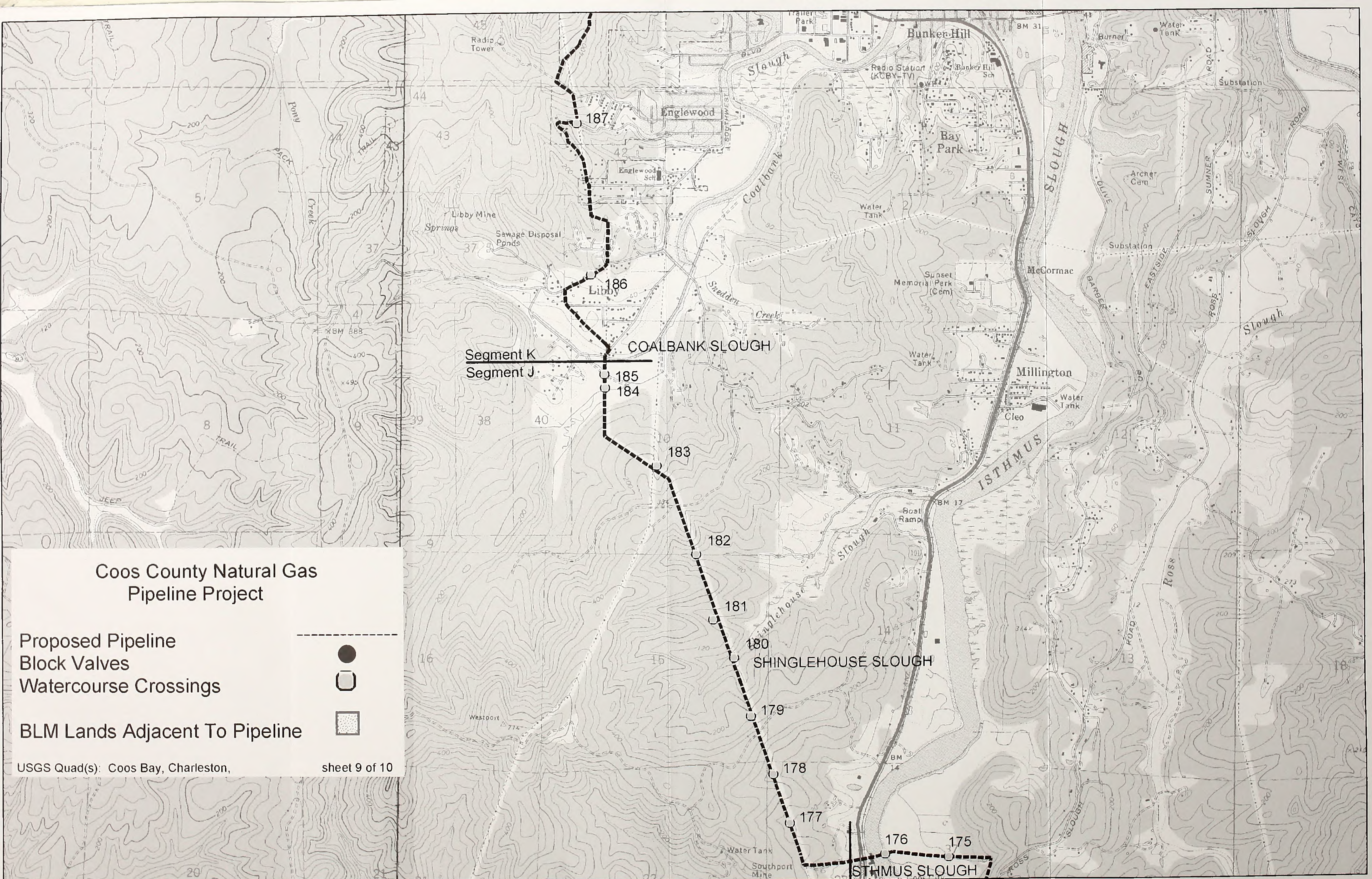

Proposed Pipeline

Block Valves

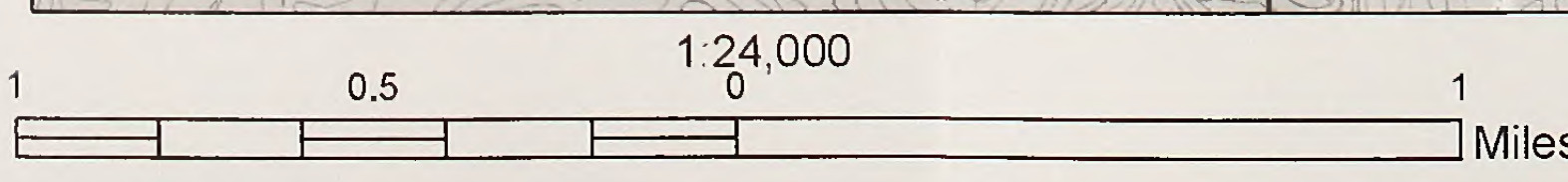




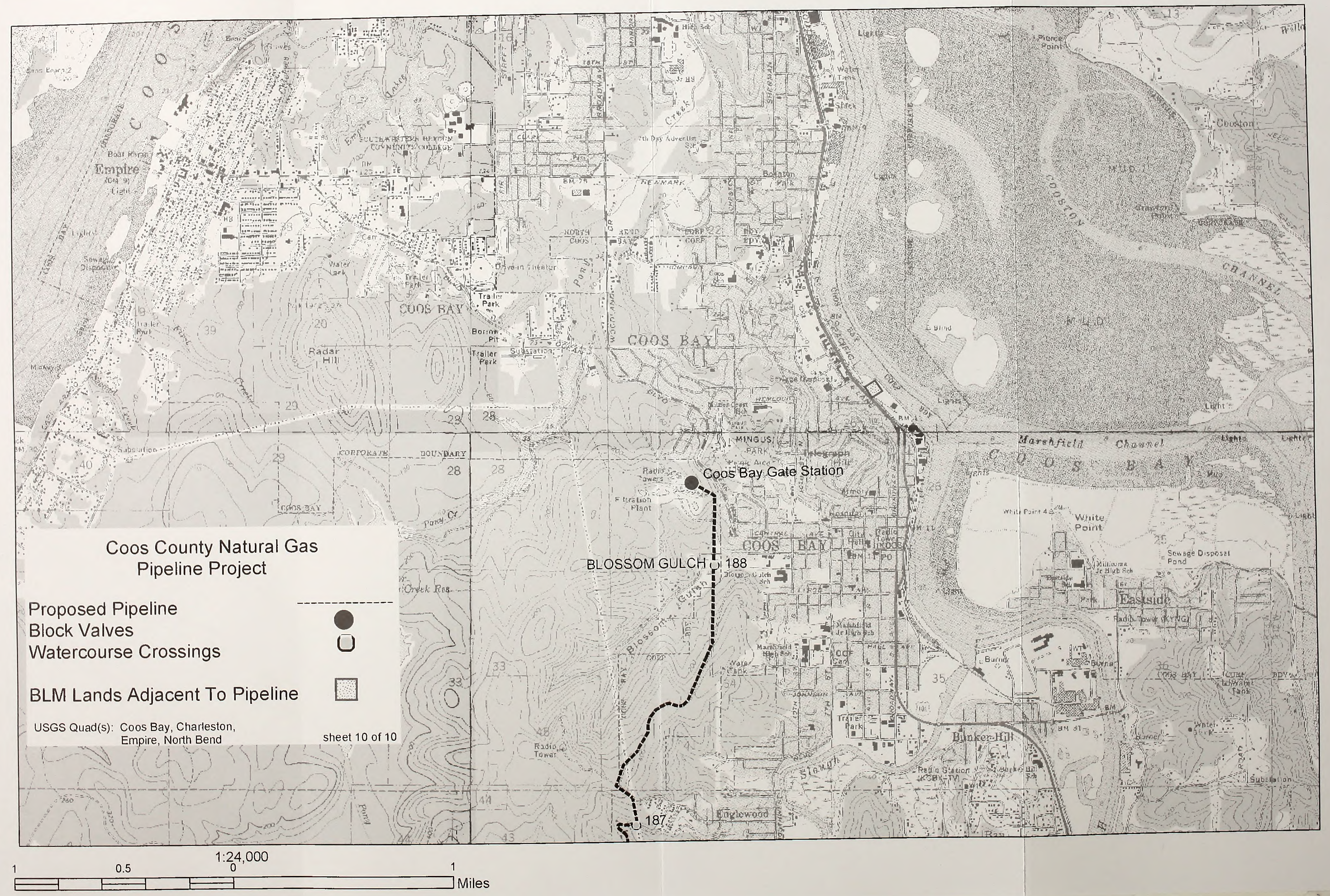




\title{
Appendix D.
}

No significant changes have been made to this appendix.

\section{Agency Management Plans for Resources Adjacent to the Proposed Action}

\author{
Prepared By: \\ Brian T. Cox \\ Biological Information Specialists, Inc. \\ P.O. Box 27 \\ Camas Valley, OR 97416 \\ October 1, 2001
}




\section{Appendix D. Agency Management Plans for Resources Adjacent to the Proposed Action}

The BLM Northwest Forest Plan includes management classifications and criteria for a wide variety of aspects throughout the forest ecosystem. Below is a listing of such classifications and criteria pertinent to the proposed action.

\section{Visual Resource Management}

The visual resource management (VRM) classes and objectives for BLM lands within the proposed action corridor are as follows:

Class I - Objective of this class is to provide for natural ecological changes in VRM I areas. Some very limited management activities may occur in these areas. The level of change to the characteristic landscape should be very low and must not attract attention. Changes should repeat the basic elements of form, line, color, texture, and scale found in the predominant natural features of the characteristic landscape.

Class II - Objective of this class is to manage lands for low levels of change to the characteristic landscape. Management activities may be seen but should not attract the attention of the casual observer. Changes should repeat the basic elements of form, line, color, texture, and scale found in the predominant natural features of the characteristic landscape.

Class III - Objective of this class is to provide for management activities for moderate levels of change to the characteristic landscape. Management activities may attract attention but should not dominate the view of the casual observer. Changes should repeat the basic elements of form, line, color, texture, and scale found in the predominant natural features of the characteristic landscape.

Class IV - Objective of this class is to provide for management activities which may dominate the view and be the major focus of the viewer's attention. Every attempt should be made to minimize the impact of these activities through careful pipeline location, minimum disturbance and repetition of the basic elements of form, line, color, and texture.

Descriptions of other VRM classes and objectives are in the Coos Bay BLM District RMP EIS (1995).

\section{Riparian Reserve and Aquatic Conservation Strategy Management}

Overall objective: Restore and maintain the ecological health of watersheds.

Other objectives:

a. Provide a scientific basis for protecting aquatic ecosystem using Riparian Reserve Scenarios and Watershed Analysis.

b. Enable planning for sustainable resource management (watershed restoration).

c. Conserve at-risk species through Key Watershed Management and through Riparian Reserve Management. 


\section{Watershed Management Plans}

- Conduct Watershed Analysis to meet ACS objectives.

- Identify Key Watersheds needing restoration efforts which provide the requisites of at-risk species.

\section{BLM Land-Use Allocations}

The land-use allocation areas listed below are located adjacent to or near the alternative routes (including the proposed action). For further information about these, refer to the Coos Bay or Roseburg RMPs.

\section{Late-Succession Forest Reserve (LSR)}

The proposed action corridor is adjacent to approximately 4.5 miles of LSR. The Hwy 42 alternative is adjacent to approximately 3 miles of LSR.

\section{Area of Critical Environmental Concern (ACEC)}

Part of the North Spit of Coos Bay is designated as an ACEC. Depending on where NW Natural decides to extend its distribution network in Coos Bay, it may cross under a portion of the North Spit ACEC. However, all ground disturbance in the North Spit would occur in road or utility ROW.

The proposed action and Hwy 42 alternative would not cross any ACEC on other designated special areas.

\section{Research Natural Areas}

No Research Natural Areas exist within or near the proposed action corridor. The Cherry Creek Research Natural Area is located just over 3 miles north of Dora and the CBW Road. This area is set aside for protection of its special status plant and animal habitats, and recreational development is precluded from this area.

\section{Coquille Forest Special Management Areas}

None of the alternative routes (including the proposed action) enter the Coquille Forests.

\section{Native American Religious Concerns}

No known Native American religious sites exist within or adjacent to the proposed action corridor or the other alternative routes. Also see Appendix B. 


\section{Appendix E. Aquatic Biological Assessment}

The following changes between the Draft and Final Environmental Impact Statement were made in Appendix E.

- Appendix E, formerly the Aquatic Ecosystem Assessment, has been replaced with an Aquatic Biological Assessment due to the Federal Ninth Circuit Court of Appeals ruling on December 14, 2001, reinstating protections under the federal Endangered Species Act for central Oregon Coho salmon.

- Appendix A to this Biological Assessment is Appendix J of the Final Coos County Pipeline EIS.

- Appendix B to this Biological Assessment is Appendix H of the Final Coos County Pipeline EIS.

Prepared By:

Brian Cox

and

Melanie Little

Biological Information Specialists, Inc.

P.O. Box 27

Camas Valley, OR 97416

October 1, 2001 


\section{Appendix E. Aquatic Biological Assessment}

\section{INTRODUCTION}

This Biological Assessment (BA) addresses the impacts of the proposed 59.1-mile new 12-inch natural gas steel pipeline, which will connect the Williams Gas Pipeline near Happy Valley, approximately 4 miles southwest of I-5 freeway exit 124. See the Coos County Pipeline Draft Environmental lmpact Statement published January 2002. This document assesses the effects of the proposed action on the threatened Oregon Coast ESU coho salmon (Oncorhynchus kisutch), as well as Oregon coast steelhead (Oncorhynchus mykiss) and the Oregon Coast ESU coastal cutthroat (Oncorhynchus clarki clarki), which have candidate status.

The purpose of this proposed action is to gain a permanent easement to cross approximately 3 miles of federally managed lands. If an easement is not granted, a "No Action", for the purposes of this project, is defined as no federal discretionary action, but would result in the construction of a natural gas pipeline that would not cross federally managed lands. Refer to the Coos County Pipeline Draft Environmental Impact Statement published January 2002 for preferred alternatives.

\section{INTERRELATED AND INTERDEPENDENT EFFECTS}

The proposed action is to grant a perpetual Right-of-Way (ROW) to Coos County to access federal lands to facilitate the construction of a natural gas pipeline from Roseburg to Coos Bay Oregon. This BA documents the effects of the proposed activities to threatened and candidate fish species by the Coos Bay District and Roseburg District of the Bureau of Land Management (BLM). This document covers these actions for the duration of the project, unless new information, change in project design or anticipated effects warrants re-initiation of consultation.

Approximately 56 miles of private lands, including 184 stream crossings, would be affected by the proposed action (Table 2). All stream crossings affected by the proposed action occurring on the Coos Bay Wagon Road (CBW Road) are not evaluated as federally managed, as they occur on Coos County maintained properties. Project Design Criteria (PDC) would be implemented on both federal and private lands; therefore, effects to both federally managed lands and private lands are evaluated equally in this document.

\section{DESCRIPTION OF THE PROPOSED ACTION}

Natural gas is available near Roseburg from Williams Gas Pipeline - West, formerly Northwest Pipeline Company. The Williams pipeline system transports gas from producing wells in the Rocky Mountain regions of the U.S. and Canada. The natural gas produced from the wells is stripped of corrosive elements, excess water and heavier hydrocarbons before entering the pipeline system. The natural gas is delivered via pipeline from these wells to Portland and the Willamette Valley. The Williams Grants Pass lateral extends south of Eugene, generally along Interstate-5, to Grants Pass.

In the Roseburg area, Williams maintains a single 10-inch steel pipeline operating at 500 to 800 pounds per squareinch (psi). The proposed action would be construction of a 12 -inch steel pipeline connecting to the existing 10 -inch pipeline a few miles south of Roseburg.

The pipeline would be buried for its entire length. Its only aboveground components would be line markers, test stations, several bridge crossings and valve settings. It would be built and hydrostatically tested to 1,500 psi, which allows a Maximum Allowable Operating Pressure (MAOP) of 1,000 psi. It would operate at the same pressure as the Williams pipeline, which is normally 500 to 800 psi.

Approximately 3 miles, including 4 unnamed intermittent streams, of the proposed action would occur on Bureau of Land Management (BLM)-managed lands within the Bonneville Power Administration (BPA) power line ROW.

The remainder of the pipeline would be located within the ROWs of the CBW Road and other public roads, or within Pacificorp, hereafter referred to as Pacific Power and Light (PP\&L) and BPA ROWs crossing privately owned land. 
The pipeline would terminate at Ocean Boulevard in Coos Bay where a North West Natural Gas (hereafter referred to as NW Natural) distribution system would be built. NW Natural has been granted "exclusive territory" rights for gas distribution in Coos County, excluding the City of Bandon.

The straight-line distance from the Williams connection location (just south of Roseburg) to Ocean Boulevard is approximately 44 miles, whereas the proposed action traverses approximately 60 miles. The proposed action within existing road and utility corridors is the shortest practical route from source to destination.

The permanent easement on BLM-managed lands would total approximately 14 acres. Additional temporary utility corridor construction ROW width (as necessary) is also requested. The additional utility corridor construction area (approximately 7 acres) would also be entirely within the BPA utility corridor and returned to BLM control after completion of construction and site restoration.

Several delivery stations would deliver gas to end users at various locations in Coos and Douglas Counties. No delivery stations would be located on BLM-managed lands. For safety reasons, the proposed action includes 5 block valves (Figure J-4 in Appendix A) placed at intervals along the pipeline corridor. Placement of the valves is based upon pipeline safety regulations and operational factors such as local distribution and lateral pipeline placement. No block valves would be installed on BLM-managed lands.

Because no industrial commitments have yet occurred, it is not possible to quantify potential environmental impacts of unknown facilities and their potential locations.

\section{SUMMARY OF THE PROPOSED ACTION}

Potential impacts and route description of the proposed action are given in Table E-1.

Table E-1. Proposed Action Route Summary

\begin{tabular}{|l|l|l|}
\hline \multicolumn{1}{|c|}{ Description } & \multicolumn{1}{|c|}{ Private Ownership } & \multicolumn{1}{|c|}{ Federally Managed } \\
\hline Total length (miles) & 56 & 3 \\
\hline Total number of streams crossed & 184 & 4 \\
\hline Large streams (30+ feet summer wetted width) & 2 & 0 \\
\hline Medium streams (15 - 30 feet summer wetted width) & 6 & 0 \\
\hline Small streams (less than 15 feet summer wetted width) & 176 & 4 \\
\hline Total number of wetlands & 1 & 0 \\
\hline Adjacent floodplains (miles) & 2.2 & 0 \\
\hline
\end{tabular}

\section{Location of Proposed Action}

The corridor for the proposed action would traverse the Coast Range in Southern Oregon from the western region of Douglas County Township 27 South, Range 6 West, Section 33 (T27S, R6W, Sec. 33) to the western region of Coos County (T25S, R 13W, Sec. 27). The terrain varies from gentle to very steep as the corridor follows 230 kilovolt $(\mathrm{kV})$ transmission lines operated by BPA and PP\&L, the CBW Road, and BPA and PP\&L $115 \mathrm{kV}$ transmission lines and roads into Coos Bay.

The proposed action would connect to the Williams Gas Pipeline near Happy Valley, approximately 4 miles southwest of I-5 freeway exit 124 (Harvard Avenue) in Roseburg. The pipeline route would continue - as described below - to its delivery facility at Ocean Boulevard. Refer to sheets 1 through 10 in Appendix $C$ of the FEIS.

The following is a sequential list (east to west) of section locations that contain a portion of the proposed action: 


\section{Douglas County:}

T27S, R6W, Sections 33, 32, and 31

T27S, R7W, Sections 36, 35, 34, 33, 32, and 31

T28S, R7W, Section 6

T28S, R7 1/2W, Section 6

T28S, R8W, Sections 15, 17, and 7.

T28S, R8W, Sections 1, 2, 11, 14, 15, 16, 17, 18 and 7.

\section{Sections in Douglas County affecting BLM managed lands:}

T28S, R8W, Sections15, 17, and 7.

\section{Coos County:}

T28S, R9W, Sections $12,13,14,11,10,9,8$ and 7

T28S, R10W, Sections 12, 11, 10, 9, 8, 5 and 6

T28S, R11W, Sections 12, 11, 10, 3, and 4

T27S, R11W, Sections 33, 32, 29, 30 and 19

T27S, R12W, Sections 24, 23, 14, 15, 16, 9, 10 and 4

T26S, R12W, Sections 30, 32, 33, 29 and 19

T26S, R13W, Sections 24, 25, 23, 14, 15, 10 and 3

T25S, R13W, Sections 27 and 34

\section{Sections in Coos County affecting BLM managed lands:}

T28S, R9W, Sections 12

T28S, R11W, Sections 3

T27S, R11W, Sections 2919

\section{Construction Methods and Operations}

Refer to Appendix B: Design, Construction, Operation \& Maintenance Plan (A revised version of Appendix $\mathbf{J}$ from Coos County Pipeline Draft EIS Published January 2002).

\section{Project Design Criteria}

None of the proposed action will negatively affect habitat in the short-term or long-term for anadromous fish (Appendix A).

- All aquatic construction operations involving trenching through streams or directional drilling will be conducted during the in stream work period (July 1 through September 15).

- Apply an additional lift of rock to the area of road that can influence the stream if rill erosion is evident in the road tread near live stream crossings.

- Deteriorating stream and cross-drain culverts will be replaced during construction.

- Contain any offsite movement of sediment from the road or ditchflow near streams with silt fence or sediment entrapping bales/blankets. The control measures will allow for the free passage of water without detention or plugging. These control structures and applications will receive frequent maintenance, and will be removed 30 days after completion of that pipeline construction segment.

- The gravel portions of the CBW Road (approximately 15 miles) will be paved after pipeline construction. If paving does not occur prior to the first wet season, storm-proofing measures will be implemented (Appendix A). 
- All streams with active water flow will be directionally drilled or trenched above on CBW Road roadway fill or using the bag and flume method.

- All construction operations with potential delivery mechanisms to stream or riparian areas will utilize sediment barriers.

- Coos County has appointed an Environmental Compliance Representative to monitor the above measures on site (Appendix A).

- Management of potential contaminants, such as fuel, is described in Appendix B.

\section{EVALUATION OF CONSISTANCY WITH WATERSHED ANALYSIS (WA) PIPE- LINE CONSTRUCTION TREATMENTS}

After pipcline construction is finished, there are no plans for management actions other than normal pipeline monitoring and maintenance.

\section{Road Treatments}

Roads can affect the quality of the ecosystem at both localized and landscape levels. Roads allow increased human disturbance, which may disrupt local ecosystem function on a temporal basis. Roads reduce the area for vegetation growth at an approximate rate of five acres per road-mile. Hydrologic function, landslide rates, sedimentation and pollution from dumping or spills are all potential local and landscape effects of roads. Roads may increase/decrease the utility of interior habitats for certain wildlife species. Roads may create movement barriers for certain species. Extensive riparian road networks may encroach on streams, extend channels, re-route sediment and disconnect streams from floodplains. All of the Watershed Analyses recommended that no new road construction occur within interior habitats or on erosive/unstable soils.

No new road treatments are planned for the proposed action. Only cxisting road networks will be used in the proposed action. Graveled portions of the CBW Road will be paved after pipeline construction to reduce sediment production. Deteriorating stream and cross-drain culverts will be replaced. Extra cross-drain culverts will be added to reduce ditchline sediment production. These treatments are consistent with the WA recommendations.

\section{Riparian Reserve Reduction}

The proposed action contains no Riparian Reserve reductions or treatments. There are no proposed federal foreststand treatments in this project. These treatments are consistent with the WA recommendations.

\section{Transient Snow Zone}

The pipeline corridor does not occur within a transient snow zone, and no impacts to overstory forest vegetation occur from the proposed action or its interrelated actions. These treatments are consistent with the WA recommendations. 


\section{EVALUATION Of CONSISTENCY WITH NATIONAL MARINE FISHERY SER- VICE'S (NMFS) MARCH 18, 1997 LAND RESOURCE MANAGEMENT PLAN- LEVEL BIOLOGICAL OPINION (LRMP BO):}

\section{Conservation Recommendations}

Four of the WAs included assessments of the aquatic ecosystem, which addressed salmonid conservation as a main issue. This meets LRMP BO Conservation Recommendation 3. The East Fork Coquille and North Fork Coquille Watershed Analyses included recommendations for restoration projects, including projects that promote long-term recovery. This is consistent with LRMP BO Conservation Recommendations 5 and 6 . As part of the watershed analysis, Transportation Management Plans were completed. This meets Conservation Recommendation 11 . No other Conservation Recommendations specifically apply to this proposed action. Effects analyzed for the proposed action, including interrelated and interdependent effects, were determined using the same criteria for private lands as were for federal lands.

\section{Reasonable and Prudent Measures}

During the WA process, the interdisciplinary team used applicable criteria in the Northwest Forest Plan ROD to ensure that proposed actions are fully consistent with applicable standards and guidelines and ACS objectives. This is consistent with Reasonable and Prudent Measure 1. The NMFS is currently reviewing the proposed actions. This is consistent with Reasonable and Prudent Measure 2. Based on the ACS Evaluation, proposed actions would not detract from long-term ecosystem recovery. This is consistent with Reasonable and Prudent Measure 4. All related roadwork on both federal and private lands would be completed during the dry season utilizing Best Management Practices (BMPs) and PDCs to minimize construction impacts (See Appendix A). This is consistent with Reasonable and Prudent Measures 5 and 6. No other Conservation Recommendations specifically apply to this proposed action.

\section{Terms and Conditions}

No other terms and conditions specifically apply to this proposed action.

\section{LRMP BO Consistency}

LRMP BO consistency is determined at the 5th field HUC watershed level. 
Table E-2: Matrix of Factors and Indicators (all WAs \& NMFS, 1998)

\begin{tabular}{|c|c|c|c|c|}
\hline PATHWAYS & INDICATORS & $\begin{array}{c}\text { PROPERLY } \\
\text { FUNCTIONING (PF) }\end{array}$ & $\begin{array}{c}\text { AT RISK (All situations } \\
\text { not described as PF or } \\
\text { NPF) }\end{array}$ & $\begin{array}{c}\text { NOT PROPERLY } \\
\text { FUNCTIONING (NPF) }\end{array}$ \\
\hline \multirow{3}{*}{ Water Quality: } & Maximum Temperature & $<60^{\circ} \mathrm{F}$ & $60-68 \mathrm{~F}$ & $>68^{\circ} \mathrm{F}$ \\
\hline & Turbidity & $\begin{array}{l}\text { Similar frequency and } \\
\text { duration relative to } \\
\text { unimpacted streams in } \\
\text { basin. }\end{array}$ & $\begin{array}{l}\text { Moderately higher fre- } \\
\text { quency and duration rela- } \\
\text { tive to unimpacted streams } \\
\text { in basin. }\end{array}$ & $\begin{array}{l}\text { Higher frequency and dura- } \\
\text { tion relative to unimpacted } \\
\text { streams in basin. }\end{array}$ \\
\hline & $\begin{array}{l}\text { Chemical Concentration/ } \\
\text { Nutrients }\end{array}$ & $\begin{array}{l}\text { No biological evidence } \\
\text { of contamination. }\end{array}$ & & $\begin{array}{l}\text { Obvious biological cvidence } \\
\text { of contamination (e.g., fish } \\
\text { kills, algal blooms, deformi- } \\
\text { ties) }\end{array}$ \\
\hline Habitat Access: & Physical Barriers & $\begin{array}{l}\text { No man-made barriers } \\
\text { in watershed that pre- } \\
\text { vent upstream and } \\
\text { downstream passage of } \\
\text { any age of salmonids. }\end{array}$ & & $\begin{array}{l}\text { Any man-made barriers in } \\
\text { watershed prevent upstream } \\
\text { or downstream passage of } \\
\text { any age of salmonids }\end{array}$ \\
\hline \multirow[t]{7}{*}{ Habitat Elements: } & Substrate/Sediment & $\begin{array}{l}50 \% \text { of riffle habitat is } \\
\text { gravel dominated, with } \\
\text { very little embeddeness. } \\
>5 \% \text { of riffles are domi- } \\
\text { nated by fines - or- In } \\
\text { low gradient riffle, } \\
<10 \% \text { of substrate is } \\
\text { sand or silt }\end{array}$ & $\begin{array}{l}\text { Gravel and cobble is sub- } \\
\text { dominant, or if dominant, } \\
\text { embeddedness } 20-30 \%\end{array}$ & $\begin{array}{l}<20 \% \text { of riffle habitat is } \\
\text { gravel dominated or gravel/ } \\
\text { cobble with large degree of } \\
\text { embeddedness. }>10 \% \text { of rif- } \\
\text { fles are dominated by fines - } \\
\text { or - Low gradient riffle has } \\
>25 \% \text { sand or silt }\end{array}$ \\
\hline & $\begin{array}{l}\text { Large Woody Debris } \\
\text { (LWD) }\end{array}$ & $\begin{array}{l}>80 \text { Pieces } / \text { mile, }>24 " \\
\text { diameter, }>50 \text { ' length. } \\
\text { Little or no evidence of } \\
\text { stream clean-out or } \\
\text { management related } \\
\text { debris flows. }\end{array}$ & $\begin{array}{l}30-80 \text { pieces/mile, }>24 \text { " in } \\
\text { diameter, }>50 \text { 'length. } \\
\text { Some evidence of stream } \\
\text { clean-out and/or manage- } \\
\text { ment related debris flow }\end{array}$ & $\begin{array}{l}<30 \text { pieces/mile, } 24 " \text { in } \\
\text { diameter. }>50^{\prime} \text { length. Evi- } \\
\text { dence of stream clean-out } \\
\text { and/or management related } \\
\text { debris flows is widespread. }\end{array}$ \\
\hline & Pool Area & $\begin{array}{l}\text { Basaltic Headlands } \\
>35 \%\end{array}$ & $\begin{array}{l}\text { Basaltic Headlands } 20- \\
35 \%\end{array}$ & Basaltic Headlands $<20 \%$ \\
\hline & & Rest of Province: $>50 \%$ & Rest of Province: $30-50 \%$ & Rest of Province: $<30 \%$ \\
\hline & Pool Quality & $\begin{array}{l}>20 \% \text { pool habitat by } \\
\text { area is }>1 \text { meter deep. }\end{array}$ & $\begin{array}{l}10-20 \% \text { pool habital by } \\
\text { area is }>1 \text { meter deep. }\end{array}$ & $\begin{array}{l}<10 \% \text { pool habitat by area is } \\
>1 \text { meter deep. }\end{array}$ \\
\hline & Pool Frequency & $\begin{array}{l}<8 \text { channel widths } \\
\text { between pools. }\end{array}$ & $\begin{array}{l}8-19 \text { channel widths } \\
\text { between pools. }\end{array}$ & $\begin{array}{l}>20 \text { channel widths between } \\
\text { pools. }\end{array}$ \\
\hline & Off-Channel Habitat & $\begin{array}{l}\text { Frequent backwaters w/ } \\
\text { cover, \& low-energy } \\
\text { channel areas (ponds, } \\
\text { oxbows) are }<10 \% \text { of } \\
\text { total area. }\end{array}$ & $\begin{array}{l}\text { Less frequent backwaters } \\
\text { w/cover, \& low-energy } \\
\text { channel areas (ponds, } \\
\text { oxbows) are } 5-10 \% \text { of } \\
\text { total area. }\end{array}$ & $\begin{array}{l}\text { Infrequent backwaters w/ } \\
\text { cover \& low-energy channel } \\
\text { areas (ponds, oxbows) are } \\
>10 \% \text { of total area. }\end{array}$ \\
\hline
\end{tabular}


Table E-2: Matrix of Factors and Indicators (all WAs \& NMFS, 1998)

\begin{tabular}{|c|c|c|c|c|}
\hline PATHWAYS & INDICATORS & $\begin{array}{c}\text { PROPERILY } \\
\text { FUNCTIONING (PF) }\end{array}$ & $\begin{array}{l}\text { AT RISK (All situations } \\
\text { not described as PF or } \\
\text { NPF) }\end{array}$ & $\begin{array}{c}\text { NOT PROPERLY } \\
\text { FUNCTIONING (NPF) }\end{array}$ \\
\hline \multirow[t]{3}{*}{$\begin{array}{l}\text { Channel } \\
\text { Condition and } \\
\text { Dynamics: }\end{array}$} & $\begin{array}{l}\text { Width/Depth Ratio and } \\
\text { channel type }\end{array}$ & 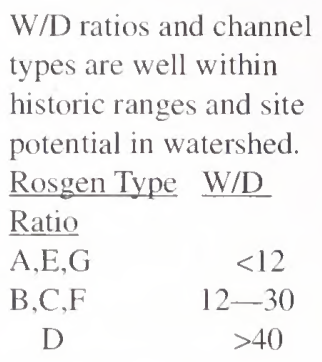 & $\begin{array}{l}\text { W/D ratios an/or channel } \\
\text { types in portions of water- } \\
\text { shed are outside historic } \\
\text { ranges and/or site poten- } \\
\text { tials }\end{array}$ & $\begin{array}{l}\text { W.D ratios and channel } \\
\text { types throughout the water- } \\
\text { shed are well outside of his- } \\
\text { toric ranges and/or site } \\
\text { potential }\end{array}$ \\
\hline & Stream bank Condition & $\begin{array}{l}\text { Relatively stable banks, } \\
\text { few or no areas of addi- } \\
\text { tive erosion }\end{array}$ & $\begin{array}{l}\text { Moderately stable banks, } \\
\text { few areas of additive ero- } \\
\text { sion }\end{array}$ & $\begin{array}{l}\text { Highly unstable banks. } \\
\text { Many areas of exposed soil } \\
\text { and streambank cutting }\end{array}$ \\
\hline & $\begin{array}{l}\text { Floodplain } \\
\text { Connectivity }\end{array}$ & $\begin{array}{l}\text { Logjams and other fea- } \\
\text { tures create pools \& } \\
\text { secondary channels, } \\
\text { which trap debris and } \\
\text { food and maintain a } \\
\text { high water table that } \\
\text { provides cooled late- } \\
\text { season flows. Flooplain } \\
\text { is well-vegetated }\end{array}$ & $\begin{array}{l}\text { Logjams and other fea- } \\
\text { tures create some pools \& } \\
\text { secondary channels, } \\
\text { which trap debris and food } \\
\text { and maintain enough } \\
\text { water table to provide } \\
\text { some cooled late-season } \\
\text { flows. Flooplain is mostly } \\
\text { well-vegetated. }\end{array}$ & $\begin{array}{l}\text { Secondary channels lack- } \\
\text { ing. Unconstrained main } \\
\text { channel often downcut to } \\
\text { bedrock and relatively short, } \\
\text { lacking pools, meanders and } \\
\text { collections of food and } \\
\text { debris. Warm, low, late-sea- } \\
\text { son flows. }\end{array}$ \\
\hline \multirow[t]{2}{*}{ Flow/Hydrology } & Change Peak/Base Flows & $\begin{array}{l}\text { Timber harvest and } \\
\text { roading history is such } \\
\text { that little or no change } \\
\text { to the natural flow } \\
\text { regime has occurred. }\end{array}$ & $\begin{array}{l}\text { Moderate amounts of tim- } \\
\text { ber harvest and roading } \\
\text { have likely altered the } \\
\text { flow regime to some } \\
\text { extent. }\end{array}$ & $\begin{array}{l}\text { Relatively high levels of tim- } \\
\text { ber harvest and roading have } \\
\text { likely had a large effect on } \\
\text { the flow regime }\end{array}$ \\
\hline & Drainage Network & $\begin{array}{l}\text { Zero or minimum } \\
\text { increase in drainage } \\
\text { network density due to } \\
\text { roads. }\end{array}$ & $\begin{array}{l}\text { Moderate increases in } \\
\text { drainage network due to } \\
\text { roads }\end{array}$ & $\begin{array}{l}\text { Significant increases in } \\
\text { drainage network density } \\
\text { due to roads }\end{array}$ \\
\hline \multirow[t]{2}{*}{$\begin{array}{l}\text { Watershed Condi- } \\
\text { tion: }\end{array}$} & $\begin{array}{l}\text { Road Density and Loca- } \\
\text { tion/Drainage Network }\end{array}$ & $\begin{array}{l}\text { Road density }<2 \text { miles } \\
\text { per square mile; with no } \\
\text { valley bottom roads. If } \\
\text { unstable areas exist, no } \\
\text { midslope roads. }\end{array}$ & $\begin{array}{l}\text { Road density } 2-3 \text { miles per } \\
\text { square mile with few val- } \\
\text { ley bottom roads }\end{array}$ & $\begin{array}{l}\text { Road density }>3 \text { miles per } \\
\text { mile, with valley bottom } \\
\text { roads }\end{array}$ \\
\hline & Disturbance History & $\begin{array}{l}<5 \% \text { ECA/decade } \\
\text { (entire watershed) with } \\
\text { no concentration of dis- } \\
\text { turbance in unstable or } \\
\text { potentially unstable } \\
\text { areas, and/or Riparian } \\
\text { Reserves; and for } \\
\text { NWFP area (except } \\
\text { AMAs) }>15 \% \text { reten- } \\
\text { tion of LSOG in water- } \\
\text { shed }\end{array}$ & $\begin{array}{l}<5 \% \text { ECA/decade (entire } \\
\text { watershed but disturbance } \\
\text { concentration in unstable } \\
\text { or potentially unstable } \\
\text { areas, and/or Riparian } \\
\text { Reserves; and for NWFP } \\
\text { area (except AMAs) } \\
>15 \% \text { retention of LSOG } \\
\text { in watershed }\end{array}$ & $\begin{array}{l}<5 \% \text { ECA/decade (entire } \\
\text { watershed) and disturbance } \\
\text { concentration in unstable or } \\
\text { potentially unstable areas, } \\
\text { and/or Riparian Reserves; } \\
\text { does not meet NWFP stan- } \\
\text { dard for LSOG in watershed }\end{array}$ \\
\hline
\end{tabular}


Table E-2: Matrix of Factors and Indicators (all WAs \& NMFS, 1998)

\begin{tabular}{|c|c|c|c|c|}
\hline PATHWAYS & INDICATORS & $\begin{array}{c}\text { PROPERLY } \\
\text { FUNCTIONING (PE) }\end{array}$ & $\begin{array}{l}\text { AT RISK (All situations } \\
\text { not described as PF or } \\
\text { NPF) }\end{array}$ & $\begin{array}{c}\text { NOT PROPERLY } \\
\text { FUNCTIONING (NPF) }\end{array}$ \\
\hline & Riparian Reserves & $\begin{array}{l}\text { Terrestrial vegetation } \\
\text { conditions show that the } \\
\text { watershed is relatively } \\
\text { intact. }\end{array}$ & & $\begin{array}{l}\text { Watershed is fragmented and } \\
\text { highly impacted. }\end{array}$ \\
\hline & Landslide Rates & $\begin{array}{l}\text { Within } 10-20 \% \text { of his- } \\
\text { toric, natural rates. } \\
\text { Stream conditions not } \\
\text { evidently altered due to } \\
\text { management caused } \\
\text { landslides }\end{array}$ & $\begin{array}{l}\text { Some subdrainages with } \\
>20 \% \text { of landslides related } \\
\text { land management activi- } \\
\text { ties. Some stream condi- } \\
\text { tions evidently altered by } \\
\text { management related land- } \\
\text { slides }\end{array}$ & $\begin{array}{l}\text { Many subdrainages with } \\
>25 \% \text { of landslides related to } \\
\text { land management activities. } \\
\text { Stream conditions obviously } \\
\text { and/or dramatically altered } \\
\text { by management related land- } \\
\text { slides }\end{array}$ \\
\hline & Refugia & $\begin{array}{l}\text { Habitat refugia exist } \\
\text { and are adequately buff- } \\
\text { ered. Existing refugia } \\
\text { are sufficient in size, } \\
\text { number, and connectiv- } \\
\text { ity to maintain viable } \\
\text { populations or subpopu- } \\
\text { lation }\end{array}$ & $\begin{array}{l}\text { Habitat refugia exist, but } \\
\text { some are not adequately } \\
\text { buffered. Existing refugia } \\
\text { may be insufficient in } \\
\text { size, number, and connec- } \\
\text { tivity to maintain viable } \\
\text { sub-populations. }\end{array}$ & $\begin{array}{l}\text { Adequate habitat refugia do } \\
\text { not exist to maintain viable } \\
\text { fish populations. }\end{array}$ \\
\hline
\end{tabular}




\section{RATIONALE USED IN COMPLETING THE CHECKLIST FOR DOCUMENTING ENVIRONMENTAL BASELINE AND THE EFFECTS OF PROPOSED ACTION(S) ON RELEVANT INDICATORS WITH RESPECT TO THE EAST FORK COQUILLE WATERSHED}

Note: Unless cited otherwise, the information source used for accessing the environmental baseline is contained in the East Fork Coquille Watershed Analysis (4/14/99). The size of the East Fork Coquille watershed is $130 \mathrm{mi}^{2}$.

\section{Water Quality}

Temperature - The E. Fork Coquille River is included in the Oregon DEQ's 303(d) list of temperature-limited water bodies from its mouth to the confluence of Lost Creek. Water temperature monitoring data for the E. Fork Coquille (1994-1996) indicated 7-day average daily maximums of $73.6^{\circ} \mathrm{F}$ at the mouth to $64.4^{\circ} \mathrm{F}$ at $\mathrm{RM} 23.2$; the standard $\left(64^{\circ} \mathrm{F}\right)$ was exceeded for up to 94 days per year. The watershed was therefore determined to be "Not Properly Functioning" with respect to water temperature during the migrating and rearing period.

These proposed actions contain no riparian overstory tree removal and were determined to "Maintain" the temperature baseline.

Turbidity - Stream habitat inventory data from 1992-1997 documented greater than 17 percent fines in riffles (spawning habitat) in 21 of 56 reaches surveyed in the E. Fork Coquille Sub-basin. BLM data collected during the winter of 1995/96 indicated that, following storm events, turbidity levels at several sampling stations in the Lower E. Fork Coquille River and adjacent tributaries consistently exceeded 50 Nephelometric Turbidity Units (NTU). The highest recorded turbidity was 164 NTU.

Turbidity in the 25-50 NTU range has been implicated in the reduction of growth in young coho salmon and steelhead (Sigler et al. 1984). Berg and Northcote (1985) reported that feeding and territorial behavior of juvenile coho salmon were disrupted by short-term exposures (2.5-4.5 days) to turbid water up to 60 NTUs. Furthermore, sudden, dramatic increases in turbidity may result in elimination of benthic macro invertebrates, the primary food source of stream salmonids (Waters 1972). Turbidity data collected on the E. Fork Coquille indicates that the stream regularly produces levels of turbidity that are known to adversely affect fish behavior and growth, suggesting that the watershed is "Not Properly Functioning" with respect to turbidity.

In this watershed, the proposed action crosses 57 intermittent and small perennial streams when dry or during the low flows of summer. Of these 57 streams, 55 would be crossed in road fill, bridges or directionally-drilled. Small amounts of increased transitory turbidity may occur during pipeline construction prior to seeding and mulching of ground-disturbed areas of the other 2 streams. However, project BMPs and PDCs will minimize sedimentation potential to very low levels for a brief time (Appendix A). Sediment barriers and site revegetation are required throughout the construction project corridor to eliminate continuous turbidity impacts where delivery mechanisms to streams exist. Larger streams will be directionally-drilled or attached to bridges, avoiding all construction-induced turbidity at those crossings. PDCs include new stream culverts, new cross-drains in the CBW Road, and paving 10.3 miles of gravel road.

The proposed actions were determined to have insignificant effects at the site and at the $5^{\text {th }}$ field, therefore determined to "Maintain" the turbidity baseline. The effects would be insignificant because of the implementation of PDCs and the ECP (Appendix A), specifically the bag and flume technique.

Chemical Contaminants - The watershed analysis indicates that some $\mathrm{pH}$-measurements collected exceeded the DEQ pH-standard of 6.5-8.5. No assessments, measurements or duration criteria of "management-related inputs" data were collected or analyzed. However, it does suggest meeting the criteria for "Not Properly Functioning."

The proposed actions do not utilize chemicals in the construction process other than products for running the machinery. This project was determined to "Maintain" the chemical contaminant baseline.

\section{Habitat Access}

Physical Barriers - BLM data and culvert inventories by the Coquille Watershed Association document severat instances of culverts that present barriers to fish passage at a range of flows, resulting in a "Not Properly Functioning" designation in this category. 
Three new fish friendly stream culverts (Knapper Creek and two unnamed perennial streams) will replace the deteriorating culverts where fish passage is blocked in the CBW Road. The effects would be insignificant at the site and at the $5^{\text {th }}$ field, therefore determined to "Maintain" the physical barrier baseline.

\section{Habitat Elements}

Substrate/Sediment - Data from 1992-1997 stream habitat inventories of tributaries to the E. Fork Coquille River indicate that gravels/cobbles are the dominant substrates in approximately 60 percent of the streams surveyed. Embeddedness was not directly measured during these surveys. However, silt, sand and organics in riffles substantially exceeded the ODFW benchmark standard of 10 percent in over half of the surveyed reaches. (Refer to tables in Appendix $\mathrm{H}$ in the E. Fork Coquille WA.) As a result, the watershed was determined to be "Not Properly Functioning" with respect to substrate and sediments.

In this watershed, the proposed action crosses 57 intermittent and small perennial streams when dry or during the low flows of summer. Of these 57 streams, 55 would be crossed in road fill, bridges or directionally-drilled. Small amounts of increased transitory turbidity may occur during pipeline construction prior to seeding and mulching of ground-disturbed areas of the other 2 streams. However, project BMPs, PDCs will minimize sedimentation potential to very low levels for a brief time (Appendix A). Sediment barriers and site revegetation are required throughout the construction project corridor to eliminate continuous turbidity impacts where delivery mechanisms to streams exist. Larger streams will be directionally-drilled or attached to bridges, avoiding all construction-induced turbidity at those crossings. The proposed action would include new fish friendly stream culverts, new cross-drains in the CBW Road, and paving 10.3 miles of gravel road.

The proposed actions were determined to have insignificant effects at the site and at the $5^{\text {th }}$ field, therefore determined to "Maintain" the substrate/sediment baseline. The effects would be insignificant because of the implementation of PDCs and the ECP (Appendix A), specifically the bag and flume technique.

Large Wood Debris (LWD) - According to Wolniakowski et. al. ( 1990) and Farnell (1979) splash dams and stream cleaning occurred on the main stem of the E. Fork Coquille River and two major tributaries (Steel Creek and Elk Creek). Stream habitat inventory data from 1992-1997 (Appendix H of the WA) clearly demonstrates poor LWD loading and/or pool complexity in substantial portions of nearly every surveyed tributary. Furthermore, the main stem of the E. Fork Coquille River below Brewster Gorge is practically devoid of any wood (personal observation). This is probably due to salvage logging, stream cleaning and lack of recruitment from the riparian area. As a result, the watershed was determined to be "Not Properly Functioning" with respect to LWD. No tree removal occurs within 200 feet of any stream in this watershed. Proposed actions are limited to powerline utility corridors and the CBW Road. Hence, the proposed actions were determined to "Maintain" the baseline for LWD.

Pool Character and Quality - According to 1992-1997 Stream Habitat Inventory data on E. Fork Coquille tributaries, pool frequency (pools/mile) is below the benchmark set forth in the Matrix of Pathways and Indicators in 40 out of the 56 surveyed reaches. However, the criteria for this benchmark were derived for the Upper Columbia River Basin and may not readily apply to Southwest Oregon Coast Range streams. It should be noted that only 10 of the 56 surveyed reaches rated "poor" against the ODFW Habitat Benchmarks (1997) for pool area and/or pool frequency (channel widths/pool). Stream habitat inventory data from the Oregon Coast Range was used in the formulation of the ODFW Benchmark criteria.

The 1992-1997 Stream Habitat Inventory data also indicates that pools $>1$ meter deep are uncommon on most surveyed tributaries. Furthermore, over half of the stream reaches surveyed rated poorly with respect to pool habitat complexity. The previously mentioned water temperature problems in the E. Fork Coquille River also compromise the overall quality of the available pool habitat. Reduction of pool volume due to fine sediments has not been demonstrated within the E. Fork Coquille sub-basin. The watershed was therefore determined to be "At Risk" with respect to pool area and quality.

Proposed actions are limited to powerline ROWs and the CBW Road. Hence, the proposed actions were determined to "Maintain" the baseline for pool character and quality.

Off-channel Habitat - Due to its proximity to roads and a history of stream cleaning and splash dams, any segments of the E. Fork Coquille are severely downcut and isolated from the natural floodplain. As a result, few, if any, backwaters pools, alcoves or other off-channel areas exist. Many of the tributaries are constrained by hill slopes and are not likely to contain off-channel areas. Because of these conditions in the E. Fork Coquille River, the watershed is determined to be "Not Properly Functioning" with respect to these criteria. 
Proposed actions are limited to powerline ROWs and the CBW Road. Hence, the proposed actions were determined to "Maintain" the baseline for off-channel habitat.

\section{Channel Conditions and Dynamics}

Width-Depth Ratio - Current information on riffle width and depth is lacking for the main stem of the E. Fork Coquille River, but has been collected for several tributaries in the basin. Reaches in Steel Creek have W/D ratios of 40.5 and 34.2; the Camas Creek W/D ratio is 26.0. Therefore, the watershed was determined to be "Not Properly Functioning" with respect to this baseline.

Proposed actions are limited to powerline ROWs and the CBW Road. Therefore, the proposed actions were determined to "Maintain" the baseline for width-depth ratio.

Streambank Condition - Streambank condition is good for many of the tributaries of the E. Fork Coquille; however, many areas along the E. Fork Coquille are highly unstable and actively eroding (pers. com. B. Hudson and M.

Kellett, Coos Bay BLM). The watershed was therefore determined to be "Not Properly Functioning" with respect to streambank condition.

Proposed actions have adequate preventive measures (Appendix A) to maintain streambank integrity during and after construction in the riparian areas of the two streams that would be trenched in this watershed. Thus, the proposed actions were determined to "Maintain" the baseline for streambank condition.

Floodplain Connectivity - Due to its proximity to roads and a history of stream cleaning and splash dams, many segments of the E. Fork Coquille are severely downcut. Few, if any, aggregations of large wood remain to create large pools, secondary channels and maintain a high water table. Where the river is unconstrained by hillslopes or terraces, floodplain vegetation is primarily agricultural or residential. The watershed is therefore determined to be "Not Properly Functioning" with respect to floodplain connectivity.

There are no activities in the 100-year floodplain within this watershed. Hence, the proposed actions were determined to "Maintain" the baseline for floodplain connectivity.

\section{Watershed Condition}

Road Density \& Location/Drainage Network - Road densities throughout the E. Fork Coquille Watershed are high (average of 4.4 miles of road per square mile). Additionally, most of the wider valley bottoms contain roads and many of the larger tributaries of the E. Fork Coquille River have roads along much of their length. The watershed is therefore determined to be "Not Properly Functioning" with respect to this baseline. Proposed actions are limited to powerline ROWs and the CBW Road. Thus, the proposed actions were determined to "Maintain" the baseline for road density and location/drainage network.

Disturbance History - The watershed contains greater than 15 percent Late Successional-Old-Growth (LSOG). However, disturbance activities such as road building, stream cleaning and splash dams have been concentrated in riparian areas. Furthermore, the high percentage of hardwoods in riparian areas documented in stream surveys along several tributaries of the E. Fork Coquille River (W. Fork Brummet, Peevey, Camas, and Steel Cr.) show a high level of disturbance. Lane (1987) indicates a high rate of mass movements in some road and logged areas. Therefore, the watershed was determined to be "Not Properly Functioning" with respect to disturbance history.

Proposed actions are limited to human-disturbed sites (utility corridors and roadways). Therefore, the proposed actions were determined to "Maintain" the baseline for disturbance history.

Landslide Rates - In the Relations Between Geology and Mass Movement Features in a part of the East Fork Coquille River Watershed, Southern Coast Range, Oregon, Lane (1987) indicates that a disproportionately high percentage ( 47 percent) of debris avalanches in the watershed are concentrated in road and logged areas which made up only 13 percent of the landscape. As a result, the watershed was determined to be "Not Properly Functioning" for landslide rates. The proposed action does not include new road construction or tree removal, therefore was determined to "Maintain" the baseline for landslide rates.

Riparian Reserves - Federal ownership in the E. Fork Coquille River watershed follows a "checkerboard" pattern and, as a result, the riparian reserve system is highly fragmented. Additionally, high water temperatures in the E. Fork Coquille River indicate that riparian zones throughout the watershed may not be providing adequate shade. The watershed is therefore determined to be "Not Properly Functioning" with respect to riparian reserves. The proposed actions will not impact any overstory riparian vegetation. Therefore, the proposed actions were determined to

"Maintain" the baseline for Riparian Reserves. 
Table E-3. Checklist for Documenting Environmental Baseline and Effects of Proposed Actions on Relevant Indicators

\author{
Name and location: Coos Bay District BLM \\ Basin: 5th field: East Fork Coquille River
}

\begin{tabular}{|c|c|c|c|c|c|c|}
\hline \multirow{2}{*}{$\begin{array}{l}\text { Pathways } \\
\text { Indicators }\end{array}$} & \multicolumn{3}{|c|}{ Environmental Baseline } & \multicolumn{3}{|c|}{ Effects of the Actions ${ }^{2}$} \\
\hline & $\begin{array}{c}\text { Properly } \\
\text { Functioning }{ }^{3}\end{array}$ & At Risk ${ }^{3}$ & $\begin{array}{l}\text { Not Properly } \\
\text { Functioning }\end{array}$ & Restore $^{4}$ & Maintain ${ }^{4}$ & Degrade $^{4}$ \\
\hline$\frac{\text { Water Quality }}{\text { Temperature }}$ & & & WA, MON & & PJ & \\
\hline Turbidity & & & WA & & PJ & \\
\hline Chemical Concentration/ Nutrients & & & PJ & & PJ & \\
\hline 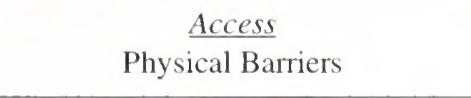 & & & WA & & PJ & \\
\hline$\frac{\text { Habitat Elements }}{\text { Substrate/Sediment }}$ & & & WA & & PJ & \\
\hline Large Wood & & & WA & & PJ & \\
\hline Pool Area & & WA & & & PJ & \\
\hline Pool Quality & & WA & & & PJ & \\
\hline Off-Channel Habitat & & & WA & & PJ & \\
\hline$\frac{\text { Channel Condition \& Dynamics }}{\text { Width/Depth Ratio }}$ & & & PJ, WA & & PJ & \\
\hline Streambank Condition & & & PJ, WA & & PJ & \\
\hline Floodplain Connectivity & & & PJ, WA & & PJ & \\
\hline $\begin{array}{l}\text { Watershed Conditions } \\
\text { Road Density and Location }\end{array}$ & & & PJ, WA & & PJ & \\
\hline Human Disturbance History & & & PJ, WA & & PJ & \\
\hline Landslide Rates & & & WA & & PJ & \\
\hline Riparian Reserves & & & PJ, WA & & PJ & \\
\hline
\end{tabular}

1. Environmental Baseline conditions are derived from BLM stream survey data and synthesis of watershed analysis findings: MONMonitoring; WA- East Fork Coquille Watershed Analyses; SS- Stream Surveys; PJ- Professional Judgment.

2. Effects of the Actions are derived from this Biological Assessment and description of proposed project actions.

3. These three categories of function ("properly functioning", "at risk", "not properly functioning") are defined for each indicator in the "Matrix of Pathways and Indicators" (Table E-2).

4. For the purposes of this checklist (Table E-3), "restore" means to change the function of an "at risk" indicator to "properly functioning", "not properly functioning" to "at risk" and "properly functioning" moving towards recovery. "Short-term" effects, for the purposes of this checklist, are defined as: intermittent or inconsistently occurring effects (i.e., hauling more than 10 loads per day during heavy-rain events) that are brief in duration (i.e., days). "Long-term" effects, for the purposes of this checklist, are defined as consistently occurring effects (i.e., new permanent road construction) that are lengthy in duration (i.e., months/years). 
VIII. RATIONALE USED IN COMPLETING THE CHECKLIST FOR DOCUMENTING ENVIRONMENTAL BASELINE AND THE EFFECTS OF PROPOSED ACTION(S) ON RELEVANT INDICATORS WITH RESPECT TO THE LOWER COOS RIVER/COOS BAY WATERSHED

Note: BLM has not completed a watershed analysis for this 5 th field watershed because of the minimal amount of BLM-administered lands within the watershed. The BLM IDT lacks data on the habitat conditions across the watershed, and much of the evaluation of baseline conditions is based on their professional judgment and personal knowledge of various fish-bearing streams across the watershed.

\section{Water Quality}

Temperature - An assessment by Oregon DEQ and the professional judgment of BLM fisheries biologists indicate this watershed to be "At Risk" with respect to temperature.

The proposed actions contain no riparian overstory tree removal and were determined to "Maintain" the temperature baseline.

Turbidity - The professional judgment of BLM fisheries biologists indicate this watershed to be "Not Properly Functioning" with respect to turbidity.

In this watershed, the proposed action would cross 42 intermittent and small perennial streams (see Table 4). When intermittent streams are dry and during perennial streams' summer low flows. Of these 42 streams, 29 will be crossed in road fill and 2 would be directionally-drilled Of the 11 streams to be trenched, 7 would be dry during the period of construction, and 4 would be trenched using the "bag and flume" method. Small amounts of increased transitory turbidity may occur during pipeline construction prior to seeding and mulching of ground-disturbed areas. However, the BMPs, PDCs and the ECP will minimize sedimentation potential to very low levels for a brief time (Appendix A). Sediment barriers and site revegetation are required throughout the construction project corridor to eliminate continuous turbidity impacts where delivery mechanisms to streams exist. Larger streams will be directionally-drilled to avoid all construction-induced turbidity at those crossings. PDCs include new cross-drains in the CBW Road, and paving 1.9 miles of gravel road.

The proposed actions were determined to have insignificant effects at the site and at the $5^{\text {th }}$ field, therefore determined to "Maintain" the turbidity baseline. The effects would be insignificant because of the implementation of $s$ and the ECP (Appendix A), specifically the bag and flume technique

Chemical Contaminants and Nutrients - An assessment by Oregon DEQ and the professional judgment of BLM fisheries biologists indicate this watershed to be "Not Properly Functioning" with respect to chemical contaminants and nutrients. The proposed actions do not utilize chemicals in the construction process other than products for running the machinery. This project was determined to "Maintain" the chemical contaminant baseline.

\section{Habitat Access}

Physical Barriers - Data provided from state field surveys show that more than 3 culverts block fish passage in this watershed, meeting the criteria for "Not Properly Functioning" with respect to physical barriers. The proposed actions contain no new permanent in-stream structures. Hence, the proposed actions were determined to "Maintain" the baseline for physical barriers.

\section{Habitat Elements}

Substrate/Sediment - The professional judgment of BLM fisheries biologists indicate this watershed to be "At Risk" with respect to substrate and sediment factors.

In this watershed, the proposed action would cross 42 intermittent and small perennial streams in the Lower Coos River/Coos Bay Watershed, when intermittent streams are dry and during perennial streams' summer low flows. Of these 42 streams, 29 will be crossed in road fill and 2 would be directionally-drilled. Of the 11 streams to be trenched, 7 would be dry during the period of construction, and 4 would be trenched using the "bag and flume" method. Small amounts of increased transitory turbidity may occur during pipeline construction prior to seeding and mulching of ground-disturbed areas. However, the BMPs, PDCs and the ECP will minimize sedimentation potential to very low levels for a brief time (Appendix A). Sediment barriers and site revegetation are required throughout the 
construction project corridor to eliminate continuous turbidity impacts where delivery mechanisms to streams exist. Larger streams will be directionally-drilled to avoid all construction-induced turbidity at those crossings. PDCs include new cross-drains in the CBW Road, and paving 1.9 miles of gravel road.

The proposed actions were determined to have insignificant effects at the site and at the $5^{\text {th }}$ field, therefore determined to maintain the substrate/sediment. The effects would be insignificant because of the implementation of PDCs and the ECP (Appendix A), specifically the bag and flume technique.

Large Woody Debris (LWD) - The professional judgment of BLM fisheries biologists indicate this watershed meets the criteria for "Not Properly Functioning" with respect to LWD.

No tree removal occurs within the watershed. Proposed actions are limited to powerline utility corridors and the CBW Road. Hence, the proposed actions were determined to "Maintain" the baseline for LWD.

Pool Area/ Pool Quality - The professional judgment of BLM fisheries biologists indicate this watershed to be "Not Properly Functioning" with respect to percent pool area/quality. Proposed actions are limited to powerline ROWs and the CBW Road. Hence, the proposed actions were determined to "Maintain" the baseline for pool character and quality.

Off-Channel Habitat - The professional judgment of BLM fisheries biologists indicate this watershed meets the criteria for "At Risk" with respect to off-channel habitat. Proposed actions are limited to powerline ROWs and the CBW Road. Hence, the proposed actions were determined to "Maintain" the baseline for off-channel habitat.

\section{Channel Condition and Dynamics}

Width/Depth Ratio - The professional judgment of BLM fisheries biologists indicate this watershed to be "Not Properly Functioning" with respect to width/depth ratio. Proposed actions are limited to powerline ROWs and the CBW Road. Therefore, the proposed actions were determined to "Maintain" the baseline for width-depth ratio.

Streambank Condition - The professional judgment of BLM fisheries biologists indicate this watershed meets the criteria for "At Risk" with respect to streambank condition. The Proposed actions have adequate ECP measures (Appendix A) to maintain streambank integrity during and after construction. Thus, the proposed actions were determincd to "Maintain" the baseline for streambank condition.

Floodplain Connectivity - The professional judgment of BLM fisheries biologists indicate this watershed meets the criteria for "At Risk" with respect to floodplain connectivity. Proposed actions are adjacent to 0.9-mile of floodplain in the watershed. Activities in this area are limited to the CBW Road, which sits on 5 feet of fill. Hence, the proposed actions were determined to "Maintain" the baseline for floodplain connectivity.

\section{Watershed Condition}

Road Density/Location - The professional judgment of BLM fisheries biologists indicate this watershed to be "Not Properly Functioning" with respect to road densities and location. Proposed actions are limited to powerline ROWs and the CBW Road. Thus, the proposed actions were determined to "Maintain" the baseline for road density and location/drainage network.

Disturbance History - The professional judgment of BLM fisheries biologists indicate this watershed meets the criteria for "Not Properly Functioning" with respect to disturbance history. Proposed actions are limited to human-disturbed sites (utility corridors and roadways). Therefore, the proposed actions were determined to "Maintain" the baseline for disturbance history.

Landslide Rates - The professional judgment of BLM fish biologists indicate this watershed meets the criteria for "At Risk" with respect to landslide rates. The proposed action does not include new road construction or tree removal, therefore was determined to "Maintain" the baseline for landslide rates.

Riparian Reserves - The professional judgment of BLM fisheries biologists indicate this watershed meets the criteria for "Not Properly Functioning" with respect to riparian reserves.

The proposed actions will not impact any overstory riparian vegetation. Therefore, the proposed actions were determined to "Maintain" the baseline for Riparian Reserves. 
Table E-4. Checklist for Documenting Environmental Baseline and Effects of Proposed Actions on Relevant Indicators.

\author{
Name and location: Coos Bay District - BLM \\ Basin: $5^{\text {th }}$ field: Lower Coos River
}

\begin{tabular}{|c|c|c|c|c|c|c|}
\hline \multirow[b]{2}{*}{$\begin{array}{l}\text { Pathways } \\
\text { Indicators }\end{array}$} & \multicolumn{3}{|c|}{ Environmental Baseline } & \multicolumn{3}{|c|}{ Effects of the Actions ${ }^{2}$} \\
\hline & $\begin{array}{c}\text { Properly } \\
\text { Functioning }^{3}\end{array}$ & At Risk ${ }^{3}$ & $\begin{array}{c}\text { Not } \\
\text { Properly } \\
\text { Functioning } \\
3\end{array}$ & Restore $^{4}$ & Maintain ${ }^{4}$ & Degrade $^{4}$ \\
\hline$\frac{\text { Water Quality }}{\text { Temperature }}$ & & PJ, DEQ & & & PJ & \\
\hline Turbidity & & & PJ & & PJ & \\
\hline Chemical Concentration/ Nutrients & & & PJ, DEQ & & PJ & \\
\hline Physical Barriers & & & DS & & PJ & \\
\hline$\frac{\text { Habitat Elements }}{\text { Substrate/Sediment }}$ & & PJ & PJ & & PJ & \\
\hline Large Wood & & & PJ & & PJ & \\
\hline Pool Area (\%) & & & PJ & & PJ & \\
\hline Pool Quality & & & & & PJ & \\
\hline Off-Channel Habitat & & PJ & & & PJ & \\
\hline$\frac{\text { Channel Condition \& Dynamics }}{\text { Width/Depth Ratio }}$ & & & PJ & & PJ & \\
\hline Streambank Condition & & PJ & & & PJ & \\
\hline Floodplain Connectivity & & PJ & & & PJ & \\
\hline $\begin{array}{l}\text { Watershed Conditions } \\
\text { Road Density and Location }\end{array}$ & & & PJ & & PJ & \\
\hline Human Disturbance History & & & PJ & & PJ & \\
\hline Landslide Rates & & PJ & & & PJ & \\
\hline Riparian Reserves & & & PJ & & PJ & \\
\hline
\end{tabular}

1. Environmental Baseline conditions are derived from BLM stream survey data and synthesis of watershed analysis findings: DEQ Oregon Department of Environmental Quality; DS - Data from surveys, PJ- Professional Judgment.

2. Effects of the Actions are derived from this Biological Assessment and description of proposed project actions.

3. These three categories of function ("properly functioning", "at risk", "not properly functioning") are defined for each indicator in the "Matrix of Pathways and Indicators" (Table E-2).

4. For the purposes of this checklist (Table E-4), "restore" means to change the function of an "at risk" indicator to "properly functioning", "not properly functioning" to "at risk" and "properly functioning" moving towards recovery. "Short-term" effects, for the purposes of this checklist, are defined as: intermittent or inconsistently occurring effects (i.e., hauling more than 10 loads per day during heavy-rain events) that are brief in duration (i.e., days). "Long-term" effects, for the purposes of this checklist, are defined as consistently occurring effects (i.e., new permanent road construction) that are lengthy in duration (i.e., months/years). 


\section{Rationale Used in Completing the Checklist for Documenting Environmental Baseline and the Effects of Proposed Action(s) on Relevant Indicators With Respect to the North Fork Coquille Watershed}

Note: Unless cited otherwise, the information source used for accessing the environmental baseline is contained in the North Fork Coquille Watershed Analysis in preparation by the Coos Bay District Umpqua Resource Area (07/20/ 2001). The watershed covers approximately 98,467 acres.

\section{Water Quality}

Temperature - The N. Fork Coquille River is included in the Oregon DEQ 303(d) list of temperature-limited water bodies from its mouth to the confluence of Lost Creek. Water temperature monitoring data for the N. Fork Coquille (1986-1994) indicate 7-day average daily maximums of $69.9^{\circ} \mathrm{F}$ between the mouth to Middle Creek and Middle Creek to Little N. Fork; the standard $\left(64^{\circ} \mathrm{F}\right)$ was exceeded for up to 96 days per year. The watershed was therefore determined to be "Not Properly Functioning" with respect to water temperature during the migrating/rearing period.

These proposed actions contain no riparian overstory tree removal and "Maintain" the temperature baseline.

Turbidity - No direct quantitative analysis of turbidity occurred in the WA. However, page 30 of chapter 8 documents that the headwaters of Woodward Creek are down cutting through a clay deposit which enters into suspension and imparts a milky turbidity to the creek. The watershed was therefore determined to be "Not Properly Functioning" with respect to water turbidity.

In this watershed, the proposed action would cross 5 intermittent and 11 perennial streams when dry or during summer low flows. Of these 16 streams, 5 will be crossed in road fill and 4 would be directionally-drilled. Of the 7 streams to be trenched, 1 would be dry during the period of construction, and 6 would be trenched using the "bag and flume" method. Small amounts of increased transitory turbidity may occur during pipeline construction, prior to seeding and mulching of ground-disturbed areas. However, the BMPs, PDCs and ECP will minimize sedimentation potential to very low levels for a brief time (Appendix A). Sediment barriers and site revegetation are required throughout the construction project corridor to eliminate continuous turbidity impacts where delivery mechanisms to streams exist. Larger streams will be directionally-drilled to avoid all construction-induced turbidity at those crossings. PDCs include new cross-drains in the CBW Road and paving 1.0 mile of gravel road.

The proposed actions were determined to have insignificant effects at the site and at the $5^{\text {th }}$ field, therefore determined to "Maintain" the turbidity baseline. The effects would be insignificant because of the implementation of PDCs and the ECP (Appendix A), specifically the bag and flume technique.

Chemical Contaminants - The Oregon DEQ identified the Coquille River as potentially water limited as early as 1973 and confirmed it as a "Waterbody of Concern" in the 1988 Water Quality Report. Furthermore, Table WQ-11 lists the N. Fork Coquille River from the Mouth to Middle Creek exceeding fecal coliform FWS standard values, thus meeting the criteria for "Not Properly Functioning."

The proposed actions do not utilize chemicals in the construction process other than products for running the machinery. This project was determined to "Maintain" the chemical contaminant baseline.Habitat Access

Physical Barriers - Page 5 in chapter 8 of the WA states, "...many culverts in the subwatershed partially or entirely block fish and amphibian passage." Additionally, page 19 of chapter 8 discusses anadromous fish having been eliminated from some former suitable habitat by blockages created by impassable culverts in this watershed, thus meeting the criteria for "Not Properly Functioning" with respect to physical barriers.

The proposed actions contain no new permanent in-stream structures. Hence, the proposed actions were determined to "Maintain" the baseline for physical barriers.

\section{Habitat Access}

Physical Barriers - Page 5 in chapter 8 of the WA states, "...many culverts in the subwatershed partially or entirely block fish and amphibian passage." Additionally, page 19 of chapter 8 discusses anadromous fish having been eliminated from some former suitable habitat by blockages created by impassable culverts in this watershed, thus meeting the criteria for "Not Properly Functioning" with respect to physical barriers.

The proposed actions contain no new permanent in-stream structures. Hence, the proposed actions were determined to "Maintain" the baseline for physical barriers. 


\section{Habitat Elements}

Substrate/Sediment - Page 17 in chapter 7 of the WA states that sediment from road failure was considered the greatest water quality problem, and erosion of soils exposed by severe slash burning on steep slopes was often the principle cause of surface erosion.

The watershed was therefore determined to be "At Risk" with respect to water substrate and sediment.

In this watershed, the proposed action would cross 5 intermittent and 11 perennial streams when dry or during summer low flows. Of these 16 streams, 5 will be crossed in road fill and 4 would be directionally-drilled. Of the 7 streams to be trenched, 1 would be dry during the period of construction, and 6 would be trenched using the "bag and flume" method. Small amounts of increased transitory turbidity may occur during pipeline construction, prior to seeding and mulching of ground-disturbed areas. However, the BMPs, PDCs and ECP will minimize sedimentation potential to very low levels for a brief time (Appendix A). Sediment barriers and site revegetation are required throughout the construction project corridor to eliminate continuous turbidity impacts where delivery mechanisms to streams exist. Larger streams will be directionally-drilled to avoid all construction-induced turbidity at those crossings. PDCs include new cross-drains in the CBW Road and paving 1.0 mile of gravel road.

The proposed actions were determined to have insignificant effects at the site and at the $5^{\text {th }}$ field, therefore determined to maintain the turbidity baseline. The effects would be insignificant because of the implementation of PDCs and the ECP (Appendix A), specifically the bag and flume technique.

Large Wood Debris (LWD) - During the early 1900s, stream "improvements" including eliminating vegetation along the river banks, blasting channel boulders and removing large woody debris and snags from the river channel occurred on the main stem of the N. Fork Coquille. Much of this "improvement and maintenance" was in association with splash damming. Page 15 in chapter 8 of the WA reveals that stream cleaning was required on BLM timber sales conducted from 1965 through 1991. Furthermore, stated on page 28 in chapter 8 of the WA, "While stream cleaning and salvaging from streams and riparian areas has been stopped, the legacy of the cleaning process remains. It will be many years before the in-stream habitat improvement options of the State water protection rules will be applied to sections of the North Fork Coquille River, if they ever will be." As a result, the watershed was determined to be "Not Properly Functioning" with respect to LWD.

No tree removal occurs within this watershed. Proposed actions are limited to powerline utility corridors and the CBW Road. Hence, the proposed actions were determined to "Maintain" the baseline for LWD.

Pool Area (\%) - Page 5 in chapter 8 of the WA reports only 2 pools with a maximum depth of $>3$ feet were documented along 2 miles of stream inventoried. The percent pool area was rated fair for the 4th order reaches, and poor in 0.2-mile of 3rd-order channels. The watershed was therefore determined to be "At Risk" with respect to pool area.

Proposed actions are limited to powerline ROWs and the CBW Road. Hence, the proposed actions were determined to "Maintain" the baseline for pool area.

Pool Quality - The professional judgment of a BLM fisheries biologists indicate this watershed to be "Not Properly Functioning" with respect to percent pool area/quality.

Proposed actions are limited to powerline ROWs and the CBW Road. Hence, the proposed actions were determined to "Maintain" the baseline for pool character and quality.

Off-channel Habitat - Due to its proximity to roads and a history of stream cleaning and splash dams, many segments of the N. Fork Coquille River are severely downcut and isolated from the natural floodplain. As a result, few, if any, backwaters pools, alcoves or other off-channel areas exist.

Many of the tributaries are constrained by hillslopes and are not likely to contain off-channel areas. However, because of the condition of the N. Fork Coquille River, the watershed is determined to be "At Risk" with respect to these criteria.

Proposed actions are limited to powerline ROWs and the CBW Road. Hence, the proposed actions were determined to "Maintain" the baseline for off-channel habitat.

\section{Channel Conditions and Dynamics}

Width-Depth Ratio - Current information on riffle width and depth is lacking for the main stem of the N. Fork Coquille River but has been summarized for the 1997 Middle Main Coquille-North Coquille Mouth-Catching Creek Watershed Analysis. It is revealed on page 6 of chapter 9 of the WA that many channels have become wider with a 
corresponding reduction in stream depth. Thus, this watershed was determined to be "Not Properly Functioning" due to the degraded aquatic habitat caused by past logging and past and current agricultural practices. Proposed actions are limited to powerline ROWs and the CBW Road. Therefore, the proposed actions were determined to "Maintain" the baseline for width-depth ratio.

Streambank Condition - Page 5 of chapter 8 discusses some of the primary reasons for the degraded conditions, including stream-bank damage from livestock, down-cutting of streams due to the removal of stream-side vegetation and in-stream structure, as well as the confinement of stream channels. The watershed was therefore determined to be "At Risk" with respect to streambank condition. The proposed actions have adequate measures (see attached Appendix) to maintain streambank integrity during and after construction. Thus, the proposed actions were determined to "Maintain" the baseline for streambank condition.

Floodplain Connectivity - Page 6 of chapter 5 states, "Large areas of floodplain have been cleared and drained for development. The loss of vegetation maintained stream bank stability resulted in increased stream bank erosion. The loss of wood recruitment to the channel, along with loss of stream bank vegetation, reduced channel roughness. This in turn resulted in higher stream velocities that contribute to increased stream bank erosion, downcutting and the loss and/or simplification of habitat, especially aquatic habitat that is critical during high flows. The watershed is therefore determined to be "Not Properly Functioning" with respect to floodplain connectivity. In the floodplain area of this watershed, the proposed action is limited to the CBW Road, which sits on 5 feet of fill. Hence, the proposed actions were determined to "Maintain" the baseline for floodplain connectivity.

\section{Watershed Condition}

Road Density - Table Intro-4, page 5 in chapter 1 of the WA, gives an estimate of total roads in the WA as 751.3 miles. Table Intro-1, page 3 in chapter 1, lists total area in the WA as 98,476 acres, which translates to 639 square miles. These numbers can be expressed as 1.2 miles of road per square mile within the WA. Although this is a relatively low road density, the location of roads and effects to drainage network are discussed on page 5 in chaptcr 8 of the WA, where it is stated, "Roads paralleling streams and crossing tributaries restrict interactions between the aquatic and riparian areas" and further stated, "Road construction along streams has resulted in the establishment of alders next to the stream channels, thus reducing the future recruitment of large, durable conifers." Thus, this watershed was determined to be "Not Properly Functioning" with respect to road density \& location/drainage network. Proposed actions are limited to existing powerline ROWs and the CBW Road. Thus, the proposed actions were determined to "Maintain" the baseline for road density.

Disturbance History - Page 5 in chapter 8 of the WA discusses the combined impacts of agricultural practices, past timber practices and the associated land management activities. Some of the disturbance effects included harvesting of large conifers next to streams, the removal of LWD through stream cleaning and salvage practices, poorly constructed culverts and poorly located and/or constructed roads. The watershed was therefore determined to be "At Risk" with respect to disturbance history. Proposed actions are limited to human-disturbed sites (utility corridors and roadways). Therefore, the proposed actions were determined to "Maintain" the baseline for disturbance history.

Landslide Rates - Page 11 in the WA Erosion Process Appendix discusses landslides and debris avalanches and states "In the Late 1950s through the mid-1970s, human-related soil/slope failures dominated as road construction and clearcutting reached the middle and upper parts of the subwatershed. In this period, there were 106 humanrelated landslides, 64 of which were directly related to road construction." As a result, the watershed was determined to be "Not Properly Functioning" for landslide rates. The proposed action does not include new road construction or tree removal, therefore was determined to "Maintain" the baseline for landslide rates.

Riparian Reserves - Chapter 5 of the WA discusses the current condition and pattern of vegetation within the watershed. Stated on page 3 in chapter 5 , "Current vegetation patterns are a result of past management actions, harvest practices and associated road building, land ownership, fires, human settlements, agriculture and farming. Early or mid-seral stands occupy most of the private forest land in the watershed. Approximately 9,358 acres are agricultural and rural residential lands." The watershed is therefore determined to be "Not Properly Functioning" with respect to riparian reserves. The proposed actions in this watershed will not impact any overstory riparian vegetation. Therefore, the proposed actions were determined to "Maintain" the baseline for Riparian Reserves. 
Table E-5. Checklist for Documenting Environmental Baseline and Effects of Proposed Actions on Relevant Indicators.

Name and location: Coos Bay District - BLM

Basin: $5^{\text {th }}$ field: North Fork Coquille

\begin{tabular}{|c|c|c|c|c|c|c|}
\hline \multirow[b]{2}{*}{$\begin{array}{l}\text { Pathways } \\
\text { Indicators }\end{array}$} & \multicolumn{3}{|c|}{ Environmental Baseline } & \multicolumn{3}{|c|}{ Effects of the Actions ${ }^{2}$} \\
\hline & $\begin{array}{c}\text { Properly } \\
\text { Functioning }\end{array}$ & At Risk ${ }^{3}$ & $\begin{array}{c}\text { Not } \\
\text { Properly } \\
\text { Functionin } \\
\mathrm{g}^{3}\end{array}$ & Restore $^{4}$ & Maintain $^{4}$ & Degrade $^{4}$ \\
\hline$\frac{\text { Water Quality }}{\text { Temperature }}$ & & & $\mathrm{DEQ}$ & & PJ & \\
\hline Turbidity & & & PJ, WA & & PJ & \\
\hline Chemical Concentration/ Nutrients & & & DEQ & & PJ & \\
\hline $\begin{array}{l}\text { Access } \\
\text { Physical Barriers }\end{array}$ & & & WA & & PJ & \\
\hline $\begin{array}{l}\text { Habitat Elements } \\
\text { Substrate/Sediment }\end{array}$ & & PJ, WA & & & PJ & \\
\hline Large Wood & & & WA & & PJ & \\
\hline Pool Area & & PJ,WA & & & PJ & \\
\hline Pool Quality & & & PJ & & PJ & \\
\hline Off-Channel Habitat & & PJ,WA & & & PJ & \\
\hline $\begin{array}{c}\text { Channel Condition \& Dynamics } \\
\text { Width/Depth Ratio }\end{array}$ & & & PJ,WA & & PJ & \\
\hline Streambank Condition & & PJ,WA & & & PJ & \\
\hline Floodplain Connectivity & & & PJ,WA & & PJ & \\
\hline $\begin{array}{l}\text { Watershed Conditions } \\
\text { Road Density and Location }\end{array}$ & & & PJ,WA & & PJ & \\
\hline Human Disturbance History & & PJ,WA & & & PJ & \\
\hline Landslide Rates & & & PJ,WA & & PJ & \\
\hline Riparian Reserves & & & PJ,WA & & PJ & \\
\hline
\end{tabular}

1. Environmental Baseline conditions are derived from BLM stream survey data and synthesis of watershed analysis findings: WA-

North Fork Coquille Watershed Analyses, PJ- Professional Judgment.

2. Effects of the Actions are derived from this Biological Assessment and description of proposed project actions.

3. These three categories of function ("properly functioning", "at risk", "not properly functioning") are defined for each indicator in the "Matrix of Pathways and Indicators" (Table E-2).

4. For the purposes of this checklist (Table E-5), "restore" means to change the function of an "at risk" indicator to "properly functioning", "not properly functioning" to "at risk" and "properly functioning" moving towards recovery. "Short-term" effects, for the purposes of this checklist, are defined as: intermittent or inconsistently occurring effects (i.e., hauling more than 10 loads per day during heavy-rain events) that are brief in duration (i.e., days). "Long-term" effects, for the purposes of this checklist, are defined as consistently occurring effects (i.e., new permanent road construction) that are lengthy in duration (i.e., months/years). 


\section{RATIONALE USED IN COMPLETING THE CHECKLIST FOR DOCUMENTING ENVIRONMENTAL BASELINE AND THE EFFECTS OF PROPOSED ACTION(S) ON RELEVANT INDICATORS WITH RESPECT TO THE LOWER SOUTH UMPQUA WATERSHED}

Note: Unless cited otherwise, the information source used for accessing the environmental baseline is contained in the Lower South Umpqua Watershed Analysis prepared by the Roseburg District South River Resource Area (05/30/ 2000). The WA covers approximately 110,419 acres.

\section{Water Quality}

Maximum Temperature - Table C-2, found in appendix C of the WA, rates the watershed as "Poor" (temperatures $>70^{\circ} \mathrm{F}$ ), thereby meeting the criteria for "Not Properly Functioning."

These proposed actions contain no riparian overstory tree removal and were determined to "Maintain" the temperature baseline.

Sediment/Turbidity - No direct quantitative analysis of turbidity occurred in the WA. However, a definition is given on page 82: "Turbidity is a function of suspended sediments and algal growth in a stream." Also stated in this section, "Roads have the potential to affect the sediment regime. Erosional effects can occur when culverts become plugged or cannot handle peak flows, diverting streams out of their original channel, flowing down the road and entering another stream channel." Page 84 of the WA states "Many roads within the WAU have not been maintained on a regular schedule. The lack of routine road maintenance may lead to increased sedimentation from the road surfaces, landslides from road failures, and an increased risk of culvert problems." Page 83 discusses the increased sedimentation to the WAU caused by human-related activities (e.g., agriculture, urbanization and road construction).

Assessments, inferred from these data, suggest that sediment/turbidity in this watershed is of higher frequency and duration relative to unimpacted streams in the basin. This meets the criteria for "Not Properly Functioning" with respect to sediment and turbidity.

In this watershed, the proposed action would cross 8 intermittent streams when dry. Small amounts of increased transitory turbidity may occur during precipitation events after pipeline construction and prior to seeding and mulching of ground-disturbed areas.

The proposed actions were determined to have insignificant effects at the site and at the $5^{\text {th }}$ field, therefore determined to "Maintain" the sediment/turbidity baseline. The effects would be insignificant because of the implementation of PDCs and the ECP (Appendix A), specifically the bag and flume technique.

\section{Habitat Access}

Physical Barriers - Fish migration barriers are considered a data gap for the Lower South Umpqua WA and were not specifically quantified. However, high road densities (WA page 77, Table 25) and numerous stream crossings (WA page 73), 57 percent of which are within 100 feet of a stream, indicate this watershed to be "At Risk" with respect to physical barriers.

The proposed actions contain no new permanent in-stream structures. Hence, the proposed actions were determined to "Maintain" the baseline for physical barriers.

\section{Habitat Elements}

Large Woody Debris (LWD) - Page 93 of the WA states, "Recent ODFW Aquatic Habitat Inventory data indicates well-distributed or frequently occurring LWD is lacking in the survey stream reaches." Large woody debris frequency (Table C-3) in this watershed averages 35 pieces/mile, thus meeting the criteria for "At Risk."

No tree removal occurs within this watershed. Proposed actions are limited to powerline utility corridors. Hence, the proposed actions were determined to "Maintain" the baseline for LWD.

Substrate - Table C-2 (in Appendix C of the WA) lists the dominant substrate as gravel with a subdominant substrate of cobble and embeddedness is rated as "Fair" (26-49 percent), meeting the criteria for "At Risk" with respect to substrate. 
The proposed actions were determined to have insignificant effects at the site and at the $5^{\text {th }}$ field, therefore determined to "Maintain" the substrate baseline. The effects would be insignificant because of the implementation of PDCs and the ECP (Appendix A), specifically the bag and flume technique.

Pool Characteristics - Table C-2 in Appendix C of the WA rates percent pool area as "Fair" (16-29 percent) meeting the criteria for "At Risk" (less than 30 percent pool habitat).

In this watershed, the proposed actions are limited to the powerline ROWs. Hence, the proposed actions were determined to "Maintain" the baseline for pool characteristics.

Off-Channel Habitat - No data quantified this indicator in the WA. However, page 84 of the WA describes the watershed as having less complex stream channels, degraded substrate and poor fish habitat in some areas of the watershed. This is attributed to the removal of LWD from the stream channels (a key component for creating offchannel habitat), cutting trees along many streams (off-channel shading) and road construction (primary constituent for channelization) in and adjacent to riparian areas. Based on this impacts list of factors in the WA, it was determined to be "At Risk" with respect to off-channel habitat. In this watershed, the proposed actions are limited to the powerline ROWs, therefore the proposed actions were determined to "Maintain" the baseline for off-channel habitat.

\section{Channel Condition and Dynamics}

Width/Depth Ratio - Although current width to depth ratios given in table C-2 of the WA are rated as "Good", page 85 discusses the significant changes in historical stream width occurring within the South Umpqua River Basin stating, "Thirteen of the 14 stream reaches located in areas where timber harvesting occurred were significantly wider than in 1937." Also, lack of LWD within the basin projects poor recruitment for continuation of a high width/depth ratio rating, creating conditions where the present rating of "Good" in table C-2 may not be sustained. Thus, with respect to width/depth ratio, this watershed meets the criteria for "At Risk." In this watershed, the proposed actions are limited to the powerline ROWs. Therefore, the proposed actions were determined to "Maintain" the baseline for width-depth ratio.

Streambank Condition - There is no direct mention of this indicator in the WA. However, inferences from the WA can be made. Page 70 states, "Many low gradient stream channels in the watershed have been eroded down to bedrock, probably due to increased peak flows as a result of timber harvesting, road construction, channel downcutting due to over grazing on streambanks, and the lack of LWD due to stream cleaning practices." This indicates consistent levels of human disturbance both historically and ongoing, leaving some of the streams within the watershed with unstable banks. Thus, based on inferences from the data, streambank condition meets the criteria for "At Risk."

The proposed action has adequate measures (Appendix A) to maintain streambank integrity during and after construction. Thus, the proposed actions were determined to "Maintain" the baseline for streambank condition.

Floodplain Connectivity - No direct mention of this indicator occurred in the WA. However, page 83 of the WA discusses the negative impacts to streams and stream flow due to removing water for irrigation and riparian vegetation. Some areas of wetlands and floodplains within the watershed are blocked by human development (such as roads and agricultural development) during summer low flows, which reduce linkages and degrade the wetland/riparian vegetation ecological functions. Also, there is a high density of roads and stream crossings throughout the basin. Inferences from these factors indicate floodplain connectivity to be "At Risk."

There are no activities in the 100-year floodplain within this watershed. Hence, the proposed actions were determined to "Maintain" the baseline for floodplain connectivity.

\section{Flow/Hydrology}

Change in Peak/Base Flow - Page 79 of the WA discusses drainages in the watershed with high road densities, high stream crossing densities, previously harvested and/or in the transient snow zone areas as being susceptible to increased peak flows. Additionally, it is stated on page 79, "The majority of roads within the watershed were constructed with ditches and/or insloped road surfaces designed to carry water off of the road surface. Once the water is in the ditch, much of it may reach the stream faster than in an unroaded area. In fact, some ditchlines effectively function as stream channels extending the actual length of flowing streams during rain storms. Increased drainage density due to road construction may increase peak flows and mean annual floods." Based on these observations, it was determined to be "Not Properly Functioning" with respect to peak/base flow.

The proposed actions contain no new road construction or timber harvest within the basin; therefore, it was determined to "Maintain" the change in peak/base flow. 
Drainage Network - High road densities (WA, Table 23) and the resulting increase in drainage density (discussed on page 79 of the WA) indicate this watershed meets the criteria for "Not Properly Functioning" with respect to drainage network. In this watershed, the proposed actions are limited to the powerline ROWs. Therefore, the proposed actions will "Maintain" the baseline with respect to drainage network.

\section{Watershed Condition}

Road Density/Location - Road densities in the Lower South Umpqua WAU average $5.66 \mathrm{miles} / \mathrm{mi}^{2}$ (Table 23, WA) meeting the criteria for "Not Properly Functioning." In this watershed, the proposed actions are limited to the powerline ROWs. Thus, the proposed actions were determined to "Maintain" the baseline for road density and location/ drainage network.

Disturbance History - Pages 10-13 of the WA list past and current human land uses in the Lower South Umpqua River watershed as agriculture/grazing, timber harvesting, collection of special forest products and recreation (including ATV and motorcycle use). Additionally, the WA states, "The city of Roseburg is located in the WAU and provides food, gas, and other essentials for tourists, commercial travelers and local residents. Roseburg is the center of commerce for the local area."

High levels of human activity in conjunction with the high road densities in this watershed meet the criteria for "Not Properly Functioning" with respect to disturbance history. In this watershed, the proposed actions are limited to the powerline ROWs (human-disturbed sites). Therefore, the proposed actions were determined to "Maintain" the baseline for disturbance history.

Riparian Reserves - Table 9 in the WA lists the current riparian reserve age class distribution for this watershed, demonstrating approximately 34 percent (less than the 60 percent criteria) of the forested areas are in late seral successional stages. This meets the criteria for "Not Properly Functioning" with respect to riparian reserves.

The proposed actions will not impact any overstory riparian vegetation. Therefore, the proposed actions were determined to "Maintain" the baseline for Riparian Reserves.

Landslide Rates - Page 84 of the WA discusses the increased risk of landslides and road failures due to timber harvesting and improper maintenance of existing roads. Therefore, with respect to landslide rates, this watershed meets the criteria for "At Risk."

The proposed action does not include new road construction or tree removal, therefore was determined to "Maintain" the baseline for landslide rates.

Refugia - Channelization from high road densities, lack of LWD recruitment and poor off-channel habitat conditions throughout the basin and sub-basin are direct indicators of available refugia within the watershed. From these assessments, it was inferred to meet the criteria for "At Risk." In this watershed, the proposed actions are limited to the powerline ROWs. Thus, the proposed actions were determined to "Maintain" the baseline for refugia. 
Table E-6. Checklist for Documenting Environmental Baseline and Effects of Proposed Actions on Relevant Indicators.

\section{Name and location: Roseburg District South River Resource Area - BLM}

Basin: $5^{\text {th }}$ field: Lower South Umpqua

\begin{tabular}{|c|c|c|c|c|c|c|}
\hline \multirow{2}{*}{$\begin{array}{l}\text { Pathways } \\
\text { Indicators }\end{array}$} & \multicolumn{3}{|c|}{ Environmental Baseline } & \multicolumn{3}{|c|}{ Effects of the Actions ${ }^{2}$} \\
\hline & $\begin{array}{c}\text { Properly } \\
\text { Functioning }\end{array}$ & At Risk $^{3}$ & $\begin{array}{l}\text { Not Properly } \\
\text { Functioning }\end{array}$ & Restore $^{4}$ & Maintain $^{4}$ & Degrade $^{4}$ \\
\hline$\frac{\text { Water Quality }}{\text { Temperature }}$ & & & WA & & PJ & \\
\hline Turbidity & & & WA, PJ & & PJ & \\
\hline $\begin{array}{l}\text { Chemical Concentration/ } \\
\text { Nutrients }\end{array}$ & & WA, PJ & & & PJ & \\
\hline$\frac{\text { Access }}{\text { Physical Barriers }}$ & & WA & & & PJ & \\
\hline $\begin{array}{l}\text { Habitat Elements } \\
\text { Substrate/Sediment }\end{array}$ & & WA & & & PJ & \\
\hline Large Wood & & WA & & & PJ & \\
\hline Pool Area & & WA, PJ & & & PJ & \\
\hline Pool Quality & & WA, PJ & & & PJ & \\
\hline Off-Channel Habitat & & WA, PJ & & & PJ & \\
\hline $\begin{array}{l}\text { Channel Condition \& } \\
\text { Dynamics } \\
\text { Width/Depth Ratio }\end{array}$ & & WA & & & PJ & \\
\hline Streambank Condition & & & WA, PJ & & PJ & \\
\hline Floodplain Connectivity & & & WA & & PJ & \\
\hline$\frac{\text { Watershed Conditions }}{\text { Road Density and Location }}$ & & & WA & & PJ & \\
\hline Human Disturbance History & & & WA & & PJ & \\
\hline Landslide Rates & & & WA & & PJ & \\
\hline Riparian Reserves & & WA & & & PJ & \\
\hline
\end{tabular}

1. Environmental Baseline conditions are derived from BLM stream survey data and synthesis of watershed analysis findings: WALower South Umpqua Watershed Analyses, PJ- Professional Judgment.

2. Effects of the Actions are derived from this Biological Assessment and description of proposed project actions.

3. These three categories of function ("properly functioning", "at risk", "not properly functioning") are defined for each indicator in the "Matrix of Pathways and Indicators" (Table E-2).

4. For the purposes of this checklist (Table E-6), "restore" means to change the function of an "at risk" indicator to "properly functioning", "not properly functioning" to "at risk" and "properly functioning" moving towards recovery. "Short-term" effects, for the purposes of this checklist, are defined as: intermittent or inconsistently occurring effects (i.e., hauling more than 10 loads per day during heavy-rain events) that are brief in duration (i.e., days). "Long-term" effects, for the purposes of this checklist, are defined as consistently occurring effects (i.e., new permanent road construction) that are lengthy in duration (i.e., months/years). 


\section{RATIONALE USED IN COMPLETING THE CHECKLIST FOR DOCUMENTING ENVIRONMENTAL BASELINE AND THE EFFECTS OF PROPOSED ACTION(S) ON RELEVANT INDICATORS WITH RESPECT TO THE MIDDLE MAIN COQUILLE WATERSHED}

Note: Unless cited otherwise, the information source used for accessing the environmental baseline is contained in the Middle Main Coquille Watershed Analysis prepared by the Umpqua Resource Area, Coos Bay District Bureau of Land Management (09/30/1997). The WA includes 3 subwatersheds: North Coquille Mouth, Middle Main Coquille and Catching Creek. North Coquille Mouth Subwatershed is part of the North Fork Coquille 5th field watershed. Middle Main Coquille and Catching Creek Subwatersheds together make up the Middle Main Coquille 5th field watershed. The watershed covers approximately 55,728 acres.

\section{Water Quality}

Temperature - The Little North Fork Coquille and Catching Creek are listed on Oregon's 303 (d) list as water quality limited due to temperature and the South, North and Middle Forks, as well as the main stem of the Coquille River, are also warmer than optimum (WA, page 19). John's Creek, however, is considered to be properly functioning (WA, table FISH-3). There is little other mention of water temperature in the watershed analysis and no mention of 7-day maximum averages. Riparian vegetation on BLM land is said to be in good condition (WA, page 25) and riparian vegetation is said to be partially responsible for the lack of change from historic conditions of type A and B channels (WA, page 18). It appears that upper reaches of the watershed are receiving adequate shading. Lower portions of the watershed that have been converted to farmland and grazing do not have intact riparian corridors (WA, page 18), therefore, any heating of the water due to lack of shading would likely be occurring in the lower portions of the watershed. Based on these data and observations, it was determined to be "Not Properly Functioning" with respect to temperature.

These proposed actions contain no riparian overstory tree removal and were determined to "Maintain" the temperature baseline.

Turbidity - Roughly 12 percent of the watershed is located on soils that generally yield silt and clay sediments (WA, pg. 5), which tend to remain suspended longer (WA, pg. 10), whereas larger particles, such as sand and gravel, tend to settle out of the water column sooner. Because of this assessment, it was determined to be "At Risk" with regards to turbidity.

In this watershed, the proposed action would cross over top 17 intermittent and small perennial streams on road fill when streams are dry or during summer low flows. Small amounts of increased transitory turbidity may occur during pipeline construction, prior to repaving of the CBW Road. However, the ECP measures will minimize sedimentation potential to very low levels for a brief time (Appendix A). Sediment barriers are required throughout the construction project corridor, eliminating continuous turbidity impacts where delivery mechanisms to streams exist. In this watershed, no vegetation removal will occur as construction is limited to the CBW Road. PDCs include new crossdrains in the CBW Road and paving 1.9 miles of gravel road.

The proposed actions were determined to have insignificant effects at the site and at the $5^{\text {th }}$ field, therefore determined to "Maintain" the sediment/turbidity baseline. The effects would be insignificant because of the implementation of PDCs and the ECP (Appendix A), specifically the bag and flume technique.

Chemical Contamination/Nutrients - In the 1986 Water Quality Report the Oregon DEQ listed the Coquille River as a "Waterbody of Concern." In 1991, it specifically identified wastewater treatment plants in Myrtle Point and Coquille for producing nutrient and coliform bacteria and toxic substances as areas of concern for the Coquille River. However, no record of fish kills or other biological evidence of serious or chronic contamination exist. Therefore, with respect to chemical contamination/nutrients, it was determined to be "At Risk."

The proposed actions do not utilize chemicals in the construction process other than products for running the machinery. This project was determined to "Maintain" the chemical contaminant baseline.

\section{Habitat Access}

Physical Barriers - On pages 21 to 26 of the WA, culverts acting as artificial barriers to salmonid passage are discussed. This meets the criteria to be classified as "Not Properly Functioning" with respect to physical barriers. 
The proposed actions contain no new permanent in-stream structures. Hence, the proposed actions were determined to "Maintain" the baseline for physical barriers.

\section{Habitat Elements}

Substrate/Sediment - The only analysis area for which substrate was sampled (as percent gravel in the riffles) is John's Creek, which was rated as "Good" with regard to gravel and "Fair" with regard to silt/sand/organics (WA, Table FISH-1). Pages I 8 \& I9 of the WA state, "However, the substrate composition... [sic] has changed in response to man's activities..." and, "Many larger channels have scoured to bedrock or migrated laterally, and have difficulty retaining substrate. The systems that could retain substrate may have difficulty recruiting it because streamside and mid-slope roads function as terraces that trap material that would otherwise proceed downhill to the channel." Based on these references, it was inferred to be "Not Properly Functioning" with respect to substrate/sediment.

The proposed actions contain no new road construction. Sediment barriers will be placed along the entire pipeline corridor in areas where delivery mechanisms to streams exist, as well as all stream crossings. In this watershed, the pipeline would cross in road fill 6 intermittent and 11 small perennial streams, when dry or during summer low flows. Small amounts of transitory sediment may enter the streams after construction during the first precipitation prior to repaving. Sediment barriers are required throughout the construction project corridor to eliminate sedimentation impacts. In this watershed, no vegetation removal will occur as construction is limited to the CBW Road. PDCs include paving 1.9 miles of gravel road.

The proposed actions were determined to have insignificant effects at the site and at the $5^{\text {th }}$ field, therefore determined to "Maintain" the sediment/turbidity baseline. The effects would be insignificant because of the implementation of PDCs and the ECP (Appendix A), specifically the bag and flume technique.

Large Woody Debris (LWD) - The only place where the WA specifically addresses large woody debris in terms of pieces/mile is table FISH-1 which only covers John's Creek. The table lists the number as 20 pieces/mile and classifies it as "Fair." Table FISH- 3, however, gives large woody debris as "Unknown" for John's Creek and "Not Properly Functioning" for Wimer Creek.

Pages 18 and 20 of the WA indicate that much large woody debris has been removed from the channels, and page 20 also indicates that future recruitment of large woody debris will be limited (at least in the near-term) by historical management actions in the basin. Based on this information, the watershed was determined to be "Not Properly Functioning" in relation to LWD.

No vegetation removal would occur in this watershed from the pipeline project, as the proposed actions are limited to the CBW Road. Hence, the proposed actions were determined to "Maintain" the baseline for LWD.

Pool Area (\%) - Pool area is listed as I7 percent (average) for John's Creek in table F1SH-1 of the WA and is considered "Not Properly Functioning" in table FISH-3. The other indication of pool area for the watershed is the statement, "...beaver populations are probably much lower currently than historically, and that beaver dams have decreased proportionately" (WA, pages $24 \& 25$ ). Pool area would be expected to be less in upper reaches of a watershed (such as John's Creek) where the slopes are steeper than lower down in the watershed. Based on these observations and current trends, it was given a rating of "At Risk" with respect to pool area.

In this watershed, proposed actions are limited to the CBW Road. Hence, the proposed actions were determined to "Maintain" the baseline for pool area.

Pool Quality - Table FISH-3 in the WA rates pool quality as "Not Properly Functioning" for John's Creek and Wimer Creek; while, table FISH-I rates it as "Good" for John's Creek. It is assumed that as stream order increases, pool depth will increase as well. Based on these inferences and the decrease in beaver activity in the watershed, which can be a prime source of deep, high quality pools (WA, pages $24 \& 25$ ), the watershed appears to be "At Risk" with regard to pool quality.

Proposed actions are limited to the CBW Road in this watershed. Hence, the proposed actions were determined to "Maintain" the baseline for pool quality.

\section{Channel Condition and Dynamics}

Off-Channel Habitat - Off-channel habitat is considered to be "At Risk" in both John's Creek and Wimer Creek (see table FISH-3). Throughout the rest of the WA, the only mention is on page 18 where it states, "The floodplains have been cleared and drained for development resulting in the loss or simplification of habitat; especially, aquatic habitat 
that is critical during high flows." Based on these references, it was determined that the watershed is "At Risk" with respect to off-channel habitat.

Proposed actions are limited to the CBW Road in this watershed. Hence, the proposed actions were determined to "Maintain" the baseline for off-channel habitat.

Width/Depth Ratio - Page 23 of the WA states concerning John's Creek, "The width/depth ratio of riffles was fair for all stream reaches." Increased erosion and sedimentation resulting from logging, road building, and agricultural activities (WA, page 5), have altered the substrate composition of the watershed (WA, page 18). Increased sedimentation also directly acts to increase width/depth ratios. The watershed, therefore, was rated "At Risk" regarding width/depth ratios.

Proposed actions are limited to the CBW Road in this watershed. Hence, the proposed actions were determined to "Maintain" the baseline for width/depth ratios.

Streambank Condition - Page 17 of the WA states, "Most of the assessment area has a dendritic drainage pattern and is steep, water-cut, deeply dissected, and forested." This portion would be classified under the Rosgen Stream Types as A and B type channels which are relatively stable. Page 18 indicates that $\mathrm{C}$ type channels in the watershed have decreased bank stability due to human manipulations. Because of anticipated ongoing human impacts, it was determined to be "At Risk" with respect to streambank condition.

Proposed actions are limited to the CBW Road in this watershed. Thus, the proposed actions were determined to "Maintain" the baseline for streambank condition.

Floodplain Connectivity - Floodplain connectivity is discussed on page 18 of the WA; it states, "Removal of vegetation, ditching and draining, and construction of flood control structures has... [sic]... significantly altered the channels and their interaction with the floodplain." Also, "The floodplains have been cleared and drained for

development." Table F1SH-3 assesses John's Creek and Wimer Creek as both being "At Risk" regarding floodplain connectivity. However, most of the floodplain occurs lower down in the drainage system, where heavy disconnecting of floodplains from road construction exists. Therefore, with respect to floodplain connectivity, the watershed was determined to be "Not Properly Functioning."

There are no activities in the 100-year floodplain within this watershed. Hence, the proposed actions were determined to "Maintain" the baseline for floodplain connectivity.

\section{Watershed Conditions}

Road Density \& Location/Drainage Network - While there is insufficient data to estimate road densities in nonBLM land in the watershed (WA, page 2), it is listed for John's Creek and Wimer Creek both as being "Not Properly Functioning" (table FISH-3). Page 49 of the WA gives the road density on BLM administered lands as 3.92 miles per square mile (table EROD-3 gives the road density for BLM administered lands as 3.82 miles per square mile), and page 23 indicates that some roads were constructed along streams. Map EROD-6 shows many intersections of roads and streams. Combined, these indicate that the watershed is "Not Properly Functioning" with regard to road density and location/drainage network.

Proposed actions are limited to the CBW Road in this watershed. Thus, the proposed actions were determined to "Maintain" the baseline for road density location network.

Disturbance History - Page 23 of the WA says, "The combined impacts of agricultural practices, past timber harvest practices, and the associated land management activities have degraded stream habitat conditions in the Area (watershed)." Table Veg-3 (WA, page 14) indicates that although a high percentage of BLM-managed land is currently in mid- to late-seral stages; it is a small percentage of the entire land base. WA pages $40 \& 41$ highlight historic splash damming in the watershed causing bank erosion and stream scouring. These references illustrate that the watershed is "Not Properly Functioning" with respect to disturbance history.

Proposed actions are limited to human-disturbed sites (CBW Road). Therefore, the proposed actions were determined to "Maintain" the baseline for disturbance history.

Landslide Rates - Page 6 of the WA indicates that of the 182 known slides in the watershed, 63 percent were associated with recent timber-yarding; while, 16 percent were associated with roads. These data meet the criteria for "Not Properly Functioning" with regard to landslide rates. The proposed action does not include new road construction or tree removal, therefore was determined to "Maintain" the baseline for landslide rates. 
Riparian Reserves - Page 25 of the WA states that riparian buffers on BLM-managed lands are intact and that future recruitment of large wood "appears to be good." For the watershed as a whole, however, page 18 indicates that $\mathrm{C}$ type channels have had considerable disturbance of stream-side vegetation, and page 23 indicates that considerable areas on private land do not have the potential to provide large wood to the streams. Because of the riparian management on private land in the basin, the watershed was determined to be "Not Properly Functioning" with respect to Riparian Reserves.

The proposed actions will not impact any overstory riparian vegetation. Therefore, the proposed actions were determined to "Maintain" the baseline for Riparian Reserves. 
Table E-7. Checklist for Documenting Environmental Baseline and Effects of Proposed Actions on Relevant Indicators.

\author{
Name and location: Coos Bay District - BLM \\ Basin: $5^{\text {th }}$ field: Middle Main Coquille
}

\begin{tabular}{|c|c|c|c|c|c|c|}
\hline \multirow{2}{*}{$\begin{array}{l}\text { Pathways } \\
\text { Indicators }\end{array}$} & \multicolumn{3}{|c|}{ Environmental Baseline } & \multicolumn{3}{|c|}{ Effects of the Actions ${ }^{2}$} \\
\hline & $\begin{array}{c}\text { Properly } \\
\text { Functioning }\end{array}$ & At Risk ${ }^{3}$ & $\begin{array}{l}\text { Not Properly } \\
\text { Functioning }\end{array}$ & Restore $^{4}$ & Maintain ${ }^{4}$ & Degrade $^{4}$ \\
\hline $\begin{array}{l}\text { Water Quality } \\
\text { Temperature }\end{array}$ & & & WA, PJ & & PJ & \\
\hline Turbidity & & WA, PJ & & & PJ & \\
\hline Chemical Concentration/ Nutrients & & WA & & & PJ & \\
\hline $\begin{array}{l}\text { Access } \\
\text { Physical Barriers }\end{array}$ & & & WA & & PJ & \\
\hline $\begin{array}{l}\text { Habitat Elements } \\
\text { Substrate/Sediment }\end{array}$ & & & WA, PJ & & PJ & \\
\hline Large Wood & & & WA, PJ & & PJ & \\
\hline Pool Area & & WA & & & PJ & \\
\hline Pool Quality & & WA, PJ & & & PJ & \\
\hline Off-Channel Habitat & & WA & & & PJ & \\
\hline $\begin{array}{l}\text { Channel Condition \& Dynamics } \\
\text { Width/Depth Ratio }\end{array}$ & & WA, PJ & & & PJ & \\
\hline Streambank Condition & & WA & & & PJ & \\
\hline Floodplain Connectivity & & & WA & & PJ & \\
\hline $\begin{array}{l}\text { Watershed Conditions } \\
\text { Road Density and Location }\end{array}$ & & & WA & & PJ & \\
\hline Human Disturbance History & & & WA, PJ & & PJ & \\
\hline Landslide Rates & & & WA, PJ & & PJ & \\
\hline Riparian Reserves & & & WA & & PJ & \\
\hline
\end{tabular}

1. Environmental Baseline conditions are derived from BLM stream survey data and synthesis of watershed analysis findings: WA- Middle Main Coquille North Coquille Mouth Catching Creek Watershed Analyses, PJ- Professional Judgment.

2. Effects of the Actions are derived from this Biological Assessment and description of proposed project actions.

3. These three categories of function ("properly functioning", "at risk", "not properly functioning") are defined for each indicator in the "Matrix of Pathways and lndicators" (Table E-2).

4. For the purposes of this checklist (Table E-7), "restore" means to change the function of an "at risk" indicator to "properly functioning", "not properly functioning" to "at risk" and "properly functioning" moving towards recovery. "Short-term" effects, for the purposes of this checklist, are defined as: intermittent or inconsistently occurring effects (i.e., hauling more than 10 loads per day during heavy-rain events) that are brief in duration (i.e., days). "Long-term" effects, for the purposes of this checklist, are defined as consistently occurring effects (i.e., new permanent road construction) that are lengthy in duration (i.e., months/years). 


\section{RATIONALE USED IN COMPLETING THE CHECKLIST FOR DOCUMENTING ENVIRONMENTAL BASELINE AND THE EFFECTS OF PROPOSED ACTION(S) ON RELEVANT INDICATORS WITH RESPECT TO THE OLALLA - LOOKINGGLASS WATERSHED}

Note: Unless documented otherwise, the information source used for accessing the environmental baseline is contained in the Olalla-Lookingglass Watershed Analysis prepared by the Roseburg District South River Resource Area (04/02/1998). The watershed covers approximately 103,109 acres.

\section{Water Quality}

Temperature - Pages 72 and 73 from Olalla-Lookingglass Watershed Analysis (WA) indicate that the 7-day maximum water temperature of Olalla Creek exceeds $68^{\circ} \mathrm{F}$, thus meeting the criteria for "Not Properly Functioning" with respect to temperature.

These proposed actions contain no riparian overstory tree removal and were determined to "Maintain" the temperature baseline.

Turbidity - Pages 71 and 75 of the WA report that problems with turbidity were identified by DEQ on Thompson Creek within the Olalla-Lookingglass WAU. A weighted average of "Fair" was derived from ODFW habitat surveys (table C-6 in WA) of percent area covered in silt/sand in the watershed. From this data, it was inferred to be "At Risk" with respect to turbidity.

The proposed action would cross 48 intermittent and small perennial streams in this watershed when dry or during summer low flows. Of these 48 stream crossings, 30 would be trenched dry during summer construction and 8 would be in road fill. Ten small (less than $0.1 \mathrm{cfs}$ ) perennial streams would be trenched using the "bag and flume" method during low flows. Small amounts of increased transitory turbidity may occur during pipeline construction prior to seeding and mulching of ground-disturbed areas. However, the BMPs, PDCs and ECP minimize sedimentation potential to very low levels for a brief time (Appendix A). Sediment barriers and site revegetation are required throughout the construction project corridor, to eliminate continuous turbidity impacts where delivery mechanisms to streams exist. PDCs include new cross-drains in the CBW Road.

The proposed actions were determined to have insignificant effects at the site and at the $5^{\text {th }}$ field, therefore determined to "Maintain" the sediment/turbidity baseline. The effects would be insignificant because of the implementation of PDCs and the ECP (Appendix A), specifically the bag and flume technique.

Contaminants and Nutrients - Pages 72 and 75 state that one $\mathrm{pH}$ measurement collected in 1996 was 8.0, which was within the standards set by DEQ of 6.5-8.5. No assessments, measurements or duration criteria of managementrelated inputs data were collected or analyzed. Table C-6 rated organics as fair for the watershed. However, due to continued impacts from human development (residences, agriculture, logging, etc.), there is potential for future increases in contaminants. Because of this potential increase, it was determined to be "At Risk" with respect to contaminants and nutrients.

The proposed actions do not utilize chemicals in the construction process other than products for running the machinery. This project was determined to "Maintain" the chemical contaminant baseline.

\section{Habitat Access}

Physical Barriers - Pages 63 - 68 and Appendix C of the WA discuss the high road densities (greater than 3 miles of road per square mile of area) and their impacts within the Olalla-Lookingglass watershed. There are roughly 2 stream crossings per stream mile within the watershed. Some culverts in the watershed likely inhibit fish passage during high or low flows. Based on these data, it was determined to be "At Risk" with respect to physical barriers.

The proposed actions contain no new permanent in-stream structures. Hence, the proposed actions were determined to "Maintain" the baseline for physical barriers.

\section{Habitat Elements}

Substrate/Sediment - Pages 63 - 68 and Appendix C of the WA discuss the impacts of high road densities ( $>3 \mathrm{mi} /$ $\mathrm{mi} 2$ area) and their ability to increase sedimentation. Although road-related surface erosion was not quantified for this WA, pages 71 \& 75 indicate that problems with sedimentation were specifically identified by DEQ within the 
Olalla-Lookingglass watershed. Table C-6 gives embeddedness as 26 - 49 percent with cobble as the dominant substrate. This indicates that the watershed is "At Risk" with respect to substrate/sediment.

The proposed action would cross 48 intermittent and small perennial streams in this watershed when dry or during summer low flows. Of these 48 stream crossings, 30 would be trenched dry during summer construction and 8 would be in road fill. Ten small perennial streams would be trenched using the "bag and flume" method during low flows. PDCs include new cross-drains in the CBW Road.

The proposed actions were determined to have insignificant effects at the site and at the $5^{\text {th }}$ field, therefore determined to "Maintain" the substrate/sediment baseline. The effects would be insignificant because of the implementation of PDCs and the ECP (Appendix A), specifically the bag and flume technique.

Large Woody Debris (LWD) - Pages 68 and 69 state that LWD is lacking in many stream channels within the watershed because of previous stream cleaning practices. However, aquatic inventory data in Appendix $\mathrm{C}$ of the WA reports an average of 220.2 pieces of LWD per mile of stream, which is well above the criteria of greater than 80 pieces required for a "Properly Functioning" classification.

No tree removal occurs within this watershed from the proposed action. Proposed actions are limited to powerline utility corridors and the CBW Road. Hence, the proposed actions were determined to "Maintain" the baseline for LWD.

Pool Area and Pool Quality -Table C-6 gives a weighted average of "Fair" (16 - 29 percent) for the watershed as a whole with respect to pool area. According to the WA, this corresponds with the NMFS designation of "At Risk."

Proposed actions are limited to powerline ROWs and the CBW Road. Hence, the proposed actions were determined to "Maintain" the baseline for pool quality.

Off-Channel Habitat - No quantification of this indicator occurred in the WA. However, due to its high density of roads and a history of stream cleaning, severe downcutting has occurred, thus isolating the natural floodplain. From this, it was inferred to be "Not Properly Functioning" with respect to off-channel habitat.

Proposed actions are limited to powerline ROWs and the CBW Road. Hence, the proposed actions were determined to "Maintain" the baseline for off-channel habitat.

\section{Channel Condition \& Dynamics}

Width/Depth Ratio - Page 69 and table C-6 in Appendix C from the WA indicate that the width/depth ratio exceeds 12, thus meeting the criteria for "Not Properly Functioning."

Proposed actions are limited to powerline ROWs and the CBW Road. Hence, the proposed actions were determined to "Maintain" the baseline for width/depth ratio.

Streambank Condition - Page 68 from the WA discusses field surveys which found that stream channels are downcutting and causing accelerated bank erosion. It was inferred from these observations that streambank condition could meet the criteria for "Not Properly Functioning."

The proposed actions have adequate measures (Appendix A) to maintain streambank integrity during and after construction. Thus, the proposed actions were determined to "Maintain" the baseline for streambank condition.

Floodplain Connectivity - This indicator was indirectly assessed as overall hydrologic flows through out the watershed (WA, pages 59-68). Page 58 states that, "...increased drainage densities, due to road construction, may increase peak flows and mean annual floods." Based on these comments in the context of high road densities prevalent within the watershed, it was determined to be "At Risk" with respect to floodplain connectivity.

There are no activities in the 100-year floodplain within this watershed. Hence, the proposed actions were determined to "Maintain" the baseline for floodplain connectivity.

\section{Watershed Condition}

Road Density and Location/Drainage Network - Appendix C, page 63, as well as pages 66-68 from the WA, indicate that the road density/drainage network exceeds 3 road miles per square mile with an average of 4.49 miles of road per square mile. Also, many of the wider valley bottoms contain roads and many of the larger tributaries within the watershed have roads along much of their length. The watershed was determined to be "Not Properly Functioning" with respect to road density and location/drainage network. 
Proposed project actions are limited to powerline ROWs and the CBW Road. Thus, the proposed actions were determined to "Maintain" the baseline for road density location network.

Disturbance History - Pages 15-29 of the WA discuss the disturbance history of the watershed. Vegetation data from 1936, when compared with vegetation data from 1997, reveals a shift in the watershed to a higher proportion of early seral vegetation. Therefore, stem exclusion conditions are over-represented within the landscape, fragmenting the forest matrix with early seral patches (age 0-30). Also, the proportion of the landscape classified as nonforested has grown significantly, because of urban and agricultural land uses, each of which display a high intensity disturbance regime. Historically, natural disturbances such as slides, fire, storm events, etc., played a significant role in defining the landscape of the watershed (WA pages 15-29). However, landscape changes from 1936-1997 were primarily attributed to human-induced influences. Based on this information, it was determined to be "Not Properly Functioning" with respect to disturbance history.

Proposed project actions are limited to human-disturbed sites (utility corridors and roadways). Therefore, the proposed actions were determined to "Maintain" the baseline for disturbance history.

Landslide Rates - Page 53 of the WA indicates that landslide rates can be increased by human activity, such as road building. There was no quantified measure of landslide rates in the WA. However, since human impacts (such as road densities) throughout the Olalla-Lookingglass Watershed are high, it seems likely that landslide rates are above historical levels. Based on these inferences, the watershed was determined to be "At Risk" with respect to landslide rates.

The proposed action does not include new road construction or tree removal, therefore was determined to "Maintain" the baseline for landslide rates.

Riparian Reserves - Riparian reserves within the Olalla-Lookingglass basin are highly impacted and fragmented from human activities as a result of the "checkerboard" federal ownership pattern that exists within the watershed. Table C-2 shows that the Lookingglass Creek subwatershed is less than 70 percent intact. This meets the criteria for "Not Properly Functioning" with respect to Riparian Reserves.

The proposed project actions will not impact any overstory riparian vegetation. Therefore, the proposed actions were determined to "Maintain" the baseline for Riparian Reserves. 


\section{Stream Crossings with Potential for Listed Fish Presence at Pipeline Crossing Sites:}

\section{Morgan Creek, Rock Creek, and Tenmile Creek}

These three streams are located (on private ground) in the Umpqua River basin, South Umpqua River subbasin, Olalla-Lookingglass $5^{\text {th }}$ field watershed. Each of the streams supports populations of coho salmon. The Coos Bay Wagon Road crosses each of these streams utilizing short-span bridges. Based upon the small size of the streams $\left(<10^{\prime}\right.$ active channel width), bridge locations, and other complexities associated with pipeline boring technologies, it was determined that these crossings would not utilize boring techniques, or be hung on the bridges with exposed pipe. At these locations, the proposal is to cross each respective stream in the vicinity of the Coos Bay Wagon Road bridges by utilizing pipeline trenching equipment.

Juvenile OC coho salmon rear in freshwater (typically in their natal stream) for about a year before outmigrating to the Pacific Ocean, and could be in the vicinity of the project sites if water quality and temperatures are suitable. The in-stream and riparian habitat conditions adjacent to the pipeline crossing areas are moderately degraded. These conditions are primarily a result of land management practices (agricultural clearing, riparian grazing, and riparian timber harvest).

At each of the specific pipeline crossing sites, in-stream habitat consists of shallow riffles, separated by small pools. Stream gradients range from a low of approximately $2 \%$ on Morgan Creek, to a high of roughly $6 \%$ on upper Tenmile Creek. During periods of low summer flow,

surface flow virtually disappears in riffle areas of these streams, with only residual pools containing water throughout the summer. Riparian vegetation in these areas consists of sparse alder, willow, pasture grasses, and scattered conifers. The South Fork of the Umpqua River, including Ollala-Lookingglass Creek, is currently listed on the Department of Environmental Quality (DEQ) 303(d) list for water temperature, habitat, and low stream flows. Stream temperatures and flow conditions in the vicinity of the proposed crossings may reach levels that prevent salmonids from inhabiting these areas. Salmonids would most likely be found outside of these areas, in deeper, cooler pools.

Based on information gathered and interpreted by BIS staff, the proposed pipeline crossings discussed above are not likely to adversely affect OC coho salmon because: (1) Migration timing of OC coho salmon adults and smolts is such that none are likely to be present within the project areas during the proposed work period; (2) rearing juvenile (fry) OC coho salmon may be present if stream temperatures are suitable, but they would likely inhabit pools upstream or downstream of the proposed riffle crossing areas; (3) appropriate sediment control measures (bag and flume stream crossing techniques - refer to Erosion Control Plan) would maintain in-stream habitat indicators in the short-term, and minimize or eliminate turbidity effects on juvenile OC coho in the vicinity of the project areas; (4) riffle areas where pipeline trenching and construction activities would take place are likely to be dry during the period of pipeline construction; (5) vegetative disturbance would be minimal in riparian areas, so riparian habitat conditions would be maintained; and (6) effects to the stream channel (habitat alteration, etc.) would be negligible since use of equipment within the stream channel would be limited to riffle areas, and the stream bed would be restored to its original contour following trenching activities.

The scale of the action at the sites, timing and time needed to accomplish the trenching (approximately 2 hours per site) would result in insignificant effects to listed OC coho salmon. Thus, there is less than a negligible likelihood of adverse effects or incidental take of OC coho salmon occurring due to this project. 
Table E-8. Checklist for Documenting Environmental Baseline and Effects of Proposed Actions on Relevant Indicators.

Name and location: Roseburg District South River Resource Area - BLM

Basin: $5^{\text {th }}$ field: Olalla-Lookingglass

\begin{tabular}{|c|c|c|c|c|c|c|}
\hline \multirow{2}{*}{$\begin{array}{l}\text { Pathways } \\
\text { Indicators }\end{array}$} & \multicolumn{3}{|c|}{ Environmental Baseline } & \multicolumn{3}{|c|}{ Effects of the Actions ${ }^{2}$} \\
\hline & $\begin{array}{c}\text { Properly } \\
\text { Functioning }^{3}\end{array}$ & At Risk ${ }^{3}$ & $\begin{array}{l}\text { Not Properly } \\
\text { Functioning }^{3}\end{array}$ & Restore $^{4}$ & Maintain ${ }^{4}$ & Degrade $^{4}$ \\
\hline$\frac{\text { Water Quality }}{\text { Temperature }}$ & & & WA & & PJ & \\
\hline Turbidity & & WA, PJ & & & PJ & \\
\hline Chemical Concentration/ Nutrients & & DEQ & & & PJ & \\
\hline$\stackrel{\text { Access }}{\text { Physical Barriers }}$ & & WA, PJ & & & PJ & \\
\hline$\frac{\text { Habitat Elements }}{\text { Substrate/Sediment }}$ & & WA & & & PJ & \\
\hline Large Wood & WA & & & & PJ & \\
\hline Pool Area & & WA & & & PJ & \\
\hline Pool Quality & & & WA, PJ & & PJ & \\
\hline Off-Channel Habitat & & & WA & & PJ & \\
\hline $\begin{array}{c}\text { Channel Condition \& Dynamics } \\
\text { Width/Depth Ratio }\end{array}$ & & & WA, PJ & & PJ & \\
\hline Streambank Condition & & WA, PJ & & & PJ & \\
\hline Floodplain Connectivity & & & WA & & PJ & \\
\hline $\begin{array}{l}\text { Watershed Conditions } \\
\text { Road Density and Location }\end{array}$ & & & WA, PJ & & PJ & \\
\hline Human Disturbance History & & WA, PJ & & & PJ & \\
\hline Landslide Rates & & & WA & & PJ & \\
\hline Riparian Reserves & & & WA & & PJ & \\
\hline
\end{tabular}

1. Environmental Baseline conditions are derived from BLM stream survey data and synthesis of watershed analysis findings: WALower South Umpqua Watershed Analyses, PJ- Professional Judgment, and DEQ - Oregon Department of Environmental Quality.

2. Effects of the Actions are derived from this Biological Assessment and description of proposed project actions.

3. These three categories of function ("properly functioning", "at risk", "not properly functioning") are defined for each indicator in the "Matrix of Pathways and Indicators" (Table E-2).

4. For the purposes of this checklist (Table E- 8), "restore" means to change the function of an "at risk" indicator to "properly functioning", "not properly functioning" to "at risk" and "properly functioning" moving towards recovery. "Short-term" effects, for the purposes of this checklist, are defined as: intermittent or inconsistently occurring effects (i.e., hauling more than 10 loads per day during heavy-rain events) that are brief in duration (i.e., days). "Long-term" effects, for the purposes of this checklist, are defined as consistently occurring effects (i.e., new permanent road construction) that are lengthy in duration (i.e., months/years). 


\section{DICHOTOMOUS KEY FOR SECTION 7 DETERMINATION OF EFFECTS}

Name and location of action: Coos County Pipeline, route location list is on page 1 of this document, and maps are provided as attachments.

\section{Name of species: Coho salmon and Oregon Coast Steelhead}

1. Are there any proposed/listed anadromous salmonids and/or proposed designated critical habitat in the watershed, or downstream from the watershed?

$\mathrm{NO}$ No effect

YES May affect, go to 2

2. Will the proposed actions have any affect whatsoever on the species and/or critical habitat? NO. No effect

YES Go to 3

3. Do the proposed actions have the potential to hinder attainment of relevant properly functioning indicators (from checklist)?

NO Go to 4

YES. Likely to adversely affect

4. Does the proposed action(s) have the potential to result in "take" of proposed/listed anadromous salmonids, or destruction/adverse modification of proposed/designated critical habitat?

A. There is a negligible probability Not likely to adversely affect

B. There is more than a negligible probability Likely to adversely affect 


\section{LIST OF REFERENCES}

Coos Bay District, Bureau of Land Management. September 30, 1999. East Fork Coquille River Watershed Analysis. North Bend, Oregon.

Coos Bay District, Bureau of Land Management. July 20, 2001. North Fork Coquille Watershed Analysis. North Bend, Oregon.

Coos Bay District, Bureau of Land Management. September 30, 1997. Middle Main Coquille Watershed Analysis. North Bend, Oregon.

Coos Bay District, Bureau of Land Management. January, 2002. Coos County Pipeline Draft Environmental Impact Statement.

Oregon Department of Fish and Wildlife. 2000. Oregon Guidelines for Timing of In-Stream Work to Protect Fish and Wildlife Resources.

Oregon Department of Transportation. December, 1999. Erosion and Sediment Control Manual.

Porior, Don. January, 2000. Designing For Stream Simulation At Road Crossings.

Roseburg District, Bureau of Land Management. April 2, 1998. Olalla-Lookingglass Watershed Analysis. Roseburg, Oregon.

Roseburg District, Bureau of Land Management. May 30, 2000. Lower South Umpqua Watershed Analysis. Roseburg, Oregon.

USDA and USDI. 1994. Standards and Guidelines for Management of Habitat for Late-Successional and OldGrowth Forest Related Species Within the Range of the Northern Spotted Owl ROD.

USDA and USDI. 2001. Record of Decision (ROD) and Standards and Guidelines for Amendments to the Survey and Manage, Protection Buffer, and other Mitigation Measures Standards and Guidelines. Portland, Oregon.

USDA Forest Service. 1991. Road Construction and Maintenance In: Influences of Forest and Rangeland Management On Salmonid Fishes and Their Habitats. W.R. Meehan, editor. pages 297-323.

USDA Forest Service and US Department of Transportation. November 1990. Fish Passage Through Culverts. $67 \mathrm{pp}$.

USDA Forest Service. 1973. Protecting Fish Habitat During Forest Road Development.

USDI Bureau of Land Management. 1986. Northwest Area Noxious Weed Control Program Record of Decision (ROD). Portland, Oregon.

USDI Bureau of Land Management. 1987. Supplement to the Northwest Area Noxious Weed Control Program Record of Decision (ROD). Portland, Oregon.

USDI Bureau of Land Management. 1995a. Record of Decision (ROD) and Resource Management Plan. Coos Bay Oregon and Roseburg, Oregon 


\section{Appendix A: \\ Design, Construction, Operation \& Maintenance Plan}

(Note: this is a revised version of Appendix J from Coos County Pipeline EIS Published January 2002) 


\section{Appendix B: \\ Erosion Control Plan}

(Note: this is a revised version of Appendix $\mathrm{H}$ from Coos County Pipeline EIS Published January 2002) 


\section{Appendix E1. Essential Fish Habitat Assessment}

There have been no significant changes to this appendix.

ESSENTIAL FISH HABITAT ASSESSMENT for the COOS COUNTY NATURAL GAS PIPLINE, COOS BAY DISTRICT, BUREAU OF LAND MANAGEMENT, COOS COUNTY, OREGON

Prepared By: Brian Cox

Biological Information Specialists, Inc.

P.O. Box 27

Camas Valley, OR 97416

October 1,2001 


\section{INTRODUCTION}

Coos County proposes to construct a natural gas pipeline from Roseburg, Oregon, to Coos Bay, Oregon. This pipeline is approximately 60 miles in length and crosses approximately 3 miles of land managed by the Bureau of Land Management (BLM), Coos Bay District.

\section{PURPOSE}

An Essential Fish Habitat (EFH) assessment is required to ensure BLM actions and/or proposed actions on BLM lands are compliant with the Magnuson-Stevens Fishery Conservation and Management Act. EFH is defined as those waters and substrate necessary to fish for spawning, breeding, feeding or growth to maturity.

\section{BACKGROUND}

The act was originally passed in 1976 and provided the NMFS legislative authority for fisheries regulation in the United States offshore areas. The 1996 amendments to the Act require the identification of EFH for federally managed fish species and implementation of measures to conserve and enhance this habitat as described in federal fishery management plans. Essential Fish Habitat designated by the Pacific Fisheries Management Council includes freshwater habitats in BLM administered lands in California, Oregon, Washington and Idaho.

The Act requires all federal agencies to consult with National Marine Fisheries Service (NMFS) on all new federal actions that have been determined to adversely affect EFH.

Consultation is not required for existing actions, nor for actions determined not likely to adversely affect EFH.

\section{POLICY/ACTION}

I. For any project within designated EFH areas, the project-level National Environmental Policy Act (NEPA) analysis must assess potential effects to EFH, and the results of that analysis must be documented in the Environmental Impact Statement (EIS) or Environmental Assessment (EA) for the project.

II. If the EFH effects analysis supports a conclusion that EFH will not be adversely affected, no EFH consultation with NMFS is required.

III. If the EFH analysis results in a conclusion that adverse effects to EFH may result from the action, EFH consultation with NMFS is required.

\section{CONCLUSIONS}

The Aquatic Ecosystem Assessment (Appendix E of this EIS) evaluates impacts of the proposed action as compared to baseline conditions for each watershed occurring within the proposed action area with respect to "Matrix of Factors and Indicators" (NMFS 1998). NMFS has determined this assessment to be adequate for assessing EFH (Frank Bird pers. com.). Potential impacts from both the Hwy 42 alternative and proposed action were determined to "Not Adversely Effect" with respect to EFH. 


\section{Appendix F. U.S. Fish and Wildlife Service Endan- gered Species Consultation Letter of Concurrence}

The following changes between the Draft and Final Environmental Impact Statement were made in Appendix F.

- The USFWS Endangered Species Consultation Letter of Concurrence was not available prior to the publication of the Draft EIS. This has now been received and inserted into this appendix..

United States Department of the Interior

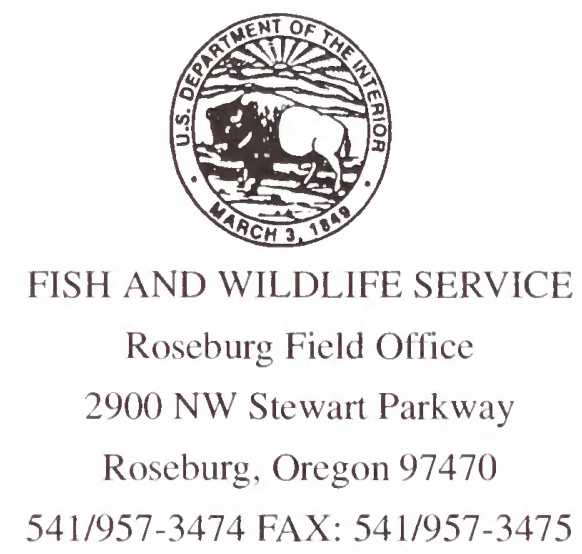

Reply to: $8330.2764(02)$

File name: BLM-CoosCo. Pipeline February 12, 2002

TS\#: 02-635

Memorandum

To: Sue E. Richardson, District Manager, Coos Bay District, Bureau of Land Management

From:Craig A. Tuss, Field Supervisor, Roseburg Field Office, U.S. Fish and Wildlife Service

Subject:Request for Section 7 Consultation and written concurrence on effects determinations for the Coos Country Natural Gas Pipeline in Coos and Douglas Counties, Oregon (\#1-15-02-I-276).

This responds to your January 18, 2002 request for written concurrence with your determination of effects for the subject project. Consultation was initiated on January 18, 2002 when the U.S. Fish and Wildlife Service (Service) received your written request. This consultation is being conducted pursuant to section 7 of the Endangered Species Act of 1973 (16 U.S.C. 153 et seq.), as amended. This consultation is based on information provided to the Service in 
conversations between our staffs, in your written correspondence, the Environmental Impact Statement (EIS) and the Biological Assessment prepared by your consultant, Brian Cox, of BIS, P.O. Box 27, Camas Valley, OR, which was received with.your consultation request letter. At issue in this consultation are the impacts of the subject project on the northern spotted owl (Strix occidentalis caurina) (spotted owl) and marbled murrelet (Brachyramphus mannoratus) (marbled murrelet).

You requested written concurrence with your determination that the proposed project "may affect, but is not likely to adversely affect" spotted owls or marbled murrelets, "and there is "no affect" on their critical habitats". You also determined that the project would have no affect on the bald eagle (Haliaeetus leucocephalus). The EIS stated that field surveys found no listed, proposed, or candidate plant species within the proposed action area. Therefore, the extent of the impacts are limited to possible disturbance to spotted owls and marbled murrelets from human activity and noise produced by the associated construction equipment during the construction of the pipeline.

Because the proposed action is not anticipated to affect these species or their habitats, the following will not be addressed further in this consultation: spotted owl critical habitat, marbled murrelet critical habitat, and bald eagle. (Haliaeetus leucocephalus). Any potential impacts to listed anadromous fish species should be addressed in a separate consultation with the National Marine Fisheries Service.

According to information provided to the Service, the proposed 59.1 mile long 12 inch steel pipeline will be buried underground and the only above ground components will be plastic line markers, test stations and various valve features. The requested permanent right-of-way width is 40 feet ( 20 feet either side of the pipeline). The easement on Bureau of Land Management (BLM) lands would total approximately 13 acres. Additional construction width would range from 10 to 40 feet, depending on slope and soil conditions. This additional area for construction would involve a possible 7 acres which would be restored and returned to BLM control after pipeline construction and site restoration. All wetland areas and stream crossing impacts will be avoided by directional drilling.

The proposed route is within existing right-of-ways of the Bonneville Power Administration and the CBW Road, and would bisect two spotted owl Critical habitat Units and one murrelet critical habitat unit. Because the proposed route is within existing right-of-ways of the Bonneville Power Administration and the CBW Road, the construction activities will not remove or degrade suitable habitat.

In general, construction activities in the project area with the potential to disturb spotted owls and marbled murrelets would not occur during their critical breeding season of March 1st to June 30th (owls) and April 1st to August 5th (murrelets). These restrictions would be imposed within their species-specific disturbance. areas of 0.25 mile (See attached project design criteria). Blasting would not be done within one mile of occupied spotted owl nest sites from March V to September 30Ih, suitable habitat March I to June 30", or marbled murrelet occupied or unsurveyed suitable habitat from April 1st to September 15th. No new roads will be constructed and no helicopter activities will occur.

The construction of the pipeline may affect spotted owls and marbled murrelets, because of short-duration $(<10$ days $)$ moderate noise above normal ambient levels. Project design criteria have been designed to minimize potential disturbance effects detrimental to any listed species by providing daily and seasonal timing restrictions within established buffer zones that should eliminate all adverse affects (See attached). Therefore, the Service concurs with your determination that the project, "may affect, but is not likely to adversely affect" the spotted owl or marbled murrelet.

This concludes informal consultation on the proposed Coos County Natural Gas Pipeline Project. If any changes to the proposed project occur or new information becomes available, reinitiation of consultation may be required. If you have any questions, please contact David Peterson at 541/957-3471 or myself.

Attachment (1)

cc: (with attachment)Lee Folliard, OFWO, Portland, OR

Office Files, OFWO, Portland, OR

Ken Phippen, NMFS, Roseburg, OR 


\section{BIOLOGICAL ASSESSMENT}

\section{FOR THE COOS COUNTY PIPELINE}

\section{PROJECT DESIGN CRITERIA}

Project Design Criteria (PDCs) are mitigation measures applied to project activities to minimize potential detrimental effects to proposed or listed species. Some PDCs apply to all species, but most apply to specific species. Habitat removal and/or degradation and disturbance are considered for this proposed project. In general, project areas with the potential to disturb spotted owls, marbled murrelets and bald eagles would not occur during their critical breeding season if their actions would occur within their species-specific disturbance-buffer.

"Habitat or Individuals" PDCs apply in situations where currently suitable habitat will be affected or where individual animals could be directly or indirectly affected (e.g. actually harms or kills).

"Disturbance" PDCs apply to projects that do not affect currently suitable habitat, but where animals near suitable habitat could be disturbed.

\section{Bald Eagle}

Habitat or Individuals

(I) No suitable habitat trees will be cut.

\section{Disturbance}

(I) Work activities that cause disturbance would not take place within 1312 feet $(400 \mathrm{~m})$ of active nests and roosts, or within 2625 feet $(800 \mathrm{~m})$ line-of-sight from nests and roosts during periods of eagle use unless field surveys demonstrate that the nest or roosts are not being used during the normal season of use. For nests, the period of eagle use is January 1 st to August 31 st (or two weeks postfledging). For roosts, the period of eagle use is November 15 th to March 15th.

(II) No helicopter activities will occur.

\section{Northern Spotted Owl}

Habitat and Individuals

(I) No suitable habitat will be removed.

\section{Disturbance}

(I) Work activities such as trenching, road reco siruction and repaving, etc. will not take place within 1/4mile of any nest site or activity center of known pairs and resident singles between March $\mathrm{V}^{\prime}$ and June $301 \mathrm{~h}$.

(II) The boundary of the 1/4 mile "disturbance-free" area may be modified on a site-specific basis due to topographic breaks or other localized factors.

(III) This PDC may be waived in a particular year if nesting or reproductive success surveys conducted according to the Service-endorsed survey guidelines reveal that spotted owls are non-nesting or that no young-of-the-year are 
present. Waivers are only valid until March I" of the following year. Previously known sites and activity centers are assumed occupied unless surveys indicate otherwise.

(IV) No helicopter activities will occur.

(V) Blasting would not occur within one (1) mile of suitable habitat March 1st, to June 30th.

(VI) Blasting would not occur within one (1) mile of known nest sites March 1st to September 30th unless the Service's protocol surveys indicate: 1) owls are not present; 2) owls present are not nesting, or 3) the young-of-the year have dispersed.

\section{Marbled Murrelet}

Habitat or Individuals

(I) No suitable habitat will be removed.

Disturbance

(I) Daily timing of the project's "Moderately above ambient noise levels for $<1$ week" and related activities 'occurring within 1/4 mile of unsurveyed suitable habitat, shall be no earlier than 2 hours after sunrise and no later than 2 hours before sunset from April 1st to August 5th.

(II) Daily timing of the project's "Moderately above ambient noise levels for $<1$ week" and related activities occurring within '/4mile of occupied habitat, shall be seasonally restricted from April 1st to August 5th.

(III) Daily timing of the project's "Moderately above ambient noise levels for $<1$ week" and related activities occurring within $1 / 4$ mile of occupied habitat, shall be no earlier than 2 hours after sunrise and no later than 2 hours before sunset from August 6h to September 15th.

(IV) No blasting will occur within one mile of occupied habitat or within one mile of unsurveyed suitable habitat April 1st to September 15th.

(V) No helicopter activities will occur. 


\section{Appendix G. Questions and Concerns from the Public}

No significant changes have been made to this section.

The questions and comments listed below are derived from the many questions and comments sent from the public as a result of the public meetings and publications made available to the public. In many instances, the questions and comments of various individuals addressed the same issue. These questions or comments were addressed with a single question or comment. Some of the questions were received while an Environmental Assessment (EA) was being worked on and some were received during the public comment period (and later) for this EIS. Thus, there are references to both an EA and EIS within this Appendix.

As much as possible, the questions and comments (within their respective sections) are arranged keeping similar topics together.

\section{Questions from the Public}

\section{Question:}

Why is the pipeline route changed from the route proposed in the referendum (Hwy 42) submitted to the voters in November of 1999 ?

Answer:

The Highway 42 route was chosen by the County's bond issue consultant RMI Navigant, who also assessed the CBW Road. Navigant said the choice between the two routes was difficult but they narrowly preferred the Highway 42 route because of their belief environmental permitting would be easier — such is probably not the case. Relative to the original Highway 42 route, the now-preferred CBW Road is about 25 miles shorter, about $\$ 20$ million less expensive to construct, and the pipeline will be much less susceptible to thirdparty dig-in damage. The currently proposed route impacts far fewer streams and wetlands, and will not disrupt traffic on Highway 42 for thousands of travelers per day during construction. Additionally, worker safety will be greater on the CBW Road versus working on the Highway 42 route

2. Question: The questions of two individuals are addressed together in Question 2.

Given the current BPA moratorium on installation of pipelines in their ROW, what are the risks of having a natural gas pipeline in the vicinity of a power line ROW? Why are the risks not significant? Is it wise to use utility corridors for the pipeline corridor?

Answer:

The primary perceived risk of locating a gas pipeline near a power line is related to a gas explosion or fire which could possibly damage a tower or a conductor. Such events could also cause a forest fire, which could spread and cause damage to the electrical system. Natural gas pipeline incident statistics indicate that the risk for significant damage to occur to the BPA electrical system is very small. In fact, there has never been a report of such an incident in the history of gas pipeline safety regulation by the US DOT since 1970.

Because the risk is insignificant compared with reduced impact on environment and population, most Federal, state and local government agencies prefer to have gas pipelines located in existing utility corridors, such as the preferred CBW Road/BPA/PP\&L route.

\section{Question:}

Is it true the pipeline will be installed under an elementary school and within its playground located within the eastern end of the corridor? If so, what direct, indirect, or cumulative effects are involved at this location? 
Answer:

The pipeline will not be installed under a school, nor will it be installed closer than 50 feet to any occupied building. The preferred route follows a PP\&L power corridor which passes about 300 feet south of the Lookingglass School in Douglas County. Even a catastrophic failure of the pipeline could not be expected to damage the school at that distance.

4. Question: The questions of two individuals are addressed together in Question 4.

Is the Environmental Assessment study assessing the impacts on county and private lands (including infringement of rights held by private land owners) located along the proposed pipeline corridor?

\section{Answer:}

The environmental study must, by law, assess the impacts of the proposed pipeline on all lands, regardless of ownership. The entire 60-mile route is reviewed, even though the current proposal will only impact approximately 3 miles of BLM land.

\section{Question:}

Will this pipeline cause future problems if roads in which it is constructed are closed, restored or recontoured?

Answer:

There is almost no chance of any road along the preferred route being closed. If the road is closed, the pipeline will not be impacted. If restored or recontoured, the location of the pipeline will be considered when the work is done.

\section{Question:}

What rural fire protection access is available along the pipeline route (in the event of an pipeline accident causing a fire)?

Answer:

Rural Fire Departments are located at Lookingglass, Dora, and Fairview. Fire equipment is also located at Winston and Roseburg in Douglas County, and Coquille, Myrtle Point, Millington and Coos Bay in Coos County. Federal regulations (49CFR 192.615) provide that local emergency response personnel be informed about the pipeline location and operations and be involved in the development of emergency response plans for the pipeline.

7. Question: The questions of two individuals are addressed together in Question 7.

In the event of a gas line explosion or a leakage causing stream pollution, will the county have insurance coverage for such an event? Could you please explain the likely process for cleaning up surface or ground water polluted from a natural gas leakage? What consideration will be given to fish kill and fish or marine habitat destruction? Will such an event be a taxpayer liability?

Answer:

Natural gas is composed of inert components and consequently does not pollute or dissolve into water. Natural gas is 35\% lighter than air. Any gas leak from the pipeline would pass through the soil or groundwater and then dissipate into the air. There is usually no effect of a gas leak on habitat, fish or wildlife. A catastrophic failure of this 12-inch pipeline at its usual operating pressure may cause surface damage within about 50 feet of the rupture. The gas escaping from a pipeline rupture could explode or otherwise burn if a source of ignition is contacted by the gas; therefore, a larger area could be affected by a fire. Once the gas flow is shut off, there would be no residue left from the gas. In comparison, a petroleum liquids pipeline rupture would spill products that could leave behind residual product that would require a "clean-up" operation even after the pipeline had been shut off. With regards to taxpayer liability, Coos County will carry general liability insurance to cover potential losses and to limit taxpayer liability. 


\section{Question:}

Given the fact construction activities are noisy, are the sensitive raptors, protected under the Endangered Species Act, given full consideration in the Environmental Assessment regarding their need for quiet nesting habitat (Spring survey requirements, for example)?

\section{Answer:}

Any effects of construction, including noise and dust, will be of a short duration. For a typical quarter mile section of pipe, the entire construction sequence will likely be started and finished within a week. Coos County has agreed to abide by any time-of-day and time-of-year restrictions on work for raptors and other species. All sensitive and T\&E sites have been identified through surveys, and these are directly addressed in the Terrestrial Biological Assessment (for the U.S. Fish \& Wildlife Service Letter of Concurrence) and the Environmental Assessment.

\section{Question:}

What are the current decisions and contingencies of the communities of Coquille, Myrtle Point, Bandon and North Bend regarding their commitment to hook up secondary (feeder) pipelines to the porposed pipeline?

Answer:

Refer to the answer given for Question 10 for information regarding North Bend hookups. Coquille and Myrtle Point are included in the NW Natural exclusive territory. NW Natural has agreed to terms with Coos County that will require NW Natural to perform market surveys in each community and to construct a substantial distribution system in each town within 3 years of Coos County starting construction of the pipeline. Bandon distributes electricity within its incorporated area, and they have asked to be removed from NW Natural's expanded territory application with OPUC. Bandon will be asked to decide who (if any entity) will distribute gas in Bandon, before their pipeline lateral is built from Coquille.

\section{Question:}

Exactly where (street location) are the "city gates" for the pipeline's natural gas deliveries to the cities of Coos Bay, North Bend, Coquille, and Myrtle Point?

Answer:

The exact location of "gate stations" will depend on the availability of a small parcel (about 50 feet square) of land. A gate station is currently planned near Ocean Blvd. in the Coos Bay / North Bend area on Water Board property. The Coquille and Myrtle Point gate stations would be along Highway 42 or existing railroad grade corridors.

\section{Question:}

Is Bandon planning to hook up to the proposed pipeline?

\section{Answer:}

There are no definitive plans for Bandon, until it decides its fate (refer to the answer given for Question 9).

\section{Question:}

Will all the pipeline laterals (to areas other than Coos Bay) be in place when taxpayers begin paying down the bond for the pipeline's costs?

Answer:

Yes. The laterals are included in the current project plan and cost estimates, and will be built soon after the mainline construction begins.

\section{Question:}

Will the lateral pipelines to these "gates" impact more BLM lands? 
Answer:

The laterals will not be located on BLM or other Federal land.

14. Question: The questions of several individuals are addressed together in Question 14.

Given the fact (the policy decision) the proposed natural gas pipeline is supposed to attract heavy industry to the County, due to the newly available supply of "cheaper energy" (natural gas), how are the following questions answered:

a. What is driving this desire for attracting heavy industry as opposed to being content with attracting industries whose needs are met with the fiber-optic line recently established?

Answer:

Natural gas will benefit ALL energy users in the service area, from existing industries to schools, hospitals and public buildings, restaurants and other businesses, and individual homes. Any business - "heavy" or "light" - will benefit if energy costs are lower.

b. What are the motives of the major participants promoting this policy?

Answer:

Coos County government and community leaders wish to stabilize the local economy by making the area more attractive to new and established commerce through lower energy costs.

c. Are land use planning considerations (state regulations) being utilized to determine industrial siting?

Answer:

Coos County is required to follow all land use regulations.

d. Will the U.S.A. trend toward more tourism and less manufacturing cause this policy to fail simply because it is based on a false premise for promoting economic development?

Answer:

Without regard to the "U.S.A. trend toward to more tourism and less manufacturing", "manufacturing" is not the only type of economic development that could possibly be attracted to Coos County as a result of the natural gas pipeline project.

e. Does the Environmental Assessment assess heavy industry's impacts (direct, indirect, and cumulative effects) to the estuary, to the waters of Coos Bay, and to the waters of the oceanline?

Answer:

No. The Environmental Assessment must consider impacts enabled by the pipeline construction, but it does not address speculative issues such as the impact of any or all of the thousands of possible industrial processes which use natural gas. Once a specific project is proposed, the impact of that project would be addressed in a separate document.

f. Does the Environmental Assessment assess industry-caused impacts to the visual, sound and air quality of the region surrounding the industrial park (the airport area, and the North Spit)? 
Answer:

No. It is not possible to know what future industries, if any, will locate in the area. It is accurate to state that any use of natural gas will reduce air pollution from existing processes and energy uses.

g. Does the Environmental Assessment assess the impact to the County if retirees move out of the County to get away from the heavy industry?

Answer:

No. It is not possible to state whether a possible future industry would change the quality of life in Coos County, as this is speculative. If a new industry or business is recruited for Coos County, the environmental impacts (if any) will have to be weighed against the economic impacts (if any) of the quality and quantity of jobs brought in.

h. Does the Environmental Assessment assess the impact of new heavy industry on the fishing and tourism industry already established in the County?

Answer:

No, that would be a speculative assessment.

i. Does the Environmental Assessment assess the potential for increases in the already-high risk and high incidence of lung cancer, bronchial asthma and other respiratory problems known to exist in the County?

Answer:

Yes. Since most existing energy needs other than from electricity are supplied through fuel oil, bunker fuel and wood waste, the use of cleaner-burning natural gas is expected to improve air quality.

15. Question: The questions of two individuals are addressed together in Question 15.

Are the road systems and the railroad system leading to the potential industrial sites (the North Spit and the airport areas) adequate for the required shipments of raw materials and finished products.

Answer:

This issue is not pertinent to this Environmental Assessment.

\section{Question:}

What will be done with the industrial waste produced by the heavy industry this pipeline is supposed to attract? What level of toxic wastes from these newly introduced industries (utilizing natural gas) will be allowed to flow into the waters, the air or the soils? Will the release of such toxic wastes cause a transition from "acceptable" to "significant and unacceptable" levels of change in the ecosystems of the bay (including its estuaries) and the population (people and wildlife)?

Answer:

These issues are not addressed in the Environmental Assessment, since they are not pertinent to the proposed action, which is construction and operation of a natural gas pipeline. The question issues regarding toxic wastes would be addressed through the permitting process when a specific project is proposed. 
17. Question: The questions of two individuals are addressed together in Question 17.

Since the private sector found this pipeline project to be economically infeasible, and since the County failed to properly manage the land fill/incinerator facility (referring to the recent embezzlement case), what makes the County believe it will succeed in proper management of the proposed pipeline operation (which should include economic success)?

Answer:

No private company would bear the risk of the pipeline investment without a guaranteed market. The Coos County project cannot be slowly developed - it is 50 miles of pipe to the first customer of any size. Most pipeline and utility companies, such as Williams and NW Natural, have dozens of projects which can earn their expected rates of return, so there is no reason for them to take much risk. The State of Oregon granted the project \$24 million to aid in economic development. With that grant covering most of the risk, the project is feasible. The County plans to contract operations and maintenance of the pipeline to experienced pipeline operators. Additionally, the County will have contracts with shippers that will ensure recovery of operating expenses.

\section{Question:}

Do we really want the County owning another utility (the gas pipeline)? Is not this a trend toward more Socialism? Do the principles of Socialism really work?

Answer:

Without speculating on the "principles of Socialism", the concept of publicly owned utilities is very well proven. Most cities and towns own and operate their own water and sewer systems. Much of the country's electricity distribution is done by not-for-profit public agencies such as City of Bandon, Coos-Curry Electric and the Bonneville Power Administration. Also, the "utility" function will be served by NW Natural, not Coos County. Coos County will not be directly involved with the distribution of natural gas to the public, but rather only the transportation of natural gas to NW Natural.

\section{Question:}

Is there really enough evidence to support a likely improvement to the economic status of Coos County once the proposed pipeline is established?

Answer:

There are dozens of pipeline extensions around the U.S. with which to compare the Coos County pipeline. In each case, natural gas captures a significant portion of the heating load within the first few years. Refer to the economic analysis in this Environmental Assessment for quantitative evidence supporting economic improvements to the County from the pipeline. (Note: The economic analysis is contained in Chapter 4 of the EIS).

20. Question: The questions of several individuals are addressed together in Question 20.

Does the Environmental Assessment include an assessment for each of the tax implications listed below?

a. The tax burden to the County residents will be increased, due to the passage of ballot measure \# 6-63

(Nov. 1999). Indirect tax increases may result, due to the need for road improvements to accommodate the needs of heavy industry, which might be attracted to the County.

Answer:

The EA is not required to review a ballot measure already voted upon. The County residents voted in a 1999 double majority (i.e., more than half the registered voters voted, and a majority of those voting approved the measure) to authorize up to $\$ 27$ million in county bonds to fund the balance of the pipeline project. Roads and road improvements are paid for with gas tax monies only. 
b. The tax burden coald shift if new large employers - coming to invest in the "Enterprise Zone" of the Coos Bay/North Bend area - are given 15 years of exemption from real estate taxes, plus a $62 \%$ payroll tax credit.

Answer: This issue is not pertinent to the EA.

c. The impact of the tax burden (imposed from passage of the bond initiative approved for the pipeline project) as it relates to the scenario which lacks major industrial commitments to purchase natural gas.

Answer:

The county has committed that the pipeline will not be built unless the annual operating expenses will be covered by gas transporters. NW Natural has agreed to this concept. Thus, the lack of a major industrial commitment will not affect the County's coverage of operation and maintenance costs (O\&M costs), nor will it change the cost of the project or repayment of county bonds.

d. Changes to real estate values (especially to properties of the North Spit, where heavy industry is expected to locate its facilities).

Answer:

This issue is highly speculative, and it is not part of the EA.

\section{Question:}

Does the proposed action have potential of causing deregulation of electrical utilities in the state of Oregon? Answer:

No.

22. Question: The questions of several individuals are addressed together in Question 22.

Does the Environmental Assessment address the economic concerns listed below?

a. Changes to current market conditions — due to supply and demand — can and do occur; is the proposed action economically viable when such conditions change (including the pricing of natural gas, the pricing of alternate forms of energy, and the pricing of manufacturing raw materials which new industries attracted to Coos County might depend upon)?

Answer:

We do not expect the economics of the pipeline project to changc over time. Please review the economic assessment in this EA (Chapter 4 of the EIS). Wholesale prices of energy media (natural gas, propane, fuel oil, electricity, bunker fuel, coal, wood waste) fluctuate widely. The major energy media are traded on the commodity markets, but the prices of each of the media are related closely to one another (i.e., pricing of propane relates to pricing of natural gas and oil, and pricing of electricity relates to pricing of coal and natural gas), and they are loosely related to all of the others. In the last three decades, those price relationships have been out of synchronization only briefly. There is no fundamental reason or mechanism which should change the relationship between natural gas and its alternate forms of industrial energy. Raw materials prices are largely connected to energy prices. Therefore, the component costs of manufacturing and commerce rise and fall together (in general).

b. The proposed action could have adverse impact to existing businesses in Coos County. 
Answer:

The EA includes an updated economic analysis done by ECO Northwest, which published earlier studies for use in the bond election (see Chapter 4 of the EIS). This analysis lists several propane and fuel oil businesses which may be adversely affected by natural gas availability. There are no other entities which are expected to be significantly and negatively impacted by this project.

c. The gas distribution company's actions could adversely affect future pipeline operations. (Lack of commitment, for example, to invest sufficient funds for marketing and delivering the natural gas to a suitable customer base within the County).

Answer:

NW Natural has agreed to a contractual commitment to a significant construction and marketing effort which will result in widespread availability and use of natural gas.

\section{Question:}

What arrangements will ensure the pipeline's self-sufficiency (i.e., operating costs and contingency funds will be paid on an on-going basis)?

Answer:

Refer to the answer given for Question 20c.

24. Question: The questions of two individuals are addressed together in Question 24.

The proposed action needs "firm capacity demands" (For example, potential customers giving Letter of Intent to purchase natural gas, or the natural gas distribution company obligates itself to purchase the amount of gas required to make the County's costs for operating the pipeline economically viable) to assure its success over the first 5 years of its operation. Are such assurances being given?

Answer:

As long as the O\&M costs are a contractual obligation paid by shippers (see 20c, 22c and 23 above), the County does not need "firm capacity demands" in order to pay operating and maintenance costs.

25. Question:

Will NW Natural pay the cost to extend the pipeline across the bay to the "North Spit"? Answer:

Yes - NW Natural or some entity other than Coos County will pay for the cost of the connection to the North Spit.

\section{Question:}

What "surcharges" could be applied (by Northwest Natural Gas) to the gas users? Under what conditions would these surcharges be applied?

Answer:

There is currently no plan by NW Natural to charge a "surcharge" to Coos County natural gas customers.

\section{Question:}

Why was the MOU between the County and BLM not available to the public until four months after it was created? Answer:

The MOU is a public document, which has been discussed for months. It has been available upon request 
since its execution last summer.

\section{Question:}

Where is the County's "Plan of Development" for the proposed action?

Answer:

There is no section titled "Plan of Development" in the EIS, but wording equivalent to that required by a

"Plan of Development" is included in EIS; incorporating descriptions of the project, the project route, and the construction processes required to complete the project.

\section{Question:}

Are the BPA studies (for the Draft EIS for the 500 kilowatt [Kw] transmission line project) truly qualified as a source of data for the Environmental Assessment of the proposed corridor, since this Draft EIS never received public review?

Answer:

The BPA process gathered a Iot of pertinent information on the exact route now deemed the preferred route. The information also received public review through public meetings, although the EIS was never finalized. The Project Advisors and B.I.S., Inc. have added much pertinent information to the BPA efforts. All of the old and new data will be analyzed and available for review.

\section{Question:}

What assurances (documentation) can the following entities give to show an unbiased approach to the EIS (no financial interest will accrue to them upon acceptance of this project, and they have no other interest driving them toward causing the acceptance outcome of this project)?
a). Coos Bay BLM District
b). Pipeline Solutions Inc.
c). Industrial Gas Services, Inc.
d). BIS, Inc.
e). Coos County Commissioners

Answer:

A statement of financial disclosure was submitted to the BLM for the Project Advisors (Pipeline Solutions, Inc., and Industrial Gas Services, Inc.) and for the environmental contractor, BIS, Inc. The Coos County Commissioners represent Coos County and, although Coos County will economically benefit from the proposed action, the Coos County Commissioners, as publicly elected officials, are prohibited by state Iaw from personally receiving economic benefit from the proposed pipeline project. The Coos Bay BLM District is the agency overseeing development of the EA (and subsequent EIS) and thus can have no financial interest or benefit accruing from approval of the proposed pipeline project.

\section{Question:}

There have been indications that the proposed route will cross some Indian campgrounds and burial grounds. Have the affected tribes been consulted?

Answer:

The pipeline ROW were purposely chosen to avoid known Indian archaeological sites. The Indian tribes in Coos County have been consulted throughout the entire permitting process and will identify any areas of concern. Additionally, representatives from the Indian tribes will be on site or readily available during construction to help identify any archaeological sites located during construction. 


\section{Question:}

Will the EIS determine the effects to the environment if the pipeline were subject to rain storms causing normal and abnormal landslides in the notoriously unstable Coastal Mountain range? The 100 year flood event must be considered.

Answer:

The pipeline ROW were purposely chosen to avoid potential slide areas. Geotechnical concerns, including the possible impact of a "100 year flood event", have been addressed in the geotechnical report.

\section{Question:}

I am confused about the relationship of the different players, specifically: BLM, the County, Project Advisors, Pipeline Solutions, Inc., Industrial Gas Services, Inc., and Biological Information Specialists. The Information for Environmental Assessment states that the "Project Advisors cannot prepare the EA." But the project advisors and the regional firm selected to prepare the EIS, BIS, have the same e-mail address. Is it true that the consultants, Industrial Gas Services and Pipeline Solutions have no financial or other interest in the outcome of the Environmental Analysis? Did they also sign a Statement of Financial Interest as required by 40 CFR 1506.5 (c)?

Answer:

Steve Shute is principal of Pipeline Solutions, Inc., and Steve and Bob Oxford are Vice President and President, respectively, of Industrial Gas Services, Inc. Both companies are jointly under contract with Coos County as Project Advisors.

Neither company has a financial ownership interest in the pipeline project nor has the BLM required either company to file a Statement of Financial Interest. In order to address the concern presented above, both companies have signed a Statement of Financial Interest and that Statement is on file with the BLM. Biological Information Specialists, Inc. (BIS) is a contractor hired by the County to perform the environmental work required by the BLM's MOU and revised MOU. As a contractor performing environmental services, BIS has signed and filed a Statement of Financial Interest with the BLM. Brian Cox is the principal contact with BIS for the EIS work.

The "coosproj" e-mail address was set up as a convenient site to use when collecting comments during the EA process. All comments received at the coosproj address were also forwarded to the BLM and to BIS. Occasionally, a Project Advisor responded directly to comments received at the coosproj e-mail address but those comments were also forwarded to others involved in the project.

\section{Question:}

Will the Environmental Assessment be released by the BLM for public review?

Answer:

The EA was never completed and is not considered a final document by the BLM. Because the EA was not completed, it will not be released to the public. An EIS is being prepared and will be available to the public for review and comments.

\section{Question:}

I have concerns regarding the fact that the Environmental Assessment study plans to utilize studies done by BPA for the Transmission Line EIS but which have not even been published in draft form for public perusal. I question the use of such studies in a process which has the potential for bypassing public input.

Answer:

Questions about an EA are moot because the Coos Bay BLM has decided to abandon work on an EA and to begin work on an Environmental Impact Statement. The terms under which that work will be performed were clearly stated to the public and are addressed in the BLM's revised Memorandum of Understanding (MOU) with Coos County. Terms and conditions under which Coos County may construct a pipeline in the BPA corridor are still under negotiation. 


\section{Question:}

When the leak or explosion occurs deep in the back country, will we have insurance to cover such a disaster, and will this infringe on private property owners as well?

Answer:

Coos County will carry general liability insurance to cover damage incurred to property owned by others in the event of a pipeline leak or explosion.

\section{Question:}

Since the taxpayers bond is only to take the pipeline to the gates of the cities, is everyone in agreement that NW Natural will pay the cost to cross the bay and not the taxpayers?

Answer:

We do not know if "everyone is in agreement" but NW Natural has agreed with Coos County that NW Natural rather than Coos County will construct a pipeline across Coos Bay to the North Spit. Coos County pipeline construction funds will not be used to construct the Coos Bay pipeline crossing.

\section{Comments from the Public}

1. Comment: The following comment is a compilation of the sentiments of several individuals.

WE DON'T NEED THE PIPELINE! The rationale supporting heavy industrial development, which the pipeline is supposed to attract, does not address the needs of the public. The chief asset to coastal southern Oregon - a high quality of life - will be threatened by the pollution of heavy industry. There are many concerned citizens who did not want the pipeline bond; the measure passed by a margin of $300+$ votes - this is a small margin.

Response:

The EA does not address speculative issues or voting margins.

\section{Comment:}

We strongly support construction of the pipeline. Plcase do all you can to further this project.

Response:

Thank you for your positive support.

\section{Comment:}

I favor getting natural gas to Coos County, but I have concerns about the project's appearance of economic irrationality.

Response:

Please see the economic assessment in this EA (Chapter 4 of the EIS).

\section{Comment:}

The County officials have listed the following industries as "desirable heavy industry" for the County: Steel mills, and manufacturers of plastics, glass, and gypsum. It appears they will welcome any heavy industry. These heavy industries are also heavy polluters. There is no evidence the regulatory agencies (EPA and DEQ) will provide the County any locally tailored protection against these toxins.

Response:

The EA does not address speculative issues. It is unknown which industries may or may not attempt to develop facilities in the future. 


\section{Comment:}

The availability of natural gas in Coos County will not, in and of itself, attract industry to the area.

Response:

Please see the economic assessment in this EA This question has been addressed in numerous public meetings and it has been publicly stated that the availability of natural gas, in and of itself, is not the sole factor that any new business ("industry") would use to determine whether or not to choose a site in Coos County.

6. Comment: The following comment is a compilation of the sentiments of several individuals.

We feel the process currently underway - Environmental Assessment of the pipeline project - is flawed. The public deserves ample opportunity to provide input after the release of the Environmental Assessment.

When the Environmental Assessment explores the possible direct and indirect environmental and socio-economic effects of enabling establishment of heavy industry on the North Spit and near the airport, the need for a full Environmental Impact Study (an EIS) will be evident.

Response:

Please see the economic assessment in this EA (Chapter 4 of the EIS) and the response to Comment \#4.

Additionally, the BLM and Coos County have decided to prepare an EIS in consideration of these comments.

The public will have the opportunity to review and comment on the EIS.

\section{Comment:}

This gas line is a very bad thing. It destroys the CBW Road, and it causes grave damage to the creatures inhabiting the proposed pipeline corridor.

Response:

Virtually no damage to the CBW Road or creatures in the corridor is anticipated. Any effects will be so insignificant as to be unmeasurable (i.e., negligible).

\section{Comment:}

The way natural gas prices are soaring, no one will be able to afford hooking up to the gas. Response:

All forms of energy presently used in Coos County have suffered significant price increases during the past year.

\section{Comment:}

I would like to see this issue resubmitted to the voters of Coos County. The County Commissioners failed to properly inform the voters of all the pertinent factors prior to the original vote.

Response:

EAs do not assess public votes.

\section{Comment:}

We should ask for the help of Representative Peter DeFazio. He should oversee this Environmental Assessment process.

Response:

He is welcome to comment on this EA, as are all citizens.

\section{Comment:}

My family and I strongly support construction of the natural gas pipeline. The few noisy people...want nothing that will cost any taxes regardless of the long-term benefits of any project. They do not represent the majority of us in Coos County. Please do all you can to further this project.

Response:

Thank you for your support. 


\section{Appendix G1. Letters Received During Draft Environmental Impact Statement Comment Period}

The following Appendices have been added to this document.

- Appendix G-1: Letters Received During the Draft Environmental Impact Statement Comment Period.

- Appendix G-2: Responses to Letters Received During the Draft Environmental Impact Statement Comment Period. 
G-1 - 2 


\section{Oregon}

January 29,2002 Department of Fish and Wildlife Charleston District Office
63538 Bost Basin Drve
Po Box 5430

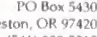

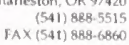

Bob Gunther, Project Coordinator Coos County Natural Gas Pipeline DEIS

5

1300 Airport Lane

Dear Mr Gunther

Thave just completed a review of the Coos County Natural Gas Pipeline DEIS and offer the following comments:

1. The Oregon Dept. Fish \& Wildlife suppons the selection of the Proposed Atemative (CBW Road), as opposed to the Highway 42 Alternative Route. The Proposod
Aternative minimizes impacts to fish and wildsife resources by reducing the number of stream crossings, wetland crossings, and pipeline construction within floodplain.

2. Pages 10-11: It is difficult at this time to comment on impacts from construction of the anticipated Lateral Routes and the Coos Bay-North Spit crossing, since these projects are

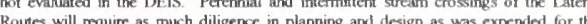
current DEIS

3. Page 13: Paving of the gravel sections east of Sitkurn and north of Fairview has the potential to improve water quality and thus fish/wildlife habitat in the North and East Fork Coquille subbasins. In doing $\$ 0$, however, consideration must be made for drainage dinches, culvers, akeration of runoff pattern, and increased difficulty of future culven

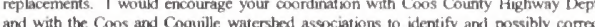
deficient culverts and drainage problems prior to paving.

4. Table S, Page 25: Oregon Coast cunthroan trout are widespread in the Coquille Basin They have the potential to be encountered at neasly every fish-bearing stream to be crossed by the pipeline comdor. Onherwise, I believe you have fairly captured the majo

5. Page 27: Insects are also an important source of food for fish, amphibians, and mammals

6. Page 30-Affected Environment-Recreation: just a heads-up that anglers and other fish/wildlife-oriented recreationists use the proposed roule. A salmon fishery occurs in Isthrmus Stough in the fall (heaviest in September and Ocioher), and construction scheduling shouid avoid the slough crossing at this time of year.

\section{GAS PIPELINE DEIS COMMENTS-Page 2-January 29, 2002}

7. Page 38-1 concur with the "Proposed Action Effects Summation". On a larger scale $\left(5^{\text {th }}\right.$ HUC) impacts will be minimal Site-specific ( $7^{\text {h }}$ HUC and higher) impacts to fish and the projoct has the potertial to cause long-term improvement in habitat quality and access (Iish passage).

8. Appendix A-7: the geotochnical report indicates some poternial for mass soil movement during the life of the projoct. This risk may actually be increased by construction of the pipeline via disturbeance of presently stablized solls. A comminment to periodic inspoction process.

9. Appendix H-2 and H-3: The second BMP "bullet" is good. The trapped sediments should be collected, disposed of in an upland site, and seeded or otherwise sabilized

10. Appendix H-4: During the "Bag and Flume" installation, contractors muss ensure that no fish become trapped in de-watered sections of the stream. Upon installation of the upstream sandbag dam, personnel must inspect pooled water below the dam for trappert
fish. Such fish should be captured and released in the waterod section below the flume ouffall.

11. Appendix H-6: good poirt on wet/green cement, and asphatt. Keep in mind that for "Bag and Flume" sites, the area will not be de-watered for 21 days, so use of cement is no feasible. Heavy equipment leak inspections should be frequent. Stotage and transfer of fevices should be immediately on "ready" when fucl or lubricants are present

12. Appendix 1-2: Inwater blasting permits are required by ODFW. The rules for issuance of inwater blasting permits include a period of public notification, so application must be
made well in advance.

13. Appendix J-S (Pipeline bedding): where backfill will be imported road basc, and excess rative soil will be hauled, the County should have this upland disposal site aranged in advance, and such disposed soils should be seeded for sabilization unt I noeded in other road operations.

14. Appendix J-11 (Pipeline patrols): such patrols should be made more frequently than annual in the first two years, since soils will be disturbed in the pipeline construction. At least one of the patrols should be done after winter-spring heavy runoff (i.e. mid- to lat

15. Appendix KI-VII: White-tailed deer?
GAS PIPELINE DEIS COMMENTS - Page 3-January 29, 2002

Thank you for the opportunity to comment on the DEIS for the Natural Gas Pipeline Project. Please note that 1 did not review'the portions of the DEIS pertaining to the Umpqua Basin This area $\mathrm{k}$ within the administrative jurisdictions of Dave Loomis (District Fish Biologist from these ODFW biologists

Sincerely.

thike Gray

Mike Gray

District Fish Biologist

Umpou Watersted District, Charleston Field Office

c: Sleve Denney, ODFW SW Region/Roseburg

Dave McAllister, ODFW Habitat Division/HQ

Dave Loomis, ODF W SW Region-Roseburg

Terry Farrell, ODFW SW Region/Roseburg

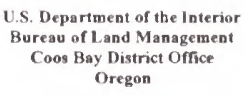

Cureau of Land Management

Oregon

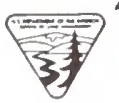

Leave comments at the registration table or mail them to. Bureau of Land Managernent, Coos Bay Distric Office, 1300 Airport Lane, North Bend, Oregon 97459. Attn. Project Manager; Bob Gunther

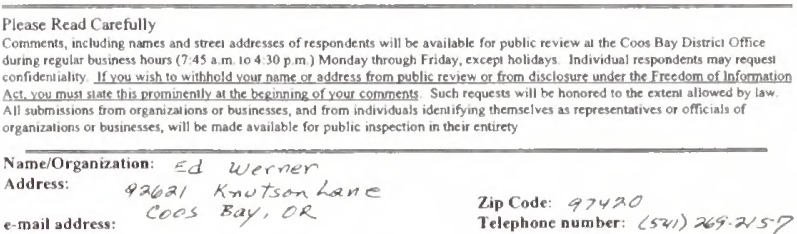

e-mail address: Coos Bay, OR Telephone number: (54) 269.2/5?

Would you like to be included on the project mailing list? Yes $\not$ No

Comments:

Shining in the conatry near coolede, I will not bengfit

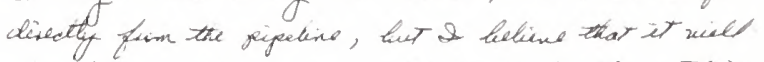

benefit one extexe comminuty economically so that

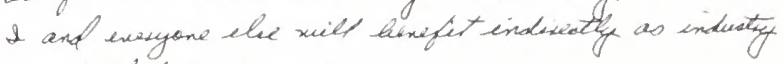

is attrector on anea.

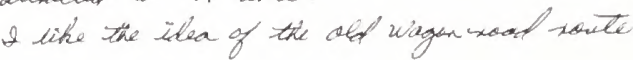

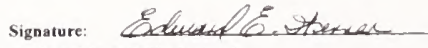

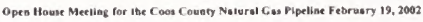


Leave comments at the registration table or mail them to: Bureau of Land Management; Coos Bay Distriot Office, 1300 Airport Lane, North Bend, Oregon 97459, Attn. Project Manager; Bob Gunther.

Please Read Carefully
Comments, including names and street addresses of respondents will be available for public review at the Caos Bay District Office confidentialiny If you wish to withold Acl, you must state this prominentily at the be Binning of your conmenges. Such requests will be honored to the extent allowed by law. All submissions from organizations or businesses, and from individuals identifyng thernselves as representatives or officials of

Name/Organization: Debli hoT

Address: 526 sum the Curs ber, GR Zip Code: $\$ 7420$

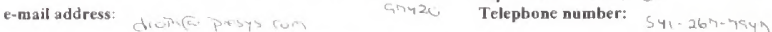

Would you like to be included on the project mailing list? Yes $\_$No

Comments:
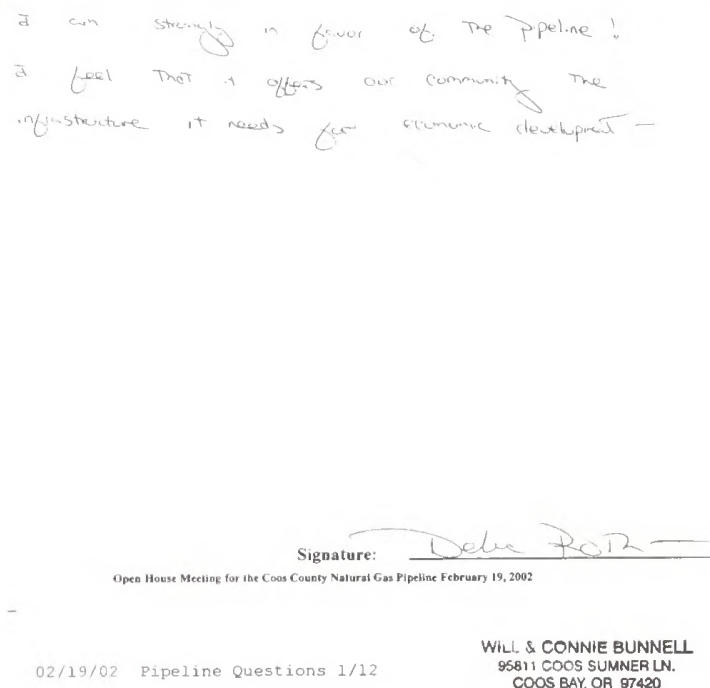

02/19/02 Pipeline Questions $1 / 12$ $95 B 11$ COOS SUMNER LN.
COOS BAY, OR 97420

Pipeline Questions

1 Comparable Installations

- What other rural roads in oregon have pipelines installed in like manner to this proposal

- Wher were these installations made?

2 Residential Involvement

- How many residences are located within 30 to 50 feet of the proposed route?

- How many residences are located within 51 to 100 feet of the proposed route?

- How many residences are located within 101 to 200 feet of the proposed route?

- How many residences are located within 201 to 500 feet of the proposed route?

- In case of a major leak, how fay away must nonemergency personnel remain?

- What is the estimated damage perimeter in case of a major pipeline gas leak and fire?

3 Notification to Property Owners

- Has every property owner along this new route been notifled that you are planning to lay this pipeline through or adjacent to his property?

4 Residential Insurance

- What effect will installation of the pipeline have on residential insurance rates?
Leave comments at the registration table or mail them to: Bureau of Land Management; Coos Bay District Office, 1300 Airport Lane, North Bend, Oregon 97459, Attn. Project Manager; Bob Gunther.

Please Read Carefully

Comments, including names and street addresses of respondents will be available for public review at the Coos Bay District Office confidentiality If you wish to with a.mold to 4:30 p.M.). Monday through Friday, except holidays. Individual respondents may request Ach, you muss state this prominently at the beginning of your comments. Such requests will be hornored to the extent allowed by law.

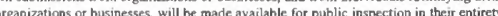

Name/Organization: WiLC C. Bentele

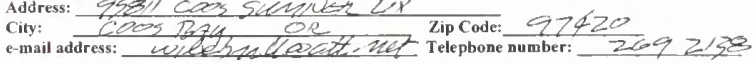

Would you like to be included on the project mailing list? Yes $X$ No

Comment: SOE ATTACHNGT PEASE (12 DACSS)
02/19/02 Pipeline Questions 2/12

5 Cost Considerations

- How is this project to be funded?

- What is the cost differential between the original route and the proposed route?

- If there is to be money saved by adopting this proposed route, how much money is involved?

- What are you going to do with this money?

- what happered to the plan to sell to the public $\$ 20$ milition worth of bonds on this project?

6 Pipeline Ownership and Liability

- Who is to own the pipeline?

Who is to be liable in case of damage attributable to pipeline installation?

- Who is to be liable in case of damage attributable to pipeline operation?

- who is to be liable in case of damage attributable to pipeline maintenance?

7 Installation Information

Where in the coos Bay wagon Road right-of-way will the line be located?

- How deep will the line be buried?

- What thermal expansion (feet/mile, for example) is anticipated?

- What expansion due to operating pressure (feet/mile, for example) will the pipeline undergo? 
02/19/02 Pipeline Questions $3 / 12$

- What provisions are to be made to control or compensate forces caused by expansion and contraction

- How is the pipeline to be shaped to conform to the road, cold bent, cut/welded, flexed?

- what effect does expansion and contraction have on these shapes and construction methods?

- How will movement or drift of the line due to expansion and contraction be controlled?

8 Installation Impacts on Road and Residential Access

- Will the road be resurfaced after the pipeline is laid?

- How extensive will the road resurfacing be

- How much of existing gravel surface will be paved as part of this project?

- will any part of the existing CBWR be improved prior to pipeline installation?

- will the road be widened at any place? - Will the road be straightened (vertical, horizontal)
at any place?

- Are road resurfacing costs to be charged to the pipeline project or the county?

- who will do the work (county, contractor)?

9 Installation Schedule and Access Questions

- when is the project start date, and end date?

- what is the installation schedule, per segment of coos Bay wagon Road (CBWR)?
02/19/02 Pipeline Questions $4 / 12$

What is the schedule for residential access blockaqe during installation?

- What is the schedule for access restrictions to businesses, farms, and logging operations, durins installation?

What is the schedule for route blockage along CBWR during installation?

- What provision will be made for school bus access along CBWR during installation?

What proviston will be made for emergency services (fire, ambulance, law enforcement) to all areas

- What provision will be made for Sumner Rural fire Department to draft fire protection water from their designated areas on wilson creek?

\section{Safety Valves/Nents}

- where are cutoff safety valves located?

- How are cutoff safety valves operated?

- From what locations are cutoff safety valves

- where is power to operate safety valves obtained?

- Are backups for this safety valve power to be provided? - How are signals to safety valves to be conveyed or
routed?

- What procedures are to be followed upon loss of safety valve signal capability

- Are safety vents to be provided?

- where are the safety vents to be located

11 Pipeline Capacity - How many standard cubic feet of gas are contained in
the line between safety valves?

- In case of a major leak, how long will it take to bleed the gas constrained between safety valves to

12 Landslides and Erosion

What procedures are to be followed in case of landslides?

- What provigion is made for road erosion?

- will a pipeline representative or overseer be present when road repairs due to landslides or

\section{Weather}

- How will the pipeline be protected from lightenin strikes? Lightening can strike the ground strikes? Lightening can strike the ground,

14 Geological Questions

- What geologic faults are crossed by this proposed route?

- what is the fault movement history?

- Which of these faults is in the vicinity of existing residences or improvements along the CBNR?

15 Earthquakes

- What is the probable movement of faults near the pipeline in case of earthquake?

02/19/02 Pipeline evestions $6 / 12$

- How will the pipe line be protected in the vicinity these faults?

What provisions are to be built in to protect homes and other property in the vicinity of fault lines in

16 Emergency and Fire Safety

- How will pipeline operations respond to emergencies along the pipeline, such as wild land fires, MVA,

- Where are pipeline emergency crews located? Are they on duty $24 / 7$ ?

- How will fire fighter crews be trained how to deal with emergencies in proximity to this line?

- Who will be responsible for fire ground Incident

- who is responsible for controlling fires related to the pipeline?

- What is the role to be played by Rural Fire Protection District in fires potentialiy involving

17 Motor Vehicle Accidents

- what procedures are to be followed by pipeline project operations when there are vehicle accidents

- what procedures are to be followed if a log truck in a MVA or other vehicle in an accident catches fire? - What procedures are to be followed by local
emergency services personnel in these cases? 
02/19/02 Pipeline Questions 7/12

\section{Road Traffic}

- What studies have been made of the impact of high-pressure gas pipeline buried in that road?

19 Road Maintenance

- What procedures are to be followed when road maintenance is required?

- How are road crews to be trained to work on this

- What procedures are to be followed when road improvements are desired? Especially if dangerous ps/dips, or blind intersections are to be

- Will future road maintenance costs be charged to the pipeline or the county?

- How is financial responsibility to be decided?

\section{Property Protection}

- How are adjacent property owners to have their property protected in case of evacuation, due to landslides, fires, accidents, earthquakes

- will shelter be provided in case of evacuation?

- How will farm animals be cared for in case the owners are evacuated? due to evacuations? constant traffic of heavy log trucks $(80,000$ lbs. traveling equipment transporters (105,

- Who is to be financially liable for losses incurred

02/19/02 Pipeline Questions $8 / 12$

\section{Pipeline Operation}

- What is the operating pressure of the line?

- Ooes the line erit a noise as the gas flows through

- Where are the operations crews located?

- How will pipeline crews know there is a problem on

- what procedures do they follow when problems are detected?

- What procedures do they follow when problems are reported?

- Are they on duty $24 / 7$ ?

\section{Gas Leaks}

- How are gas leaks detected?

- what procedures are followed if a leak is detected?

- Ooes the leaking gas ever travel underground?

- Can leaking gas appear in an adjacent residence or building?

- Ooes this gas have an odor?

- What procedures are followed if there is a leak in the vicinity of a residence?

- What procedures are followed if the house is unoccupied at the time?

23 Inspection and Testing

- How is the pipe to be inspected?

02/19/02 Pipeline Questions 10/12

- What are the criteria for deciding if this project is a "taking"?

- Is this proposed route on CBWR a "taking"?

- How will you compute change in property values along this route?

- How will you compensate adjacent landowners for loss in property values brought on by this line?

26 Signatures

We, the undersigned, request answers to the above questions.

Name Address

- what procedures will be used?

- Where are maintenance crews located? Are they on duty 24/7?

- How is the pipe coated or covered to protect it?

- How long will this protection last?

- How will the protective coating be inspected?

- How will the protection be repaired or replaced?

- How will corrosion be guarded against?

\section{Legal Questions}

- What statements in the road easement give the courty the right to place a HPGL in the road?

- My deed to the property states that I own all the property over which the road passes. There is no mention in the deed whatsoever of a county road

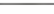


02/19/02 Pipeline Questions 12/12

Name Addres: Te1
Kate Kenyon

52075 Big Creek Rd

Bob Gunther, Project Coordinator

1300 Airport Lane
North Bend OR 97459

February 21, 2002

Dear Ms. Gunther,

After reading the draft EIS, I had a few questions that $f$ would like to have addressed

Where will the money come from to pay the increase in insurance premiurns for the Coos County liability insurance

What were the costs of the studies for each route, and who was paid to do those studies? How much did the County pay BLM for the EIS?

The City of Portiand requires that each home have an automatic safety shut-off valve installed. Why Will the gas provider (NWN) be required to provide automatic sufery shut-oft valves to the residents whose homes will have access to natural gas? Why or

$\sum_{\text {Katc Kenyon }}^{\text {Thank you }}$ Caregen
CONFEDERATFD TRIBES OF

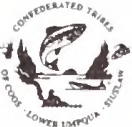
COOS, LOWER UMPQUA AND SIUSLAW INDIANS TRIBAL GOVERNMENT OFFICES

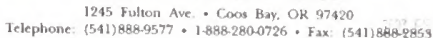

February 20, 2002

Bob Gunther, Project Coordinator

Coos Bay District BLM Project Coord

1300 Airport Lane

Dear Mq. Gunthes:

Thank you for the opportunity to respond to the Draft Environmental Impact Statement for the Coos County Natural Gas Pipeline.

The information put forward indicates that a low impact to cultural resources is likely because the proposed route largely follows existing road right-of-way. Because this is a

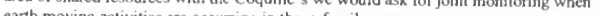

Sincerely,

Conthier tormel

Cynthia Hovind

Cultural/Historical Coordinator

Cc: Isaiah Ursprung, Natural Resources

Don Ivy, Director, Cultural Resources

Coquille Nation 


\section{JOE T, BRISCOE \\ POST OFFICE BOX 116 \\ BANDON, OREGON 97.71 TELEPHE 5.1.347.7232 \\ E-mail}

February 22, 2002

\section{Mr. Bob Gunther, Project Coordinator}

Bureau of Land Management

Coos Bay Distrit Office

North Bend, Oregon 97459

Re. Natural Gas Pipeline Environmental Impact Stateneot

Dear Mr. Gurther

After reviewing the issue regarding the routing and the vanous impacas of the proposed route for the natural gas pipeline from approximately Drain, Oregon to

Yours very truly,

Gar J Suran

Joe T Bnscoe
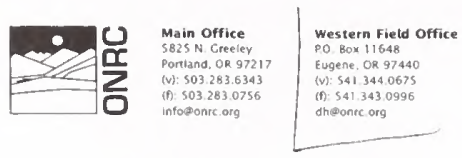

Eastern field office 16 NW. Kansas Ave
Bend. OR 97701 (iv) 541.382 .2616 (f) $541,385,3370$
tifonre. 0 .

outhern field office 943 Lake shore Drive
kimmath 5 alls, OR 9760 (v). 541.885 .48866 (i)

February 25,2002

Sue Richardson, District Manager

Coos Bay District Bureau of Land Managemen

Corth Bend OR 97

Subject: ONRC comments on the natural gas pipeline

Dear BLM:

Please accept the following comments from Oregon Natural Resources Council Fund (ONRC) concerning the Coos County Natural Gas Pipeline Draft Environmental Impact Statement, dated December 2001.

1. The no action alternative (described on page vi) involves building 63 miles of pipeline at a cost of \$36.3 million. This is not "no action."

2. The DEIS is unclear whether the purpose of the natural gas is for residential use or industrial use. Will there be local distribution networks constructed? What are the impacts? If you build it, will dirty heavy industry come to the North Spit? What are the impacts.

3. The DEIS discussion of scoping is inadequate. How was public input considered during scoping? How were the issues arrived at? Why was mas soil tisks and fire risks to the $\mathrm{CHU}$ not considered important enough to be discussed at length All the scoping input seems to be summed up and "expers" who we are just supposed to trust

4. The 188 stream crossings are a concern for sediment production and de livery. You simply can't get a 12 inch pipe under a stream (or buried in fill over a stream) without some serious earth moving

5. The DEIS contains only a very generalized description of mass soil movernent risks. (page A.7)

6. Many of the streams crossings are in the road fill above the stream can simply be wiped out and with it the high pressure gas pipeline. The
DEIS does not disclose the consequences of this.
7. The DEIS does not adequately explain whether the route considered, follows, or avoids roads that will later need to be closed to conform to resource conagenent requirements or road dens

g. The DEIS should disclose how many intermittent or other streams will be directionally drilled vs. trenched.

9. Page A-16 concludes that the risks of pipeline failure due to mass soll movement are small, but the geotech report admits that it is only a conceptual report and the report simply guesses without any analytical

10. The geotech report also admits that they lacked information to analyze the risk that landslides induced by upslope clearcutting of other forest management that might cause a pipeline failure. This is unacceptable NEPA analysis

11. The aquatic analysis is based on only one (watershed) scale of analysis when the Northwest Forest Plan requires that all scales be considered. See the 9th Circuit opinion in PCFF A v. NMFS

12. The DEIS fails to disclose if Port Orford Cedar root disease migh be spread to new areas not currently infected.

13. The EIS must address the indirect effects of the proposed action. including stimulation of other economic activity that is clearly contemplated by this proposal. These other economic activities can have life, etc. The DEIS does not disclose the effects of future developments such as the laterals. future industrial development of the North Spit, etc.

14. Please explain the risks of having a natural gas pipeline in the vicinity of a powerline right-of-way abes this propo clearance from the holders of the electricity rights of way?

15. Will this pipeline be inst If there is a gas leak could it cause a large fire in the spotted owl critical habitat unit? The DEIS fails to disclose this very significant risk

16. A thorough econornic analysis of alternative fuels and altemative energy processes must also be included

17. All Northwest Forest Plan requirements, including wildlife survey and resource protection requirements should be followed.

18. The BLM/County failed to seek out or allow public input during the scoping process.

Sincerely,

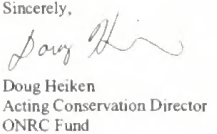




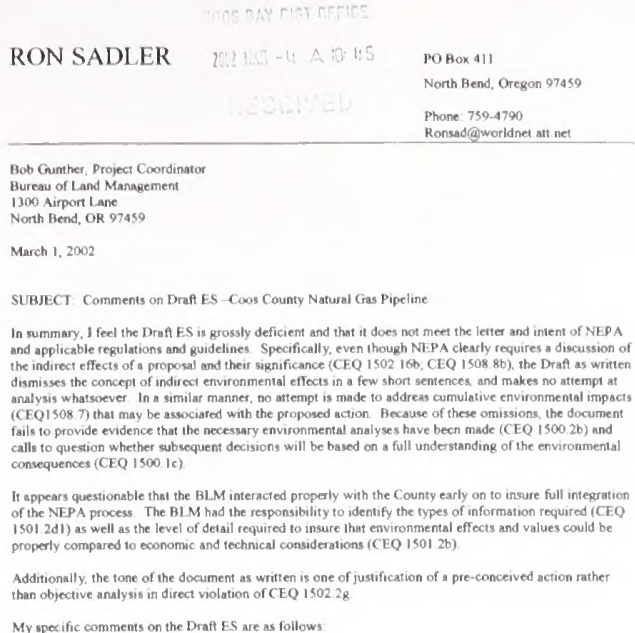

INTRODUCTION

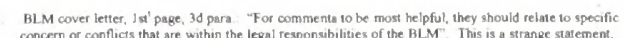

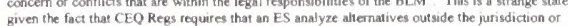

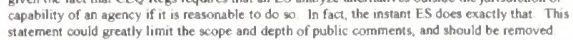

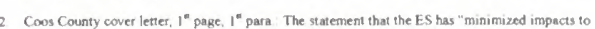

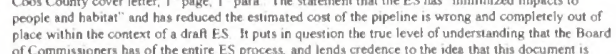

primarily intended to jusify and promote a decision already made rather than objectively aralyze a
situation

SUMMARY

3. Page v. "Need for Action". As writiten, this paragraph complecely misses the point This section
should oulline the cartert socio-economic condtions in the Coos Bay arca that indicale a need for enhesed conomie ond induetrial development

4 Pagev. "Purpose of the Proposed Action". The natural gas pipeline is cclcarly a project designed to
foster and facilitate industrial development in the Coos Bay ares of this, there can be lirtle doubt. 作

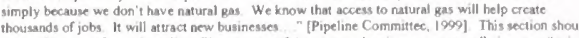
be rewriten to seflect this resblity. The purpose of the proposed action most assuredly is not to "ganin a

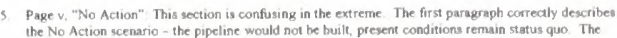
the No Action scenario - the pipeline would not be built, presert conditions remain status quo The
sccond paragraph suddenly jumps all the way to the docision process as it relates to the Proposed second paragraph suddenly jumps all the way to the docision process as it relates ro the Proposed
Action it states that if the Proposed Action is not selectod for implementuation, the county will go

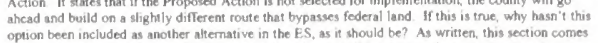
option been included as another aternative in the ES, as it should be? As written, this section comica
across as trying lo send a signal to potentiat $E S$ reviewers - "if you come down too hard on the

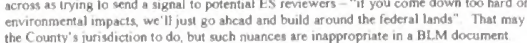

6. Page vi, Table S-2 the "No Action" column is wrong it shows numbers for the COunty's" "dodge the is not constructed.

PURPOSE OF AND NEED FOR. ACTION 7 Page 3. "Pupose and Need" Comments "13 and HA above also apply here This section also makes the

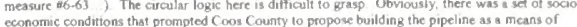
fostering economic development. Measure 46.63 was simply the mesns lo fund the pipeline proposal

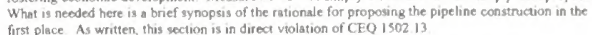

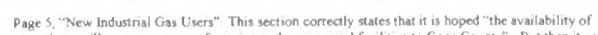
natual gas will attract new manufacturing and commercial facilities to Coos County" But then it goes on to squelch any sor of mcaningful analysis by stating "II is not possible fo quantify the potential environmental impacts of unknown future faccilities and their porential locations" This illustrates the
serious pro-development bias and unbalanced analystical methods that permeate the entire ES It is disingenuous to disniss any sort of porrayal of environmental impacts because of "unknown

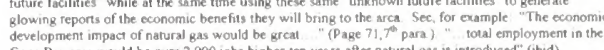

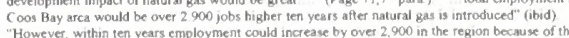

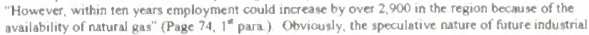

were harvesting on private lands far in excess of sustainabie levers, the expon of raw logs for processing outside of the timber producing regions, and, chingent
manpower necds per unit output This should be rewritten.

Page 30 " "Recreation". This should be rewritten to include a description of the significant recreastional

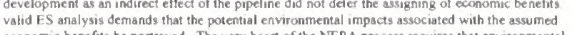

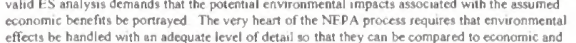
effects be handled with an adequate level
lechnical consider ations (CEQ 1501 2b)

It appears that the nature of future industrial developments that may be triggered by the pipeline are
not as "uniknown" as the dratt ES would have us believe The ES Itself states that "ratural gas may make in possible, or at minimum more practical, to build a metal fabricating plant of armmonia fervilize

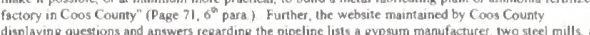

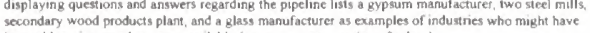

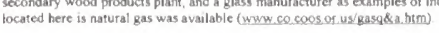

Nor should identifying the "potential locations" of future industrial development be a problem The Port of Coos Bay maintains an inventory of industrial sites in Coos County, and in shows the
all available industrisl lasts are adjacent to or closely a ssociated with the Coos Bay estuary

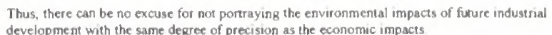

This section of the ES should be rewriten to embrace a bal anced analysis of both the environmental

AL.TERNATIVES INCLUDING THE PROPOSED ACTION

9. Page 14, "No Action Aternative" This contains the confusing discussion of the County's sallback
position if the BLM easernent is nol granted Sec discussion under Comment H5 and "t6 above

AFFECIED ENVIRONMENT

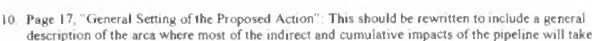
description of the arca where most of
place - namely, the Coos Bay Estuary

11. Page 18, "Air Quality". The statement "no data is availabte regarding the current levels of noxious gates "is simply not true It reflects the pervasive bias throughout the document aganst identifying and analy ying indirect and cumulative effects At a mimimum, this section should be rewsititen to
include the moss current dats from EPA's Toxics Pelease Invernlory, as well as the emissions of record from the Bcaver Hill munsicipal waste incinerator

12. Page 20, "Water Quality" It is astounding that a discussion of water quality as a function of the

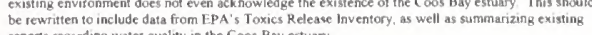

13. Page 28. "Public Hiealth" How is it possible to discuss public health, as a function of the present
situation, and not mention the fact that Coos County has the highest cancer rate anong all mid-sized to gon State Cancer Resistry, 1996-1990)

14 Page 29 "Coos County General Economic Data". The statement "limber production diminished
significantly following the impacts of several forestry-related environmental issues" perpetuates an incorrect mylh. In sealiry, several studies forecasted a downturn in timber production and timber

\section{ENVIRONMENTAL CONSEQUENCES}

16. Page 39" "Ait Qualiti" This section well illusirntes the inadequacy of the Draft ES. We are told that

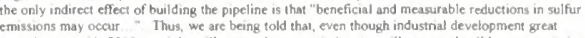
enough to provide 2900 new jobs will occur, these new industres will sppasently all be zero-emission

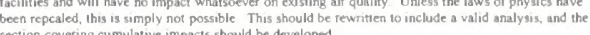
section covering comulative impants stould be developed

17 Page 65. "Aquatic Ecosystem - Indirect and Cumulative Effects". This section does not even mention

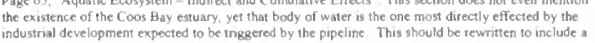

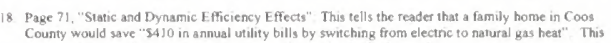
does not appear to include the cost of conversion which is significiant in Coos County because mast cost of conversion be included

19 Page 73, "Summary of Direct, Indirect and Cumulative Economic Effects" No mention is made of the

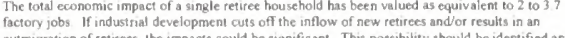
oulmigration of retirees, the impacts could be significant. This possibility should be identified and

20. Page 74, " Public Health and Safety" This section should address, given the existing level of air and

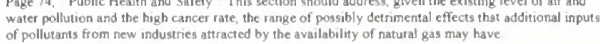

ibelieve that an adequate discassion of the indirect and cumulative effects, specifically relating to the enabling and fostering of industrial development in the vicisinty of the Coos Bay estuary by the pipeling insignificant in reality, they mect veveral of the CEQ critena for significance

The Coos Bay estuarine ecosystem is a unique and imporant arca. It has bect compromised to some Iegree by past actions, and receives inputs of toxic pollutants on a continuing basis presently The effects of adding significast new poliutants are highly uncertain and involve the unique risk of pushing the
ecosystem to the threshold of catastrophic collapse, thes meeting the criterion at CEQ 1508 . 7 bs

Publishing an ES with the limined analysis depicted in the Draft may establish a precedent whereby future
federal actions (for example' the federal permits that will be required to extend the pipeline act oss the bay 

to the North Spit) will also find it unnecessary to discuss indired and cumbulative effects. The existence of
this possibitity meets the test of significance at CEQ 15082706 .

The pipeline has been described in the Draft $E S$ as one of a number of actions that will be needed to enhance the economy of the Coos Bay area It can be inferred, given the lack of any attempt to depict or
analyze curnulative effects, the BLM considers them insignificant. However, CEQ $150827 \mathrm{~b} 7$ states that signtificance exists if it is reasonable to anticipate a curnulatively significant impact on the environnent

RECOMMENDATION: 1 feei that the Draft ES is so inadequate as to preclude meaningtul analysis, and I 作

I nust point out that the incompleteness of unavailability of portions of the selevant dara percining to the Coos Bay ecosystem is not an excuse in cases such as this. The tact that data are incomplete and
unavailable in fach th

Ron Sadier

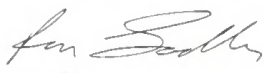

P.O. Bos: 206
L.kes1e, OF 97449
2/26/02

Eob Guntuer, Project coorcinator RE: 2800 Draft EI

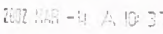

BI.

1300 A1rport lane
Sorth Bend, OR 97459

Corrents on Draft EIS:

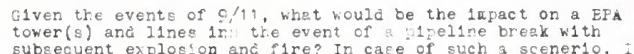
subsequent explosion anc flre? In case of such 3 scener1o,
belleve the followine ouestion to be ermone:

a. If such break occurres at 2 ar in section of plifeline east of Falrviek, how
and ekut the eag off?

b. What woulo be the 1 inpact of an explosion of this tagnituce of the tower(s)?

c. What would be the ex ected teaperatures of the flakes at
ounc level? at line level? how lone would the towers w1thotand these tederetures. How lone would the overheec lines withostano these temperatures? Is $1 \mathrm{t}$ reasonable to assuxe thet the tower
and lines woulo survive the 1nitiol explosion?

d. In the event of a tower collacoe or transmiesion line fellto the South coast?

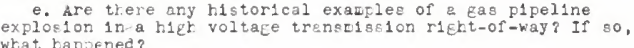

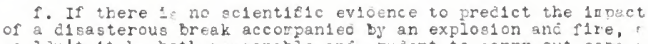
weston tit te both ressonable anc miesion rifit-of-wey?

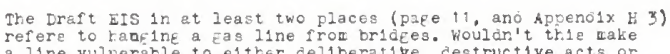
thoushtlese vencal1 sc? AEain, how lon woulo one expect it to. be turned off? hinat would be the effects of a gas-fed fire on the typlcal bridge in the area?

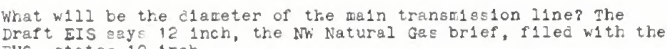
Draft EIs agy 12 1nch.
Fuc, etateo 10 inch.

P.O. BOx 206

The Draft IIS, rage 10 , has the tranetiss 1 on line extenotng of Coos Bay. Early discussions placeo the COOE Bay the N1lington area was the fiost corfonly ientioned site. Now, however, the p1peline w111 run though Coos Bey for Eevera mile to a spot near the CB/AB Water Eoard orflce. What enviorniental, Eeograph1 1 or regulatory factors
dictateo euch a change? what 15 the additlonal cost to the tax payer?

As a result of shifting the terainus point, will any area be excluoed rror eas servi

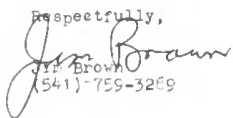

Project Coordinator, Bob Gunther

\section{OREgON INTERNATIONAL
Port Of COOS BCY}

March 6, 2002

US. Bureau of Land Management - Coos Bay District

Environmental Impact Statement - Coos County Natural Gas Pipeline

1300 Airport Lane 1 North Bend, OR 97459

Statement For The Record In Support of the

Proposed Action Alternative - Coos Bay Wagon Road Route

The Board of Commissioners of the Oregon Intemational Port of Coos Bay supports the construction area in Coos County, utilizing the Proposed Action Alternative - Coos Bay Wagon Road Route.

In reviewing the matenal supplied in the Draft Environmental Impact Statement (EIS), it is evident this

route will. produce the least short-term impact on various ecosystems (habitat and wildife) delineated produce the least
through the EIS.

prevent unnecessary disruption of traffic flow on a major state highway (Oregon 42) minimize the total amount of public funds required for construction, and consequently the future rate of pipeline-related property lax increases for Coos County residents, and

We strongly urge adoption of the Proposed Action Altemative through approval of the Draft Environmental Impact Statement by alt cooperating federal and state agencies and all intereste entities representing the private sector. The avarlabinty of natural gas as an energy source for

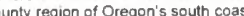

Sincerely.

the waldor

Mike Waldrop, President

Board of Commissioners

Board of Commissioners - Oregon Intemational Port of Coos Bay

Mike Waldrop, President; Gary Gregor, Ph. D. Vice President

Ingvar Doessing, Secrelary, Cheryl Scoth, Treasurer.

CC Coos County Board of Commissioners

Coos County Pipeline Project Office

Northwest Natural Gas

City of Coos Bay

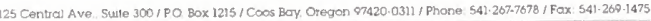

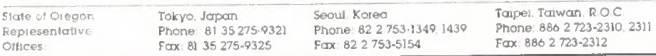


March 13, 2002

Bob Gunther

Project Coordinator

Cons Bay District, BL

1300 Airport Lane

h Bend, OR 97459

Mr. Gunther:

The following represents ny revicw and comments on the Draft E.I.S. for The Coos County Natural Gas Pipeline. Please include my vicws as part of the public input.

\section{Chapter 2 Alternatives:}

CONCERN:

Three allernatives are listed, but the second paragraph under NO ACTION on pages $v$, and the discussion on page $14 \mathrm{secm}$ to contain an additional alternative. Should it also $\mathrm{be}$ listed?

Chapter 3 Affected Environmen

CONCERNS

On page vi the summary identifies five categorics of potential impacts on the natural and built environment used in this E.I.S evaluation. Then it describes the results using a different category that was not on the
confusing and possibly misleading.

The only impacts listed are restricted to the construction and operation of the pipeline No mention is made of irspacts, direct, indirect and cumulative, on the Coos Bay Estuary which will harbor the industries brought in by the existence of the pipeline. Those same
industries are the very purpose for the pipeline. The impacts of those industries have to be addressed for the Draft EIS to be relevant

No mention is found in the EIS of the potential industrial emissions impacting ai and water quaity, public health or recreational fishing, crabbing and claming. - There is no mention of potential impacts on existing commercial fisheries that are dependent on natural biological productivity of the Coos Bay Estuary - There is no consideration of impacts on local transportation, housing, industrial water supply and related services. I find these omissions to be major shortconings of the document

The EIS, with a voice of authority, gives quant itative direct, indirect and cumulative economic affects of the pipeline in terms of jobs, dollars and annual dollar impact on the hay area on page 73. Yet the Draft EIS on page 5 stales that, "It is not possible to quaritify locations " This statement is unfounded.
- The Coos Bay Area has already identified and zoned Industrial sites based on prior planning. That is where future industries will locate. Tho se known areas should he mapped and included in the EIS. Most of them front the estuay. The compilers of the EIS could have applied the same strategies used on page 73 to quantify data on custent emissions by existing metal fabrication and ammonia fertilizer plants which are identified on page 71 as possible fit ure industries. Existing plants could have been selected from various locations in the U.S. They could then identify the types and amounts of air and water borne chemicals particulates, and thermal emissions related to those plants for examples of what to expect. This comparitive data would be at least as accurate, from a scicntific viewpoint, as the projected job and economic numbers found on page 73 and elsewhere, and as the information comparing population growth as a function of
available natural gas found on pages $71-72$.

The Draft EIS does not cite easily available, and reasonably recent, data on any of the following:

existing economic impacts of commercial etab, salmon, clam, and oyster harvest in the Coos Bay Estuary.

h) existing economic impacts of sports crabbing, claming, and fishing in the

estuary.

Envifonmental Protection Agency listing of major environmental problems in the $\operatorname{Cos}$ Bay Estuary, i.c.: toxic chemicals; high rates of juvenile salmon mortality, high bacteria loading; degraded commercial shellfish beds

d) Coos County air quality with pollutants listed by weigh

c) Coos Bay Estuary water quality listing existing heavy metals and other toxics Studies

Chapter 4 Environmental Consequences of Each Alternative

CONCERNS

See concerns listed ahove.

In summary, the Draft EIS on the Coos County Natural Gas Pipeline does not seem to consider or identify the major impacts on the Coos Bay Estuary that will derive directly. indirectly and cunulatively from the pipeline project. We are already paying for mistakes of the past. The potential for degradation of the bay requires that those conditions he dentified and quantified to protect against future loses. This deficiency needs to he addressed

Respectfully submitted,

Biec Peppe

Bit: Poppe

94550 Argler Lane
North Bend, OR 97459
DEPARTMENT OF THE ARMY

POST OFFICE BOX X 2346
PONGI

March 15. 2002

Operations Division

Regulatory Branch

Corps No: 2000-00544

Ms. Sue E Richardson

Mureau of land Managenon

Coos Bay District Manage

1300 Airport Lane

North Bend, Oregon 97459-2000

Dear Ms. Richardson

The following comments are being provided by the U.S. Army Corps of Engineers (Corps) in response to the Coos County Natural Gas Pipeline. Draft Environmental Impact Statement, dated December 2001

(Tahle S-1) The Corps authority is under Section 10 of the Rivers and Harbors Act and Section 404 of the Clean Water Act If approved, the Corps will issue a permit under these Section 404 of the

In the abstract and the proposed action description, it states that the pipeline would cross 188 strearns and one wetland. It is recomnended rewording the statements as follows, "the pipeline
would cross 188 streams and/or wetlands". A stream could have wetlands adjacent to it or within the stream's corridor

Chapter 1 (Authorizing Actions and Relationship to Statues and Regulations): We

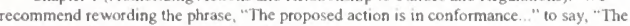
proposed action would comply with.."

Chapter 2 (Alternatives Including Proposed Action): No comment.

Chapter 3 (Affected Environment), Tatile 5: The Oregon Coast Coho Salmon has been listed as threatened under the Endangered Species Act. We reconmend that an additional appendix be added for National Marine Fisheries Service Endangered Species Consultation on the coho salmon. Since the Oregon Coast Steelhead is a candidate species, conferencing is not required; however, it would be prudent to include the steclhead in the request for endangered species consultation letter

Chapter 4 (Environmental Consequences), Tables 13 through 22: A review of these tables indicates that there are 188 pipe crossings, of which 112 of them are above stream, within soad crossings. Just a point of information, if a pipe crossing is embedded within a roadway and above the elevation of a culvert where the stream passes, a separale permit is not required for the pipe crossing because there would be no additional fill in a water of the United States

Chapter 5 (Consultation and Coordination): No comment

Appendix " $\mathrm{C}$ ". Maps: We recommend adding a map of the preferred pipeline route that shows the 188 pipeline crossings of streams and/or wetlands. The map should indicate the crossing sites by numbering them from 1 to 188 . In addition, it is recommended that the map in Appendix $\mathrm{C}$ showing the location of the block valves along the pipeline route be amended to reflect the crossings. Although a number of the 188 crossings may not require Department of the Army authorization from the Corps, we recommend that all 188 crossings be reflected

We recommend that the cut and fill volumes for each of the 188 crossings are reflected. This could be prepared as a table

Thank your for the opportunity to provide comment on the Draft Environmental Impact The Statement. If additional information or clarifica
letterhead address or telephone (503) $526-4390$

Sincerely.

Copies Furnished;

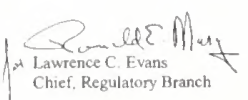

Coos Bay Field Office (Urbanck)

Oregon Division of Statc Lands (Lobdell) 


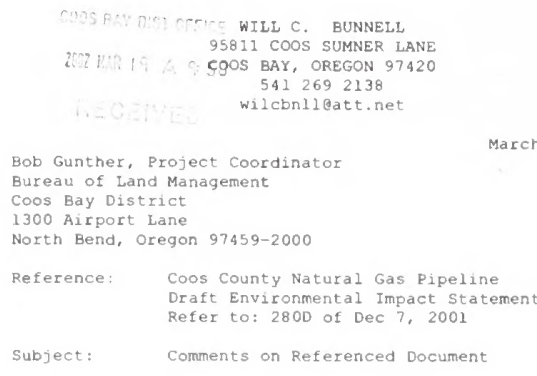

The material in this letter is in addition to a 12-page set of quest

\section{Summary:}

The Draft EIS does not convey enough information to allow an informed judgement to be made among the proposed alternatives. An economic and environmental baseline, consisting of no pipeline installation, should be included.

2. The Draft EIS does not adeguately describe, nor does it adequately analyze, the benefits and detriments of varied geologic formations the pipeline will encounter on alternate routes.

3. The Draft EIS does not adequately establish a wellnor were such criterla used in evaluating the proposed pipeline alter

4. The Draft EIS does not adeguately address many critical issues, among them economic factors, environmental operation, and repair or safety, during construction. pipeline alternatives. reasoned and properly weighted set of selection criteria, 5. The Draft EIS makes no mention of industrial production
potential of up to (the cited) 24 billion cubic feet of natural gas per annum. For example, how many tons of natural gas per annum. For example, how many tons electrical energy per annum, or what by-product production (type and quantity) might be produced. No
references from potential industries are cited. No references from potential industries are cited. No experts from these industries were consulted. Other than analysis of the economic impact of this production

6. The Draft EIS does not adequately present project organization and assignment of responsibilities for the major phases of the project: evaluation, design, construction, operation, and maintenance. These factors issues, and they will involve health and public safety, well.

The Draft EIS does not adequately address how project supervision and technical responsibility during project hatailed.

8. The Draft EIS does not adequately describe how oversight supervision and control of construction will be maintained, nor how final acceptance/rejection criteri and final authority will be handled.

9. The Draft EIS does not adequately discuss the roles to be played by Douglas County and Coos County governments as

10. The Draft EIS does not adequately discuss financial liability during pipeline construction, operation, and repair or maintenance.

11. The Draft EIS does not adequately present project cost breakdowns and budget allocations for each implementation phase, for each alternative considered. Contract vehicles (fixed price, time and materials, incentive fee, any way, yet they can have profound impact on project 2 costs. No mention is made of a subcontracting plan, nox of subcontract administration. No mention is made of

construction reserves or the cost of construction delays. No mention is made of funds to be retained for use in carrying operational costs unt 1 enough paying natural gas customers can be hooked up to make the pipeline economically viable. Nor does the EIS give any time frame when breakeven operation of the pipeline can be expected to occur, nor whether any or all laterals must
be connected to make the project viable. No schedule is be connected to make the project viable. No schedule is planned customer area. Although it is planned that start-up operational costs for the first year will be carried by the gas supplier (NW Natural Gas) breakeven may occur much latez than that. Note also that the gas customers eventually will have to pay all these costs, however well hidden they may be. The EIS should show in

2. The Draft EIS does not adeguately address questions of operation and safety for each pipeline routing alternative during periods of weather disturbance, in which access roads may be closed and power and telephone service may be lost due to wind-toppled trees. Eloods and landslides can be expected to differentially affect alternate routes as well, but the EIS does not address these issues.

13. The Draft EIS significantly lacks adequate discussion Dafety for each pipeline routing alternative during and following earthquakes.

14. There is a significant lack of quantified data in the Draft EIS. Few of the quantities that do appear are adequately justified or traced to theis origins. Moreover, measurement data are not presented in standard format tmean, stanard deviation, and number in samplei. Nor are estimated data presented with ealculations and estimation bases, nor are data ranges or upper and lower data change over time, with their upper and lower bounds if estimated, or with measurement deviations if the data are historical.

15. Data obtained by aid of computers do not show sufficient relevant factors about computer programs used to permit independent evaluation. The EIS should show as entered, methods of program calculation and logic, collection and formatting of results.

16. I realize that in many areas, useable data are currently urivailable. But this circumstance makes it imperative that relentless effort be expended to develop and present credible data. I suggest that rewrites presented, quantified data,

Specific comments:

ECONorthwest, and a related computer proqram, are cited, the structure of the savings of $\$ 6.7$ million should be spelled out in detail, at least in an appendix. The EIS should show the savings by year, by industry, by consumer type. The savings should also show costs to taxpayers, (individual and industrial) of construction, operation, and maintenance of the pipeline. The savings should also existing energy sources to natural gas.

2.p. v: The "No Action Alternative", as described in the should be addressed as such. In contrast, the "No Action Alternative" should address the consequences of not suitable time period, say ten years. This will form

3. p. Vi: Table $S-2$ : It appears that "Estimated costs" in this table reflects immediate cost of pipeline entries should be made (with full justification in an appendix) to reflect estimated costs of operation and see above, over perlods of, say, with time cost (bond pay out and retirement) should be included and the numbers should be worked through to show as a bottom line the actual annual tax cost to representative coos county tax payers will be over these time periods. The "No Action" column should be completely reworked as described in comment 2 above. this document should vigolously supply properly

p. v: "Need for Action" Although a reference, EIS, is merely an alternative pipeline routing, and installing the pipeline at all; this should be done in quantitative economic and environmental terms, over a construction only. If this is the case, additional maintenance of each alternative (including "No Action", 
4.p. 3: Purpose and Need: The purpose of the proposed action is to install and operate a natural gas pipeline, laterals, and related terminal equipment, is it not? The purpose of the EIS, on the other hand, is to present the
environmental and economic implications and trade-offs of environmental and economic implications and trade-ofts various alternative approaches to achieve that end.
Thus, the EIS should contain sufficient information to Thus, the EIS should contain sufficient information to alternative and with the baseline alternative of not installing a pipeline at all. This definitely means that the environmental and economic impact of operating each pipeline alternative must be fully considered.

5. The only need shown in the EIS for this pipeline is economic. The EIs seems to take the position that operation of this pipeline will reduce environmental feduction is to be taken as a "need", then that position, and the means by which pipeline operation can serve that need, should be completely justified in the $\varepsilon I S$, in fully researched, credible, engineering detai

6. P. 4: Statutes and Regulations: Are all relevant exlstar vor Act of $2000^{n}$ to be addressed?

-p. 4: Anticipated Future Gas Pipeline Projects: Future costs, environmental as well as financial, of the contemplated lateral pipelines to other communities and industries in the ared should likewise be addressed. atrest EIS.

B. p. 5: New Industrial Gas Users: "...no industrial commitments have been made..." The EIS should address by Eeference here, and spell out later in the document. pollution. This should industrial environmental emission standards, calibrated to lowable pollutant industrial environments (for which see the baseline environment) for a suitable selection of typical heav industries, say, steel fabrication mills, fertilizer plants, and other such, known

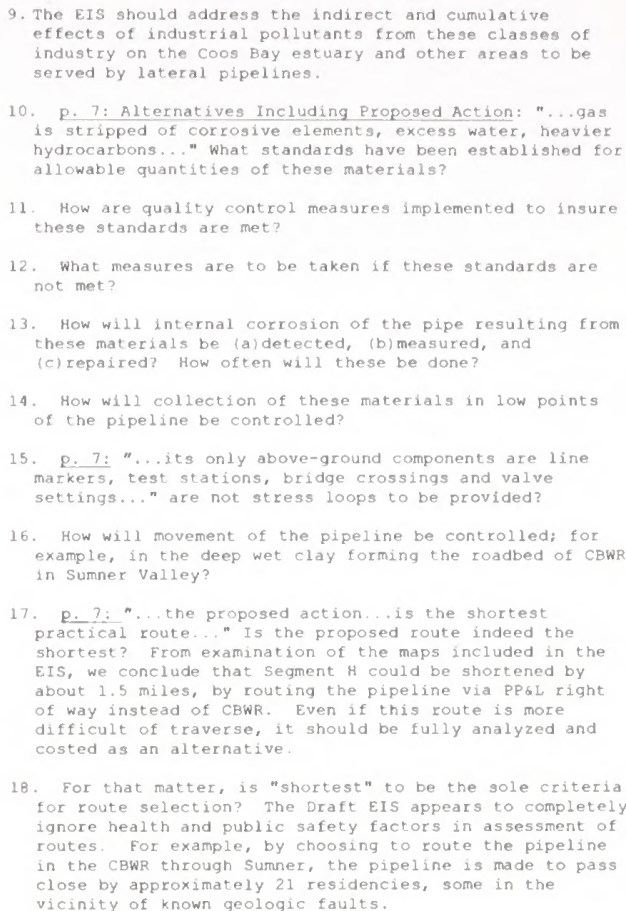

9. The EIS should address the indirect and cumulative effects of industrial pollutants from these classes of industry on the coos bay estuary and other axeas to be served by lateral pipelines.

10. p. 7: Alternatives Including Proposed Action: "...gas hydrocarbons..." what standards have been established for allowable quantities of these materials?

11. How are quality control measures implemented to insure these standards are met?

12. What measures are to be taken if these standards are

13. How will internal corrosion of the pipe resulting from these materials be (a) detected, (b) measured, and

c) repaired? How often will these be done?

14. How will collection of these materials in low points or the pipeline be controlled?

15. P. 7: "...its only above-ground components are line markers, test stations, bridge crossings and valve
settings...n are not stress loops to be provided?

16. How will movement of the pipeline be controlled; for example, in the deep wet clay forming the roadbed of CBWB in sumner valley?

17. P. 7: "...the proposed action... is the shortest practical route. "Is the proposed route indeed the Shortest? From examination of the maps included in the about 1.5 miles, by routing the pipeline via ppis right of way instead of CBWR. Ever if this route is more difficult of traverse, it should be fully analyzed and costed as an alternative.

18. For that matter, is "shortest" to be the sole criteria Lor route selection? The Draft EIS appears to completely lanore health and public safety factors in assessment of routes. For example, by choosing to route the pipeline in the CBWR through Surner, the pipeline is made to pass wicinity of known geologic faults.

19. I suggest that the planners consider in detail a number of route and installation alternatives. The impact of this pipeline will be felt with ever increasing power for years into the future, when many factors, population, economic, and environmental, can be expected to assume changing importance. The fact that many of these factor are currentiy unknown makes the need for this type of forward thinking and planning even more compelling.

20. For one alternate routing example, the main pipeline could be routed from Fairview to Coquille, where a large

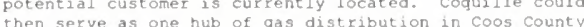
with another hub being located in coos Bay. In this example, the pipeline could be routed from coquille to coos Bay along Highway 42 , or the existing railroad right of way, with minimal impact. A lateral could be extended to the Beaver Hill waste treatment facility, along Highway 101, or as another alternate route, from North Bank Road, taking the Beaver Hill road from there to extended to Bandon along yighway 101 .

21. P. 7: "...the proposed action includes 5 block valves..." What is the amount (in standard cubic feet) of valve and the Isthmus Slough block valve?

22. In case of pipeline rupture (various kinds) how long witl it take to bleed this gas to atmospheric pressure. after the block valves are closed?

23. How are the block values to be operated?

24. What automatic safety features are to be provided?

25. Will local volunteer fire protection personnel and ther local energency personnel be trained to operate these valves

26. In case they are, who is to bear the liability burden?

27. Will local volunteer fire protection personnel be be paid?
. Assume that there is a pipeline rupture and fire, for example, in front of Sumner store. What will be the duties of the local volunteer tire department personnel Fairview and isthmus Slough both outside Sumner RFPD boundaries)?

29. If the block valves are to be operated remotely by signal lines, where is the control center to be located?

30. If there is to be a control center, haw does the control center monitor the pipeline? Who will operate it? How do emergency personnel communicate with the provided?

31. Where will the block valve signal lines and communication lines be located?

32. If overhead, what happens when windstorms push trees over onto the lines?

33. If buried, what happens when an earthquake not only ruptures the pipeline in several place

34. How are these block valves to be tested and maintained? How often?

35. For that matter, questions about pipeline leaks and their potential impact on health, public safety, and the natural environment are not adequately addressed in the Library on 19 February, that pipeline personnel plan to walk or drive slowly along the pipeline every year, or "...more often, if needed..." looking for discolored vegetation, ground disturbance, odor of gas, etc., to detect leaks. Since, in the currentiy "preferred alternative," the road will be paved, with the pipeline burled beneath the pavenent, these disturbances presumably wile road, or residencies, when leaks are found, n...they fix them..." This obviously means they have to dig down to the pipe, in the middle of the road, shore the trench, where it may be 5 or more feet deep in saturated wet clay, find by some means the actual leak(s), and " $f i x$ 
it (them)" by some undescribed means, possibly depressurizing the pipeline. This will be a very interesting exercise after even a minor earthquake in our area has produced possibly several dozen breaks or leaks of various sizes. In this connection, a lead pipeline consulting engineer stated in the cited meeting, "...in case of an earthquake, the pipeline will break in only one place..." Perhaps a geologic/engineering analysis and plan can be included in the EIS that will show those of us outside the gas pipeline industry how this result is

36. P. Il Schedule, Sizing and Route Selection Factors: .. scheduled for completion into coos Bay by the end 0 start and end dates for each construction phase, for each segment of each alternative route.

37. The schedules governing road blockages should include provisions to insure that emergency services if ire, medical, law enforcement) can be furnished at alre, times construction route.

38. p. 11: In reference to a potential lateral to the Bandon area, several alternative usage profiles in the Bandon area are mentioned in the EIS. Each of these alternatives (including the "No Action" or baseline alternative should be adequately explored as to cost, environmental impact, direct, indirect, and cun and economicis
businesses

39. P. 11: In reference to a potential lateral to the Beaver Hill site, in its role as a waste disposal faclity, and in its potential role as a power generation direct, indirect, and cumulative should be shown, as wel as cost, cost recovery, and economic impact.

40. None of these laterals and consequent natural gas related usage would be possible without the construction and operation of the main pipeline, and so are a direc: addressed in the EIS.
41. D. 13: Proposed Action Utility Corridors and CBW Road: construction of the pipeline." what is the reasod after this paving?

42. Is the pipeline project funding the paving? 43. What entity is responsible for maintenance funding of
the paving?

44. What entity is responsible for funding maintenance of the road and paving when pipeline maintenance or aply to both Douglas and coos countions. These quest

45. Do the existing gravel-surfaced sections meet state and other relevant criteria as to contour, grade, load-
bearing capacity, width, shoulder, guard rail, signage, and other such requirements for paved roads ?

46. What changes (1.e.: which curves, grades, etc., at what mileposts) must be made before paving? What other existing road contours (paved and unpaved) will be pipeline?

47. If no changes are to be made, then what is the justification from a public safety standpoint for not
doing so?

48. The EIS should explain in detail what additional procedures (and their costs) would be imposed on road improvement efforts by the existence of the pipeline in

9. How are future road maintenance and improvement cost increments, arising as a result of having to work around
the pipeline, factored into future pipeline costs? Who will pay these costs?

50. P. 13: "...NW Natural anticipates to initially deliver 2 billion cubic feet..." How many businesses and households must be converted to natural gas achieve this number? 51. The EIS should provide estimated conversion costs
(plans, permits, material, labor, inspections,

52. The EIS should show the results of surveys conducted to determine how many homeowners and businesses in the planned delivery area are actualiy willing to conv

53. P. 13: ". . the maximum potential... is 25 billion cubic eet per year... From EIS Appendix J, it appears that in the 12-inch pipelined by calculating the maximum flow lateral pipe flow does this include?

54. How many steel mills, fertilizer plants, power generation plants of what size, etc., will this 25 generation plants of what $s$ ilion
billion cf/yr flow sustain?

55. Even more importantly, what is the economic and environmental impact on each region of this potential industrial population?

56. P. 15: Highway 42 (continued): "...traffic disruption would be considerable... for 6 months or more...traffic would be delayed... the ers should show, segment by routing for the Highway 42 pipeline alternative

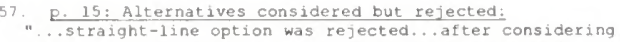
costs..." The EIS should show the relevant cost and

8. p. 18: Air Quality: "...no data is available regarding the current levels of noxious gases..." "...airborne particulates are at low levels...minor and temporary increases in dust partieutate leve1s... a minor amount of data. These data should be available in current federa (EPA) and oregon (DEQ) reports. If relevant data do not exist, the BLM should take positive steps to measure these data and establish baselines. These data should be included in the region environmental baseline. They will and cumulative aspects of this pipeline.

59. P. 13?: Water Quality: conspicuous by its absence. I oversight, and that a full discussion of water quality, as impacted -- not just by construction -- but most importantly by operation of this pipeline and its consequent industries, on rivers, lakes, streams,
wetlands, floodplains, bays, estuaries, sloughs, and wetlands, floodplains, bays, estuaries, sloughs, recreational aspects thereof, in all affected regions, from Bandon to North Spit to Roseburg, will be included in the next revision.

60. P. 28: Public Health and Safety:-"...accidents are possible... if pedestrians or vehicles fail to heed...flaggers...n Indeed. I would suggest that this paragraph be rewritten in its entirety.

61. P. 28: Socio-economics with the Proposed Action: entities, is also adjacent to 37 rural residencies. . " Alternate routes should be detailed that avoid these adjacencies

62. P. 28: Regional Assessment of the Natural Gas Market: as, ...40 percent in outlying areas use natural gas... The EIS should make clear the limits of distribution of hatural gas into the coating be available in the sumner or Fairview areas, for example?

63. P. 31: CBW Road: Several segments of CBWR are listed in general terms as to type and amount of traffic. The EIS should show what the traffic load actually is on each of the road segments; that is, how many units per day of each type of vehicie, segregated by welght; delivery trucks and trailers less than 10,0 trucks 80,000 and up trucks $10,000 \mathrm{c}$ 105,000 $1 \mathrm{bs}$, and up. The EIs should equil show how often each segment is used for emergency services (fire and ambulance). The expected interaction of this traffic with the proposed CBWR pipeline route should be shown in detail, with relevant historical dat from comparable installations, together with complete soil engineering analyses of the CBWR roadbeds. Note that the clay loadbeds of parts of abe subject to complete 
water saturation for much of the year. In this capacity ance, the material has little load bearing liquefaction in case of factors, affecting health and public safety should be addressed in detail.

64. D. 35: Fiber optic Line: "...pipeline Anstruction... Would not affect the fiber optic line. Actualide the fiber optic line crosses under the CBWR the ErS should optic crossovers, and especially who is to be responsible for any costs involved in disruption of the fiber-optic ine.

65. P. 38: Proposed Action Effects Summation: "...the toct, prdirect, and cumulative impacts are so small as to be negligible. brought to the coos Bay region, there to be burned or converted to other substances, in a variety of heavy industrial contexts. These industrial activities will most certainly have long-term environmental conseguences They will heavily impact every aspect of $l$ ife and nature completely rewritten, to provide a realiste, quantified,

66. p. 38: Proposed Action Summation: "...the long-term direct and cumulative effect of the proposed action is a reduction in sulfurous emissions from fossil and wood fuels utilized by industries and private residences... as users switch to natural gas..." Quantitative data of these effects should be shown. While it is on the pollutants (including sulfurous emissions) to be added as pollutants result of pipeline-related industrial activity.

67. P. 38: Proposed Action Summation: "... the short-term 作 coos county seeks to construct a natural gas pipeline... indeed. And this Eis should show in guantitative terms envirosmental and wonomic costs. As it stands, the EIS fails to do this.
Bunnell 15/15

electric neat to gas. The EIS should show what support

3. p. 71: "...ECONorthwest previously estimated...1500 new jobs after 10 years...ECONorthwest estimates...total employment... to be over 2900 jobs higher ten years after natural gas is introduced..." The EIS should detail what the components of these numbers are. In particular, reasons for the increase from 1500 to 2900 should be shown. Upper and lower bounds of employment number depending on economic conditions and industrial population number and size of steel mills, fertilizer These numbers may well be contained in the EcoNorthwest report or elsewhere; nevertheless, they should be shown and developed as reguired here, in credible detail. After all, this EIS paragraph contains the very heart, the sole justification for construction of this pipeline.

74. p. 73: Summary of Direct, Indirect and Cumulative Economic Effects for Action Alternatives: This paragraph addresses in a quantitative way only the direct. immediate, construction costs of the pipeline. It does not sumarize in a meaningful way any direct, indirect, or cumulative economic effects for the project outyears

2900 employment figure.

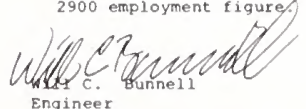

68. P. $67-71$ : Tables 23 through 31: It is encouraging that thought was given to the immediate economic impact the pipeline. But to be complete, similar analyses for each alternate should be provided. The se analyges should be extended to show the long-term costs of maintaining the pipeline in each of the alternative environments.

69. The EIS should present a comprehensive breakeven analysis of the project. For each alternative route, each type must be made each year, and how much indust usage must be added each year, to achleve breskeven status, and when that will occur, considering as well the time value of all pipeline costs. All environmental impacts resulting from these time-based conversions should also be shown. The time-valued costs of conversion to be borne by customers to achiev for each alternative should also be shown.

70. In this connection, the analysis should include the effects of profected natural gas cost variation. particularly detailing the conseguences of yearly natural gas price increases of various percentages best, most likely, worst). This analys is should extend over at least a ten-year period.

71. P. 71: Static and Dynamic Efficiency Effects: "... typical single family home would save $\$ 410$ in annual theat EIS should show the cost of actually switching from electric (typically un-ducted heat to gas heat, including the cost of obtaining plans, permits, labor, materials, and inspections. Maintenance costs of gas heat should be included. Ranged estimates of natural gas price escalation should be included. Finally, consumers indirect costs in the form of increased taxes needed to retire the pipeline construction debt should also be

2. P. 71: "...ECONorthwest estimates that by the tenth year, consumers will save over $\$ 6.7$ million per year... Osing the $\$ 410$ figure given above, this means about
16,341 homes in the service area have converted from

\section{Klamath-Siskiyou Wildlands Center}

$\mathrm{POB}$ s02 Ashland OR $97520(54)_{4} 4_{88-5789}$ joseph@ $\mathrm{kswild}$ org

Boh Gunther

Coos Bay District

1300 Airport Lane
North Bend, OR 97459

RE: Coos Councy Natural Gas Pipeline Draft EIS

Greetings,

These are Klamath-Siskiyou Wildlands Center's (KS Wild) and Umpqua Wate rsheds, Inc. official comments on the Coos County Natural Gas Draft EIS March. These are updated comments to those that you received in your office on included in these comments. those comments, as all issues raised the rein are

Please consider these in the evaluation of the DEIS and the in the formation of you hinal environmental analysis. The proposed pipeline will cross approximately 60 pipeline will require to fect of space pipeline will require 40 feet of space to be kept clear of larger brush and trees. and access for ope rations and maintenance.

KS Wild and Umpqua Watersheds Inc. support the use of natural gas and especially from the proposed action. However, we do have some concerns teafter Bay Areaa pipeline and associated development that would likely occur in the Bay Area as a

The DEIS is Inadequate

We want the Final EIS (FEIS) to explore in more detail the impact that the proposed action would have on the human environment. NEPA requires an EIA to comparative merits" " CFR section isos "that reviewers may evaluate their

NEPA requires documenting Connected, Indirect and Cumulative effects.

The FEIS should determine the effects to the environment if the pipeline were nstable Coastal Mountain range. The too-year flood event must be considesty Likewise, The Coast Range is naturally subject to stand replacing forest fires. If ground, what would the effect the right-of-way, protruding their limbs into the must be assessed in for a route that traverses under a road with he cause explosions 


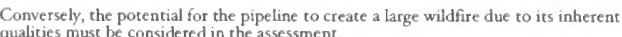

Part of the pipeline is proposed to go under (or next to) the playground at the
Lookingglass Grade School. The grade school is close to the Roseburg BLM land the-right-of-way is planned for. If Roseburg BLM right-of-way, enabling the pipeline to go in proxin
the FEIS.

We are concerned that the DEIS did not discuss the potential for a gas leak. The public should be informed about the likelithood of such an event, with at least anecdotal evidence of existing or past such pipeline in remote areas. Do these pipe
ever leak and what would be the worst case scenario if such events occur? This is important question the FEIS should consider in depth as many imporrant resources occur in the project area. Mitigation measures to prevent such an unlikely event should be proposed and evaluated

If indeed chere are specific business which have expressed interest in moving to the Bay Area and other effected communities if natural gas were avaiablable, these connected to the proposed must be disclosed in the FEIS.

The BLM should completely document the Need for this project. If the need is to attract business to the Bay Area, the cumulative effects analysis must assess the impacts of this project. The Coos County website, for instance, gives examples of industries that lailed to locate in the area because "we don't have narural gas" as two steel companies and a gypsum plant, If the act of BLM granting the right-of-way will include an analysis of the negative environmental impacts the right-of-way would enable. Indirect effects $\mathrm{m}$ us also be included in this analysis. These may include growth inducing effects and changes in the pattern of land use and subsequent

Cost Considerations

We are opposed to taking short curs if spending a litcle more money would afford greater protection to natural resources or endanger human lives. The citizens of have to be taken At the Public meeting on Nov, 29, it was announced that the cost estimate would be $\$ 30$ million instead of $\$ \$ 1$ million originally projected. There is no reason for any cost cutting measures that would result in less environmental

Public Lands

The BLM should survey for Survey and Manage species. Adhere to the federal

Fish Habitat

We are very interested in the fish habitat improvement that is a part of this projec We support the increased fish passage that would be attained as a part of the

through sedimentation would occur. Is there a way that fish improvement projects

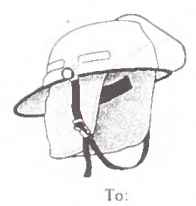

To:$$
\text { in: }
$$

FAIRVIEW RURAL FIRE PROTECTION DISTRICT 96775 Fairview Sumner Lane

Coquille, Oregon 97423

Phone (541) 396-3473

Fax (541) 396-6223

J.S. Department of the Interior

Bureau of Land Management

Coos Bay district

North Bend, Oregon 97459

From: Virgil Williams, Chief

Eairview Rural Firc Protection Distric

96775 Fairview Sumner Lane

Subject: There are several concerns that Fairview R. F. P. D. has that would inhibit the fire departments ablity to provide fire and life safety for the citizens that live whin the fire ditrict

Reference: Coos Cousty Natural Gas Pipeline Draft Environmental Impact Statement.

A. Reference Map (Page 7 of 10) Indicates a block valve will be installed in the 12" natural gas pipeline adjacent to Fairview Road, Bonneville Power Administration, and Pacific Power \& Light I ransmission line crossing.

In most cases with pipeline damage the initial result in a release of natural gas. The second event would be a massive natural gas spill that would require the response of a hazardous materiai team Should natural gas find an ignition source a fireball

2. The by-product of a natural gas fire is dense black smoke that can easily reach 3000 feet. Flame impingement would be high enough to reach the transmission lines, and result in damage to

3. Should such an incident occur the travel of mutual aid from Coquile would be limited because Fairview Road would have to be shut down. This not orly would harnper firefighting activities, but also would disupt one or the main evactuation can move forward wiehout the proposed action' Can you describe the fish habitat
improvement in more detail? New road construction or reconstruction is regarded improvement in more detail New road construction or reconstruction is regarded as reduces pool volumes, and may additionally impact deep pools, which can serve as temperanure refugia for fish.

Waterways

The BLM must comply with state water quality standards promulgated under the
Clean Water Act.

Soils

Do not exceed soil compaction Standards and Guidelines. This project should not increase soil erosion, particularly entering waterways. Past, present and future activities are required to be considered when evaluating soil conditions.

Noxious Weeds

This project has the potential to serious weeds into areas less infested with these species. What is the likelihood that the mitigation measures would prevent of stop the spread of noxious weeds? The BLM must disclose the consistent failure of its
criteria to prevent the spread of noxious weeds in the past.

Species Concerns

Please protect Sensitive, Threatened and Endangered Species. Do no Lead to a trend to list any species. Maintain viable populations of all native species and do no
degrade habitat for any Management Indicator or other target species.

Archeological Sites and Sigrificant Native American Sites

Prevent any potential impact to any tradition Native American uses of the area and any archeological sites. The proper procedure for identifying cultural resources traditional value is located in on page 1 of the National register Bulle tin \# 38 .

Thank you for this opportunity to comments and ple ase keep us informed as this project progresses.

Respectfully,

Goued/s lect

Joseph Vaile
For KS Wild and

Francis Earherington
Umpqua Watersheds, Inc

Roseburg, OR 97470 the winter months, and from Lee Valley in the summer on the south side of the block valve location, and from Evans Creek to the north.

4. The time it takes to get a pipeline operator to close the block valve at the town of Dora would range from 30 minutes to over an hour. Closing block valves is the safest, and most effective method of extinguishing a pipeline fire. With this type of incident fire departments usually concentrate their activities to protecting exposures. The amount of water required for this action would be
approximately 2500 gallons per minute. This fire flow is beyond the capacity of the existing fire department equipmen

B. Reference EIS Draft (Chapter 3, Page 28, Second Paragraph "Public Healtb and Safety")

1. The last sentence in this paragraph reads " after construction is completed, the primary issue for public safety and pipeline operation would be damage from someone digging without permission and heavy equipment (such as a backhoe) of unauthorized use of explosives in the near vicinity of the pipeline.

2. Reference EIS Draft (Page J-7, and Page 3-8) With the block valve footprint surrounded with a chain link fence with a locked gate, and depending on location, traftic barricades. Page J-8 indicated that the block valve control extend S' $g$ " above grade. Will the fence, and barticades prevent fuel trucks, log trucks, or a lowboy truck with a shovel from damaging this block valve assembly?

3. In my opinion the block valve at Fairview needs to be relocated away from the main route of travel, and at a distance that would prevent flame and smoke impingement on the
Bonneville Sub Station, Pacific Power \& Light, and Bonneville Power Administration 230 and $115 \mathrm{KV}$ transmission lines.

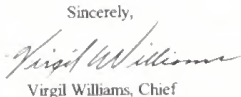

Virgil Williams, Chief
Fairview R. F. P. D. 
fao Bob Gunther

Project Coordinato

Coos Bay Distric

1300 Airport Lane

North Ben
OR 97459

$3 / 22 / 2002$

Dear Mr Gunther

Re: Coos Countr Gas Pipeline. Draft Environmental Impact Statement.

Firstly, thank you to BLM for inituating and publishing this documem

We request that our names and address are withbeld from public review and dischesure.

It is claimed that the installation of this pipeline will provide approximatefy 2900 jobs for the Coos Bay area. Yet page 5 of Chapter I states that 'because no industrial conste to quantify the potential environmental impacts of unknown fisture facilities and their potential locations.

If a specific number of jobs can be quantified then an assumption must have been made about who potent tal employers are, which means that the potential environmental tmpaci can be assessed.

Even if it is nol possible to quantify numbers of new jobs there are certain types of industries to whom the availability of natural gas would be an attraction to locating in this can still he assessed.

PS Chapter I states that 'future new facilities utilizing nalural gas will he required to Pndergo their own environnental impacts analyses, within the required perminting books at the particular facility under review and does not take into account the cumulative impact of emissions from neighboring facilities

Availability of industriat zoned land, transportation and communication systems strongly

Shlices la fao Bob Gunther

Project Coordinator

Coos Bay District

BLM

1300 Airport Lan

North Bend

$3 / 22 / 2002$

Coos Bay and surrounding arca has considerahic natural charm and resources, which arc not yet fully capitalized upon in terms of attracting all types of tourists, and 'clean' and more environmentally friendly industries such
of gas burming industry affect this secnario?

We respectfully offer as our comment on this draft EIS that it does not address the We respectutly offer as our comment ontalis draf the gas pipeline on Coos bay and surrounding area.

Sincerely

\section{Oregon}

March 21, 2002

Mr. Bob Gunther. Project Coordinator

Bureas of Land Management

1300 Aurpor Lane

Coos Bay, OR 97459

Dear Mr. Gunther.

Subject: Draft Environmental Impact Statement - Coos County Natural Gas Pipeline

The Department of Land Conservation and Development (DLCD) has reviewed the drat entronmentah impact statement, DEIS) for the above referenced project. The Bureas of Lan Management (BLM) is the lead federal agency for the National Environmental Policy Act review addressing construction of a natural gas pipeline from southwest of Roseburg, Douglas County Coos Bay. Coos count. The preterred route for the pipetine runs through Reston. Dauglas pounty and then roughy paratict to the Coos Bay Wagon Road to Coos Bay, Coos County. Administratan, and the Wagon road. The pipeline would deliver natural gas to distrower facilities in Coos Bay and North Bend, with smaller laterals built to serve Coquille. Myrtle Point, and perhapss Bandon

In a letter dated April 27, 2001, the Department provided detailed comments to BLM in response a the scoping notice for the proposed project. We are ressubmitting those comments as an attachmerl to this ictier since our Teview of the DEIS indicates that those comments have large ! not been addressed. As we stated in our previous letter, the proposed federal action is subject to

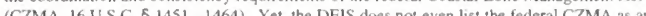

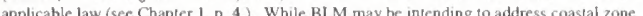
consistency a the finaplEIS stage, we are surprised 0 find no discussion on this most zone witho DEIS.

In closing, fecl free to contact the Department should you have any questions abous this letter. the attached April 27, 2001 letter, or the OCMP. Information aboul the OCMP can also be found

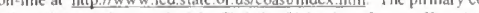
373-0050 X250 or by e-mail at christine valentine@ state. or.us.

Sincerely.

haikcoes

Nan Evans, Manager

Oregon Coastal Management Progran

ODFW-Portla

DEQ-Porland

Conf Tribes Coos,

Bonneville Power Administration

Biological Information Specialists Inc 


\section{Oregon}

April 27, 2001

Ms. Sue E. Richardson, District Manage

Burcau of Land Managemen

Coos Bay District Office

1300 Airport Lane
Coos Bay, OR 97459

Dear Ms. Richardson,

Subject: Seoping - Coos County Natural Gas Pipeline

The Department of Land Conservation and Developrnent (DLCD) has reviewed the March 29, 2001 scoping Jetter and associated website matenals describing the Bureau of Land Management's (BLM) proposal to direct the preparation of an environmentad impact statement (EIS) addressing construction of a natural gas pipeline from southwest of Roseburg, Douglas County to Coos Bay, Coos County. The EIS is required before BLM can issue a right-of-way fo the project to cross federal lands. A preferred route for the pipeline has already been identified based on a 1999 feasibility study. The proposed route would nun through Reston, Douglas

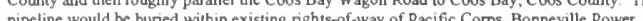
pipeline wata be buried whin existing nights-of-way or pacinc Corps, Bonneville Power facilities in Coos Bay and Nort Bend, with smaller laterals buils to serve Coquille. Myrule Point and perhaps Bandon. The location of the laterals has not yet been determined

The above-described federal proposal is subject to the coordination and consistency requirement of the federal Coastal Zone Management Act (CZMA, 16 U.S.C. \$1451-1464). The project area crosses through and terminates within Oregon's "coastal zone", designated under the federally approved Oregon Coastal Management Program (OCMP). Construction of the pipeline is reasonably likely to affect land and water uses and nanural resources of Oregon's coastal zone. As such, the federal development project and any associated facilities or actions must be state's designated coastal zone management agency, will ultimately be responsible for concurning that BLM's proposed action will be consistent with OCMP requirements.

As part of federal evaluation process, BLM will need to prepare a coastal zone consistency determination addressing how the proposed project, including associated facilities or actions, would comply with OCMP requirements. Your consistency determination will need to include a bref statement indicating whether BLM believes the project complies with the OCMP and mus be supported by an evaluation of the proposed actions vs. the relevant coastal program policies. A detailed project description, information regarding any associated facilities and sufficient information to explain coastal zone effects must also be provided in support of BLM's information to expl
Ms. Sue E. Richardson, BLM

-2 -

April 27, 2001

DLCD generally reviews projects requiring an EIS at the final EIS stage to ensure that a second review to address project modifications is not necessary and to allow the consistency determination and the state's review to concentrate on a selected preferred alternative vs. multiple alternatives. We would hope to address all federal actions associated with the project comprehensively but are not yet certain of whether BLM, as the lead agency, would be addressing coastal zone requirements for other federal agencies. We also ask BLM to explain when and how local, state, and fedcral permit requirements will
local project sponsor might be responsible for obtaining permits.

We anticipate that there will be considerable overlap in the issues that must be addressed in the We anticipate that there will be considerable overlap in the issues that must be addressed in the addressed includes: socio economic impacts, soil erosion, water quality, fish and wildlife, traditional tribal uses of the area, archaeological sites, and noxious weeds. We concur that these topics need to be addressed in the EIS but also find that waterway resources and wetlands, endargered and threatened species, and land use must be addressed in the EIS. With those inclusions, we believe the BLM list and coastal zone management list of topies that must be addressed will be comparable

BLM can choose to include the consistency determination as part of the project EIS or can prepare a separate docurnent with the EIS provided as supporting information. While it is BLM's responsibility to prepare the consistency determination, OCMP staff is available to discuss any questions you may have about coastal zone management requirements. BLM will need to

- The comprebensive land use plans and implemen ting regulations of affeeted local jurisdictions.
jurs

For this project, BL.M will need to consider multiple local comprehensive plans and implementing land use regulations since the project will occur in multiple cousties and cities. BLM will need to coordinate with the Douglas County and Coos County planning departments determine how the county land use programs apply to the proposed actions. Since the project will terminate in the Cing BLM also would need to coordinate with the planning departments of these communities.

BLM should identify all land use policies and standards applicable to the various alternatives and specific actions contemplated under those alternatives - which are described in the EIS. W would expect the land use analysis to be most thorough for the preferred alternative but for land use requirements to be a consideration in all allernatives under revew in the Bis. For a least the preferred alterrative, any needed land use approvals should be identied, and the EIS should als contain an analysis of how the applicable land use polictes and standards will be meet, i.e. to the extent practicable provide the justification for needed local decisions. Thens or goal exceptions:
Ms. Sue E. Richardson, BLM

-3 -

April 27, 2001

see below for more on this topic. Alternatively, the more detailed analysis and justification could ultimately be provided in a separate coastal zone consistency deternination. A goal "exception" is required when a proposed action is specifically not allowed by the requirements of an applicable goal. If the selected alternative would involve actions that do no comply with the local land use program and the statewide planning goals, then the EIS or consistency determination must contain adequatc information to support an exception. The exceptions process and standards are described at OAR 660 Division 004 . At this time, we is very limited, but we are available to work with the county and BLM with the goal of guiding the yanous alternatives and actions to not trigger the need for goal exceptions.

\footnotetext{
(2) The Statewide Planning Goals (OAR 660-15), as applicable
}

The statewide planning goals are state regulations that are generally implemented through the applicable local comprehensive plan(s) and ordinances. The goals and associated rules can be aceessed via DLCD's website [uwww. Icd. state. or.us ]. Local plans are acknowledged by the Land Conservation and Development Commission to meet the requirements of the goals However, the goals apply disectly in cases where an action is proposed that is inconsistent with a local land use program and a plan amendment or goal exception is pursued. A goal provision may also brought into compliance with the updated requirements, Goal 19 for ocean resources is also applied directly by state agencies vs. local governments, but goal 19 does not apply to this projest.

We recommend that BLM review the statewide planning goals as a way to begin to understand the types of policies and standards contained in local land use programs that would likely be applicable to a proposed project. Specifically, BLM should look at Goal 2 (Land Use Planning. Goal 3 (Agriculural Lands), Goal 4 (Porest Lands). Goal 5 (Natral Resources, Scenic and Histonc Areas, and Open Spaces), Goal 6 (Air, Water and Land Resources Quality) Goal 7 (Public Facilities and Services), Goal 13 (Energy Conservation), Goal 16 (Estruarine resources) and Goal 17 (Coastal shorelands)

- The standards of selected state environmental laws (e. . . Removal/ Fill Law, state Numerous state laws addressing the management of specific natural resources and land and water uses of the coastal zone have been incorporated into the OCMP. Based on our knowledge of the proposed project to date, we believe that the following laws incopporated into the OCMP could be applicabich project, Blectiction steps that will be taken to avoid and minimize resource impacts or cormpensate for unavoidable
Ms. Sue E. Richardson, BLM

$-4$.

April 27, 2001

impacts. BLM also needs to consult with the state agencies identified below to determine the applicablity of these authorities and how to demonstrate compliance with these laws:

\begin{tabular}{ll} 
State Authorities & State Agency \\
\hline Removal-Fill Law & Oregon Division of State Lands \\
State Submerged and Submersible Lands & \multicolumn{1}{c}{} \\
General Protective Regulations & Oregon Department of Fish and Wildlife \\
Air, Land \& Water Quality & Oregon Department of Environmental Quality
\end{tabular}

The above list is not intended to suggest that BLM should not coordinate with other state agencies; the above list is only intended to highlight the key statutory requirements that DLCD would likely need to consider when reviewing BLM's consistency determination. As part of the whether the proposed project would be in compliance with these state authorities.

in closing, feel free to contact the Department should you have any questions about this letter or the OCMP. The OCMP is deseribed at http://wrww.led.state.or. us/coastindex. htm. Or you may also contact Christine Valentine, coastal agency coordinator, at 503-373-0050 X250 or by e-mail at christinc.valentine Q astate. or. us for more information. I ask that you also please address future

Sincerely,

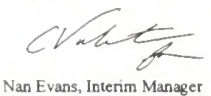

Nan Evans, Interim Manager

Oregon Coastal Management Program

c. Coos County

Douglas County

City of North Bend

City of Coquille

City of Myrtle Poin

City of Bandon

DSL

ODFW-Porland

DEQ-Porland

onf. Tribes Coquille Indians

作, Low

Corps of Engineers 
(典)

Reply To
UNITED STATES ENVIRONMENTAL PROTECTON AGENCY

\section{AEGION to
1200 Sixth Avent}

1200 Sixth Avenue
Seatte, Washington 9810 .

March 19, 2002

Bob Gunther, Project Coordinater

Bureau of Land Management

Coos Bay District

1300 Airpore Lare

Nerth Bend, Oregon 97459

Dear Mr Gunther

The Environmental Protection Agency has received the Draft Environnental lmpact Statement (EIS) for the proposed Coos County Natural Gas Pipeline (CEQ No. 020024) for
review in accordance with our responsiblatities under the National Enviromental Policy Act and Section 309 of the Clean Air Act.

EPA Region 10 has used a screening tool to conduct a limited review of the draft EIS and, based upon the screen, we do not foresee having any environnental objections to the proposed project. Therefore, we will not be conducting a detalced revicw of the draft ElS

Should you have any questions, please contact Bill Ryan of my staff at (206) 553-8561

$$
\begin{gathered}
\text { Suncerely, } \\
\text { Mudith Leckrone lee. Manager } \\
\text { Geographic limplementation Unit }
\end{gathered}
$$

0

To: U.S leat i the hiterer

Burean of Land mavegemet

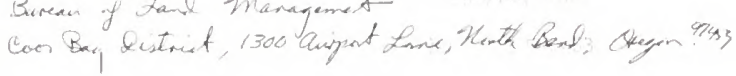

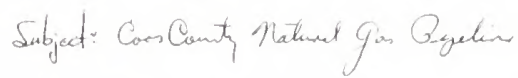

From: Coos, Coqwille Elders Aquaculture Board

Co. Chair Gearge Bartan Goost Cape Axayo thuy Gus Bay

Sir/mam

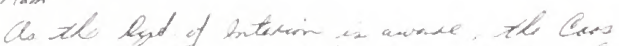

Trile and the Eywill Inbe have poind thas

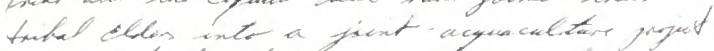

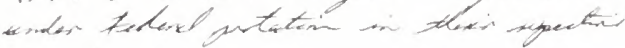

serrear arease.

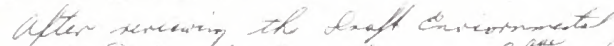

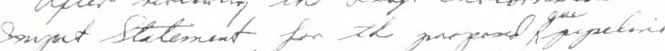

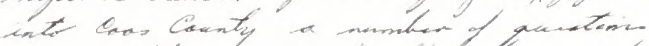

ansere thet were sut ablumase ti th

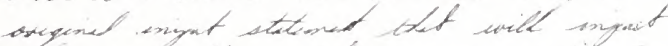

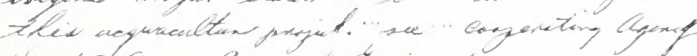
questions

the it S. Alxmy Coxper of Cingiveenis

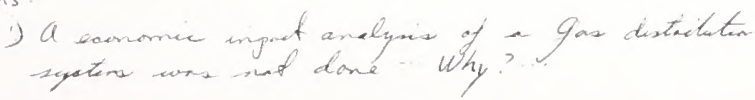

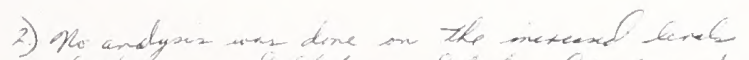

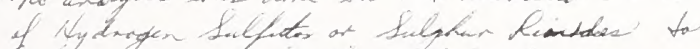

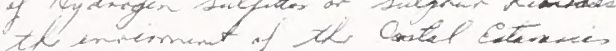

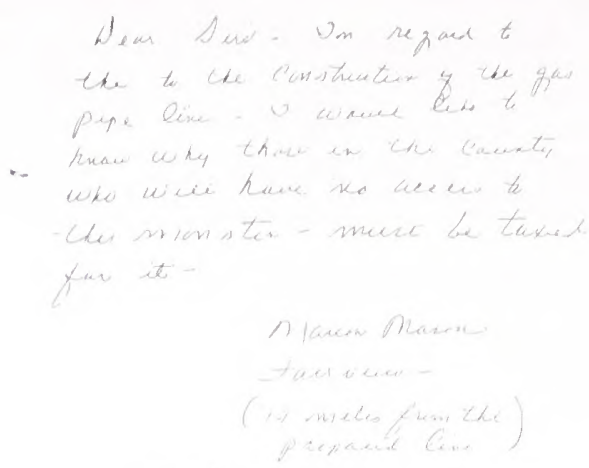

3) No andyow wor done an the candelted

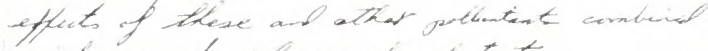

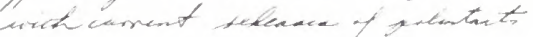

Mistory

Sence the deliverd gas (in tolal or

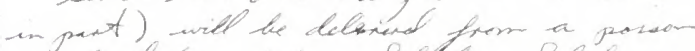

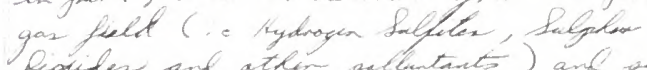
peciles and athin palkentants) and surec

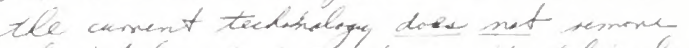

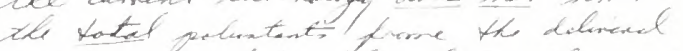
sucthe gae bury delevend to Tle uses,

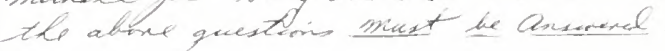

\section{Caso in Point: Then wowe chree} - masain till -off of fink ot ele Butish

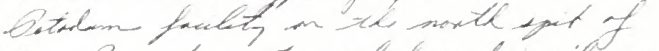

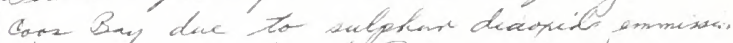
from the Minzll but Roch Ball. This is document red ic - We thave The Files -

We look frowand to ite answeres to these quatione for forther letals plese contact

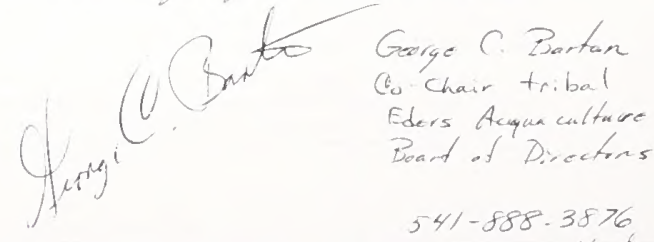




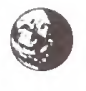

Bob Gunther,

The pipeline EIS muss have a map showing. the BLM land being crossed by the pipeline.

The draft proposal allows suppositions concerming numbers of jobs created but does not allow suppositions about

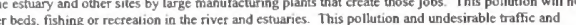
demand a clean environment Therefore, there should be an accounting in the draft for the economic loss due to the increased pollution on such
things as oysters, fishing, recreation, lourissm diminishing, retirees moving away, hesith impact due to contaminated ais \& water, of views being blocked by smoke slacks,

Our ridiculous striving for economic de
for retirement Such shortsighiedness.

I do NOT want the pipeline built. I resent the additional taxes, potlution and congestion If it cannot, then I I do NOT wannt the EIS to simply make the pipeline go around the BLM teritory (which isn't even
shown in the draft), because that would add unnecessarily to the cosis of the pipeline and solve NO real problemsis created by the pipelin

I had such hopes for an EIS. I have since decided that it is a very expensive farce, al least the way I see it being

implemented here! Lel me quole from Ron Sadler's lener to the County Planning department:

"The public conment period on the Draff EIS is open until March 25, 2002. In spite of this fact, your March 8 memo to the Planning Connission announces that hey will be discussing conditional use approval of "the only feasible "oute" Is this not prima facie evidence that the choice of reasonable allematives has, in fact, beenl limited? Could any action be betrer designed lo discourage and squelch he rational public discussion of onter reasonable

"Your action makes a mockery of the EIS processs It indicates that a decision as to "the only feasible route" has already been made, and Coos County and the BLM view the EIS process as a pro forma cxercise withoul any read witherability of process that is already on shaky eround legally"

Pal Simpson 541-3477.2597 patiohns@iucinet.com 435 Michigan NE

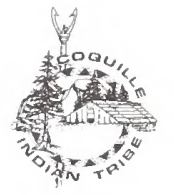

COQUILLE INDIAN TRIBE

P. O Box 783 - 3050 Tremiont - North Bend, OR 9745

March 23, 2002

Mr. Bob Gunther, Project Coordinater

BLM Coos Bay District

1300 Airport Lane
North Bend, OR 97459

Re: Coos County Natural Gas Pipeline Draft EIS

Dear Mr. Gunther

The Coquille Tribe has reviewed the Coos County Natural Gas Pipejine Draft EIS document and submits the following comments specific to archeological and cultural resource concern

Pipeline Laterals (p. 10)

Altbough the possibilities of laterals to the communities of Coquille, Myrtle Point, and Bandon have not been "finalized," It is apparenl thal they are intended. The EIS should strongly emphasize the need for thorough cultural resource surveys along each of the proposed tactral routes, particularly in the Fairview area (see comments concerni

Effected Environment; Cultural Resources. Direci Impacts (p. 40)

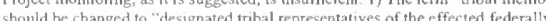

recognized tribes "2) Language should be amended to include the possibulity of

inadvertent discovery of archeological sites and/or isolales, and ihat mitigalion of such discovenes should occur immediately and in consultation with the appropriale tribal representatives. 3) Language should strongly emphasize that cultural resources surveys were limuted to exposed suraces only (see Appendix B.12), and that monilonng may be required in areas of "polential" or "probability". especially; 1) those areas in the projec

Appendix B. Culcural Resources

The B.IS. Repon, prepared by Hentage Research Associales, does not address the need there is only one SuPO-reconde and project monitoring in the Fairview area. Although
Steve \& Wesa Liles $\cdots 24$ 96955 Lone Pine Lane

$\operatorname{March~23,2002}$

\section{Bureau of Land tangement}

1300 Airport Lane
North Bend, Ore

These are our reasons for not excepting the Gas Pipe Line on opr property we have a total of 300 feet of BPA right to go, as we have a water supply in this right of way that will be drained by the drilling under the river.

other reasons are Envirnomental impact on the watershed Engra the study.

sincerely

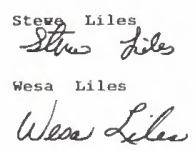

informanis, coupled with the oral bistones of the local tribes, suggest tbe very strong potential for mucb of the Farview valley to be one very large and extenive arcbeological site. The B.IS. report also does nol address the pipetine laterals, and thus has little ment in considenng the scope or areas of focus for cultural resource surveys along any of those

In closing, the comments here are intended only to address cultural sesource concerms Other issues that the Coquille Tribe might have as a government- or as a major Coquille Tribal Council or the Coquille Economic Development Corporation (CEDCO)

Thank you for the opportunity to comment

Sincerely,

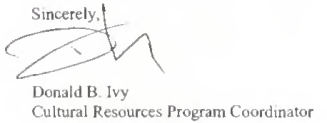

C:

Culture Conn Confederated Coos Tribes 
March 25, 2002

54628 Gciger Crock Rd

Bandon, OR 974
$\mathrm{Ph}: 347-4305$

Bob Gunther, Project Coordirator

Bureay of Land Management

1300 Alsport Lane

SUBJ: Comments on Coos County Natural Gas Pipeline Draft EIS

I make no pretense of being an experi on LIS docunents. However, even a cursory look al this document reveals that BLM has produced a completely deficienl study:

- CLQ $3502.2 \mathrm{~g}$ requires an objective analysis, not a justification of the action alseady decided upon

NEPA (CEQ 1502.16h and CEQ 1508.8b) requires a study of the indirect effects. There is no allempt made to discuss cumulative envisonmental impacts as required

p. 05 New Industrial Gas Users

"Because no industrial commitments have yet occurred, it is not possible to quantify the potential environinental inpacts of uniknown future facifities and their potential locations "

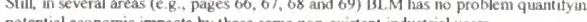

T. IR AIR OHIAIITY

The statement is made "... no data is available regarding the current levels of noxious gases. I his is talse. Data is available tron the LPA's Ioxics Release Inventory and I know that a record of emission releases from the Beaver Hill municipal wasls meinerator is a matter of

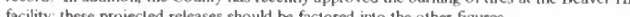

p. 34 Utility Corridors

The concern was raised in my previous comments aboul the siting of a gas pipeline within or adjacent to The BPA power wies, in as much as BPA had declared a moratorium on that practice bocause of safely concerns. Unless I have missed it, this issue has not been addressed

We don't know as much as we should concerning this pipeline that is about to be put in, but as a longtime resident of the fairvew area we are a littie concerned about the safety issues being raised from the fire depariments stand point We are volunteer firefighters as well as residents of the area and from what we can see from all the maps and statistics on the issue we are very eoncerned about being able to protect the citizens of the area and possible escape routes if there were to be any type of leak or fire

I think that the layout needs to be rethought as to where the block valves are placed in relation to populated areas so that the residents of the arcas are better protected Thank you for your time and please consider all of the possibilities involved in this project

Sincerely

Bill and Pam Nelson

\section{SIMMARY}

This document, page after page, addresses eumulative environmental effects, if at all, as "no impact," "no anticipated impact," "nonc," "no forsecable incremental eltects," or as being to impress upon the reader the economic benelits of the pipeline while lotally ignoring the statements on Page 3 of the Economic Impact S1udy.

"The inpacts forecast in this report depend on speculative assumpsions about the future provided to ECONorthwest by Nonthest Natural and Forefront Economics. ECONorthwest ande predictions aboul future market conditions... Whije we belic ve they are reasont speculative" (my emphasis added ]

Thank you for the opportunity lor ollering these comments. Kegardless of the Ihreat made under the No Action Altemative on page v of the Summary, significant revisions must be made to this document for in to meet the requirements of NEPA.

cabinte Revalt

Roherna Stewart
I have deep concems aboul the northwest nalural gas line running through the lown of Fairview, OR.

1. The placement of a block valve on the edge of the main road nearly vertical under bonneville power main transmission lines.

This would enlail a 12 inch pipe wilh approximately $900 \mathrm{lbs}$. pressure, as we are sitting on an earthquake fault line and our insurance company assures us that it is not an if but a when a sizeable quake will hit us $A$ line break and explosion could create a hellish blow lorch, flames $10300 \mathrm{ft}$. high and melting all Iransmission lines from the Fairview sub station leading to all of southwest Oregon

2. Broken lines could block any escape route for people trapped, plus prevenl any help from reaching us from town

3. There are Indian grave sites \& camping areas where the gas line is to cross the river. and siles where they plan to put the block valve in, I cannot tolerate the desecration of my ancestors to satisfy the ego of the Coos County Commissioners.

4 I have noticed the agreement between Northwest Natural Gas and our county commissioners states that coos county would be responsible for any breaks, explosions. leaks caused by quake, slide, flood, or any other reason. it seerns $10 \mathrm{me}$ a major disasler could be avoided by simply relocaling the pipeline and block valve

could lum out that Fairview and its people would be the sacrificial

\section{sincerely.}

Jim Metcalt 
Hello,

I'm writing to express my concern on the proposed natural gas pipeline. My original understanding was it would be rouled down highway 42 . That would have made the line easily accessible in an emergency, earthquake, fire, ect.I have many doubts about changing the route to the old wagon road but safety is by far the biggest issue. My questions regarding a break in the line, fire, explosion, natural disaster, ect. , have not been addressed What is the environmental impact in these situations? I think since the new route will take it through my front yard my questions deserve to be addressed.

This purposed new route is not what 1 voted on. 1 feel the coos county commissioners have changed the original plan to suit their needs and wants without consulting the taxpayers. They have ignored the fairview residents concems about safety and romental issues.

In conclusion I only have this to say, I will not allow this on my land nor will my nieghbors.

$$
\text { sincerey. michelle Clarson }
$$

Hello,

I'm writing this letter with concern as to the safety of my family and the other residents of fairview

This letter pertains to the proposed pipeline project that will split down the middie of Fairview, or Fairview Summner rd

I'm the owner of Double C Disk and U.S.A Jet Door co. We are a tire recycling plant that provides ground gear for trawl fisheries in the U.S. Canada, Mexico, Russia, Japan, my understanding that the proposed pipeline route will run between $30 \mathrm{ft}$. up to $1.500 \mathrm{ft}$ from our main building.

I'm very concerned that the pipeline will be routed through our area. Let me tell you a situation that occurred not long ago. Being a $10 \mathrm{yr}$... member of the Faiview Fire Department I was involved in a rescue a few years ago when our dept. was called out on a man with senous health complications. Heavy rains had caused landslides on Hungry closed roung had closed Summner ra. and Lee Valiey. All access to Faiview was Mountain. slide to the waiting ambulance A complicated rescue due only across a dangerous what it would be like in event of an earthquake out in our ar. How will a.d imagine residents ? What if its in the middle of summer with a fire or leaking gas line to boot?Who will come to our aid then?

I feel our business, our lives, and our future are in jeopardy with the pipeline going through the middle of our community The pipeline representatives that have visited our small valley have not been honest or forth coming with answers to our concems

There has been no guarantee as to our safety with an open ground valve adjacent to our property. Who is responsible for the environmental impact statement? Disaster he residents ? Safety of my employees?

stake.

Thank You,

Jody Clawson
To: $541751-4303$

Dana Gaab

Box 991

North Bend, or 974.59

Bob Gunther, project coordinator [Natural Gas Pipeline]

1300 Airport Lame

North Bend, or 97459

As stated the draft E IS document will "analyize

the proposed action as compared to two atternatives,

including no action

Considering the County Plannimg Departments recent memo to the County Planning Commission seeking approval to allow the pipeline along the Coos Bay Wagon Rad as "the only feasible route I find the county's actions at odds with the intended process. Specifically CEQ regutation 1506 . 10.2

As a citizen of Coos County I demand the

BLM adhere to all applicable regulations and complete

a full and objective EIS

I further urge the BLM ts find the "no-action atternative to be in the best interests of the

citicans of coos county.

$$
\text { Darabaak }
$$

BLM

1300 Airport Lane

Re Coos County Pipeline EIS

Dear Sue Richardson My question to you, and to the entire Bureau of Land Management, is this. Why on
eaith would you involve yourself and our lands in what promises to be all ongong boondoggle when the county commissioners have openly said on numerous
occasions in public meetings that if they had any trouble with you then they'd simply clange the route?

1 reconmend that you find against going across BLM-managed lands. As noted in the FIS, the county has at least two altemative routes that don't involve you Let the EIS, the coun
them use thein

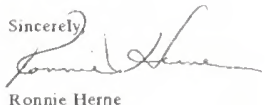

cc: State, Fed 
Robert W. \& Carol N. Doty

P. O. BOX 511

Bandon, OR 97411

March 25, 2002

Bob Gunther, Project Coordinator

Coos County Natural Gas Pipeline

Coos Bay Distrita, BiM

1300 Airport lane

North Bend, OR 97459

Dear Mr. Gunther:

Today we are e-mailing these comments to you, and will aiso have them postmarked hy $5 \mathrm{pm}$ in order to comply with the close of the 60-day comment period. Please place these comments in the record concerning the Pipeline Environmental Impact Statement.

Our expertise is in land use planning and Oregon's land use laws. The EIS provides limited discussion to land uses (forestry, grazing, recreation, and transportation) and the affects of the pipelines on land uses. We draw your attention to the County's adopted and state-acknowledged Coos Bay Estuary Management Plan, and we were disappolnted to see that no mention has been made of this plan which is part of the Coos County Zoning and Land Development Ordinance. In fart, no consideration has been given in Chapter 3 or Chapter 4 to the effects pipeline construction and the hoped-for resuiting industrial devefopment will have on the Goos Bay Estuary This was very disappointing when we consider that much of the economic and environgentat health of the county is depentent upon the health of the Estuary.

The county's Estuary Management Plan devotes 376 pages to the Uses, Activities, Management Objectives, and land Development Standards to be addressed in the Upper and Lower Bays, the isthmus Stough, the North spit and other portions of the Estuary which may be affected by land uses and activities. The construction of a pipeline is a land use, and anticipated and potential development should also be a part of the Environmental impact Statement

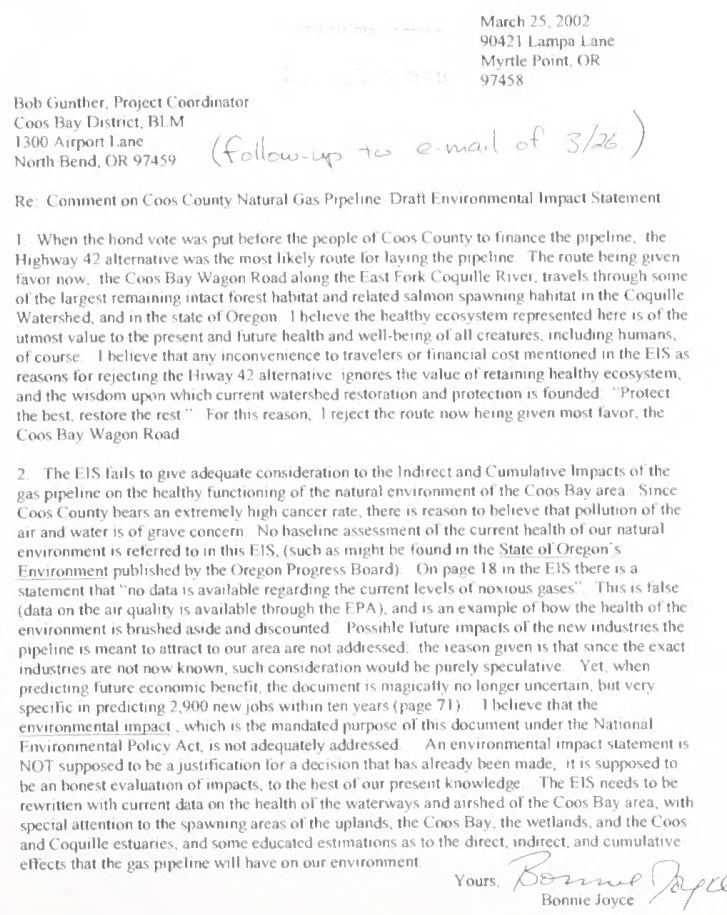

Both Chapters 3 and 4 requite serious attention to the Estuary Management Plan, and at a minimum, how negative impacts will be mitigated in order to comply with county and state law.

To be specific and to provlde an example: p. 20 of the Es lists the isthmus Slough as an estuary which will be crossed if the proposed plan is approved. Pages 129-130, and pages 354-417 of the County's Estuary and special condtions which must be applied when the Slough is affected

in order for the county to construct the plpeline, it will be necessary for it to make appitcation for and prove that pipeline construction wilt comply with those applicable portions of the Coos Bay Estuary Management Plan. Any future use, activity or development in the Estuary must bear the Aurden of proof that it complies with the plan.

Whille we are not fully knowledgeahle about the routes being considered for the pipeline, we believe each route plans to cross sloughs and hays which must be addressed by the is in ilght of retevant portions of the Estuary Management Plan. We request that this he done prior to
completion of the final draft.

Finaliy, two general concerns about the project:

(1) We isve in an area, the City of Bandon, which may never receive service through the proposed project. We belleve we are heiping to pay for part of the construction through the state's $\$ 20$ million contrihution, and that perhaps it is not fair for us to hear additional costs. That has not been addressed in the economic anaiysis portion of the EIS.

(2) The project appears to have heen ilt-concelved in that deciston makers did not conduct a serious evaluation of how realistic the profections are for job creation in coos County, yet the major reason given for buiking the pipeline is to provide an economic boost to the people of the county.

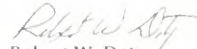

dere 70 Aly
Carol N. Doty
(3) DHop 2880@aol.com To: 8ob_Cunther@or btrm.gov 03/26/020931 aM Subject Fwd envilomentat Impact statement

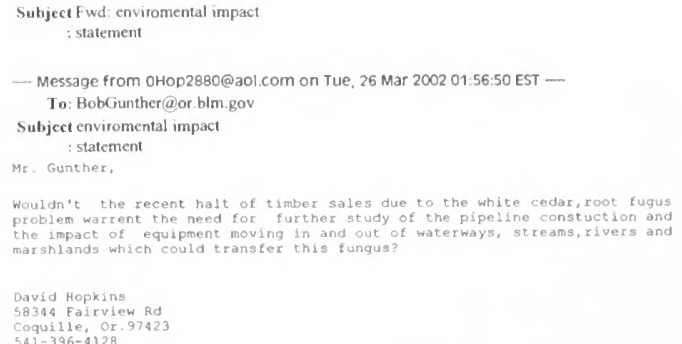


To: Bob Gunther, project condinatos natural bee Piqceline $541751-4303$

Freom: Monion Schreiber

Mansh 25,2002 concermed citizen

fur 5412565762 ph- 2522042

Dear Son,

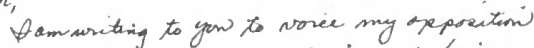
to the natural geo pipeleme aw it it now being propased for ton County.

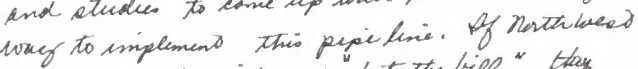
Natural is not willing to "fort the bied", thes munt hase deviled it is nct a gordbueness Lecioion at theo timi. They reve the experto. $\checkmark$ am apraled to see pepelene expenditures in the esmoniscioners agenda. Ham haring much diffeicity in reesneiling on corsmasioners actions wich ow sommenity need. They are supposed to repreant un.

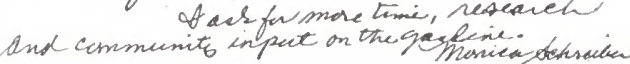
BX 1824

pipeline below the stream bed. Boring, which has more soil erosion, is recommended for the larger streams and Isthmus Slough. Pipeline construction, with the type of equipment used, requires a working area of $30^{\prime}$ to $60^{\prime}$ along the entire length of the pipeline. (The 60' width requirement occurs in steep slope areas.) This increases soll erosion. There is also evidence of landstides and geologic movement due to previous earthquakes (Cascadia fault line). Despite the

The study does not address the above ground features of the pipeline

8. Indirect and cumuiative effects: The draft EIS ignores the indirect and cumulative effects by ignoring the heavy industry Coos Bay and North Bend hope to attract with the natural gas pipeline. A metal fabncating plant and ammonia fertilizer factory is mentioned on page 71 of the draft $\mathrm{EIS}$. These two industries would have a tremendous negative affect on the environment, directly and cumulatively. particulary to the air and water. Coos County has a higher incidence of cancer than Multnomah County - the introduction of heavy industry would not improve this statistic. This cumulative health and environmental cost should be included in the natural gas pipeline EIS

As a property owner and a source of funding for the EIS and the natural gas pipeline, would prefer to get the most formy property tax dollars and not harm the environment and the creatures in that environment, including myself.

Sincerely,

Yyour tery

Lynne Leisy

88643 Weiss Estate

Bhone: (541) 347-2641
Bob Gunther

BLM, Coos Bay Distric

1300 Airport Lane

North Bend, Or 97459

March 26, 2002

RE: Coos County Natural Gas Pipeline Draft Environmental Impact Statement

Dear Mr. Gunther

Following are comments on the Draft EIS for the Coos County Natural Gas Pipeline

1. Lack of EIS for the laterals to Coquille, Myrtle Point. North Spit, and Bandon. The lateral to Bandon appears to be in doubt as to whether it will be constructed or not However, the draft EIS should, but does not, include the laterals to the other three areas.

2. Right of way issues: Of the various public and private property owners, including the 37 residents (page 28), how many have agreed to right of way easements? The study does not address pipeline effects to the residential property owners or their willingness to sign easement agreements. I know one of the residential property construction, and the value of their property being decreased due to the pipeline night of way easement.

3. The U. S. Army Corps of Engineers is listed as a cooperating agency, but I did not find their input anywhere, especially in regards to stream and wetland crossings

4. Appendix F. the letter from the U. S. Fish and Wildlife Service Endangered Species Consultation Letter of Concurrence, could not be commented upon since it was not received tor publication. Whin

5. Lack of substantiation: Statements as to effect are given, more as an opinion than fact, since there are no studies or substantive backing. For example, plant and and described as to their habitat and foraging. From this description, which could be derived from any encyclopedia or nature book, the study then draws the conclusion that there will be no adverse effect during construction. This may well be, but the study does not address long term or cumulative effects to the flora and fauna of the area.

6. Contradictory findings: In Appendix $A$, the Geotechnical Engineening Repor discusses erosion around stream crossings, and the preference for conventional

March 25, 2002

Peter Ryan and Christina Alexander

500 Dean Mountain Rd

Response to the Coos County Natural Gas Pipeline Draft Environmental Impact

Response to
Statement

Chapter 4, p. 38, Proposed Action Effects Surmmation

Paragraph 6 sums it up very neatly: "The shon-term and long-term direct, indirect and cumulative economic benefits of the proposed action are the primary reasons Coos County seeks to construct a natural gas pipeline." It is abundantly clecr from the EIS Draft, media accounts, and statements by public officials these expected bene fits would come from the heavy industrial manufacturing that natura gas avents and matrers of public is also quite clear from media accounts, public otficials statemenis and murban renewal record that this desired economic activity wilte steereds managed by the Port of Coos area

The Council on Environmental Quality guidelines (CEQ 1508.8) describe the "effects" The Councilon Ensidered in an EIS and the BLM seems to have complied with those evidelines in the sections that address the gcological, envisonmental, and socialcultural effects of the pipeline construction itself. However the Draft completely falts apart when
it comes to the effects of activities the pipeline will enable.

The BLM seems to have taken the position that it is impossible to analyze the negative impacts that might accormpany the "short-term, long-term and cumulative benefis" of enabled activities because it is not knolines for areas of analysis where there is "EQQ entirely.

There are many consultants and non-profils that could supply the "summary of credible scientific evidence rekvant to evaluating reasonably foreseeable adverse impacts" mandated by CEQ1502.22b3. The cost of this information would not be "exorbitant".

Perhaps a scientist in the employ of the National Association of Manufacturers might disagrec, but most people wouk concur that heavy industral as liquid and solid effluents one kind of anwither, be it noxios gase, arects, esthetic blight etc. A reasonable person as well as possole that these effects might have curnulative impact and that the closer might also coral activities are to population centers and significant bodies of water, the these ind ressible impacts. And that reasonable person might also wonder how much 
ahility our lands and water have to absorb these pollutants. CEQ1502b states "impacts thall he discussed in proportion to their significance". In nor discussing what might be grave environmental, economic, and social effects of the en
the BL.M saying these possibilities are of too significance?

There is compelling evidence that negative coonomic impacts of the very gencrous tax breaks offered in Enterprise Zones such as the North Spi//Aipont lands might erode the tax base and strain the budgets of our poor conmunities when industries and their workers place heavy demands on infrastructure and public services. This is not discussed. There is no discussion in the Draft of whether new jobs created by the enabled activities would actually be filled by local residents or experienced workers from outside the area

If beal leaders realize their dream of attracting manufacturing industrics to the Nortb Spit and Airport lands in close physical, visual, and auditory proximity to residential areas and life, thealth real cestate values and to the viahility of oconomic activitics that rely on "natural heauty" or esthetic values. In short, the very perception of the greater Coos Bay area could change from that of an attractive place to visit or live to onc of an ugly smokestack-industry town. The CEQ1502 instructions require this be discussed.

Stroukd the BLM, in preparing its final version of the EIS, decide to comply with the CEQ guidelines which regulate its work as a federal agency and require a theoretica assessment of possible negative impacts of enabled activities, it could slan by assessing the possible impacts of any and all or the past industries that have shown an interest desirate candidates and is is the best indication of uhat could he expectod in the futer

In the Pipe line Draft EIS the BLM has returned to the public a seriously flawed and deficient document. There is the appearance of a double standard in play. The projections of Coos County and ECONorthwest that the availability of natural gas will stimulate beneficial economic activity ( even though they can not say which industries will come are trcated as acceptable and reasonable. The projections of the responding public that such activity might also have negative environmental, cconomic, and social impacts are locate bere.

In Appendix G, Questions and Concerns from the Public, are BLM answers to fwo comments which are most telling

Comment 2 p.Gl 4 : "We strongly support construction of the pipeline. Please do all you can to furher this project." The persoo registering the comment clearly regards the BLM rok in the EIS as one to further and cnable, not objectively evaluate, the Pipelise project. To which, the BL.M says "Thank you for your support."

Comment II p. G16: "My family and I strongly support construction of the natural gas pipeline. The few noisy people, want nothing that will cost any taxes regard less of the

60 North Folsom St

March 25 2002

Bob Gunther

Project Coordinator

Coos Bay District

Bureau of Land Managemen

300 Airport Lane

Re. Comment in response to dref Environmental lamact Statement (FIS) for proposed natural gas pipetine from Roseburg to Coos Bay, reference $\# 2800$

It is my understanding that while preparing an EIS it is necessary to address the Direct, the Indirect as well as the Cumulative effects of the proposed project it is my belief that these items were not sufficiently addressed in this draft EIS

Item. Chapter 1. Purpose of and Need For Action, Page S, paragraph 2

- Points out the fact that a natural gas pipeline would not necessarily bring new manufacturing facilities to the area, questioning the projects purpose

- It avoids the most pertinent issue of the whole project, that being the impact of bringing new industry to the North Spit arca and its effects on the Bay as well as the Estuary and surrounding areas.

- The potential effects on these areas cannot be separated from the direct impact of the pipelines construction itself They would undoubtedly fal under indirect as well as cumulative impact due to the pipelines construction. An EIS prepared without taking these iss

Item. Chapter 3, Affected Environment; Page 18, Air Quality, paragraph 2

Effects to final destination of pipeline not considered

- Coos Bay as well as the adjoining estuary and surrounding land areas. particularly those down wind of any new industrial facilities, would be impacted both indirectly as well as cumulatively as a result of the construction of the proposed pipeline long-term benefits of any project. Please do all you can to further this project." Again, the commentime parites regard the BLM as an agency to advance the project. And to this the BLM again says "Thank you for your suppont"

One has to surmise that this is, indeed, how the BLM sces it role. It is the only reasonable explanation for a deft EIS that is rife with serious omissions, mistepresentations, and explanaton for a draft EIS that is rife with serious ons.

Peler lya

Chistina) Alexander

Peter Ryan

Christina Alexande

\footnotetext{
- Although it is not possible to evaluate precise impacts for unkrown future industry, it is possible to obtain current air quality levels for this finial destination area and to prepare projected impact levels for potential new the pipelines construction, the EIS is incomplete

Item. Chapter 3, Affected Environment, Page 20. Water Quality

Effects to final destination of pipeline not considered

- Coos Bay and the adjoining estuary would be impacted both indirectly as well as cumulatively as a result of the construction of the proposed pipeline - Although it is not possible to evaluate precise impacts for unknown future
industry, it is possible to obtain current water quality tevels for this final destination area and to prepare projected impact levels for potential new industry to the area Without this further inquiry into impacts created by the pipelines construction, the E1S is incomplete

Page 28, Public Health and Safety

Effects to final destination of pipeline not considered

- Coos Bay as well as the adjoining estuary and surrounding land areas. particularly those down wind of any new industrial facilities, would construction of the proposed pipeline This matter has no other foreseeabie conclusion except that of becoming a threat to both public health and safety

- This issue has not been properly addressed With the inevitable increase in evels of pollution erce presty papdressed Wir he ivity in the finial destination area The end point habiat and its inhabitant's ability to absor these incrcased toxicity levels needs to be ascertained, pror to any further consideration of a gas pipeline project, whose primary purpose is industrial development in an area alscady at risk

- Coos County has one of the highest cancer rates in the sate of Oregon.We need to examine why that is, before we undertake projects that will knowingly increase probable polluting elements responsible for such public health and safety issues
} 
Page 30, Land Uses, Recreation along the Proposed Action.

Effects to final destination of pipeline not considered

- Coos Bay as well as the adjoining estuary and surrounding Land areas, particularly those down wind of any new industrial facilities, would be impacted both indirectly as well as cumulatively as a result of the

- Again the extent of any study concerning the construction of the proposed

gas pipeline cannot warrant validity without the inclusion of the

In summary I would propose that an EIS that truly undertook the entire scope of the effects associated with the proposed gas pipeline, (Direct, Indirect and

Curmulative) be required.

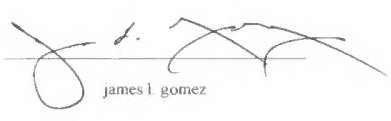

(3) 


\section{Appendix G2. Responses to Letters Received During Draft EIS Comment Period}

The questions and comments in Appendix G of the Draft Environmental Impact Statement (DEIS) were received by Coos County from 1999 through 2001 during preparation for an Environmental Assessment and may reflect responses from Coos County rather than the BLM.

Letters included in G-1 were received during the formal public comment period for the DEIS and the responses from the BLM reflect directly on the DEIS. The Project Advisors provided technical details for some responses.

1. Letter:

Oregon Department of Fish and Wildlife:

Response:

Thank you for your comments. They are incorporated into the final EIS. As stated in Appendix $\mathbf{J}$ of the DEIS, the construction of the lateral pipelines will follow the same project design criteria (PDC) as the rest of the pipeline project.

2. Letter:

Werner

Response:

Thank you for your comments.

3. Letter:

Roth

Response:

Thank you for your comments.

4. Letter:

Bunnell

Response:

Mr. Bunnell has raised questions in 25 separate categories. Answers to his questions in each category are as follows:

1. Comparable Installations: Much of the gas transmission pipeline from Klamath Falls to Medford was installed in 1995 alongside rural roads. Gas and liquid transmission lines are more commonly installed under roads in urban areas but in Coos County, there is already a fiber optic line installed alongside the road along the proposed pipeline route so the pipeline must be installed in the roadway.

2. Residential Involvement: There are approximately 25 homes located within 50 feet of the pipeline route and an additional 28 homes within 75 feet of the pipeline route. At least 25 of those homes are located in the "Libby" area. The rest of the homes are scattered along the rest of the pipeline route.

In the case of a "major leak", such as a pipeline rupture, emergency response personnel will require people to remain as far away as possible from the ruptured area to prevent loss of human life.

If a fire has resulted from a "major leak", then the heat resulting from that fire will determine for emergency responders the safe distance. If a fire has not resulted, then a safe distance will be determined by emergency responders and can range from 50 feet to several miles. The exact distance that people are kept from the leak site will usually depend on the experience of the emergency responders.

It is impossible to determine the "estimate damage perimeter" without making several assumptions. Please refer to the new Pipeline Safety and Fire Data secton under Public Health and Safety in Chapter 4.

3. Notification to Property Owners: As a required by the Coos County and Douglas County Conditional Use Permit applications, property owners affected by the proposed pipeline route have been notified.

4. Residential Insurance: The Project Advisors are unaware of any effect, positive or negative, that the 
pipeline installation will have on residential insurance rates.

5. Cost Considerations: The pipeline project is funded in part through Economic Development funds granted to Coos County by the Oregon state legislature (approximately $\$ 24$ million) and in part by money to be raised by the sale of some sort of financial instrument by Coos County (up to $\$ 27$ million). Coos County residents approved the Coos County funds in a November 1999 double majority vote.

If Highway 42 is considered to be the "original route", then the currently proposed route should cost approximately $\$ 15$ million less than the estimated $\$ 51$ million for the Highway 42 route.

The money "saved" by choosing a route other than Highway 42 cannot really be called "savings" as normally defined because the money represents funds that were never actually raised or available for use. The difference in costs represents money that Coos County will not have to raise, thereby "saving" Coos County taxpayers the interest amount that would be paid on that additional money.

Any costs over the funds available from the state will have to be raised by Coos County, thus "nothing" happened to the plan to sell to the public "bonds" or some other sort of security.

6. Pipeline Ownership and Liability: Coos County will own the pipeline and maintain liability insurance on the pipeline. The pipeline construction contractor and possibly others would likely be held liable in case of property damage attributable to improper pipeline installation. Coos County and the pipeline operator will likely be held responsible in case of damage attributable to pipeline operation or maintenance and Coos County and the pipeline operator will carry liability insurance.

7. Installation Information: The pipeline will typically be installed somewhere in the uphill lane of the CBW RoadCBW Road. The pipeline will be buried with at least three feet of cover where possible.

Thermal expansion is not a design consideration or concern with buried welded steel natural gas pipelines because once buried, the pipe remains at a nearly constant temperature and does not expand or contract.

Where a "bend" is required, either a manufactured bend will be installed or the pipeline will likely be bent using a bending machine specially designed for bending high strength steel pipe.

8. Installation Impacts on Road and Residential Access: The project includes paving the CBW Road along the entire route of the pipeline installation. No horizontal or vertical road realignment, improvement or widening is planned.

The current plan is for costs of road paving or re-paving to be borne by the pipeline project. The county roads department will bid and manage the paving work.

9. Installation Schedule and Access Questions: Work will not start on the pipeline construction before the middle of June, 2002. That date, and all other questions related to project construction schedules are dependent on the issuance dates of several pending permits, including the BLM's Record of Decision on the Environmental Impact Statement.

The County anticipates being able to provide at least a week notice to residents that may be affected by a road closure. The intent is to leave at least one access route open at all times but that may not be possible at all points on the Wagon Road.

The County plans to work with the Myrtle Point and Coquille school bus operations to schedule construction activities in such a manner to minimize the impact on school bus routes.

The County will work with State, County and local emergency response personnel to provide access at all times during construction.

The pipeline construction should have not affect on the ability of the Sumner Rural Fire Department to draft water from Wilson Creek. As previously stated, the pipeline project personnel will be working with emergency response personnel to provide access as required.

10. Safety Valves/Vents: In general, "block valves" are planned for the Lookingglass, Ten Mile, Dora, Fairview, and Isthmus Slough areas. As currently planned, the Lookingglass, and Fairview valves will have automatic or remote control closure devices. The Ten Mile, Dora, and Isthmus Slough valves will be manually operated.

The valves with automatic or remote control closure devices will be operated primarily with natural gas from the pipeline and nitrogen from external bottles as a backup source of gas pressure. The "computing" and "communication" portion of the valve closure devices will be connected to external power for battery charging to allow actuation of the valve in case of power failure. The valve closure devices will be attached to a telephone line but the closure device will capable of automatically closing the valve in case of telephone line failure. Additionally, someone will be able to close a valve with "local" controls at the valve site. 
Each block valve will be equipped with pressure blow down valves, which will not have automatic devices attached. The blow downs will have to be manually opened and will only be opened if necessary to vent pressure from a section of the pipeline for repair or possibly in case of an emergency.

11. Pipeline Capacity: The block valves will be placed between 4 and 19 miles apart. If the pipeline is pressurized to 600 pounds per square inch (psig), then between 600 thousand standard cubic feet and 3200 thousand standard cubic feet will be contained between the valves.

Depending on the distance between block valves, if the pipeline is completely severed, then the time to bleed the pipeline to atmospheric pressure would range from 3 to 6 minutes after the block valves on either side of the rupture were closed.

12. Landslides and Erosion: Please refer to Appendix A of the Draft Environmental Impact Statement for the Geotechnical Engineering Report. In general, a landslide that results in dirt being deposited on top of the pipeline route will have no impact on the pipeline. A landslide that results in soil movement around the pipeline could result in a rupture. There is no record or collective memory of such an event disrupting the Wagon Road in any section planned for pipeline construction.

Road erosion is mitigated by the installation of eulverts. Additional eulverts will be installed during the pipeline construction as necessary. Paving the Wagon Road after construction will also help to reduce road erosion in the future.

A representative of the pipeline operator should be present anytime digging is performed near the pipeline as required by the Operations and Maintenance Plan.

13. Weather: Lightning will have no affect on the integrity of the pipeline. It is possible that a direet lightning strike could disable electronic equipment on the pipeline but that would be a temporary condition and all mechanical equipment would continue to function properly.

14.-15. Geological Questions \& Earthquakes: Please refer to Appendix A of the Draft Environmental Impact Statement for the Geotechnical Engineering Report. The pipeline construction will not cross any active faults. The automatic or remote controlled block valves will help to minimize property damage that might be caused if the pipeline were ruptured in the event of an earthquake.

16. Emergency and Fire Safety: The County and Project Advisors have stated that Pipeline emergency response personnel will be available 24 hours each day and 7 days each week. The contract pipeline operator will control the location of personnel but it is likely that those employees will operate out of the Coos Bay/

North Bend area. Those employees will not normally respond to fires or other emergeneies unless those emergencies directly affect the pipeline facilities.

Per USDOT regulations, area public emergeney response personnel will be trained in issues related to the properties of natural gas and the proper response to leaks or suspected leaks. "Fire fighting" is not normally required because a fire issuing from a pipeline is not normally extinguished, but rather allowed to burn until no further natural gas is available to support combustion.

The Project Advisors state that Incident Command is normally the function of the first emergency responder on the scene. If the first emergency responder is a natural gas pipeline employee, then Incident Command is turned over to the first public emergency response person at the incident.

The responsibility for controlling a fire that results from a pipeline incident will not change from the responsibility present today. The Fire Department responding to forest fires or structure fires today will respond after the pipeline is built.

17. Motor Vehicle Accidents: A vehicle accident on the road over the pipeline will not damage the pipeline unless the accident causes the pipeline to be physically exposed. If a vehicle hits an aboveground portion of the pipeline, then an inspection will be performed to determine if the pipeline has been damaged and if repairs are necessary.

18. Road Traffic: Calculations and experience with similar pipeline operations indicate that $80-105,000$ gross vehicle weight ( $g v w$ ) vehicles will have no impact on the pipeline where the pipeline is buried in the roadway.

19. Road Maintenance: Normal road maintenance practices will not be affected by having a pipeline buried in the road. Culvert maintenance will require additional supervision by the pipeline operator and extra heavy gas pipe will be installed in the roadway over all culverts.

The County has no plans to improve the Wagon Road but if improvements are planned in the future then the present location of the pipeline will have to be considered when making those road improvements.

Future road maintenance costs will be borne by the County general budget, unless that road maintenance is 
caused by pipeline maintenance, in which case the pipeline operations budget will pay to repair the road. 20. Property Protection: The County will carry liability insurance to cover catastrophic losses due to an incident on the pipeline system. Shelter, animal provisions, and property protection measures will be handled in case of a pipeline incident in the same manner that the County would handle any other emergency.

21. Pipeline Operation: The pipeline operators will be on duty " $24 / 7$ " (refer to Item \#16). The pipeline will normally operate at a maximum pressure of $600 \mathrm{psig}$. There will be no human detectable noise emitted from the pipeline during normal operations, even at aboveground facilities. At an aboveground section of pipeline, it may be possible to hear natural gas moving in the pipeline if one's ear were to be placed against the pipeline.

Pipeline operators will become aware of a problem on the pipeline either because of remote instrumentation or because of a "911" or other telephone call alerting the operators of a problem. The exact procedures that the operators will follow will be part of an Operations and Maintenance Plan which will be made available to emergency response organizations along the pipeline route.

22. Gas Leaks: Gas leaks are detected by odor, blowing sounds or debris along the pipeline route, or vegetation changes. Natural gas has no readily detectable odor so odorant, usually a mercaptan type that has a "skunk" odor, is added to the natural gas so that natural gas is detectable at a level of $1 \%$ gas in air. The lower explosive limit of natural gas in air is $3-5 \%$ gas in air.

Natural gas can travel through soils. Because natural gas is lighter than air, it tends to seek a path of escape to the surface. If a leak is detected or suspected in the vicinity of a residence, then "bar-hole" tests are performed in an attempt to isolate the location of the leak. If the residence is unoccupied at the time of a leak, then local emergency response personnel may need to enter a home to remove any possible source of ignition.

23. Inspection and Testing: The required inspection intervals are determined by regulations in $49 \mathrm{CFR}$, part 192. In general, all block valves will be inspected annually and all road, stream, and bridge crossings will be inspected quarterly and atmospheric corrosion is inspected at least once every three years. Other inspections are also required by 49CFR, part 192. More frequent intervals of inspection are likely but will be determined between the County and the pipeline operator and will be detailed in an Operations and Maintenance Plan.

A "line pressure test" is performed to $150 \%$ of MAOP during construction. The pipeline is checked annually for leaks. There is no regulation or reason to require another subsequent pressure test of the system.

24. Pipe Line Maintenance: (For several of the questions, please refer to previous responses).

The underground portion of the pipeline will be coated with a protective coating that is expected to last for the life of the pipeline, which is in excess of 100 years. Additionally, the pipeline will be "cathodically protected" with anodes that will prevent metal loss by corrosion.

The cathodic protection system will be inspected at least once per year for proper operation. Portions of the cathodic protection system that are not operating properly at the time of inspection will be repaired or replaced. The coating on the buried pipe will only be inspected if the pipeline is exposed at any time. The surface facilities will be painted to protect them from corrosion.

25. Legal Questions: Legal questions of the sort raised by Mr. Bunnell should be referred to the County Commissioners and/or County Legal Counsel.

\section{Letter:}

Kenyon

Response:

The amount of insurance money required as a result of the pipeline operations will be considered part of the Operations and Maintenance budget and will be paid for by users of the pipeline.

The cost of the EIS studies is available from Coos County.

In response to the question concerning the use of excess flow valves, NW Natural provided the following response: "Northwest's company policy requires the installation of excess flow valves on all new residential service lines (and all residential service lines replaced by the company for any reason) providing natural gas 
service to single family residential dwellings, as specified by the federal pipeline safety code 40 CFR Part 192.383. The excess flow valve is installed near the main line, and is designed to provide an additional margin of safety by interrupting the flow of gas in the unlikely event the single family residential service line is severely damaged anywhere between the main and the meter set. Northwest intends to apply the same excess flow valve installation policy to all new single-family residential services installed in Coos County."

\section{Letter:}

Confederated Tribes

Response:

The BLM and County are committed to having a Tribal representative present or on-call during construction operations. Please refer to page 18 of Appendix B.

\section{Letter:}

\section{Briscoe}

Response:

Thank you for your comments.

\section{Letter:}

\section{ONRC}

Response:

Thank you for your comments. In response to each comment raised by your letter:

1. Please see the revised "no action" alternative in the Final EIS which describes in greater detail the actions that Coos County might take if the BLM selects the no action alternative on the EIS.

2. On page 3 (Purpose and Need) and page 5 (New Industrial Gas Users) of the DEIS, it is stated clearly that the purpose of constructing the pipeline is to encourage economic development in Coos County. A significant benefit to Coos County citizens will be the availability of natural gas for residential and commercial use (page 5 - Natural Gas Distribution System) and the potential conversion of existing industries that currently burn other fuels. Any new industry that wants to site a facility on the North Spit or anywhere else in Coos County will be required to apply for and abide by numerous permits, including those affecting air and water quality.

3. As shown on page 84 of the DEIS, public scoping meetings were held on numerous occasions at various locations. The risks of soil movement and damage to the pipeline were considered important and were addressed in the Geotechnical Engineering Report. The County carefully reviewed the credentials of the experts that prepared the DEIS and supports their opinions.

4. Appendix $\mathrm{H}$ addresses methods that will be used to prevent soil erosion and thus sediment migration into streams.

5. Mass soil movement risks are addressed on page A7 and on pages A16 and A17. Soil creep is unlikely to cause damage to the pipeline. Massive soil movement may cause damage to the pipeline, though in analogous soil movement cases in the Pacific Northwest, pipelines constructed using the latest construction techniques have not failed or been damaged.

6. The Geotechnical Engineering Report review and discussions with Coos County Road Department personnel did not indicate that it was likely that a debris flow would cause Wagon Road fill to be completely "wiped out". Even if a section of Wagon Road fill were to be wiped out by a debris flow, the impacted area would be small and the pipeline can "free span" at least 30 feet of open area without harming the pipe. There is no record or collective memory of such an event disrupting the Wagon Road in any section planned for pipeline construction. Debris flow is most likely to occur near culverts, where the pipeline will be built with extra heavy pipe. Please refer to the Geotechnical Engineering Report in Appendix A.

7. There are no anticipated plans associated with this project to close any BLM roads in the area through which the pipeline crosses. Where the pipeline is installed in a power line corridor, existing power line access roads will be used to access and maintain the pipeline. Those are private roads over which the BLM has no jurisdiction. 
8. The Final EIS includes a table of streams and the method by which those streams will be crossed. (Refer to Appendix I of the FEIS).

9. Mass soil movement, or a "landslide" onto the top of the pipeline will not damage the pipeline. See the response to questions \#5 and \#6 for additional information.

10. It is possible that upslope timber cutting operations could cause a landslide to occur. As previously discussed, a landslide that deposits dirt onto the top of the pipeline will not damage the pipeline.

11. Appendices E, and I include a stream-by stream analysis and the 5th field analysis.

12. Please see the PDCs in the final EIS for a discussion of the Port-Orford-cedar.

13. The PDCs will have no direct effect on the Coos Bay estuary. NW Natural is responsible for designing and constructing the gas distribution systems. The construction of those distribution systems will have to follow PDCs dictated by the municipalities in which those distribution systems are installed. See statements on Air Quality in Chapter 4. There is no new industrial development currently proposed for construction in Coos County but at such time as any new industrial development is proposed, either on the North Spit or at any other Coos County site, then that new development will have to be analyzed for impacts to Coos County and possibly to the Coos Bay estuary.

14. Based on US DOT statistics for similar pipelines, the risks of the pipeline being installed in the power line corridor appear to be minimal. This issue has been discussed in numerous public meetings. Coos County will have clearance from BPA and PP\&L to install and operate the pipeline in the power line corridors. BPA is currently finalizing an agreement with Coos County.

15. In analogous Pacific Northwest pipeline incidents that resulted in fire, no more than two to three acres of trees were damaged. These incidents involved pipelines twice the size of the Coos County pipeline. Thus, the pipelines in the analogous incidents actually contained about 8 times as much natural gas capacity and there were no automatic closure valves on those pipelines. Automatic valves are part of the PDC for the Coos County pipeline, thus if a pipeline rupture occurred, the amount of gas that would escape should be much less than in the analogous incidents.

16. An analysis of "alternate fuels" and "alternate energy processes" was not part of the DEIS scope and those items were thus not studied. All data presented by ECONorthwest and NW Natural and the Project Advisors (during public meetings) indicates that the pipeline would not be constructed if some alternate fuel were cleaner burning or more economical to use than natural gas.

17. All Northwest Forest Plan requirements have been followed.

18. Please see answer \#3 above. In addition to the referenced meetings, notices requesting scoping comments and comments on the DEIS scoping were published in the Federal Register and in local newspapers.

\section{Letter:}

\section{Sadler}

Response:

Thank you for your comments. In response to specific areas of concern:

Introduction: The commenter is concerned that a particular statement would limit the scope of comments received from the public. The volume and variety of comments received during the comment period would seem to allay this concern.

The commenter has misread the statement letter by Coos County. Coos County correctly stated that the pipeline route as detailed in the DEIS was selected to minimize impacts to people and habitat. One of the benefits of the selected pipeline route will be a lower than expected cost to the Coos County taxpayers. Coos County did not select the route merely on the basis of cost.

Summary: Need for Action: Please see the revised Need for Action statement.

Purpose of the Proposed Action: Please see the revised statement.

No Action: Please see the revised statement.

Purpose of and Need for Action: Please see the revised "Purpose of and Need for Action" statement in the Final EIS. It is correct to state that the reason for building the pipeline is to encourage economic development. It is speculative to state that any new industrial development must occur in order for the pipeline to be built. In fact, NW Natural has stated in public meetings and documents that they do not need new industrial development in order to justify constructing their distribution systems. 
It is false to assume that the only place that an industrial facility might be sited is somewhere on the Coos Bay estuary. In fact, there are numerous areas in Coos County that are zoned for industrial use, including several Tribal owned parcels of property which are not loeated along Coos Bay. Also, the commenter assumes that certain types of industrial facilities might be enabled by the pipeline project. Any new industrial facility constructed in Coos County will have to be permitted under Federal, State, and local regulations.

Any industrial facilities mentioned in public meetings or public documents to date have been examples only of industrial facilities that might choose to consider locating in Coos County. There has been no evidence that those industries would actually have chosen to locate in Coos County if natural gas had been available. There has been no public announcement of any industry that is currently planning to locate in Coos County. Alternatives Including the Proposed Action: Please see the revise No Action Alternative in the Final EIS.

Affected Environment: Coos County and BLM do not agree that most of the indirect and cumulative impacts of the pipeline will take place in the Coos Bay Estuary.

Current emissions data from the Beaver Hill municipal waste incinerator is not relevant to the pipeline project or the DEIS scope. Coos County air quality will not be harmed as a result of the pipeline project. In fact there is qualitative evidence that Coos County air quality could be improved if existing users of fuel oil and wood convert to natural gas. Please see other responses dealing with this issue and additions to Environment, Air Quality (Chapter 4).

Water quality of the Coos Bay estuary will not be negatively impacted by the pipeline project. In fact, as previously stated, water quality could be improved if sulfur dioxide and heavy metal emissions from users of fuel oil were reduced by conversion to natural gas.

The commenter implies that the Coos County cancer rate is somehow tied to the presence of past or present industries in Coos County. There is no credible evidence to that effect. There are no air or water emissions from a natural gas pipeline, which might affect a cancer rate.

Statements about the timber industry were considered when reviewing the DEIS for final revisions.

Various agencies have concluded that the pipeline project will not affect the Coos Bay estuary, thus recreational use of the Coos Bay estuary will also not be affected.

Environmental Consequences: Please see previous discussions concerning air quality issues. Regarding "2900 jobs, please read pages 65 and 66 of the DEIS, "Background", where ECONorthwest discusses the statement about 2900 jobs. Additionally, ECONorthwest states that those jobs may not be present for at least 10 years after the pipeline is constructed. NW Natural does not rely upon this level of job growth in their plans for distribution systems.

See previous discussions of the Coos Bay estuary issues.

Static \& Dynamic Effects: An analysis of the economics of gas distribution systems and the costs of conversions is not part of the scope of the DEIS and is not relevant to Coos County's project. ECONorthwest did not include the cost of conversion in their savings estimates.

Summary of ... Economic Effects: There is no evidence that suggests that inflow or outflow of retirees would change if the pipeline were constructed. In fact, ECONorthwest states that the quality of life in a community for all residents improves when natural gas becomes available.

Public Health: Please see previous comments concerning the effeet of the pipeline on cancer rates in Coos County.

\section{Letter:}

Brown:

Response:

1. The automatic valve closures to be installed on the pipeline would detect a massive leak within a few minutes and then would close a valve. The pipeline pressure would then bleed to atmospheric pressure in 3-6 minutes.

2. The sudden combustion of natural gas following a massive pipeline rupture might directly damage a power line transmission tower only if it was directly adjacent.

3. The most likely scenario for tower damage is for the pipeline to have a massive rupture, with resulting fire, occurring directly underneath a power line and lasting for a sustained period. The power line might then 
part, with the result that the nearest towers could fail due to uneven strain on the tower structural members. It is unlikely that the initial combustion alone would significantly damage a tower or the power lines.

4. BPA and the County are entering into an agreement whereby BPA would be paid to have extra equipment on hand to mitigate the possible consequences of a pipeline incident that affects the electric transmission system. BPA specified a 2-day limit for outage of electric service to the South Coast.

5. After preparing the DEIS, project consultants found evidence of only one incident where damage occurred to a natural gas pipeline located near high voltage power lines. In 1999, a contractor dug into a 16" Endevco natural gas pipeline, located virtually underneath TXU high voltage power lines in Texas. The resulting fire from the natural gas leak caused conductors to fail, resulting in the collapse of seventeen towers. The Endevco pipeline was larger and the power line conductors were physically closer (15 to 30 feet versus 50 feet or more for BPA conductors) to the pipeline than any of the BPA conductors will be to the Coos County pipeline.

6. The project consultants are not aware of any "tests" that could be performed to provide the type of data that Mr. Brown suggests gathering.

As Mr. Brown suggests, the pipeline will be vulnerable to deliberate destructive acts or thoughtless vandalism at every place where the pipeline has aboveground facilities. The same hazards now exist for BPA towers, bridges and water facilities. The County has attempted to minimize the possibility of a major problem occurring by specifying extra heavy pipe in all of the aboveground locations. While the County does not believe that a gas fed fire at a bridge-crossing site will render a bridge unusable, it is possible that a bridge could be damaged and require repair.

The main transmission pipeline from the Roseburg area to the Coos Bay/North Bend Water Board area will be a 12.75 " outside diameter pipeline, commonly referred to as a " 12 inch" pipeline. The Northwest Natural filing with the PUC specified "at least a 10-inch" pipeline.

The County has always maintained that the pipeline will be built to the "urban growth boundary" of each city. The original study showed the Coos Bay delivery at Central Boulevard and US 101. Since that route and terminus is impractical, the county selected a route through Libby to the Water Board property. Any "cost difference" due to the substantial change in pipeline terminus was moot because the original Highway 42 route is impractical.

The decision to serve specific areas will be made by NW Natural. Public statements by NW Natural suggest that the terminus of the pipeline on the Water Board site will facilitate more extensive natural gas service in the Coos Bay/North Bend area than a terminus at a point further south.

11. Letter:

Port of Coos Bay

Response:

Thank you for your comments.

12. Letter:

Poppe

Response:

Thank you for your comments. Responses to your comments are as follows:

1. No Action Alternative: Please see the revised No Action Alternative in the Final ElS.

2. As noted in other comment responses, nobody can accurately speculate on the location of or type of future industrial facilities. These comments seem to speculate that the pipeline construction will somehow result in an increase of pollutants in and around the Coos Bay area. The E1S does not speculate on that issue but states that air quality is expected to improve as a direct result of the pipeline construction (see responses to Letter \#8 and others).

3. See also Appendix F for the USF\&W letter of concurrence and responses to Letter \#9.

\section{Letter:}

COE 


\section{Response:}

Recommendations are incorporated into the Final EIS.

\section{Letter:}

Bunnell

Response:

Mr. Bunnell has provided over 70 specific comments. Responses to those comments are as follows:

1. Need for Action \& 2. No Action Alternative: Wording is revised in the Final EIS.

3. Table S-2: It would be impossible to calculate the "tax cost" to taxpayers without knowing the exact cost of the project, the exact mechanism by which the County will finance their share of the project, and the exact tax situation of each County taxpayer.

4. and 5. Purpose and Need: Wording is revised in the Final EIS.

6. Statutes and Regulations: Legislative acts, such as the "Pipeline Safety and Community Protection Act of 2000" have no impact on natural gas pipclines until regulations are promulgated by the U.S. Department of Transportation Office of Pipeline Safety. No such regulations related to the Pipeline Safety and Community Protection Act of 2000 have been promulgated to date.

7. Anticipated Future Pipeline Projects: The estimated costs of pipeline laterals to Coquille, Myrtle Point, and Bandon are included in the draft EIS. The same project design criteria (PDC) and best management practices (BMP) will be used for the lateral construction. None of those laterals are expected to impact BLM lands.

8. and 9. New Industrial Gas Users: The commenter has assumed that only "heavy industries" will be potential users of natural gas. The EIS cannot address such speculation any more than this commenter or any other commenter can definitively state that "steel mills and fertilizer plants" will be the only future users of natural gas.

10.-14. Alternatives ...: Although there are "industry standards" for contaminants that may be allowed in natural gas, in practice each pipeline sets their own specific standards. Those standards allow virtually undetectable quantities of sulfides and carbon dioxide, which contribute to corrosion in the presence of water. Natural gas in the Williams pipeline is monitored by chromatographs (gas component analyzers) for the presence of contaminants. The pipeline would be shut down if necessary to rid the pipeline of the contaminants. Conscquently, internal corrosion resulting from the presence of contaminants is not a problem for existing Williams customers, and is not an issue for or a concern for the Coos County pipeline.

15.-16. See answers to Letter \#4

17. Shortest Route: The proposed route is indeed not the shortest route, point to point. The shortest route for the pipeline would traverse forested areas, requiring significant timber harvesting, and would traverse areas where pipeline construction would be nearly impossible.

18. Criteria is Shortest?: The current proposed pipeline routc is a combination of the best constructability, least environmental impact, least impact on landowners, and construction cost factors possible.

19.-20. Routes: All of the route suggestions presented have been discussed in prior public meetings.

21.-32. Refer to answers to Letter \#4 and Appendix $J$ of the Final EIS

33. Earthquake: The Geotechnical Engineering Report disputes the notion that earthquakes are frequent or common. Nevertheless, in the event of an earthquake, there is no particular ground movement mechanism that will cause the pipeline to rupture in more than one place, if it ruptures at all. A recent earthquake near Tacoma affected much of the I-5 corridor from Canada to Portland, but no pipelines were damaged.

34. Refer to answers to Letter \#4 and Appendix $J$ of the Final EIS.

35. Pipeline Repair: The EIS is not intended to be a treatise in pipeline operations, maintenance, and repair procedures. The contract operator must formulate a detailed Operation \& Maintenance Plan, including an emergency procedures plan.

36. Construction Schedule: The pipeline construction schedule is not relevant to the EIS as long as various "construction windows", as detailed in the EIS, are followed.

37. Road Blockages: See answers to Letter \#4.

38.-40. Laterals: None of the requested items are part of the scoping for this EIS. 
41. Paving: Paving will improve the "quality of life" for users of the Wagon Road and inhabitants along the Wagon Road. Additionally, paving will improve drainage and reduced erosion along the Wagon Road.

42.-44. Wagon Road: The pipeline project will provide funds for initial paving and repairs when pipeline maintenance is performed. Coos County will provide maintenance once the pipeline is installed.

45. Existing Roads: The respective county roads departments are responsible for meeting existing standards on county roads.

46.-47. Road Improvements: Please see answers to Letter \#4. Questions concerning Wagon Road safety issues should be addressed to the Coos County Road Department.

48.-49. Wagon Road Maintenance: Very little additional Wagon Road maintenance cost will be incurred in the future by Coos County as a result of the pipeline installation in the roadway.

50.-52. Distribution System Details: The gas distribution systems are the responsibility of NW Natural.

53. Pipeline Potential: The pipeline can flow 72 million cubic feet per day (mmcfd) at typical Williams inlet pressure. Few pipelines operate at full capacity every day. The potential flow through the laterals is variable and based on the load on the main section of pipeline and whether any individual natural gas consumer installed compression at their facility. The pipeline capacity is several times the existing industrial, commercial and residential heat load in Coos County.

54. Industry Size: There are no active proposals for any industrial development in Coos County at this time, including a possible "steel mill, fertilizer plant, or generation facility", therefore nobody can accurately speculate on how many of any of those facilities the pipeline could support.

55. Any response is entirely speculative as to which industries might come, where they might be located, and economic and environmental effects which might occur.

56. Highway 42: Highway 42 is not a viable alternative route.

57. Alternate Route: It is not in the scope of the EIS to review rejected routes.

58. Air Quality: See comments in the Final EIS.

59. Water Quality: Please see air quality comments in the Final EIS. Water quality is affected by air emissions and any new industry must be permitted.

60. Public Health: Suggestions have been considered.

61. Socio-Economics: Alternate routes have been considered.

62. Regional Gas Usage: NW Natural will decide whether to distribute natural gas to Sumner and Fairview. Local residents can contact NW Natural and/or the Oregon Public Utilities Commission for answers to questions regarding natural gas service in Coos County.

63. Wagon Road Issues: As stated in other responses, local traffic and emergency response traffic on the Wagon Road may be interrupted during construction and that close coordination with emergency response services and communication with residents will be necessary.

When unsuitable materials are removed from the pipeline installation ditch in the Wagon Road, clean dry material will be installed in place of the unsuitable material removed from the ditch in order to achieve desired compaction results. The Geotechnical Engineering Report did not reveal the existence of any soils along the pipeline route that may be subject to liquefaction in case of an earthquake. Please refer to page A8.

64. Fiber Optic Cable: The pipeline construction contractor will be responsible for any damage caused to the fiber optic cable if its operator has properly located the fiber optic cable. In general, the pipeline will be placed underneath the fiber optic cable at places where it crosses the pipeline installation path.

65.-67. Proposed Action Summary: The EIS scope does not include speculation as to the effect of possible future industrial activity. Comments have been added to the EIS to deal with possible emissions reductions from existing industries.

68. Maintenance Costs: The BLM is not concerned with the maintenance costs of various alternative pipeline routes.

69. Breakeven Analysis: The economic aspects of the pipeline project have been discussed thoroughly in numerous public meetings.

70. Natural Gas Prices: Such an analysis would have no relevance to the EIS, but if done, would show that natural gas has historically had an economic advantage over all other competitive fuels except fuel oil.

71.-74: Economic Benefits: These suggestions have been considered. 


\section{Letter:}

Klamath-Siskiyou Wildlands Center

Response:

Thank you for your comments. You have raised numerous issues, including the proximity of the pipeline to the Lookingglass School. The pipeline does not cross Roseburg BLM lands but will be installed on property adjacent to the Lookingglass School. Coos County, the Winston-Dillard School District, and the Douglas County Planning Commission have all discussed the safety issues and have agreed to several mitigation features that should result in safe pipeline installation and operation. Burning trees or a tree limb from a fallen tree protruding into the ground would not harm the pipeline. Please see responses to Letter \#14 and information provided in Appendix $\mathrm{J}$, which also address fire and safety concerns.

1. Cost Considerations: No cost cutting measures have been taken at the expense of environmental issues. In fact, ODFW has written a letter in support of the proposed route over the original Highway 42. Most of the cost "savings" have occurred as a result of construction cost differences.

2. Public Lands: Survey and Manage species surveys have been conducted.

3. Fish Habitat: There is no new road construction or re-construction planned for this project. Where possible, "fish friendly" culverts will be installed to replace existing culverts and Wagon Road paving after the pipeline construction will lessen sedimentation in the streams and rivers in the future.

4. Waterways: Please see Chapter 4 of the EIS.

5. Soils: Please see Chapter 4 of the EIS.

6. Noxious Weeds: Please see Chapter 4 of the EIS.

7. Species Concerns: Please see Chapters $3-5$ of the EIS.

8. Archaeological Sites and Significant Native American Sites: Please see Appendix B of the DEIS.

16. Letter:

Fairview Rural Fire Protection District

Response:

A.1. It is possible that if the pipeline is damaged, natural gas could be released and ignited. In general, a natural gas fire is not considered a situation requiring a hazardous material team response.

A.2. The letter describes the appearance of a liquid petroleum fire. Natural gas combustion does not produce any smoke. (see responses to Letters \#4, \#10, and \#14).

A.3. It is possible that a pipeline rupture could result in one or more area roads being closed for a short period of time by emergency response personnel. Due to the installation of automatic or remote controlled shut-off valves on the pipeline, the duration of time for gas escaping the pipeline should be less than 10 minutes, at which time, the only remaining fire to extinguish would be that resulting from a structure fire or grass or forest fire.

A.4. Closing block valves is the safest and most effective method of extinguishing a pipeline fire. That is why automatic or remote control valves are included as part of the design for the pipeline block valves.

B.1. US DOT statistics show that "third party damage" is the most likely manner in which a new pipeline could be damaged after construction. That is why public education is mandated by the US DOT Office of Pipeline Safety (49CFR, part 192.616).

B.2. Nobody can guarantee that any protective devices will prevent a block valve or any other pipeline facility from being damaged by all outside sources. Gas utility experience shows that "jersey barricades" and bollards are a reasonably effective means of preventing pipeline facility damage from vehicles.

B.3. The comments have been considered. Block valves need to be located in a readily accessible location. The site chosen for the Fairview block valve is the best location in the Fairview area, considering all aspects of pipeline and lateral design and environmental and safety issues.

\section{Letter:}

Name Withheld by Request

Response: 
Please see responses to Letter 9 regarding the issue of " 2900 jobs". As with others, this commenter has assumed that "all industry is dirty" when in fact there are numerous industrial facilities, which could site in Coos County without adding to existing pollution levels in Coos County. Also, as stated in other comment responses, the EIS cannot assume or speculate as to the possible location of any new industry in Coos County because numerous properties throughout the county are zoned for industrial use.

Coos County disagrees with this commenter's statement of "fact" and have no evidence to the effect that the environmental assessment process involved with siting a new industry would be "myopic" and ignoring of any cumulative emissions impact.

\section{Letter:}

Oregon Department of Land Conservation and Developmen Response:

Included in Chapter 4 and Appendix $\mathrm{N}$ of the Final EIS is a consistency statement, which addresses the Coos and Douglas County Land Use plans and the Coos Bay Estuary Management Plan.

\section{Letter:}

Oregon Department of Land Conservation and Development Response:

Please see response to Letter \#18.

20. Letter:

United States Environmental Protection Agency

Response:

Thank you for your comments.

\section{Letter:}

\section{Mason}

Response:

This issue was adequately addressed in public meetings.

\section{Letter:}

Coquille Elders Aquaculture Board/Barton

Response:

1. The "economic impact analysis" of a "gas distribution system" was addressed on Page 70 of the DEIS.

2. Natural gas in the interstate pipeline system that will feed the Coos Bay pipeline contains virtually unmeasurable amounts of sulfur components (see air quality statements in the Final EIS). The products of combustion of the natural gas will be primarily water and carbon dioxide, with trace amounts of nitrous oxides and unburned hydrocarbons.

3. The Coos Bay estuary will not be directly affected by the pipeline project, as proposed. NW Natural is responsible for planning the gas distribution systems, but the construction of those distribution systems will have to follow PDCs dictated by the municipalities in which those distribution systems are installed. Air and water quality in the area will be improved when residents, commercial facilities, and industries change to natural gas fuel from burning fuel oil and wood. Please see the air quality section of the Final EIS.

\section{Letter:}

\section{Simpson}

Response: 
BLM lands will be delineated in the final EIS.

The draft EIS has adequately addressed economic issues.

The issue of pipeline construction, economics, and politics has been adequately addressed in public meetings and in the DEIS.

The application from the pipeline project to the Coos County Planning Commission has no impact on the BLM or the EIS process. The actions of the planning commission have no impact on any decision the BLM will make.

On May 2, 2002, the Coos County Planning Commission denied the county's application for a Conditional Use Permit to cross certain lands zoned for farm and forest use. This application included the BLM segments in Coos County. The reason for denial was stated as the county's failure to prove that the pipeline would not "Significantly increase the risk of fire, or the cost or danger of fire suppression".

The County has extensively researched the US DOT pipeline incident statistics for the entire country, for this size and type of pipeline, and for Oregon and Washington incidents near forested lands. (See Appendix $\mathbf{J}$ of the Final EIS for details.) There is very little statistical chance that this pipeline will ever suffer a serious incident, and no precedent in Oregon or Washington that such an incident would cause a serious forest fire. Coos County will appeal the action of the planning commission. The planning commission restricted the submission of pipeline safety information before the May 2 meeting, and did not allow any interpretation of or member questions about the data. The County believes it will prevail on this issue upon appeal, and does not plan to change the route or the EIS because of this decision.

\section{Letter:}

\section{Liles}

Response:

Directionally drilling the pipeline under the river on this property will not drain a water supply. The drilling fluid used during directional drilling contains additives that prevents fluid flow into or out of the drill hole. Once the pipe is installed under the river, the drill hole will close around the pipe and not allow fluid to flow along the path of the pipe installation.

See also the air quality section of the Final EIS and previous letter responses.

\section{Letter:}

Coquille Indian Tribe

Response:

The same PDCs and BMPs will be used for the laterals as is used for the main pipeline construction. These would include cultural surveys and project monitoring.

Revisions have been made to project monitoring language as suggested.

Refer to Appendix B of the draft EIS. All parties believe that joint monitoring will result in adequate identification and mitigation of archaeological and cultural sites that have not already been identified.

\section{Letter:}

Stewart

Response:

Please refer to previous responses regarding environmental assessments.

BPA has not formally announced nor rescinded their "moratorium" but Coos County and the BPA have agreed on a method by which the pipeline can be installed in the BPA corridor where necessary. No formal document has been issued by BPA to date.

\section{Letter:}

\section{Nelson}

Response: 
Thank you for your comments. Your concerns have been addressed in responses to other letters.

28. Letter:

Metcalf

Response:

The Geotechnical Engineering Report in Appendix A has adequately addressed the location of active faults. Based on cultural review to date, the County is not aware of the Indian grave and camping sites mentioned in this letter. Joint monitoring, by Indian tribal representatives and County inspectors is intended to insure that no cultural resources are desecrated.

\section{Letter:}

Clawson

Response:

Thank you for your comments. Please see the responses to previous letters.

30. Letter:

Clawson

Response:

Thank you for your comments. Please see the responses to previous letters.

\section{Letter:}

Gaab

Response:

The application submitted to the Coos County Planning Commission has no relation to this Environmental Impact Statement.

\section{Letter:}

Herne

Response:

The BLM is "involved" because a permit application was submitted to the Coos Bay BLM office and this Environmental Impact Statement is a result of that permit application.

\section{Letter:}

\section{Doty}

Response:

Please refer to previous responses regarding environmental assessments. Please refer to Chapter 4 and Appendix $\mathrm{N}$ of the Final EIS for consistency with state and local plans.

The issue of project economics and the participation in the pipeline project or lack thereof by Bandon has been adequately addressed in numerous public meetings.

\section{Letter:}

Joyce

Response:

The issue of route selection has been adequately addressed in numerous public meetings and in the draft EIS. Please refer to previous responses regarding environmental assessments. Refer to responses to Letter \#9. 


\section{Letter:}

Hopkins

Response:

Thank you for your comments. Please see the Final EIS concerning the Port-Orford-cedar.

\section{Letter:}

Schricber

Response:

Thank you for your comments. Your issues have been raised and answered in numerous public meetings.

\section{Letter:}

\section{Leisy}

Response:

Thank you for your comments. In response to each of the items in your letter:

1. Construction of those laterals will be required to follow the same PDCs and BMPs as the main pipeline construction.

2. ROW issues involve Civil Law legal determinations that are not relevant to the EIS.

3. COE input has been received throughout the DEIS process, even though PDC or other comments may not be specifically attributed to the COE.

4. Please see Appendix F for the USFWS concurrence letter.

5. The conclusion of the biologists involved in the preparation of the DEIS was that there will be no long term or cumulative effect to the flora and fauna in Coos County as a result of the pipeline construction and subsequent operation of the pipeline.

6. The project consultants did not locate the contradictory findings that are referenced in this comment. Directional drilling (sometimes also referred to as "boring") will virtually eliminate the possibility of erosion around the pipeline stream crossing. The Geotechnical Engineering Report in Appendix A found no evidence of active faults or active landslides. Appendix $\mathrm{H}$, as revised for the Final EIS, has adequately addressed PDCs and BMPs to be used to prevent soil erosion.

7. Aboveground pipeline facilities are mentioned and described in several places in the DEIS but specifically in Appendix $\mathrm{J}$.

8. See air quality statements and responses to previous letters.

\section{Letter:}

Ryan

Response:

This commenter has assumed that negative effects will occur or be enabled as a result of the pipeline construction. Certainly, Coos County has promoted the project as a means of increasing economic development. Because there are no current economic development projects proposed, it is speculative and out of the scope of the DEIS to assume that "heavy" or "polluting" industry will want to locate in Coos County merely as a result of the presence of natural gas. In fact, NW Natural is constructing their distribution system using the assumption that no new industry will come to Coos County. Please see also answer \#8 to Letter \#37.

It is also speculative and out of the scope of the DEIS to attempt to address the exact location of a future industrial facility. There are numerous sites in Coos County, other than the North Spit, designated for industrial use.

The County is unaware of any evidence that "tax breaks" in "Enterprise Zones" creates budget problems for local governments and ECONorthwest did not identify any such problem.

The issue of whether new jobs would be filled by current residents or "experienced workers from outside the 
area" should not be addressed by the EIS but rather by local governments when new projects are proposed. As noted in the opening paragraph of this Appendix, some of the comments in the DEIS Appendix G were those of Coos County and not necessarily of the BLM.

\section{Letter:}

Gomez

Response:

Thank you for your comments. In response to specific comments:

1. The "Purpose of and Need for Action" correctly states that there is no guarantee that if the pipeline is built then any new economic development will occur.

2. It is speculative and not in the scope of the Final EIS to assume that any specific type of industrial facility will be sited in Coos County. In fact, as stated in the EIS and in previous comment responses, the air quality of Coos County should be improved by making natural gas available to Coos County residents and businesses.

3. The parties believe that the Final EIS has adequately addressed cumulative and indirect effects to Coos Bay and the Coos Bay estuary.

4. As previously stated, it is not in the scope of the DEIS to study the causes and incidences of cancer in Coos County. It is entirely speculative to assume that the pipeline construction would have any effect on cancer rates in Coos County. 


\section{Appendix H. Erosion Control Plan}

The following changes between the Draft and Final Environmental Impact Statement were made to Appendix H.

- A revised Appendix H: Erosion Control Plan has replaced the former Erosion Control Plan providing additional Project Design Criteria.

Prepared by:

Bob Oxford

Industrial Gas Services, Inc.

3760 Vance St., Suite 200

Wheat Ridge, CO 80033 


\section{Appendix H. Erosion Control Plan}

Table H-1: Fish-bearing Streams Identified for Avoiding Ground Disturbance within them

\begin{tabular}{|c|c|c|}
\hline Stream & Description & \\
\hline East Fork Coquille River & East Fork Coquille Watershed & place on 2 bridges \\
\hline Brummit Creek & East Fork Coquille Watershed & directional-drill \\
\hline China Creek & East Fork Coquille Watershed & in road over culvert \\
\hline Steel Creek & East Fork Coquille Watershed & place on bridge \\
\hline Hantz Creek & East Fork Coquille Watershed & in road over culvert \\
\hline Cherry Creek & East Fork Coquille Watershed & directional-drill \\
\hline Middle Creek & East Fork Coquille Watershed & place on bridge \\
\hline North Fork Coquille River & North Fork Coquille Watershed & directional-drill \\
\hline Panther Creek & Lower Coos River/Coos Bay Watershed & in road over culvert \\
\hline Cardwell Creek & Lower Coos River/Coos Bay Watershed & in road over culvert \\
\hline Catching Creek & Lower Coos River/Coos Bay Watershed & directional-drill \\
\hline Isthmus Slough & Lower Coos River/Coos Bay Watershed & directional-drill \\
\hline Shinglehouse Slough & Lower Coos River/Coos Bay Watershed & directional-drill \\
\hline Coal Bank Slough & Lower Coos River/Coos Bay Watershed & directional-drill \\
\hline Blossom Gulch & Lower Coos River/Coos Bay Watershed & directional drill \\
\hline
\end{tabular}

\section{Best Management Practices (BMPs)}

BMPs are measures used during construction activities to minimize potential impacts to the aquatic environment to the point where those impacts become negligible. The BMPs for the proposed actions are as follows:

Prior to activities, apply an additional lift of rock to the area of road that can influence the stream if rill erosion is evident in the road tread near live stream crossings.

Contain any offsite movement of sediment from the road or ditchflow near streams using silt fence or sediment entrapping blankets. Such control measures must allow for the free passage of water without detention or plugging. These control structures and applications should receive frequent maintenance and will be removed upon completion of that pipeline construction segment.

All construction operations will utilize sediment barriers along the CBW Road corridor where needed and within 100 feet of all streams when working in the utility corridor.

All stream crossings, except Rock Creek, Morgan Creek and Tenmile Creek, and other streams with very low flow, will be directionally-drilled, trenched in road fill or have the pipe placed on bridges to avoid sedimentation impacts. 


\section{Environmental Compliance Representative}

The County has appointed Paul Slater the Environmental Compliance Representative to administer the ECR. He will specify erosion control plan controls and modifications, and perform environmental monitoring to ensure the BMPs and PDCs of the ECP are being implemented and that water quality is being maintained.

\section{Active Stream Crossing Project Design Criteria (PDC)}

PDCs are preventive measures applied to project activities to minimize potential detrimental effects to proposed, listed, or candidate species. For the purpose of this ECP, PDCs are in effect BMPs in order to meet the objectives of the Endangered Species Act (ESA) and the Clean Water Act (CWA).

\section{Minimization and Avoidance}

BMPs for surface and shoulder activity types will includeManagement of Oil, Grease,and Fuels:

- Fuel will not be used as a releasing or cleaning agent.

- A spill containment plan will be in place prior to the start of the project.

- No refueling is permitted within $25 \mathrm{ft}$. of stream crossings.

- The contractor shall have ample absorbent blankets and other clean-up materials on site in case of an accidental spill.

- Using environmentally sensitive cleaning and releasing agents.

- Using heat sources to heat and clean tack nozzles during operations.

- Carrying adequate erosion control supplies and keep materials out of water bodies.

- Disposing of excess material at appropriate sites, depending upon material being disposed (Disposal would be approved by ECR).

\section{Timing}

All stream channel crossing work shall take place during the "In-Water Work Period" of July 1 through September 15. Work outside of streams including excavating, trenching work, re-filling of trenches, clean-up and restoration activities should be completed during the dry season (June-October). Any work undertaken outside of this period will need more substantial ECP controls in order to retain soil material on site and not exceed the State water quality standards.

\section{Transportation Corridor}

Excavated soil material should be placed on the outside of the roadway away from the ditch line. Soil material that is stockpiled in this manner for more than 7 days should be covered with plastic sheeting. Silt fence, bio-filter bags or sediment entrapping blankets should be used around all stream channels, springs, wetlands or roadside ditches where disturbance soil material could be mobilized and enter a drainageway or wetland by rainwater. The onsite environmental compliance representative could excuse some of these requirements if no precipitation is forecast for the next seven days (summer conditions). If vegetation is removed from the road shoulders during clean-up of soil material, these areas should be grass seeded, fertilized and mulched with certified weed free straw at the minimum application rate of $2500 \mathrm{lbs}$. per acre.

The road disturbance areas will be storm proofed by compacting the ditch and road surfacing with crushed rock, such that sediment will not enter ditchlines, catch basins or stream channels. New paving or repaving the Coos Bay Wagon Road will not be completed the same season of disturbance. All disturbed areas will be grass seeded, fertilized and mulched with certified weed free straw at the minimum application rate of $2500 \mathrm{lbs}$. per acre.

Grade control culverts, removed for pipeline installation, shall be replaced. Inlets and outlets, and a minimum of 50' of ditch line that feeds the culvert should be open, not constricted and free draining. 


\section{Soil Material Management on Steep Slopes}

Excavated soil material and other disturbance will be managed on steep slopes ( $>30 \%$ ) so that land resources will not erode, causing rilling or gullying and/or enter a stream channel. Contour sediment fences will be used where needed. Drivable waterbars or inverted waterbars (referred to as flavels) on the access roads may be needed and frequency will be determined by the slope angle and soil properties. The intent of these controls is to curtail rilling and gullying on the tread of these steep access roads. Soil material that is stockpiled for more than 7 days will be covered with plastic sheeting. Benches developed for pipeline construction will be constructed with regard to natural contours. All disturbed areas will be grass seeded, fertilized and mulched with certified weed free straw at the minimum application rate of $2500 \mathrm{lbs}$. per acre.

\section{Borrow/Stockpile Sites}

All borrow or stockpile sites will be identified prior to the start of the project and cleared by the ECR. Borrow or stockpile sties shall be placed outside of riparian areas as much as possible. Where appropriate, the sites will be graded, seeded, fertilized and mulched at a minimum application rate of $2500 \mathrm{lbs}$. per acre with certified weed free straw at the closure of the project.

\section{Utility Stream Crossing}

Definition: A strategy for crossing small waterways when in-stream utility construction is involved.

\section{Purposes:}

1) To prevent sediment from entering the stream from construction within approach areas.

2) To minimize the amount of disturbance within the stream and riparian area.

Conditions Where Practice Applies: Generally applicable to small perennial and intermittent streams with drainage areas less than 130 hectares (ha), 320 equivalent acres. Methodology for crossing streams with larger drainage areas or to avoid designated sensitive crossings, will be directional-drilled, hanging pipe on bridge or trenching above culverts on CBW Road fill.

Planning Considerations: Directionally-drilling a pipe below the streambed, which would avoid disturbance within the watercourse, is the preferred method if it is practical. However, in cases where it is impractical and where instream work is unavoidable, consideration must be given to providing adequate mitigation of sediment loss while minimizing the amount of encroachment and time spent working in the channel. There is some "give and take" as far as the installation of controls.

Sometimes there is less damage to the environment created by providing substantial controls for the approach areas and by refraining from installing extensive measures in the stream itself. However, if the installation of the pipeline within the streambed and its banks will take an extended period of construction time (more than 10 hours), substantial in-stream controls or stream diversion is necessary to prevent excessive sedimentation damage. For the action alternatives, all stream-crossings that will not be directionally-drilled will take far less than the 72 -hour recommendation for utility line crossing using the "Bag and Flume" technique. The "Bag and Flume" method utilized in pipeline construction will take approximately 6-8 hours per stream crossing. The following is the method the action alternatives would use for dealing with utility stream crossings; these criteria allow for "work in the dry" conditions to prevent sedimentation in flowing streams:

\section{Crossing Streams}

There are four types of stream crossings: 1.) Culvert in Road; 2.) Trench using the bag \& flume method, 3.) Bridge; and 4.) Directional Drill.

\section{Stream Crossing Above A Culvert}

The Coos Pipeline will be routed along county roads for approximately 33 miles. Those roads cross about 120 inventoried streams, most of which are very small ephemeral drainage channels, $1-3 \mathrm{ft}$ in width and dry most of the year. Approximately 105 of those channels cross the road through culverts, typically 24 " corrugated metal pipe (CMP) culverts about $30 \mathrm{ft}$ long. 
A few of the culverts have enough soil coverage to allow the pipeline to cross above the culvert. Bills Creek and Hantz Creek are typical examples, where the culvert is 4 to $8 \mathrm{ft}$ below the road surface. This is the preferred method of crossing with the least impact to the drainage channel. When the pipeline can cross above the culvert:

1. Plan to finish a culvert crossing in one day. The culvert must be intact overnight, or when rain is forecast.

2. Excavate pipeline ditch below the road surface, typically 30 " wide and deep enough to allow 36 " of cover above the pipe.

3. Allow at least 12" clearance between the pipeline and the CMP. The pipeline and CMP must not touch.

4. If 36 " of cover above the pipe to the road surface is not practical, then the pipe can be protected with lowstrength concrete or other suitable protection. In no case shall the depth of cover be less than 24 " to top of pipe. Backfill and compact as necessary to road authority specifications.

\section{Stream Crossing Under A Culvert}

Most of the culverts have only 18-24" of soil coverage, which is not enough to allow the pipeline to cross above the culvert. Many of these culverts are in poor condition and would have to be replaced in the next 10 years. When the pipeline does not have clearance to cross above the culvert:

1. Plan to finish a culvert crossing in one day. The culvert must be intact overnight, or when rain is forecast.

2. Excavate normal pipeline ditch to within $15 \mathrm{ft}$ of the culvert. The normal trench is typically 30 " wide and deep enough to allow 36 " of cover above the pipe.

3. Determine whether or not the culvert should be replaced. Factors include whether the culvert is under-sized (eg less than 24"); bent, crushed or damaged, especially at the ends, and whether the steel pipe is starting to rust and show through the galvanized zinc coating. The ECR will make the decision to replace. If so, the culvert should be replaced with an appropriately sized culvert to match the estimated water flow, and approximately the same length as the existing pipe (as approved by the ECR.)

4. Strip out the old culvert pipe and remove it. This will typically require an excavation 36" wide by the depth of the existing pipe, across the full width of the road. If the existing culvert is adequate and will not be replaced, the pipeline can be tunneled under the culvert.

5. Complete the pipeline ditch through the culvert area, deep enough to allow at least 12 " clearance between the pipeline and the CMP.

6. Install the pipeline in the ditch through the culvert area and shade the pipe, with a 12" clearance to the expected finish grade of the culvert. The pipeline and CMP cannot touch.

7. Install the new culvert on the appropriate skew and grade. If necessary, run pipeline test wires to a test station at the uphill side of the road for cathodic protection or line location. Backfill and compact as necessary to road authority specifications.

8. It is desired that, if practical, any new culvert be installed on grade as "fish-friendly". In all such work around culverts existing and new, it is critical that the footprint of the road not be changed. That is, the pipeline construction and culvert replacement work must be done without adding fill to the creek bed.

9. Apply erosion control measures as necessary to the sides of the road and inlet / outlet of the culvert.

\section{Trench Across Stream}

If a stream is not flowing water and no immediate rain is forecast, no sediment control is required. If a low flowing stream can be crossed in a manner such that turbidity is not increased for more than 2 hours, no sediment control is required. Otherwise, controls will be put in place before construction begins. If there is no turbidity disturbance downstream in 2 hours, then no bag and flume or any method of sediment control is required. The Environmental Compliance Representative must approve any stream crossing where no sediment control is planned. For such trenched stream crossings, the sides of the stream will be cut back and the stream channel widened to a 1 to $11 / 2$ slope. After the trench is through the stream, rocks will be installed over the pipe trench if necessary to stabilize the ditch. The stream sides will then be recontoured to original shape.

The stream will be restored within the active stream channel by using the size rock in the streambed that is the typical stream armor layer. Banks above the active channel will be reshaped with like soil material and compacted to the 
original configuration. The cross section channel geometry will be similar to the preexisting condition. Bank stabilization may include the use of soil material, rock or large wood or root wads. Where trees or vegetative root structure is removed, tree plantings in the next dormant season may be appropriate.

Any fill or constructed benches within riparian areas or within 100 feet of a stream channel on steep slopes ( $>30 \%)$ will be pulled back to a natural ground configuration.

If a stream crossing involves any amount of water and the crossing time will exceed 2 hours, the "bag and flume" specification will apply. Controls including the rerouting of water will be in place prior to trenching activities. Under DEQ's turbidity water quality guidance, adequate controls will be in place to meet the 401 certification requirements.

- Filter cloth should be used in the construction of the utility crossing.

- If there are trapped fish, the fish should be removed and placed in another part of the stream (ODFW will be contacted to remove fish.).

- Water diverting structures ("Bag and Flume") should be used at all trenching and/or construction road approaches 30 meters ( 100 feet) on either side of the crossing.

\section{For “Bag-and-Flume” Stream Trenching:}

1. The drainage area should be no greater than 130 ha (320 acres).

2. Filter cloth should be used in the construction of the pipeline crossing.

3. If there are trapped fish the fish should be removed and placed in another part of the stream.

4. Water diverting structures should be used at all trenching and/or construction road approaches 30 meters ( 100 feet) on either side of the crossing.

"Bag and Flume" Construction Specifications: The bag \& flume crossing method will be used when in-stream construction will last more than 2 hours and less than 72 hours, and stream is narrow, making "directional-drilling" construction impractical. This will be the method used to trench flowing streams (Figure H-1). If there are trapped fish they should be removed and placed in another part of the stream. Diverted water will be put back into same stream as close to the culvert as possible. The amount of stream to be dry will be the minimum necessary to perform work.

The flume pipe crossing must be made operational prior to the start of construction in the stream. A large flexible flume pipe of an adequate size to support normal water channel flow shall then be installed in the streambed across the proposed action's trench centerline. Sandbags shall be placed close to each end of the flume pipe so as to dam off the creek forcing the water to flow through the flume pipe (Figure H-1).

The entrapped water can then flow from the creek within the dammed-off area and in the trench centerline back into the bypassed stream. The trench can then be dug adjacent to the flume pipe. The pipe sections will then be installed to the proper depth. After pipeline sections are installed, the ditch will be back-filled and restabilization shall be carried out. Turbid water in newly dug trenches will be pumped onto a vegetative floodplain or gentle hillslope, where it can filter-out fine sediments naturally.

The stream will be restored within the active stream channel by using the size rock in the streambed that is the typical stream armor layer. Banks above the active channel will be reshaped with like soil material and compacted to the original configuration. The cross section channel geometry will be similar to the preexisting condition. Bank stabilization may include the use of soil material, rock or large wood or root wads. Where trees or vegetative root structure is removed, tree plantings in the next dormant season may be appropriate.

After completion of back-filling operation and restoration of stream/creek banks and leveling of streambed, the flume pipe can be removed. The gravel can be removed or spread in the streambed depending on permit requirements. Sediment control in approach areas shall not be removed until all construction is completed in the stream/creek crossing area. All ground contours shall be returned to their original condition. 


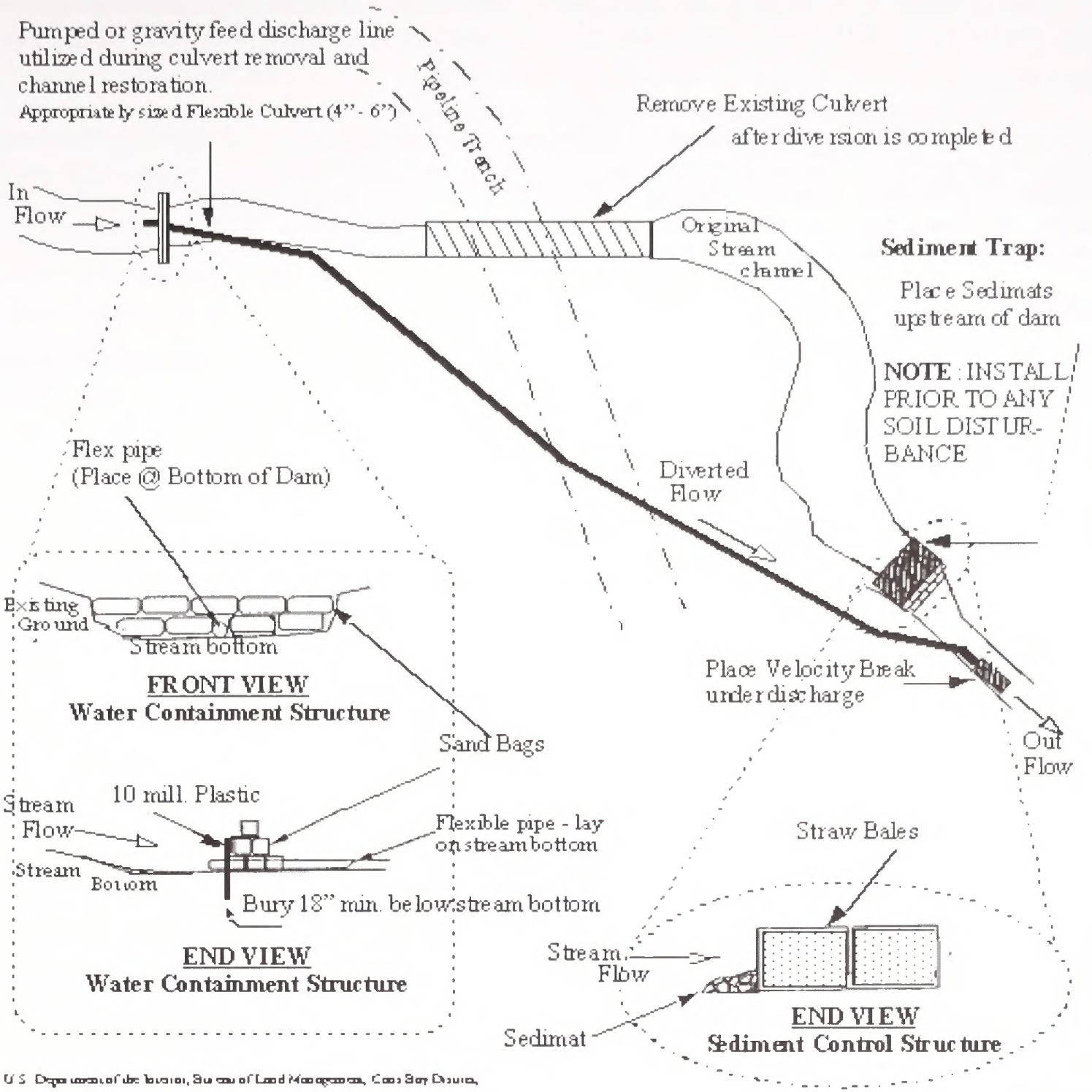

Figure H-1: Stream Crossing: Trenching across an active stream bed

\section{Bridge Crossings}


The pipe will be hung by specially designed hangers along side and beneath a bridge at road crossings on fish habitat streams to ensure uninterrupted upstream and downstream movement of all aquatic species. Water velocity is generally the most critical factor during the time of year that fish require access to spawning and rearing areas.

\section{Directional Drilling}

Directionally-drilling a pipe below the streambed, which would avoid disturbance within the watercourse, is the preferred method if it is practical. The drilling operations, including fluid pits, will be located well outside of riparian areas. Fluid pits will be lined. Any residual material will be disposed of at an approved upland site. When drilling operations are completed fluid pits will be filled in, recontoured, and revegetated. An illustration of the directionaldrilling method is given in Appendix $\mathbf{J}$ of the FEIS.

\section{Maintenance}

Care must be taken to inspect any stream crossing area at the end of each day to make sure that the construction materials are positioned securely. This will ensure that the work area stays dry and that no construction materials move downstream. The ECR will inspect work periodically to ensure compliance with this ESCP and all local, state, and federal laws.

\section{Project Design Criteria for Culvert Installation and Removal}

- The ODFW in-stream work period for the proposed action is shown below. Needs for working outside these time periods would be approved only on a site specific basis with ODFW concurrence. These dates apply to any intermittent or perennial channel showing annual scour, as defined by the Northwest Forest Plan:

Coquille River

Umpqua River

\section{July 1 - September 15}

July 1 - September 15

- Bridges, bottomless culverts and pipe arches in descending order of preference should be used at road crossing on fish habitat to ensure uninterrupted upstream and downstream movement of all aquatic species. Water velocity is generally the most critical factor during the time of year that fish require access to spawning and rearing areas. ECR will approve structure type and design specifications on a site specific basis.

- At all "Bag and Flume" stream crossings, the approach will be as near a right angle to the stream as possible to minimize disturbance to streambanks and riparian habitat.

- Road crossings on all fish-bearing streams will be designed to maintain natural streambed substrate and site gradient, while minimizing long-term maintenance needs.

- Width of a crossing structure should be at least as wide as the mean bankfull width at the crossing site; to be measured by the ECR. A structure less than bankfull width will constrict high streamflow and increase water velocity, resulting in sour at the outlet (perching), little to no deposition of streambed substrate in closed bottom structure and possible velocity barrier to fish.

- Divert the streamflow around the work area in a manner (e.g., a pipe or lined ditch) that will minimize stream sedimentation. Stream flow will be returned to channel at first available point on downstream end of work area to minimize the length of dry channel. The diverted stream should not be returned to the channel through the project area until all in-stream work has been completed.

- Reduce movement of sediment downstream from the project site with the use of straw bales, geotextile fabric or coconut fiber $\log$ s/bales immediately downstream of the work area.

- Wet or green (wet: fresh enough to flow; green: hardened but less than 21 days old) cement and new or old asphalt have acute and chronic adverse effects on aquatic life and should not be allowed to enter a stream. This includes water used to clean tools. If the stream is de-watered before construction begins, aquatic species will be unaffected.

- Maintain aquatic connectivity on non fish-bearing streams to ensure upstream and downstream movement of other (non-fish) aquatic species.

- Bare soil areas will be mulched with hydro-seeding, weed-free straw, bark chips, etc. and native seed or other 
approved seed mix prior to fall rain or when moisture conditions are appropriate to discourage invasion of noxious plant species and to reduce soil erosion.

- Location of stockpile and borrow sites will be confined to dry areas so sediment will not enter aquatic resources. ECR will pre-approve areas before they are used.

- The contractor(s) will be notified that they are responsible for meeting all state and federal requirements for maintaining water quality. Standard contracts will include the following:

- Heavy equipment should be inspected and cleaned as necessary before moving onto the project site in order to remove oil and grease, noxious weeds and excessive soil.

- Hydraulic fluid and fuel lines on heavy mechanized equipment must be in proper working condition in order to minimize leakage into streams

- Waste diesel, oil, hydraulic fluid and other hazardous materials and contaminated soil near the stream will be removed from the site and disposed of offsite and in accordance with DEQ regulations. Areas that have been saturated with toxic materials would be excavated to a depth of 12 inches beyond the contaminated material or as required by DEQ.

- Equipment refueling would be conducted within a confined, secured area outside the stream channel (minimum of $25^{\prime}$ away) such that there is minimal chance that toxic materials could enter a stream.

- Use spill containment booms or kits as required by DEQ.

- Equipment containing toxic fluids should not be stored in a stream channel at anytime.

- Construct a control weir at a culvert outlet as insurance that water velocity through a new culvert will not cause "perching": a control weir consists of burying 1-3 foot diameter rock at the culvert outlet across the stream channel to control the stream grade. ECR will approve designs of such structures before they are installed as well as construction of said structures.

\section{Approved Materials for Use - ODOT Construction Manual}

Biofilter Bags: Biofilter bags shall be $460 \mathrm{~mm}$ x $150 \mathrm{~mm}$ x $760 \mathrm{~mm}$ minimum bags made of $13 \mathrm{~mm}$ plastic mesh, weighing approximately $20 \mathrm{~kg}$, and filled with clean, 100 percent recycled wood-product waste.

Check Dams: Aggregate: Shall meet the requirements of 00330.16 with a maximum diameter from 75 to $150 \mathrm{~mm}$.

- Straw Bale: Standard rectangular bales shall meet the requirements of 00280.10 (n)(6).

- Biofilter Bags: Shall meet the requirements of 00280.10(a).

- Sand Bags: Shall meet the requirements of $00280.10(1)$.

Construction Entrances: Aggregate shall meet the requirements of 00330.16 with a maximum diameter of $150 \mathrm{~mm}$.

Subgrade geotextile shall meet the requirements of Sections 00350 and 02320 . Provide written "Level B" documentation according to 02320.10 (c).

Diversion Dike/Swale: Aggregate shall meet the requirements of 00330.16 with a maximum diameter of $25 \mathrm{~mm}$ to $100 \mathrm{~mm}$.

Seeding shall meet the requirements of Section 01030 for Seeding (Temporary).

Temporary Drainage Curbs: Commercial Grade Concrete shall meet the requirements of 00480.11.

Dust Control: Non-toxic materials shall not have an adverse effect on soil structure or establishment and growth of vegetation, and be approved by Coos County Highway Department Roadmaster and/or the ECR.

Flow Spreader: Shall meet the requirements of 00330.16 with a maximum diameter of $150 \mathrm{~mm}$. Inlet Protection

\section{Inlet Protection}

1. Geotextile for Sediment Fence, Supported: Shall meet the requirements of Sections 00350 and 02320. Provide written "Level B" documentation according to 02320.10(c).

2. Aggregate: Shall meet the requirements of 00330.16 with a maximum diameter of $25 \mathrm{~mm}$ to $100 \mathrm{~mm}$.

3. Biofilter Bags: Shall meet the requirements of 00280.10(a). 
4. Stakes: Shall be as follows:

a) Supported Sediment Fence: Commercial grade metal posts weighing at least $2 \mathrm{~kg} / \mathrm{m}$.

b) Unsupported Sediment Fence: $38 \mathrm{~mm}$ x $38 \mathrm{~mm}$ x 1,200mm minimum wooden posts.

c) Bio-filter Bags: $25 \mathrm{~mm}$ x $50 \mathrm{~mm}$ x $450 \mathrm{~mm}$ minimum wooden posts.

4. Wire Mesh: Shall be one millimeter gauge steel-wire mesh with $10 \mathrm{~mm} \times 10 \mathrm{~mm}$ openings.

5. Concrete Masonry Unit: Shall be $200 \mathrm{~mm}$ x $200 \mathrm{~mm}$ x $400 \mathrm{~mm}$, $70 \mathrm{~kg}$ concrete building blocks with two $140 \mathrm{~mm} \times$ $140 \mathrm{~mm}$ openings and $25 \mathrm{~mm}$ minimum outer wall thickness.

6. Sod: Grass sod shall be grown on agricultural land that is cultivated specifically for turf sod. Sod shall be free of weeds, diseases, nematodes and insects. Sod shall be mature and not less than 10 months old. Sod shall be machine cut to a uniform thickness of $16 \mathrm{~mm}$ or more, excluding top growth and thatch. Broken pieces and torn or uneven ends will not be accepted. Sod shall be planted within 36 hours of harvest.

7. Prefabricated Filter Insert: Shall be manufactured specifically for collecting sediment in drainage inlets. The insert shall consist of a porous, geotextile material and include handles and/or fasteners sufficient to keep the insert from falling into the inlet during maintenance and removal of the insert from the inlet (such as rebar, per 02510.0, sewn into the fabric).

8. Matting: Materials tested by Texas DOT/TTI Hydraulics and Erosion Control Laboratory shall meet the performance criteria for the following categories:

a) (Type A) - Slope protection mat for slopes 1:3 or flatter - clay soils

b) (Type B) - Slope protection mat for slopes 1:3 or flatter - sandy soils

c) (Type C) - Slope protection mat for slopes steeper than 1:3 - clay soils

d) (Type D) - Slope protection mat for slopes steeper than 1:3 - sandy soils

e) (Type E) - Flexible channel liner for shear stress from 0-96 Pa.

f) (Type F) - Flexible channel liner for shear stress from 0-192 Pa.

g) (Type G) - Flexible channel liner for shear stress from 0-287 Pa.

h) (Type H) - Flexible channel liner for shear stress from 0-383 Pa.

i) Check Slot - Shall be as follows:

- Channel Application: Compacted class 25 riprap shall meet the requirements of Section 00390.

- Slope Application: Compacted native material.

j) Staples: Shall be heavy duty pins or U-shaped wires staples as follows:

- Staples: $2 \mathrm{~mm}$ gage steel wires staples. $25 \mathrm{~mm}$ "U" width with a length of $150 \mathrm{~mm}$ for cohesive soils and 200 mm minimum for non-cohesive soils.

- Pins: $4.75 \mathrm{~mm}$ diameter steep pin with a $50 \mathrm{~mm}$ diameter steel washer secured at the head of the pin. The length shall be $450 \mathrm{~mm}$ minimum. All mat blanket, staple and other materials shall meet or exceed the manufacturer's specifications and recommendations. Provide the manufacturer's material and installation specifications to the Agency prior to installation.

10. Temporary Mulching: Shall be free of noxious weed seeds, plants and other substances detrimental to plant life.

The kind of mulch material(s) acceptable for use will are shown belo

a) Hydromulching: Cellulose fiber shall be produced from a single, or combination of, virgin wood or straw, or paper fiber product(s) approved by the Agency. Process the wood or straw mulch so that the fibers remain uniformly suspended under agitation in water. The processed mulch shall have the ability to cover and hold grass seed in contact with soil and shall exhibit no growth or germination-inhibiting factors. The wood or straw fiber shall have moisture-absorption and percolation properties to form a blotter-like ground cover. Ship wood or straw cellulose fiber in packages of uniform mass (plus or minus 5 percent) and label with the manufacturer's name and air-dry mass.

b) Straw: Straw mulch for non-hydroseeding applications shall be straw from bentgrass, bluegrass, fescue or ryegrass singly or in combination. If no grass seed straw is available, straw from barley, oat, or wheat is 
allowed if approved by the Agency. The straw shall not be moldy, caked, decayed or of otherwise low quality. Submit verification from the supplier that the straw is free of noxious weeds. Acceptable documentation submitted shall show either (1) that the straw source is from an "Oregon Certified Seed" field, or (2) the seed lab test results of the seed harvested from the straw meet minimum Oregon Certified Seed quality for weed seed content. The minimum requirements of Oregon certified seed are as published in the current year's Oregon Certified Seed Handbook available from County Extension Offices or Oregon State University.

c) Tackifier: Shall be commercially available, containing no agents toxic to plant life. The tackifier shall be either a liquid stabilizing emulsion or a dry powder tackifier complying with the following:

- Liquid Stabilizer Emulsion - Shall be a liquid polyvinyl acetate using emulsion resins and containing 60 percent (plus or minus 1 percent) total solids by mass. When diluted with water, and upon drying, the emulsion shall form a transparent, net-like film having a permeability that allows exchange of air and moisture and has an effective life of one year or more.

- Dry Powder Tackifier - Shall consist of one or more active hydrocolloids from natural plant sources which will hydrate in water and blend with other slurry materials. Upon application and drying it shall tack the slurry particles to the soil surface, and exhibit no growth or germination-inhibiting factors.

11. Plastic Sheeting: Plastic slope protection, anchor system and erosion protection at the toe of the plastic with a minimum thickness of $0.15 \mathrm{~mm}$. The anchoring system shall have the following standards:

a) Anchoring weights $30 \mathrm{~kg}$ minimum each, with non-puncture characteristics.

b) Tethers - Cords or ropes with adequate strength to support the anchoring weights on the slope.

c) Chain Link Fence - New or used material shall meet the requirements of 03010.20.

d) Stakes - Commercial grade metal posts shall weigh at least $2 \mathrm{~kg} / \mathrm{m}$.

e) Toe Protection - Class 25 rip rap shall meet the requirements of Section 00390.

12. Sandbags: $610 \mathrm{~mm} \times 300 \mathrm{~mm} \times 150 \mathrm{~mm}$ durable, weather-resistant, tightly woven bags sufficient to prohibit leakage of filler material. Bags shall be filled with firmly packed sand filler material weighing at least $34 \mathrm{~kg}$.

13. Temporary Scour Holes: Class 50 riprap shall meet the requirements of Section 00390.

14. Sediment Barriers include the following:

a) Bio-filter Bag - Shall meet the requirements of 00280.10(a).

b) Brush Barrier - Shall consist of woody debris $150 \mathrm{~mm}$ in diameter maximum, or topsoil strippings. Sediment Fence Geotextile shall meet the requirements of Sections 00350 and 02320 . Provide written "Level B" documentation according to $02320.10(\mathrm{c})$.

c) Filter Berm and Rock Filter - Aggregate shall; meet the requirements of 00330.16 with a maximum diameter of $25 \mathrm{~mm}$ to $100 \mathrm{~mm}$. Subgrade Geotextile shall meet the requirements of Sections 00350 and 02320 . Provide written "Level B" documentation according to 02320.10 (c).

d) Sand Bags - Shall meet the requirements of 00280.10(1).

e) Stakes - Shall conform to the following:

- Biofilter Bags - $25 \mathrm{~mm}$ x $50 \mathrm{~mm}$ x $450 \mathrm{~mm}$ minimum wood posts

- Brush Barrier - $25 \mathrm{~mm}$ x $50 \mathrm{~mm}$ x $450 \mathrm{~mm}$ minimum wood posts.

- Straw Bales - $38 \mathrm{~mm}$ x $25 \mathrm{~mm}$ x $900 \mathrm{~mm}$ minimum wood posts.

- Wattle - $25 \mathrm{~mm}$ x $25 \mathrm{~mm}$ x $600 \mathrm{~mm}$ minimum wood posts.

f) Straw Bale - Shall be standard $20 \mathrm{~kg}$ to $30 \mathrm{~kg}$ rectangular bales that are wire-bound or string-tied. Straw material shall be straw from bentgrass, bluegrass, fescue, or ryegrass singly or in combination. If no grass seed straw is available, straw from barley, oat or wheat is allowed if approved by the Agency. The straw shall not be moldy. caked, decayed or of otherwise low quality. Submit verification from the supplier that the straw is free of noxious weeds. Acceptable documentation submitted shall show either (1) that the straw source is from an "Oregon Certified Seed" field, or (2) the seed lab test results of the seed harvested from the straw meet minimum, Oregon Certified Seed quality for weed seed content./ The minimum requirements of Oregon certified seed are as published in the current year's Oregon Certified Seed Handbook available from County Extension 
Offices or Oregon State University.

g) Wattle - Shall be manufactured from rice or coconut straw and shall be between $200 \mathrm{~mm}$ and $260 \mathrm{~mm}$ in diameter. The straw shall not be moldy, caked, decayed or of otherwise low quality. Submit verification from the supplier that the straw is free of noxious weeds. Acceptable documentation submitted shall show the seed lab test results of the seed harvested from the straw meet minimum Oregon Certified Seed quality for weed seed content. The minimum requirements of Oregon certified seed are as published in the current year's Oregon Certified Seed Handbook available from County Extension Offices or Oregon State University. The straw shall be wrapped in a tubular plastic netting. The netting shall have a minimum strand thickness of $0.08 \mathrm{~mm}$, a knot thickness of $1.4 \mathrm{~mm}$, and a weight of 32.6 grams per meter (plus or minus 10 percent) and shall be made from 85 percent high density polyethylene, 14 percent ethyl vinyl acetate and 1 percent color for UV inhibition.

15. Sediment fence specifications are as follows:

a) Geotextile - Shall meet the requirements of Sections 00350 and 02320 . Provide written "Level B" documentation according to $02320.10(\mathrm{c})$.

b) Posts - Shall conform to the following:

- Sediment Fence, Supported - Commercial grade metal posts weighing at least $2 \mathrm{~kg} / \mathrm{m}$.

- Sediment Fence, Unsupported - $38 \mathrm{~mm}$ x $38 \mathrm{~mm}$ x $1200 \mathrm{~mm}$ minimum wooden posts.

- Wire Mesh - $2 \mathrm{~mm}$ gauge steel-wire mesh with $51 \mathrm{~mm}$ x $51 \mathrm{~mm}$ openings. A perforated polymeric mesh of equivalent grab tensile strength $(3100 \mathrm{~N})$, in accordance with ASTM D4632, may be substituted for the steelwire mesh.

16. Temporary Sediment Trap specifications are as follows:

a) Geotextile - Shall meet the requirements of Sections 00350 and 02320 . Provide written "Level B" documentation according to $02320.10(\mathrm{c})$.

b) Aggregate and Rock - Shall meet the requirements of 00330.16 with a maximum diameter varying from 19 to $38 \mathrm{~mm}$ for aggregate and 75 to $150 \mathrm{~mm}$ for rock.

17. Temporary Slope Drains: Shall meet the requirements of Section 02410 for plastic pipe, or Section 02420 for metal pipe. End sections, pipe stubs and elbow sections shall be from 150 to $300 \mathrm{~mm}$ in diameter. Refer to the plans and special provisions for contributing area and diameter. If the contributing area is not established, use $300 \mathrm{~mm}$ diameter.

18. Slope Berm: Shall be common material used for embankment construction or aggregate. Aggregate Base material shall meet the requirements of 00330.16 with a maximum diameter of $25 \mathrm{~mm}$ to $100 \mathrm{~mm}$.

19. Tire Wash Facility specifications are as follows:

a) Aggregate: Aggregate Base material shall meet the requirements of Sections 00641 and 02630.

b) Reinforcing Steel: Reinforcing steel shall meet the requirements of 02510.10 , with a minimum diameter of 22.2 $\mathrm{mm}$.

c) Geotextile: Subgrade geotextile shall meet the requirements of Sections 00350 and 02320 . Provide written "Level B" documentation according to 02320.10(c).

\section{Mulching Application Specifications}

\section{Straw Mulch}

Apply on slopes 1:1.5 or flatter. Spread straw mulch by hand or blower. Place approximately $50 \mathrm{~mm}$ deep, in loose condition, at a rate between 4.5 and $6.7 \mathrm{Mg} / \mathrm{ha}$ of dry mulch. Place straw mulch so that it is loose enough for sunlight to penetrate and air to circulate, but dense enough to shade the ground, reduce water evaporation, and materially reduce soil erosion. Anchor using hydraulically applied tackifier, crimping disc, or sheep's-foot roller approved by the Agency or methods specified in the special provisions.

- Blower - Blower equipment shall use air pressure with an adjustable spout that uniformly applies dry mulch at constantly measured rates. Apply the materials using a sweeping, horizontal motion of the nozzle. 


\section{Hydromulch}

Place waterborne cellulose fiber material using hydraulic equipment which continuously mixes and agitates the slurry and applies the mixture uniformly through a pressure-spray system providing a continuous, nonfluctuation delivery. Distribution and discharge lines shall be large enough to prevent stoppage and be equipped with a set of hydraulic discharge spray nozzles that will provide a uniform distribution of the slurry. Apply the materials using a sweeping, horizontal motion of the nozzle. Hydraulically apply at the following spread rates:

- Slopes 1:1.5 or flatter - $2.7 \mathrm{Mg} / \mathrm{ha}$ based on dry fiber weight.

- Slopes steeper than 1:1.5 - 3.4 Mg/ha cellulose fiber material that incudes a tackifier.

\section{Tack - Hydraulically Applied}

Hydromulch or straw mulch may be tackified using hydraulically applied liquid stabilizer emulsions or dry powder tacking agents at the following rates of application:

1. Liquid Stabilizer Emulsions - Apply at the following liters per hectare rates unless the manufacturer recommends a greater rate of application
a) Long term control of exposed soil surfaces: 325 1/ha diluted at 20:1. For steep slopes with raveling small rocks: 435 1/ha diluted at 10:1.
b) Seeding, Fertilizing or Mulching: 270 1/ha diluted at 30:1.
c) Dust Control: 270 1/ha diluted with water at a ration of $30: 1$.

2. Dry Powder Tackifier - Apply at the following kilograms per hectare rates unless the manufacturer recommends a greater rate of application:
a) 1:2 slopes and flatter: $67 \mathrm{~kg} / \mathrm{ha}$ mixed with hydromulch fibers at the rate specified.
b) Slopes steeper than 1:2:112 kg/ha mixed with hydromulch fibers at the rate specified.
c) Overspray for tacking pre-applied combinations of or singularly applied straw mulch, seed, or fertilizer: $90 \mathrm{~kg} /$ ha with $880 \mathrm{~kg}$ of hydromulch fiber.
d) Dust control and short term stabilization of exposed soil surfaces: $157 \mathrm{~kg} / \mathrm{ha}$.

\section{Tack - Mechanically Applied}

1. Straw Mulch may be mechanically tackified using a crimping disk or sheep's-foot roller.

a) Crimping Disc - A heavy disk with flat, scalloped discs approximately $6 \mathrm{~mm}$ thick, having dull edges and spaced no more than $230 \mathrm{~mm}$ apart.

b) Sheep's-foot Roller - Modified sheep's-foot roller equipped with straight studs, made of approximately $20 \mathrm{~mm}$ steel plate, placed approximately $200 \mathrm{~mm}$ apart and staggered. The studs shall not be less than $150 \mathrm{~mm}$ long nor more than $150 \mathrm{~mm}$ wide and shall be rounded to prevent withdrawing the straw from the soil. The roller shall be of such mass as to incorporate the straw sufficiently into the soil providing a uniform surface cover.

\section{Plastic Sheeting}

Place plastic sheeting on disturbed, temporary slopes where immediate protection is required and mulching or other methods of soil stabilization are not feasible. Steep slopes include vertical excavations for retaining walls and other temporary soil excavations and embankments related to structural work. Cover exposed soils and secure tightly in place using an anchoring system consisting of sandbags, chain link fence, or other approved methods. The anchoring system shall not puncture the plastic. Trench plastic at the top of slope and secure adequately to maintain cover during reasonably expected conditions in the area. Direct water away from areas above the plastic to prevent erosion from undermining the plastic. Control drainage from areas covered by the plastic sheeting so that the discharge occurs onto the toe protection. 
Table H-2 Specified ODOT Seed Mixture for Coast Range

\begin{tabular}{|l|c|}
\hline \multicolumn{1}{|c|}{ Botanical Name (Common Name) } & $\begin{array}{c}\text { Minimum *(PLS) per surface } \\
\text { hectare (kg/ha) }\end{array}$ \\
\hline Agrostis tenuis (Colonial Bentgrass) & 3 \\
\hline Festuca rubra (Creeping Red Fescue) & 11 \\
\hline Festuca rura commutata (Chewings Fescue) & 11 \\
\hline Lolium perenne (Perennial Ryegrass) & 17 \\
\hline Trifolium repens Grassland Huia (New Zealand White Clover) & 2 \\
\hline & Total \\
\hline
\end{tabular}

*PLS - Pure Live Seed 


\section{Appendix I.}

\section{Watersheds and Streams}

The following changes between the Draft and Final Environmental Impact Statement were made in Appendix I.

- Additional information, including crossing method was added to the tables in Appendix I.

Table I-1. Stream and Wetland Crossing Detail for the Proposed Action

\begin{tabular}{|c|c|c|c|c|c|c|c|c|c|}
\hline $\begin{array}{c}\text { Stream } \\
\text { No. }\end{array}$ & Segment & $\begin{array}{c}\text { Intermittent } \\
\text { Perennial } \\
(\mathbf{I} / \mathbf{P})\end{array}$ & $\begin{array}{c}\text { Width } \\
\text { (ft.) }\end{array}$ & $\begin{array}{l}\text { Stream } \\
\text { Name } \\
\text { (if } \\
\text { known) }\end{array}$ & $\begin{array}{c}\text { Land } \\
\text { Owner }\end{array}$ & $\begin{array}{l}\text { Crossing } \\
\text { Method }\end{array}$ & $\begin{array}{l}\text { Existing } \\
\text { Corridor }\end{array}$ & $\begin{array}{l}\text { Cut \& } \\
\text { Fill } \\
\text { (yd.) }\end{array}$ & Watershed \\
\hline 1 & $\mathrm{~A}$ & I & $05-10$ & & Private & ditch & powerline & 11 & Lower S. Fork Umpqua \\
\hline 2 & A & 1 & $00-05$ & & Private & ditch & powerline & 11 & Lower S. Fork Umpqua \\
\hline 3 & A & I & $05-10$ & & Private & ditch & powerline & 11 & Lower S. Fork Umpqua \\
\hline 4 & A & I & $05-10$ & $\begin{array}{l}\text { Powder- } \\
\text { house } \\
\text { Canyon } \\
\text { Drive }\end{array}$ & Private & ditch & powerline & 11 & Lower S. Fork Umpqua \\
\hline 5 & A & I & $00-05$ & & Private & ditch & powerline & 11 & Lower S. Fork Umpqua \\
\hline 6 & $\mathrm{~A}$ & I & $05-10$ & & Private & ditch & powerline & 11 & Lower S. Fork Umpqua \\
\hline 7 & A & I & $05-10$ & & Private & ditch & powerline & 11 & Lower S. Fork Umpqua \\
\hline 8 & A & I & $05-10$ & & Private & ditch & powerline & 11 & Lower S. Fork Umpqua \\
\hline 9 & $\mathrm{~A}$ & $\mathrm{P}$ & $15-20$ & & Private & ditch & powerline & 11 & Ollala/Lookingglass \\
\hline 10 & $\mathrm{~A}$ & 1 & $05-10$ & & Private & ditch & powerline & 11 & Ollala/Lookingglass \\
\hline 11 & A & I & $00-05$ & & Private & ditch & powerline & 11 & Ollala/Lookingglass \\
\hline 12 & A & I & $00-05$ & & Private & ditch & powerline & 11 & Ollala/Lookingglass \\
\hline 13 & A & I & $00-05$ & & Private & ditch & powerline & 11 & Ollala/Lookingglass \\
\hline 14 & A & I & $00-05$ & & Private & ditch & powerline & 11 & Ollala/Lookingglass \\
\hline 15 & A & I & $00-05$ & & Private & ditch & powerline & 11 & Ollala/Lookingglass \\
\hline 16 & A & I & $00-05$ & & Private & ditch & powerline & 11 & Ollala/Lookingglass \\
\hline 17 & A & I & $00-05$ & & Private & ditch & powerline & 11 & Ollala/Lookingglass \\
\hline 18 & A & 1 & $00-05$ & & Private & ditch & powerline & 11 & Ollala/Lookingglass \\
\hline 19 & A & 1 & $00-05$ & & Private & ditch & powerline & 11 & Ollala/Lookingglass \\
\hline 20 & A & I & $00-05$ & & Private & ditch & powerline & 11 & Ollala/Lookingglass \\
\hline 21 & A & 1 & $00-05$ & & Private & ditch & powerline & 11 & Ollala/Lookingglass \\
\hline
\end{tabular}


Table I-1. Stream and Wetland Crossing Detail for the Proposed Action (Continued)

\begin{tabular}{|c|c|c|c|c|c|c|c|c|c|}
\hline $\begin{array}{c}\text { Stream } \\
\text { No. }\end{array}$ & Segment & $\begin{array}{c}\text { Intermittent } \\
\text { Perennial } \\
\text { (I/P) }\end{array}$ & $\begin{array}{c}\text { Width } \\
\text { (ft.) }\end{array}$ & $\begin{array}{c}\text { Stream } \\
\text { Name } \\
\text { (if } \\
\text { known) }\end{array}$ & $\begin{array}{c}\text { Land } \\
\text { Owner }\end{array}$ & $\begin{array}{l}\text { Crossing } \\
\text { Method }\end{array}$ & $\begin{array}{l}\text { Existing } \\
\text { Corridor }\end{array}$ & $\begin{array}{l}\text { Cut \& } \\
\text { Fill } \\
\text { (yd.) }\end{array}$ & Watershed \\
\hline 22 & A & 1 & $00-05$ & & Private & ditch & pavement & 11 & Ollala/Lookingglass \\
\hline 23 & A & $\mathrm{P}$ & $10-15$ & $\begin{array}{l}\text { Morgan } \\
\text { Creek }\end{array}$ & Private & ditch & pavement & 22 & Ollala/Lookingglass \\
\hline 24 & A & 1 & $00-05$ & & Private & ditch & pavement & 11 & Ollala/Lookingglass \\
\hline 25 & A & 1 & $00-05$ & & Private & ditch & pavement & 11 & Ollala/Lookingglass \\
\hline 26 & B & $\mathrm{P}$ & $05-10$ & & Private & ditch & pavement & 11 & Ollala/Lookingglass \\
\hline 27 & $\mathrm{~B}$ & I & $00-05$ & & Private & ditch & powerline & 11 & Ollala/Lookingglass \\
\hline 28 & B & 1 & $00-05$ & & Private & ditch & powerline & 11 & Ollala/Lookingglass \\
\hline 29 & B & $\mathrm{P}$ & $00-05$ & & Private & ditch & pavement & 11 & Ollala/Lookingglass \\
\hline 30 & B & $\mathrm{P}$ & $00-05$ & & Private & ditch & powerline & 11 & Ollala/Lookingglass \\
\hline 31 & $\mathrm{~B}$ & $\mathrm{P}$ & $00-05$ & & Private & ditch & powerline & 11 & Ollala/Lookingglass \\
\hline 32 & $\mathrm{~B}$ & 1 & $00-05$ & & Private & ditch & powerline & 11 & Ollala/Lookingglass \\
\hline 33 & B & 1 & $00-05$ & & Private & ditch & powerline & 11 & Ollala/Lookingglass \\
\hline 34 & B & 1 & $00-05$ & & Private & ditch & powerline & 11 & Ollala/Lookingglass \\
\hline 35 & B & 1 & $00-05$ & & Private & ditch & powerline & 11 & Ollala/Lookingglass \\
\hline 36 & B & $\mathrm{P}$ & $00-05$ & & Private & ditch & powerline & 11 & Ollala/Lookingglass \\
\hline 37 & $\mathrm{~B}$ & $\mathrm{P}$ & $10-15$ & $\begin{array}{l}\text { Rock Cr. } \\
\text { (south of } \\
\text { BPA } \\
\text { ROW) }\end{array}$ & Private & ditch & powerline & 22 & Ollala/Lookingglass \\
\hline 38 & $\mathrm{~B}$ & I & $00-05$ & & Private & ditch & powerline & 11 & Ollala/Lookingglass \\
\hline 39 & B & $\mathrm{P}$ & $05-10$ & & Private & ditch & powerline & 11 & Ollala/Lookingglass \\
\hline 40 & $\mathrm{~B}$ & 1 & $00-05$ & & Private & ditch & powerline & 11 & Ollala/Lookingglass \\
\hline 41 & B & 1 & $00-05$ & & Private & ditch & powerline & 11 & Ollala/Lookingglass \\
\hline 42 & B & 1 & $00-05$ & & Private & ditch & powerline & 11 & Ollala/Lookingglass \\
\hline 43 & B & 1 & $00-05$ & & Private & ditch & powerline & 11 & Ollala/Lookingglass \\
\hline 44 & B & 1 & $00-05$ & & Private & ditch & powerline & 11 & Ollala/Lookingglass \\
\hline 45 & B & 1 & $00-05$ & & Private & ditch & powerline & 11 & Ollala/Lookingglass \\
\hline 46 & $\mathrm{~B}$ & 1 & $00-05$ & & Private & ditch & powerline & 11 & Ollala/Lookingglass \\
\hline 47 & B & 1 & $00-05$ & & Private & ditch & powerline & 11 & Ollala/Lookingglass \\
\hline 48 & $\mathrm{~B}$ & I & $00-05$ & & Private & ditch & powerline & 11 & Ollala/Lookingglass \\
\hline
\end{tabular}


Table I-1. Stream and Wetland Crossing Detail for the Proposed Action (Continued)

\begin{tabular}{|c|c|c|c|c|c|c|c|c|c|}
\hline $\begin{array}{c}\text { Stream } \\
\text { No. }\end{array}$ & Segment & $\begin{array}{l}\text { Intermittent } \\
\text { Perennial } \\
\text { (I/P) }\end{array}$ & $\begin{array}{l}\text { Width } \\
\text { (ft.) }\end{array}$ & $\begin{array}{l}\text { Stream } \\
\text { Name } \\
\text { (if } \\
\text { known) }\end{array}$ & $\begin{array}{l}\text { Land } \\
\text { Owner }\end{array}$ & $\begin{array}{l}\text { Crossing } \\
\text { Method }\end{array}$ & $\begin{array}{l}\text { Existing } \\
\text { Corridor }\end{array}$ & $\begin{array}{c}\text { Cut \& } \\
\text { Fill } \\
\text { (yd.) }\end{array}$ & Watershed \\
\hline 49 & $\mathrm{~B}$ & $\mathrm{P}$ & $05-10$ & $\begin{array}{l}\text { Tenmile } \\
\mathrm{Cr} \text {. }\end{array}$ & Private & ditch & pavement & 22 & Ollala/Lookingglass \\
\hline 50 & B & I & $00-05$ & & BLM & ditch & powerline & 11 & Ollala/Lookingglass \\
\hline 51 & C & I & $00-05$ & & BLM & ditch & powerline & 11 & Ollala/Lookingglass \\
\hline 52 & $\mathrm{C}$ & I & $00-05$ & & BLM & ditch & powerline & 11 & E. Fork Coquille \\
\hline 53 & $\mathrm{D}$ & $P$ & $10-15$ & $\begin{array}{l}\text { Knapper } \\
\text { Cr. }\end{array}$ & County & $\begin{array}{l}\text { under cul- } \\
\text { vert }\end{array}$ & gravel rd. & 23 & E. Fork Coquille \\
\hline 54 & $\mathrm{D}$ & I & $00-05$ & & County & $\begin{array}{l}\text { under cul- } \\
\text { vert }\end{array}$ & gravel rd. & 23 & E. Fork Coquille \\
\hline 55 & $\mathrm{D}$ & 1 & $00-05$ & & County & $\begin{array}{l}\text { under cul- } \\
\text { vert }\end{array}$ & gravel rd. & 23 & E. Fork Coquille \\
\hline 56 & $\mathrm{D}$ & $\mathrm{P}$ & $00-05$ & & County & $\begin{array}{l}\text { under cul- } \\
\text { vert }\end{array}$ & gravel rd. & 23 & E. Fork Coquille \\
\hline 57 & $\mathrm{D}$ & $\mathrm{P}$ & $00-05$ & & County & $\begin{array}{l}\text { under cul- } \\
\text { vert }\end{array}$ & gravel rd. & 23 & E. Fork Coquille \\
\hline 58 & $\mathrm{D}$ & $\mathrm{P}$ & $00-05$ & & County & $\begin{array}{l}\text { under cul- } \\
\text { vert }\end{array}$ & gravel rd. & 23 & E. Fork Coquille \\
\hline 59 & $\mathrm{D}$ & I & $00-05$ & & County & $\begin{array}{l}\text { under cul- } \\
\text { vert }\end{array}$ & gravel rd. & 23 & E. Fork Coquille \\
\hline 60 & $\mathrm{D}$ & I & $00-05$ & & County & $\begin{array}{l}\text { under cul- } \\
\text { vert }\end{array}$ & gravel rd. & 23 & E. Fork Coquille \\
\hline 61 & $\mathrm{D}$ & I & $00-05$ & & County & $\begin{array}{l}\text { under cul- } \\
\text { vert }\end{array}$ & gravel rd. & 23 & E. Fork Coquille \\
\hline 62 & $\mathrm{D}$ & I & $00-05$ & & County & $\begin{array}{l}\text { under cul- } \\
\text { vert }\end{array}$ & gravel rd. & 23 & E. Fork Coquille \\
\hline 63 & $\mathrm{D}$ & $\mathrm{P}$ & $00-05$ & & County & $\begin{array}{l}\text { under cul- } \\
\text { vert }\end{array}$ & gravel rd. & 23 & E. Fork Coquille \\
\hline 64 & $\mathrm{D}$ & $\mathrm{P}$ & $00-05$ & & County & $\begin{array}{l}\text { under cul- } \\
\text { vert }\end{array}$ & gravel rd. & 23 & E. Fork Coquille \\
\hline 65 & $\mathrm{D}$ & I & $00-05$ & & County & $\begin{array}{l}\text { under cul- } \\
\text { vert }\end{array}$ & gravel rd. & 23 & E. Fork Coquille \\
\hline 66 & $\mathrm{D}$ & I & $00-05$ & & County & $\begin{array}{l}\text { under cul- } \\
\text { vert }\end{array}$ & gravel rd. & 23 & E. Fork Coquille \\
\hline 67 & $\mathrm{D}$ & I & $00-05$ & & County & $\begin{array}{l}\text { under cul- } \\
\text { vert }\end{array}$ & gravel rd. & 23 & E. Fork Coquille \\
\hline 68 & $\mathrm{D}$ & I & $00-05$ & & County & $\begin{array}{l}\text { under cul- } \\
\text { vert }\end{array}$ & gravel rd. & 23 & E. Fork Coquille \\
\hline
\end{tabular}


Table I-1. Stream and Wetland Crossing Detail for the Proposed Action (Continued)

\begin{tabular}{|c|c|c|c|c|c|c|c|c|c|}
\hline $\begin{array}{c}\text { Stream } \\
\text { No. }\end{array}$ & Segment & $\begin{array}{c}\text { Intermittent } \\
\text { Perennial } \\
(\mathrm{I} / \mathrm{P})\end{array}$ & $\begin{array}{c}\text { Width } \\
\text { (ft.) }\end{array}$ & $\begin{array}{c}\text { Stream } \\
\text { Name } \\
\text { (if } \\
\text { known) }\end{array}$ & $\begin{array}{c}\text { Land } \\
\text { Owner }\end{array}$ & $\begin{array}{l}\text { Crossing } \\
\text { Method }\end{array}$ & $\begin{array}{l}\text { Existing } \\
\text { Corridor }\end{array}$ & $\begin{array}{c}\text { Cut \& } \\
\text { Fill } \\
(y d .)\end{array}$ & Watershed \\
\hline 69 & $\mathrm{D}$ & $P$ & $05-10$ & & County & $\begin{array}{l}\text { under cul- } \\
\text { vert }\end{array}$ & gravel rd. & 23 & E. Fork Coquille \\
\hline 70 & $\mathrm{D}$ & $\mathrm{P}$ & $20-25$ & $\begin{array}{l}\text { E. Fork } \\
\text { Coquille }\end{array}$ & County & bridge & gravel rd. & 0 & E. Fork Coquille \\
\hline 71 & $\mathrm{D}$ & I & $00-05$ & & County & $\begin{array}{l}\text { under cul- } \\
\text { vert }\end{array}$ & gravel rd. & 23 & E. Fork Coquille \\
\hline 72 & $\mathrm{D}$ & I & $00-05$ & & County & $\begin{array}{l}\text { under cul- } \\
\text { vert }\end{array}$ & gravel rd. & 23 & E. Fork Coquille \\
\hline 73 & $\mathrm{D}$ & I & $00-05$ & & County & $\begin{array}{l}\text { under cul- } \\
\text { vert }\end{array}$ & gravel rd. & 23 & E. Fork Coquille \\
\hline 74 & $\mathrm{D}$ & $\mathrm{P}$ & $00-05$ & & County & $\begin{array}{l}\text { under cul- } \\
\text { vert }\end{array}$ & gravel rd. & 23 & E. Fork Coquille \\
\hline 75 & $\mathrm{D}$ & I & $00-05$ & & County & $\begin{array}{l}\text { under cul- } \\
\text { vert }\end{array}$ & gravel rd. & 23 & E. Fork Coquille \\
\hline 76 & $\mathrm{D}$ & I & $00-05$ & & County & $\begin{array}{l}\text { under cul- } \\
\text { vert }\end{array}$ & gravel rd. & 23 & E. Fork Coquille \\
\hline 77 & $\mathrm{D}$ & I & $00-05$ & & County & $\begin{array}{l}\text { under cul- } \\
\text { vert }\end{array}$ & gravel rd. & 23 & E. Fork Coquille \\
\hline 78 & $\mathrm{D}$ & I & $00-05$ & & County & $\begin{array}{l}\text { under cul- } \\
\text { vert }\end{array}$ & gravel rd. & 23 & E. Fork Coquille \\
\hline 79 & $\mathrm{D}$ & I & $00-05$ & & County & $\begin{array}{l}\text { under cul- } \\
\text { vert }\end{array}$ & gravel rd. & 23 & E. Fork Coquille \\
\hline 80 & $\mathrm{D}$ & $\mathrm{P}$ & $05-10$ & & County & $\begin{array}{l}\text { under cul- } \\
\text { vert }\end{array}$ & gravel rd. & 23 & E. Fork Coquille \\
\hline 81 & $\mathrm{D}$ & I & $00-05$ & & County & $\begin{array}{l}\text { under cul- } \\
\text { vert }\end{array}$ & gravel rd. & 23 & E. Fork Coquille \\
\hline 82 & $\mathrm{D}$ & I & $00-05$ & & County & $\begin{array}{l}\text { under cul- } \\
\text { vert }\end{array}$ & gravel rd. & 23 & E. Fork Coquille \\
\hline 83 & $\mathrm{D}$ & $\mathrm{P}$ & $00-05$ & & County & $\begin{array}{l}\text { under cul- } \\
\text { vert }\end{array}$ & gravel rd. & 23 & E. Fork Coquille \\
\hline 84 & $\mathrm{D}$ & $\mathrm{P}$ & $20-25$ & $\begin{array}{l}\text { E. Fork } \\
\text { Coquille }\end{array}$ & County & bridge & gravel rd. & 0 & E. Fork Coquille \\
\hline 85 & $\mathrm{D}$ & I & $00-05$ & & County & $\begin{array}{l}\text { under cul- } \\
\text { vert }\end{array}$ & gravel rd. & 23 & E. Fork Coquille \\
\hline 86 & $\mathrm{D}$ & I & $00-05$ & & County & $\begin{array}{l}\text { under cul- } \\
\text { vert }\end{array}$ & gravel rd. & 23 & E. Fork Coquille \\
\hline
\end{tabular}


Table I-1. Stream and Wetland Crossing Detail for the Proposed Action (Continued)

\begin{tabular}{|c|c|c|c|c|c|c|c|c|c|}
\hline $\begin{array}{l}\text { Stream } \\
\text { No. }\end{array}$ & Segment & $\begin{array}{l}\text { Intermittent } \\
\text { Perennial } \\
\text { (I/P) }\end{array}$ & $\begin{array}{c}\text { Width } \\
\text { (ft.) }\end{array}$ & $\begin{array}{l}\text { Stream } \\
\text { Name } \\
\text { (if } \\
\text { known) }\end{array}$ & $\begin{array}{l}\text { Land } \\
\text { Owner }\end{array}$ & $\begin{array}{l}\text { Crossing } \\
\text { Method }\end{array}$ & $\begin{array}{l}\text { Existing } \\
\text { Corridor }\end{array}$ & $\begin{array}{c}\text { Cut \& } \\
\text { Fill } \\
\text { (yd.) }\end{array}$ & Watershed \\
\hline 87 & D & I & $00-05$ & & County & $\begin{array}{l}\text { under cul- } \\
\text { vert }\end{array}$ & gravel rd. & 23 & E. Fork Coquille \\
\hline 88 & $\mathrm{D}$ & I & $00-05$ & & County & $\begin{array}{l}\text { under cul- } \\
\text { vert }\end{array}$ & gravel rd. & 23 & E. Fork Coquille \\
\hline 89 & $\mathrm{D}$ & I & $00-05$ & & County & $\begin{array}{l}\text { under cul- } \\
\text { vert }\end{array}$ & gravel rd. & 23 & E. Fork Coquille \\
\hline 90 & $\mathrm{D}$ & $\mathrm{P}$ & $00-05$ & & County & $\begin{array}{l}\text { under cul- } \\
\text { vert }\end{array}$ & gravel rd. & 23 & E. Fork Coquille \\
\hline 91 & $\mathrm{D}$ & $\mathrm{P}$ & $05-10$ & & County & $\begin{array}{l}\text { under cul- } \\
\text { vert }\end{array}$ & gravel rd. & 23 & E. Fork Coquille \\
\hline 92 & $\mathrm{D}$ & I & $00-05$ & & County & $\begin{array}{l}\text { under cul- } \\
\text { vert }\end{array}$ & gravel rd. & 23 & E. Fork Coquille \\
\hline 93 & $\mathrm{D}$ & I & $00-05$ & & County & $\begin{array}{l}\text { under cul- } \\
\text { vert }\end{array}$ & gravel rd. & 23 & E. Fork Coquille \\
\hline 94 & $\mathrm{D}$ & $\mathrm{P}$ & $15-20$ & $\begin{array}{l}\text { Brummit } \\
\mathrm{Cr} \text {. }\end{array}$ & County & drill & pavement & 23 & E. Fork Coquille \\
\hline 95 & $\mathrm{D}$ & I & $00-05$ & & County & $\begin{array}{l}\text { under cul- } \\
\text { vert }\end{array}$ & pavement & 23 & E. Fork Coquille \\
\hline 96 & $\mathrm{D}$ & $\mathrm{P}$ & $00-05$ & & County & $\begin{array}{l}\text { under cul- } \\
\text { vert }\end{array}$ & pavement & 23 & E. Fork Coquille \\
\hline 97 & $\mathrm{D}$ & $P$ & $15-20$ & & County & $\begin{array}{l}\text { under cul- } \\
\text { vert }\end{array}$ & pavement & 23 & E. Fork Coquille \\
\hline 98 & $\mathrm{D}$ & $\mathrm{P}$ & $00-05$ & & County & $\begin{array}{l}\text { under cul- } \\
\text { vert }\end{array}$ & pavement & 23 & E. Fork Coquille \\
\hline 99 & $\mathrm{D}$ & $\mathrm{P}$ & $00-05$ & & County & $\begin{array}{l}\text { under cul- } \\
\text { vert }\end{array}$ & pavement & 23 & E. Fork Coquille \\
\hline 100 & $\mathrm{D}$ & $\mathrm{P}$ & $00-05$ & & County & $\begin{array}{l}\text { under cul- } \\
\text { vert }\end{array}$ & pavement & 23 & E. Fork Coquille \\
\hline 101 & $\mathrm{D}$ & $\mathrm{P}$ & $10-15$ & China Cr. & County & $\begin{array}{l}\text { over cul- } \\
\text { vert }\end{array}$ & pavement & 0 & E. Fork Coquille \\
\hline 102 & $\mathrm{D}$ & $\mathrm{P}$ & $00-05$ & Bills Cr. & County & $\begin{array}{l}\text { over cul- } \\
\text { vert }\end{array}$ & pavement & 0 & E. Fork Coquille \\
\hline 103 & $\mathrm{D}$ & 1 & $00-05$ & & County & $\begin{array}{l}\text { under cul- } \\
\text { vert }\end{array}$ & pavement & 23 & E. Fork Coquille \\
\hline 104 & $\mathrm{D}$ & 1 & $00-05$ & & County & $\begin{array}{l}\text { under cul- } \\
\text { vert }\end{array}$ & pavement & 23 & E. Fork Coquille \\
\hline
\end{tabular}


Table I-1. Stream and Wetland Crossing Detail for the Proposed Action (Continued)

\begin{tabular}{|c|c|c|c|c|c|c|c|c|c|}
\hline $\begin{array}{c}\text { Stream } \\
\text { No. }\end{array}$ & Segment & $\begin{array}{c}\text { Intermittent } \\
\text { Perennial } \\
(\mathbf{I} / \mathbf{P})\end{array}$ & $\begin{array}{c}\text { Width } \\
\text { (ft.) }\end{array}$ & $\begin{array}{c}\text { Stream } \\
\text { Name } \\
\text { (if } \\
\text { known) }\end{array}$ & $\begin{array}{c}\text { Land } \\
\text { Owner }\end{array}$ & $\begin{array}{l}\text { Crossing } \\
\text { Method }\end{array}$ & $\begin{array}{l}\text { Existing } \\
\text { Corridor }\end{array}$ & $\begin{array}{c}\text { Cut \& } \\
\text { Fill } \\
(y d .)\end{array}$ & Watershed \\
\hline 105 & $\mathrm{D}$ & 1 & $00-05$ & & County & $\begin{array}{l}\text { over cul- } \\
\text { vert }\end{array}$ & pavement & 23 & E. Fork Coquille \\
\hline 106 & $\mathrm{D}$ & $\mathrm{P}$ & $00-05$ & & County & $\begin{array}{l}\text { over cul- } \\
\text { vert }\end{array}$ & pavement & 0 & E. Fork Coquille \\
\hline 107 & $\mathrm{D}$ & 1 & $00-05$ & & County & $\begin{array}{l}\text { under cul- } \\
\text { vert }\end{array}$ & pavement & 23 & E. Fork Coquille \\
\hline 108 & $\mathrm{D}$ & $\mathrm{P}$ & $10-15$ & Steel Cr. & County & bridge & pavement & 0 & E. Fork Coquille \\
\hline 109 & $\mathrm{D}$ & $\mathrm{P}$ & $10-15$ & Hantz Cr. & County & $\begin{array}{l}\text { over cul- } \\
\text { vert }\end{array}$ & pavement & 0 & E. Fork Coquille \\
\hline 110 & $\mathrm{D}$ & $\mathrm{P}$ & $00-05$ & & County & $\begin{array}{l}\text { under cul- } \\
\text { vert }\end{array}$ & pavement & 23 & E. Fork Coquille \\
\hline 111 & $\mathrm{D}$ & I & $00-05$ & & Private & ditch & powerline & 11 & E. Fork Coquille \\
\hline 112 & $\mathrm{D}$ & $\mathrm{P}$ & $00-05$ & & BLM & ditch & powerline & 11 & E. Fork Coquille \\
\hline 113 & $\mathrm{D}$ & $P$ & $20-25$ & Cherry $\mathrm{Cr}$. & Private & drill & powerline & 0 & N. Fork Coquille \\
\hline 114 & $\mathrm{D}$ & $\mathrm{P}$ & $25-30$ & $\begin{array}{l}\text { Middle } \\
\mathrm{Cr} \text {. }\end{array}$ & $\begin{array}{l}\text { CBW } \\
\text { Road }\end{array}$ & drill & powerline & 0 & N. Fork Coquille \\
\hline 115 & $\mathrm{D}$ & $P$ & $00-05$ & & Private & ditch & powerline & 11 & N. Fork Coquille \\
\hline 116 & $\mathrm{E}$ & I & $00-05$ & & Private & ditch & pavement & 11 & N. Fork Coquille \\
\hline 117 & $\mathrm{E}$ & $\mathrm{P}$ & $00-05$ & & Private & ditch & powerline & 11 & N. Fork Coquille \\
\hline 118 & $\mathrm{E}$ & $\mathrm{P}$ & $00-05$ & & Private & ditch & powerline & 11 & N. Fork Coquille \\
\hline 119 & $\mathrm{E}$ & $\mathrm{P}$ & $00-05$ & & Private & ditch & powerline & 11 & N. Fork Coquille \\
\hline 120 & $\mathrm{~F}$ & $\mathrm{P}$ & $00-05$ & & Private & ditch & powerline & 11 & N. Fork Coquille \\
\hline 121 & G & $\mathrm{P}$ & 90 & $\begin{array}{l}\text { N. Fork of } \\
\text { Coquille } \\
\text { R. }\end{array}$ & Private & drill & powerline & 0 & N. Fork Coquille \\
\hline 122 & G & $\begin{array}{l}\text { Seasonal } \\
\text { Wetland }\end{array}$ & 300 & $\begin{array}{l}\text { Fairview } \\
\text { wetland }\end{array}$ & Private & ditch & grass & 111 & N. Fork Coquille \\
\hline 123 & G & 1 & $00-05$ & & County & $\begin{array}{l}\text { under cul- } \\
\text { vert }\end{array}$ & pavement & 23 & N. Fork Coquille \\
\hline 124 & G & I & $00-05$ & & County & $\begin{array}{l}\text { under cul- } \\
\text { vert }\end{array}$ & pavement & 23 & N. Fork Coquille \\
\hline 125 & G & P & $00-05$ & & County & $\begin{array}{l}\text { under cul- } \\
\text { vert }\end{array}$ & pavement & 23 & N. Fork Coquille \\
\hline 126 & G & I & $00-05$ & & County & $\begin{array}{l}\text { under cul- } \\
\text { vert }\end{array}$ & gravel rd. & 23 & N. Fork Coquille \\
\hline
\end{tabular}


Table I-1. Stream and Wetland Crossing Detail for the Proposed Action (Continued)

\begin{tabular}{|c|c|c|c|c|c|c|c|c|c|}
\hline $\begin{array}{c}\text { Stream } \\
\text { No. }\end{array}$ & Segment & $\begin{array}{c}\text { Intermittent } \\
\text { Perennial } \\
\text { (I/P) }\end{array}$ & $\begin{array}{c}\text { Width } \\
\text { (ft.) }\end{array}$ & $\begin{array}{c}\text { Stream } \\
\text { Name } \\
\text { (if } \\
\text { known) }\end{array}$ & $\begin{array}{l}\text { Land } \\
\text { Owner }\end{array}$ & $\begin{array}{l}\text { Crossing } \\
\text { Method }\end{array}$ & $\begin{array}{l}\text { Existing } \\
\text { Corridor }\end{array}$ & $\begin{array}{l}\text { Cut \& } \\
\text { Fill } \\
\text { (yd.) }\end{array}$ & Watershed \\
\hline 127 & G & I & $00-05$ & & County & $\begin{array}{l}\text { under cul- } \\
\text { vert }\end{array}$ & gravel rd. & 23 & N. Fork Coquille \\
\hline 128 & $\mathrm{H}$ & I & $00-05$ & & County & $\begin{array}{l}\text { under cul- } \\
\text { vert }\end{array}$ & gravel rd. & 23 & N. Fork Coquille \\
\hline 129 & $\mathrm{H}$ & I & $00-05$ & & County & $\begin{array}{l}\text { under cul- } \\
\text { vert }\end{array}$ & gravel rd. & 23 & Middle Main Coquille \\
\hline 130 & $\mathrm{H}$ & I & $00-05$ & & County & $\begin{array}{l}\text { under cul- } \\
\text { vert }\end{array}$ & gravel rd. & 23 & Middle Main Coquille \\
\hline 131 & $\mathrm{H}$ & I & $00-05$ & & County & $\begin{array}{l}\text { under cul- } \\
\text { vert }\end{array}$ & gravel rd. & 23 & Middle Main Coquille \\
\hline 132 & $\mathrm{H}$ & $\mathrm{P}$ & $00-05$ & & County & $\begin{array}{l}\text { under cul- } \\
\text { vert }\end{array}$ & gravel rd. & 23 & Middle Main Coquille \\
\hline 133 & $\mathrm{H}$ & $\mathrm{P}$ & $00-05$ & & County & $\begin{array}{l}\text { under cul- } \\
\text { vert }\end{array}$ & gravel rd. & 23 & Middle Main Coquille \\
\hline 134 & $\mathrm{H}$ & $\mathrm{P}$ & $00-05$ & & County & $\begin{array}{l}\text { under cul- } \\
\text { vert }\end{array}$ & gravel rd. & 23 & Middle Main Coquille \\
\hline 135 & $\mathrm{H}$ & $\mathrm{P}$ & $00-05$ & & County & $\begin{array}{l}\text { under cul- } \\
\text { vert }\end{array}$ & gravel rd. & 23 & Middle Main Coquille \\
\hline 136 & $\mathrm{H}$ & $\mathrm{P}$ & $00-05$ & & County & $\begin{array}{l}\text { under cul- } \\
\text { vert }\end{array}$ & gravel rd. & 23 & Middle Main Coquille \\
\hline 137 & $\mathrm{H}$ & I & $00-05$ & & County & $\begin{array}{l}\text { under cul- } \\
\text { vert }\end{array}$ & gravel rd. & 23 & Middle Main Coquille \\
\hline 138 & $\mathrm{H}$ & $\mathrm{P}$ & $00-05$ & & County & $\begin{array}{l}\text { under cul- } \\
\text { vert }\end{array}$ & gravel rd. & 23 & Middle Main Coquille \\
\hline 139 & $\mathrm{H}$ & $\mathrm{P}$ & $00-05$ & & County & $\begin{array}{l}\text { under cul- } \\
\text { vert }\end{array}$ & gravel rd. & 23 & Middle Main Coquille \\
\hline 140 & $\mathrm{H}$ & $\mathrm{P}$ & $00-05$ & & County & $\begin{array}{l}\text { under cul- } \\
\text { vert }\end{array}$ & gravel rd. & 23 & Middle Main Coquille \\
\hline 141 & $\mathrm{H}$ & $P$ & $00-05$ & & County & $\begin{array}{l}\text { under cul- } \\
\text { vert }\end{array}$ & gravel rd. & 23 & Middle Main Coquille \\
\hline 142 & $\mathrm{H}$ & I & $00-05$ & & County & $\begin{array}{l}\text { under cul- } \\
\text { vert }\end{array}$ & gravel rd. & 23 & Middle Main Coquille \\
\hline 143 & $\mathrm{H}$ & I & $00-05$ & & County & $\begin{array}{l}\text { under cul- } \\
\text { vert }\end{array}$ & gravel rd. & 23 & Middle Main Coquille \\
\hline 144 & $\mathrm{H}$ & $P$ & $00-05$ & & County & $\begin{array}{l}\text { under cul- } \\
\text { vert }\end{array}$ & gravel rd. & 23 & Middle Main Coquille \\
\hline
\end{tabular}


Table I-1. Stream and Wetland Crossing Detail for the Proposed Action (Continued)

\begin{tabular}{|c|c|c|c|c|c|c|c|c|c|}
\hline $\begin{array}{c}\text { Stream } \\
\text { No. }\end{array}$ & Segment & $\begin{array}{c}\text { Intermittent } \\
\text { Perennial } \\
(\mathbf{I} / \mathbf{P})\end{array}$ & $\begin{array}{c}\text { Width } \\
\text { (ft.) }\end{array}$ & $\begin{array}{c}\text { Stream } \\
\text { Name } \\
\text { (if } \\
\text { known) }\end{array}$ & $\begin{array}{c}\text { Land } \\
\text { Owner }\end{array}$ & $\begin{array}{l}\text { Crossing } \\
\text { Method }\end{array}$ & $\begin{array}{l}\text { Existing } \\
\text { Corridor }\end{array}$ & $\begin{array}{l}\text { Cut \& } \\
\text { Fill } \\
\text { (yd.) }\end{array}$ & Watershed \\
\hline 145 & $\mathrm{H}$ & $\mathrm{P}$ & $00-05$ & & County & $\begin{array}{l}\text { under cul- } \\
\text { vert }\end{array}$ & gravel rd. & 23 & Middle Main Coquille \\
\hline 146 & $\mathrm{H}$ & $\mathrm{P}$ & $00-05$ & & County & $\begin{array}{l}\text { under cul- } \\
\text { vert }\end{array}$ & gravel rd. & 23 & Lower Coos/Coos Bay \\
\hline 147 & $\mathrm{H}$ & 1 & $00-05$ & & County & $\begin{array}{l}\text { under cul- } \\
\text { vert }\end{array}$ & gravel rd. & 23 & Lower Coos/Coos Bay \\
\hline 148 & $\mathrm{H}$ & 1 & $00-05$ & & County & $\begin{array}{l}\text { under cul- } \\
\text { vert }\end{array}$ & gravel rd. & 23 & Lower Coos/Coos Bay \\
\hline 149 & $\mathrm{H}$ & I & $00-05$ & & County & $\begin{array}{l}\text { under cul- } \\
\text { vert }\end{array}$ & gravel rd. & 23 & Lower Coos/Coos Bay \\
\hline 150 & $\mathrm{H}$ & $\mathrm{P}$ & $05-10$ & & County & $\begin{array}{l}\text { under cul- } \\
\text { vert }\end{array}$ & pavement & 23 & Lower Coos/Coos Bay \\
\hline 151 & $\mathrm{H}$ & $\mathrm{P}$ & $00-05$ & & County & $\begin{array}{l}\text { under cul- } \\
\text { vert }\end{array}$ & pavement & 23 & Lower Coos/Coos Bay \\
\hline 152 & $\mathrm{H}$ & $\mathrm{P}$ & $05-10$ & $\begin{array}{l}\text { Panther } \\
\mathrm{Cr} \text {. }\end{array}$ & County & $\begin{array}{l}\text { over cul- } \\
\text { vert }\end{array}$ & pavement & 0 & Lower Coos/Coos Bay \\
\hline 153 & $\mathrm{H}$ & $\mathrm{P}$ & $05-10$ & $\begin{array}{l}\text { Cardwell } \\
\text { Cr. }\end{array}$ & County & $\begin{array}{l}\text { over cul- } \\
\text { vert }\end{array}$ & pavement & 0 & Lower Coos/Coos Bay \\
\hline 154 & $\mathrm{H}$ & $\mathrm{P}$ & $00-05$ & & County & $\begin{array}{l}\text { under cul- } \\
\text { vert }\end{array}$ & pavement & 23 & Lower Coos/Coos Bay \\
\hline 155 & $\mathrm{H}$ & $\mathrm{P}$ & $00-05$ & & County & $\begin{array}{l}\text { under cul- } \\
\text { vert }\end{array}$ & pavement & 23 & Lower Coos/Coos Bay \\
\hline 156 & $\mathrm{H}$ & $\mathrm{P}$ & $00-05$ & & County & $\begin{array}{l}\text { under cul- } \\
\text { vert }\end{array}$ & pavement & 23 & Lower Coos/Coos Bay \\
\hline 157 & $\mathrm{H}$ & $\mathrm{P}$ & $00-05$ & & County & $\begin{array}{l}\text { under cul- } \\
\text { vert }\end{array}$ & pavement & 23 & Lower Coos/Coos Bay \\
\hline 158 & $\mathrm{H}$ & $\mathrm{P}$ & $00-05$ & & County & $\begin{array}{l}\text { under cul- } \\
\text { vert }\end{array}$ & pavement & 23 & Lower Coos/Coos Bay \\
\hline 159 & $\mathrm{H}$ & $\mathrm{P}$ & $10-15$ & $\begin{array}{l}\text { Catching } \\
\mathrm{Cr} \text {. }\end{array}$ & County & drill & pavement & 0 & Lower Coos/Coos Bay \\
\hline 160 & $\mathrm{H}$ & 1 & $00-05$ & & County & $\begin{array}{l}\text { under cul- } \\
\text { vert }\end{array}$ & pavement & 23 & Lower Coos/Coos Bay \\
\hline 161 & $\mathrm{H}$ & I & $00-05$ & & County & $\begin{array}{l}\text { under cul- } \\
\text { vert }\end{array}$ & pavement & 23 & Lower Coos/Coos Bay \\
\hline 162 & $\mathrm{H}$ & 1 & $00-05$ & & County & $\begin{array}{l}\text { under cul- } \\
\text { vert }\end{array}$ & pavement & 23 & Lower Coos/Coos Bay \\
\hline
\end{tabular}


Table I-1. Stream and Wetland Crossing Detail for the Proposed Action (Continued)

\begin{tabular}{|c|c|c|c|c|c|c|c|c|c|}
\hline $\begin{array}{l}\text { Stream } \\
\text { No. }\end{array}$ & Segment & $\begin{array}{c}\text { Intermittent } \\
\text { Perennial } \\
\text { (I/P) }\end{array}$ & $\begin{array}{l}\text { Width } \\
\text { (ft.) }\end{array}$ & $\begin{array}{l}\text { Stream } \\
\text { Name } \\
\text { (if } \\
\text { known) }\end{array}$ & $\begin{array}{l}\text { Land } \\
\text { Owner }\end{array}$ & $\begin{array}{l}\text { Crossing } \\
\text { Method }\end{array}$ & $\begin{array}{l}\text { Existing } \\
\text { Corridor }\end{array}$ & $\begin{array}{c}\text { Cut \& } \\
\text { Fill } \\
\text { (yd.) }\end{array}$ & Watershed \\
\hline 163 & $\mathrm{H}$ & $\mathrm{P}$ & $00-05$ & & County & $\begin{array}{l}\text { under cul- } \\
\text { vert }\end{array}$ & pavement & 23 & Lower Coos/Coos Bay \\
\hline 164 & $\mathrm{H}$ & $\mathrm{P}$ & $00-05$ & & County & $\begin{array}{l}\text { under cul- } \\
\text { vert }\end{array}$ & pavement & 23 & Lower Coos/Coos Bay \\
\hline 165 & $\mathrm{H}$ & 1 & $00-05$ & & County & $\begin{array}{l}\text { under cul- } \\
\text { vert }\end{array}$ & pavement & 23 & Lower Coos/Coos Bay \\
\hline 166 & $\mathrm{H}$ & $\mathrm{P}$ & $00-05$ & & County & $\begin{array}{l}\text { under cul- } \\
\text { vert }\end{array}$ & pavement & 23 & Lower Coos/Coos Bay \\
\hline 167 & $\mathrm{H}$ & I & $00-05$ & & County & ditch & powerline & 11 & Lower Coos/Coos Bay \\
\hline 168 & $\mathrm{H}$ & I & $00-05$ & & County & $\begin{array}{l}\text { under cul- } \\
\text { vert }\end{array}$ & pavement & 23 & Lower Coos/Coos Bay \\
\hline 169 & $\mathrm{H}$ & $\mathrm{P}$ & $00-05$ & & County & $\begin{array}{l}\text { under cul- } \\
\text { vert }\end{array}$ & pavement & 23 & Lower Coos/Coos Bay \\
\hline 170 & $\mathrm{H}$ & I & $00-05$ & & County & ditch & powerline & 11 & Lower Coos/Coos Bay \\
\hline 171 & $\mathrm{H}$ & $\mathrm{P}$ & $00-05$ & & County & $\begin{array}{l}\text { under cul- } \\
\text { vert }\end{array}$ & pavement & 23 & Lower Coos/Coos Bay \\
\hline 172 & $\mathrm{H}$ & I & $00-05$ & & County & $\begin{array}{l}\text { under cul- } \\
\text { vert }\end{array}$ & pavement & 23 & Lower Coos/Coos Bay \\
\hline 173 & $\mathrm{H}$ & $\mathrm{P}$ & $00-05$ & & County & $\begin{array}{l}\text { under cul- } \\
\text { vert }\end{array}$ & pavement & 23 & Lower Coos/Coos Bay \\
\hline 174 & $\mathrm{H}$ & $\mathrm{P}$ & $00-05$ & & County & $\begin{array}{l}\text { under cul- } \\
\text { vert }\end{array}$ & pavement & 23 & Lower Coos/Coos Bay \\
\hline 175 & $\mathrm{H}$ & Wetland & 1000 & $\begin{array}{l}\text { Isthmus } \\
\text { Slough } \\
\text { bottoms }\end{array}$ & Private & ditch & pasture & 370 & Lower Coos/Coos Bay \\
\hline 176 & $\mathrm{H}$ & $\mathrm{P}$ & 400 & $\begin{array}{l}\text { Isthmus } \\
\text { Slough } \\
\text { east end }\end{array}$ & Private & drill & pasture & 40 & Lower Coos/Coos Bay \\
\hline 177 & & 1 & $00-05$ & & Private & ditch & powerline & 11 & Lower Coos/Coos Bay \\
\hline 178 & & I & $00-05$ & & Private & ditch & powerline & 11 & Lower Coos/Coos Bay \\
\hline 179 & & I & $00-05$ & & Private & ditch & powerline & 11 & Lower Coos/Coos Bay \\
\hline 180 & & $\mathrm{P}$ & $10-15$ & $\begin{array}{l}\text { Shingle- } \\
\text { house } \\
\text { Slough } \\
\text { tributary }\end{array}$ & Private & drill & powerline & 0 & Lower Coos/Coos Bay \\
\hline 181 & & $P$ & $00-05$ & & Private & ditch & powerline & 11 & Lower Coos/Coos Bay \\
\hline 182 & & 1 & 00-05 & & Private & ditch & powerline & 11 & Lower Coos/Coos Bay \\
\hline
\end{tabular}


Table I-1. Stream and Wetland Crossing Detail for the Proposed Action (Continued)

\begin{tabular}{|c|c|c|c|c|c|c|c|c|c|}
\hline $\begin{array}{l}\text { Stream } \\
\text { No. }\end{array}$ & Segment & $\begin{array}{c}\text { Intermittent } \\
\text { Perennial } \\
(\mathbf{I} / \mathbf{P})\end{array}$ & $\begin{array}{c}\text { Width } \\
\text { (ft.) }\end{array}$ & $\begin{array}{l}\text { Stream } \\
\text { Name } \\
\text { (if } \\
\text { known) }\end{array}$ & $\begin{array}{l}\text { Land } \\
\text { Owner }\end{array}$ & $\begin{array}{l}\text { Crossing } \\
\text { Method }\end{array}$ & $\begin{array}{l}\text { Existing } \\
\text { Corridor }\end{array}$ & $\begin{array}{c}\text { Cut \& } \\
\text { Fill } \\
\text { (yd.) }\end{array}$ & Watershed \\
\hline I 83 & & I & $00-05$ & & Private & ditch & powerline & 11 & Lower Coos/Coos Bay \\
\hline 184 & $\mathrm{~J}$ & $\mathrm{P}$ & $10-15$ & $\begin{array}{l}\text { Coalbank } \\
\text { Slough } \\
\text { tributary }\end{array}$ & Private & drill & powerline & 0 & Lower Coos/Coos Bay \\
\hline I 85 & $\mathrm{~J}$ & I & $00-05$ & $\begin{array}{l}\text { Coal-bank } \\
\text { Slough } \\
\text { tributary }\end{array}$ & Private & drill & powerline & 0 & Lower Coos/Coos Bay \\
\hline 186 & $\mathrm{~K}$ & I & $00-05$ & & County & $\begin{array}{l}\text { over cul- } \\
\text { vert }\end{array}$ & powerline & 0 & Lower Coos/Coos Bay \\
\hline 187 & $\mathrm{~K}$ & I & $00-05$ & & Private & ditch & powerline & 11 & Lower Coos/Coos Bay \\
\hline 188 & $\mathrm{~K}$ & $P$ & 05-10 & $\begin{array}{l}\text { Blossom } \\
\text { Gulch \& } \\
\text { wetlands }\end{array}$ & Private & drill & powerline & 0 & Lower Coos/Coos Bay \\
\hline
\end{tabular}




\section{Appendix J Pipeline Design, Construction, Operation and Maintenance Plan}

The following changes between the Draft and Final Environmental Impact Statement were made to Appendix J.

- A revised Appendix J Pipeline Design, Construction, Operation \& Maintenance has replaced the former Appendix J.

Prepared by:

Steven Shute, PE

Pipeline Solutions, Inc.

P.O. Box 1054

Glenwood Springs, CO 81602 


\section{Appendix J Pipeline Design, Construction, Operation \& Maintenance}

\section{Construction Methods and Operations}

The design, construction, testing and operation of the pipeline are addressed in US DOT gas pipeline safety regulations at 49 CFR Part 192. Coos Pipeline will meet or exceed all relevant regulations applicable to gas transmission pipelines. Coos County will contract with a qualified operator to operate and maintain the gas transmission system under Part 192. The Contract operator will be required to formulate and follow a detailed Operation and Maintenance Plan (O\&M) for this system, including an Emergency Procedures Plan.

This section addresses some of the major issues of design, construction and operation of the 12-inch mainline. The smaller laterals will be built and run to the same standards outlined here, in the operator's O\&M and Emergency plans, and in 49 CFR Part 192.

\section{Project Design Criteria}

The proposed natural gas pipeline would originate at an existing Williams Gas pipeline just south of Roseburg; extend southwest for approximately 60 miles where it would terminate at a distribution facility that would be built in Coos Bay. The line will take gas at Williams' operating pressure and deliver without pressure regulation to various delivery points in Douglas and Coos counties. Williams' system in the Roseburg area is currently limited to maximum allowable operating pressure (MAOP) of 896 pounds per square inch (psi). However, other parts of its system have been expanded and up-rated to $960 \mathrm{psi}$. The Coos Pipeline will be rated at 1000 pounds/square inch (psi) to anticipate any system upgrades that Williams might make in the near future.

\section{Pipe Design}

Pipe design is covered in Part 192 Subpart C (starting at paragraph 192.101). Pipe strength specifications depend on population density and MAOP. Most of the pipeline will be constructed of pipe with the following specifications:

-12-3/4-inch outside diameter .250 inch wall API 5LX-52 carbon steel line pipe

- Specified Minimum Yield Strength: 2039 psi

- Typical Operating Pressure at Williams: 600 to 800 psi

- Maximum Allowable Operating Pressure: 1000 psi (Class 3)

- Minimum Test Pressure: 1500 psi (Class 3)

More than 90 percent of the route is very rural, with 10 or fewer buildings per mile for human occupancy specified at 192.5 as a Class 1 location. Some scattered portions of the route are in Class 2 locations near rural communities with 11 to 45 buildings per mile. Some of those areas such as Fairview and Libby could become Class 3 locations ( 46 or more homes per mile). The pipeline passes within 100 yards of Lookingglass School and Coos Country Club, both gathering places which could also be defined as Class 3 , if occupied by at least 20 persons at least 5 days per week for 10 weeks per year. To avoid any confusion between class locations and different pipe specifications, the entire pipeline will be built and tested to Class 3 specifications

\section{Extra Strength Pipe}

In some areas where strength and reliability are especially critical, the pipeline will be built with heavier wall thickness pipe. This extra-strength pipe can withstand higher test and operating pressures:

-12-3/4-inch outside diameter .375-inch wall API 5LX-52 carbon steel line pipe 
- Specified Minimum Yield Strength: 3059 psi

The communities of Lookingglass, Dora, Fairview, Sumner, Coos City (country club area), Libby and the outskirts of Coos Bay now have (or could eventually have) Class 3 areas. Heavier pipe will be used in these potential Class 3 areas and all bores and many stream, wetland and road crossings.

\section{Test Design}

Part 192 Subpart J specifies testing procedures. Part 192.619 requires the test pressure to be 150 percent of MAOP at Class 3 locations. The minimum required test pressure at any point during the test will be 1500 psi, to assure that every point along the system can be operated to 1000 psi MAOP.

Parts 192.503 and 505 address other test requirements. The test must maintain pressure for at least 8 hours. Natural gas can be used as a test medium, but the maximum test pressure is insufficient for the desired MAOP in any class location. Air or inert gas (usually nitrogen) also has a pressure limitation, but can be used to qualify the entire pipeline for 1000 psi MAOP in Class 2 areas.

There are two further limitations to nitrogen testing: any occupied building within 100 yards would have to be evacuated during the test; and existing or potential Class 3 areas would have to be separately hydrotested. Because of these limitations most, of the pipeline will be tested with water (hydrotested) to allow unrestricted Class 3 operations.

Hydrotesting is a common practice with little risk, even with the high pressures that are routinely used. Clean water is pumped into the pipeline at one end, usually pushing a foam plug or "pig" in front to eliminate air. When the pipeline is full, a high pressure pump is used to raise the internal pressure up to the design pressure. Since water is nearly incompressible, this additional pressure takes very few gallons of water. Conversely, even a tiny leak in the pipe is very evident, as the pressure recorder shows a definite drop.

Every point in a test section must experience the minimum required test pressure. Since water is a dense medium, the ups-and-downs of the terrain translate into changes in pressure within the pipe, at about 1 psi per 2.4 feet of elevation change. The Coos Pipeline starts at Williams at $600 \mathrm{ft}$ elevation (or "MSL" for feet above mean sea level), rises to approximately $3000 \mathrm{ft}$ at Reston Ridge, and drops to near sea level near Coos Bay. The range in pressures will exceed the limits of the 12-inch line pipe.

Because of that, the test sections must be carefully chosen to ensure the minimum test pressures at all high elevations points, while not exceeding the Specified Minimum Yield Strength (SMYS) rating of the pipe at the lowest point. The mainline will be tested in at least 4 sections. The lateral pipe has a wider pressure range and can be tested as one section.

\section{Testing and Inspection:}

Weld testing and inspection: Each weld will be visually inspected by a certified welding inspector, and X-rayed to detect invisible defects.

Hydrostatic leak test: Every joint of the pipe is hydrostatically tested (e.g., pressure-tested with water at the factory) to comply with the DOT and American Petroleum Institute (API) specifications. The finished pipeline would be hydrostatically pressure tested to at least $1,500 \mathrm{psi}$, to detect leakage or failure. This is 150 percent of pipeline's MAOP. Because of the elevation differences, testing must be done in sections to avoid exceeding the SMYS of the pipe $(2,039$ psi).

\section{Corrosion Protection}

Part 192 Subpart 1 specifies that all new buried steel pipelines must be protected from corrosion. The pipeline must be coated with a suitable protective and electrically insulating coating. Coos Pipeline will have a 3-layered epoxy and polyethylene coating system. The welds are covered with a polyethylene heat-shrink sleeve, and the entire coating is electrically inspected for coating faults as it is lowered into the ditch. Select padding and rock shield will be used to protect the coating from damage.

DOT also requires active corrosion prevention, provided with "cathodic protection" applied during construction or soon after. A system of sacrificial anodes is connected to the pipeline. The anodes produce an electrical current which flows through the earth and collects on the pipeline cathode. The anodes corrode and the pipeline is protected 
as long as this current flows. Anodes can be made of magnesium, which produces a natural galvanic current when coupled with steel, or graphite or steel anodes, through which current is driven from an external impressed current source.

The effectiveness of the coating and cathodic protection is easily checked with a volt meter and electrode at least once per year, per DOT. Cathodic test stations are installed about every mile. A wire is attached directly to the pipe from the station, and is used to check the cathodic protection level, and to attach an electronic locator to find the pipe.

\section{Block Valves}

Block valve settings provide means of stopping flow through the pipeline, with blowdown valves to release gas pressure if necessary. Part 192.179 specifies maximum distances between block valves. Coos Pipeline will have several valves capable of automatic (self-closing) or remote (offsite human or computer) operation. Coos Pipeline will also install check valves in one or more block valves, which allow flow in only one direction, and prevent backflow. These types of valves can reduce the response and exposure time in the event of a line break.

The contract pipeline operator will have final authority over the selection and installation of these types of valves. All valves are checked, lubricated and operated at least one per year, per DOT.

\section{Other Pipeline Appurtenances}

Other sections of Part 192 address design, construction and operation of other pipeline appurtenances. Line markers, cathodic test stations, exposed sections, meters and regulators are some of the design features covered by Part 192.

\section{General Methods}

\section{Safety}

Fire hazard (in situ flammables and flammable materials) - During construction, the contractor will be required to abide

by state fire regulations. Any flammable materials must be transported, contained, and used in accordance with Office of

a) Safety and Health Administration (OSHA) requirements. Any empty containers (if applicable) must be disposed of properly, in accordance with EPA requirements.

b) Toxic materials hazard - All toxic materials must be used in accordance with OSHA standards.

c) Explosive materials hazard - All explosives must be used in accordance with OSHA requirements.

d) Mechanical hazard: The construction contractor would be required to follow OSHA requirements for operation of all equipment at the construction site.

e) Electrical Hazard: Within Bonneville Power Administration (BPA) and Pacific Power \& Light (PP\&L) rights-of-way, the high voltage powerlines could induce a current in the pipeline, especially long welded sections exposed in or above the trench. The construction contractor shall be required to have and follow a plan to continuously ground the pipe, such that construction workers would be protected from electrical shock by these induced currents.

f) Susceptibility of hazard to public - The public is susceptible to hazard under the following conditions:

- If the contractor fails to follow required safety procedures during public's presence at or near the construction site;

- If the public enters the construction site without proper approval;

- If, during the public's presence at or near the construction site, an act of God occurs. 


\section{Access Road Construction Methods}

No new roads would be built. BPA and PP\&L currently maintain all exisiting roads and access roads within the proposed action corridor.

\section{Pipeline Construction Methods}

\section{Work area:}

Pipeline construction would require a working space, which varies from 20 to 60 feet wide. In the Coos Bay Wagon Road (CBW Road), construction would take place entirely within the roadbed, which is about 20 feet wide. In a few areas along the power corridor with steep side slopes, the disturbed area could be 60 feet wide. In most sections, the area of disturbance would be 30 to 40 feet wide. Some grading would be required to install the pipe, but the grade would be substantially restored to its original state before revegetation.

\section{Assembly and Refueling Areas:}

Assembly and refueling activities would be confined to designated roads.

\section{Road Closures:}

Roads would be closed only when construction is active and within the road right-of-way. No night construction is expected, and crews normally work 6 days per week. Most paved road crossings would be bored-under, which would require traffic control (flaggers) but no road closure. Work within the CBW Road would force road closure during the ditch, lay and backfill stages. In the remote section east of Sitkum (10 miles), the CBW Road would be closed during daytime working hours, and re-opened in the evenings and off-days. There may be some night closure in the most difficult sections. In the canyon section from Sitkum to Dora (4 miles), the wider working space should allow limited traffic flow during the day, such as on the hour. Most work along the CBW Road would require traffic control for other operations, such as preparation and final cleanup.

\section{Site preparation prescriptions:}

In the powerline corridor, herbaceous vegetation within 20 feet of the trench is removed. The following types of sites are expected to occur along the proposed pipeline route. Each type of construction has an estimated amount of time to prepare the right-of-way and excavate the ditch. After the ditch is prepared, then stringing, welding, laying and backfill can be done at up to one mile per day.

a) Level or gently sloping surfaces on clay or silty soils: Site preparation consists of clearing of brush and trees mentioned above. Typical progress would be 4,000 to 10,000 linear feet per day.

b) Moderate to steep topography: Temporary grading would be required in topography too steep for safe operation of trenching and pipe laying equipment. The scope and nature of soil disturbance would be consistent with that found in the Erosion Control Plan (ECP) (Appendix H in the FEIS). Progress along slopes is slower than progress on soils of the same type on level or gentle slopes, depending upon the slope gradient, but would typically range from 2,000 to 4,000 feet per day. The very steep approach to Reston Ridge would be slower.

c) Road bed site: Pipeline construction within or near the road bed (the width between the road shoulders) requires traffic management (signs and flaggers), pavement cutting and pavement disposal. Typical progress is 1,000 to 2,000 linear feet per day.

d) Bedrock or rock face situations: Burial of the pipeline within rock sites requires extra work ripping, rock sawing or trenching, or drilling and blasting. Rock sawing and trenching typically progress at 500 to 1,000 feet per day. Drilling and blasting activities normally progress at 200 to 400 feet per day.

e) Talus sites: Digging within talus sites requires site preparation similar to that of steep slopes (temporary grading to enable safe equipment operations), with the additional requirement of constructing pre-engineered soil retention structures (usually rock-filled cages) at the foot of the cut slope, which prevents soil movement above the work area. There are no known talus sites along the corridor. 
f) Along streams: Construction parallel to streams would be planned to avoid operation of equipment within riparian zones. Procedures would follow the ECP (Appendix H in the FEIS), using sediment barriers to prevent materials from entering the stream. The rate of progress depends upon soil conditions and topography; a typical maximum rate is 1,000 to 2,000 linear feet per day.

g) Stream crossings: Stream crossings would be accomplished using one of the following methods, depending upon existing conditions.

- Large or particularly sensitive streams, estuaries and large wetlands would be crossed with directional-drilling equipment. Site preparation is usually minimal - the entry and target locations are carefully chosen to be flat and open and the entry point would have a small excavation for the initial drill entry. Directional-drill activity takes from 3 to 10 days, depending on length, rock strata, and complexity. See subsection 7a for details, as well as Figures J-1 through J-3.

- Small streams with active flows would be crossed using a Bag-and-Flume method. The stream is dammed with sandbags to temporarily contain stream flow and a flume directs flow around the construction area. After "bagging and fluming', the streambed is trenched using conventional excavators and rock removal techniques. The stream banks may be cut back to soften the approach angle, then restored after construction to original grade. Such a crossing would typically take less than a day (6-8 hours).

- Trenching across a dry stream bed or runoff channel does not require additional site preparation. Site preparation and pipeline crossing of an inactive small stream (intermittent) would take between one and two hours.

h) Wetland crossings: Wetland crossings would be directionally-drilled to avoid impacts (Figures J-1 through J$3)$.

\section{Installation:}

The pipe would be installed to a minimum depth of 36 inches to top of pipe. In bedrock, installation would be a minimum of 24 inch depth to top of pipe. Bedrock is expected for 10-20 percent of the route between Reston and Dora.

Installation process: All equipment would be operated in accordance with OSHA and DEQ standards and guidelines. This includes procedures for operating equipment in or near streams, wetlands, talus slopes, steep terrain, and exposed bedrock sites. The following operations are included in the installation process:
a) Ditch digging
b) Pipe joint welding
c) Lay pipe and backfill ditch (replace and compact original soil)
d) Tie-ins (includes installation of block valves, road bores, and stream crossings)
e) Testing \& Cleanup (hydrostatic testing, install line markers and cathodic test stations, painting and locking of block valves)

\section{Pipeline bedding:}

Along most of the route, the native soil would be returned to the ditch and compacted around the pipe. In areas where the backfill is too coarse or rocky and would damage the coating, then pipe padding material (such as sand or volcanic ash) is imported to compact around the pipe, with native backfill above that. In the segment within the CBW Road, most of the backfill would be imported road base. The excess native soil would be hauled and stored for use by Coos County in its ongoing road department operations. 


\section{Directional-Drilling and Reaming Procedures}

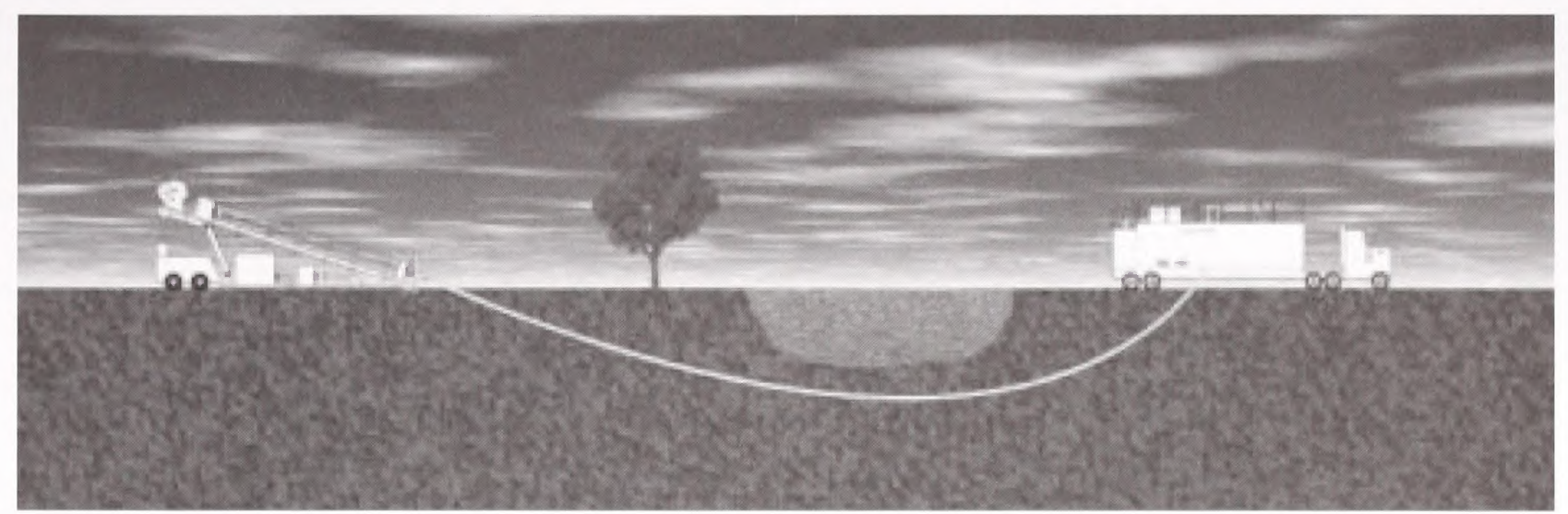

Figure J-1 Directional-Drill Crossing: Pilot Hole

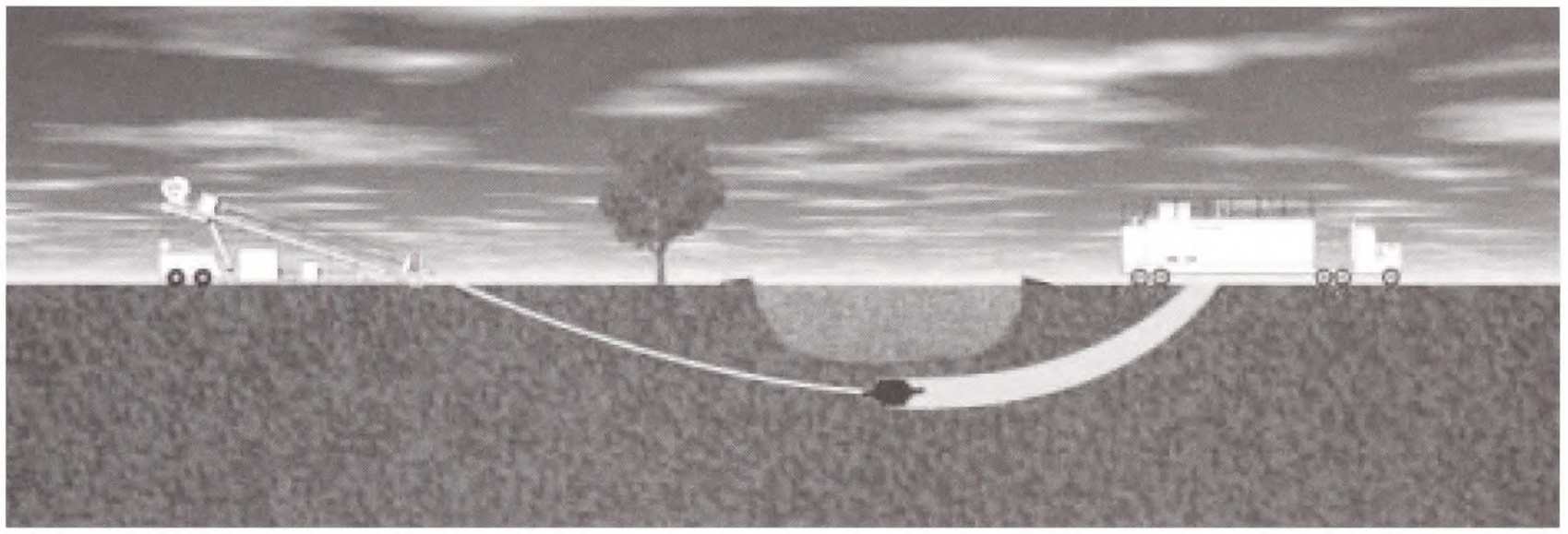

Figure J-2: Reaming Process

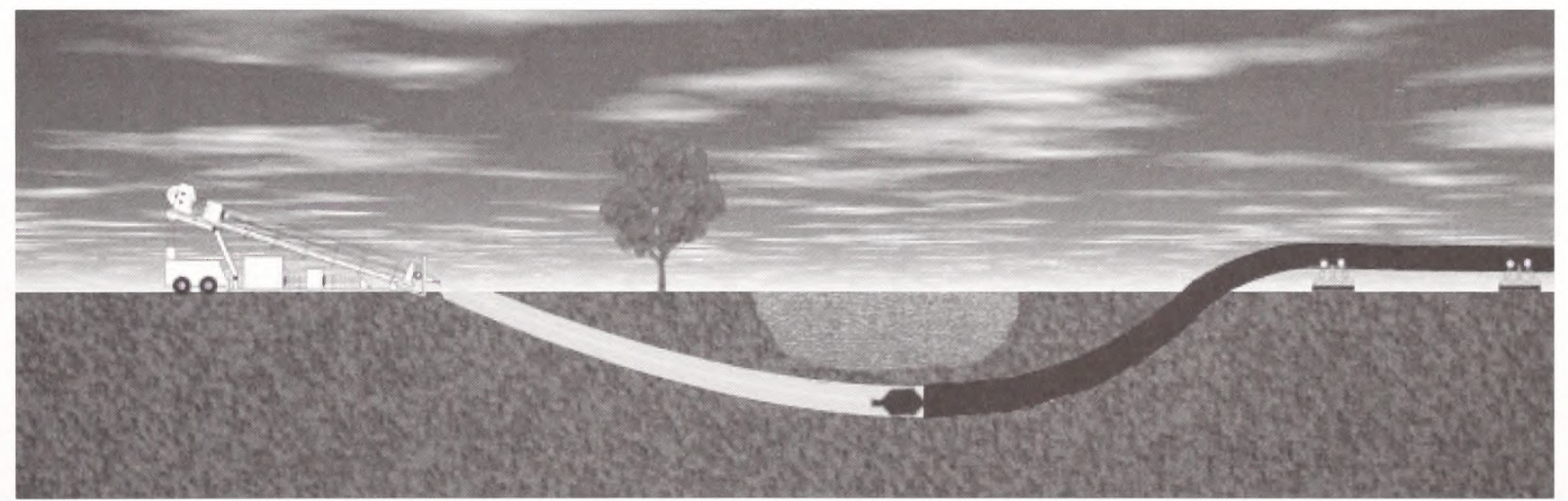

Figure J-3: Pull-Back 


\section{Pipeline installation procedures for sensitive or difficult sites:}

a) Directional boring of stream and wetland crossings: Horizontal drilling beneath the stream bed requires drilling at a shallow angle from one side of the stream, boring at a safe distance beneath the stream bed, and exiting on the other side well away from the stream channel. A small "pilot" hole is drilled first, typically about 4 to 6 inches in diameter (Figure J-1). From the exit point, a larger reamer is pulled back through the pilot hole to enlarge the bore. This process continues until the bore is 30 percent to 50 percent oversize, such as a 16-inch bore for this 12-inch pipeline (see Figure J-2). The pipeline for the entire length of the bore is welded together on the opposite side of the drilling unit. After the joints are coated and pipe is pressure tested, it is pulled back through the ground-bore in a continuous operation. (see Figure J-3).

b) Steep terrain and sharp turns require the pipe to be bent with specialized pipe bending equipment. After backfill, water bars and other erosion control measures will be applied in steep areas.

c) Narrow roadway requires use of smaller crews and equipment working more slowly due to the reduced width of the working space.

d) Bedrock sometimes cannot be broken with a tractor-mounted excavator. Specialized techniques for rock removal are used, depending on the hardness and fracturing of the rock layer. Rock trenchers have carbide teeth and are effective on softer rock. Rock saws are also used to cut a well-defined trench wall. The hardest rock requires drilling and blasting.

\section{Grade restoration and site revegetation:}

Each site would be restored to original grade; the surface would be reseeded to establish native plants in accordance with the ECP in Appendix H of the FEIS.

\section{Cleanup:}

All litter and materials remaining after completion of construction would be removed from the site. Equipment would be removed from the right-of-way as soon as possible, after completion of its assigned task.

\section{Construction Related to Ancillary Facilities}

The EIS describes in detail the construction of the 12 inch pipeline to Coos Bay, including the block valves, delivery and city gate stations, and other appurtenances. Coos County also plans to build smaller pipeline laterals to Coquille, Myrtle Point and Bandon. NW Natural and possibly the City of Bandon plan to build gas distribution networks in those towns. The present plans for laterals and distribution networks are described in this document, and are subject to change. Apart from these projects, there are no ancillary facilities planned.

The following assemblies are required in the proposed action:

a) Meter Station - required at the delivery points from Williams near Roseburg and to NW Natural in Coos Bay. Each meter station would be fabricated offsite in a controlled welding facility. The station site would need to be leveled, graveled and fenced. Construction of modest concrete supports will be required for the piping and metering building. Site preparation, installation and testing take about two weeks for each station.

b) Block valve with blowdowns - required at 5 strategic locations along the route. Each block valve will require about one day for site preparation, installation and testing.

\section{Pipeline Joining system}

The pipe sections would be welded together. A suitable protective coating would be applied over the welded joints to prevent corrosion of the uncoated weld area. 


\section{Block valve assembly}

This assembly is approximately 4 feet long (Figure $\mathrm{J}-4$ ) and includes the following:

- Block valve: A 12-inch ball valve is welded directly inline with the buried pipeline. The stainless steel ball rotates around a steel axle or "stem", which is turned by hand or (for valves 6-inch and larger) a series of gears. On buried valves such as this, the stem is extended above ground in a pipe casing. These 12 -inch valves would be fitted with gear boxes and hand wheels for manual operation, or with pneumatic or gas-powered operators for automatic or remote operation. The valve operator would be 30 to 48 inches above ground, and would be about the same size as a five gallon bucket.

- Blowdown valves: A "blowdown" valve would be positioned vertically from the pipeline, one on each side of, and about 2 feet away from, the block valve. Each valve consists of a 4-inch pipeline stem extending above grade. Near its upper end is a valve and a heavy threaded cap (Refer to "Operation Description" or "Pipeline Shutdown" for a description of the purpose for a blowdown valve.)

- Block valve protection: All valves will be locked with a key available only to pipeline operators. The entire footprint will be surrounded with a chain link fence with locked gate. Depending on location and traffic volume, the fence and valve will be protected with concrete or pipe barricades.

Block valve Protection: The entire block valve footing (about 2 feet wide and 8 feet long) would be suitably protected from physical damage, vandalism and unauthorized operation.

Pipeline Supporting Materials: Native soil, or imported gravel and roadbase material.

Fuels: Diesel would be used for most of the large equipment in the construction project. Gasoline would be used in transport vehicles.

Chemicals (coolant, lubricants, cleaning materials, etc.): as needed to support the construction machinery and equipment.

Pipeline markers: DOT requires pipeline markers as needed to delineate the route. These are typically bright yellow composite plastic line markers showing location information (station number) and a warning, spaced at about 10 per mile, or more in difficult terrain or populated areas.

Cathodic test stations: Plastic support pipe with copper wire leads to the pipeline would be spaced at intervals of approximately one mile, to provide for pipeline location and periodic cathodic protection testing.

Erosion control construction materials: See Appendix H of the FEIS. 


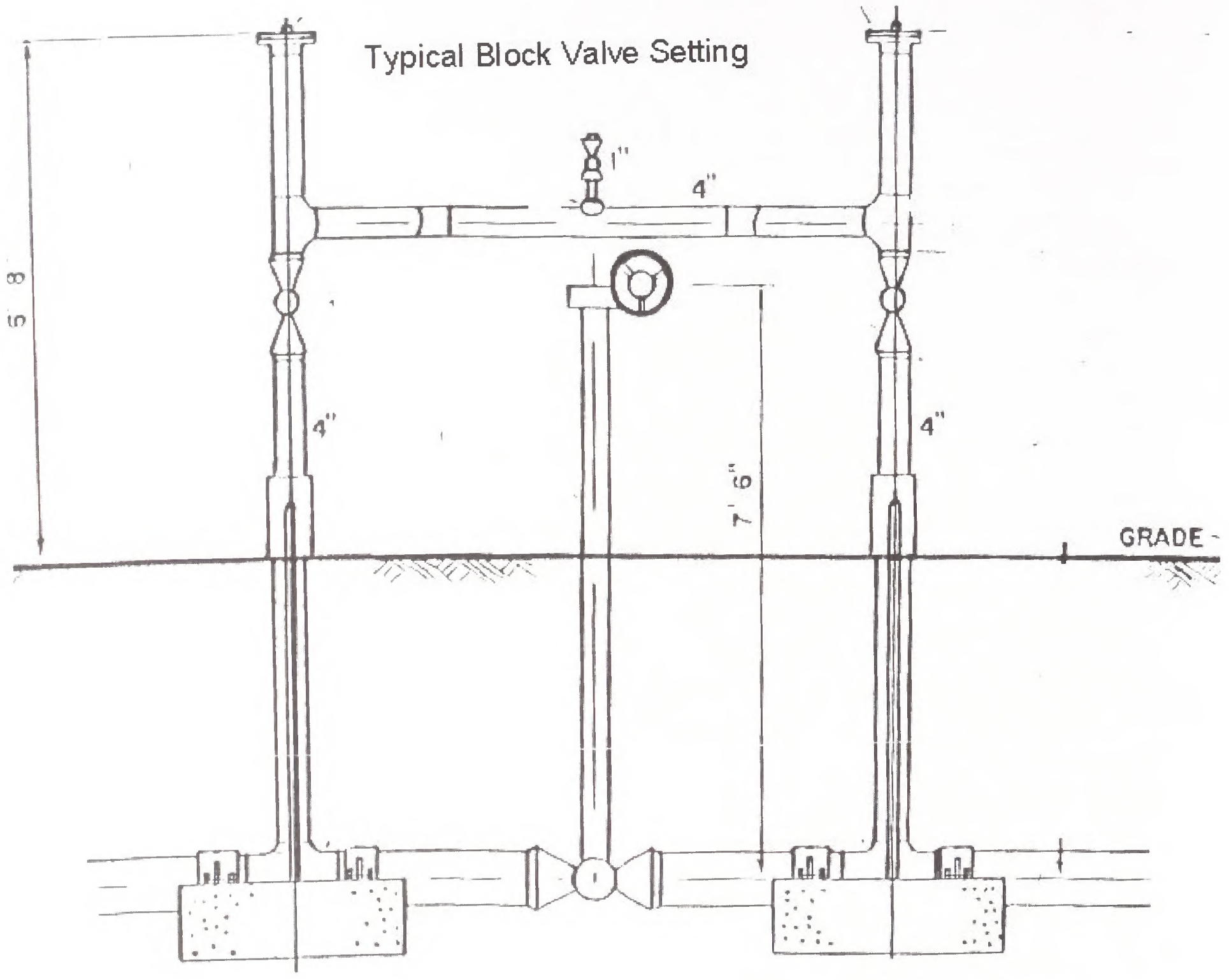

Figure J-4: Typical Block Valve Setting 


\section{Equipment Required During Construction}

Diesel freight truck with flat-bed trailer and low-boy trailer options, backhoe, bulldozer, side-boom pipe-layer, frontend loader, air driven tools, impact wrench, various hand tools and equipment necessary for welding the pipeline segments together.

\section{Hauling Schedule}

The pipeline segments would arrive at either Roseburg or Coos Bay (depending upon shipping methods). Materials delivery from a Roseburg or Coos Bay storage area would arrive on a just-in-time basis; these materials would then be placed into their permanent configuration at the construction site within a few days of delivery. Deliveries of pipe and materials would be expected to occur every day. One full truck load of pipe carries about 1,200 feet of pipe. Therefore, deliveries should not exceed one to two trucks per day.

\section{Construction Schedule}

The entire construction sequence - clearing, trenching, pipe string and weld, laying in and backfill, cleanup and mulching - would typically take place over just a few days for any particular 200 yard segment. Each of those steps would take about 1 or 2 hours for a short segment, then the noise and dust from the next segment would be greatly diminished and quickly return to normal. The steps are not usually consecutive, though, as the construction group or "spread" literally spreads down the corridor. A typical sequence could be: ground clearing in the morning, ditching early afternoon, pipe stringing late in the day, weld and backfill next day, cleanup and mulch the third day.

The total length of time for completing of any local segment depends on the type of terrain and speed of travel. On most of the segments along PP\&L or BPA, the entire process would usually be finished over a span of 1 to 3 days. Steeper sections and road sections could span 3 or 4 days, as digging and logistics are more difficult. The narrowest, rockiest portions of the CBW Road could take up to 7 days from start to finish. There are just a few short sections where this could be expected, in the canyons both directions from Sitkum.

The directional-drilling crews and tie-in crews are independent of the mainline spreads. The bores could be done weeks or months ahead of the mainline (or vice versa), and then a separate tie-in crew would tie together the loose ends, backfill and cleanup. For any particular short segment, however, the cumulative local impact will be much less than 7 days.

Construction can be scheduled in accordance with specific time-of-day or time-of-year restrictions applicable to wildlife or other concerns on public lands.

\section{Labor Force}

The construction contractor could employ up to 200 workers distributed among several separate construction groups or "spreads" in the pipeline corridor. Spreads would merge or divide as needed. In the corridor portions characterized by open terrain, each spread could employ a large workforce ( 30 or more workers). When the terrain is narrow canyons or steep slopes, the spread would likely be closer to a dozen workers. Additional crews - with just a few workers each - would accomplish specialized aspects of the project, such as manage road traffic, boring and drilling, tie-ins, hydrostatic testing, meter station and block valve construction, and erosion control/revegetation tasks.

All work would take place during daylight hours, which are adjustable to any justifiable need throughout the course of the construction. The operations of the spreads would be managed by the construction contractor's supervisors.

\section{Construction Inspectors}

Full-time onsite inspectors will be hired by Coos County to observe different critical phases of construction. These inspectors have authorization to change contractor procedures, to excavate work already buried, and to shut down construction if needed, in the pursuit of a high-quality finished pipeline. 
Welding inspectors and X-ray technicians are highly specialized pipeline industry workers, who are onsite to examine every finished weld joint. Ditch and backfill inspectors watch the trenching, pipe laying and covering/compaction/cleanup process. This inspector will watch the electronic "jeeping" of the coating just before backfill.

Other inspectors watch road and stream crossings and tie-ins to pre-built sections, if separate from the main spread of construction workers. A chief inspector watches over the whole process and assigns inspectors to tasks as needed.

In addition to the traditional pipeline inspectors, the Coos Pipeline will have other specialty inspectors. An archaeological consultant will look for disturbance of cultural resources. The ECR will watch for compliance with the ECP. A wildlife biologist will look for disturbance of wildlife and wildlife habitat. Work within public road ROW may be monitored by a road department inspector.

\section{System Description}

\section{Pipeline}

The pipeline's expected life span is unlimited. The system components are as follows:

- Delivery station from Williams Gas Pipeline near Roseburg.

- Pipeline (entirely buried except for bridge crossings).

- Block valves, including above-ground "blowdown" valves.

- Magnesium corrosion prevention anodes are buried below the pipe.

- Cathodic test stations are plastic above ground test stations with copper wire leads to a pipeline connection below ground.

- Line markers (above-ground).

- End-point at City Gate Station at Ocean Boulevard.

\section{A Delivery Station consists of:}

- A steel pipe manifold and pigging facilities;

- Pressure regulators (if required);

- Electronic measuring instruments to relay critical parameter data (gas pressure, gas temperature, gas flow rate, and alarms) to Williams' Supervisory Control and Data Acquisition (SCADA) facility in real-time sequence;

- A meter building (approximately 240 sq. ft.);

- A steel fence surrounding the plot.

\section{City Gate Station}

A city gate station is usually built at the edge of a city, to deliver gas from the high-pressure transmission pipeline to a lower pressure local distribution system. In many ways, the city gate station is exactly analogous to an electrical substation. A city gate station includes the following:

- Block Valve and Blowdown: A ball valve and single blowdown are the end of the transmission pipeline. The block valve is the same size as the pipeline, and the blowdown is usually two or three pipe sizes smaller. The block valve could be buried inline or above-ground, and could be fitted with pneumatic or gas-powered operators for automatic or remote operation.

- Meter: A gas meter would be installed to measure the volume of gas flowing to the customer. Meters are usually fitted with electronic totalizing computers and SCADA equipment to relay flow and pressure information to a remote monitoring center.

- Pressure Regulators: The city gate stations for the Coos Pipeline will not include pressure regulators. The distribution entity (Bandon or NW Natural to Coos Bay, Coquille and Myrtle Point) will install regulators as needed to reduce the pressure to distribution pressure, which is typically 60 psi or less.

- Station Protection: All valves will be locked with a key available only to pipeline operators. The entire footprint will be surrounded with a chain link fence with locked gate. Depending on location and traffic volume, 
the fence and valve will be protected with concrete or pipe barricades.

\section{Associated Facilities}

The Coos County Pipeline would have no other facilities.

\section{Operation Description}

The pipeline would operate continuously. The County plans to contract the pipeline operation to an experienced pipeline operator. A crew of trained operators employed by the pipeline operations contractor would operate and maintain the pipeline in accordance with DOT requirements and a comprehensive O\&M Plan tailored to this system. The Oregon Public Utilities Commission would routinely inspect the pipeline operations.

\section{Pipeline Capacity:}

The 12-inch pipeline can transport natural gas at a flow rate of up to 70 million cubic feet per day, assuming a line pressure of $800 \mathrm{psi}$. This capacity could be expanded 20 percent by boosting the pressure to 1,000 psi, with the addition of a compressor station near the Williams delivery connection in Douglas County. At the Williams' current operating pressures, the Coos pipeline would operate with stresses around 30 to 40 percent of the SMYS of the pipeline steel. The addition of a compressor station is allowable and within the prescribed safety limits of the pipe, but this added capacity is not likely to become necessary.

\section{Pipeline Monitoring:}

The contract pipeline operator will be required to monitor pressures and flow rates at critical points in the system. For example, the Williams delivery station and the Coos Bay city gate are monitoring points. The operator must monitor conditions full-time 24 hours/7 days, and must be equipped to immediately respond to and solve an abnormal condition. Most candidates for contract operation have 24/7 call centers and control rooms for this purpose.

The operator will have final authority over the selection and installation of remote or automatic valves to be used to isolate abnormal conditions.

\section{Pipeline Shutdown:}

Any or all block valves can be used to interrupt the flow of the gas in the pipeline. If the pipeline needs to be emptied, the natural gas is "bled off" by opening the "blow down" valve within the isolated segment of pipeline.

\section{Maintenance Description}

\section{Access roads}

All access roads would be maintained to the degree necessary to provide access for pipeline inspection and maintenance. These roads are currently maintained by BPA and PP\&L.

\section{Vegetation Removal}

Minimal vegetation removal would be required for pipeline maintenance because brush removal is periodically done for powerline corridor maintenance.

\section{Pipeline Patrols}

DOT requires an annual inspection of the entire pipeline right-of-way for encroachments, unauthorized digging activity, soil erosion, earth movement, drainage problems, and gas leaks. 


\section{Corrosion Control Survey}

Cathodic test stations would be located along the pipeline at regular intervals up to a mile. Test stations allow a direct connection for electronically locating the pipeline, and for checking the corrosion control system. A survey of the level of cathodic protection is required once per calendar year under DOT Part 192 regulations.

\section{Maintenance of Facilities}

Apart from regular patrols, corrosion inspections and painting, the pipeline requires very little maintenance. Block and blowdown valves must be cycled closed and open once per year and lubricated, if possible. Erosion (such as sunken ditches) will be addressed as needed with water bars, mulching or other measures taken as necessary to stop it. There is usually no reason to excavate a section of pipe after construction, except to expose a few feet for utility crossings or to repair damage done by a third party excavator.

\section{Abandonment Description}

In the event the proposed pipeline is permanently abandoned, it would remain empty in its constructed configuration with all valves in a closed position. If a portion of this abandoned pipeline were to obstruct future construction projects, or otherwise interfere with the environment, the County would contract an operator to remove the portion(s) causing the impact, and the resultant openings in the pipeline would be capped. 


\section{Appendix K.}

\section{Survey and Manage Species}

No significant changes have been made to Appendices K and K-1.

Table K-1. Survey and Manage Fungi, Lichens, Bryophytes and Vascular Plants

\begin{tabular}{|c|c|}
\hline Species & Species \\
\hline \multicolumn{2}{|c|}{ Fungi } \\
\hline Albatrellus avellaneus & Collybia racemosa \\
\hline Albatrellus caeruleoporus & Cordyceps capitata \\
\hline Albatrellus ellisii & Cordyceps ophioglossoides \\
\hline Albatrellus flettii & Cortinarius barlowensis \\
\hline Arcangeliella camphorata & Cortinarius cyanites \\
\hline Asterophopra lycoperdoides & Cortinarius depauperatus \\
\hline Asterophora parasitica & Cortinarius olympianus \\
\hline Baeospora myriadophylla & Corinarius tabularis \\
\hline Balsamia nigrens & Cortinarius valgus \\
\hline Boletus pulcherrimus & Craterellus tubaeformis \\
\hline Bondarzewia mesenterica & Cudonia monticola \\
\hline Cantharellus subalbidus & Cyphillostereum laeve \\
\hline Catasthelasma ventricosa & Dermocybe humboldtensis \\
\hline Chalciporus piperatus & Destuntzia fusca \\
\hline Chamonixia caespitosa & Destuntzia rubra \\
\hline Chromosera cyanophylla & Endogone oregonensis \\
\hline Chrysomphalina grossula & Fayodia bisphaerigera \\
\hline Clavariadelphus ligula & Galerina atkinsoniana \\
\hline Clavariadelphus occidentalis & Galerina cerina \\
\hline Clavariadelphus sachalinensis & Galerina heterocystis \\
\hline Clavariadelphus truncatus & Galerina sphagnicola \\
\hline Clavulina castanopes $v$. lignocola & Galerina vittaeformis \\
\hline
\end{tabular}


Table K-1. Survey and Manage Fungi, Lichens, Bryophytes and Vascular Plants (Continued)

\begin{tabular}{|c|c|}
\hline Species & Species \\
\hline Clitocybe senilis & Gastroboletus turbinatus \\
\hline \multicolumn{2}{|c|}{ Fungi (continued) } \\
\hline Gomphus bonarii & Phaeocollybia kauffmanii \\
\hline Gyromitra esculenta & Phaeocollybia oregonensis \\
\hline Gyromitra infula & Phaeocollybia picea \\
\hline Gyromitra melaleucoide & Phaeocollybia pseudofestiva \\
\hline Gyromitra montana & Phaeocollybia scatesiae \\
\hline Helvella elastica & Phaeocollybia sipei \\
\hline Helvella maculata & Phaeocollybia spadicea \\
\hline Hydnum umbilicatum & Phellodon atratus \\
\hline Hydropus marginellus & Pholiota albivelata \\
\hline Hygrophorus karstenii & Plectaria melastoma \\
\hline Hypomycs luteovirens & Podostroma alutaceum \\
\hline Leucogaster citrinus & Pseudaleuria quinaultiana \\
\hline Lencogaster microsporus & Ramaria abientina \\
\hline Macowanites chlorinosmus & Ramaria celerivirescens \\
\hline Mycena quinaulterrsis & Ramaria concolor f. tsugina \\
\hline Mycena tenax & Ramaria conjunctipes $v$ sparsiramosa \\
\hline Mythicomyces comeipes & Ramaria coulterae \\
\hline Neolentinus kauffmanii & Ramaria cyaneigranosa \\
\hline Neournula pouchetii & Ramaria gelatiniaurantia \\
\hline Otidea leporina & Ramaria rainierensis \\
\hline Otidea onotica & Rannaria rubella v. blanda \\
\hline Otidea smithii & Ramaria nubribrumescens \\
\hline Phaeocollybia attenuata & Ramaria rubrievanescens \\
\hline Phaeocollybia californica & Ramaria rubripermanens \\
\hline Phaeocollybia dissilens & Ramaria stuntzii \\
\hline Fungi (continued) & Lichens \\
\hline
\end{tabular}


Table K-1. Survey and Manage Fungi, Lichens, Bryophytes and Vascular Plants (Continued)

\begin{tabular}{|c|c|}
\hline Species & Species \\
\hline Ramaria suecica & Bryoria subcana \\
\hline Ramaria verlotensis & Bryoria tortuosa \\
\hline Rickenella swartzii & Buellia oidalea \\
\hline Russula mustelina & Calicium abietinum \\
\hline Sarcodon fuscoindicus & Calicium glaucellum \\
\hline Sarcodon imbricatus & Calicium viride \\
\hline Sarcosoma latahense & Cetrelia cetrarioides \\
\hline Sarcosphaera coronaria & Chaenotheca chrysocephala \\
\hline Sowerbyella rhenana & Chaenotheca ferruginea \\
\hline Sparassis crispa & Chaenotheca furfuracea \\
\hline Spathularia flavida & Chaenothecopsis pusilla \\
\hline Stagnicola perplexa & Cladonia norvegica \\
\hline Thaxterogaster pavelekii & Hypogymnia duplicata \\
\hline Thaxterogaster pingue & Lobaria linita \\
\hline Tremiscus helvelloides & Nephroma bellum \\
\hline Tuber asa & Pannaria saubinetii \\
\hline Tuber pacificum & Peltigera pacifica \\
\hline Bryophytes & Platismatia lacunosa \\
\hline Buxbaumia viridis & Psuedocyphellaria rainierensis \\
\hline Diplophyllum albicans & Ramalima pollinaria \\
\hline Diplophyllum plicatum & Ramalina thrausta \\
\hline Encalyptra brevicolla v. crumiana & Stenocybe clavata \\
\hline Schistostega pennata & Usnea longissima \\
\hline \multirow[t]{2}{*}{ Tetraphis geniculata } & Vascular Plants \\
\hline & Cypripedium fasciculatum \\
\hline
\end{tabular}




\title{
Appendix K1. Special Status Species
}

\author{
Special Status Fungi, Lichens, Bryophytes and Vascular Plants
}

Table K1-1. Special Status Fungi, Lichens, Bryophytes and Vascular Plants

\begin{tabular}{|c|c|}
\hline Species & Common Name \\
\hline \multicolumn{2}{|c|}{ Fungi } \\
\hline Bridgeopoprus nobilissimus & Giant Polypore Fungus \\
\hline \multicolumn{2}{|c|}{ Bryophytes } \\
\hline Andreaea schofieldiana & Moss \\
\hline Calypogeia sphagnicola & Liverwort \\
\hline Campylopus schmidii & Moss \\
\hline Cephaloziella spinigera & Liverwort \\
\hline Crumia latifolia & Moss \\
\hline Cryptomitrium tenerum & Liverwort \\
\hline Diplophyllum plicatum & Liverwort \\
\hline Encalypta brevicolla varcrumiana & Moss \\
\hline Funaria muklenbergii & Moss \\
\hline Limbella fryei & Moss \\
\hline Lophozia laxa & Liverwort \\
\hline Pholia sphagnicola & Moss \\
\hline Polytrichum strictum & Moss \\
\hline Pseudolenskeella serpentinensis & Moss \\
\hline Tayloria serrata & Moss \\
\hline Tripterocladium leucocladulum & Moss \\
\hline \multicolumn{2}{|c|}{ Lichen } \\
\hline Bryoria psendocapillaris & Lichen \\
\hline Bryoria spiralifera & Lichen \\
\hline Cladidium bolanderi & Lichen \\
\hline
\end{tabular}


Table K1-1. Special Status Fungi, Lichens, Bryophytes and Vascular Plants

\begin{tabular}{|c|c|}
\hline Species & Common Name \\
\hline Erioderma sorediatum & Lichen \\
\hline Hypogymnia pulverata & Lichen \\
\hline \multicolumn{2}{|c|}{ Lichen (continued) } \\
\hline Hypogymnia subphysodes & Lichen \\
\hline Leioderma sorediatum & Lichen \\
\hline Nephroma occultum & Lichen \\
\hline Pilophorus nigricaulis & Lichen \\
\hline Sulcaria badia & Lichen \\
\hline Teloschites flavicans & Lichen \\
\hline \multicolumn{2}{|c|}{ Vascular Plants } \\
\hline Arctostaphylos hispidula & hairy manzanita \\
\hline Artemisia pycnocephala & coastal sagewort \\
\hline Bensoniella oregana & vensonia \\
\hline Brodiaea terrestris & dwarf brodiaea \\
\hline Cardamine nuttalii var. gemmata & toothwort \\
\hline Carex gigas & Siskiyou sedge \\
\hline Carex macrocephala & bighead sedge \\
\hline Cicendia quadrangularis & timwort \\
\hline Cimicifuga elata & tall bugbane \\
\hline Cochlearia officinalis & spoonwort \\
\hline Cordylanthus maritimus ssp. palustris & Point Reye's \\
\hline \multicolumn{2}{|c|}{ Vascular Plants (continued) } \\
\hline Cypripedium fasciculatum & clustered lady's-slipper \\
\hline Ericameria arbortescens & golden fleece \\
\hline Erigeron cervinus & Siskiyou daisy \\
\hline Eriophorum chamissonis & russet cotton-grass \\
\hline Erysimum menziesii ssp. concinnum & pacific wallflower \\
\hline Frasera umpquaensis & Umpqua swertia \\
\hline
\end{tabular}


Table K1-1. Special Status Fungi, Lichens, Bryophytes and Vascular Plants

\begin{tabular}{|c|c|}
\hline Species & Common Name \\
\hline Gentiana setigera & Waldo gentian \\
\hline Gilia millefoliata & seaside gilia \\
\hline Hydrocotyle verticillata & whorled marsh-pennywort \\
\hline Lasthenia macrantha ssp. prisca & large-flowered goldfields \\
\hline Iliamna latibracteata & California globe-mallow \\
\hline Lilium occidentale & western lily \\
\hline Limonium californicum & western marsh-rosemary \\
\hline Lycopodiella inundata & bog club-moss \\
\hline Microseris bigelovii & coast microseris \\
\hline Monardella purpurea & Siskiyou monardella \\
\hline Montia howellii & Howell's momtia \\
\hline \multicolumn{2}{|c|}{ Vascular Plants (continued) } \\
\hline Oenothera wolfii & Wolf's evening-primrose \\
\hline Ophioglossum pusillium & adder's-tongue \\
\hline Pellaea andromedifolia & coffee fern \\
\hline Phacelia argentea & silvery phacelia \\
\hline Poa unilateralis & San Francisco bluegrass \\
\hline Polystichum californicum & California sword-fern \\
\hline Rhynchospora capitellata & brownish beakrush \\
\hline Romanzoffia thompsonii & Thompson's mistmaiden \\
\hline Salix delnortensis & Del Norte willow \\
\hline Scirpus subterminalis & water clubrush \\
\hline Sedum laxum ssp. heckneri & Heckner's stonecrop \\
\hline Sidalcea malviflora ssp. patula & coast checker-bloom \\
\hline Trillium angustipetalum & Siskiyou trillium \\
\hline Triteleia hendersonii var. leachae & Leach's brodiaea \\
\hline Utricularia gibba & humped bladderwort \\
\hline
\end{tabular}


Table K1-1. Special Status Fungi, Lichens, Bryophytes and Vascular Plants

\begin{tabular}{|l|l|}
\hline \multicolumn{1}{|c|}{ Species } & \multicolumn{1}{|c|}{ Common Name } \\
\hline \hline Utricularia minor & lesser bladderwort \\
\hline Viola primulifolia ssp.occidentalis & western big violet \\
\hline
\end{tabular}

\section{Special Status Fish}

Table K1-2. Special Status Fish

\begin{tabular}{|l|l|}
\hline \multicolumn{1}{|c|}{ Species } & \multicolumn{1}{c|}{ Common Name } \\
\hline \hline Oncorhynchus keta & chum salmon \\
\hline Oncorhynchus kisutch & coho salmon \\
\hline Oncorhynchus mykiss ssp. & steelhead trout \\
\hline Oncorhynchus tshawytscha & chinook salmon \\
\hline Oncorhynchus clarki clarki (Oregon Coast) & cutthroat trout \\
\hline
\end{tabular}

Table K1-3. Special Status Invertebrates

\begin{tabular}{|l|l|}
\hline \multicolumn{1}{|c|}{ Species } & \multicolumn{1}{c|}{ Common Name } \\
\hline Pisidium ultramontanum & montane peaclam \\
\hline Helminthoglypta hertleini & Oregon shoulderband (snail) \\
\hline Lanx subrotundata & rotund lanx (snail) \\
\hline Megomphix hemphilli & Oregon Megomphix (snail) \\
\hline Monadenia fidelis beryllica & green sideband (snail) \\
\hline Mondanenia fidelis celeuthia & travelling sideband (snail) \\
\hline Pristiloma arcticum crateris & Crater Lake tightcoil (snail) \\
\hline Prophysaon dubium & papillose tail-dropper \\
\hline Bombus franklini & Franklin's bumblebee \\
\hline Icaricia Icarioides fenderi & Fender's blue butterfly \\
\hline
\end{tabular}


Table K1-3. Special Status Invertebrates

\begin{tabular}{|l|l|}
\hline \multicolumn{1}{|c|}{ Species } & \multicolumn{1}{c|}{ Common Name } \\
\hline \hline Incisalia polia obscura & obscure elfin \\
\hline Plebejus saepiolus insulanus & insular blue butterfly \\
\hline Polites mardon & Mardon skipper (butterfly) \\
\hline Driloleirus ( megascolides) macelfreshi & Oregon giant earthworm \\
\hline
\end{tabular}

Table K1-4. Special Status Wildlife

\begin{tabular}{|c|c|}
\hline Species & Common Name \\
\hline \multicolumn{2}{|c|}{ Birds } \\
\hline Brachyramphus marmoratus & Marbled Murrelet \\
\hline Pelecanus occidentalis & Brown Pelican \\
\hline Branta canandensis leucopareia & Aleutian Canada Goose \\
\hline Haliaeetus leucocephalus & Bald Eagle \\
\hline Accipiter gentilis & Northern Goshawk \\
\hline Falco peregrinus anatum & American Peregrine Falcon \\
\hline Falco peregrinus tundrius & Arctic Peregrine Falcon \\
\hline Speotyto cunicularia hypugaea & Burrowing Owl \\
\hline Strix occidentalis caurina & Northern Spotted Owl \\
\hline Charadrius alexandrinus nivosus & Western Snowy Plover \\
\hline Pooecetes gramineus affinis & Oregon Vesper Sparrow \\
\hline \multicolumn{2}{|c|}{ Mammals } \\
\hline Corynorhinus touwnsendii & Townsend's Big-Eared Bat \\
\hline Myotis thysanodes & Fringed myotis \\
\hline Lasionycteris noctivagans & Silver-haired bat \\
\hline Myotis ciliolabrum & Western small-footed bat \\
\hline Myotis evotis & Long-eared myotis \\
\hline Myotis volans & Western long-eared bat \\
\hline
\end{tabular}


Table K1-4. Special Status Wildlife (Continued)

\begin{tabular}{|l|l|}
\hline \multicolumn{1}{|c|}{ Species } & \multicolumn{1}{c|}{ Common Name } \\
\hline \hline Martes pennati & Fisher \\
\hline \multicolumn{2}{|c|}{ Amphibians } \\
\hline Aneides flavipunctatus & Black Salamander \\
\hline \hline \multicolumn{2}{|c|}{ Reptiles } \\
\hline Chrysemys picta & Painted Turtle \\
\hline Clemmys marmorata & Western Pond Turtle \\
\hline Caretta caretta & Loggerhead Sea Turtle \\
\hline
\end{tabular}




\title{
Appendix L.
}

\section{Glossary of Terms}

\begin{abstract}
Alluvium - A general term for clay, silt, sand, gravel or similar unconsolidated material deposited by a stream or other body of running water.
\end{abstract}

Anadromous Fish - Fish that are born and reared in freshwater, move to the ocean to grow and mature, and return to freshwater to reproduce. Salmon, steelhead, and shad are examples.

Anode - The electrode at which oxidation or corrosion occurs. (opposite of cathode)

Anthropogenic - Relating to or resulting from the influence humans have on the natural world.

Areas of Critical Environmental Concern (ACEC) - A designated area on public lands where special management attention is required (1) to protect and prevent irreparable damage to fish and wildlife, important historic, cultural, or scenic values, or other natural systems or processes; or (2) to protect life and safety from natural hazards.

Arkosic - Sedimentary rock formed by the cementation of sand-sized grains of feldspar and quartz.

Artifacts - Any product of human cultural activity; more specifically, any tools, artwork, or objects found in an archaeological context.

Backfill - (noun) Material used to replace soil and earth removed during mining. (verb) To fill excavation ditch after pipeline placement.

Basalt - Dark colored extrusive igneous rock composed chiefly of calcium plagioclase and pyroxene. Extrusive equivalent of gabbro; underlies the ocean basins and comprises oceanic crust.

Bedrock 1) - Any solid rock exposed at the Earth's surface or overlain by unconsolidated material.

Bedrock 2) - The solid rock beneath a layer of soil, rock fragments, or gravel. Also called substratum.

Bentonite - Light-colored valuable clay that expands with the addition of water and is used as oil-well drilling mud and as filler in the building, paper, soap, and pharmaceutical industries.

Berm - The space between the toe of a slope and excavation made for intercepting ditches or borrow.

Best Management Practices (BMPs) - A practice or combination of practices that are determined to be the most effective and practicable (including technological, economic and institutional considerations) means of point and non-point pollutants at levels compatible with environmental quality goals.

Block Valve - When closed, the valve can block gas flow in both directions.

Blowdown - The venting of pressure from a pipeline.

Bore - A generally horizontal opening produced underground primarily for the purpose of installing services.

Bryophytes - A nonflowering plant, often growing in damp places, that has separate gamete-bearing and spore-bearing forms.

Cathode - The terminal of a semi conductor diode that is negative with respect to the other terminal when the diode is biased in the forward direction.

Cathodic protection - A process by which the corrosion of a metal pipeline is prevented by the use of an electrical current through replaceable anodes.

City Gate - A city gate station is usually built at the edge of a city to deliver gas from the high-pressure transmission pipeline to a lower pressure local distribution system. In many ways a city gate is analogous to an electrical substation.

Chert - A mainly opaque, fairly granular, silicate rock with a dull shiny luster and a great range of colors, used as raw material for the manufacture of chipped stone artifacts. 
Climax Vegetation - The final vegetation community and highest ecological development of a plant community that emerges after a series of successive vegetational stages. The climax community perpetuates itself indefinitely unless disturbed by outside forces.

Colloids - Very small, finely divided solids (that do not dissolve) that remain dispersed in a liquid for a long time due to their small size and electrical charge

Colluvium - Loose rock and soil at the base of a cliff or steep slope.

Consultation - Formal consultation is a process that occurs between the Fish and Wildlife Service or the National Marine Fisheries Service and a federal agency that commences with the federal agency's written request for consultation under Section 7(a)(2) of the ESA regarding a federal action which may affect a listed species or its critical habitat. It concludes with the issuance of the biological opinion under Section 7(b)(3) of the Act. Informal consultation is an optional process that includes all discussions, correspondence, etc., between the Fish and Wildlife Service and the federal agency, or the designated non federal representative, prior to formal consultation, if required. If the listing agency determines that there is no likely adverse affect to the listed species, it may concur with the action agency that formal consultation is unnecessary.

Critical Habitat - Under the ESA, critical habitat is defined as (1) the specific areas within the geographic area occupied by a federally listed species on which are found physical and biological features essential to the conservation of the species, and that may require special management considerations or protection; and (2) specific areas outside the geographic area occupied by a listed species, when it is determined that such areas are essential for the conservation of that species.

Cryogenic - Having or relating to extremely low temperatures.

Cumulative effects - Those effects on the environment that result from the incremental effect of the action when added to the past, present, and reasonable foreseeable future actions regardless of what agency (Federal or non federal) or person undertakes such other actions. Cumulative effects can result from individually minor but collectively significant actions taking place over a period of time.

Danger tree - Any tree (leaning or otherwise) considered as having potential to fall against the power lines.

Directional drilling - A steerable system for the installation of pipes, conduits and cables in a shallow arc using a surface launched drilling rig.

Drilling fluid - a mixture of water and usually bentonite and/or polymer continuously pumped to the cutting head to facilitate cutting, reduce required torque, facilitate the removal of cuttings, stabilize the borehole, cool the head and lubricate the installation of the Product Pipe. In suitable soil conditions water alone may be used.

Easement - Anon-ownership interest in a land parcel that provides the interest-holder with rights to perform designated actions. It may also limit actions by a landowner.

Effects - Effects, impacts, and consequences, as used in this environmental impact statement, are synonymous.

Effects may be direct, indirect or cumulative.

Estuaries - The wide lower course of a river where the tide flows in, causing fresh and salt water to mix.

Extirpation - The elimination of a species from a particular area.

Fauna - The animal life of a region or geological period.

Fish-Bearing Streams - Any stream containing any species of fish for any period of time.

Flakes - Small pieces and chips of rock and stone that have come off a larger rock, as a result creating stone tools.

Floodplain - Level lowland bordering a stream or river onto which the flow spreads at flood stage.

Flora - The plant life of a region or geological period.

Flow Spreader - A device used to dissipate concentrated water flow into sheet flow.

Flume - (Flume Pipe) A pipe or lined channel used to divert water from a stream while construction activities occur in the streambed.

Groundfish - A species or group of fish that spends most of its life on or near the sea floor. 
Hydrocarbons - An organic compound made up of the elements of carbon and hydrogen that exists as a gas or liquid at ambient conditions.

Hydrocolloids - A substance that forms a gel when mixed with water.

Hydroelectric - Generated by converting the pressure of falling or running water to electricity by means of a turbine coupled to a generator.

Hydrostatic Test - A test of the strength and leak resistance of a vessel or pipe by internal pressurization with a test liquid, such as water.

Indigenous - Originating in and typical of a geographic area.

Interdisciplinary Team (IDT) - A group of individuals with varying areas of specialty assembled to solve a problem or perform a task.

Intermittent - Any non-permanent flowing drainage feature having a definable channel and evidence of annual scour or deposition.

Knoll - A small rounded hill or mound.

Lateral - A service line that transports a product from individual buildings to a main pipeline.

Late-Succession Forest - Forest seral stages which include mature and old-growth age classes.

Late-Successional Reserve (LSR) - A forest in its mature and/or old-growth stages that has been reserved under each option in this report.

Liquefaction -A change in the phase of a substance to the liquid state; usually, a change from the gaseous to the liquid state, especially of a substance which is a gas at normal pressure and temperature.

Lithics - Artifacts or ecofacts made of stone or rock. Sometimes the term lithics refers to the raw materials used to make stone tools.

Mains - Pipe used to deliver natural gas to an end user.

Mitigation - Modifications of actions that (1) avoid impacts by not taking a certain action or parts of an action; (2) minimize impacts by limiting the degree or magnitude of the action and its implementation; (3) rectify impacts by repairing, rehabilitating, or restoring the affected environment; (4) reduce or eliminate impacts over time by preservation and maintenance operations during the life of the action; or (5) compensate for impacts by replacing or providing substitute resources or environments.

Monitoring - A process of collecting information to evaluate if objective and anticipated or assumed results of a management plan are being realized or if implementation is proceeding as planned.

Noxious Weed - According to the Federal Noxious Weed Act (PL 93-629), a weed that causes disease on has other adverse effects on humans and their environment and is therefore detrimental to public health and the agriculture and commerce of the United States

Off-channel habitat - Channels or ponds in a floodplain, at least seasonally connected to the primary channel that are in addition to and frequently parallel the primary flowing channel.

Old-growth forest - A forested stand usually at least 180-200 tears old with moderate to high canopy closure; a multilayered, multispecies canopy dominated by large overstory trees and high incidence of large trees.

Palustrine Emergent Wetland - Better known as marshes - are usually dominated by grass-like plants - such as cattails, sedges or bulrush - which are rooted in bottom sediments, but "emerge" above the surface of the water.

Palustrine Forested Wetland - Forested system including any inland wetland which lacks flowing water and contains ocean derived salts in concentrations of less than $0.05 \%$.

Parent rock - The unconsolidated and more or less chemically weathered mineral or organic matter from which the solum of soils is developed by pedogenic processes.

Pedological features - Recognizable units within a soil material which are distinguishable from the enclosing material for any reason such as origin (deposition as an entity), differences in concentration of some fraction of the plasma, or differences in arrangement of the constituents (fabric).

Pelagic - Of or in the open ocean or open water. 
Perennial Stream - A stream that typically has running water on a year-round basis.

Pig - A device inserted and forced through a pipeline to clean, dry, or measure characteristics of a pipeline.

Pilot hole - A hole excavated at the beginning of the directional drill crossing.

Piping Manifold - A configuration of pipes used to direct natural gas in different directions or through different pieces of equipment.

Polyethylene (PE) - A ductile, durable, virtually inert thermoplastic composed of polymers of ethylene.

Project Design Criteria (PDC) - Preventive measures applied to project activities to minimize potential detrimental effects to proposed, listed or candidate species.

Protohistoric - A period prior to the beginning of written records in an area, but after that area has been initially mentioned in reports written elsewhere.

Pullback - When the pipe is pulled into the reamed hole back to the drill rig.

Radiocarbon Dating - An absolute dating method based on the radioactive decay of Carbon-14 contained in organic materials.

Reamer - A downhole tool used to smooth the wall of a borehole, enlarge the borehole, stabilize the drill bit, and straighten the borehole axis where kinks or doglegs are encountered.

Record of Decision (ROD) - A document separate from but associated with an environmental impact statement that states the management decision, identifies all alternatives including both the environmentally preferable and selected alternatives, states whether all practical means to avoid environmental harm from the selected alternative have been adopted, and if not, why not.

Refugia - Locations and habitats that support populations of organisms that are limited to small fragments of their previous geographic range.

Research Natural Areas - An area set aside by a public or private agency specifically to preserve a representative sample of an ecological community, primarily for scientific and educational purposes.

Residual Soil - Soil presumed to have developed in place as the product of decomposition and disintegration of bedrock.

Rill erosion - Rill erosion is the removal of soil by concentrated water running through little streamlets, or headcuts. Detachment in a rill occurs if the sediment in the flow is below the amount the load can transport and if the flow exceeds the soil's resistance to detachment.

Riparian reserves - Designated riparian areas found outside Late-Successional Reserves.

Ripping - The process of breaking up or loosening compacted soil and rock to facilitate excavation.

Riprap - Rough stone of various sizes placed compactly or irregularly in a channel to prevent scour by water or debris.

Riverine wetland - The riverine system...includes all wetlands and deepwater habitats contained within a channel, with two exceptions: (1) wetlands dominated by trees, shrubs, persistent emergents, emergent mosses, or lichens, and (2) habitats with water containing ocean-derived salts in excess of $0.5 \mathrm{ppt}$.

Saprolite - soft disintegrating igneous rock that remains where it was located when solid, formed by heavy weathering in a humid environment.

Scoping - An early and open process for determining the scope of issues to be addressed in an environmental impact statement and for identifying the significant issues related to a proposed action. Scoping may involve public meetings; field interviews with representatives of agencies and interest groups; discussions with resource specialists and managers; and written comments in response to news releases, direct mailings, and articles about the proposed action and scoping meetings.

Scour - Evidence of movement of material, erosion or deposition, in a downslope direction due to transport of water.

Second Growth - Relatively young forests that have developed following a disturbance.

Seeps - Places where water oozes from the ground to form a pool. 
Special Status species - Those species that (1) have appeared in the Federal Register as proposed for classification and are under consideration for official listing as endangered or threatened species or (2) are on an official state list or (3) are recognized by the BLM or other management agencies as needing special management or prevent their being placed on Federal or state lists.

Solum - The upper layers of a soil profile where the formation of new soil takes place and where most plant roots and soil animals are found.

Subduction - To be carried under the edge of an adjoining continental or oceanic plate, causing tensions in the Earth's crust that can produce earthquakes or volcanic eruptions.

Substrate - Any object or material upon which an organism grows or is attached.

Tackifier - A chemical used to help mulch stick to bare soil.

Tapping Tee - A device used to physically connect a customer's plastic service line from a plastic main to the customer's facility.

Talus - A slope landform, typically covered by coarse rock debris forming a more or less continuous layer that may or may not be covered by duff and litter.

Tectonic - Relating to the forces that produce movement and deformation of the earth's crust.

Trenching - Method in which access is gained by excavation from ground level to the required level underground for the installation, maintenance or inspection of a pipe, conduit or cable. The excavation is then backfilled and the surface reinstated.

Turbidity - Suspended matter in water that scatters or otherwise interferes with the passage of light through the water.

Valve - Mechanism that controls the volume or direction of flow. A valve can be closed, partially open, or fully open.

Watershed - The drainage basin contributing water, organic matter, dissolved nutrients, and sediments to a stream or lake. 


\section{Appendix M.}

\section{List of References.}

Beissinger, S.B. 1995. Population trends of the marbled murrelet projected from demographic analysis. Pages $385-$ 394 in Ralph et. al. (eds.). Ecology and Conservation of the Marbled Murrelet. Gen. Tech. Rep. PSW-GTR-152.

Betlejewski, Frank. 1994. Port-Orford-cedar Management Guidelines. USDI, BLM. 32 pages.

Burnham, K.P., D.R. Anderson, and G.C. White. 1994. Estimation of vital rates of the northern spotted owl. Appendix J, 1-26 in USDA Forest Service, Final Supplemental Environmental Impact Statement. Portland, Oregon. Vol.II.

BLM, Coos Bay District. 1997. Watershed Analysis - Middle Main Coquille, North Coquille Mouth, and Catching Creek. 52 pp.

BLM Manual 3100. 1999. Code of Federal Regulations. Title 43, Vol. 2, Part 3100-Oil and gas leasing, subpart 3101-Issuance of leases, sec. 3101.1-2-Surface use rights.

BLM, Roseburg District. 1998. Olalla-Lookingglass Watershed Analysis. 127 pp.

BLM, Roseburg District. 2000. Lower South Umpqua Watershed Analysis. 134 pp.

Coos County. May 17, 2000a. "Application for transportation and utility systems and facilities on Federal lands." STD Form 299 (BLM Form).

Coos County. May 17, 2000b. "Supplement to Application for a Natural Gas Pipeline to Coos County, Oregon"; Supplement to STD Form 299 (BLM form). 17 pp.

Coos County. August 2000c. "Supplement to Application for a Natural Gas Pipeline to Coos County, Oregon Supplement to STD Form BPA F 4300.03e". 8 pp.

Coos County. December 1, 2000d. Coos County Natural Gas Pipeline Project - Information for Environmental Assessment." http://www.co.coos.or.us/ngas/gasea.htm. 5 pp.

Coos/Curry/Douglas Regional Investment Board and CCD Business Development Corporation (Roseburg, OR). 2000. "Coos, Curry and Douglas Regional Investment Plan." http://www.co.coos.or.us/regplan.htm.

ECONorthwest. 1999; "The Economic and Fiscal 1mpacts of Building and Operating a Natural Gas Pipeline in Coos County"

ECONorthwest. 2000; "The Economic Impact of Building and Operating a Natural Gas Pipeline in Coos County, Oregon"

Forsman, E., and R. Anthony. 1999. Analysis of demographic rates of northern spotted owls, executive summary, 19 March 1999. Unpublished preliminary report on file at Coos Bay District Office.

Gas Reasearch 1nstitute Report 00/0077 2000. “The Safety Performance of Natural Gas Transmission and Gathering Systems". Prepared for Hartford Steam Boiler Inspection \& Insurace Co.

Helvoigt, Ted. 2000. “Oregon's Rural Unemployment Rate”. Oregon Labor Market information System (OLMIS). http://olmis.emp.state.or.us/olmisj/ArticleReader?itemid=00001071.

Holzman, S. 1995. Personal communication. U.S. Fish and Wildlife. Portland, Oregon.

Jones \& Stokes Associates, Inc. 1998. "Biological Resources Technical Report - South Oregon Coast Reinforcement Project". Bellevue, Washington. Chapters 1 - 3;40 pp.

Marshall, D.B. 1988. Status of the marbled murrelet in North America; with special emphasis on populations in California, Oregon, and Washington. Audubon Society of Portland. $42 \mathrm{pp}$.

Maser, Chris. 1998. Mammals of the Pacific Northwest: from the coast to the high Cascades. Oregon State University Press, Corvallis, OR. Pp. 306-314.

Maxwell, Duchemin, Hallis \& Trotter LLC. 1999. "Coos County Annual Financial Report”. CPA Report. Eugene, Oregon. http://www.co.coos.or.us/auditrpt.doc. 89 pp.

NIOSH. 2000. "Online NIOSH pocket guide to chemical hazards" http://www.cdc.gov/niosh/npg/nengapdx.html 
O’Dell, T.E. 1999. Survey Protocols for Seven Protection Buffer Fungi Version 1.3 USDA and USDI, Portland, Oregon.

Oregon Department of Fish and Wildlife. 2000. Oregon Guidelines for Timing of In-Stream Work to Protect Fish and Wildlife Resources.

Prior, Don. January 2000. Designing For Stream Simulation At Road Crossings.

Ralph, C.J., G.L. Hunt Jr., M.G. Raphael, and J.F. Piatt, Technical Editors. 1995. Ecology and conservation of the marbled murrelet. Gen. Tech. Rep. PSW-GTR-152. Albany, California. Pacific Southwest Research Station, Forest Service, U.S. Department of Agriculture. 420 pp.

Ralph, C.J., and S.L. Miller. 1995. Offshore population estimates of marbled murrelets in California. Pages 353360 in Ralph, et al. (eds.). Ecology and Conservation of the Marbled Murrelet. Gen. Tech. Rep. PSW-GTR-152.

Spiech, S.M., and T.R. Wahl. 1995. Marbled murrelet populations of Washington - marine habitat preferences and variability of occurrence. Pages 313-326 in Ralph et al. (eds.). Ecology and Conservation of the Marbled Murrelet. Gen.Tech.Rep.PSW-GTR-152.

Strong, C.S., B.K. Keitt, W.R. McIver, C.J. Palmer, and I. Gaffney. 1995. Distribution and population estimates of marbled murrelets at sea in Oregon during the summers of 1992 and 1993. Pages 339-352 in Ralph et al. (eds.).

Ecology and Conservation of the Marbled Murrelet. Gen. Tech. Rep. PSW-GTR-152.

Thomas, J.W., E.D. Forsman, J.B. Lint, E.C. Meslow, B.R. Noon, and J. Verner. 1990. A conservation strategy for the northern spotted owl. A Report by the Interagency Scientific Committee to address the conservation of the northern spotted owl. U.S. Department of Agriculture, Forest Service, and U.S. Department of the Interior, Fish and Wildlife Service, Bureau of Land Management, and National Park Service. Portland, Oregon. 427 pp.

U.S. Department of Agriculture, Forest Service. 1973. Protection of Fish Habitat During Forest Road Development.

U.S. Department of Agriculture. 1983. Forest Ecosystem Management: An Ecological, Economic and Social Assessment. Report of the Forest Ecosystem Management Assessment Team. Pg II-73

U.S. Department of Agriculture Forest Service and U.S. Department of Transportation. November 1990. Fish Passage Through Culverts. 67pp.

U.S. Department of Agriculture, Forest Service. 1991. Road Construction and Maintenance In: Influences of Forest and Rangeland Management On Salmonid Fishes and Their Habitats. W.R. Meehan, editor. pp. 297-323.

U.S. Department of Agriculture, U.S. Department of Interior. 1994. Standards and Guidelines for Management of Habitat for Late-Successional and Old-Growth Forest Related Species Within the Range of the Northern Spotted Owl Record of Decision.

U.S. Department of Agriculture, U.S. Department of Interior. 1994a. Record of Decision for amendments to Forest Service and Bureau of Land Management planning documents within the range of the northern spotted owl. Forest Service, Bureau of Land Management. Portland, Oregon.

U.S. Department of Agriculture, U.S. Department of the Interior. 1994b. Final supplemental environmental impact statement on management of habitat for late-successional and old-growth forest related species within the range of the northern spotted owl. Forest Service, Bureau of Land Management. Portland, Oregon.

U.S. Department of Agriculture, U.S. Department of Interior. 1996. Draft Management Recommendations for Buxbaumia viridis. Section 3 In Draft Management Recommendations for Bryophytes Installment 2. Portland Oregon.

U.S. Department of Agriculture, U.S. Department of Interior. 1997. Late-Successional Reserve Assessment Oregon Coast Range Province - Southern Portion.

U.S. Department of the Interior, U.S. Department of Agriculture. 1998. South Coast - Northern Klamath Late-Successional Reserve assessment. May 1998. 109 pp plus appendices.

U.S. Department of Agriculture, U.S. Department of Interior. 2000. FSEIS: For Amendment to the Survey and Manage Protection Buffer, and other Mitigation Measures Standards and Guidelines.

U.S. Department of Agriculture, U.S. Department of Interior. 2001. Record of Decision and Standards and Guidelines for Amendments to the Survey and Manage, Protection Buffer, and other Mitigation Measures Standards and Guidelines. Portland Oregon. 
U.S. Department of Energy. 1995. Research conducted by the Pacific Northwest National Laboratory. http://www.pnl.gov/fta/5_nat.htm

U.S. Department of Interior, BLM. 1986. Northwest Area Noxious Weed Control Program Record of Decision. Portland Oregon.

U.S. Department of Interior, BLM. 1987. Supplement to the Northwest Area Noxious Weed Control Program Record of Decision. Portland Oregon.

U.S. Department of the Interior. 1994. Final biological opinion for the proposed action of the supplemental environmental impact statement on management of habitat for late-successional and old-growth forest related species within the range of the northern spotted owl. U.S. Fish and Wildlife Service. Portland, Oregon.

U.S. Department of Interior, BLM. 1995a. Record of Decision and Resource Management Plan. Roseburg Oregon.

U.S. Department of Interior, BLM. 1995b. Integrated Weed Control Plant Environmental Assessment. Roseburg Oregon.

U.S. Department of Interior, BLM. 1996. Partners Against Weeds, An Action Plan For the Bureau of Land Management Washington DC.

U.S. Department of the Interior, BLM. 1996. "Revision of Timber Sale E-4 Special Provision for Protection of Threatened and Endangered Species, and Suspension, Modification, and Termination of Timber Sale Contracts." Instruction Memorandum No. OR-96-78. Attachment 2.

U.S. Department of the Interior, U.S. Department of Agriculture. 1998. South Coast - Northern Klamath Late-Successional Reserve assessment. May 1998. 109 pp plus appendices.

U.S. Department of the Interior. 1986. Pacific bald eagle recovery plan. U.S. Fish and Wildlife Service. 163 pp.

U.S. Department of the Interior. 1987. The northern spotted owl; a status review. U.S. Fish and Wildlife Service. Portland, Oregon. 47 pp.

U.S. Department of the Interior. 1989. The northern spotted owl; a status review supplement. U.S. Fish and Wildlife Service. Portland, Oregon.

U.S. Department of the Interior. 1990a. 1990 Status Review: northern spotted owl; Strix occidentalis caurina. Report to the Fish and Wildlife Service. Portland, Oregon. 95 pp.

U.S. Department of the Interior. 1990b. Endangered and threatened wildlife and plants; determination of threatened status for the northern spotted owl; final rule. Pages 26114-26194, Federal Register, June 26, 1990.

U.S. Department of the Interior. 1992a. Endangered and threatened wildlife and plants; determination of critical habitat for the northern spotted owl; final rule. Pages 1796-1838, Federal Register, January 15, 1992.

U.S. Department of the Interior. 1992b. Endangered and threatened wildlife and plants; determination of threatened status for the Washington, Oregon, and California population of the marbled murrelet; final rule. Pages 4523845337, Federal Register, October 1, 1992.

U.S. Department of the Interior. 1994a. Coos Bay District Proposed Resource Management Plan Environmental Impact Statement. vol. II, appendix W. Bureau of Land Management. North Bend, Oregon.

U.S. Department of the Interior. 1994b. Roseburg District Proposed Resource Management Plan/Environmental Impact Statement. Appendix EE. Bureau of Land Management. Roseburg, Oregon.

U.S. Department of the Interior. 1994c. Final biological opinion for the proposed action of the supplemental environmental impact statement on management of habitat for late-successional and old-growth forest related species within the range of the northern spotted owl. U.S. Fish and Wildlife Service. Portland, Oregon.

U.S. Department of the Interior. 1995a. Coos Bay District Record of Decision and Resource Management Plan. Bureau of Land Management. North Bend, Oregon.

U.S. Department of the Interior. 1995b. Roseburg District Record of Decision and Resource Management Plan. Bureau of Land Management. Roseburg, Oregon.

U.S. Department of the Interior. 1996. Endangered and threatened wildlife and plants; determination of critical habitat for the marbled murrelet; final rule. Pages 26255-26320, Federal Register, May 24, 1996. 
U.S. Department of the Interior. 1997. Recovery Plan for the Marbled Murrelet (Washington, Oregon, and California Populations). U.S. Fish and Wildlife Service. Portland, Oregon. 203 pp.

U.S. Fish and Wildlife Service. 1999. Endangered and Threatened Wildlife and Plants; Proposed Rule To Remove the Bald Eagle in the Lower 48 States From the List of Endangered and Threatened Wildlife; Proposed Rule. Fed. Reg. vol. 64, number 128 (July 6): 36453-36464.

U.S. Government Printing Office. 2000. http://www.gpo.org. December.

Varoujean, D.H., and W.A. Williams. 1995. Abundance and distribution of marbled murrelets in Oregon and Washington based on aerial surveys. Pages 327338 in Ralph et al. (eds.). Ecology and Conservation of the Marbled Murrelet. Gen. Tech. Rep. PSW-GTR-152.

Wall Street Journal. January 5, 2001. "Jobless Claims Continued to Rise Last Week". Article including a summary of the U.S. Labor Department report for November, 2000. 


\section{Appendix N Consistency Determination}

Appendix N "Consistency Determination" has been added to this document.

\section{Federal Agencies}

The Proposed Action is believed to be consistent with the following plans of other federal agencies:

- The Record of Decision for Amendments to Forest Service and Bureau of Land Management Planning Documents Within the Range of the Northern Spotted Owl.

- The Coastal Barrier Improvement Act of 1990 and draft (proposed) Pacific Coastal Barriers Study for areas under consideration for inclusion in the Coastal Barriers Resource System, as administered by the U.S. Fish \& Wildlife Service.

- The Bonneville Power Administration's latest annual Transmission System Facilities Resource Program.

- The Endangered Species Act and the following Fish and Wildlife Service plans (see Effects on Threatened and Endangered Species and Appendix F for the letter of concurrence from the U.S. Fish and Wildlife Service. See also Appendix E-1 for the letter of Concurrence from the National Marine Fisheries Service).

- This pipeline will fall under the jurisdiction of the US Department of Transportation (DOT), Office of Pipeline Safety, as a gas transmission pipeline. It will be built and operated to all current specifications in 49 CFR Part 192 (Natural Gas Pipelines) and other relevant sections. The Oregon Public Utilities Commission has authority to administer DOT regulations over intrastate pipelines in Oregon.

- The COE will be responsible for issuing a fill and removal permit for waters under their jurisdiction.

\section{State Government}

The Proposed Action is believed to be consistent with the following plans, programs, and policies of State of Oregon agencies:

Department of Environmental Quality

Smoke Management Plan (see affects on Air).

Water Quality (this will be addressed thru a 401 certification linked to federal permits).

Water Resources Department river basin programs for the Mid-Coast, Umpqua, South Coast, and Rogue

River basins.

Water Resources Commission rules and statutes.

Department of Human Resources, Health Division, standards for public water systems.

Department of Agriculture

Weed control plans.

State-listed endangered plant species (see Effects on Special Status and SEIS Special Attention Species).

Division of State Lands.

Removal - Fill Law (Both the Division of State Lands and the U. S. Army Corps of Engineers will be issuing

fill and removal permit for the proposed action).

Parks and Recreation Department.

Statewide Comprehensive Outdoor Recreation Plan. 
State Historic Preservation Program. (See Appendix B).

Department of Transportation, Highway Division.

Oregon Highway Plan.

Economic Development Department, Regional Economic Development Strategies.

Department of Fish and Wildlife (ODFW)

Oregon Statutory Wildlife Policy

State Plan/Statute - Oregon Threatened and Endangered Species Act

State Plan/Statute - Oregon's Sensitive Species Rule

State Plan/Statute - Nongame Wildlife Plan

State Plan/Statute - Big Game Population Management Objectives

State Plan/Statute - Wild Fish Policy

State Plan/Statute - Coho, Steelhead and Trout Plans

State Plan/Statute - Basin Fish Management Plans

The ODFW mitigation policy and in-water work guidelines.

Department of Forestry

State Plan/Statute - Oregon Forest Practices Act Rules

Consistency with the statewide planning goals and guidelines administered by the Land Conservation and Development Commission (LCDC) through the Department of Land Conservation and Development is variable among the 15 goals relevant to the proposed action. A complex body of land use policy and goal interpretations exists due to the acknowledgment process, goal amendments, LCDC rule making, and Land Use Board of Appeals and appellate court decisions. The matter of BLM consistency with the statewide goals involves a number of interrelated issues of policy, intergovernmental coordination, and state and federal legal requirements. Consistency with these goals is characterized below. That discussion also addresses consistency of BLM's proposed action with the goals established for the Oregon Coastal Management Program (OCMP).

The statewide planning goals are legally binding on all planning activity relating to land use undertaken by cities, counties, special districts, and state agencies. The planning goals function similarly for affected federal agencies that make consistency determinations under the OCMP in accordance with the (Federal) Coastal Zone Management Act (CZMA). All applicable local government plans have been acknowledged by LCDC to be in conformance with the CZMA.

A section of the CZMA requires that "each federal agency conducting or supporting activities directly affecting the coastal zone shall conduct or support those activities in a manner which is, to the maximum extent practicable, consistent with approved state management programs" [15 CFR Part 930, Subpart 930.32 (a)(1)]. The term "consistent to the maximum extent practicable" means fully consistent with the enforceable policies of management programs unless full consistency is prohibited by existing law applicable to the Federal agency.

The OCMP mandatory enforceable policies consist of the statewide planning goals, acknowledged city and county comprehensive plans and land use regulations, and the statutory authorities and regulations of state agencies listed in the OCMP. Although federal lands are excluded from the boundaries of the coastal zone, the "affecting" provision requires federal agencies to examine their activities for offsite effects. An effect may be either a primary, secondary, or cumulative effect on the coastal zone.

\section{Local Government}

The Oregon statewide planning program attached substantial importance to the coordination of federal plans with acknowledged local comprehensive plans. To the extent that BLM actions and programs are consistent with acknowledged county and city comprehensive plans and land use regulations, they can also be considered consistent with statewide planning goals.

The District has contributed data for development of county comprehensive plans, followed the development of those plans through the years, and consulted on issues of mutual interest. Based on knowledge gained through this 
involvement, the district planning staff believes that the Proposed Action is consistent with the comprehensive plans, and land use regulations cited above, and Coos County, as the project proponent, is seeking all required local government approvals.

\section{Tribal and Other Agency Plans}

The Confederated Tribes of Coos, Lower Umpqua, and Siuslaw, and the Coquille Indian Tribes control lands within the planning area, but the proposed action does not cross or affect any of these lands. Consultation and communications with the Tribes have occurred regularly throughout the project development.

\section{Consistency of the Proposed Action with Oregon Statewide LCDC Planning Goals and Objectives}

\section{Statewide Goal Number 1: Citizen Involvement}

Description - To develop a citizen involvement program that ensures the opportunity for citizens to be involved in all phases of the planning process. Federal and other agencies shall coordinate their planning efforts with the affected government bodies and make use of existing local citizen involvement programs established by cities and counties.

Consistency of the Proposed Action - BLM's planning process provides for public input at various stages. Public input was specifically requested in developing issues and planning criteria (during the Scoping process). The public was also afforded the opportunity to comment on the Draft and Final EIS. Numerous informational public meetings were held throughout the process, and Coos County and the Coos Bay District developed websites to provide information on the project and answer questions. Coordination with affected government bodies, has been ongoing and will continue. BLM has used county planning departments to provide linkage to local citizen involvement programs.

\section{Statewide Goal Number 2: Land Use Planning}

Description - To establish a land use planning process and policy framework as a basis for all decisions and actions related to use of land and to assure an adequate factual base for such decisions and actions.

Consistency of the Proposed Action - The proposed action has been developed in accordance with the land use planning process authorized by the Federal Land Policy and Management Act of 1976, which provides a policy framework for all decisions and actions. The process includes issue identification, inventories, and evaluation of alternative choices of action. The proposed action has been reviewed by both the Coos and Douglas County planning departments for consistency with applicable County Comprehensive Plans. Necessary Conditional Use Permits have been issued by the respective County. The proposed action is also considered to be consistent with the Coos Bay Estuary Management Plan. Intergovernmental coordination in the planning process is discussed in Chapter 5 of the EIS.

\section{Statewide Goal Number 3: Agricultural Land}

Description - To preserve and maintain existing commercial agricultural lands for farm use, consistent with existing and future needs for agricultural products, forest, and open space.

Consistency of the Proposed Action - The proposed action is located within an existing designated ROW corridor and would be constructed within existing roads or under existing electronic transmission lines. The proposed action does not exclude grazing use or affect the use of other lands for agriculture use. The Planning Departments for both Coos and Douglas Counties granted conditional use permits for construction of the pipeline within the Forest and Exclusive Farm Use Zones. 


\section{Statewide Goal Number 4: Forest Lands}

Description - To conserve forest lands by maintaining the forest land base and to protect the state's forest economy by making possible economically efficient forest practices that assure the continuous growing and harvesting of forest tree species as the leading use on forest land consistent with the sound management of soil, air, water, and fish and wildlife resources and provision for recreational opportunities and agriculture.

Consistency of the Proposed Action - BLM-administered and private lands within the proposed action have been previously converted to a designated ROW corridor for an electronic transmission line. Conversion areas such as utility rights-of-way have been limited to the minimum width necessary for management and safety, and limited to existing corridors where practical. The proposed action is located entirely within existing road and powerline ROW, with approximately 0.2 acres of 20 -year old trees under the powerline to be removed. The proposed action is consistent with the state's forest land protection policies.

\section{Statewide Goal Number 5: Natural Resources, Scenic and Historic Areas, and Open Spaces}

Description - To protect natural resources and conserve scenic and historic areas and open spaces.

Programs shall be provided that will:

- Protect natural resources and conserve scenic, historic, and open space resources for present and future generations.

- Promote a healthy environment and natural landscape that contributes to Oregon's livability.

The location, quality and quantity of the following resources shall be inventoried:

- Riparian corridors, including water and riparian areas and fish-habitat.

- Wetlands.

- Wildlife-habitat;

- Federal Wild and Scenic Rivers;

- State Scenic Waterways;

- Groundwater resources;

- Approved Oregon Recreation Trails;

- Natural Areas;

- Wilderness Areas;

- Mineral and Aggregate resources;

- Energy sources;

- Cultural areas.

Local governments and state agencies are encouraged to maintain current inventories of the following resources:

- Historic Resources.

- Open Space;

- Scenic Views and Sites.

Following procedures, standards, and definitions contained in commission rules, local governments shall determine significant sites for inventoried resources and develop programs to achieve the goal.

Consistency of the Proposed Action - The resources listed above were considered in the development of the proposed action. Availability of mineral, aggregate and energy sources would continue. The proposed action would have no impact on Federal Wild and Scenic Rivers, Natural Areas, State Scenic Waterways, Approved Oregon Recreation Trails, or Wilderness Areas. 
Adverse impacts to Riparian corridors, including water and riparian areas and fish-habitat, wetlands, wildlife-habitat, groundwater resources or; Cultural areas would be slight. Potentially impacted resources would be protected to the maximum extent practicable through the use of project design criteria and best management practices. See Chapter 4 for further discussions.

The DSL and COE permit process will address avoidance, minimization, and compensation for impacts to wetland and stream resources.

The proposed action attempts to balance conflicting uses in light of their consequences. Conflicting resource uses are most often resolved by protecting the Goal 5 resource sites or severely limiting conflicting uses to meet environmental goals.

\section{Statewide Goal Number 6: Air, Water and Land Resources Quality}

Description - To maintain and improve the quality of the air, water, and land resources of the state.

Consistency of the Proposed Action - The federal and state water quality standards would be met and water quality would be maintained and/or improved. See Chapter 4, Effects on Water, for discussion. Burning of natural gas rather than continuing the use of existing fuels would have a potential beneficial effect on air quality. The proposed action would not affect the Oregon Smoke Management Plan and the state implementation plan. Any future development that might be encouraged by the availability of natural gas would be regulated in accord with all applicable County, State, and Federal permit requirements. See Chapter 4 for further discussion.

\section{Statewide Goal Number 7: Areas Subject to Natural Disasters and Hazards}

Description - To protect life and property from natural disasters and hazards.

Consistency of the Proposed Action - Natural hazard areas, including wetlands, floodplains, earthquakes, and areas with highly erosive soils, have been identified and evaluated. The proposed action, including the use of project design criteria and best management practices provides for appropriate management of natural hazard areas (see Appendix A, Geotechnical Engineering Report for further discussions). Permits required for the construction, maintenance, and operation of the natural gas pipeline will also address requirements for public safety.

\section{Statewide Goal Number 8: Recreational Needs}

Description - To satisfy the recreational needs of the citizens of the state and visitors and, where appropriate, to provide for the siting of necessary recreational facilities including destination resorts.

Consistency of the Proposed Action - The proposed action would not result in any long-term impact on the ability to satisfy the recreational needs within the project area. Short-term impacts may result from delayed access to recreational sites during the construction period. Opportunities would continue to be provided to meet recreation demand (identified in Oregon's Statewide Comprehensive Outdoor Recreation Plan). There has been no specific interest in development of destination resort sites on BLM-administered lands.

\section{Statewide Goal Number 9: Economic Development}

Description - To provide adequate opportunities throughout the state for a variety of economic activities vital to the health, welfare, and prosperity of Oregon's citizens.

Consistency of the Proposed Action - The proposed action would provide opportunity for residential, commercial, or industrial users within the immediate service area to utilize natural gas. Natural gas has traditionally been a clean, economical, efficient fuel for use to heat dwellings and water at a lower cost than existing available fuels. Providing this opportunity to the service area may also encourage future commercial and/or industrial development for this economically depressed area. Any future development that might be encouraged by the availability of natural gas would be regulated in accord with all applicable County, State, and Federal permit requirements, and would be subject to its own consistency determination. See Chapter 4, Effects on Socioeconomic Conditions, for further discussion. 


\section{Statewide Goal Number 10: Housing}

Not considered applicable.

\section{Statewide Goal Number 11: Public Facilities and Services}

Description - To plan and develop a timely, orderly, and efficient arrangement of public facilities and services to serve as a framework for urban and rural development.

Consistency of the Proposed Action - BLM-administered lands within the designated ROW corridor have been made available for development of the natural gas pipeline project by Coos county as permitted under the local government comprehensive plan and land use regulations and the relevant state siting requirements.

\section{Statewide Goal Number 12: Transportation}

Description - To provide and encourage a safe, convenient, and economic transportation system.

Consistency of the Proposed Action - The proposed action provides for the construction, operation, and maintenance of a natural gas pipeline within a designated right-of way corridor. Consideration of existing use of public roads/user safety resulted in the selection of the location for the proposed action. Project design criteria and best management practices as required by the various State and Federal permits further address the safety issue.

\section{Statewide Goal Number 13: Energy Conservation}

Not considered applicable.

\section{Statewide Goal Number 14: Urbanization}

Not considered applicable.

\section{Statewide Goal Number 15: Willamette Greenway}

Not considered applicable.

\section{Statewide Goal Number 16: Estuarine Resources}

Description - To recognize and protect the unique environmental, economic, and social values of each estuary and associated wetlands; and to protect, maintain, where appropriate develop, and where appropriate restore the long-term environmental, economic, and social values, diversity, and benefits of Oregon's estuaries.

Consistency of the Proposed Action - The construction, operation, and maintenance of the proposed natural gas pipeline are considered to be consistent with the Coos Bay Estuary management Plan. No measurable impacts on estuarine resources from BLM-authorized activities are anticipated. Any future development that might be encouraged by the availability of natural gas would be regulated in accord with all applicable County, State, and Federal permit requirements.

\section{Statewide Goal Number 17: Coastal Shorelands}

Description - To conserve, protect, where appropriate, develop, and where appropriate restore the resources and benefits of all coastal shorelands, recognizing their value for protection and maintenance of water quality, fish and wildlife habitat, water-dependent uses, economic resources, recreation, and aesthetics. The management of these shoreland areas shall be compatible with the characteristics of the adjacent coastal waters. To reduce the hazard to 
human life and property, and the adverse effects upon water quality and fish and wildlife habitat, resulting from the use and enjoyment of Oregon's coastal shorelands.

Consistency of the Proposed Action - The proposed action would preserve and protect BLM-administered and other coastal shorelands delineated in acknowledged city and county comprehensive plans and land use regulations, and the Coos Bay Estuary management Plan. Any future development that might be encouraged by the availability of natural gas would be regulated in accord with all applicable County, State, and Federal permit requirements.

\section{Statewide Goal Number 18: Beaches and Dunes}

Not considered applicable.

\section{Statewide Goal Number 19: Ocean Resources}

Not considered applicable. 


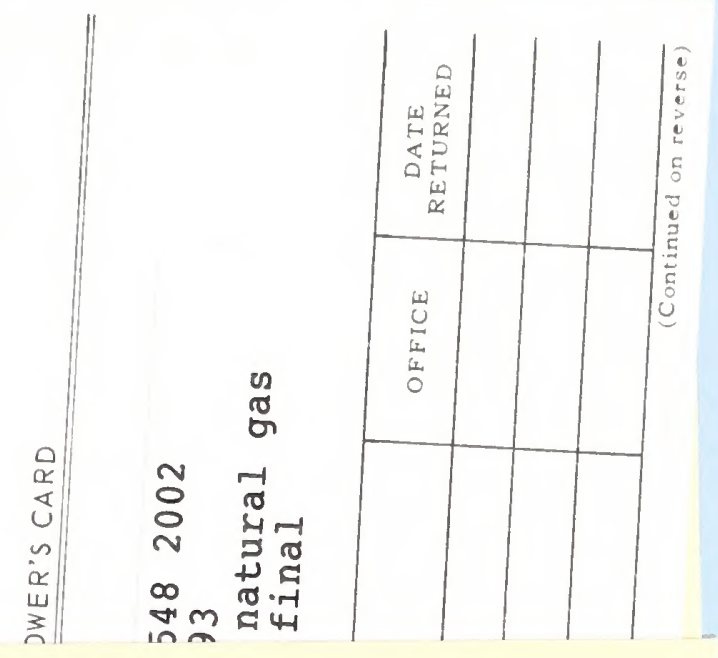

TN $879.5 . C 548 \quad 2002$

88056893

Coos county natural gas

pipeline : final

DLIVT LIBNAMT

BLDG 50, ST-150A

DENVER FEDERAL CENTER

P.O. BOX 25047

DENVER, COLORADO 80225 

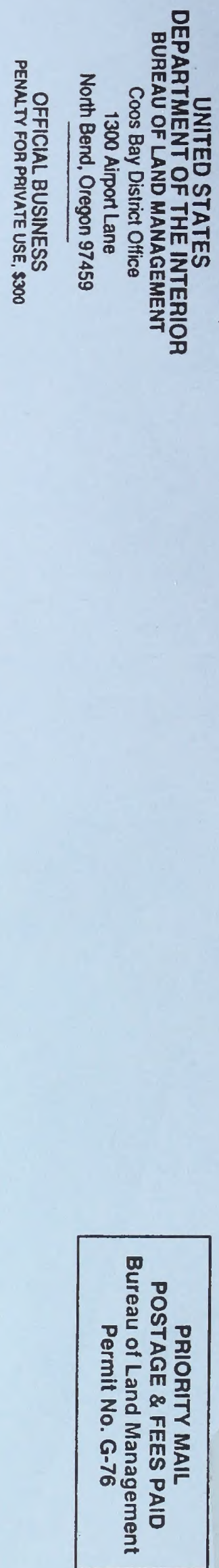